Andreas Klärner · Markus Gamper

Sylvia Keim-Klärner · Irene Moor

Holger von der Lippe · Nico Vonneilich Hrsg.

Soziale Netzwerke

und gesundheitliche

Ungleichheiten

Eine neue Perspektive für

die Forschung 
Soziale Netzwerke und gesundheitliche Ungleichheiten 
Andreas Klärner · Markus Gamper · Sylvia Keim-Klärner · Irene Moor · Holger von der Lippe · Nico Vonneilich (Hrsg.)

\section{Soziale Netzwerke und gesundheitliche Ungleichheiten}

Eine neue Perspektive für die Forschung 
Hrsg.

Andreas Klärner

Thünen-Institut für Ländliche Räume

Braunschweig, Deutschland

Sylvia Keim-Klärner

Thünen-Institut für Ländliche Räume

Braunschweig, Deutschland

Holger von der Lippe

MSB Medical School Berlin

Berlin, Deutschland

\author{
Markus Gamper \\ Universität zu Köln \\ Köln, Deutschland
}

Irene Moor

Martin-Luther-Universität

Halle-Wittenberg

Halle, Deutschland

Nico Vonneilich

Universitätsklinikum

Hamburg-Eppendorf

Hamburg, Deutschland

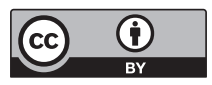

ISBN 978-3-658-21658-0 ISBN 978-3-658-21659-7 (eBook)

https://doi.org/10.1007/978-3-658-21659-7

Die Deutsche Nationalbibliothek verzeichnet diese Publikation in der Deutschen Nationalbibliografie; detaillierte bibliografische Daten sind im Internet über http://dnb.d-nb.de abrufbar.

Springer VS

(C) Der/Die Herausgeber und der/die Autor(en) 2020 Dieses Buch ist eine Open-AccessPublikation.

Open Access Dieses Buch wird unter der Creative Commons Namensnennung 4.0 International Lizenz (http://creativecommons.org/licenses/by/4.0/deed.de) veröffentlicht, welche die Nutzung, Vervielfältigung, Bearbeitung, Verbreitung und Wiedergabe in jeglichem Medium und Format erlaubt, sofern Sie den/die ursprünglichen Autor(en) und die Quelle ordnungsgemäß nennen, einen Link zur Creative Commons Lizenz beifügen und angeben, ob Änderungen vorgenommen wurden. Die in diesem Buch enthaltenen Bilder und sonstiges Drittmaterial unterliegen ebenfalls der genannten Creative Commons Lizenz, sofern sich aus der Abbildungslegende nichts anderes ergibt. Sofern das betreffende Material nicht unter der genannten Creative Commons Lizenz steht und die betreffende Handlung nicht nach gesetzlichen Vorschriften erlaubt ist, ist für die oben aufgeführten Weiterverwendungen des Materials die Einwilligung des jeweiligen Rechteinhabers einzuholen.

Die Wiedergabe von allgemein beschreibenden Bezeichnungen, Marken, Unternehmensnamen etc. in diesem Werk bedeutet nicht, dass diese frei durch jedermann benutzt werden dürfen. Die Berechtigung zur Benutzung unterliegt, auch ohne gesonderten Hinweis hierzu, den Regeln des Markenrechts. Die Rechte des jeweiligen Zeicheninhabers sind zu beachten.

Der Verlag, die Autoren und die Herausgeber gehen davon aus, dass die Angaben und Informationen in diesem Werk zum Zeitpunkt der Veröffentlichung vollständig und korrekt sind. Weder der Verlag, noch die Autoren oder die Herausgeber übernehmen, ausdrücklich oder implizit, Gewähr für den Inhalt des Werkes, etwaige Fehler oder Äußerungen. Der Verlag bleibt im Hinblick auf geografische Zuordnungen und Gebietsbezeichnungen in veröffentlichten Karten und Institutionsadressen neutral.

Springer VS ist ein Imprint der eingetragenen Gesellschaft Springer Fachmedien Wiesbaden GmbH und ist ein Teil von Springer Nature.

Die Anschrift der Gesellschaft ist: Abraham-Lincoln-Str. 46, 65189 Wiesbaden, Germany 


\section{Inhaltsverzeichnis}

Soziale Netzwerke und gesundheitliche Ungleichheiten - eine neue Perspektive für die Forschung . . . . . . . . . . . . . . . . .

Andreas Klärner, Markus Gamper, Sylvia Keim-Klärner,

Holger von der Lippe, Irene Moor, Matthias Richter und Nico Vonneilich

Theoretische und methodische Grundlagen

Soziale Beziehungen, soziales Kapital und soziale

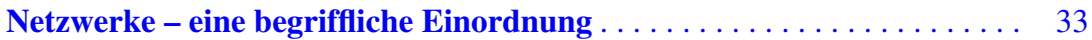

Nico Vonneilich

Netzwerktheorie(n) - Ein Überblick . . . . . . . . . . . . . . . . . . . . 49

Markus Gamper

Wirkmechanismen in sozialen Netzwerken $\ldots \ldots \ldots \ldots \ldots \ldots \ldots 65$

Andreas Klärner und Holger von der Lippe

Negative Beziehungsaspekte und gesundheitliche Ungleichheiten. . . . . . 87

Philip Adebahr

Netzwerkanalyse - eine methodische Annäherung . . . . . . . . . . . 109

Markus Gamper

Lebenslauf

Soziale Netzwerke, familiales Sozialkapital und kindliche Gesundheit. . . 137

Daniel Lois 
Soziale Netzwerke, Gesundheit und gesundheitliche Ungleichheiten im Jugendalter.

Irene Moor, Laura Hoffmann, Martin Mlinarić und Matthias Richter

Soziale Netzwerke und gesundheitliche Ungleichheiten im jungen und mittleren Erwachsenenalter

Holger von der Lippe und Olaf Reis

Soziale Netzwerke und gesundheitliche Ungleichheiten im Alter. . . . . . . 227

Britta Müller und Lea Ellwardt

\section{Ungleichheitsdimensionen}

Sozialer Status, soziale Beziehungen und Gesundheit. . .

Nico Vonneilich

Geschlecht und gesundheitliche Ungleichheiten - Soziale Netzwerke im Kontext von Gesundheit und Gesundheitsverhalten . . .

Markus Gamper, Julia Seidel, Annett Kupfer, Sylvia Keim-Klärner und Andreas Klärner

Arbeitslosigkeit, soziale Netzwerke und gesundheitliche Ungleichheiten.

Gerhard Krug, Stefan Brandt, Markus Gamper, André Knabe und Andreas Klärner

Soziale Netzwerke und die Gesundheit von Alleinerziehenden

Sylvia Keim-Klärner

Soziale Netzwerke und Behinderung - Zugang und Stabilisierung der Einbindung in den allgemeinen Arbeitsmarkt

Stefan Zapfel, Nancy Reims und Mathilde Niehaus

Migration als gesundheitliche Ungleichheitsdimension?

Natio-ethno-kulturelle Zugehörigkeit, Gesundheit

und soziale Netzwerke

Annett Kupfer und Markus Gamper 
Desiderata: Soziale Netzwerk und gesundheitliche

Ungleichheiten - welche Fragen bleiben offen?

Olaf Reis, Philip Adebahr, Stefan Brandt, Lea Ellwardt, Markus Gamper, Laura Hoffmann, Sylvia Keim-Klärner, Andreas Klärner, André Knabe, Gerhard Krug, Annett Kupfer, Daniel Lois, Martin Mlinarić, Irene Moor, Britta Müller, Mathilde Niehaus, Nancy Reims, Matthias Richter, Julia Seidel, Holger von der Lippe, Nico Vonneilich und Stefan Zapfel 


\section{Herausgeber- und Autorenverzeichnis}

\section{Über die Herausgeber}

PD Dr. Andreas Klärner ist Wissenschaftlicher Rat am Thünen-Institut für Ländliche Räume und Privatdozent an der Wirtschafts- und Sozialwissenschaftlichen Fakultät der Universität Rostock.

PD Dr. Markus Gamper ist Akademischer Rat am Institut für vergleichende Bildungsforschung und Sozialwissenschaften der Universität zu Köln.

Dr. Sylvia Keim-Klärner ist Wissenschaftliche Mitarbeiterin am Thünen-Institut für Ländliche Räume in Braunschweig.

Dr. Irene Moor ist Wissenschaftliche Mitarbeiterin am Institut für Medizinische Soziologie (IMS) der Martin-Luther-Universität Halle-Wittenberg.

Prof. Dr. Holger von der Lippe ist Professor für Entwicklungspsychologie an der Fakultät Naturwissenschaften der MSB Medical School Berlin.

Dr. Nico Vonneilich ist Wissenschaftlicher Mitarbeiter am Institut für Medizinische Soziologie (IMS) des Universitätsklinikums Hamburg-Eppendorf (UKE).

\section{Autorenverzeichnis}

Philip Adebahr M.A., ist wissenschaftlicher Mitarbeiter an der Professur für Soziologie mit dem Schwerpunkt Gesundheitsforschung am Institut für Soziologie der Technischen Universität Chemnitz. 
Stefan Brandt ist als wissenschaftlicher Mitarbeiter im DFG-geförderten Forschungsprojekt „Kiez in der Tourismusfalle? Eine Untersuchung zur Veränderung von Wohnqualität durch touristische Übernachtungsmöglichkeiten in ausgewählten Berliner Wohnquartieren“ an der Technischen Universität Berlin tätig.

Jun.-Prof. Dr. Lea Ellwardt ist Juniorprofessorin am Institut für Soziologie und Sozialpsychologie der Universität zu Köln.

PD Dr. Markus Gamper ist Akademischer Rat am Institut für vergleichendeBildungsforschung und Sozialwissenschaften der Universität zu Köln.

Laura Hoffmann, M.A., ist wissenschaftliche Mitarbeiterin am Institut für Medizinische Soziologie der Martin-Luther-Universität Halle-Wittenberg sowie im Fachbereich Wirtschafts- und Sozialwissenschaften der Hochschule Nordhausen.

PD Dr. Andreas Klärner ist Wissenschaftlicher Rat am Thünen-Institut fürLändliche Räume und Privatdozent an der Wirtschafts- und SozialwissenschaftlichenFakultät der Universität Rostock.

Dr. Sylvia Keim-Klärner ist Wissenschaftliche Mitarbeiterin am Thünen-Institutfür Ländliche Räume in Braunschweig.

André Knabe, M.Sc., ist wissenschaftlicher Mitarbeiter am Institut für Soziologie und Demographie an der Universität Rostock.

PD Dr. Gerhard Krug ist Wissenschaftlicher Mitarbeiter am Institut für Arbeitsmarkt- und Berufsforschung (IAB), Gastwissenschaftler am Lehrstuhl für Empirische Wirtschaftssoziologie der Universität Erlangen-Nürnberg und Privatdozent am Institut für Soziologie der Universität Hannover.

Dr. Annett Kupfer ist Wissenschaftliche Mitarbeiterin am Institut für Sozialpädagogik, Sozialarbeit und Wohlfahrtswissenschaften der Fakultät Erziehungswissenschaften der Technischen Universität Dresden.

Prof. Dr. Holger von der Lippe ist Professor für Entwicklungspsychologie ander Fakultät Naturwissenschaften der MSB Medical School Berlin.

Prof. Dr. Daniel Lois ist Professor für Sozialwissenschaftliche Methodenlehre an der Fakultät für Humanwissenschaften der Universität der Bundeswehr München.

Dr. Martin Mlinarić ist Wissenschaftlicher Mitarbeiter am Institut für Medizinische Soziologie (IMS) an der Martin-Luther-Universität Halle-Wittenberg. 
Dr. Irene Moor ist Wissenschaftliche Mitarbeiterin am Institut für MedizinischeSoziologie (IMS) der Martin-Luther-Universität Halle-Wittenberg.

Dr. Britta Müller ist wissenschaftliche Mitarbeiterin am Institut für Medizinische Psychologie und Medizinische Soziologie (IMPMS) der Universität Rostock.

Univ.-Prof. Dr. Mathilde Niehaus ist Professorin für Arbeit und Berufliche Rehabilitation an der Humanwissenschaftlichen Fakultät der Universität zu Köln.

Dr. Nancy Reims ist Wissenschaftliche Mitarbeiterin am Institut für Arbeitsmarkt- und Berufsforschung.

PD Dr. Olaf Reis ist Leiter der Abteilung Forschung an der Klinik für Psychiatrie, Neurologie, Psychosomatik und Psychotherapie im Kindes- und Jugendalter der Universitätsmedizin Rostock.

Prof. Dr. Matthias Richter ist Professor und Direktor des Instituts für Medizinische Soziologie an der Medizinischen Fakultät der Martin-Luther-Universität Halle-Wittenberg.

Julia Seidel, M.A., ist wissenschaftliche Mitarbeiterin am Institut für Sozialpädagogik, Sozialarbeit und Wohlfahrtswissenschaften an der Technischen Universität Dresden.

Dr. Nico Vonneilich ist Wissenschaftlicher Mitarbeiter am Institut für Medizinische Soziologie (IMS) des Universitätsklinikums Hamburg-Eppendorf (UKE).

Dr. Stefan Zapfel ist stellv. Geschäftsführer und wissenschaftlicher Mitarbeiter am Institut für empirische Soziologie an der Friedrich-Alexander-Universität Erlangen-Nürnberg (IfeS). 


\title{
Soziale Netzwerke und gesundheitliche Ungleichheiten - eine neue Perspektive für die Forschung
}

\section{Andreas Klärner, Markus Gamper, Sylvia Keim-Klärner, Holger von der Lippe, Irene Moor, Matthias Richter und Nico Vonneilich}

„Sag mir, wie viel Deine Freunde verdienen, und ich sage Dir, ob Du rauchst, welche Krankheiten Du hast und wie alt Du werden wirst!" Ein Teil dieser Aussage dürfte für all jene, die sich für den Zusammenhang von sozialer Ungleichheit und Gesundheit interessieren, vertraut sein. Menschen mit vergleichsweise niedrigerem sozioökonomischem Status tragen höhere gesundheitliche Risiken, werden häufiger krank und sie sterben auch früher als jene, die ein höheres

\author{
A. Klärner $(\bowtie) \cdot S$. Keim-Klärner \\ Braunschweig, Deutschland \\ E-Mail: andreas.klaerner@thuenen.de \\ S. Keim-Klärner \\ E-Mail: sylvia.keim-klaerner@thuenen.de \\ M. Gamper \\ Köln, Deutschland \\ E-Mail: m.gamper@uni-koeln.de \\ H. von der Lippe \\ Berlin, Deutschland \\ E-Mail: holger.vonderlippe@ medicalschool-berlin.de \\ I. Moor · M. Richter \\ Halle (Saale), Deutschland \\ E-Mail: irene.moor@medizin.uni-halle.de \\ M. Richter \\ E-Mail: m.richter@medizin.uni-halle.de \\ N. Vonneilich \\ Hamburg, Deutschland \\ E-Mail:n.vonneilich@uke.de
}


Einkommen, einen höheren Schulabschluss oder einen prestigeträchtigeren Beruf haben. Dieser Zusammenhang, oftmals auch als ,sozialer Gradient" bezeichnet, ist vielfach belegt und lässt sich in (fast) allen Ländern der Welt und auch in Deutschland anhand unterschiedlicher Gesundheitsindikatoren zeigen (vgl. z. B. Richter und Hurrelmann 2009).

In dem Satz wird aber nicht nach dem eigenen Einkommen gefragt, sondern nach dem Einkommen der Freunde. Ist diese Information wirklich aussagekräftig? Macht es wirklich einen Unterschied für die eigene Gesundheit, mit wem man befreundet ist, mit wem man sich in seinem Alltag umgibt und welche soziale Position diese Personen haben?

Wissenschaftlich gesprochen stellt dieser Satz einen Zusammenhang zwischen der sozialen Stellung von Akteuren im Beziehungsnetzwerk eines Menschen und dessen eigenem Gesundheitsverhalten, seiner Morbidität und seiner Mortalität her. Die Auskunft über den sozialen Status der Freunde einer Person - es können möglicherweise auch Familienangehörige, die Kollegen, Nachbarn oder andere, entfernter bekannte Personen sein - soll uns also Rückschlüsse auf das Gesundheitsverhalten, auf die Anfälligkeit für bestimmte Krankheiten und die Lebenserwartung geben und ggf. auch auf schichtspezifische Unterschiede in der Gesundheit. Für Familienangehörige liegt es nahe, wenn sie zusammen leben und einen gemeinsamen Haushalt führen, ein ähnliches Gesundheitsverhalten, ähnliche Gesundheitsrisiken und Belastungen anzunehmen, wie auch Einflüsse auf die Lebenserwartung und Erkrankungen, die erblich bedingt sind. Aber haben auch Personen aus dem weiteren Freundes- und Bekanntenkreis einen Einfluss auf meine Gesundheit? Welche neuen Perspektiven und Ergebnisse im Zusammenhang mit Gesundheit und gesundheitlicher Ungleichheit kann die Betrachtung von sozialen Beziehungen ergeben?

Dieser Fragestellung werden die Beiträge des vorliegenden Sammelbandes nachgehen. Aber nicht nur das, sie werden nicht nur danach fragen, ob es einzelne soziale Beziehungen sind (etwa ein Freund, der raucht und andere zum Rauchen animiert), die einen Einfluss auf individuelle Gesundheit haben, sondern auch, inwieweit es beispielsweise einen Unterschied macht, ob der eigene Freundeskreis sich untereinander kennt und mag, oder eben nicht? Ob meine Gesundheit oder mein Gesundheitsverhalten eher von mir ähnlichen oder mir eher unähnlichen Personen beeinflusst wird? Kurz: Die Beiträge des Bandes fragen danach, ob die Struktur sozialer Beziehungen - die sozialen Netzwerke, in die wir alle in unserem Wahrnehmen, Denken und Handeln eingebettet sind - einen Einfluss auf uns haben, dass einige von uns mit einer gewissen Wahrscheinlichkeit eher erkranken oder früher sterben als andere. Damit stellt sich auch die Frage, ob die Betrachtung sozialer Netzwerke sowie die Beschäftigung mit der soziologischen und inzwischen interdisziplinären Netzwerkforschung einen Beitrag zum Verstehen und Erklären gesundheitlicher Ungleichheiten leisten können. 
Dieser Sammelband ist ein Ergebnis einer mehrjährigen Zusammenarbeit von Forscherinnen und Forschern aus unterschiedlichen Disziplinen (Soziologie, Medizinische Soziologie, Psychologie, Public Health, Erziehungswissenschaften, Gesundheitswissenschaften) mit unterschiedlichen theoretischen und methodischen Ausrichtungen. Diese Zusammenarbeit wurde als Wissenschaftliches Netzwerk "Soziale Netzwerke und gesundheitliche Ungleichheiten (SoNegU)“ von der Deutschen Forschungsgemeinschaft (DFG) seit 2016 für eine Laufzeit von drei Jahren gefördert. Ziele des Netzwerks waren es, 1) die soziologische Netzwerkforschung in der deutschsprachigen Gesundheitsforschung bekannter und 2) die Netzwerkperspektive für die Erklärung gesundheitlicher Ungleichheiten fruchtbar zu machen. Das Ziel dieser Buchpublikation ist es, den Forschungsstand aufzubereiten, Forschungsdesiderate zu benennen und Perspektiven für die zukünftige Forschung aufzuzeigen.

In dieser Einleitung soll gezeigt werden, dass der Einbezug der Netzwerkperspektive in der Erforschung gesundheitlicher Ungleichheiten gewinnbringend sein kann, was dann in den weiteren Kapiteln des Bandes vertiefend vorgestellt und diskutiert wird. Dazu führen wir zunächst in die Analyse sozialer Netzwerke ein (Abschn. 1) und geben daran anschließend (Abschn. 2) einen kurzen Überblick zu empirischen Befunden über gesundheitliche Ungleichheiten in Deutschland und präsentieren zwei wichtige theoretische Modelle zur Erklärung gesundheitlicher Ungleichheiten. Wir arbeiten heraus, welche Rolle soziale Beziehungen und soziale Netzwerke im Rahmen dieser Erklärungsmodelle spielen. Im Anschluss (Abschn. 3) legen wir dar, welche Rolle die soziologische Netzwerkforschung in diesem Zusammenhang einnehmen kann und stellen ein eigenes konzeptionelles Theoriemodell vor, welches auch für viele der einzelnen Beiträge als orientierender Rahmen fungiert. Wir enden dann mit einer Übersicht der Beiträge dieses Bandes in Abschn. 4.

\section{Die soziologische Netzwerkforschung}

Mit sozialen Netzwerken greifen wir ein sozialwissenschaftliches Konzept auf, das sich an handlungstheoretischen Grundannahmen orientiert, die davon ausgehen, dass Individuen nicht als Atome handeln, sondern „eingebettet“ sind in ein relationales Netzwerk zwischenmenschlicher Beziehungen (vgl. Burt 1982; Elias 2014; Emirbayer 1997; Fuhse und Mützel 2010; Granovetter 1985). Die Beziehungen zwischen den Akteuren sind dabei prägend für das Verhalten der Netzwerkmitglieder (vgl. z. B. Wellman 1988). Dieser relationale Denkansatz (vgl. Emirbayer und Goodwin 1994; s. auch Klärner und Keim 2019) geht davon 
aus, dass soziale Prozesse sowie Handlungen nicht alleine durch akteursspezifische Attribute wie beispielsweise soziodemografische Merkmale der Individuen (z. B. Alter, Geschlecht, Ethnie, Bildungsstand) zu erklären sind, sondern durch die Einbettung in ihr soziales Umfeld wie Familie, Freunde, Verwandte oder Bekannte. Die Netzwerkperspektive fokussiert damit auf die Meso-Ebene ${ }^{1}$ der sozialen Beziehungen zwischen Individuen. Das soziale Umfeld wird somit als Struktur der sozialen Beziehungen verstanden, die Handlungsspielräume eröffnet oder einschränkt und etwa auch die Art und Weise beeinflusst, wie die Akteure sich selbst und ihre Handlungsfähigkeit wahrnehmen (vgl. Gamper 2015).

Zentral ist dabei, dass im Rahmen der Netzwerkforschung nicht nur einzelne Beziehungen oder Dyaden analysiert werden, sondern auch, wie einzelne Beziehungen untereinander verflochten sind und welche Struktur diese Beziehungsgeflechte aufweisen (Häußling 2010) ${ }^{2}$. Interagierende Individuen, Paare, Familien und andere Interaktionseinheiten (auch Institutionen oder Organisationen) lassen sich demnach als „Gruppen interdependenter Menschen“ bzw. als „Netzwerke von Individuen“ (Elias 2014, S. 12 und 14) begreifen, und kulturelle Normen und Werte von Individuen werden in Sozialisationsprozessen sowie in alltäglichen Interaktionen mit ihren Mitmenschen gelernt, reproduziert, aber auch verändert. In der Sprache der neueren Netzwerktheorie werden Individuen (oder auch Organisationen und Institutionen) als Akteure begriffen, die „eingebettet“ (Granovetter 1985) sind in ein relationales Netzwerk sozialer Beziehungen, das Handlungsmöglichkeiten eröffnet oder restringiert (vgl. Burt 1982; Emirbayer und Mische 1998; Fuhse und Mützel 2010; Häußling 2010; Wellman 1988). Je nach der Stellung bzw. „Einbettung“ des Individuums in ein solches Netzwerk und nach der Netzwerkzusammensetzung und -struktur, hat das Individuum beispielsweise einen ganz spezifischen Zugang zu Ressourcen

\footnotetext{
${ }^{1}$ Als Mikroebene kann die des individuellen Akteurs, als Makroebene der gesellschaftliche Kontext (Systemebene) und die Rahmenbedingungen verstanden werden.

${ }^{2}$ Der Begriff des sozialen Netzwerks hat nicht zuletzt durch soziale Medien wie Facebook und Twitter an Popularität gewonnen, wird sowohl alltagssprachlich als auch in wissenschaftlichen Kontexten in zunehmendem Maße genutzt. In vielen Studien wird er aber lediglich als Metapher für Beziehungen oder Interaktionen verwandt, ohne dass hier tatsächlich die Strukturen dieser Beziehungen betrachtet werden, strukturale Analysen durchgeführt werden oder eine Einbettung in theoretische Überlegungen der Netzwerkforschung gesucht wird. Daher ist es wichtig zu bedenken, dass nicht alle Arbeiten, die den Netzwerkbegriff verwenden, auch eine strukturelle Netzwerkperspektive einnehmen, wie wir sie hier propagieren und als gewinnbringend erachten.
} 
und Informationen. Damit soll mithilfe des sozialen Netzwerkansatzes das aktive Handeln und Erleben einzelner Personen im Rahmen zwischenmenschlicher Beziehungen konzeptuell verstehbar und methodisch rekonstruierbar gemacht werden (siehe Kap. „Netzwerktheorie(n)“").

Auch wenn erste Ideen zu ,Wechselwirkungen“ mit anderen Individuen, zu „sozialen Kreisen“ oder der Einbindung in Beziehungsmuster oder „Figurationen“ schon bei Klassikern der Soziologie und Psychologie wie Georg Simmel, Norbert Elias oder Urie Bronfenbrenner zu finden sind (vgl. z. B. Simmel 1999; Elias 2014; zur Rezeption dieser Klassiker in der aktuellen Netzwerkforschung siehe Hollstein 2010; Willems 2010; Flammer 2009), ist das methodische Vorgehen und die damit zusammenhängende Strukturanalyse noch relativ neu. In den letzten Jahren kam es zu einer sehr dynamischen und auch innovativen Entwicklung hinsichtlich der Analysetools, auch von großen Datensätzen, und seit geraumer Zeit existiert ein breites Instrumentarium an spezifischen Erhebungs- und Analysemethoden, die sowohl in qualitativer als auch in quantitativer Forschung sowie in methodenintegrativen (mixed methods) Designs eingesetzt werden können. Das Hauptaugenmerk liegt dennoch auf der quantitativen Auswertung der Netzwerkdaten und damit auf den kausalen sowie statistischen Zusammenhängen (zur ausführlichen Darstellung der Geschichte relationaler Wissenschaft auch (Gamper 2015); siehe Kap. „Netzwerkanalyse“).

Diese Konzepte und Methoden haben in der anglo-amerikanischen Forschung schon lange Einzug gehalten, zu nennen wären hier beispielsweise die Analyse von starken und schwachen Beziehungen bei der Arbeitssuche (Granovetter 1973), von Diffusionsprozessen ,guter Ideen“ (Burt 2004), der Aufteilung der zu erledigen Hausarbeit in Paarbeziehungen (Bott 1957) und auch im Bereich der Gesundheit (Valente 2010). Noch immer wird aber eine mangelnde handlungstheoretische Fundierung und eine nicht ausreichende Kenntnis über die in sozialen Netzwerken wirkenden Mechanismen u. a. des sozialen Einflusses konstatiert (vgl. z. B. Smith und Christakis 2008; Gulati und Srivasta 2014). Dies ist z. T. auch auf den methodischen Fokus, nämlich der quantitativen Forschung, zurückzuführen. Ferner wird in der bisherigen Forschung der Blick häufig auf positiv wirkende, unterstützende Beziehungen gerichtet, andere und (intendierte oder nicht intendierte) negative Effekte von sozialen Beziehungen und ihren Strukturen, wie etwa Kontrolle und Korruption oder auch die Wirkung und Dynamik konflikthafter Beziehungen (siehe dazu Kap. „Negative Beziehungsaspekte und gesundheitliche Ungleichheiten“), sind bisher kaum untersucht.

In Deutschland erlangt die Netzwerkforschung erst seit neuerem an Popularität (vgl. z. B. Gamper et al. 2012; Hollstein und Straus 2006; Stegbauer 2010; Stegbauer und Häußling 2010). 


\section{Gesundheitliche Ungleichheiten}

In der internationalen und nationalen Forschung gilt der Zusammenhang zwischen sozialen Ungleichheiten und der Gesundheit als empirisch gut bestätigt, dies zeigt sich in praktisch allen Ländern, in denen Daten zur Verfügung stehen (vgl. z. B. CSDH 2008; Marmot 2005; Rostila 2013; Schneider 2008; Thurston 2014; Vonneilich et al. 2011; Weyers et al. 2008, sowie die Beiträge in Richter und Hurrelmann 2009). Soziale Ungleichheiten - d. h. Benachteiligungen in vor allem den vertikalen Dimensionen „Bildung“, „Beruf“, „Einkommen“ - wirken sich demnach negativ sowohl auf den Gesundheitszustand (Morbidität, Mortalität) als auch auf das Gesundheitsverhalten (z. B. Substanzkonsum, Ernährung, Bewegung) aus (siehe u. a. Braveman et al. 2011; Brownson et al. 2005; Kanjilal et al. 2006; von dem Knesebeck und Schäfer 2009; Walque 2010; für Deutschland vgl. Richter et al. 2013). Auch horizontale Dimensionen sozialer Ungleichheit wie beispielsweise Geschlecht und Migrationshintergrund konnten bereits mit verschiedenen Gesundheitsindikatoren in Zusammenhang gebracht werden (siehe u. a. Babitsch 2000; Hurrelmann und Quenzel 2011; Singh und Hiatt 2006; Wengler 2013).

Erste Forschungsarbeiten zu gesellschaftlichen Ursachen von Krankheit und vorzeitiger Sterblichkeit gibt es in Deutschland bereits seit Mitte des 19. Jahrhunderts und als wissenschaftliche Disziplin, die auch politisch relevant wird, etablierte sich die „Sozialepidemiologie“ in den 1990er/2000er Jahren (z. B. in der Gesundheitsberichterstattung des Bundes durch das Robert-Koch-Institut) (vgl. Lampert et al. 2015; Marmot und Wilkinson 2006; Mielck 1994; Richter und Hurrelmann 2016; Siegrist 2005).

Aktuelle Forschungsergebnisse zeigen für Deutschland erhebliche soziale Unterschiede bezüglich der Morbidität und Mortalität auf:

- Die mittlere Lebenserwartung des untersten Einkommensquintils liegt 8,6 Jahre unter der des obersten Einkommensquintils bei Männern und etwa 4,4 Jahre bei Frauen (Lampert et al. 2019). Wird die fernere Lebenserwartung ab dem 65. Lebensjahr herangezogen, so beträgt die Differenz 3,7 Jahre bei Frauen und noch 6,6 Jahre bei Männern (ebd.).

- Erwerbslose haben im Vergleich zur Gesamtbevölkerung ein um 63 \% höheres Mortalitätsrisiko (Roelfs et al. 2011).

- Die koronare Herzerkrankung (KHK) als wichtigste Todesursache in Deutschland folgt einem sozialen Gradienten: Die Lebenszeitprävalenz einer KHK in hohen sozialen Statusgruppen beträgt knapp $7 \%$, in mittleren Statusgruppen knapp $9 \%$ und in niedrigen Statusgruppen fast $14 \%$ (Gößwald et al. 2013). 
- Soziale Unterschiede zeigen sich auch im Hinblick auf andere Krankheitsbilder und Formen gesundheitlicher Beeinträchtigungen wie Diabetes mellitus, Adipositas, depressive Symptomatik oder auch bei Krebserkrankungen (vgl. Lampert et al. 2013; Lange 2014).

- Psychische Belastungen wie Stress und psychotische Symptome treten häufiger bei Personen mit niedrigem Sozialstatus auf (Robert Koch-Institut 2017; vgl. auch Siegrist 2005).

- Soziale Ungleichheiten stehen in Zusammenhang mit Unterschieden in der gesundheitlichen Versorgung: Janßen et al. (2012) finden in einem systematischen Review etwa, dass 20 von 23 überprüften Studien klare Belege liefern für signifikante Zusammenhänge zwischen einem höheren sozialen Status und einer stärkeren Inanspruchnahme von Gesundheitsvorsorgeleistungen und -angeboten.

- Das Gesundheitsverhalten unterscheidet sich meist deutlich je nach sozialem Status: Je niedriger der soziale Status, desto größer der Anteil der Raucher, derjenigen, die sich ungesund ernähren und körperlich inaktiv sind (Lampert 2010; Mackenbach 2006; Mielck 2005), nur beim Alkoholkonsum lassen sich diese Zusammenhänge nicht so eindeutig und nicht in der erwarteten Form finden.

- Trotz aller Bemühungen konnten gesundheitliche Ungleichheiten in den letzten Jahren und Jahrzenten kaum verringert werden. Oftmals sind sie konstant geblieben oder zeigen eine Vergrößerung dieser Ungleichheiten. Dieser Trend zeigt sich für verschiedene Outcomes wie subjektive Gesundheit oder Mortalität sowohl international (Mackenbach et al. 2016; Granström et al. 2015) als auch für Deutschland (Moor et al. 2018; Pförtner und Elgar 2016; Kroll und Lampert 2011; Lampert et al. 2019; Siegel et al. 2014).

Insgesamt zeigt sich, dass gesundheitliche Ungleichheiten nach Ländern, aber auch nach Alter, Geschlecht oder auch nach Morbidität variieren (Kunst 2009; Lampert et al. 2013; Richter und Hurrelmann 2009).

Für die Erklärung gesundheitlicher Ungleichheiten gibt es unterschiedliche theoretische Modelle (vgl. Lampert 2016). Zu den einflussreichsten, in vielen Variationen weiterentwickelten gehören im internationalen Kontext das Modell von Dahlgren und Whitehead (1991) und im deutschsprachigen Kontext das von Elkeles und Mielck (vgl. Elkeles und Mielck 1997; Mielck 2005). Die Modelle eint, dass sie unterschiedliche Abstraktions- und Analyseebenen in ein Verhältnis setzen und den Einfluss von Makrostrukturen, genauer: gesellschaftlichen Ungleichheitsstrukturen, auf die Mikroebene der Individuen, ihres gesundheitlichen Status, ihrer Morbidität und Mortalität durch verschiede vermittelnde Mesoebenen und der dort wirkenden Faktoren aufklären wollen. 
Bei Dahlgren und Whitehead (1991) sind es auf der gesellschaftlichen Makroebene die allgemeinen sozioökonomischen Bedingungen, zu denen z. B. die wirtschaftliche Situation und die Entwicklung der jeweiligen Volkswirtschaft, die technische Infrastruktur, das Rechtssystem und Fragen von Frieden und Sicherheit zu zählen sind. Zu den Makrofaktoren gehört auch die kulturelle Umwelt, zu der auch das politische System, das Mediensystem und der Grad der Verfügbarkeit von Informationen, aber auch das Verhältnis der Geschlechter zu zählen ist. Ebenfalls bedeutsam ist die physische Umwelt, z. B. in Form besonderer klimatischer Bedingungen, Bodenqualität und Rohstoffreichtum, allgemein: der Zustand der Natur.

Diese Makrobedingungen haben im Modell von Dahlgren und Whitehead (Abb. 1) nun Einfluss auf die schon konkreteren Lebens- und Arbeitsbedingungen von Menschen bzw. von sozialen Gruppen in der Gesellschaft: Lebensmittelversorgung und -produktion, Bildung, Arbeits- und Wohnverhältnisse, Zugang zu Wasser, Hygienebedingungen, das Gesundheitssystem, Mobilität, Freizeitangebote etc. sind hier zu nennen. Vermittelt, d. h. tradiert und institutionalisiert durch familiäre, schulische und außerschulische Sozialisationsprozesse, und in sozialen Interaktionen verstärkt oder abgemildert werden diese Lebens- und Arbeitsbedingungen durch soziale und Gemeinde-Netzwerke (social and community networks): Familie, Freunde, Nachbarn, Kollegen, Vereine, die Gemeinde.

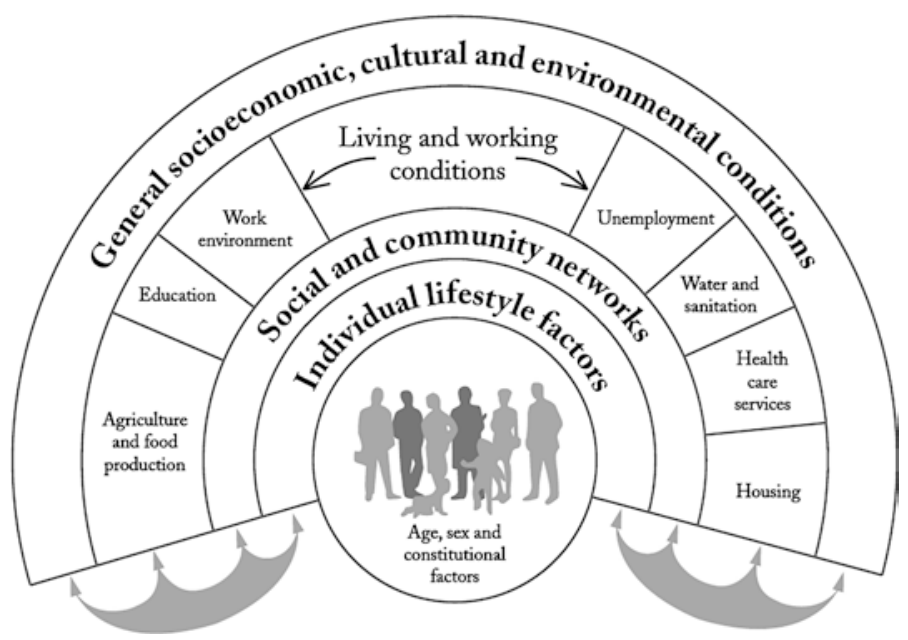

Abb. 1 Determinanten der Gesundheit - Modell von Dahlgren und Whitehead (1991). (Quelle: Dahlgren und Whitehead 2006 (zuerst erschienen in Dahlgren und Whitehead 1991)) 
Individuelle Lebensstile (individual lifestyle factors), Ess- und Trinkgewohnheiten, Substanzkonsum, sportliche Betätigung, gesundheitliche Vorsorge, aber auch der durch Schule, Arbeit, Familie etc. geprägte Tagesrhythmus beeinflussen die individuelle Gesundheit, die nicht zuletzt auch von Alter, Geschlecht und den Erbanlagen mitbestimmt wird.

Das im deutschsprachigen Raum populäre und ebenfalls vielfach weiterentwickelte Modell von Elkeles und Mielck (vgl. Elkeles und Mielck 1997; Mielck 2005) zeichnet sich dadurch aus, dass es genauer als das eben beschriebene Modell von Dahlgren und Whitehead Wirkungspfade postuliert und dabei auf allgemeine soziologische Theorien der Reproduktion sozialer Ungleichheit Bezug nimmt (vgl. dazu auch Röding 2018).

Das Modell (Abb. 2) orientiert sich an den klassischen, vertikalen sozialen Ungleichheiten nach Bildung, beruflicher Stellung und Einkommen, kurz: dem sozioökonomischen Status bzw. der Position einer Person oder einer sozialen Gruppe in einer gesellschaftlichen Ungleichheitsstruktur (Klasse, Schicht, Milieu etc.). Der Zusammenhang zwischen sozialer Ungleichheit und Gesundheit wird vermittelt durch Unterschiede in den gesundheitlichen Belastungen und Bewältigungsressourcen, z. B. strukturelle Aspekte wie Wohn- und Lebensbedingungen, Erholungs- und Freizeitmöglichkeiten, materielle Aspekte wie

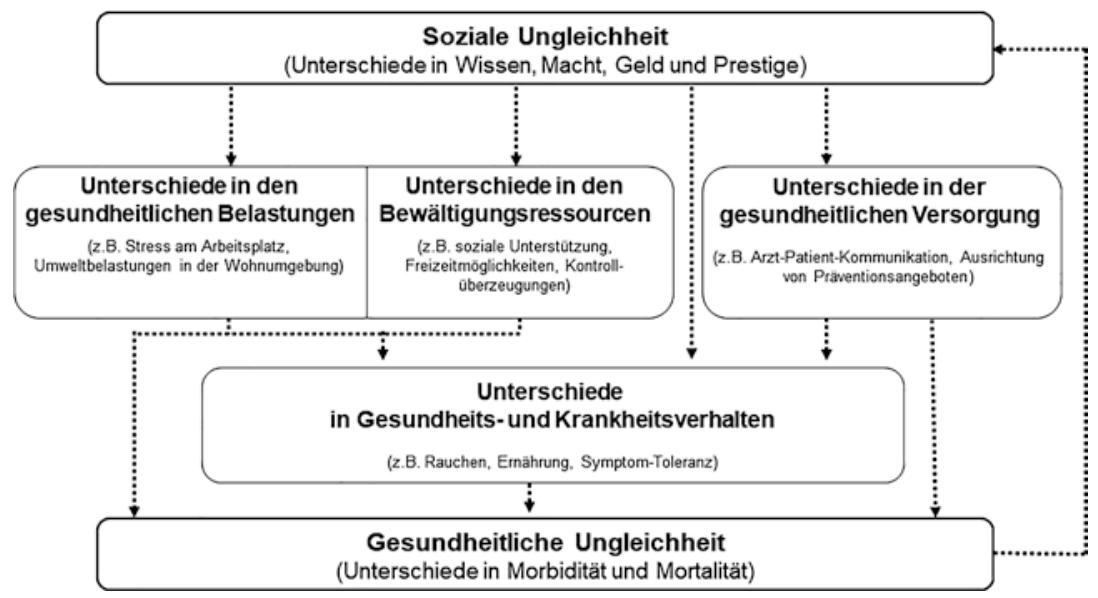

Abb. 2 Zusammenhänge zwischen sozialer und gesundheitlicher Ungleichheit nach Elkeles und Mielck (1997). (Quelle: Elkeles und Mielck (1997), leicht modifizierte eigene Darstellung) 
z. B. Einkommen und psychosoziale Aspekte wie Stress, soziale Unterstützung und Kontrollüberzeugungen (vgl. von dem Knesebeck 2005; Mielck 2005; Richter et al. 2009; Richter et al. 2012; Thurston 2014; Vonneilich et al. 2012). Die Bedeutung zur Erklärung gesundheitlicher Ungleichheiten wurde in einem systematischen Review zusammengetragen und zeigt auf, dass ein Großteil der Ungleichheiten durch diese drei Faktoren erklärt werden kann (Moor et al. 2016).

Des Weiteren spielen Unterschiede in der gesundheitlichen Versorgung und Unterschiede im Gesundheits- und Krankheitsverhalten eine wichtige Rolle. Die einzelnen Mechanismen stehen miteinander in Verbindung. So kann eine weniger vorteilhafte Position im Klassen- oder Schichtungsgefüge einer Gesellschaft zu Unterschieden in den gesundheitlichen Belastungen führen, die etwa durch mehr oder weniger gesundheitsförderliche Wohn- und Arbeitsbedingungen (materielle/strukturelle Faktoren) hervorgerufen werden. Bewältigungsressourcen - wie soziale Unterstützung - können die krankmachende Wirkung gesundheitlicher Belastungen abfedern, sind sie jedoch bei Personen mit einem geringeren Einkommen oder geringerer Bildung weniger stark ausgeprägt, tragen sie auch dazu bei, gesundheitliche Ungleichheiten weiter zu verstärken.

In beiden vorgestellten Modellen werden in unterschiedlicher Weise soziale Beziehungen thematisiert und als relevant erachtet. Im Modell von Dahlgren und Whitehead ist in diesem Zusammenhang die Rede von „social and community networks", d. h., die unseren Fokus bildenden sozialen Netzwerke werden explizit und prominent erwähnt, wenn auch eher als Metapher und nicht in einem netzwerkanalytischen Sinne (siehe Kap. „Netzwerktheorie(n)“). Im Modell von Elkeles und Mielck kommen sie eher implizit, etwas versteckt in den Bewältigungsressourcen zum Vorschein, wenn dort „soziale Unterstützung“ als ein Faktor genannt wird, der z. B. Gesundheitsverhalten und Lebensqualität beeinflussen kann. Eine darüber hinausgehende, explizit netzwerkstrukturelle Perspektive ist in beiden Modellen nicht enthalten.

\section{Soziale Netzwerke und gesundheitliche Ungleichheiten}

Im Bereich der Gesundheitsforschung weisen zahlreiche Studien darauf hin, dass eine netzwerkanalytische Perspektive und eine Berücksichtigung von Mechanismen, die in diesen Netzwerken wirken (siehe Kap. „Wirkmechanismen in sozialen Netzwerken"), einen wichtigen Beitrag zur Erklärung verschiedener Dimension von Gesundheit und Gesundheitsverhalten leisten können (vgl. dazu Valente 2010 sowie folgende Reviews: De et al. 2007; Fletcher et al. 2011; Macdonald-Wallis 
et al. 2012; Seo und Huang 2012; Smith und Christakis 2008). Mit Daten der Alameda-County-Studie etwa konnten Berkman und Syme (1979) zeigen, dass sozial weniger eingebundene Personen ein höheres Mortalitätsrisiko aufweisen. Schwarzer und Knoll (2007) belegen, dass soziale Unterstützung das Coping mit den Folgen einer Herzoperation begünstigen kann und die Studien von Christakis, Fowler und Kollegen weisen darauf hin, dass Glück, Fettleibigkeit, Alkoholkonsum und Rauchverhalten in Netzwerken ansteckend wirken (Christakis und Fowler 2007, 2008; Fowler und Christakis 2008; Rosenquist et al. 2010).

Im Zusammenhang mit der Erforschung gesundheitlicher Ungleichheiten wird der Netzwerkansatz allerdings bisher nur selten angewandt. Dies gilt, wie DiMaggio und Garip (2012) zeigen, auch für andere Bereiche der Ungleichheitsforschung, und dass obwohl theoretisch davon auszugehen ist, dass etwa die in Netzwerken zu findenden Mechanismen der Homophilie - ,gleich und gleich gesellt sich gerne“ - und der Transitivität - ,der Freund meines Freundes ist mein Freund" - zur Reproduktion sozialer Zugehörigkeiten führen und soziale Ungleichheiten damit verstärken können. Der soziale Status beeinflusst Gelegenheitsstrukturen, Kontakte zu knüpfen, indem etwa durch eine höhere Position der Zugang zu sozialen Kreisen (Clubs etc.) ermöglicht wird, die (beruflich) förderliche soziale Kontakte vermitteln. Empirisch konnte gezeigt werden, dass Personen mit einem höheren Status über größere Netzwerke mit geringerer Dichte, einem geringeren Verwandtenanteil und einer höheren räumlichen Spannweite verfügen (Mewes 2010; Fuhse 2010). Dass diese Netzwerkstruktur, in der sich auch ein höherer Anteil an schwachen Beziehungen findet, etwa bei der Suche nach einem Job hilfreich ist, hat Granovetter (1973) in seiner Studie gezeigt. Im Kontrast dazu kann der Mangel an finanziellen Mitteln, der etwa bei Erwerbslosen zu finden ist, die Aufrechterhaltung von Reziprozität(serwartungen) in Netzwerken bedrohen, damit zum Verlust von Beziehungen führen und die Überwindung von Arbeitslosigkeit erschweren (siehe Kap. „Arbeitslosigkeit, soziale Netzwerke und gesundheitliche Ungleichheit").

Relativ häufig finden sich in Arbeiten zu gesundheitlichen Ungleichheiten mit dem Konzept der sozialen Netzwerke eng verbundene Konzepte wie ,soziale Beziehungen“, „soziale Unterstützung“ oder „,soziales Kapital“ und diskutieren deren möglichen Erklärungsbeitrag für gesundheitliche Ungleichheiten (für einen Überblick z. B. Blättner und Waller 2011; Hurrelmann 2010; Kawachi und Kennedy 1997; Kroll und Lampert 2007; Kroll und Lampert 2011; Siegrist et al. 2009; Vonneilich 2016; Vonneilich et al. 2011; Vonneilich et al. 2012). Diesen Ansätzen liegt häufig die Vorstellung zugrunde, dass benachteiligte sozioökonomische Schichten der Gesellschaft möglichweise auch dadurch höhere Morbiditäts- und Mortalitätsraten aufweisen, da sie weniger auf hilfreiches, 
unterstützendes und gesundheitsförderliches soziales Kapital bzw. soziale Unterstützung zurückgreifen können als jene Schichten, die per sozioökonomischer Lage mehr davon zur Verfügung haben. Da sich eine netzwerktheoretische und -analytische Perspektive für die Erforschung von Gesundheit, Krankheit und Sterblichkeit als gewinnbringend erwiesen hat und auch bereits mit sozialen Netzwerken eng verbundene Konzepte wie soziale Unterstützung auf die Erforschung gesundheitlicher Ungleichheiten angewendet werden, gehen wir davon aus, dass eine soziologische Netzwerkperspektive auch für die Erforschung gesundheitlicher Ungleichheiten relevant sein kann. Mit dieser Einleitung und mit den Beiträgen dieses Bandes regen wir daher an, durch den Einbezug einer soziologische Netzwerkperspektive über die in der Forschung beziehungsweise in den theoretischen Erklärungsmodellen zu gesundheitlichen Ungleichheiten erwähnten Aspekte der sozialen Beziehungen und der sozialen Unterstützung hinauszugehen.

Im Rahmen des Wissenschaftlichen Netzwerks „Soziale Netzwerke und gesundheitliche Ungleichheiten“ (SoNegU) haben wir dafür ein netzwerktheoretisches Erklärungsmodell entwickelt (siehe Abb. 3), das wir im Folgenden vorstellen wollen.

Beziehen können wir uns mit dem netzwerktheoretischen Erklärungsmodell gesundheitlicher Ungleichheiten neben den Modellen von Dahlgren und Whitehead sowie von Elkeles und Mielck auf ein von Berkman zusammen mit Glass publiziertes wegweisendes Modell, in dem unterschiedliche theoretische Konzepte zu sozialen Netzwerken, sozialer Integration, sozialem Einfluss, sozialer Unterstützung etc. und deren Einfluss auf Gesundheit zusammengeführt werden (Berkman und Glass 2000; siehe dazu ausführlicher Kap. „Sozialer Status, soziale Beziehungen und Gesundheit"). Bei der Systematisierung der Netzwerkmechanismen orientieren wir uns neben dem Vorschlag von Berkman und Glass auch an Arbeiten von Bernardi, Keim und Kollegen (Bernardi und Klaerner 2014; Keim 2011; Keim et al. 2009); siehe auch Kap. „Wirkmechanismen in sozialen Netzwerken“), die sich intensiv mit den Wirkmechanismen in sozialen Netzwerken auseinandergesetzt haben.

In unserem Modell, das explizit nur einen Ausschnitt aus den theoretisch möglichen und in den oben erwähnten Modellen ausführlicher berücksichtigten Erklärungspfaden und Zusammenhängen von sozialen und gesundheitlichen Ungleichheiten aufgreift, gehen wir davon aus, dass Ungleichheiten sowohl auf der Ebene von Bildung, beruflicher Stellung und Einkommen, als auch auf einer Ebene von Alter, Geschlecht, natio-ethno-kultureller Zugehörigkeit etc. einen Einfluss haben auf die Struktur und die Art der Beziehungen innerhalb der sozialen Netzwerke, in die Akteure und Individuen eingebettet sind. So zeigen 


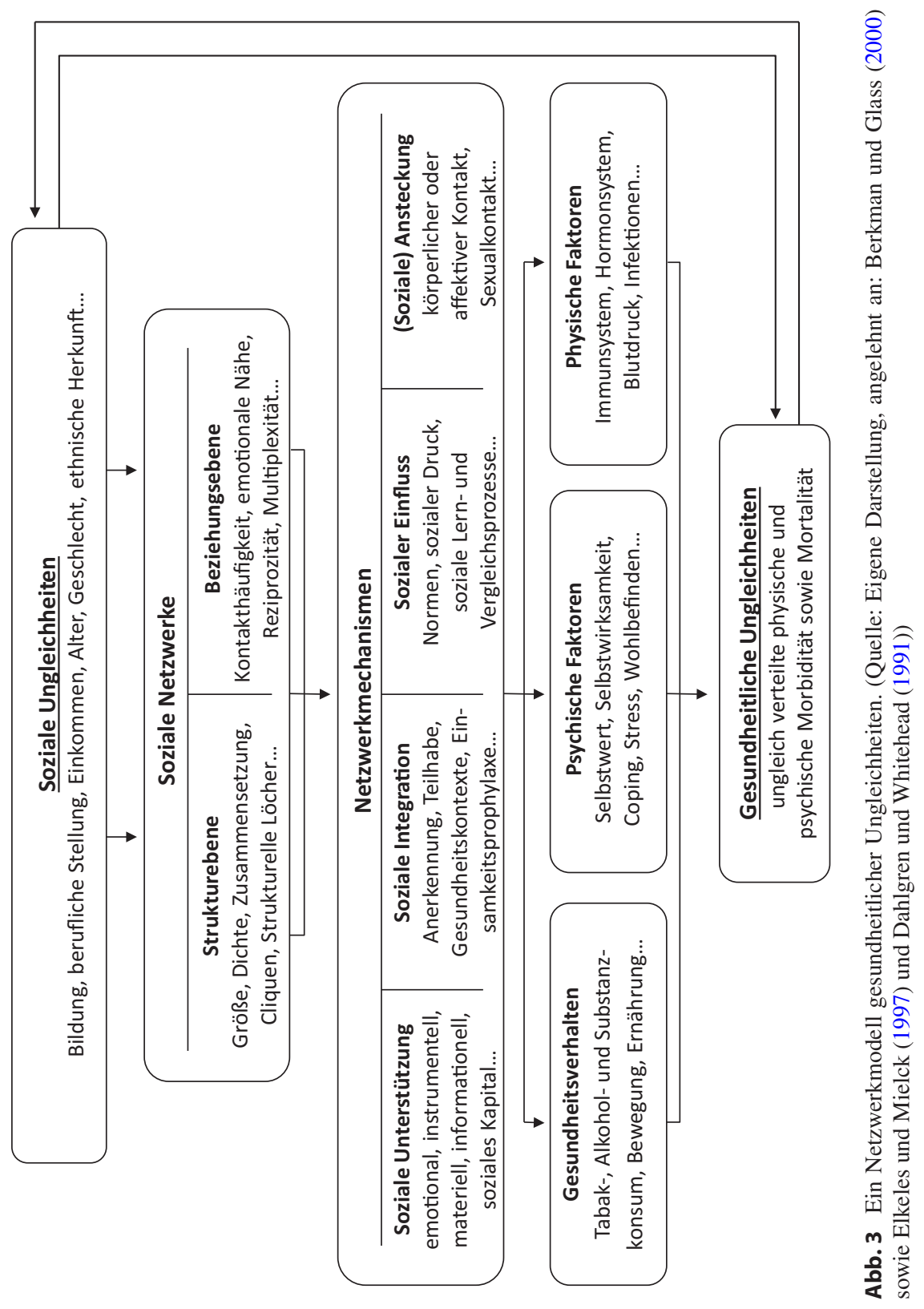


beispielsweise zahlreiche Untersuchungen, dass eine höhere Bildung, ein höheres Einkommen und eine höhere berufliche Position in der Regel mit größeren Netzwerken, mehr Unterstützungsbeziehungen und Freundschaftsbeziehungen und einer stärkeren sozialen Einbindung einhergehen (Diewald und Lüdicke 2007; Böhnke 2007; Levy und Pescosolido 2002; Stringhini et al. 2012); siehe Kap. „Sozialer Status, soziale Beziehungen und Gesundheit“). Sowohl Alter als auch Geschlecht haben sich als relevant für die Netzwerkstruktur erwiesen, so steht beispielsweise ein hohes Alter in negativem Zusammenhang mit sozialer Einbindung (Böhnke 2007; siehe Kap.,,Soziale Netzwerke und gesundheitliche Ungleichheiten im Alter") und Frauen haben in der Regel größere Netzwerke als Männer (McLaughlin et al. 2010; Schwartz und Litwin 2018; siehe Kap. „Geschlecht").

Wir gehen davon aus, dass diese Netzwerkstrukturen und Charakteristika der Beziehungsebene über spezifische Mechanismen auf individuelles Erleben und Handeln auf der Mikroebene wirken. Wir schlagen vor, die folgenden Netzwerkmechanismen zu unterscheiden (siehe dazu genauer Kap. „Soziale Beziehungen, soziales Kapital und soziale Netzwerke“ und „Wirkmechanismen in sozialen Netzwerken"):

- Soziale Unterstützung, womit zunächst der allgemeine Prozess des Austausches von materiellen wie immateriellen Gütern und Dienstleistungen zwischen miteinander verbundenen Akteuren gemeint ist. Von besonderer Bedeutung für Gesundheit und gesundheitliche Ungleichheiten sind die emotionale und motivationale Unterstützung (z. B. Trost, Verständnis, Ermunterung, Motivation), die materielle Unterstützung (z. B. Geld, Wohnraum), die praktische Unterstützung (z. B. Pflege, Hilfe) sowie die informationelle Unterstützung (z. B. Tipps, Wissen). Eng damit zusammen hängt der Begriff des sozialen Kaptials.

- Soziale Integration, worunter Mechanismen und Phänomene wie soziale Anerkennung, Isolation etc. gefasst werden, die darauf fokussieren, dass Menschen als soziale Wesen nicht nur funktional (etwa qua Unterstützung), sondern auch emotional und konativ (handlungsbezogen, z. B. „geselliges Beisammensein") auf den Kontakt und den Austausch mit anderen Menschen sowie auf deren Anerkennung (social validation) reagieren. Soziale Integration bahnt dabei häufig (z. T. indirekt) weitere wichtige Leistungen wie z. B. den Zugang zu Ressourcen oder Gütern, Kontakten oder allgemeinen Informationen, die sich meist nicht als direkte „Unterstützungsleistungen“ konzipieren lassen, aber mittelbar auch auf Gesundheitsmöglichkeiten des Individuums einwirken, indem sie etwa das Coping mit Krankheit beeinflussen. 
- Sozialer Einfluss, was als Sammelbezeichnung für schwer voneinander abgrenzbare Prozesse wie soziales Lernen oder sozialer Druck zu verstehen ist, in denen Akteure im Netzwerk mit ihren Handlungen, ihrer An- oder Abwesenheit bewusst oder unbewusst aufeinander einwirken und damit auch beispielsweise das Gesundheitsverhalten prägen oder beeinflussen.

- (Soziale) Ansteckung, was die unmittelbare physische oder affektive Übertragung von gesundheitsrelevanten Einheiten durch persönliche oder intime Kontakte bezeichnet. Als breiter Oberbegriff sind hiermit sowohl die Ansteckung im Sinne der Übertragung von Krankheitserregern in Beziehungsnetzen (z. B. durch Sexualkontakte, Spritzentausch bei Drogenabhängigen etc.) als auch die emotional-affekte Ansteckung mit neuen Verhaltensweisen oder Wissensinhalten wie etwa der Begeisterung für neue Gesundheitstrends oder auch für problematisches Gesundheitsverhalten wie Impfgegnerschaft gemeint.

Diese breit konzipierten Netzwerkmechanismen bieten eine theoretische wie empirische Möglichkeit, genaueres über die von Berkman und Glass (2000) vorgeschlagenen drei Wirkpfade (pathways) auszusagen, über die sich soziale Netzwerkbeziehungen auf Gesundheit und gesundheitliche Ungleichheiten auswirken können: Dies sind die Pfade des Gesundheitsverhaltens, der psychologischen sowie der physiologischen Vermittlungsprozesse. Materielle Einflussfaktoren, wie sie in den Modellen von Dahlgren und Whitehead sowie von Elkeles und Mielck (siehe Abschn. 2) etwa im Einfluss von Umwelt- und Arbeitsbedingungen auf Gesundheit vorkommen, sind selbstverständlich hoch bedeutsam und ebenfalls wirksam, stehen aber nicht im Zentrum des netzwerkanalytischen Erklärungsansatzes.

Das individuelle Gesundheitsverhalten ist das Gesamt aller gesundheitsförderlichen wie auch der Risiko-Verhaltensweisen, also die individuellen Ausmaße des Tabak- und Alkoholkonsums, der Ernährung und körperlichen Betätigung oder des Einhaltens medizinischer Verordnungen oder Empfehlungen (Knoll et al. 2011). Alle vier vorgeschlagenen Netzwerkmechanismen sind grundsätzlich für diese Verhaltensweisen denkbar bzw. wurden mit diesen bereits in einen Zusammenhang gebracht (vgl. Kienle und Stadler 2012; Wills und Ainette 2012). Beispielsweise zeigte die Arbeit von Demas et al. (2005), dass soziale Integration in eine Selbsthilfegruppe bei HIV-Patientinnen zu einer stärkeren Behandlungs-Adhärenz führte. In der Arbeit von Lee et al. (2007) zu Jugendlichen mit einem an AIDS erkrankten Elternteil zeigten die Befragten bei erlebter sozialer Unterstützung weniger eigenes Risikoverhalten, es sei denn, dass es zu negativem sozialen Einfluss durch Familienmitglieder, die selbst Risikoverhalten 
praktizierten, kam. Und Salvy et al. (2009) zeigten zur sozialen Ansteckung in einer experimentellen Studie mit 54 Erwachsenen, dass die gemeinsame körperliche Aktivität mit Anderen geeignet war, die Kalorienzufuhr bei Probanden zu reduzieren.

Einen wichtigen weiteren Pfad stellt schließlich der sogenannte psychologische Pfad dar, in dem soziale Netzwerke auf psychische Faktoren wirken. Prominente Beispiele stellen das individuelle Selbstwertgefühl, das Coping mit Stress oder das allgemeine Wohlbefinden dar. Schwarzer und Knoll (2007) diskutieren hierzu zwei Aspekte von sozialen Einwirkungen auf diese Größen: Soziale Beziehungsnetze können den Autoren zufolge Individuen zum einen dazu befähigen, mit individuellen Belastungen adaptiv umzugehen (also unter Beibehaltung eines hohen Funktionsniveaus), indem sie Belastungen abmildern oder bei der Bewältigung mit Rat und Tat unterstützen. Zum anderen stellen soziale Beziehungsnetze für den Einzelnen aber auch Gelegenheiten dar, soziale Prozesse für das eigene Wohlergeben nutzbar zu machen, etwa indem sich der Einzelne in als angenehm empfundene Kontexte einbringen oder bei Bedarf konkrete Leistungen mobilisieren kann (Kienle und Stadler 2012).

Der physiologische Pfad beschreibt die Wirkung kardiovaskulärer, neuroendokriner und immunologischer Mechanismen auf die individuelle Gesundheit (Uchino 2006). Zum Zusammenhang dieser Mechanismen mit sozialen Netzwerkmechanismen hat in den letzten Jahrzehnten eine lebhafte Forschungstätigkeit stattgefunden, und es ist überraschend, wie stark physiologische Maße wie z. B. die Herzrate, Blutdruck, Stresshormone oder Immunzellenkonzentrationen von der Anwesenheit und der Unterstützung anderer Personen abhängt. Hier scheint ein wichtiger Mechanismus vorzuliegen, wobei wohl nur ein Teil des Zusammenhangs zwischen Netzwerken und Gesundheit dadurch miterklärt werden kann (Kienle und Stadler 2012, S. 755).

Somit wird durch dieses Modell eine klare kausale Wirkrichtung von sozialen Ungleichheiten auf die Gesundheit über soziale Netzwerke postuliert: Wenn es zutrifft, dass je nach sozialen Ungleichheitsdimensionen von Individuen oder Bevölkerungsteilen die Netzwerkmechanismen in unterschiedlicher Ausformung und Intensität in ihren Beziehungsnetzen vorliegen, dann werden sich die drei Wirkungspfade auch unterschiedlich darstellen und a la longue zu unterschiedlichen Gesundheitsstati der Individuen bzw. Bevölkerungsgruppen führen. Die weitergehende Frage ist dann (siehe Kap. „Sozialer Status, soziale Beziehungen und Gesundheit"), ob es einen Erklärungsbeitrag sozialer Netzwerke zum Zusammenhang zwischen sozialem Status und Gesundheit gibt (Mediator-Effekt sozialer Netzwerke), oder ob der Zusammenhang von sozialen Netzwerken und Gesundheit je nach sozialer Statusgruppe variiert (Moderator-Effekt des sozialen 
Status). Betrachten wir allerdings den aktuellen Forschungsstand dazu und zu den im Modell benannten Faktoren, wird rasch deutlich, dass ,die von Berkman et al. (2000) beklagte Forschungslücke zum Einfluss der soziokulturellen Bedingungen auf die Gesundheit eines Individuums - vermittelt über die Netzwerkstrukturen weiterhin fortzubestehen (scheint)“ (Kienle und Stadler 2012, S. 750). Dieser Sammelband hat sich zum Ziel gesetzt, den Forschungsstand in unterschiedlichen thematischen Feldern aufzuarbeiten und herauszuarbeiten, welcher Forschungsbedarf besteht.

\section{Die Beiträge des Bandes}

Wir wollen mit dem vorliegenden Sammelband die Netzwerkperspektive theoretisch und methodisch genauer vorstellen und für unterschiedliche Themenfelder im Bereich gesundheitlicher Ungleichheiten zeigen, welche Rolle diese Perspektive in den vorhandenen Studien spielt und welchen Beitrag sie in diesem Themenfeld gegebenenfalls leisten kann. Die Themenfelder umfassen zum einen aus einer Lebenslaufperspektive unterschiedliche biografische Phasen, zum anderen beleuchten sie spezifische Ungleichheitsdimensionen wie sozialen Status, Geschlecht und Migrationshintergrund.

Der vorliegende Sammelband untergliedert sich in vier Teile.

Der erste Teil beschäftigt sich mit den theoretischen und methodischen Grundlagen der Netzwerkforschung. Nico Vonneilich nimmt im Kap. „Soziale Beziehungen, soziales Kapital und soziale Netzwerke" eine begriffliche Einordnung der wesentlichen in diesem Band genutzten Konzepte vor und grenzt dabei soziale Beziehungen, soziales Kapital und soziale Netzwerke definitorisch voneinander ab. Markus Gamper stellt im Kap. „Netzwerktheorie(n)“ die netzwerktheoretischen Grundlagen und wichtigen Konzepte aus der Netzwerkforschung vor. Andreas Klärner und Holger von der Lippe betrachten dann die Wirkmechanismen soziale Unterstützung, soziale Integration, sozialer Einfluss und (soziale) Ansteckung in sozialen Netzwerken in einer interdisziplinären Übersicht v. a. über soziologische und psychologische Effekte genauer (siehe Kap. „Wirkmechanismen in sozialen Netzwerken“). Philip Adebahr schließlich bringt eine Perspektive ein, der bisher in der Forschung zu Netzwerken und Gesundheit bzw. gesundheitlichen Ungleichheiten noch zu wenig Beachtung findet: die negativen Aspekte sozialer Beziehungen (siehe Kap. „Negative Beziehungsaspekte und gesundheitliche Ungleichheiten"). Dieser erste Teil schließt mit einem Kapitel von Markus Gamper über quantitative, qualitative und kombinierte Methoden der Netzwerkanalyse (siehe Kap. „Netzwerkanalyse“). 
Die beiden folgenden Teile befassen sich mit unterschiedlichen Feldern der Ungleichheitsforschung und gehen der Frage nach, inwieweit netzwerkanalytische Ansätze im Feld der gesundheitlichen Ungleichheiten eine Rolle spielen und welche Forschungslücken bestehen. Der zweite Teil bezieht sich dabei zunächst auf eine Lebenslaufperspektive (Bengtson und Allen 1993; Elder et al. 2003; Mayer 1998). Diese geht u. a. davon aus, dass verschiedene biografische Phasen (z. B. der Auszug aus dem Elternhaus, der Übergang in die Elternschaft, Übergänge in Erwerbslosigkeit) durch die dynamischen Interaktionen der verschiedenen Stränge einer Individualbiografie (z. B. Bildungs-, Erwerbs-, Mobilitäts-, Familienbiografie) geprägt sind, was wiederum, so unsere These, Einfluss auf die Struktur und Zusammensetzung der individuellen sozialen Netzwerke hat.

Daniel Lois zeigt im Kap.,,Soziale Netzwerke, familiales Sozialkapital und kindliche Gesundheit", dass die kindliche Gesundheit zum einen direkt durch das soziale Netzwerk des Kindes beeinflusst wird als auch indirekt durch das soziale Netzwerk der Eltern. Er zeigt auch, dass von den verschiedenen theoretischen Mechanismen, die zur Erklärung dieser Befunde infrage kommen, der Unterstützungsmechanismus am besten empirisch bestätigt ist. Familiales Sozialkapital, das sich aus den Netzwerkbeziehungen speist, korreliert in westlichen Industrienationen positiv mit den sozioökonomischen Ressourcen der Eltern. Für Schwellen- und Entwicklungsländer zeigt sich, dass das Vorhandensein sozialer Unterstützung hier ein besonders kritischer Faktor für die kindliche Gesundheit ist.

Irene Moor, Laura Hoffmann, Martin Mlinarić und Matthias Richter gehen im Kap.,,Soziale Netzwerke, Gesundheit und gesundheitliche Ungleichheiten im Jugendalter" insbesondere auf die Forschung zum Gesundheitsverhalten von Schülerinnen und Schülern ein. Sie zeigen, dass die These des sozialen Einflusses (d. h., Freunde beeinflussen das [Gesundheits-]Verhalten und die Einstellungen der Jugendlichen und sie adaptieren diese) und die These der Selektion (d. h., Jugendliche suchen ihre Freunde danach aus, ob sie ähnliche Einstellungen und [Gesundheits-]Verhaltensweisen haben wie sie selbst) empirisch belegt werden können. Forschungsbedarf besteht jedoch darin, welche Bedeutung den sozialen Netzwerken zur Erklärung gesundheitlicher Ungleichheiten im Jugendalter zukommt.

Holger von der Lippe und Olaf Reis gehen im Kap. „Soziale Netzwerke und gesundheitliche Ungleichheiten im jungen und mittleren Erwachsenenalter" vor allem auf Zusammenhänge zwischen sozialen und gesundheitlichen Ungleichheiten, biografischen Transitionen, sozialen Beziehungsnetzen und individuellem Gesundheitsverhalten ein. Nach aktueller Forschungslage ist den Autoren zufolge ein Mediatoreffekt sozialer Netzwerke für den Einfluss sozialer Ungleichheiten auf Gesundheit wahrscheinlich. Dieser dürfte sich besonders deutlich im Kontext biografischer Übergänge bzw. Umbrüche zeigen, in denen es sozialen Schichten 
unterschiedlich gut gelingt, von sozialen Netzwerken im Hinblick auf Gesundheit zu profitieren.

Britta Müller und Lea Ellwardt schließlich konzentrieren sich im Kap. „Soziale Netzwerke und gesundheitliche Ungleichheiten im Alter“ auf Personen in der nachberuflichen Lebensphase. Entlang dreier im Alter relevanter Gesundheitsparameter: des Sterblichkeits-, des Demenz- und des Depressionsrisikos zeigen die Autorinnen, dass diese Parameter sowohl mit dem sozioökonomischen Status als auch mit sozialen Netzwerkmerkmalen assoziiert sind. Die Vermittlungsmechanismen von Gesundheit, sozioökonomischem Status und sozialem Netzwerk können durch vorliegende Studien noch nicht hinreichend erklärt werden. Moderatoreffekte von Netzwerkmerkmalen auf gesundheitliche Ungleichheit im Alter scheinen aber bislang am wahrscheinlichsten.

Im dritten Teil des Bandes werden anschließend unterschiedliche Ungleichheitsdimensionen betrachtet. Einführend trägt Nico Vonneilich im Kap. ,Sozialer Status, soziale Beziehungen und Gesundheit" den aktuellen Stand der Forschung zu den Zusammenhängen von sozialem Status, sozialen Beziehungen und Gesundheit zusammen. Dabei stehen zwei Fragestellungen im Vordergrund: 1. Gibt es Hinweise auf einen Erklärungsbeitrag sozialer Beziehungen zum Zusammenhang zwischen sozialem Status und Gesundheit (Mediator-Effekt sozialer Beziehungen)? 2. Variiert der Zusammenhang von sozialen Beziehungen und Gesundheit je nach sozialer Statusgruppe (Moderator-Effekt des sozialen Status)? In der Forschung finden sich demnach Hinweise, wonach soziale Beziehungen zu einer Erklärung gesundheitlicher Ungleichheiten beitragen können, während die bisherige Studienlage zum moderierenden Effekt weniger eindeutig ist. Dies könnte u. a. daran liegen, dass eine komplexe Erfassung sozialer Beziehung, wie beispielsweise sozialer Netzwerke, bisher kaum stattgefunden hat.

Ausgehend von dem empirisch gut belegten Befund, dass Erwerbslosigkeit zu Beeinträchtigungen der physischen und psychischen Gesundheit führt, gehen Gerhard Krug, Stefan Brandt, Markus Gamper, André Knabe und Andreas Klärner im Kap. „Arbeitslosigkeit, soziale Netzwerke und gesundheitliche Ungleichheit" zwei wichtigen Thesen zur Rolle sozialer Netzwerke für diesen Zusammenhang nach. ${ }^{3}$ These 1 geht davon aus, dass Erwerbslosigkeit soziale

\footnotetext{
${ }^{3}$ In dem Beitrag wird der Begriff Arbeitslosigkeit verwendet, mit dem im Allgemeinen sowohl in der Alltagssprache als auch in der Wissenschaft das Fehlen von Erwerbsarbeit bezeichnet wird. Damit können auch Personen, die einer aus individueller und gesellschaftlicher Sicht produktiven Arbeit nachgehen (z. B. im Haushalt oder im Ehrenamt), in diesem Sinne arbeitslos sein. Damit ist explizit keine bewertende Aussage zu nicht-entlohnten Arbeiten verbunden.
} 
Netzwerke so verändert, dass sie ihre positive Funktion für die Gesundheit nicht mehr erfüllen (Mediatorthese). These 2 besagt, dass Erwerbslosigkeit soziale Netzwerke unverändert lässt und Personen mit ressourcenreichen Netzwerken weniger unter Gesundheitseinbußen durch Erwerbslosigkeit leiden (Moderatorthese). $\mathrm{Zu}$ beiden Thesen existiert bisher aber nur wenig empirische Evidenz.

Wie bei Erwerbslosen, so ist auch bei Alleinerziehenden empirisch gut belegt, dass diese über eine schlechtere psychische und physische Gesundheit als verheiratete Eltern verfügen. Sylvia Keim-Klärner geht daher im Kap. „Soziale Netzwerke und die Gesundheit von Alleinerziehenden" der Frage nach, welche Relevanz soziale Netzwerke und ihre Charakteristika in diesem Zusammenhang haben. Spezifisch netzwerkanalytische Studien zur Gesundheit Alleinerziehender sind selten, der Effekt von sozialer Unterstützung hingegen ist recht gut belegt. Eine netzwerkanalytische Perspektive öffnet den Blick auch für konflikthafte Beziehungen oder ambivalente Beziehungsinhalte und lenkt das Forschungsinteresse auf das Zusammenspiel unterstützender und belastender Beziehungen. Damit verbunden ist auch die Frage danach, auf welche Weise soziale Beziehungsgeflechte die Gesundheitswirksamkeit sozialer Ungleichheiten verstärken oder abmildern können.

Im Kap. „Geschlecht und gesundheitliche Ungleichheiten“ nehmen die Autor*innen Markus Gamper, Julia Seidel, Annett Kupfer, Sylvia Keim-Klärner und Andreas Klärner Bezug auf die gut belegten gesundheitlichen Unterschiede zwischen den Geschlechtern (s. o.). ${ }^{4}$ Viele Studien weisen auch auf Unterschiede zwischen den Geschlechtern bezüglich ihrer sozialen Netzwerke hin. Frauen besitzen größere Netzwerke, wobei der Anteil an Familienangehörigen und Verwandten höher ist als bei Männern. Es kommt aber, so die aktuelleren Studien, zu einer Angleichung. Frauen scheinen mehr und zeitaufwendigere soziale Unterstützungsaufgaben zu übernehmen. Sie scheinen auch mehr Ansprechpartner*innen für Probleme zu besitzen als Männer. Männer haben mehr berufliche Akteure in ihren Netzwerken, die höhere Positionen einnehmen. Sie verbinden mehr Subgraphen und ziehen mehr Vorteile aus beruflichen Beziehungen. Hinsichtlich der sozialen Unterstützung zeigt sich eine ungleiche Verteilung zwischen den Geschlechtern und es werden negative Seiten des Sozialkapital aufgezeigt. Beispielsweise sind Frauen durch ihr stärkeres soziales Engagement höheren psychischen Belastungen ausgesetzt. Geschlechterunterschiede mit Blick auf die

\footnotetext{
${ }^{4}$ Bezüglich der Verwendung einer geschlechtergerechten Sprache konnte zwischen den Autor*innen des Sammelbandes keine einheitliche Handhabung hergestellt werden, sodass in dem Band unterschiedliche Schreibweisen verwendet werden.
} 
Gesundheit findet man besonders im Jugendalter und im höheren Alter. In der Jugendphase steht das Risikoverhalten (z. B. Alkohol- und Zigarettenkonsum) und dessen Verbindung mit Selektions- wie Einflusseffekten von Netzwerken im Fokus. Im höheren Alter sind eher negative Auswirkungen auf die psychische wie physische Gesundheit zu beobachten, die eine Folge der u. a. durch Verwitwung kleiner werdenden Netzwerke darstellen.

Stefan Zapfel, Nancy Reims und Mathilde Niehaus konstatieren im Kap. „Soziale Netzwerke und Behinderung“, dass die arbeitsmarktbezogene Behinderungs- und Rehabilitationsforschung bisher weitestgehend auf die Verwendung von Netzwerktheorien verzichtet und ihr Analyse- und Erklärungspotenzial auf diesem Gebiet bei weitem noch nicht ausgeschöpft wurde. Wichtige wäre dies, weil Behinderungen in engem Zusammenhang mit Genese und Stabilität von Netzwerken stehen, die ihrerseits mit Zugang und Kontinuität von Beschäftigungsverhältnissen korrespondieren. Auch Netzwerkkontakte, die über wohlfahrtsstaatliche Institutionen aufgebaut oder aufrechterhalten werden, sind von Bedeutung. Die erfolgreiche Eingliederung ins Erwerbssystem hängt wesentlich von der Zugänglichkeit solcher Hilfen, dem Engagement sozialstaatlicher Akteure, deren Zusammenarbeit, der Teilnahmemotivation behinderter Menschen sowie dem individuellen Bildungshintergrund und sozialen Rückhalt ab.

Große Forschungslücken finden Annett Kupfer und Markus Gamper im Kap. „Migration als gesundheitliche Ungleichheitsdimension?“ Ethnische und migrationsbedingte Differenzen werden zwar zunehmend als Determinante gesundheitlicher Ungleichheit beforscht. Dabei sind die vorliegenden empirischen Ergebnisse zu ,Migration und Gesundheit bzw. gesundheitlichen Ungleichheiten“ zum Teil jedoch widersprüchlich. Studien, die soziale Netzwerke als Einflussvariable hinzunehmen und damit natio-ethno-kulturelle Zugehörigkeit, Gesundheit und soziale Netzwerke in ihrem Zusammenspiel beforschen, sind dagegen sehr selten und betrachten 1.) fast immer nur eine Bevölkerungsgruppe ohne 2.) den Blick zusätzlich auf vertikale Ungleichheitsdimensionen wie Einkommen oder Bildung zu weiten. Die meisten Studien benutzen 3.) den Begriff des Netzwerks eher als Metapher, als Synonym für Gruppe oder Sozialkapital, oder sie beforschen ausschließlich soziale Unterstützung als zentrale Funktion sozialer Netzwerke. Zu fragen bleibt, inwieweit die mit dem Begriff „Migration“ assoziierten Phänomene tatsächlich migrationsspezifisch, d. h., beispielsweise verbunden mit einem konkreten Migrationsprozess sind, oder ob nicht im Sinne der Intersektionalität andere soziale Gruppenzugehörigkeiten wie Klasse oder Geschlecht (höheren) Erklärungsgehalt für gesundheitliche Ungleichheiten besitzen. 
Die Beiträge dieses Sammelbandes gehen mitunter, aufgrund der teilweise noch unbefriedigenden Forschungslage, nur auf Einzelaspekte dieses Modells ein. Zusammengeführt und vor dem Hintergrund unseres theoretischen Modells diskutiert werden die Ergebnisse aus den einzelnen Bereichen daher im abschlieBenden vierten Teil des Bandes, in dem wir Forschungsdesiderata benennen und Anregungen für zukünftige Forschungen geben (siehe Kap. „Desiderata: Soziale Netzwerke und gesundheitliche Ungleichheiten"). Wir möchten damit, wie vielfach gefordert (z. B. Kienle und Stadler 2012; Govia et al. 2011), die theoretische Auseinandersetzung im Feld der Gesundheitswissenschaften bereichern und dazu beitragen, dass Begriffe wie „Soziales Netzwerk“, „Soziale Integration“ und "Soziale Unterstützung“ präziser gebraucht werden. Wenn unser Sammelband netzwerktheoretisch informierte empirische Studien zum Einfluss und zur Bedeutung sozialer Netzwerke für die Reproduktion gesundheitlicher Ungleichheiten anleiten würde, hätte unser wissenschaftliches Netzwerk sein Ziel erreicht.

Braunschweig, Berlin, Halle an der Saale, Hamburg und Köln im April 2019.

\section{Leseempfehlungen}

Berkman, L. F., \& Glass, T. (2000). Social integration, social networks, social support, and health. In L. F. Berkman \& I. Kawachi (Hrsg.), Social epidemiology (S. 137-173). New York, NY [u. a.]: Oxford University Press. Diskussion und Fruchtbarmachung wichtiger Konzepte der Netzwerktheorie und -analyse für die Gesundheitsforschung. Der Beitrag enthält ein umfassendes Makro-Meso-Mikro-Modell zum Einfluss sozialer Netzwerke auf Gesundheit.

Dahlgren, G., \& Whitehead, M. (2006). European strategies for tackling social inequities in health: Levelling up Part 2. Copenhagen: WHO Regional Office for Europe. Einflussreiches Modell zur Erklärung gesundheitlicher Ungleichheiten mit einem Fokus auf politische Handlungsstrategien zu deren Bekämpfung.

Elkeles, T, \& Mielck, A. (1997). Entwicklung eines Modells zur Erklärung gesundheitlicher Ungleichheit. Gesundheitswesen, 59, S. 137143. In der deutschsprachigen Sozialepidemiologie sehr einflussreiches Modell zur Erklärung gesundheitlicher Ungleichheiten.

Fuhse, J. (2010). Netzwerke und soziale Ungleichheit. In C. Stegbauer (Hrsg.), Netzwerkanalyse und Netzwerktheorie. Ein neues Paradigma in den Sozialwissenschaften (S. 79-90). Wiesbaden. Einer der wenigen Aufsätze, die sich explizit und systematisch mit dem Zusammenhang von sozialen Netzwerken und sozialen Ungleichheiten beschäftigen. 
Pescosolido, B. A. (2006). Of pride and prejudice: The role of sociology and social net-works in integrating the health sciences. Journal of Health and Social Behavior, 47(3), S. 189-208. Instruktiver theoretischer Beitrag, der die Bedeutung soziale Netzwerke in den Gesundheitswissenschaften hervorhebt.

Valente, T. W. (2010). Social networks and health. Models, methods, and applications. Ox-ford, New York: Oxford University Press. Englischsprachige Einführung zur Bedeutung soziale Netzwerke für Gesundheit.

\section{Literatur}

Babitsch, B. (2000). Soziale Lage, Frauen und Gesundheit. In U. Helmert, K. Bammann, W. Voges, \& R. Müller (Hrsg.), Müssen Arme früher sterben? Soziale Ungleichheit und Gesundheit in Deutschland (S. 135-158). Weinheim: Juventa.

Bengtson, V. L., \& Allen, K. R. (1993). The life course perspective applied to families over time. In P. G. Boss, W. J. Doherty, R. LaRossa, W. R. Schumm, S. K. Steinmetz, \& P. Boss (Hrsg.), Sourcebook of family theories and methods: A contextual approach (S. 469-504). New York: Springer.

Berkman, L. F., \& Glass, T. (2000). Social integration, social networks, social support, and health. In L.F. Berkman \& I. Kawachi (Hrsg.), Social epidemiology (S. 137-173). New York: Oxford University Press.

Berkman, L. F., \& Syme, S. L. (1979). social networks, host resistance, and mortality: A nine-year follow-up study of alameda county residents. American Journal of Epidemiology, 109(2), 186-204.

Berkman, L. F., Glass, T., Brissette, I., \& Seeman, T. E. (2000). From social integration to health: Durkheim in the new millennium. Social Science and Medicine, 51(6), 843-857.

Bernardi, L., \& Klaerner, A. (2014). Social networks and fertility. Demographic Research, 30(22), 641-670.

Blättner, B., \& Waller, H. (2011). Gesundheitswissenschaft: Eine Einführung in Grundlagen, Theorie und Anwendung. Stuttgart: Kohlhammer.

Böhnke, P. (2007). Solidarität im Wohlfahrtsstaat- Prekäre Lebenslagen und soziale Integration. In J. Lüdicke \& M. Diewald (Hrsg.), Soziale Netzwerke und soziale Ungleichheit: Zur Rolle von Sozialkapital in modernen Gesellschaften (S. 235-263). Wiesbaden: VS Verlag.

Bott, E. (1957). Family and social network: Roles, norms, and external relationships in ordinary urban families. New York: Free Press.

Braveman, P. A., Egerter, S. A., \& Mockenhaupt, R. E. (2011). Broadening the focusthe need to address the social determinants of health. American Journal of Preventive Medicine, 40(1), S4-S18. 
Brownson, R. C., Boehmer, T. K., \& Luke, D. A. (2005). Declining rates of physical activity in the United States: What are the contributors? Annual Review of Public Health, 26, 421-443.

Burt, R. S. (1982). Toward a structural theory of action. New York: Academic.

Burt, R. S. (2004). Structural holes and good ideas. American Journal of Sociology, 110(2), 349-399.

Christakis, N. A., \& Fowler, J. H. (2007). The Spread of obesity in a large social network over 32 years. The New England Journal of Medicine, 357, 370-379.

Christakis, N. A., \& Fowler, J. H. (2008). The collective dynamics of smoking in a large social network. New England Journal of Medicine, 358(21), 2249-2258.

CSDH. (2008). Closing the gap in a generation: Health equity through action on the social determinants of health. Final report of the commission on social determinants of health. Geneva: World Health Organization.

Dahlgren, G., \& Whitehead, M. (1991). Policies and strategies to promote social equity in health: Background document to WHO - Strategy paper for Europe. http://www. framtidsstudier.se/wp-content/uploads/2011/01/20080109110739filmZ8UVQv2wQFShMRF6cuT.pdf. Zugegriffen: 18. Apr. 2019.

Dahlgren, G., \& Whitehead, M. (2006). European strategies for tackling social inequities in health: Levelling up Part 2. Copenhagen: WHO Regional Office for Europe.

De, P., Cox, J., Boivin, J.-F., Platt, R. W., \& Jolly, A. M. (2007). The importance of social networks in their association to drug equipment sharing among injection drug users: A review. Addiction, 102(11), 1730-1739.

Demas, P. A., Thea, D. M., Weedon, J., McWayne, J., Bamji, M., Lambert, G., et al. (2005). Adherence to zidovudine for the prevention of perinatal transmission in HIV-infected pregnant women: The impact of social network factors, side effects, and perceived treatment efficacy. Women and Health, 42(1), 99-115.

de Walque, D. (2010). Education, information, and smoking decisions: Evidence from smoking histories in the United States, 1940-2000. Journal of Human Resources, 45(3), $682-717$.

Diewald, M., \& Lüdicke, J. (2007). Akzentuierung oder Kompensation? Zum Zusammenhang von Sozialkapital, sozialer Ungleichheit und subjektiver Lebensqualität. In J. Lüdicke \& M. Diewald (Hrsg.), Soziale Netzwerke und soziale Ungleichheit: Zur Rolle von Sozialkapital in modernen Gesellschaften (S. 11-51). Wiesbaden: VS Verlag.

DiMaggio, P., \& Garip, F. (2012). Network effects and social inequality. Annual Review of Sociology, 38(1), 93-118.

Elder, G. H., Johnson, M. K., \& Crosnoe, R. (2003). The emergence and development of life course theory. In J. T. Mortimer \& M. J. Shanahan (Hrsg.), Handbook of the life course (S. 3-19). New York: Kluwer \& Plenum.

Elias, N. (2014). Was ist Soziologie?. Weinheim: Beltz Juventa.

Elkeles, T., \& Mielck, A. (1997). Entwicklung eines Modells zur Erklärung gesundheitlicher Ungleichheit. Gesundheitswesen, 59, 137-143.

Emirbayer, M. (1997). Manifesto for a relational sociology. American Journal of Sociology, 103(2), 281-317.

Emirbayer, M., \& Goodwin, J. (1994). Network analysis, culture, and the problem of agency. American Journal of Sociology, 99(6), 1411-1454. 
Emirbayer, M., \& Mische, A. (1998). What is agency? American Journal of Sociology, 103(4), 962-1023.

Flammer, A. (2009). Entwicklungstheorien: Psychologische Theorien der menschlichen Entwicklung. Bern: Huber.

Fletcher, A., Bonell, C., \& Sorhaindo, A. (2011). You are what your friends eat: Systematic review of social network analyses of young people's eating behaviours and bodyweight. Journal of Epidemiology and Community Health, 65(6), 548-555.

Fowler, J. H., \& Christakis, N. A. (2008). Dynamic spread of happiness in a large social network: Longitudinal analysis over 20 years in the Framingham Heart Study. British Medical Journal (BMJ), 337, a2338.

Fuhse, J. (2010). Netzwerke und soziale Ungleichheit. In C. Stegbauer (Hrsg.), Netzwerkanalyse und Netzwerktheorie: Ein neues Paradigma in den Sozialwissenschaften (S. 79-90). Wiesbaden: VS Verlag.

Fuhse, J. A., \& Mützel, S. (Hrsg.). (2010). Relationale Soziologie: Zur kulturellen Wende der Netzwerkforschung. Wiesbaden: VS Verlag.

Gamper, M. (2015). The history of ,Relational Science“ and social network analysis. Debtors, creditors, and their networks: Social dimensions of monetary dependence from the seventeenth to the twentieth century, 3, 11-42.

Gamper, M., Reschke, L., \& Schönhuth, M. (Hrsg.). (2012). Knoten und Kanten 2.0: Soziale Netzwerkanalyse in Medienforschung und Kulturanthropologie. Bielefeld: Transcript.

Größwald, A., Schienkiewitz, A., Nowossadeck, E., \& Busch, M. A. (2013). Prävalenz von Herzinfarkt und koronarer Herzkrankheit bei Erwachsenen im Alter von 40 bis 79 Jahren in Deutschland - Ergebnisse der Studie zur Gesundheit Erwachsener in Deutschland (DEGS1). Bundesgesundheitsblatt, 56, 650-655.

Govia, I. O., Jackson, J. S., \& Sellers, S. L. (2011). Social inequalitites. In K. L. Fingerman, C. A. Berg, J. Smith, \& T. C. Antonucci (Hrsg.), Handbook of lifespan development (S. 727-744). New York: Springer.

Granovetter, M. (1973). The strength of weak ties. American Journal of Sociology, 78(6), 1360-1380.

Granovetter, M. (1985). Economic action and social structure: The problem of embeddedness. American Journal of Sociology, 91(3), 481-510.

Granström, F., Molarius, A., Garvin, P., Elo, S., Feldman, I., \& Kristenson, M. (2015). Exploring trends in and determinants of educational inequalities in self-rated health. Scandinavian Journal of Public Health, 43(7), 677-686.

Gulati, R., \& Srivasta, S. (2014). Bringing agency back into network research: Constrained agency and network action. In D. J. Brass, G. Labianca, A. Mehra, D. S. Halgin, \& S. P. Borgatti (Hrsg.), Contemporary perspectives on organizational social networks (S. 73-94). Bingley: Emerald Group Publishing Limited.

Häußling, R. (2010). Relationale Soziologie. In C. Stegbauer \& R. Häußling (Hrsg.), Handbuch Netzwerkforschung (S. 63-88). Wiesbaden: VS Verlag.

Hollstein, B. (2010). Strukturen, Akteure, Wechselwirkungen. Georg Simmels Beiträge zur Netzwerkforschung. In C. Stegbauer (Hrsg.), Netzwerkanalyse und Netzwerktheorie: Ein neues Paradigma in den Sozialwissenschaften (S. 91-103). Wiesbaden: VS Verlag.

Hollstein, B., \& Straus, F. (Hrsg.). (2006). Qualitative Netzwerkanalyse. Konzepte, Methoden, Anwendungen. Wiesbaden: VS Verlag. 
Hurrelmann, K. (2010). Entstehung von Gesundheit und Krankheit - Theoretische Ansätze. Gesundheitssoziologie: Eine Einführung in sozialwissenschaftliche Theorien von Krankheitsprävention und Gesundheitsförderung (S. 65-112). Weinheim: Juventa Verlag.

Hurrelmann, K., \& Quenzel, G. (2011). Geschlecht und Gesundheit. Public Health Forum, 19(2), 2.

Janßen, C., Sauter, S., \& Kowalski, C. (2012). The influence of social determinants on the use of prevention and health promotion services: Results of a systematic literature review. Psycho-social medicine, 9, Doc07.

Kanjilal, S., Gregg, E. W., Cheng, Y. J., Zhang, P., Nelson, D. E., Mensah, G., et al. (2006). Socioeconomic status and trends in disparities in 4 major risk factors for cardiovascular disease among US adults, 1971-2002. Archives of Internal Medicine, 166(21), 2348-2355.

Kawachi, I., \& Kennedy, B. P. (1997). Socioeconomic determinants of health: Health and social cohesion: Why care about income inequality? BMJ, 314(7086), 1037.

Keim, S. (2011). Social networks and family formation processes: Young adults' decision making about parenthood. Wiesbaden: VS Verlag.

Keim, S., Klärner, A., \& Bernardi, L. (2009). Qualifying social influence on fertility intentions: Composition, structure and meaning of fertility-relevant social networks in western Germany. Current Sociology, 57(6), 888-907.

Kienle, R., \& Stadler, G. (2012). Soziales Netzwerk und soziale Unterstützung. In E. Brähler \& B. Strauß (Hrsg.), Grundlagen der medizinischen Psychologie (S. 743-768). Göttingen: Hogrefe.

Klärner, A., \& Keim, S. (2019). Emirbayer (1997): Manifesto for a relational sociology. In B. Holzer \& C. Stegbauer (Hrsg.), Schlüsselwerke der Netzwerkforschung (S. 177-180). Wiesbaden: Springer Fachmedien.

Knesebeck, O. v. d. (2005). Die Bedeutung sozialer Beziehungen für den Zusammenhang zwischen sozialer Ungleichheit und Gesundheit im Alter. Sozial- und Präventivmedizin SPM, 50(5), S. 311-318.

Knesebeck, O. v. d., \& Schäfer, I. (2009). Gesundheitliche Ungleichheit im Alter. In M. Richter \& K. Hurrelmann (Hrsg.), Gesundheitliche Ungleichheit: Grundlagen, Probleme, Perspektiven (S. 253-265). Wiesbaden: VS Verlag \& GWV Fachverlage GmbH.

Knoll, N., Scholz, U., \& Rieckmann, N. (2011). Einführung Gesundheitspsychologie. München: Reinhardt.

Kroll, L. E., \& Lampert, T. (2007). Sozialkapital und Gesundheit in Deutschland. Das Gesundheitswesen, 69(3), 120-127.

Kroll, L. E., \& Lampert, T. (2011). Unemployment, social support and health problems: Results of the GEDA study in Germany, 2009. Deutsches Ärzteblatt, 108(4), 47-52.

Kunst, A. E. (2009). Herausforderungen bei der Beschreibung gesundheitlicher Ungleichheit in Europa: Ein Überblick aktueller Studien1. In M. Richter \& K. Hurrelmann (Hrsg.), Gesundheitliche Ungleichheit (S. 367-383). Wiesbaden: VS Verlag.

Lampert, T. (2010). Smoking, physical inactivity, and obesity: associations with social status. Deutsches Ärzteblatt international, 107(1-2), 1-7.

Lampert, T. (2016). Soziale Ungleichheit und Gesundheit. In M. Richter \& K. Hurrelmann (Hrsg.), Soziologie von Gesundheit und Krankheit (S. 121-137). Wiesbaden: Springer VS. 
Lampert, T., Hoebel, J., \& Kroll, L. E. (2019). Soziale Unterschiede in der Mortalität und Lebenserwartung in Deutschland - Aktuelle Situation und Trends. Journal of Health Monitoring, 4(1), 3-15.

Lampert, T., Kroll, L.E., von der Lippe, E., Müters, S., \& Stolzenberg, H. (2013). Sozioökonomischer Status und Gesundheit. Bundesgesundheitsblatt - Gesundheitsforschung Gesundheitsschutz, 56(5-6), 814-821.

Lampert, T., Richter, M., Schneider, S., Spallek, J., \& Dragano, N. (2015). Soziale Ungleichheit und Gesundheit: Stand und Perspektiven der sozialepidemiologischen Forschung in Deutschland. Bundesgesundheitsblatt, Gesundheitsforschung, Gesundheitsschutz, 59, 153-165.

Lange, C. (2014). Daten und Fakten: Ergebnisse der Studie „Gesundheit in Deutschland aktuell 2012“. Berlin: Robert-Koch-Inst.

Lee, S.-J., Detels, R., Rotheram-Borus, M. J., \& Duan, N. (2007). The effect of social support on mental and behavioral outcomes among adolescents with parents With HIV/ AIDS. American Journal of Public Health, 97(10), 1820-1826.

Levy, J. A., \& Pescosolido, B. A. (Hrsg.). (2002). Social networks and health. Amsterdam: JAI/Elsevier Science Ltd.

Macdonald-Wallis, K., Jago, R., \& Sterne, J. A. C. (2012). Social network analysis of childhood and youth physical activity: A systematic review. American Journal of Preventive Medicine, 43(6), 636-642.

Mackenbach, J. P. (2006). Health Inequalities: Europe in Profile: An independent, expert report commissioned by the UK Presidency of the EU. London.

Mackenbach, J. P., Kulhánová, I., Artnik, B., Bopp, M., Borrell, C., Clemens, T., et al. (2016). Changes in mortality inequalities over two decades: Register based study of European countries. BMJ (Clinical research ed.), 353, i1732.

Marmot, M. (2005). Social determinants of health inequalities. The Lancet, 365(9464), 1099-1104.

Marmot, M. G., \& Wilkinson, R. G. (Hrsg.). (2006). Social determinants of health. Oxford: Oxford University Press.

Mayer, K. U. (1998). Lebensverlauf. In B. Schäfers, W. Zapf, \& S. Misoch (Hrsg.), Handwörterbuch zur Gesellschaft Deutschlands (S. 438-451). Opladen: Leske + Budrich.

McLaughlin, D., Vagenas, D., Pachana, N. A., Begum, N., \& Dobson, A. (2010). Gender differences in social network size and satisfaction in adults in their 70s. Journal of Health Psychology, 15(5), 671-679.

Mewes, J. (2010). Ungleiche Netzwerke - Vernetzte Ungleichheit: Persönliche Beziehungen im Kontext von Bildung und Status. Wiesbaden: VS Verlag.

Mielck, A. (Hrsg.). (1994). Krankheit und soziale Ungleichheit: Ergebnisse der sozialepidemiologischen Forschung in Deutschland. Opladen: Leske + Budrich.

Mielck, A. (2005). Soziale Ungleichheit und Gesundheit: Einführung in die aktuelle Diskussion. Bern: Huber.

Moor, I., Spallek, J., \& Richter, M. (2016). Explaining socioeconomic inequalities in self-rated health: A systematic review of the relative contribution of material, psychosocial and behavioural factors. Journal of Epidemiology and Community Health, 71(6), 565-575. 
Moor, I., Günther, S., Knöchelmann, A., Hoebel, J., Pförtner, T.-K., Lampert, T., et al. (2018). Educational inequalities in subjective health in Germany from 1994 to 2014: A trend analysis using the German Socio-Economic Panel study (GSOEP). British Medical Journal Open, 8(6), e019755.

Pförtner, T.-K., \& Elgar, F. J. (2016). Widening inequalities in self-rated health by material deprivation? A trend analysis between 2001 and 2011 in Germany. Journal of Epidemiology and Community Health, 70(1), 82-89.

Richter, M., \& Hurrelmann, K. (Hrsg.). (2009). Gesundheitliche Ungleichheit: Grundlagen, Probleme, Perspektiven. Wiesbaden: VS Verlag \& GWV Fachverlage GmbH.

Richter, M., \& Hurrelmann, K. (Hrsg.). (2016). Soziologie von Gesundheit und Krankheit. Wiesbaden: Springer VS.

Richter, M., Erhart, M., Vereecken, C.A., Zambon, A., Boyce, W., \& Nic Gabhainn, S. (2009). The role of behavioural factors in explaining socio-economic differences in adolescent health: A multilevel study in 33 countries. Social science \& medicine (1982), 69(3), S. 396-403.

Richter, M., Moor, I., \& van Lenthe, F. J. (2012). Explaining socioeconomic differences in adolescent self-rated health: the contribution of material, psychosocial and behavioural factors. Journal of Epidemiology and Community Health, 66(8), 691-697.

Richter, M., Kuntsche, E., Looze, M., \& Pförtner, T.-K. (2013). Trends in socioeconomic inequalities in adolescent alcohol use in Germany between 1994 and 2006. International Journal of Public Health, 58(5), 777-784.

Robert Koch-Institut (Hrsg.) (2017). Gesundheitliche Ungleichheit in verschiedenen Lebensphasen: Gesundheitsberichterstattung des Bundes. Gemeinsam getragen von RKI und Destatis. Berlin: Robert Koch-Institut.

Röding, D. (2018). Lebenslagen, Lebensstile und Gesundheit. Berlin: LIT.

Roelfs, D.J., Shor, E., Davidson, K.W., \& Schwartz, J.E. (2011). Losing life and livelihood: A systematic review and meta-analysis of unemployment and all-cause mortality. Social science \& medicine (1982), 72(6), 840-854.

Rosenquist, J. N., Murabito, J., Fowler, J. H., \& Christakis, N. A. (2010). The spread of alcohol consumption behavior in a large social network. Annals of Internal Medicine, $152(7), 426$.

Rostila, M. (2013). Social capital and health inequality in European welfare states. New York: Palgrave Macmillan.

Salvy, S.-J., Nitecki, L. A., \& Epstein, L. H. (2009). Do social activities substitute for food in youth? Annals Of Behavioral Medicine: A Publication of the Society of Behavioral Medicine, 38(3), 205-212.

Schneider, S. (2008). Soziale Schichtunterschiede in Morbidität und Mortalität: Was sind die Ursachen? Deutsche medizinische Wochenschrift (1946), 133(6), 256-260.

Schwartz, E., \& Litwin, H. (2018). Social network changes among older Europeans: The role of gender. European Journal of Ageing, 15(4), 359-367.

Schwarzer, R., \& Knoll, N. (2007). Functional roles of social support within the stress and coping process: A theoretical and empirical overview. International Journal of Psychology, 42(4), 243-252.

Seo, D.-C., \& Huang, Y. (2012). Systematic review of social network analysis in adolescent cigarette smoking behavior. Journal of School Health, 82(1), 21-27. 
Siegel, M., Vogt, V., \& Sundmacher, L. (2014). From a conservative to a liberal welfare state: Decomposing changes in income-related health inequalities in Germany, 19942011. Social Science and Medicine, 108, 10-19.

Siegrist, J. (2005). Medizinische Soziologie: Mit 18 Tabellen. München: Elsevier, Urban \& Fischer.

Siegrist, J., Dragano, N., \& von dem Knesebeck, O. (2009). Soziales Kapital, soziale Ungleichheit und Gesundheit. In M. Richter \& K. Hurrelmann (Hrsg.), Gesundheitliche Ungleichheit: Grundlagen, Probleme, Perspektiven. Wiesbaden: VS Verlag \& GWV Fachverlage GmbH.

Simmel, G. (1999). Soziologie. Untersuchungen über die Formen der Vergesellschaftung. Frankfurt a. M.: Suhrkamp.

Singh, G. K., \& Hiatt, R. A. (2006). Trends and disparities in socioeconomic and behavioural characteristics, life expectancy, and cause-specific mortality of native-born and foreign-born populations in the United States, 1979-2003. International Journal of Epidemiology, 35(4), 903-919.

Smith, K. P., \& Christakis, N. A. (2008). Social networks and health. Annual Review of Sociology, 34(1), 405-429.

Stegbauer, C. (Hrsg.). (2010). Netzwerkanalyse und Netzwerktheorie: Ein neues Paradigma in den Sozialwissenschaften. Wiesbaden: VS Verlag.

Stegbauer, C., \& Häußling, R. (Hrsg.). (2010). Handbuch Netzwerkforschung. Wiesbaden: VS Verlag.

Stringhini, S., Berkman, L., Dugravot, A., Ferrie, J. E., Marmot, M., Kivimaki, M., et al. (2012). Socioeconomic status, structural and functional measures of social support, and mortality: The British Whitehall II cohort study, 1985-2009. American Journal of Epidemiology, 175(12), 1275-1283.

Thurston, M. (2014). Key themes in public health. New York: Routledge.

Uchino, B. N. (2006). Social support and health: A review of physiological processes potentially underlying links to disease outcomes. Journal of Behavioral Medicine, 29(4), 377-387.

Valente, T. W. (2010). Social networks and health: Models, methods, and applications. Oxford: Oxford University Press.

Vonneilich, N. (2016). Sozialer Status, soziale Beziehungen und subjektive Gesundheit. Berlin: LIT.

Vonneilich, N., Jöckel, K.-H., Erbel, R., Klein, J., Dragano, N., Weyers, S., et al. (2011). Does socioeconomic status affect the association of social relationships and health? A moderator analysis. International Journal for Equity in Health, 10(1), 43.

Vonneilich, N., Jöckel, K.-H., Erbel, R., Klein, J., Dragano, N., Siegrist, J., et al. (2012). The mediating effect of social relationships on the association between socioeconomic status and subjective health - Results from the Heinz Nixdorf Recall cohort study. BMC Public Health, 12, 285.

Wellman, B. (1988). Structural analysis: From method and metaphor to theory and substance. In B. Wellman \& S. D. Berkowitz (Hrsg.), Social structures: A social network approach (S. 19-61). Cambridge: Cambridge University Press.

Wengler, A. (2013). Ungleiche Gesundheit: Zur Situation türkischer Migranten in Deutschland. Frankfurt a. M.: Campus. 
Weyers, S., Dragano, N., Möbus, S., Beck, E.-M., Stang, A., Möhlenkamp, S., et al. (2008). Low socio-economic position is associated with poor social networks and social support: results from the Heinz Nixdorf Recall Study. International Journal for Equity in Health, 7(13).

Willems, H. (2010). Figurationssoziologie und Netzwerkansätze. In C. Stegbauer \& R. Häußling (Hrsg.), Handbuch Netzwerkforschung (S. 255-268). Wiesbaden: VS Verlag.

Wills, T. A., \& Ainette, M. G. (2012). Social networks and social support. In A. Baum, T. A. Revenson, \& J. E. Singer (Hrsg.), Handbook of health psychology (S. 465-492). New York: Psychology Press.

Open Access Dieses Kapitel wird unter der Creative Commons Namensnennung 4.0 International Lizenz (http://creativecommons.org/licenses/by/4.0/deed.de) veröffentlicht, welche die Nutzung, Vervielfältigung, Bearbeitung, Verbreitung und Wiedergabe in jeglichem Medium und Format erlaubt, sofern Sie den/die ursprünglichen Autor(en) und die Quelle ordnungsgemäß nennen, einen Link zur Creative Commons Lizenz beifügen und angeben, ob Änderungen vorgenommen wurden.

Die in diesem Kapitel enthaltenen Bilder und sonstiges Drittmaterial unterliegen ebenfalls der genannten Creative Commons Lizenz, sofern sich aus der Abbildungslegende nichts anderes ergibt. Sofern das betreffende Material nicht unter der genannten Creative Commons Lizenz steht und die betreffende Handlung nicht nach gesetzlichen Vorschriften erlaubt ist, ist für die oben aufgeführten Weiterverwendungen des Materials die Einwilligung des jeweiligen Rechteinhabers einzuholen.

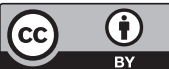


Theoretische und methodische Grundlagen 


\section{Soziale Beziehungen, soziales Kapital und soziale Netzwerke - eine begriffliche Einordnung}

\section{Nico Vonneilich}

\section{Überblick}

- Es werden die Begriffe soziale Unterstützung, soziales Kapital, soziale Kohäsion und soziales Netzwerk definiert und voneinander abgegrenzt.

- Überschneidungen und Eigenheiten der jeweiligen Konzepte werden herausgearbeitet und sollen $\mathrm{zu}$ einer begrifflichen Präzision und $\mathrm{zu}$ einem besseren Verständnis des Forschungsfeldes beitragen.

- Soziale Netzwerke lassen sich sowohl auf Ebene einzelner Individuen (Mikro-) als auch auf Ebene von Gruppen und Gemeinden (Meso-/ Makro-Ebene) beschreiben.

- Theorien des sozialen Netzwerks beinhalten sowohl quantitative Aspekte sozialer Beziehungen (Struktur) als auch qualitative Aspekte (Funktion).

\section{$1 \quad$ Einleitung und Hintergrund}

Soziale Beziehungen sind ein Kerngebiet der Soziologie, ihr Grundgerüst. Ohne soziale Beziehungen entstehen keine gesellschaftlichen Zusammenhänge. Die Untersuchung sozialer Beziehungen kann auf eine lange Forschungstradition zurückblicken und diese wird weiter fortgeführt, in stetig sich differenzierenden

\footnotetext{
N. Vonneilich $(\bowtie)$

Institut für Medizinische Soziologie, Universitätsklinikum Hamburg-Eppendorf, Hamburg, Deutschland

E-Mail: n.vonneilich@uke.de
} 
und spezialisierenden Subsystemen. Ziel des vorliegenden Kapitels ist es, einen kurzen Überblick über die Forschungstraditionen zu sozialen Beziehungen zu geben. Dabei soll es insbesondere um eine begriffliche Klärung und, wo möglich, auch um eine Abgrenzung verschiedener Konzepte voneinander gehen, die im Laufe der Beschäftigung mit sozialen Beziehungen in der Soziologie und anderen nahestehenden Disziplinen (etwa der Sozialpsychologie) entwickelt wurden. Warum ist eine solche Abgrenzung und Einordnung notwendig? In der Auseinandersetzung mit Forschungsarbeiten rund um das Thema soziale Beziehungen kann festgestellt werden, dass unterschiedliche Begriffe synonym verwendet werden und ursprünglich intendierte Abgrenzungen untereinander mit der Zeit verschwimmen. Das vorliegende Kapitel orientiert sich an den folgenden Leitfragen: Welche Begrifflichkeiten gibt es in der soziologischen Forschung zu sozialen Beziehungen? Wie werden diese definiert? Und wie kann aus diesen unterschiedlichen Begriffen ein übergreifendes Konzept zu sozialen Netzwerken entstehen? Das Forschungsfeld zu sozialen Beziehungen ist breit gefächert und ist Thema vieler Disziplinen. Es reicht von der Soziologie hin zur Sozialpsychologie, von Ökonomie über Public Health hin zur Epidemiologie, ohne dass dies eine vollständige Liste aller Fächer und Forschungsschwerpunkte sein soll, die sich mit diesem Thema befassen. Die wissenschaftliche Betrachtung sozialer Beziehungen hat in der Soziologie eine längere Geschichte: diese erstreckt sich von Durkheims bekannter Arbeit zum Selbstmord (Durkheim 1993, Original 1897), über Parsons funktionalistisch ausgerichtete Gesellschaftsanalyse (Parsons 1951), welche den sozialen Interaktionen zugrunde liegenden Werten und Normen Beachtung schenkt, bis hin zu Bourdieus Kapital-Theorien und seinen Analysen der gesellschaftlichen Differenzierung (Bourdieu 1994). Die dabei entstandene begriffliche Vielfalt ist durchaus gewünscht und zeugt von der Pluralität an Forschungsaktivitäten. Diese reicht vom sozialen Kapital über soziale Kohäsion hin zu sozialen Netzwerken. Gleichzeitig aber ist eine solche Ausdifferenzierung problematisch, wenn die Begriffe und die dahinterstehenden Konzepte sich überschneiden oder synonym verwendet werden, ohne dass damit klare Definitionen und Abgrenzungen verbunden sind (Holt-Lunstad et al. 2010; Berkman und Krishna 2014). Berkman und Glass fassen dies wie folgt prägnant zusammen: „When investigators write about the impact of social relationships on health, many terms are used loosely and interchangeably, including social networks, social support, social ties and social integration" (Berkman und Glass 2000, S. 137). Ziel der folgenden Übersicht ist es, die Begriffe zu ordnen und voneinander abzugrenzen, deren Entstehung zu skizzieren, um darauf aufbauend Zusammenhänge mit Gesundheit beschreiben und diskutieren zu können.

Soziale Beziehungen dienen im Rahmen des vorliegenden Kapitels als Oberbegriff für eine ganze Reihe unterschiedlicher Konzepte zur Beschreibung des 
sozialen Miteinanders in Gesellschaften. Dabei können unterschiedliche Merkmale differenziert werden. So lassen sich grundsätzlich die Quantität und die Qualität sozialer Beziehungen unterscheiden. Unter Quantität ist die Anzahl unterschiedlicher sozialer Kontakte oder die Häufigkeit sozialer Kontakte zu verstehen. Jedem sozialen Kontakt kann eine bestimmte Qualität zugeschrieben werden. Wie sind diese Kontakte beschaffen oder welche Ressourcen sind über diese Kontakte erreichbar? Soziale Kontakte sind Vorbedingung für den Austausch von Ressourcen und sozialer Unterstützung. Jedoch kann nicht zwingend davon ausgegangen werden, dass eine steigende Zahl sozialer Kontakte mit einer zunehmenden Verfügbarkeit von Ressourcen und Unterstützungsleistungen einhergeht. Nicht jede Person innerhalb eines sozialen Gefüges ermöglicht Ressourcenzugang.

Eine andere Unterscheidungsmöglichkeit ergibt sich durch die Ebene, auf der soziale Beziehungen eingeordnet werden können. Während auf der Mikro-Ebene soziale Beziehungen einer Einzelperson untersucht werden, sind es auf der MesoEbene (institutionelle) Netzwerke beispielsweise von Gemeinden, Kommunen, Stadtteilen oder Schulen, und entsprechend auf der Makro-Ebene Länder und Staaten. Letzteres wird häufig auf Basis von Indikatoren für Vertrauen, Normen oder staatliche Institutionen gemessen, worauf im Folgenden noch eingegangen wird.

Ausgehend von dieser grundlegenden Differenzierung sollen im Folgenden zentrale Begriffe wie soziale Unterstützung, soziales Kapital, soziale Kohäsion und soziale Netzwerke eingeführt und erörtert werden.

\section{$2 \quad$ Klärung der Begrifflichkeiten}

\subsection{Soziale Unterstützung}

Zentrale qualitative Dimension auf der Mikro-Ebene sozialer Beziehungen ist die soziale Unterstützung. Ohne soziale Kontakte, ohne eine Einbettung in soziale Netzwerke kann keine soziale Unterstützung stattfinden. Sind Anzahl und Frequenz sozialer Kontakte Maße für die Quantität sozialer Beziehungen, dann ist soziale Unterstützung ein $\mathrm{Ma}$ für die Qualität dieser Beziehungen. In der Unterstützungsforschung wird zwischen objektiven und subjektiven Aspekten von Unterstützung unterschieden (Turner und Marino 1994). Es konnte gezeigt werden, dass nicht nur die tatsächlich erhaltene Unterstützung relevant ist, sondern die subjektiv wahrgenommene Unterstützung eine zentrale Rolle spielt, gerade im Zusammenhang mit (mentaler) Gesundheit. Bereits das Gefühl, im Ernstfall über soziale Unterstützung zu verfügen, kann negative Auswirkungen von akutem 
Stress abmildern, ohne dass tatsächlich Unterstützung in Anspruch genommen wurde (Cobb 1976; House et al. 1988; Turner und Marino 1994; Uchino 2009). Zudem wurden zwischen tatsächlich erhaltener und subjektiv wahrgenommener Unterstützung nur geringe Zusammenhänge gefunden, was darauf hindeutet, dass diese als jeweils relativ eigenständige Konstrukte angesehen werden können (Barrera 1986; Lakey und Cohen 2000). Dieser funktionale Aspekt sozialer Beziehungen umfasst in der Regel Unterstützungsformen auf emotionaler, instrumenteller sowie informationeller Ebene.

Emotionale Unterstützung bezieht sich auf diejenigen sozialen Kontakte, die für Gespräche über eigene Gefühle zur Verfügung stehen, die zur Diskussion alltäglicher Ängste und Sorgen beitragen oder auch Bestätigung für Sympathie und Zuneigung bieten können (siehe Tab. 1, dazu auch Lin et al. 1999). Instrumentelle Unterstützung dagegen umfasst diejenigen Unterstützungsformen, die sich durch praktische Hilfe - beispielsweise im Haushalt, mit der Kinderbetreuung oder durch das Leihen von Geld oder anderen Waren - auszeichnen. Unter informationeller Unterstützung werden all jene Leistungen erfasst, die Wissen zum Lösen bestimmter Probleme, oder Wissen über den Zugang zu bestimmten Ressourcen wie beispielsweise innerhalb von Gemeinden, verfügbar machen. In Tab. 1 findet sich eine kurze Darstellung unterschiedlicher Aspekte sozialer Unterstützung, basierend auf Wills und Shinar (2000).

Ein wichtiges Grundprinzip, auf dessen Basis es zu unterschiedlichen Formen sozialer Unterstützung kommen kann, ist die soziale Reziprozität (Siegrist und Wahrendorf 2016). Dieses besagt, dass Menschen für eine bestimmte erbrachte Leistung auch eine entsprechende Gegenleistung erwarten (Prinzip der Gegenseitigkeit). Diese Erwartung macht viele Formen der sozialen Interaktion überhaupt erst möglich. Eine Gegenleistung muss nicht dieselbe Form wie die erhaltene Leistung haben, sollte aber als adäquat und ähnlich empfunden werden. Leistet man beispielsweise Bekannten Hilfe bei einem Umzug (instrumentelle Unterstützung), so kann erwartet werden, bei Bedarf eine ähnliche Leistung zu erhalten. Werden diese Erwartungen nicht erfüllt, wird die Reziprozitätsnorm verletzt und dauerhafter sozialer Austausch weniger wahrscheinlich. Je nachdem, in welcher Beziehung man sich mit anderen Personen befindet, kann sich die Reziprozitätsnorm verändern. Zum Beispiel ist man innerhalb der Familie, für enge Freunde oder Verwandte eher bereit, eine Leistung zu erbringen, ohne eine zeitlich (un-)mittelbare entsprechende Gegenleistung zu erwarten. Die generalisierte Reziprozität meint, dass nicht einzelne erbrachte Leistungen jeweils entsprechend erwidert werden. Vielmehr kann ein generelles reziprokes Verhalten zu einem deutlich späteren Zeitpunkt erwartet werden. Klassisches Beispiel hierfür wäre die Eltern-Kind Beziehung, in der Eltern Unterstützung für ihre Kinder 


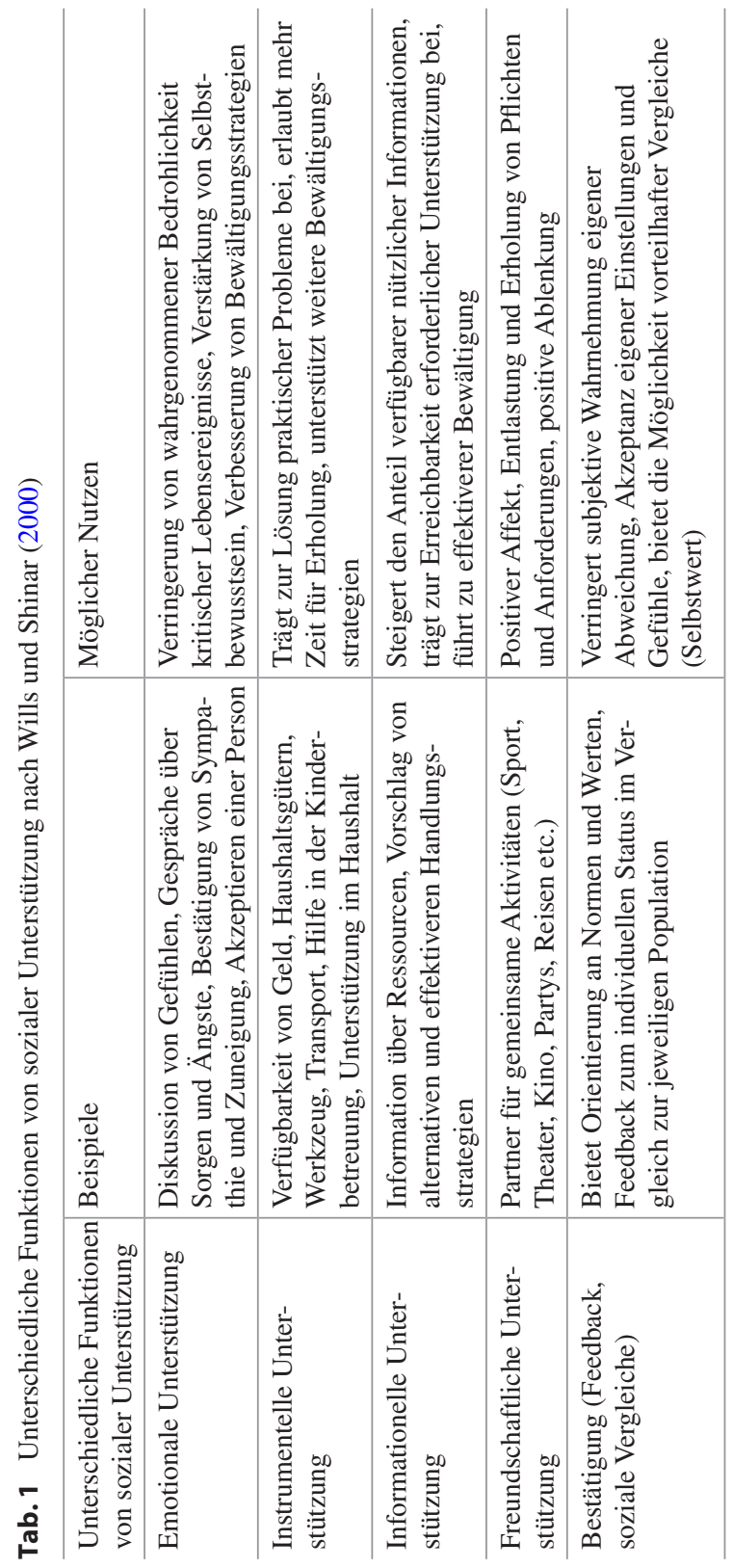


leisten, ohne dass diese jeweils direkt erwidert werden. Dafür erwarten Eltern möglicherweise im höheren Lebensalter eine entsprechende Unterstützung durch die Kinder. Der Forschungsansatz zu sozialer Unterstützung fokussiert stark auf die individuelle Ebene, sie fragt nach Unterstützungsformen, welche Einzelnen zur Verfügung steht. Da jedoch durch die Konzentrierung auf Einzelne der strukturelle Aspekt aus dem Blick gerät, wurde wiederholt von der Wissenschaft vorgeschlagen, zusätzlich die Gesamtstruktur der Netzwerke zu untersuchen, um die strukturelle Bedingtheit von individuellen Unterstützungsleistungen und -möglichkeiten herausarbeiten zu können (Holt-Lunstad 2010; Berkman 2014). Hier stehen Fragen im Vordergrund, wie soziale Beziehungsgefüge geschaffen sein müssen, damit soziale Unterstützung stattfinden kann. Welche Faktoren innerhalb sozialer Beziehungen bedingen soziale Unterstützung, welche wirken eher hinderlich? Lassen sich strukturelle Merkmale von sozialer Unterstützung identifizieren? Dies vermag eine zu sehr auf die individuelle Unterstützung fokussierte Analyse nur schwer zu beantworten.

\subsection{Soziales Kapital}

Soziales Kapital als Untersuchungsgegenstand lässt sich in verschiedenen Fachdisziplinen (Soziologie, Ökonomie, Sozialpsychologie, Politikwissenschaft) verorten. Als zentrale Gemeinsamkeiten unterschiedlicher Konzepte von sozialem Kapital lassen sich dabei die Folgenden ausmachen (Berkman und Krishna 2014; Kawachi und Berkman 2014). Soziales Kapital wird als Ressource verstanden (1), welche nicht durch Einzelne produziert wird, sondern erst durch soziale Interaktion mit Anderen entsteht (2). In der Soziologie lassen sich relativ grob zwei Forschungstraditionen unterscheiden. Auf der einen Seite eine eher französische Forschungstradition, insbesondere geprägt durch die Arbeiten von Pierre Bourdieu. Auf der anderen Seite ein eher amerikanischer Forschungszweig, hier können insbesondere James Coleman und Robert Putnam genannt werden.

Der Kapitaltheorie nach Bourdieu zufolge steht neben ökonomischem Kapital auch kulturelles und soziales Kapital zur Verfügung. Soziales Kapital meint, dass über soziale Beziehungen Zugang zu Ressourcen ermöglicht werden kann (Bourdieu 1994). Auch können Individuen gezielt in diese sozialen Beziehungen investieren, um entsprechend Zugang zu sozialem Kapital zu erhalten, was sich wiederum auf die anderen Kapitalformen auswirken kann. Es wird von einer „,...] Konkurrenz zwischen Investitionen in Sozialkapital und andere Kapitalien [...]“" gesprochen (Lüdicke und Diewald 2007, S. 15). Soziales Kapital wird als 
Merkmal einzelner Individuen betrachtet, welche mit diesem oder durch dieses handeln können.

Die Ansätze von Coleman (1990) und Putnam unterscheiden sich in ihrer Herangehensweise von Bourdieu insofern, als soziales Kapital stärker als Eigenschaft von sozialen Netzwerken verstanden wird und dementsprechend die Betonung auf der zwischenmenschlichen Ebene liegt. „Unlike other forms of capital, social capital inheres in the structure of relations between actors and among actors" (Coleman 1990, S. 98). Diese nordamerikanische Tradition entwickelt ihr Verständnis von sozialem Kapital aus der Untersuchung sozialer Netzwerke. Im Vordergrund steht dabei die Frage, wie und unter welchen Bedingungen sich soziales Kapital in sozialen Netzwerken ausbildet (Lin 2000).

Betrachtet man soziales Kapital auf der Mikro-Ebene der Individuen, so ergeben sich Überschneidungen sowohl mit dem Konzept der sozialen Unterstützung als auch mit sozialen Netzwerken. Soziale Unterstützung geht von zumeist engen, eher stärkeren sozialen Beziehungen aus. Das Konzept des sozialen Kapitals hingegen unterscheidet zwischen starken und schwachen Beziehungen und sieht gerade die Möglichkeiten der schwächeren Beziehungen, neue Informationen und Ressourcen zur Verfügung zu stellen und ist hier eng an das Konzept sozialer Netzwerke angelehnt. Dies wurde unter dem Schlagwort strength of weak ties diskutiert (Granovetter 1973; Putnam 1995). Diese von Granovetter entwickelte These besagt, dass gerade nicht die häufig frequentierten, engen und mit höherer Intensität geführten Beziehungen (auch als bonding social capital bezeichnet) relevante Ressourcen, wie etwa Zugang zum Arbeitsmarkt, zur Verfügung stellen können, sondern dass dies durch Kontakte ermöglicht werden kann, welche sich durch geringere Kontaktfrequenzen und niedrige Intensität charakterisieren lassen. Diese als bridging social capital (überbrückendes soziales Kapital) bezeichneten Kontakte zeichnen sich dadurch aus, dass sie über unterschiedliche soziale Gruppen hinweg etabliert werden und dass sie die Zugangswahrscheinlichkeit zu bestimmten Ressourcen erhöhen (Lin et al. 1999). Demgegenüber sind es die engeren Kontakte, die eher instrumentelle und emotionale Unterstützung zur Verfügung stellen (Dahl et al. 2010).

Auf der Meso- oder auch der Makro-Ebene betrachtet, lässt sich soziales Kapital zugleich als Eigenschaft sozialer Gruppen sowie als Charakteristik von Lebensräumen bestimmen. Aufbauend auf der Erfassung individueller Einschätzungen wie etwa der Reziprozität und dem Vertrauen in die jeweilige Lebensumgebung (z. B. Nachbarschaft, Stadtteil), zu sozialem und ehrenamtlichem Engagement sowie generellen Einstellungen zu Gruppen oder Lebensräumen werden Indizes auf einer Aggregatebene gebildet, welche das Ausmaß an 
sozialem Kapital widerspiegeln und entsprechend als Charakteristik von Gruppen oder umgrenzten Räumen verwendet werden. Grundlegende Annahme ist hierbei, dass erst durch erlebte Reziprozität und Vertrauen sowie auf gemeinsam getragenen Werten und Normen regelmäßige Interaktion entsteht, welche wiederum Zugang zu Ressourcen innerhalb von Gruppen ermöglicht und soziales Kapital entstehen kann (Putnam 1995; Ichida et al. 2009; Dahl et al. 2010). Je höher entsprechend das Vertrauen in die eigene Lebensumgebung ist, desto wahrscheinlicher wird der Theorie zufolge auch die Entwicklung stabiler sozialer Beziehungsgefüge, in denen soziales Kapital verfügbar ist. Eine ganze Vielzahl von Studien konnte solche Zusammenhänge bestätigen (siehe Airaksinen et al. 2015; Pickett und Pearl 2001).

\subsection{Soziale Kohäsion}

Ein weiterer Begriff, der im Zusammenhang mit der Untersuchung von sozialen Beziehungen innerhalb umgrenzter Räume immer wieder genannt wird, ist soziale Kohäsion. Damit werden vornehmlich subjektive Einschätzungen zu Verbindungen von Mitgliedern innerhalb sozialer Gruppen beschrieben. Innerhalb jeder Gruppe findet sich ein gewisser Grad an sozialer Kohäsion. Grundsätzlich kann hierbei zwischen der strukturellen Kohäsion (structural cohesion) sowie dem Zugehörigkeitsgefühl der einzelnen Mitglieder (perceived cohesion, sense of togetherness) (Bollen und Hoyle 1990). Durch die Betonung des Zugehörigkeitsgefühls, welches implizit auch gemeinsam getragene Werte und Normen beinhaltet, schließt das Konzept der perceived social cohesion eng an das Konzept des sozialen Kapitals an.

Eine hohe strukturelle soziale Kohäsion meint, dass die Mitglieder einer bestimmten Gruppe untereinander eng verbunden sind. Die stärkste Kohäsion innerhalb einer Gruppe ist demnach erreicht, wenn jedes Mitglied eines Netzwerks direkt mit jedem anderen Mitglied verbunden ist, eine geringe Kohäsion, wenn viele Mitglieder eines Netzwerks nur lose und indirekt miteinander verbunden sind. Die subjektive Kohäsion muss nicht der strukturellen Kohäsion entsprechen, denn diese können voneinander abweichen. Die soziale Kohäsion wird als ein Merkmal von Gruppen oder räumlichen Gebieten umschrieben und lässt sich daher der Meso- und Makro-Perspektive von sozialen Beziehungen zuordnen.

Soziale Kohäsion wird häufig anhand subjektiver Einschätzungen gemessen. Dabei stehen individuelle Einschätzungen und Wahrnehmungen zu den jeweiligen Gruppen im Vordergrund sowie tatsächliche Aktivitäten der Individuen innerhalb 
der Gruppen. Eine starke Kohäsion innerhalb von sozialen Gruppen geht häufiger mit höherer sozialer Kontrolle nach innen einher, während solche Gruppen nach außen relativ geschlossen bleiben (Kawachi und Berkman 2014). Beispiele solcher kohäsiver Gruppen finden sich unter Immigranten, die aufgrund ihrer ethnischen Zugehörigkeit starke Bindungen untereinander aufbauen, z. B. aufgrund sprachlicher Barrieren, aber nach außen relativ geschlossen bleiben. Ähnliches gilt für hoch vernetzte Nachbarschaften oder dörfliche Gemeinschaften.

Das Konzept der perceived social cohesion wurde kritisiert, weil es im Vergleich zum sozialen Kapital viele Überschneidungen aufweist und klare Alleinstellungsmerkmale für dieses Konzept fehlen. Da jedoch die Erfassung insbesondere von umfangreichen Strukturen des sozialen Kapitals in Gemeinden oder Nachbarschaften sehr aufwendig und schwer durchführbar ist, kann wahrgenommene soziale Kohäsion als eine alternative Form der Erfassung begriffen werden und erhält seine Berechtigung durch die methodische Umsetzbarkeit, weniger aufgrund der theoretischen Verortung.

Beide Begriffe, sowohl soziales Kapital als auch soziale Kohäsion, bergen die Möglichkeit negativer Prozesse innerhalb von sozialen Gruppen. Dazu gehören soziale Exklusion, Stigmatisierung, Diskriminierung und andere negative Effekte sozialer Beziehungen wie etwa andauernde Konflikte. Ein hoher Grad an sozialer Kohäsion und eine enge Vernetzung von Mitgliedern untereinander schließt auch die Möglichkeit der Exklusion von Nichtmitgliedern mit ein (siehe dazu Kawachi und Berkman 2014). Zudem tendieren Gruppen mit hoher sozialer Kohäsion dazu, wenig Kontakt zu anderen Gruppen zu haben. Kontakte zwischen unterschiedlichen Gruppen können positive Einstellungen gegenüber Anderen unterstützen, ebenso werden so eher Vorurteile und negative Einstellungen abgebaut. Dies wurde insbesondere im Kontext unterschiedlicher ethnischer Gruppen untersucht (Laurence und Bentley 2016; Hewstone 2015) und im Lichte zweier unterschiedlicher Theorien dazu diskutiert (conflict theory Putnam 2007, intergroup contact theory Brown und Hewstone 2005). Mangelnde soziale Kontakte zwischen Gruppen können entsprechend negative Einstellungen fördern. Weitere Ausführungen zu negativen Aspekten sozialer Beziehungen finden sich im Kap. „Negative Beziehungsaspekte und gesundheitliche Ungleichheiten“.

\subsection{Soziale Netzwerke}

Abschließend soll im Folgenden der Begriff der sozialen Netzwerke näher erläutert werden. Die soziologische Netzwerkanalyse interessiert sich für Beziehungen zwischen Individuen sowie für die Eigenschaften dieser 
Beziehungen, mehr als für die Eigenschaften der Individuen selbst. Grundgedanke ist, dass Individuen nicht unabhängig handeln, sondern dass diese Handlungen eingebettet sind in ein Netz zwischenmenschlicher Beziehungen (Burt 1982). Auch stehen nicht nur die Beziehung zwischen Ego, also dem zentralen Akteur, von dem die Betrachtung des Netzwerkes ausgeht, und verschiedenen Alteri, also Referenzpersonen von Ego im betrachteten Netzwerk, im Mittelpunkt, vielmehr geht es in der Netzwerkanalyse darum, ein gesamtes Beziehungsgeflecht zu untersuchen. Denn die Beziehung zwischen Ego und den Alteri wird auch beeinflusst durch Beziehungen der Alteri untereinander, die indirekt wiederum mit Ego verbunden sind. Soziale Interaktion und soziale Prozesse werden nicht allein durch Merkmale der Individuen, sondern durch ihre Integration in ein soziales Umfeld erklärbar (Häußling 2010). Um diese sozialen Zusammenhänge zu veranschaulichen, werden grafische Netzwerkmodelle entwickelt, die die Beziehungen sichtbar machen. Mit dem Blick der Netzwerkforschung verlässt man entsprechend schnell die Mikroperspektive der Einzelnen, hin zu einer Meso-Ebene, welche die Verflechtungen von Individuen und Gruppen sichtbar macht. Wichtiger Grundgedanke in der Netzwerkforschung ist es, dass nicht nur die Position eines Individuums innerhalb eines sozialen Netzwerks identifiziert werden kann, sondern durch Offenlegung der Strukturen eines Netzwerks auch die Möglichkeiten für Kontaktfähigkeit, Einfluss und Möglichkeiten der Kontrolle innerhalb von Netzwerken analysiert werden können. Diese Strukturen, welche sich anhand netzwerktheoretischer Begrifflichkeiten wie etwa Knoten, Dichte, Zentralität und Position beschreiben lassen, werden zur Beschreibung sozialer Phänomene hinzugezogen (Holzer 2009). Eine Erläuterung der unterschiedlichen Begrifflichkeiten findet sich im Kap. „Netzwerktheorie(n)“. Die Komplexität sozialer Netzwerke ergibt sich aus den verschiedenen möglichen Formen und Arten der Interaktion von Individuen und Gruppen untereinander.

Zudem lassen sich soziale Netzwerke nach ihrem jeweiligen Charakter unterscheiden, welcher formaler Natur sein kann, wenn es sich um Organisationen und Vereine handelt, oder informell, wenn es sich um persönliche, verwandtschaftliche oder freundschaftliche Netzwerke und Kontakte handelt. Weiterhin ist eine Differenzierung nach Frequenz, nach Intensität sowie nach Größe und Reichweite der Netzwerke, der Extension, möglich. Die frühe (soziologische) Netzwerkforschung hat sich vor allem auf diese eher quantitativen Aspekte sozialer Beziehungen konzentriert. Hier weist der Begriff der sozialen Netzwerke Überschneidungen mit dem Konzept der sozialen Integration auf. Einer Definition von Laireiter (1993) zufolge lässt sich soziale Integration als Integration von Individuen in soziale 
Gruppen, Vereine oder ehrenamtliche Organisationen, als die Anzahl sozialer Kontakte zu Familie, Verwandten und Freunden sowie die Verfügbarkeit und der Zugang zu sozialen und interpersonalen Ressourcen verstehen. Gleichzeitig verweist soziale Integration auf Normen und Werte als Orientierung für individuelle Handlungen, welche durch soziale Interaktion entstehen und durch diese verstetigt werden. Zahlreiche Indikatoren wurden entwickelt, um den Grad an sozialer Integration innerhalb sozialer Netzwerke zu erfassen. Beispielsweise lassen sich aus der sozialepidemiologischen Forschung der Social Integration Index von Berkman oder der Social Connection Index von Kaplan aufführen (Berkman und Syme 1979; Kaplan et al. 1977). In jüngerer Zeit wird nun auch in der Netzwerkforschung zunehmend versucht, das bisherige, eher quantitative Verständnis sozialer Netzwerke zu erweitern und auch qualitative Aspekte in die Erforschung sozialer Netzwerke einzubeziehen, indem beispielsweise die Verfügbarkeit von Ressourcen oder gemeinsam geteilte Normen und Werte innerhalb von Netzwerken mit in Betracht gezogen werden (Henning und Kohl 2011).

Was der soziologischen Untersuchung sozialer Netzwerke bisher weitgehend fehlt, ist eine eigenständige Theorie (Holzer 2009). Es finden sich Anknüpfungspunkte an Rational Choice-Ansätze sowie an strukturalistische Gesellschaftstheorien, auch in der Systemtheorie lassen sich Zusammenhänge zur Untersuchung von sozialen Netzwerken herstellen. In der Netzwerkforschung stehen formale und methodische Fragen im Vordergrund, weniger die Entwicklung einer gemeinsamen theoretischen Basis. In früheren Arbeiten wurde dieses Fehlen von übergeordneter Theorie auch als strukturelle Intuition der Netzwerktheorie bezeichnet (Freeman 2004). Holzer hebt dies in seinem Beitrag zur Netzwerktheorie wie folgt hervor: „Um den entscheidenden Schritt von der Netzwerkanalyse zu einer Netzwerktheorie machen zu können, muss jedoch den besonderen Konstitutionsbedingungen [der Netzwerkanalyse] Rechnung getragen werden " (Holzer 2009, S. 264). Diese Aussage bezieht sich darauf, dass bisherige Ansätze einer Netzwerktheorie in verschiedenen wissenschaftlichen Disziplinen Anklang finden, wie etwa der Physik, der Biologie, der Psychologie und der Soziologie, diese jeweiligen Ansätze aber nicht immer auf andere Bereiche übertragbar sind und eine gemeinsame theoretische Fundierung entsprechend erschweren. Es gibt bisher nur vereinzelt Ansätze, welche auf der Grundlage theoretischer Überlegungen versuchen, die relationale Analyse mit kulturellen und symbolischen Aspekten zu füllen, um so Handlungen und Interaktionen erklärbar zu machen (White 1995; Gibson 2005; Fuhse 2008). Ausführlicher auf die theoretischen Hintergründe und methodischen Aspekte der Netzwerkforschung wird im Kap. „Netzwerkanalyse“ eingegangen. 
Den Autorinnen und Autoren des vorliegenden Sammelbands liegt ein gemeinsames Verständnis sozialer Netzwerke zugrunde, welches sich von den bisher beschriebenen Begriffen abgrenzt beziehungsweise einzelne Aspekte unterschiedlicher Definitionen sozialer Beziehungen bewusst miteinbezieht. Demnach sind soziale Netzwerke zunächst einmal mehr als die sozialen Kontakte eines Individuums. Soziale Netzwerke heben sich dann von sozialer Integration $\mathrm{ab}$, wenn sie Aussagen über die Struktur sozialer Kontakte zulassen, also über die individuellen sozialen Kontakte auch die Vernetzung der Alteri untereinander sichtbar macht. Damit geht ein solcher Netzwerkbegriff über das Verständnis von Netzwerken wie etwa in den oben genannten Indizes (z. B. Social Network Index) deutlich hinaus. In Bezug auf das soziale Kapital grenzt sich der Begriff des sozialen Netzwerks insofern ab, als dass nicht nur beschrieben wird, welche Ressourcen oder Normen und Werte in bestimmten Gruppen verfügbar sind, sondern sich zudem darauf fokussiert, wie diese entstehen und reproduziert werden und welche Muster sozialer Netzwerke bestimmte Ressourcen ermöglichen oder verhindern. Ein solcher Netzwerkbegriff fragt nach der strukturellen Bedingtheit von sozialer Unterstützung und kann so die Forschung zu sozialer Unterstützung ergänzen, da diese mit einem Fokus auf individuelle Unterstützungsformen und -muster die soziale Struktur hinter der wahrgenommenen oder tatsächlichen Unterstützung vernachlässigt, wie eingangs gezeigt wurde. Soziale Kohäsion kann helfen, die Verbundenheit sozialer Netzwerke untereinander zu beschreiben und ist in dieser Funktion auch bereits in der Netzwerktheorie etabliert.

\section{$3 \quad$ Zusammenfassung und Ausblick}

Ziel des vorliegenden Beitrages ist es, die unterschiedlichen Begriffe in der Forschung zu sozialen Beziehungen zu klären und zu ordnen. Insbesondere in der Gesundheits- und der Medizin-Soziologie haben sich, teilweise unabhängig voneinander, teilweise eng miteinander verknüpft, gerade das soziale Kapital, soziale Netzwerke und soziale Unterstützung als Begrifflichkeiten in der Forschung rund um soziale Beziehungen etabliert. Ein immer wiederkehrender Vorwurf in diesem Forschungsbereich ist, dass Begrifflichkeiten unklar definiert oder auch synonym verwendet werden, was nicht zu einer Klärung der jeweiligen Begriffe beiträgt.

Aufbauend auf einer begrifflichen Klärung soll ein gemeinsamer Begriff von sozialen Netzwerken entwickelt werden. Ein umfängliches Verständnis sozialer Netzwerke umfasst sowohl quantitative als auch qualitative Aspekte sozialer 
Beziehungen. Zunächst repräsentieren soziale Netzwerke die Struktur, innerhalb welcher soziale Unterstützung und soziale Integration stattfinden können. Durch ihre Beschaffenheit ermöglichen oder verhindern soziale Netzwerke die Entstehung und die Verbreitung von sozialem Kapital. Anhand sozialer Netzwerke kann die strukturelle Bedingtheit sozialer Unterstützung gezeigt werden, in welchem Grad Individuen miteinander in Kontakt sind, wie weit diese Beziehungen reichen und wie dauerhaft diese ausgeprägt sind. Ebenso lassen sich qualitative Aspekte erfassen: die Intensität der Interaktionen, die verfügbaren Ressourcen zwischen Netzwerkmitgliedern oder auch die Normen und Werte und deren Entsprechung innerhalb von Netzwerken lassen Rückschlüsse auf die Qualität der Netzwerke zu. Insofern fließen in ein solches Verständnis auch Aspekte des sozialen Kapitals ein, in welchem postuliert wird, dass nicht nur die nahestehenden Kontakte Ressourcen zur Verfügung stellen, sondern dass dies insbesondere über schwache Verbindungen geschehen kann (weak ties).

Ebenso lassen sich Netzwerke auf unterschiedlichen Ebenen analysieren. In einer Mikro-Ebene lassen sich Kontakte zwischen Ego und verschiedenen Alteri analysieren, bei denen auch die Verbindungen der Alteri untereinander erfasst werden. Ein solches Verständnis geht über eine reine Erfassung von sozialen Kontakten hinaus. Auf einer Meso-Ebene können diese Netzwerke für gröBere Gruppen oder kleinräumige Gebiete wie Schulen oder Nachbarschaften gemessen werden. Aus einer solchen Perspektive lassen sich Rückschlüsse über Verbindungen zwischen Netzwerken ziehen. Zentraler Nachteil eines so umfassenden Verständnisses sozialer Netzwerke ist der methodische Aufwand, der zur Erfassung sozialer Netzwerke notwendig ist (siehe Kap. „Netzwerkanalyse“).

Der Aspekt der Messung und Erhebung so umfassend verstandener sozialer Netzwerke ist ein wichtiger Aspekt der vorliegenden Arbeit. Viele der bisherigen Arbeiten, insbesondere im Zusammenhang mit der Untersuchung von gesundheitlichen Ungleichheiten, konnten den Ansprüchen komplexer sozialer Netzwerke nicht genügen, da sie sich häufig auf quantitative Aspekte sozialer Netzwerke (etwa die Anzahl von Kontakten) oder auf soziale Unterstützung ohne Berücksichtigung anderer Mitglieder der sozialen Netzwerke (Alteri) konzentriert haben. Für eine komplexe Analyse sozialer Netzwerke im Zusammenhang mit gesundheitlichen Ungleichheiten fehlen neben einem gemeinsamen begrifflichen Verständnis auch entsprechende Daten. An dieser Stelle soll der vorliegende Sammelband aufzeigen, welche Möglichkeiten sich für die Forschung zu gesundheitlichen Ungleichheiten aus einem komplexeren Verständnis von sozialen Netzwerken ergeben könnten und an welchen „Leerstellen“ bisheriger Forschung mit neuen Erkenntnissen gerechnet werden könnte. 


\section{Leseempfehlungen}

Berkman, L. F., \& Krishna, A. (2014). Social Network Epidemiology. In L.F. Berkman \& I. Kawachi (Hrsg.), Social Epidemiology (S. 234-289). Oxford: University Press. Grundlegende und fundierte Aufbereitung des Themas „Soziale Netzwerke und Gesundheit“, sowohl theoretische Grundlagen als auch empirische Zusammenhänge werden dargestellt.

Henning, M., \& Kohl, S. (2011). Rahmen und Spielräume sozialer Beziehungen. Zum Einfluss des Habitus auf die Herausbildung von Netzwerkstrukturen. Wiesbaden: VS. Gute Übersichtsarbeit zur theoretischen Verortung sozialer Beziehungen.

Kawachi, I., Berkman, L. (2014). Social Cohesion, Social Capital, and Health. In L. Berkman \& I. Kawachi (Hrsg.), Social Epidemiology (S. 290319). Oxford: University Press. Sehr fundierte und ausführliche Übersichtsarbeit zum Thema „Soziales Kapital und Gesundheit“.

\section{Literatur}

Airaksinen, J., Elovainio, M., Hakulinen, C., Elovainio, M., Lehtimäki, T., Raitakari, O. T., Keltikangas-Järvinen, L., \& Jokela, M. (2015). Neighborhood effects in depressive symptoms, social support, and mistrust: Longitudinal analysis with repeated measurements. Social Science and Medicine, 136-137, 10-16.

Barrera, M. (1986). Distinctions between social support concepts, measures and models. American Journal of Community Psychology, 14(4), 413-426.

Berkman, L. F., \& Krishna, A. (2014). Social network epidemiology. In L. F. Berkman \& I. Kawachi (Hrsg.), Social epidemiology (S. 234-289). Oxford: University Press.

Berkman, L. F., \& Syme, S. L. (1979). Social networks, host resistance, and mortality: A nine-year follow-up study of Alameda County residents. American Journal of Epidemiology, 109(2), 186-204.

Berkman, L. F., Glass, T., et al. (2000). From social integration to health: Durkheim in the new millennium. Social Science and Medicine, 51(6), 843-845.

Bollen, K. A., \& Hoyle, R. H. (1990). Perceived cohesion: A conceptual and empirical examination. Social Forces, 69(2), 479-504.

Bourdieu, P. (1994). Die feinen Unterschiede. Kritik der gesellschaftlichen Urteilskraft. Frankfurt a. M.: Suhrkamp.

Brown, R. J., \& Hewstone, M. (2005). An integrative theory of intergroup contact. In M. Zanna (Hrsg.), Advances in experimental psychology (S. 255-331). San Diego: Academic.

Burt, R. S. (1982). Toward a structural theory of action. Network models of social structure, perception and action. New York: Academic. 
Cobb, S. (1976). Social support as a moderator of life stress. Psychosomatic Medicine, 38(5), 300-314.

Coleman, J. S. (1990). Foundations of social theory. Cambridge: The Belknap Press of Harvard University.

Dahl, E., \& Malmberg-Heimonen, I. (2010). Social inequality and health: The role of social capital. Sociology of Health \& Illness, 32(7), 1102-1119.

Durkheim, E. (1993). Der Selbstmord. Frankfurt a. M.: Suhrkamp.

Freeman, L. C. (2004). The development of social network analysis: A study in the sociology of science. Vancouver: Booksurge Publishing.

Fuhse, J. (2008). Netzwerke und soziale Ungleichheit. In C. Stegbauer (Hrsg.), Netzwerkanalyse und Netzwerktheorie (S. 79-90). Wiesbaden: VS.

Gibson, D. (2005). Taking turns and talking ties: Network structure and conversational sequences. American Journal of Sociology, 110(6), 1561-1597.

Granovetter, M. (1973). The strength of weak ties. American Journal of Sociology, 78(6), 1360-1380.

Häußling, R. (2010). Relationale Soziologie. In C. Stegbauer \& R. Häußling (Hrsg.), Handbuch Netzwerkforschung (S. 63-87). Wiesbaden: VS.

Henning, M., \& Kohl, S. (2011). Rahmen und Spielräume sozialer Beziehungen. Zum Einfluss des Habitus auf die Herausbildung von Netzwerkstrukturen. Wiesbaden: VS.

Hewstone, M. (2015). Consequences of diversity for social cohesion and prejudice: The missing dimension of intergroup contact. Journal of Social Issues, 71, 417-438.

Holt-Lunstad, J., Smith, T. B., et al. (2010). Social relationships and mortality risk: A meta-analytic review. PLoS One Medicine, 7(7), e1000316.

Holzer, B. (2009). Netzwerktheorie. In Kneer, G. \& Schroer, M. (Hrsg.), Handbuch Soziologische Theorien (S. 253-276). Wiesbaden: Springer VS.

House, J. S., Landis, K. R., et al. (1988). Social relationships and health. Science, 241(4865), 540-545.

Ichida, Y., Kondo, K., et al. (2009). Social capital, income inequality and self-rated health in Chita peninsula, Japan: A multilevel analysis of older people in 25 communities. Social Science and Medicine, 69(4), 489-499.

Kaplan, B. H., Cassel, J. C., et al. (1977). Social support and health. Medical Care, 15(5), 47-58.

Kawachi, I., Berkman, L. (2014). Social cohesion, social capital, and health. In L.F. Berkman I. Kawachi (Hrsg.), Social epidemiology (S. 290-319). Oxford: University Press.

Laireiter, A. (1993). Soziales Netzwerk und soziale Unterstützung: Konzepte, Methoden und Befunde. Bern: Huber.

Lakey, B. \& Cohen, S. (2000). Social support theory and measurement. In S. Cohen, L. G. Underwood et al. (Hrsg.), Social support measurement and intervention. A guide for health and social scientists (S. 29-52). Oxford: Oxford University Press.

Laurence, J., \& Bentley, L. (2016). Does ethnic diversity have a negative effect on attitudes towards the community? A longitudinal analysis of the causal claims within the ethnic diversity and social cohesion debate. European Sociological Review, 32(1), 54-67.

Lin, N. (2000). Inequality in social capital. Contemporary Sociology, 29(6), 785-795.

Lin, N., Ye, X., et al. (1999). Social support and depressed mood: A structural analysis. Journal of Health and Social Behavior, 40(4), 344-359. 
Lüdicke, J., \& Diewald, M. (2007). Soziale Netzwerke und soziale Ungleichheit. Zur Rolle von Sozialkapital in modernen Gesellschaften. Wiesbaden: VS.

Parsons, T. (1951). The social system. London: Routledge.

Pickett, K. E., \& Pearl, M. (2001). Multilevel analysis of neighbourhood socioeconomic context and health outcomes: A critical review. Journal of Epidemiology and Coтmunity Health, 55(2), 111-122.

Putnam, R. D. (1995). Tuning in, tuning out: The strange disappearance of social capital in America. Political Science and Politics, 28(4), 664-683.

Putnam, R. D. (2007). E pluribus unum: Diversity and community in the twenty-first century. The 2006 Jonathan Skytte Prize Lecture. Scandinavian Political Studies, 30, 137174.

Siegrist, J., \& Wahrendorf, M. (2016). Failed social reciprocity beyond the work role. In J. Siegrist \& M. Wahrendorf (Hrsg.), Work stress and health in a globalized economy. Aligning perspectives on health, safety and well-being (S. 275-291). Cham: Springer.

Turner, R. J., \& Marino, F. (1994). Social support and social structure: A descriptive epidemiology. Journal of Health and Social Behavior, 35(3), 193-212.

Uchino, B. N. (2009). What a lifespan approach might tell us about why distinct measures of social support have differential links to physical health. Journal of Social and Personal Relationships, 26(1), 53-62.

White, C. (1995). Network switchings and Bayesian forks: Reconstructing the social and behavioral sciences. Social Research, 62(4), 1035-1063.

Wills, T. A., \& Shinar, O. (2000). Measuring perceived and received social support. In S. Cohen, L. G. Underwood, et al. (Hrsg.), Social support measurement and intervention - A guide for health and social scientists (S. 86-135). Oxford: Oxford University Press.

Open Access Dieses Kapitel wird unter der Creative Commons Namensnennung 4.0 International Lizenz (http://creativecommons.org/licenses/by/4.0/deed.de) veröffentlicht, welche die Nutzung, Vervielfältigung, Bearbeitung, Verbreitung und Wiedergabe in jeglichem Medium und Format erlaubt, sofern Sie den/die ursprünglichen Autor(en) und die Quelle ordnungsgemäß nennen, einen Link zur Creative Commons Lizenz beifügen und angeben, ob Änderungen vorgenommen wurden.

Die in diesem Kapitel enthaltenen Bilder und sonstiges Drittmaterial unterliegen ebenfalls der genannten Creative Commons Lizenz, sofern sich aus der Abbildungslegende nichts anderes ergibt. Sofern das betreffende Material nicht unter der genannten Creative Commons Lizenz steht und die betreffende Handlung nicht nach gesetzlichen Vorschriften erlaubt ist, ist für die oben aufgeführten Weiterverwendungen des Materials die Einwilligung des jeweiligen Rechteinhabers einzuholen.

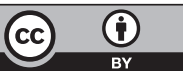




\title{
Netzwerktheorie(n) - Ein Überblick
}

\author{
Markus Gamper
}

\section{Überblick}

- Netzwerke sind auf der Meso-Ebene anzusiedeln. Sie stehen zwischen dem Individuum (Mikro-Ebene) und den Institutionen (Makro-Ebene).

- Die Theorien gehen von einer Wechselwirkung von Individuum und Netzwerken aus, wobei Beziehungen und ihre gebildeten Strukturen im Fokus der Betrachtung stehen.

- Es gibt nicht „die“ Netzwerktheorie. Vielmehr gibt es verschiedene Theorien oder auch theoretische Ansätze.

- „Grand Theories“ versuchen einen universellen Erklärungsanspruch von Netzwerken auf Akteur*innen zu erklären.

- „Theorien mittlerer Reichweite“ sind forschungsorientierte Arbeitstheorien, die z. B. Netzwerke und ihre Auswirkungen in bestimmte Bereiche wie Gesundheit in den Mittelpunkt stellen.

- „Theorien mittlerer Reichweite“ wie z. B. die strong/weak tie-Theorie finden speziell in der Netzwerkanalyse große Bedeutung und bilden die Grundlage für Hypothesen, oder werden zur Interpretation von Daten verwendet.

M. Gamper $(\bowtie)$

Köln, Deutschland

E-Mail: m.gamper@uni-koeln.de 


\section{$1 \quad$ Netzwerktheorie(n) und ein Einteilungsversuch}

Bezüglich der Netzwerktheorie stellt Scott (2011, S. 24) fest: „[...] theoretical work has long been underdeveloped in social network analysis. While the methods themselves do not require or imply any particular sociological theory, they do require theoretical contextualisation in wider debates". Auch wenn die Theoretisierung von Netzwerken, im Vergleich zu quantitativ-empirischen Verfahren, lange vernachlässigt wurde, gibt es schon seit dem frühen 20. Jahrhundert intensive theoretische Auseinandersetzungen mit dem Konzept der sozialen Beziehungen und ihren Strukturen. Allgemein geht man davon aus, dass Menschen in Beziehungen eingebettet sind und nicht losgelöst von ihren Netzwerken betrachtet werden können. Diese einzelnen Dyaden, das sind Beziehungen zwischen zwei Akteur*innen, verbinden sich wiederum zu größeren Einheiten, sogenannten Netzwerken. Netzwerke sind hierbei auf der Meso-Ebene anzusiedeln. Sie sind damit ein Bindeglied zwischen der Mikro-Ebene, das individuelle Handeln, und der Makro-Ebene, den Institutionen (Weyer 2012, S. 241). Netzwerke bestehen demnach aus Akteur*innen, die Beziehungen untereinander eingehen und damit soziale Strukturen herstellen. Das theoretische Interesse liegt nicht auf den klassischen Attributen von Individuen wie z. B. Geschlecht oder Alter oder auf Merkmale der Institutionen, sondern auf den Beziehungen, deren Strukturen, und der Einbettung der Akteur*innen innerhalb dieser Relationen. Sie bilden den Ausgang der Forschungsfrage, während die genannten Attribute auch mit in die Analyse einbezogen werden.

Hinsichtlich der Netzwerktheorie(n) kann zwischen „Grand Theory“ und „Theorien der mittleren Reichweite“ unterschieden werden. Erstere umfasst ein umfassendes Theoriegebäude mit einem universellen Erklärungsanspruch (Mills 1959), während die „Theorien mittlerer Reichweite“ zwischen Globaltheorien und forschungsorientierten Arbeitstheorien angesiedelt sind. Dies sind Theorien, die auch auf ein spezifisches Forschungsfeld beschränkt bleiben (Merton 1968). Demnach kann man drei Theorieformen in der Netzwerkforschung idealtypisch unterscheiden (Emirbayer 1997; Heidler und Gamper 2017). Als Erstes ist hier der strukturalistische Determinismus zu nennen. Dieser Zweig zieht ausschließlich relationale Merkmale für die Beschreibung von Handlungen der Akteur*innen heran. Demnach ist die Handlung allein durch die Struktur der Netzwerke und die Einbettung des Individuums in diesen Strukturen vordeterminiert. Der strukturalistische Instrumentalismus betont die Handlungsoptionen des Individuums, die sich aus seiner Netzwerkposition ergeben. Diese werden von den Akteure*innen instrumentell, im Sinne eines strukturellen Individualismus, zum eigenen Vorteil (Homo oeconomicus) genutzt. Somit rückt hier stärker als im 
strukturalistischen Determinismus das Individuum in den Blickpunkt des theoretischen Interesses. Der dritte Idealtyp ist der strukturalistische Konstruktivismus. Hier werden soziale Strukturen, kulturelle Determinanten sowie Handlung als eigene Aspekte behandelt. Netzwerke und Individuen sind somit ein Teil der Kultur und beeinflussen diese wiederum. Sie stehen gleichberechtigt nebeneinander. Beziehungen werden als durch die Akteur*innen selbst konstruierte Komponente verstanden, was die Wahrnehmung der beteiligten Akteur*innen nochmals stärker in die Analyse miteinbezieht.

Auch wenn sich die einzelnen Theorien unterscheiden, haben sie doch gemein, dass Relationen und die Einbettung von Individuen das Handeln und die Identität dieser beeinflussen. Auf der anderen Seite zeigen die Theorien aber auch, dass die Akteur*innen Netzwerke knüpfen und diese in Institutionen übergehen und verfestigt werden können. Die Schwerpunkte der Analyse mögen sich zwar unterscheiden, jedoch gehen alle vom Menschen als soziales Wesen aus, welches selbst mit anderen in Netzwerken verbunden ist. Netzwerke können daher wie folgt definiert werden: Netzwerke sind ,[...] as a specific set of linkages among a defined set of persons, with the additional property that the characteristics of these linkages as a whole may be used to interpret the social behaviour of the persons involved" (Mitchell 1969, S. 2).

Im nächsten Abschnitt sollen sowohl „Grand Theories“ und „Theorien mittlere Reichweite" exemplarisch vorgestellt werden, um dieses beschrieben relationale Denken nochmals zu konkretisieren. Der stärkere Fokus liegt jedoch auf den „Theorien mittlerer Reichweite“, da diese in der Empirie eine größere Bedeutung einnehmen.

\section{1 „Grand Theory“ der Netzwerkforschung}

Unter der ersten Gruppe befinden sich Vorläufer der empirischen Netzwerkanalyse (siehe auch Kap. „Netzwerkanalyse - eine methodische Annäherung“). Zu nennen wäre beispielsweise Georg Simmel (1908), der von einer Wechselwirkung von Individuum und Gemeinschaft ausgeht. Simmel spricht hier von sozialen Kreisen: Organische soziale Kreise sind hierbei „Netzwerke“, in die das Individuum hineingeboren wird (z. B. Familie), während rationale Kreise (z. B. Militär oder Wirtschaftsbetriebe), umfasst. Akteur*innen gehen hierbei Beziehungen ein, die wiederum Auswirkungen auf das Handeln der Individuen selber haben und ihnen Möglichkeiten eröffnen oder sie einschränken. Dabei wurden bei Simmel bereits erste einfache Strukturmerkmale herausgearbeitet (Hollstein 2001). 
Ein weiterer wichtiger relationaler Denker ist Sigfried Nadel. Der österreichische Ethnologe unterscheidet zwischen Rolle, Beziehung und sozialer Struktur. Hierbei können soziale Beziehungen einen generellen Charakter (z. B. Freundschaft) besitzen. Sie sind es, die den Wert einer Rolle beschreiben und die Rolle definieren, die wiederum Erwartungen bei den Akteur*innen im Netzwerk hervorruft: „Thus we take ,friendship' to be evidenced by a variety of mutual ways of acting, perhaps visible on different occasions, such as help in economic or emotional re-responses" (Nadel 1957, S. 9).

Für den Soziologen Nobert Elias (2006) spielen Netzwerke für seine Gesellschaftsanalyse eine essenzielle Rolle. Er spricht hier von Figurationen und meint damit, dass Individuen in Dependenzen zueinander stehen und das soziale Miteinander, und damit auch die Akteur*innen selbst, beeinflussen. Ein Netzwerk umfasst ,[...] viele Menschen, die kraft ihrer elementaren Ausgerichtetheit, ihrer Angewiesenheit aufeinander und ihrer Abhängigkeit voneinander auf die verschiedensten Weisen aneinander gebunden sind und demgemäß miteinander Interdependenzgeflechte oder Figurationen mit mehr oder weniger labilen Machtbalancen verschiedener Art bilden" (Elias 2006, S. 15). Dieser offene Mensch („Homines aperti“) besitzt demnach eine relative Autonomie, er ist jedoch von Geburt an andere Akteur*innen ausgerichtet und auf diese in einem Machtgefüge angewiesen (Elias 2006, S. 169).

Eine wichtige prägende Figur in der aktuellen theoretischen Debatte ist wohl der Physiker und Soziologe Harrison White (2008). Mithilfe des relationalen Denkens versucht er zu erklären, wie Akteur*innen ihre Identität entwickeln. Soziale Identitäten, wie beispielsweise Mann/Frau oder Migrant*in/Nicht-Migrant*in, sind nach White nicht gegebene Fakten, sondern werden in sozialen Netzwerken erst konstruiert. Sie sind nicht gegeben, vielmehr werden sie in Bezug zu anderen Akteur*innen in einem bestimmten Netzwerk ausgehandelt. Akteur*innen setzen sich demnach in Relation zu anderen und versuchen, damit ihre Identität zu konstruieren und zu stabilisieren. Diese Strukturen sind dynamisch und bestehen aus sogenannten „stories“, also Geschichten, geteilte Vergangenheiten oder ausgetauschte Erfahrungen, die Akteur*innen übereinander erzählen und miteinander teilen. Diese Geschichten (stories) konstruieren die Identitäten der Akteur*innen- und ihre Beziehungen zueinander und machen uns zu dem, was wir sind (z. B. Mann/Frau).

Die kleine Auswahl an „Grand Theories“ soll die unterschiedlichen relationalen Denkweisen kurz vorstellen und spiegelt die Debatte in sehr verkürzter Form wider: Netzwerke werden als Grundlage gesellschaftlichen Handelns oder auch von Identität gesehen. Sie sind der Ursprung des Handelns oder werden durch Handlung beeinflusst und besitzen einen universellen Erklärungsanspruch. 


\subsection{Netzwerktheorien der mittleren Reichweite}

Neben den bereits erwähnten „Grand Theories“ existieren auch kleinere „relationtheoretische Ansätze“ mittlerer Reichweite. Deren Fokus liegt zwar auch auf den sozialen Beziehungen und ihren Strukturen, diese Erklärungsmodelle sind jedoch enger gefasst. Zum Teil können die hier folgenden Ansätze auch unter diese gröBeren Theorien subsumiert werden. Es sind theoretische Konzepte, die explizit aus der Netzwerkforschung stammen und auf dieses spezifische Forschungsfeld beschränkt sind. Diese können, bevor eine Studie durchgeführt wird, helfen, Forschungsfragen zu konzipieren, oder auch Ergebnisse zu interpretieren. Einige möchten wir im folgenden Kapitel vorstellen. Dabei haben wir uns für Konzepte entschieden, die in vielen Studien auch empirisch umgesetzt werden. Hierbei handelt es sich nicht um eine vollständige Liste von Konzepten, vielmehr bietet die Auflistung einen Einblick in die konzeptionellen Herangehensweisen. Darunter fallen die theoretischen Ansätze, wie beispielsweise von starken und schwachen Beziehungen, strukturellen Löchern, Homophilie, Beliebtheit, Reziprozität, Balance-Theorie und Cliquen. Viele dieser Ideen werden im Kap. „Netzwerkanalyse - eine methodische Annäherung“" wieder aufgegriffen.

\subsubsection{Strong/weak ties}

Ein sehr wichtiges relationales Konzept geht auf Granovetter (1973) zurück. In seinem Ansatz unterscheidet der Soziologe zwei Arten von Beziehungen anhand ihrer Intensität: starke (strong) und schwache (weak) Beziehungen (ties). Die Differenzierung zwischen starken und schwachen Beziehungen ist demnach ,(probably linear) combination of the amount of time, the emotional intensity, the intimacy (mutual confiding) and the reciprocal services [...]" (Granovetter 1973, S. 1361). Starke Relationen sind geprägt durch beispielsweise Reziprozität, hohe Kontaktintensität, hohe Intimität und Emotion sowie Vertrauen. Darunter fallen z. B. Familienmitglieder oder auch gute Freund*innen. „Weak ties“ hingegen sind lose Beziehungen mit z. B. geringer Kontaktfrequenz, geringer Intimität und Multiplexität. Zu nennen wären hier beispielsweise Urlaubsbekanntschaften, Kolleg*innen und lose Bekanntschaften. Während starke Beziehungen für Aspekte, wie z. B. emotionale Unterstützung von Bedeutung sind, konnte Granovetter zeigen, dass schwache Beziehungen ihren ganz eigenen Nutzen besitzen. Sie ermöglichen einen Zugang zu neuen Informationen und Ressourcen, die nicht aus dem sozialen Nahbereich kommen, da diese, anders als starke Beziehungen, Brücken in andere Subgraphen schlagen (siehe Abb. 1). Dies ist damit begründet, dass diese Beziehungen Pfaddistanzen reduzieren und man dadurch mit Personen in 


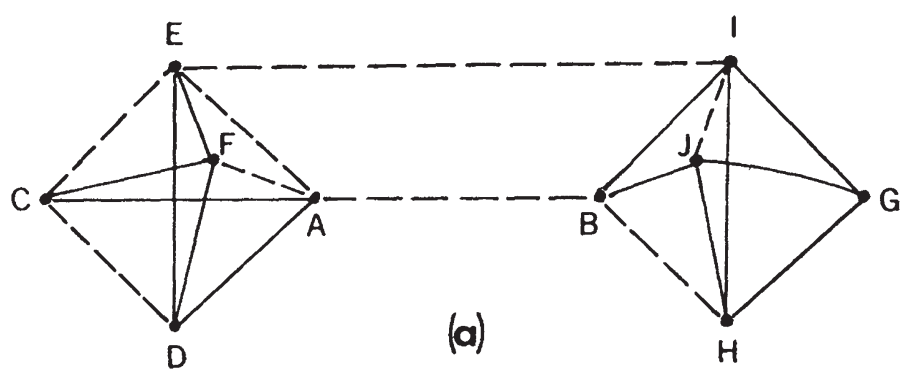

Abb. 1 Die Bedeutung von schwachen Beziehungen nach Granovetter. (Quelle: Granovetter 1973, S. 1365)

Kontakt kommt, die andere Informationen als das enge soziale Umfeld besitzen, welche uns beispielsweise hinsichtlich Interessen und Wissen sehr ähnlich sind. In seiner Studie „Getting a Job“ (Granovetter 1985) konnte Granovetter nachweisen, dass bei der Suche nach einer Arbeitsstelle im Ingenieurbereich besonders schwache Beziehungen Erfolg versprechen. Diese sind sogar von gröBerer Bedeutung als klassische Bewerbungsverfahren. Dieses theoretische Konzept ist in der Gesundheitsforschung von Interesse, wenn davon ausgegangen wird, dass unterschiedliche Beziehungsarten unterschiedliche Konsequenzen auf das Gesundheitsverhalten oder auch das subjektive Wohlbefinden nach sich ziehen. Bei einer solchen Einschätzung muss empirisch (qualitativ oder auch quantitativ) das Konzept und die Unterscheidung immer von Anfang an mitgedacht und definiert werden. $\mathrm{Zu}$ nennen wären hier Studien über die Auswirkung von schwachen Beziehungen und die Diffusion von Selbstmordgedanken (Baller und Richardson 2009) oder die vermittelnde Rolle von starken oder schwachen Beziehungen zwischen Armut, Gesundheit und Wohlbefinden (Cattell 2001). Eine genaue Unterscheidung zwischen beiden Beziehungsarten ist oft nicht eindeutig und kann sich auch von Kontext zu Kontext unterscheiden. Daher ist es für die eigene Forschung wichtig, Parameter für die Unterscheidung deutlich herauszuarbeiten und zu begründen.

\subsubsection{Strukturelle Löcher}

Wie Granovetter beschäftigt sich auch Burt (1992) mit Beziehungsarten und deren unterschiedlichen Wirkungen. Während Granovetter eher den Fokus auf die Intensität der Relation fokussiert, ist für Burt $(1992,2004)$ die Struktur und damit die Position eines Akteurs bzw. einer Akteurin im Netzwerk von essenzieller 


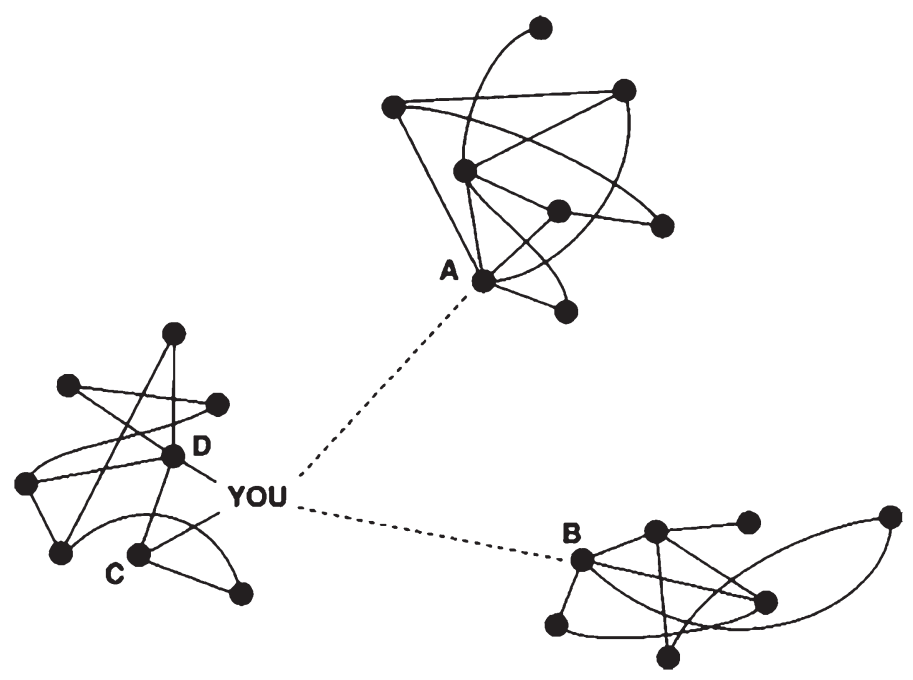

Abb. 2 Strukturelle Löcher. (Quelle: Burt 1992, S. 27)

Bedeutung: ,[...] people have an advantage because of their location in a social structure" (Burt 2004, S. 351). Damit thematisiert er die strukturelle Einbettung der Akteur*innen und den daraus erwachsenden Handlungsmöglichkeiten sowie -restriktionen. Mit strukturellen Löchern sind hierbei fehlende Beziehungen gemeint, die zwei oder mehr Subgraphen trennt (siehe Abb. 2). Diese Löcher verhindern beispielsweise die Weitergabe von Informationen oder anderen Ressourcen. Akteur*innen, die solche Löcher schließen, indem sie Subgraphen verbinden und eine Brückenfunktion einnehmen, können durch ihre strukturelle Verortung Vorteile besitzen. Ein Vorteil ist beispielsweise der Einblick in sehr unterschiedliche Subgraphen, der es erlaubt, nicht redundante Informationen zu generieren bzw. Wissen aus unterschiedlichen Bereichen zusammenzuführen. In seiner sogenannten „Broker“-Position kann er den Fluss von Informationen nach seiner Sicht gestalten (z. B. tertius gaudens ${ }^{1}$ ). Er kann beispielweise regulieren, welche Informationen wann und wie in welches Subnetzwerk weitergegeben werden und welche nicht (Scheidegger 2010).

${ }^{1}$ Damit ist der lachende Dritte gemeint. 
In der Gesundheitsforschung findet man diese Theorie nur selten wieder. $\mathrm{Zu}$ nennen wäre z. B. die egozentrierte Studie von Cornwell (2009). Der Autor geht der Frage nach, inwieweit sich der Gesundheitszustand auf die Überbrückung solcher strukturellen Löcher auswirkt. Dabei stellt der Autor fest, dass kognitive und funktionelle Gesundheit positiv signifikant mit der Überbrückung solche Löcher verbunden sind. Die Studie von Schafer (2013) geht hier einer ähnlichen Frage nach und unterstützt die Ergebnisse von Cornwell (2009).

\subsubsection{Homophilie (Einfluss/Selektion)}

Ein wichtiges Konzept in der Netzwerkforschung ist das der Homophilie. Der Begriff, wie wir ihn heute kennen, stammt von Lazarsfeld und Merton (1954), die Beobachtungen klassischer Netzwerkstudien und Forschungen der Ethnologie zur Ehebildung miteinander verbanden. Vereinfacht bedeutet dies: „Gleich und gleich gesellt sich gern“. Hierbei unterscheiden die beiden Autoren zwischen „status homophily“ und „value homophily“. Erstere bezieht sich sowohl auf zugeschriebene Merkmale wie beispielsweise Ethnie, Geschlecht als auch auf Religion und Bildung. „Value homophily“ bezieht auch auf Personen, die ähnliche Einstellungen oder Denkweisen besitzen, losgelöst von Status der jeweiligen Person. Hinsichtlich der Netzwerke bedeutet dies, dass sich Menschen Beziehungen zu Personen aufbauen, die einen ähnlich sind. McPherson et al. (2001) stellen dabei fest, dass besonders Ethnie, Alter, Religionszugehörigkeit, Bildung, Geschlecht und Beruf Faktoren sind, die innerhalb von Netzwerken wichtig sind: „Homophily in race and ethnicity creates the strongest divides in our personal environments, with age, religion, education, occupation, and gender following in roughly that order" (McPherson et al. 2001, S. 415). Wie es zur Herstellung von Homophilie in Netzwerken kommt, kann anhand zweier unterschiedlicher Prozesse erklärt werden. Zum einen geschieht dies durch Selektionsprozesse. Hier suchen sich die Akteur*innen, die sich aufgrund von einem oder mehreren Attributen ähnlich sind, gegenseitig aus und bilden ein Netzwerk. Zum anderen können sich Akteur*innen suchen, die sich in einem oder mehreren Merkmalen unterscheiden, sich aber im Austausch immer mehr angleichen (Knecht 2008). Auch wenn das Ergebnis ein hoher Homophilie-Wert ist, sind die Prozesse doch different. In der Gesundheitsforschung geht man beispielsweise der Frage nach, inwieweit sich Jugendliche in ihrem Rauchverhalten beeinflussen oder sich selektiv zusammentun (Knecht 2008). Um diese beiden genannten Effekte empirisch unterscheiden zu können, sind zwei Messzeitpunkte notwendig. 


\subsubsection{Beliebtheit: Popularität und preferential attachement}

Eine weitere Theorie der mittleren Reichweite ist die der „Beliebtheit“. In diesem Fall „besitzen“ manche Akteur*innen mehr Beziehungen als andere und sind damit beliebter. Hierbei möchten wir zwei Ansätze unterscheiden. Zum einen das Konzept, das davon ausgeht, dass bestimmte Attribute (z. B. Alter, Geschlecht, Gesundheit) sich auf die Beliebtheit von Akteur*innen auswirken, und zum anderen kann es sein, dass jemand, der bereits viele Beziehungen „besitzt“, aufgrund dieser noch mehr Beziehungsanfragen bekommt. Ersteres kann hier als Popularität bezeichnet werden. Populäre Akteur*innen sind demnach diejenigen, mit denen viele Akteur*innen eine Beziehung eingehen wollen bzw. eingehen. Erste Forschungen konnten zeigen, dass intelligente, extrovertierte und leistungsfähige Schüler*innen populärer sind als andere (Bonney 1946; Young und Cooper 1944). Vor dem Hintergrund des Gesundheitsverhaltens stellen Valente et al. (2005) heraus, dass besonders beliebte Studierende anfangen zu rauchen. „Popular middle school students were more likely to become smokers compared to their less popular peers" (Valente et al. 2005, S. 323).

Beim preferential attachement geht man auch davon aus, dass Beziehungen innerhalb eines Netzwerkes ungleich verteilt sind. Die Prämisse beruht hier jedoch auf den Beziehungen, d. h. das Akteur*innen, die bereits schon viele Beziehungen vereinigen, noch leichter Beziehungen hinzubekommen. Merton (1968) beschreibt dies als „Matthäus-Prinzip“ („Wer hat, dem wird gegeben“). Dieses Phänomen konnte z. B. De Solla Price (1976) anhand von Zitationen in Artikeln (,cumulative advantage“) und Barabási und Albert (1999) für soziale und sozial-technologische Netzwerke (Filmschauspieler*innen, Stromnetz, Internet) (,scale-free“) herausstellen.

\subsubsection{Reziprozität}

Ein wichtiges Grundprinzip, auf dessen Basis es zu unterschiedlichen Formen sozialer Netzwerke kommen kann, ist die Reziprozität (Prinzip der Gegenseitigkeit). Dieses besagt, dass Menschen für eine bestimmte erbrachte Leistung auch eine entsprechende Gegenleistung erwarten. Hier kommt es zum Prinzip von Gabe und Gegengabe (Mauss 2000) und die daraus entstehenden Netzwerke. Diese Erwartung macht viele Formen der sozialen Interaktion überhaupt erst möglich. Simmel geht so weit zu behaupten, dass es ein Grundprinzip von Gesellschaften ist (Simmel 1908 [1989]; s. oben). Hierbei sind Transaktionen zwischen den Akteur*innen nicht immer an einen Preis oder an formale Regeln gebunden. Eine Gegenleistung muss auch nicht in selber Form wie die erhaltene Leistung 
beglichen werden, dennoch sollte sie als mindestens adäquat und ähnlich von dem/der Gabenempfänger*in empfunden werden. Leistet man beispielsweise Freunden Hilfe bei einem Umzug, so kann erwartet werden, später eine ähnliche Leistung zu erhalten. Werden die Erwartungen beim Gabengebenden nicht erfüllt, wird die Reziprozitätsnorm verletzt und dauerhafter sozialer Austausch weniger wahrscheinlich. Reziprozitätsnormen sind von Kultur, historischen Aspekten und der Rolle der involvierten Akteur*innen (z. B. Freund*in, Bekannte*r) abhängig. Zum Beispiel ist man innerhalb der Familie in sogenannten westlichen Staaten für enge Freunde oder Verwandte eher bereit, eine Leistung zu erbringen, ohne eine zeitlich (un-)mittelbare entsprechende Gegenleistung zu erwarten (Sahlins 1999). Ein Recht (z. B. Vertragsrecht) existiert in der Regel nicht. Die Struktur des Austausches zwischen den jeweiligen Tauschpartner*innen kann durch quantitative Netzwerkforschung sehr gut abgebildet werden, Verpflichtungsnormen und Praktiken stehen eher der qualitativen Forschung offen (s. Kap. „Netzwerkanalyse - eine methodische Annäherung"). Beispielweise geht die qualitative Studie von Wentowski (1981) „Reciprocity and the Coping Strategies of Older People: Cultural Dimensions of Network Building“ den Fragen nach 1) wie kulturelle Regeln den Austausch von Unterstützung innerhalb der Netze regeln, und 2) wie Unterschiede in der Art und Weise, wie ältere Menschen diese Regeln bei der Schaffung von Unterstützung im Laufe der Zeit erfahren, interpretieren. Die Forschung zeigt ferner die große persönliche Bedeutung der Gegenseitigkeit für die Erhaltung des psychischen Selbstwertgefühls älterer Menschen. Dennoch stellen Abbott und Freeth (2008) heraus, dass das theoretische Modell der Reziprozität in der Gesundheitsforschung kaum Berücksichtigung findet.

\subsubsection{Balance-Theorie}

Eine psychologische Theorie, die in der Netzwerkforschung eine große Bedeutung einnimmt, ist die der Balance in Triaden. Die Balance-Theorie geht vor allem auf die Gleichgewichtstheorie, die der Konsistenztheorie ${ }^{2}$ zugerechnet $^{2}$ werden kann, zurück. Demnach versuchen Akteur*innen Einstellungen und Überzeugungen widerspruchsfrei zu gestalten (Witte 1989). Vor diesem Hintergrund befasst sich die Gleichgewichtstheorie mit Widersprüchen von Beziehungsstrukturen zwischen Akteur*innen untereinander oder zwischen Akteur*innen und

${ }^{2}$ Die Konsistenztheorie geht davon aus, dass Harmonien in kognitiven Prozessen - wie z. B. Wahrnehmung, Einstellungen - eine positive Wirkung auf das Individuum haben. 

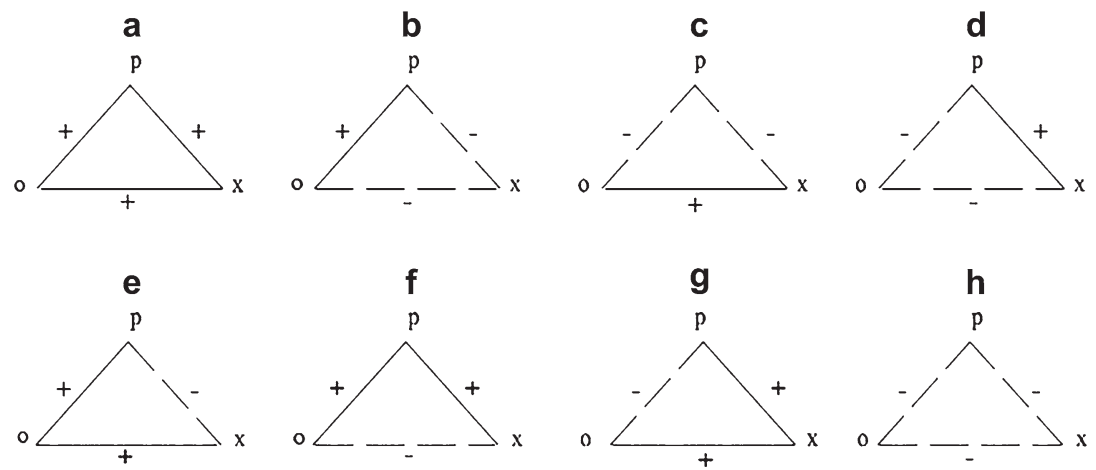

Abb. 3 Unbalancierte und balancierte Triaden. (Quelle: Durchgezogene, mit „, “ markierte Linien sind positive Beziehungen, gestrichelte, mit ,-- " markierte Linien sind negative Relationen. Die Triaden (a)-(d) sind demnach balanciert, die Triaden (e)-(g) sind unbalanciert. Triade (h) ist „unbestimmt“. (Manhart 1995, S. 120))

anderen Elementen (Manhart 1995). Es wird davon ausgegangen, dass Akteur*innen nach einem Gleichgewicht streben. Mit dem Gleichgewichtszustand ist ,[...] eine Situation gemeint, in der die Relationen zwischen den Größen harmonisch zueinander passen; es gibt keinen Drang zu einer Veränderung " (Heider 1977, S. 238). Aus der von Heider (1958) entwickelten Balancetheorie lassen sich Aussagen zu Effekten über Beziehungen ableiten. Der Psychologe ging von folgender Konstellation aus:

1. Eine Person P, eine Person O und einer Situation, ein Ereignis, eine Idee oder eine Sache (X).

2. Es gibt positive und negative Beziehungen.

3. Individuen streben danach, einen Zustand der Balance zu erreichen.

Wann ist nun eine Triade ausbalanciert? Sie ist dann ausbalanciert, wenn alle Beziehungen positiv oder zwei Beziehungen negativ und eine positiv sind. Dies soll anhand eines Beispiels erklärt werden. Nehmen wir an, Person A ist mit Person B befreundet. Gleichzeitig ist Person B aber mit Person C in einer negativen Beziehung. Eine Balance wäre z. B. dann gegeben, wenn Person A auch mit Person $\mathrm{C}$ in einem Konflikt stehen würde. In anderen Worten: Der Feind meines Freundes ist mein Feind. Ein Ungleichgewicht liegt dann vor, wenn eine Beziehung negativ und zwei Relationen positiv sind. Die unterschiedlichen Konstellationen werden in Abb. 3 nochmals dargeboten. 
Die Studie von Cornwell (2009) stellt heraus, dass schlechte Gesundheit Auswirkung auf das Ego-Alter-Alter-Beziehungssystem haben kann. Welche Beziehungen in Triaden überbrückt werden können und welche nicht, muss jedoch noch weiterhin erforscht werden.

\subsubsection{Kleingruppen - Beispiel die Clique}

Kleingruppenforschung nimmt in der Netzwerkforschung eine etablierte und wichtige Stellung ein. Unter einer Kleingruppe versteht man eine überschaubare Anzahl von Akteur*innen, die jeweils miteinander in Kontakt treten können (Homans 1951). Diese Verbindungen sind von besonderem Interesse, da sich dort soziale Mechanismen leichter erforschen lassen. Hierzu gehört z. B. die Clique. „Im alltäglichen Sprachgebrauch bezeichnet der Begriff Clique gemeinhin eine Gruppe von Individuen, welche in relativ engen, direkten und wechselseitigen Beziehungen stehen. Der gemeinsame Zweck, den die Gruppenmitglieder einer Clique verfolgen, kann dabei sehr verschieden sein: Eine Straßengang, ein Kaffeekränzchen oder ein Stammtisch sind nur einige Beispiele für derartige Kleingruppen " (Täuber 2010, S. 397).

Hierbei sind Cliquen ein Teil eines größeren Netzwerkes. Sie sind damit dichte Verbindungen zwischen Akteur*innen in einem Netzwerk. Diese Teilgruppen, so die Annahme, zeigen neben der engen Verbundenheit auch andere Merkmale, wie z. B. hohe Aktivität innerhalb des kleineren Verbundes, große Solidarität und Identifikation untereinander. Damit bilden Cliquen oder auch andere Kleingruppen innerhalb eines Netzwerkes einen eng verbundenen Subgraph bzw. Teilgraph; also ein Netzwerk in einem größeren Netzwerk. Vor dem Hintergrund der Netzwerkforschung kann z. B. eine Clique wie folgt definiert werden: „Eine Clique ist ein maximaler (knotengenerierter) vollständiger Teilgraph. Innerhalb einer Clique sind also alle Knoten durch einen Pfad der Länge 1, d. h. direkt, verbunden " (Trappmann et al. 2005, S. 74). Berechnungsverfahren werden wir im Methodenkapitel noch kennenlernen. Bezüglich der Einbindung in eine Clique und der Gesundheit zeigt die Studie von Ennett und Bauman (1993), dass Schüler*innen, die in Cliquen eingebunden sind, nicht so häufig rauchen wie isolierte Akteur*innen. Auf die psychische Gesundheit stellen Provan und Sebastian (1998) heraus, dass eine Eingebundenheit in ganze Netzwerke eher einen negativen Effekt hat, während die Einbindung in Cliquen, die sich auch überlappen, eher positiv wirken können.

Mit diesem Teil sollte verdeutlich werden, dass neben den „Großen-Theorien“ auch empirisch-orientierte Ansätze existieren. Hierbei ist es wichtig, sich vor der empirischen Umsetzung des eigenen Projekts zu überlegen, welche der 
relationalen Aspekte für die Erklärung oder das Verstehen des zu untersuchenden Phänomens in der eigenen Studie von Bedeutung sind. Hierfür gibt es bereits bestimmte, getestete Möglichkeiten unter denen ausgewählt werden kann (siehe Kap. „Netzwerkanalyse - eine methodische Annäherung“). Wichtig ist hier jedoch, dass diese immer im Bezug zur Gesundheit oder auch zum Gesundheitsverhalten in Beziehung gesetzt werden sollten.

\section{Soziale Netzwerke und Theorie - Ein Fazit}

Netzwerktheorien stellen die Einbettung von Individuen in ihre soziale Umwelt in den Fokus der Betrachtung. Sie gehen davon aus, dass das Handeln bzw. Identitäten und Institutionen in Wechselwirkung mit sozialen Strukturen stehen. Netzwerke werden somit der Mesobene zugerechnet, die zwischen dem individuellen Handeln und den Institutionen verortet sind (Weyer 2012). Wie dieses Kapitel auch gezeigt hat, gibt es jedoch nicht „die eine“ Netzwerktheorie. Allgemein kann in drei unterschiedliche Ausrichtungen unterschieden werden: der strukturalistische Determinismus, der strukturalistische Instrumentalismus und der strukturalistische Konstruktivismus (Emirbayer und Goodwin 1994). Hierbei unterscheiden die Autoren vor allem zwischen dem Bedeutungsanspruch von Relationen für das Verständnis sozialer Phänomene. Ferner variieren sie auch hinsichtlich ihres Erklärungsanspruches. Während die „Grand Theories“ einen allumfassenden Ansatz beanspruchen, mit dem ein universeller Erklärungsanspruch verfolgt wird, bleiben die ,Theorien der mittleren Reichweite“ auch auf ein spezifisches Forschungsfeld beschränkt. Auch wenn sogenannte „Grand Theories“ existieren und auch neuere Ansätze wissenschaftlich große Bedeutung haben, finden diese in der empirischen Forschung nur begrenzt Beachtung. Hier kommen vor allem Theorien mittlerer Reichweite zur Anwendung (siehe Kap. „Netzwerkanalyse - eine methodische Annäherung“). Zu nennen sind hier z. B. die strong/ weak tie-Theorie, die Theorie der strukturellen Löcher, die Triaden-Theorie, Balance-Theorie, die Theorie der Homophilie, Cliquen-Theorie oder auch die der Reziprozität. Die Theorien helfen, die Entstehung von Netzwerken, dessen Wirkung oder ihre Bedeutung für die Akteur*innen zu erklären oder diese besser zu verstehen. Sie dienen auch als Grundlage für die Hypothesenbildung. Welche der Theorien für die eigene Forschung relevant sein könnte, kann hier nicht geklärt werden; die Aufzählung soll jedoch helfen, einen Überblick zu gewinnen, um dann selbst Theorien für das eigene Forschungsvorgehen auszuwählen. 


\section{Leseempfehlungen}

McPherson, M., Smith-Lovin, L., \& Cook, J. M. (2001). Birds of a feather: Homophily in social networks. Annual review of sociology, 27 (1), S. 415444. Ein englischer Artikel zum Thema Homophilie, der einen guten Überblick zum Thema gibt.

White, H. C. (2008). Identity and control: How social formations emerge - second edition (H. C. White, Hrsg.). Princeton: Princeton University Press. Eine der wohl aktuellsten und spannendsten Theoriearbeiten zum Thema Netzwerke.

Emirbayer, M. (1997). Manifesto for a relational sociology. American journal of sociology, 103 (2), S. 281-317. Englischer Artikel, der der Frage nach der Bedeutung von relationalem Denken und relationalen Ideen in der Soziologie auf den Grund geht.

Burt, R. S. (2004). Structural holes and good ideas. American Journal of Sociology, 110, S. 349-399. Ein Artikel, der mit Daten aus der Organisationssoziologie die Idee der strukturellen Löcher und ihre Bedeutung mit einem empirischen Beispiel sehr gut beschreibt.

Granovetter, M. S. (1973). The strength of weak ties. The American Journal of Sociology, 78, S. 1360-1380. Der wohl bekannteste Artikel zum Thema schwache Relationen und deren Wert.

\section{Literatur}

Abbott, S., \& Freeth, D. (2008). Social capital and health: Starting to make sense of the role of generalized trust and reciprocity. Journal of Health Psychology, 13(7), 874-883.

Baller, R. D., \& Richardson, K. K. (2009). The "dark side" of the strength of weak ties: The diffusion of suicidal thoughts. Journal of Health and Social Behavior, 50(3), 261-276.

Barabási, A.-L., \& Albert, R. (1999). Emergence of scaling in random networks. Science, 286, 509-512.

Bonney, M. E. (1946). A sociometric study of the relationship of some factors to mutual friendships on the elementary, secondary, and college levels. Sociometry, 9, 21-47.

Burt, R. S. (1992). Structural holes: The social structure of competition. Cambridge: Harvard University Press.

Burt, R. S. (2004). Structural holes and good ideas. American Journal of Sociology, 110(2), 349-399.

Cattell, V. (2001). Poor people, poor places, and poor health: The mediating role of social networks and social capital. Social Science and Medicine, 52(10), 1501-1516. 
Clyde Mitchell, J. (1969). Social networks in urban situations: Analyses of personal relationships in central african towns. Manchester: Manchester University Press.

Cornwell, B. (2009). Good health and the bridging of structural holes. Social Networks, 31(1), 92-103.

De Solla Price, D. J. (1976). A general theory of bibliometric and other cumulative advantage processes. Journal of the American Society for Information Science, 27(5), 292-306.

Elias, N. (2006). Was ist Soziologie. Weinheim: Juventa. (Erstveröffentlichung 1970).

Emirbayer, M. (1997). Manifesto for a relational sociology. American Journal of Sociology, 103(2), 281-317.

Emirbayer, M., \& Goodwin, J. (1994). Network analysis, culture, and the problem of agency. American Journal of Sociology, 99(6), 1411-1454.

Ennett, S. T., \& Bauman, K. E. (1993). Peer group structure and adolescent cigarette smoking: A social network analysis. Journal of Health and Social Behavior, 34(3), 226-236.

Granovetter, M. S. (1973). The strength of weak ties. The American Journal of Sociology, 78, 1360-1380.

Granovetter, M. S. (1985). Getting a job: A study of contacts and careers. Chicago: University of Chicago Press.

Heider, F. (1958). The psychology of interpersonal relations. New York: Wiley.

Heider, F. (1977). Psychologie der interpersonalen Beziehungen. Stuttgart: Klett.

Heidler, R., \& Gamper, M. (2017). Ein Freund, ein guter Freund? Oder: Über blinde Flecken der stochastischen Modellierungsverfahren ERGM und SIENA am Beispiel von Freundschaften in Schulklassen. In H. Löwenstein \& M. Emirbayer (Hrsg.), Netzwerke, Kultur und Agency. Problemlösungen in relationaler Methodologie und Sozialtheorie (S. 355-380). Weinheim: Beltz Juventa.

Hollstein, B. (2001). Grenzen sozialer Integration. Zur Konzeption informeller Beziehungen und Netzwerke. Opladen: Leske \& Budrich.

Homans, G. C. (1951). The human group. Transaction: Piscataway.

Knecht, A. B. (2008). Friendship selection and friends' influence. Dynamics of networks and actor attributes in early adolescence. Utrecht University. https://dspace.library. uu.nl/handle/1874/25950

Lazarsfeld, P. F., \& Merton, R. K. (1954). Friendship as a social process: A substantive and methodological analysis. In M. Berger, T. Abel, \& C. Page (Hrsg.), Freedom and Control in Modern Society (S. 18-66). New York: Van Nostrand.

Manhart, K. (1995). KI-Modelle in den Sozialwissenschaften: Logische Struktur und wissensbasierte Systeme von Balancetheorien. München: Oldenbourg.

Mauss, M. (2000). The gift: The form and reason for exchange in archaic societies (Reissue Aufl.). New York: Norton.

McPherson, M., Smith-Lovin, L., \& Cook, J. M. (2001). Birds of a feather: Homophily in social networks. Annual Review of Sociology, 27(1), 415-444.

Merton, R. K. (1968). The Matthew effect in science. Science, 159, 56-63.

Mills, C. W. (1959). The sociological imagination. Oxford: Oxford University Press.

Nadel, S. F. (1957). The theory of social structure. London: Routledge.

Provan, K. G., \& Sebastian, J. G. (1998). Networks within networks: Service link overlap, organizational cliques, and network effectiveness. Academy of Management Journal, 41(4), 453-463. 
Sahlins, M. D. (1999). Zur Soziologie des primitiven Tauschs. Berliner Journal für Soziologie, 9(2), 149-178.

Schafer, M. H. (2013). Structural advantages of good health in old age: Investigating the health-begets-position hypothesis with a full social network. Research on Aging, 35(3), 348-370.

Scheidegger, N. (2010). Strukturelle Löcher. In C. Stegbauer \& R. Häußling (Hrsg.), Handbuch Netzwerkforschung (S. 145-155). Wiesbaden: VS.

Scott, J. (2011). Social network analysis: Developements, advances, and prospects. Social Network Analysis and Mining, 1, 21-26.

Simmel, G. (1908). Soziologie. Untersuchungen über die Formen der Vergesellschaftung. Berlin: Duncker \& Humblot. (Erstveröffentlichung 1989).

Täube, V. G. (2010). Cliquen und andere Teilgruppen sozialer Netzwerke. In C. Stegbauer \& R. Häußling (Hrsg.), Handbuch Netzwerkforschung (S. 397-406). Wiesbaden: VS.

Trappmann, M., Hummell, H. J., \& Sodeur, W. (2005). Strukturanalyse sozialer Netzwerke, Konzepte, Modelle, Methoden. Wiesbaden: VS.

Valente, T. W., Unger, J. B., \& Johnson, C. A. (2005). Do popular students smoke? The association between popularity and smoking among middle school students. Journal of Adolescent Health, 37(4), 323-329.

Wentowski, G. J. (1981). Reciprocity and the coping strategies of older people: Cultural dimensions of network building. The Gerontologist, 21(6), 600-609.

Weyer, J. (2012). Soziale Netzwerke: Konzepte und Methoden der sozialwissenschaftlichen Netzwerkforschung. München: Oldenbourg.

White, H. C. (2008). Identity and control: How social formations emerge (2. Aufl.). Princeton: Princeton University Press.

Witten, E. (1989). Quantum field theory and the Jones polynomial. Communications in Mathematical Physics, 121(3), 351-399.

Young, L. L., \& Cooper, D. H. (1944). Some factors associated with popularity. Journal of Educational Psychology, 35, 513-535.

Open Access Dieses Kapitel wird unter der Creative Commons Namensnennung 4.0 International Lizenz (http://creativecommons.org/licenses/by/4.0/deed.de) veröffentlicht, welche die Nutzung, Vervielfältigung, Bearbeitung, Verbreitung und Wiedergabe in jeglichem Medium und Format erlaubt, sofern Sie den/die ursprünglichen Autor(en) und die Quelle ordnungsgemäß nennen, einen Link zur Creative Commons Lizenz beifügen und angeben, ob Änderungen vorgenommen wurden.

Die in diesem Kapitel enthaltenen Bilder und sonstiges Drittmaterial unterliegen ebenfalls der genannten Creative Commons Lizenz, sofern sich aus der Abbildungslegende nichts anderes ergibt. Sofern das betreffende Material nicht unter der genannten Creative Commons Lizenz steht und die betreffende Handlung nicht nach gesetzlichen Vorschriften erlaubt ist, ist für die oben aufgeführten Weiterverwendungen des Materials die Einwilligung des jeweiligen Rechteinhabers einzuholen.

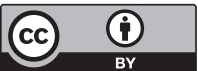




\section{Wirkmechanismen in sozialen Netzwerken}

\section{Andreas Klärner und Holger von der Lippe}

\section{Überblick}

- Soziale Beziehungsnetze gehören weder in der Soziologie noch in der Psychologie zu den Standardkonstrukten. Die Theoriebildung über ihre Effekte auf Gesundheit steht noch am Anfang.

- Wir stellen einige zentrale theoretische Begriffe sowie empirische Ergebnisse zu Netzwerkeffekten unter den Überschriften soziale Unterstützung, soziale Integration, sozialer Einfluss und soziale Ansteckung vor.

- Aktuelle Arbeiten finden oder betonen zunehmend, dass eine einfache Vorstellung zu sozialen Beziehungseffekten auf Gesundheit (etwa: „viel Support oder große Netzwerke helfen viel“") wahrscheinlich wenig realistisch ist.

- Aktuelle Studien bemühen sich stattdessen, ein möglichst differenziertes Bild von Netzwerkeffekten zu zeigen: Hierzu werden als Minimalforderung die Unterscheidungen von (1) direkten vs. indirekten, (2) positiven vs. negativen Gesundheitseffekten durch (3) verschiedene Akteure oder Sektoren des Netzwerkes postuliert.

A. Klärner $(\bowtie)$

Braunschweig, Deutschland

E-Mail: andreas.klaerner@thuenen.de

H. von der Lippe

Berlin, Deutschland

E-Mail: holger.vonderlippe@ medicalschool-berlin.de 
- $\mathrm{Zu}$ dieser differenzierteren Betrachtung von Netzwerkeffekten auf Gesundheit existiert bisher nur wenig konsolidierte Evidenz; Die Forderung nach vermehrten Forschungsanstrengungen ergibt sich daraus.

\section{$1 \quad$ Einleitung}

Der Einfluss und die Bedeutung sozialer Netzwerke in der Gesundheitsforschung sind ein immer breiter diskutiertes Phänomen (Cornwell und Hoagland 2015; Pescosolido und Levy 2002; Smith und Christakis 2008; Valente 2010, 2015). Die Perspektive der soziologischen Netzwerkforschung wird als ein Ansatz verstanden, der die Forderung nach einer stärkeren Berücksichtigung von „Kontexten“ oder der „Umgebung“, die Gesundheit und Pflege beeinflussen, erfüllt (vgl. Pescosolido 2006). Soziale Netzwerke werden als vermittelnde Meso-Ebene konzipiert, die zwischen gesellschaftlichen Makrostrukturen (z. B. Gesundheitssystem, Institutionen, Organisationen etc.) und individuellen, (nicht immer) rational handelnden Akteuren vermittelt (vgl. z. B. Berkman und Glass 2000 sowie Kap. „Soziale Netzwerke und gesundheitliche Ungleichheiten“). Diese Perspektive eröffnet die Möglichkeit, eine Vielzahl psychosozialer Mechanismen zu analysieren, über welche die individuelle Gesundheit über verschiedene Wege des (Gesundheits-)Verhaltens, der Psyche oder der Physiologie beeinflusst wird.

Weder in der allgemeinen soziologischen und psychologischen Netzwerktheorie (vgl. z. B. Agneessens und Wittek 2008; Antonucci et al. 2010; Borgatti und Foster 2003; Erickson 1988; Friedkin 2001; Marsden und Friedkin 1993; Westaby 2012) noch im Bereich der Forschung zu sozialen Netzwerkeinflüssen auf Gesundheit (vgl. z. B. Berkman und Glass 2000; Martin und DiMatteo 2017) herrscht Einigkeit darüber, welche spezifischen Wirkmechanismen unterschieden und in Betracht gezogen werden sollten (für ein ähnliches Dilemma im Bereich der Fertilitätsforschung vgl. Bernardi und Klärner 2014). Von daher ist der folgende Versuch einer Abgrenzung verschiedener Mechanismen - soziale Unterstützung, soziale Integration, sozialer Einfluss und (soziale) Ansteckung - als ein Vorschlag zu verstehen, unterschiedliche in der Literatur diskutierte Mechanismen zu systematisieren. 


\section{Unterstützung, Einbindung, Einfluss und Ansteckung}

In dem in der Einleitung dieses Bandes vorgestellten Netzwerkmodell gesundheitlicher Ungleichheiten (siehe Kap. „Soziale Netzwerke und gesundheitliche Ungleichheiten") werden auf Grundlage verschiedener theoretischer Ansätze und Modelle zum Einfluss sozialer Beziehungen und sozialer Netzwerke auf Gesundheitsverhalten sowie psychische und physische Faktoren, die Gesundheit beeinflussen, die folgenden Netzwerkmechanismen unterschieden:

- Soziale Unterstützung

- Soziale Integration

- Sozialer Einfluss

- Soziale Ansteckung

Dabei lassen sich diese Begriffe nach aktueller Forschungslage als Sammelbegriffe verstehen, die eine ganze Reihe weiterer Unterformen und Teilaspekte sozialer Netzwerkmechanismen (siehe die folgenden Unterpunkte) umschreiben. Dieser konzeptuell offene und am Überblick orientierte Zugang zu möglichen Netzwerkmechanismen auf Gesundheit, den wir in diesem Kapitel verfolgen werden, ist notwendig, da Netzwerke nicht einfach als soziologisches oder psychologisches Standardkonstrukt (wie z. B. communities, organisationale Teams, informelle Gruppen oder Familien) mit bereits gut etablierten Konzepten beschrieben werden können, sondern eine eigene Logik und Dynamik besitzen, die weder theoretisch noch empirisch bislang vollständig verstanden ist. In der Ausarbeitung der genannten Sammelbegriffe orientieren wir uns an den aktuellen Übersichtsdarstellungen bei Harkins et al. (2017).

\subsection{Soziale Unterstützung}

Soziale Unterstützung bezeichnet als Oberbegriff zunächst den allgemeinen Prozess des Austausches von materiellen wie immateriellen Gütern und Dienstleistungen zwischen miteinander verbundenen Akteuren. Das Konzept sozialer Unterstützung ist zentral für unterschiedliche soziologische Theorien, die sich mit „sozialem Kapital“ beschäftigen (z. B. Bourdieu 1986; Coleman 1988; 
Lin 1999a, für eine genauere Begriffsbestimmung siehe Kap. „Soziale Beziehungen, soziales Kapital und soziale Netzwerke").

Im Bereich der Gesundheitsforschung wurden bislang insbesondere die positiven Aspekte sozialer Unterstützung hervorgehoben. So zeigen zahlreiche Studien, die inzwischen auch Metaanalysen beinhalten (z. B. Barth et al. 2010; Röhrle und Strouse 2009; Shor et al. 2013), dass das Vorhandensein und die Inanspruchnahme sozialer Unterstützung das Wohlbefinden erhöht, die Wahrscheinlichkeit für klinischen Diagnosen reduziert und einen positiven Einfluss auf das Coping mit Krankheiten hat (vgl. z. B. Schwarzer und Knoll 2007; Uchino 2006). In einer Studie von Kouvonen et al. (2012) korrelierte etwa emotionale Unterstützung im Netzwerk mit der Aufrechterhaltung gesundheitsförderlicher Freizeitaktivitäten. Für das Verhältnis von sozialen Beziehungsnetzen (im engeren Sinne, d. h. unter Berücksichtigung von Beziehungen der Netzwerkpartner untereinander und den daraus ableitbaren Strukturmaßen, siehe Kap. „Netzwerkanalyse“) und sozialen wie gesundheitlichen Ungleichheiten liegen nach unserem besten Wissen derzeit keine Studien vor. Vonneilich et al. (2012) fanden aber Hinweise, dass soziale Beziehungen zur Erklärung gesundheitlicher Ungleichheiten beitragen. Demzufolge profitieren Personen insbesondere in unteren Statusgruppen von sozialen Kontakten und sozialer Unterstützung. Dies kann sich langfristig positiv in der Gesundheit bemerkbar machen. Soziale Unterstützung hilft, gesundheitlich negative Aspekte eines geringen sozioökonomischen Status abzufedern.

Neben den positiven Effekten sozialer Unterstützung auf Gesundheit und den negativen Effekten bei fehlender Unterstützung hat der theoretisch zu vermutende negative Einfluss gegebener und erhaltener sozialer Unterstützung bislang so gut wie keine Beachtung gefunden (siehe dazu Kap. „Negative Beziehungsaspekte und gesundheitliche Ungleichheiten"). Zwar kann auf der einen Seite das Geben von Unterstützung an Netzwerkpartner das eigene Wohlbefinden erhöhen, indem soziale Anerkennung und Respekt eine Folge der Unterstützungsleistung sind. Das Geben von Unterstützung erhöht - da Austauschprozesse in der Regel auf Reziprozität beruhen - auch die Chance darauf, in Zukunft Unterstützung zurückzubekommen. Auf der anderen Seite kann das Geben von Unterstützung aber auch die eigenen Ressourcen (finanziell, zeitlich, psychologisch etc.) in einer Art und Weise, etwa in Form von Stress, belasten, die der eigenen Gesundheit abträglich sind. Dies ist insbesondere in engen sozialen Beziehungen wie etwa mit Kindern, den eigenen Eltern oder mit dem Partner von Bedeutung (Laireiter und Lettner 1993).

Während sowohl die Sozialkapital- als auch die Unterstützungstheorie davon ausgehen, dass das Ausmaß sozialer Unterstützung entscheidend für Gesundheitseffekte ist, weisen einige Studien jedoch darauf hin, dass nicht alle Befunde 
gleich starke Effekte zeigen und dass die vermeintliche Eindeutigkeit möglicherweise einer genaueren Betrachtung bedarf - insbesondere auch im Hinblick auf die Zusammensetzung und Struktur von Unterstützungsnetzwerken. So fand etwa die Studie von DiNicola et al. (2013) anhand einer Befragung von über 400 COPD-Patienten ${ }^{1}$, dass ein hohes $\mathrm{Maß}$ an erhaltener praktischer Unterstützung durch das Netzwerk die Ängstlichkeit der Patienten sogar signifikant positiv vorhersagte. Aber es scheint mitunter auch darauf anzukommen, aus welchen konkreten Quellen eine derartige Unterstützungsleistung stammt und auch welche spezifische Form von Unterstützung dabei geleistet wird. So fanden etwa Huxhold et al. (2010) mit Daten des repräsentativen Deutschen Alterssurveys (DEAS), dass bei älteren Menschen die erhaltene instrumentelle Unterstützung durch Freunde oder Bekannte erwartungsgemäß das subjektive Wohlbefinden erhöht, während dieselbe Form der Unterstützung jedoch das Wohlbefinden reduziert, wenn sie von Verwandten geleistet wird. Für andere Formen sozialer Unterstützung scheint dies nicht in der gleichen Weise zu gelten, so fanden Primomo et al. (1990) anhand einer Studie mit 125 depressiven Frauen, dass sich die emotionale Unterstützung (affirmation), die von Familienmitgliedern geleistet wird, positiv auf die Genesung auswirkt, dieselbe Unterstützungsleistung von Freunden aber ohne Effekt bleibt.

Insgesamt besteht offenbar Bedarf nach differenzierteren, zum Beispiel netzwerkanalytischen Unterstützungsstudien, um die unterschiedlichen Wirkmechanismen eindeutiger benennen zu können. Konträr zum positiven Zusammenhang von Unterstützung und Gesundheit folgern jüngst Gleason und Iida (2015) in einer einschlägigen Übersicht, dass Unterstützungsleistungen, sofern man sie konkret beobachtet, häufiger als bislang vermutet auch negative oder keine Effekte auf Gesundheitsmaße haben können - etwa dadurch, dass der Empfänger sich für unselbstständig erachtet oder zu einer Gegenleistung genötigt sieht. So schließen die Autoren mit zahlreichen notwendigen Verbesserungen in der aktuellen Unterstützungsforschung wie zum Beispiel einer klareren Unterscheidung zwischen förderlicher und schädlicher sowie zwischen direkter (z. B. emotionaler, instrumenteller) und indirekter (z. B. absichtlicher Rückzug, Nichtbeachtung von

\footnotetext{
${ }^{1}$ COPD bedeutet „chronic obstructive pulmonary disease“, d. h. eine chronische Lungenerkrankung durch Verengung der Atemwege. Diese Krankheit bildet sich auch bei Behandlung nicht wieder vollständig zurück (vgl. https://www.lungeninformationsdienst. de/krankheiten/copd/grundlagen/index.html; Zugriff: 07.02.2019).
} 
Unterstützungswünschen) Unterstützung. Auch die Differenzierung verschiedener Unterstützungsquellen durch Akteure oder Sektoren in Netzwerken scheint unseres Erachtens eine wichtige weitere Ergänzung darzustellen.

\subsection{Soziale Integration}

Die unter dem Konzept der sozialen Einbindung (Kohäsion) bzw. der sozialen Integration gefassten Mechanismen fokussieren darauf, dass Menschen als soziale Wesen nicht nur funktional (etwa qua Unterstützung oder direkten Drucks Anderer), sondern auch emotional und konativ (handlungsbezogen, z. B. „geselliges Beisammensein") auf den Kontakt und den Austausch mit anderen Menschen sowie auf deren Anerkennung (social validation) reagieren (vgl. zu einer genaueren Begriffsbestimmung Kap. „Soziale Beziehungen, soziales Kapital und soziale Netzwerke").

Die soziale Anerkennung durch andere Netzwerkpartner (das können Personen, aber auch Institutionen sein) oder das Engagement in Gruppen und die von diesen ausgedrückten Wertschätzungen der eigenen Person können einen erheblichen positiven Einfluss auf das Selbstbewusstsein und damit auf das Wohlbefinden haben. Im Falle des Ausbleibens oder Versagens dieser Wertschätzung oder allgemeiner: einer mangelhaften sozialen Integration, können negative Folgen für das Selbstwertgefühl entstehen, die u. a. zu depressiven Symptomen führen können (Okamoto et al. 2011).

Ein klassisches Untersuchungsfeld zu diesem Thema lässt sich in der Einsamkeits- und sozialen Isolationsforschung ausmachen (z. B. Elbing 1991). Schon die frühen Untersuchungen von Berkman und Syme (1979) haben eine höhere Mortalität bei sozial weniger eingebundenen Personen nachweisen können. Aber das Konzept der Integration geht aus einer Netzwerkperspektive deutlich über die „Menge“ an sozialen Beziehungen hinaus, denn auch ein Zusammenhang zwischen Netzwerkposition (zentral/marginal/isoliert) und Verhalten lässt sich zeigen, so rauchen z. B. sozial isolierte Personen eher (Seo und Huang 2012). Eine der wenigen Studien, die sich mit dem Zusammenhang von Netzwerken, sozialen Ungleichheiten und Gesundheit beschäftigen, erbrachte den Befund, dass Homophilie, also der Kontakt zu sozial ähnlichen Personen, mit sozioökonomischem Status zunimmt und das Rauchen leicht reduziert (Lorant et al. 2017). Einen zunächst paradox erscheinenden Effekt berichten Kawachi und Berkman (2001), nach dem eine höhere Anzahl von Beziehungen mit einem Anstieg von Symptomen psychischer Krankheiten assoziiert ist. Sie finden dies für Frauen mit geringen sozioökonomischen Ressourcen und 
insbesondere dann, wenn diese Beziehungen mit der sozialen Verpflichtung verbunden sind, selbst Unterstützung für andere zu leisten.

Soziale Integration in Verwandtschafts- und Freundschaftsnetzwerke oder in (semi-)institutionelle Kontexte wie Freiwilligenarbeit und bürgerschaftliches Engagement kann, wie soziale Unterstützung, einen Puffereffekt haben und Stress, Gefühle der Isolation etc. abmildern. Gerade im Bereich der Forschung zu negativen Gesundheitsfolgen von Langzeitarbeitslosigkeit konnte gezeigt werden, dass der Mangel an sozialer Integration und soziale Isolation mit Depressionen und gesundheitsschädigendem Verhalten assoziiert sind. Das Eingebundensein in soziale Kontexte hingegen ist mit positiven Gesundheitseffekten verbunden (vgl. Gore 1978; Schwarzer et al. 1994; Avison 2001): Soziales Engagement und ein aktives soziales Netzwerk tragen zu einem Gefühl der Zugehörigkeit bei, welches wiederum zu einem verbesserten Umgang mit den Folgen psychischer Krankheiten führen kann (Argentzell et al. 2012).

Hier entsteht die Frage, warum soziale Einbettung eigentlich diese positiven Effekte haben kann. Zwei sozialpsychologische Mechanismen sind dazu in der einschlägigen Literatur formuliert worden: social facilitation und social inhibition (McCarty und Karau 2017). Beide bezeichnen das Phänomen, dass die Wahrscheinlichkeit für individuelle (Gesundheits-)Verhaltensweisen durch die Anwesenheit Anderer erhöht (facilitation) oder reduziert (inhibition) werden kann. Dies ist im Gesundheitskontext ein häufiger zu beobachtender Netzwerkeffekt, etwa dann, wenn individuell erwünschtes, aber aufwendiges Verhalten (z. B. gesunde Ernährung, regelmäßiger Sport) dann wahrscheinlicher wird, wenn man es gemeinsam mit anderen unternimmt. Umgekehrt kann individuell unerwünschtes, aber wahrscheinliches Verhalten durch die Anwesenheit Anderer reduziert werden, etwa wenn der Raucher im Beisein von Nichtrauchern auf seinen Konsum verzichtet und der Alkoholkonsument im Beisein anderer seinen Konsum kontrolliert. Hier wird eine Nähe zu den Konzepten sozialen Einflusses deutlich, wobei der wichtige Unterschied darin besteht, dass bei den Mechanismen sozialer Integration keine direkten Einwirkungen auf Gesundheit untersucht werden, sondern eher die beiläufigen und mittelbaren Folgen von Integration oder Geselligkeit betrachtet werden.

Ein weiterer diskutierter Mechanismus in sozialen Kontexten kann das sogenannte groupthink darstellen (McCarty und Karau 2017). Dies bezeichnet den Effekt, der zumeist in engen und dicht verknüpften Netzwerksegmenten (z. B. Cliquen, Familien etc.) auftritt, wenn sich mit der Zeit eine bestimmte Information oder Einstellung bezüglich einer fraglichen Verhaltensoption unter mangelnder Berücksichtigung ihrer Risiken zwischen allen Beteiligten herausbildet. Im Schulkontext ist dies beispielsweise bei peer groups untersucht 
worden. Groupthink beschreibt etwa Schulfreunde, die mit zunehmend gemeinsam verbrachter Zeit zu dem geteilten Entschluss kommen, dass die Risiken des Konsums illegaler Substanzen allgemein überbetont werden und man es daher ruhig einmal ausprobieren könne. Falls vor dem Beginn des gemeinsamen Cliquenkontaktes jeder der Beteiligten noch ganz andere Einschätzungen vertrat, dann aber mit der Zeit den Gruppenkonsens übernahm, wäre dies ein Beispiel für solche Integrationseffekte, welche wiederum gesundheitlich positiv oder negativ ausfallen können.

\subsection{Sozialer Einfluss (Lernen, Druck, Vergleichsprozesse)}

Sozialer Einfluss ist eine Sammelbezeichnung für schwer voneinander abgrenzbare Prozesse, in denen Akteure im Netzwerk mit ihren Handlungen, ihrer Anoder Abwesenheit bewusst oder unbewusst aufeinander einwirken. Im Folgenden wird auf das soziale Lernen und sozialen Druck (social pressure, auch: norm enforcement oder injunctive norms) sowie social compliance (d. h. die individuelle Bereitschaft, sozialen Einflüssen zu entsprechen, auch: norm adherence) als mögliche Netzwerkmechanismen eingegangen.

Ein wichtiger Mechanismus im Bereich sozialer Einflüsse ist zunächst der des sozialen Lernens, d. h. der Prozess der Übernahme, des Austauschs oder der gemeinsamen Bewertung von Informationen, beobachteten Handlungen etc. in einem Netzwerk. Soziales Lernen ist ein Konzept, das in der Sozialpsychologie fest etabliert ist (vgl. z. B. Miller und Dollard 1941; Bandura 1962) und kann zum Beispiel darin bestehen, dass ein bestimmtes Gesundheitsverhalten (z. B. Trampolinspringen, Fahrradfahren, Shisha und E-Zigarette rauchen etc.) von anderen Netzwerkpartnern übernommen wird. Dabei geht man davon aus, dass Individuen die Handlungen und das Verhalten von Anderen beobachten und aus deren Erfahrungen lernen. Je öfter ein Gesundheitsverhalten im Netzwerk vorkommt, desto höher ist die Wahrscheinlichkeit für das einzelne Individuum, diese zu beobachten und selbst einmal auszuprobieren. Der Begriff der „deskriptiven Norm“ bezeichnet das Ergebnis einer solchen Beobachtung: „Descriptive norms are theorized to describe what most people do in a given situation " (Guadagno 2017, S. 119). Burger und Shelton (2011) konnten beispielsweise in einer Studie mit 2643 Einzelbeobachtungen der Treppen- vs. Aufzugnutzung USamerikanischer Studierender in einem dreigeschossigen Unigebäude zeigen, dass das Aufstellen eines Schildes mit dem Hinweis auf die positiven Gesundheitseffekte des Treppensteigens die Nutzung des Aufzugs allenfalls schwach 
von $15,1 \%$ auf $13,3 \%$ reduzierte; dasselbe Schild in der Kontrollbedingungen mit dem Hinweis, dass ,über $90 \%$ aller Personen hier die Treppen nutzen“ aber signifikant stärker, nämlich von $15,3 \%$ auf $8,2 \%$.

Individuen können dabei beobachtete Verhaltens- und Handlungsmodelle von anderen freilich (bewusst oder unbewusst) annehmen, zurückweisen oder aber die Konsequenzen verschiedener Handlungen am „Modell“ vor Augen geführt bekommen. Soziales Lernen führt dann zur individuellen Verhaltensänderung, wenn Beobachtungen, Informationsweitergabe und/oder Diskussionen innerhalb eines Netzwerkes die Ansichten von Individuen über die Machbarkeit und die Konsequenzen bestimmter Handlungen und damit die eigenen Einstellungen und Intentionen bzw. Handlungsabsichten verändern. Im Bereich von Verhaltensinnovationen, z. B. dem Folgen eines neuen „Gesundheitstrends“, sind Individuen, abhängig von ihrer sozialen Position im Netzwerk sowie ihrer Persönlichkeit, in unterschiedlicher Weise und Intensität empfänglich (susceptible, Nezlek und Smith 2017), zurückhaltend oder ablehnend (vgl. Rogers 2003).

Soziales Lernen ist aus einer Netzwerkperspektive von der Art und Weise der Beziehungen und der Beziehungsstruktur in einem Netzwerk abhängig. Zahlreiche Studien im Bereich der Verbreitung von Informationen sowie technischer und sozialer Innovationen haben gezeigt, dass insbesondere schwache Beziehungen und weniger dichte Netzwerke bzw. Teilbereiche von Netzwerken eine besondere Bedeutung bei der Verbreitung von neuen Informationen bzw. Innovationen haben (engl. diffusion of innovation, z. B. Granovetter 1974; Rogers 2003).

Sozialer Druck (social pressure, bisweilen auch norm enforcement oder injunctive norms, Nolan 2017) ist ein in Soziologie und Sozialpsychologie etablierter Begriff, der den Vorgang bezeichnet, dass individuelle Akteure durch soziale Interaktionen unmittelbar dazu gebracht werden, konform mit den in einer Referenzgruppe akzeptierten sozialen Normen zu handeln, etwa um damit Anerkennung in der Gruppe zu gewinnen oder auch Konflikte mit ihren peers zu vermeiden (vgl. die klassischen Arbeiten von Festinger et al. 1950; Asch 1955 hierzu). Soziale Normen können dabei kulturübergreifend gelten, für bestimmte Kulturen oder Institutionen/Organisationen spezifisch sein, mehr oder weniger explizit formuliert und in höherem oder geringerem Maße akzeptiert sein. Normen können sich, wie etwa die Erwartungen, die an bestimmte Geschlechterrollen geknüpft sind, über die Zeit verändern (vgl. z. B. Popitz 2006). Die Chance zur Abweichung von Normen (und damit auch für Innovationen) sind in stark vernetzten, besonders dichten und überschaubaren Netzwerken geringer, weil sie von sozial ähnlichen Akteuren geteilt und weil Sanktionsmechanismen leichter eingesetzt werden können, um normgerechtes Verhalten einzufordern. 
Der Einfluss sozialen Drucks ist im Hinblick auf Gesundheitsverhalten wirksam und kann positive und auch negative Wirkungen haben, indem er sich darauf richtet, gesundheitsschädliches oder gesundheitsförderliches Verhalten aufrechtzuerhalten oder einzustellen. Die Wirkung sozialen Drucks ist von der Struktur des Netzwerkes abhängig. Zudem spielt die Bewertung des Drucks durch die Akteure und die Frage nach Rückzugs-, Ausweich-, oder Vermeidungsmöglichkeiten eine Rolle (Taylor 2015).

Sozialer Druck, der gesundheitsförderlich wirkt, kann darin bestehen, dass Netzwerkpartner (bspw. Ehepartner) darauf achten, dass ihnen nahestehende Personen im Netzwerk physische Symptome ernstnehmen und zum Arzt gehen. Druck, der gesundheitsschädliches Verhalten fördert, kann zum Beispiel von Freundes- und Peergruppen ausgeübt werden, indem sich etwa über Abstinenz von Alkohol und anderen schädlichen Substanzen lustig gemacht wird und die Zugehörigkeit zu einem sozialen Kreis nur aufrechterhalten werden kann, wenn gesundheitsschädigendes Verhalten beibehalten wird. Dies ist besonders wirksam, wenn keine alternativen Kreise vorhanden sind, in denen auf anderen Wegen soziale Anerkennung erlangt werden kann (s. Abschn. 2.2). Hierzu werden die „klassischen" psychologischen Lerntheorien wie Konditionierung oder Modelllernen im Gesundheitskontext diskutiert (z. B. Taylor 2015, S. 51-53).

Aber auch ,gut gemeinter“ sozialer Druck, bestimmte gesundheitsschädliche Verhaltensweisen oder Konsumverhalten einzustellen bzw. gesundheitsförderliches Verhalten aufzunehmen, kann negative, nicht-intendierte Folgen haben, wenn dieser etwa als Einschränkung der eigenen Freiheit erlebt wird und Akteure absichtlich gegensätzlich handeln (Reaktanz). Sozialer Druck selbst kann Stress erzeugen und damit gesundheitsschädlich wirken: etwa, wenn von nahestehenden Netzwerkpartnern Druck ausgeübt wird, um bestimmte Unterstützungsleistungen zu erhalten und damit beispielsweise finanzielle Abhängigkeiten entstehen.

Insbesondere starke, emotional nahestehende und multiplexe Beziehungen sind effektiv, wenn es darum geht, sozialen Druck auszuüben, da sie eine höhere Sanktionsmacht haben. Druck ist gleichfalls in dichten und homogenen Netzwerken, in den sich alle Netzwerkpartner gegenseitig kennen und in denen von gemeinsam geteilten Einstellungen ausgegangen wird, besonders stark und tritt dort mit einer höheren Wahrscheinlichkeit als in weniger dichten, heterogenen Netzwerken auf, wenn einzelne Netzwerkpartner nicht entsprechend der in diesen Netzwerken geltenden sozialen Normen oder Verhaltensmustern agieren (vgl. Burt 1983; Marsden 1987; Coleman 1988). Eine höhere Dichte macht Kontrolle individuellen (von der Gruppennorm abweichenden) Verhaltens und die Koordination von Anreizen und Sanktionen einfacher. 
Neben sozialem Lernen und sozialem Druck sind andere Formen sozialen Einflusses auf die Gesundheit und das Wohlbefinden von Akteuren denkbar: So können Probleme von Netzwerkpartnern wie etwa chronische und andere schwere Krankheiten, Drogensucht, Schulden, langandauernde Arbeitslosigkeit etc. auch zu Problemen von Ego und anderen, nicht direkt betroffenen Netzwerkpartnern werden. Gerade in engen, intimen Beziehungen oder in Eltern-Kind-Beziehungen ist es sogar typisch, dass Probleme dieser Art von einer Person im Netzwerk weitreichende Effekte auf andere Netzwerkmitglieder haben, auch gesundheitlicher Art (sogenannte spill-over-Effekte; Wendt et al. 2008).

Die bisherigen Ausführungen zu Einfluss- oder Druckmechanismen in Beziehungsnetzen wurden stark unter der Wirkrichtung von sozialen Beziehungen auf das Individuum konzipiert, solche Effekte werden jedoch auch in der umgekehrten Richtung untersucht. Beispielhaft für diese andere Sichtweise stehen die Begriffe der social compliance oder social conformity (Guadagno 2017; Hodges 2017). Konformität (conformity) bezeichnet dabei eine individuell initiierte oder intendierte (Gesundheits-)Verhaltensänderung mit dem Ziel, darin mit Anderen Übereinstimmung zu erreichen. Soziale Einwilligung (compliance) beschreibt eine bewusste individuelle (Gesundheits-)Verhaltensänderung, die als direkte Reaktion auf eine Anforderung Anderer geschieht. Welche genauen Bedingungen und Mechanismen dabei notwendige oder hinreichende Bedingungen gesundheitlicher Verhaltensänderungen sind, ist Gegenstand der Forschung. Aktuelle Arbeiten zeigen für beide Mechanismen die Bedeutung der sogenannten lokalen Dominanz (local dominance; vgl. Suls und Wheeler 2017, S. 82 f.). Dies bedeutet, dass emotional nahe und selbstähnliche (homophile) Beziehungen im Netzwerk eine hohe Bedeutung für Konformitäts- und Einwilligungseffekte haben. Individuen werden auch von allgemeinen deskriptiven oder injunktiven Normen zu Konformität oder Einwilligung veranlasst, diese Effekte werden aber verstärkt, wenn - so eine häufige Operationalisierung in der aktuellen Forschung - die fünf wichtigsten Bezugspersonen eines Befragten als Quelle dieser Normen genannt werden.

\subsection{Soziale Ansteckung}

Die Forschung zur sozialen Ansteckung konzentriert sich vor allem auf den konkreten Mechanismus einer unmittelbaren (häufig: physischen, emotionalen, unbewussten) Übertragung von gesundheitsrelevanten Einheiten (häufig: Krankheitserregern, Affekten, Motiven) zwischen Akteuren. Die klassische Form der 
Ansteckung in einem engeren Sinne (dann ohne das Adjektiv „sozial“) meint zunächst die Übertragung durch physischen, direkten oder indirekten Kontakt zwischen Trägern von Krankheitserregern (Viren, Bakterien etc.). Davon zu unterscheiden ist soziale Ansteckung in einem weiteren Sinne.

Seit den 1980er-Jahren haben sich zahlreiche Studien zur Verbreitung von übertragbaren Krankheiten, wie beispielsweise AIDS/HIV, Tuberkulose, Malaria oder Ebola der Erkenntnisse und Methoden der Netzwerkforschung bedient (vgl. z. B. Klovdahl 1985; Hagel et al. 2017; Read et al. 2008). Von besonderer Bedeutung für die Verbreitung von Krankheiten - und damit auch für die Eindämmung etwa durch Immunisierungs- und Aufklärungsprogramme - sind zentrale Positionen in einem Netzwerk, d. h. Personen(-gruppen) oder Institutionen, die mit einer Vielzahl von Akteuren in Verbindung stehen, und überbrückende Verbindungen (bridges) zwischen verschiedenen Teilpopulationen. Kinder im schulpflichtigen Alter sind aufgrund der im Vergleich zu Erwachsenen höheren Zahl von Kontakten durch Atemwegsinfektionen besonders gefährdet (Mossong et al. 2008). Aus sozialepidemiologischer Perspektive ist aber hinzuzufügen, dass mangelnde Hygiene und Infektionskrankheiten in den letzten 40 bis 50 Jahren wahrscheinlich nur in einem geringen Umfang ursächlich für die (Re-)Produktion gesundheitlicher Ungleichheiten waren (Bartley 2017, S. 108).

Unter sozialer Ansteckung wird der Prozess verstanden, in dem eine Person eine Idee, ein Motiv oder ein Verhalten von einer anderen Person übernimmt (Burt und Janicik 1996), meist wird als Voraussetzung für diese Übertragung die soziale Ähnlichkeit zwischen den beiden Akteuren angenommen, die die Übernahme wahrscheinlicher macht. Sozialepidemiologische Studien konnten zeigen, dass sich Netzwerkpartner häufig ähnlich verhalten und ähnliche Gesundheitsgefährdungen aufweisen (Essgewohnheiten, Übergewicht, körperliche Aktivität, Rauchen) (Christakis und Fowler 2007; Fletcher et al. 2011; Macdonald-Wallis et al. 2012; Tay et al. 2013; Valente 2015). Diese Befunde werden oft mit dem Mechanismus der (sozialen) Ansteckung (contagion) erklärt, wobei nicht selten offen bleibt, wie genau vor allem die sozialen Ansteckungsprozesse ablaufen oder wirken.

Der Prozess der sozialen Ansteckung ist dabei zunächst einmal abhängig von den Strukturen bzw. den sozialen Netzwerken, in die die Akteure eingebettet sind. Dabei erhöht die Kontakthäufigkeit und die Intensität der Kontakte zu anderen Personen oder Gruppen die Wahrscheinlichkeit der Ansteckung. Je komplexer und unübersichtlicher die Struktur ist, desto weniger wahrscheinlich ist es, dass die soziale Ähnlichkeit wahrgenommen und Ansteckungsprozesse ausgelöst werden. Eine Abgrenzung zum Mechanismus des sozialen Lernens oder auch dem des sozialen Drucks ist nicht immer möglich und teilweise wird ein rein metaphorischer Gebrauch des Begriffs kritisiert (vgl. z. B. Lois 2013). 
Eine Möglichkeit, soziale Ansteckung von den genannten Phänomenen der sozialen Integration zu unterscheiden, besteht darin, sich auf die sozialpsychologischen Konzepte emotionaler Ansteckung (emotional contagion) und der Nachahmung (mimicking; imitation) zu beziehen (Hodges 2017; vgl. Bernardi und Klärner 2014), wodurch deutlich wird, dass es hierbei nicht um die Erleichterung oder Erschwerung von ohnehin intendiertem Verhalten geht. Emotionale Ansteckung beschreibt vielmehr die Beobachtung, dass Individuen spontan emotionale Stimmungen und damit verbundenes Verhalten (Lachen, Weinen, Furcht, Freude, Aufregung etc.) von anderen Individuen oder Gruppen, mit denen sie in Kontakt kommen, aufnehmen können (vgl. Lippitt et al. 1952; Hatfield et al. 1994). Nachahmung bezeichnet die unbewusste oder unbemerkte Übernahme von Einstellungen, Zielen oder Verhaltensweisen von anderen (vgl. Aarts et al. 2004; Marsden und Friedkin 1993). Dieser Vorgang wird zwar häufig als unbewusst, aber dennoch als selektiv beschrieben, was bedeutet, dass er bestimmten Mustern folgt: Imitiert werden vermehrt andere Personen, die als verlässlich wahrgenommen werden und die selbstähnlich (homophil) bzw. Teil einer engen Clique sind (Hodges 2017). Dieser Mechanismus betont also, dass Verhalten in komplexen sozialen Umwelten wie sozialen Netzwerken auch unterhalb der eigenen Wahrnehmungs- oder Bewusstseinsschwelle beeinflusst werden kann, was in der Konsequenz die einigen soziologischen Handlungstheorien zugrunde liegenden Rationalitätsannahmen menschlichen Verhaltens etwas relativiert.

Die Mechanismen emotionaler Ansteckung und Nachahmung werden in einen Zusammenhang mit eher kurz anhaltenden und konkreten sozialen Situationen gestellt (z. B. ein jubelndes Konzertpublikum etc.), aber es gibt Hinweise darauf, dass sich auch länger währende emotionale Zustände wie Fröhlichkeit oder Einsamkeit in sozialen Netzwerken verbreiten (Cacioppo et al. 2009; Fowler und Christakis 2008; Hill et al. 2010). Martin und DiMatteo (2017) konstatieren: „[...]The social influence of health-relevant behaviors often goes largely unrecognized by the individual" (S. 386). Sie illustrieren dies am Beispiel von Forschungen zur Nahrungsaufnahme: Hetherington et al. (2006) hatten anhand einer experimentellen Studien mit 37 Erwachsenen zeigen können, dass bei der gemeinsamen Nahrungsaufnahme mit Fremden im Schnitt mehr Kalorien aufgenommen werden als beim Alleinessen - wobei keiner der Befragten sich dieses Effektes bewusst war. Salvy et al. (2009) zeigten anhand eines experimentellen Designs mit 54 Erwachsenen, dass die gemeinsame körperliche Aktivität mit Anderen geeignet sein kann, die Essensaufnahme zu ersetzen. Und Bleich et al. (2012) fanden anhand einer repräsentativen Erhebung mit 500 US-Allgemeinmedizinern, dass bei gleicher Ausbildung und gleicher formaler Qualifikation diejenigen Ärzte mit einem BMI im Normalbereich deutlich erfolgreicher 
hinsichtlich der Gewichtsreduktion ihrer Patienten waren als jene Ärzte mit Übergewicht - ebenfalls ein Beispiel für einen unterschwelligen Ansteckungsmechanismus.

\section{$3 \quad$ Fazit und Ausblick}

Aus dieser Zusammenstellung von allgemeinen Wirkmechanismen in sozialen Beziehungsnetzen - entlang der Sammelbegriffe soziale Unterstützung, sozialer Einfluss, soziale Integration und soziale Ansteckung - wird ersichtlich, dass soziale Netzwerke in ihrer Wirkung vielgestaltig und auch ambivalent sein können, d. h. sowohl der Gesundheit abträgliche als auch förderliche Wirkung entfalten können. Soziale Beziehungen und die Integration in soziale Netzwerke können Gesundheit nicht nur unterstützen, sondern auch mit negativen Vorbildern oder auch Konflikten zwischen einzelnen Netzwerkakteuren bzw. (Teil-) Gruppen in diesen Netzwerken einhergehen, was direkte und indirekte negative Gesundheitsfolgen haben kann. Diese Ambivalenzen und die gesundheitsschädlichen Wirkungen sozialer Beziehungen werden detaillierter im Kap. „Negative Beziehungsaspekte und gesundheitliche Ungleichheiten“ diskutiert.

Im Hinblick auf den Forschungsstand zu den Wirkmechanismen sozialer Netzwerke im Kontext von Gesundheit und gesundheitlichen Ungleichheiten verbleibt für uns ein zweigeteiltes Fazit. Zum einen lässt sich aus der aktuellen Literaturlage eine hinreichende Zahl von Belegen finden, die auf die grundsätzliche Bedeutung sozialer Netzwerkeffekte für Forschung und Praxis hindeuten. Oder wie Martin und DiMatteo (2017) es jüngst zusammenfassen: „The use of social influence processes holds a good deal of promise in fostering health behavior, in individuals as well as in populations. The influence of family members, friends, peers, and even perceived others can be harnessed to maximize positive health behaviors across all developmental periods" (S. 390; unsere Herv.).

Zum anderen muss aber ebenso festgehalten werden, dass dieses grundlegende Versprechen in weiten Teilen forschungsseitig noch nicht in zufriedenstellender Weise in Angriff genommen oder eingelöst bzw. umgesetzt wurde. Beispielhaft wurde das in den o.g. Ausführungen darin deutlich, dass bislang ein integratives Modell fehlt, welches alle vorgestellten Begriffe und Effekte in einen gemeinsamen Zusammenhang stellt, abgrenzt und auch präzisiert. Ein Teil der bisher vorfindlichen begrifflichen Unklarheiten, die wir oben beispielsweise an der engen Überlappung von sozialer Integration und sozialer Ansteckung oder der Vielfalt der Konstrukte zum sozialen Einfluss angedeutet haben, hat unseres 
Erachtens in der geringen Integration der verschiedenen beteiligten Disziplinen seine Ursache. Auch Heesacker (2017) führt dies auf die bisherige Distanz der beteiligten Disziplinen zurück: „Arguably the most important future direction in this area is refocusing the efforts of social influence scholars back onto clinical applications of social influence theory and research" (S. 373).

So sind die von uns gewählten vier Sammelbegriffe durchaus heuristisch nützlich, um das unübersichtliche Feld sozialer Wirkmechanismen in Beziehungsnetzen zu strukturieren. Wir haben hierbei zunächst festgestellt, dass soziale Unterstützung als Sammelbegriff Gesamtpakete übergreifender Unterstützungsleistungen für das Individuum bezeichnet (siehe dazu auch Kap. „Soziale Beziehungen, soziales Kapital und soziale Netzwerke"). Während es zu diesem Sammelbegriff bereits metaanalytische Belege gibt, die sich allerdings in der numerische Stärke der festgestellten Gesundheitseffekte weiterhin unterscheiden (zwischen schwachen bis mittleren Effekten), verbleiben insbesondere zwei Aspekte als Forschungsdesiderata. Zum einen bleibt es weiter unklar, ob es sich bei sozialer Unterstützung um ursächliche, konkomitante (Mediator-/Moderator-) oder resultierende Variablen von gesundheitlichen Ungleichheiten handelt. Dies ist also die Frage nach dem konzeptuellen Ort von sozialer Unterstützung in der Forschung zu gesundheitlichen Ungleichheiten. Zum anderen bleibt die Frage nach den konkreten Teileffekten von unterschiedlichen Netzwerksegmenten zu klären. Wie wir gesehen haben, scheinen bisweilen spezifische Unterstützungsleistungen konkreter Teilbereiche eines Netzwerkes durchweg positive, andere Leistungen anderer Teilbereiche aber auch negative Gesundheitseffekte haben zu können. Hier besteht Klärungsbedarf.

In Bezug auf den Sammelbegriff des sozialen Einflusses als Oberbegriff für direkte Gesundheitseffekte des sozialen Kontextes haben wir soziale Effekte in Form von deskriptiven und injunktiven (Druck-)Normen von den besonderen individuellen Voraussetzungen der Empfänglichkeit (susceptibility, conformity, compliance) für diese unterschieden. Die Betrachtung von Netzwerk-Person-Interaktionen erscheinen uns für die weitere Forschung in besonderem Maße angezeigt, was bislang unseres Wissens nach zu wenig umgesetzt wurde.

Aber auch indirekte Gesundheitseffekte in der Form, dass das Individuum in Form von Geselligkeit, gesellschaftlichem Engagement, Vereinen oder Arbeitskontexten in verschiedene Beziehungskontexte eingebettet ist (Einbettung war der berühmte Begriff von Granovetter), scheinen uns ein nicht zu unterschätzender zukünftiger Forschungsbereich zu sein. In diesem Forschungsbereich der sozialen Integration wird weniger als in den Bereichen zuvor nach direkten Gesundheitseffekten (etwa in Form von Normen) gesucht, sondern darauf geschaut, inwiefern 
soziale Anerkennung und Wertschätzung sowie die sozialpsychologischen Effekte von facilitation, inhibition oder groupthink indirekt dazu beitragen können, das psychische Wohlbefinden, aber auch Verhaltensweisen, die auf lange Frist gesundheitliches Wohlergehen stärken oder schwächen können, zu befördern oder aber zu verunwahrscheinlichen.

Während die drei erstgenannten Sammelbegriffe für uns für die forschungsseitige Suche nach Netzwerkfaktoren für gesundheitliche Ungleichheiten stehen, befasst sich der vierte Sammelbegriff der sozialen Ansteckung direkt mit darüber hinausgehenden, möglichen und direkten Effekten Mechanismen. Die empirische Rekonstruktion, wie und in welcher Geschwindigkeit konkrete Krankheitserreger oder gesundheitsrelevante Motive, Affekte oder Ideen in Beziehungsnetzen diffundieren (nicht selten unterhalb der Bewusstseinsschwelle der Individuen), verweist auf weitere wichtige Forschungsaspekte, welche die bereits genannte Forschung zu den Wirkfaktoren sozialer Beziehungsnetze an einer wichtigen Stelle ergänzen können.

Der Bedarf nach einem allgemeinen, sparsamen und trennscharfen theoretischen Modell ist damit freilich keineswegs befriedigt. Wenn zukünftige Forschung die angemahnten Unterscheidungen vor allem auch von 1) direkten vs. indirekten, 2) positiven vs. negativen Gesundheitseffekten durch 3) verschiedene Akteure oder Sektoren des Netzwerkes stärker beherzigt, dürfte sich mit der Zunahme empirischer Befunde auch die theoretische Lage weiter klären und vereinheitlichen lassen. Hier sehen wir die interdisziplinäre Anschlussfähigkeit des Paradigmas der sozialen Netzwerkforschung in besonderer Weise aufgerufen und geeignet, diese zukünftigen Schritte anzustoßen und konkreter als bislang auszuformulieren.

\section{Leseempfehlungen}

Berkman, L. F., \& Glass, T. (2000): Social integration, social networks, social support, and health. In: L. F. Berkman und I. Kawachi (Hrsg.), Social epidemiology. New York, NY [u. a.]: Oxford Univ. Press, S. 137173. Diskussion und Fruchtbarmachung wichtiger Konzepte der Netzwerktheorie und -analyse für die Gesundheitsforschung.

Christakis, N. A., \& Fowler, J. H. (2007). The spread of obesity in a large social network over 32 years. The New England Journal of Medicine, 357, S. 370-379. Breit rezipierte und (kritisch) diskutierte Längsschnittanalyse zur Verbreitung von Fettleibigkeit über den Mechanismus der sozialen Ansteckung (vgl. dazu auch Klärner und Keim 2019).

Harkins, S. G., Williams, K. D., \& Burger, J. M. (Hrsg.) (2017). The Oxford handbook of social influence. New York, NY, US: Oxford University 
Press. Standardwerk, in dem das sozialpsychologische Konzept des sozialen Einflusses in seinen verschiedenen Facetten, u. a. auch in Bezug zu Gesundheit, diskutiert wird.

Klovdahl, A. (1985): Social networks and the spread of infectious diseases: the AIDS example. Social Science and Medicine, 21 (11), S. 1203-16. Klassische Studie zum Netzwerkmechanismus der Ansteckung.

Valente, T. W. (2010): Social networks and health. Models, methods, and applications. Oxford, New York: Oxford University Press. Diskussion und Fruchtbarmachung wichtiger Konzepte der Netzwerktheorie und-analyse für die Gesundheitsforschung.

\section{Literatur}

Aarts, H., Gollwitzer, P. M., \& Hassin, R. R. (2004). Goal contagion: Perceiving is for pursuing. Journal of Personality and Social Psychology, 87(1), 23-37.

Agneessens, F., \& Wittek, R. (2008). Social capital and employee well-being: Disentangling intrapersonal and interpersonal selection and influence mechanisms. Revue Française de Sociologie, 49(3), 613-637.

Antonucci, T. C., Fiori, K. L., Birditt, K., \& Jackey, L. M. H. (2010). Convoys of social relations: Integrating life-span and life-course perspectives. In M. E. Lamb, A. M. Freund, \& R. M. Lerner (Hrsg.), The handbook of life-span development: Bd. 2. Social and emotional development(S. 434-473). Hoboken: Wiley.

Argentzell, E., Håkansson, C., \& Eklund, M. (2012). Experience of meaning in everyday occupations among unemployed people with severe mental illness. Scandinavian Journal of Occupational Therapy, 19(1), 49-58.

Asch, S. E. (1955). Opinions and social pressure. Scientific American, 193(5), 31-35.

Avison, W. (2001). Unemployment and its consequences for mental health. In V. W. Marshall, W. R. Heinz, H. Krüger, \& A. Verma (Hrsg.), Restructuring work and the life course (S. 177-200). Toronto: University of Toronto Press.

Bandura, A. (1962). Social learning through imitation. In M. R. Jones (Hrsg.), Nebraska symposium on motivation (S. 211-269). Lincoln: University of Nebraska Press.

Barth, J., Schneider, S., \& Von Känel, R. (2010). Lack of social support in the etiology and the prognosis of coronary heart disease: A systematic review and meta-analysis. Psychosomatic Medicine, 72(3), 229-238.

Bartley, M. (2017). Health inequality: An introduction to concepts, theories and methods. Cambridge: Polity.

Berkman, L. F., \& Glass, T. (2000). Social integration, social networks, social support, and health. In L. F. Berkman \& I. Kawachi (Hrsg.), Social epidemiology (S. 137-173). New York: Oxford University Press. 
Berkman, L. F., \& Syme, S. L. (1979): Social networks, host resistance, and mortality. A nine-year follow-up study of Alameda County residents. American Journal of Epidemiology, 109(2), 186-204.

Bernardi, L., \& Klärner, A. (2014). Social networks and fertility. Demographic Research, 30(22), 641-670.

Bleich, S. N., Bennett, W. L., Gudzune, K. A., \& Cooper, L. A. (2012). Impact of physician BMI on obesity care and beliefs. Obesity, 20(5), 999-1005.

Borgatti, S., \& Foster, P. C. (2003). The network paradigm in organizational research: A review and typology. Journal of Management, 29(6), 991-1013.

Bourdieu, P. (1986). The forms of capital. In J. G. Richardson (Hrsg.), The handbook of theory: Research for the sociology of education (S. 241-258). New York: Greenwood Press.

Burger, J. M., \& Shelton, M. (2011). Changing everyday health behaviors through descriptive norm manipulations. Social Influence, 6(2), 69-77.

Burt, R. S. (1983). Applied Network Analysis. Beverly Hills: SAGE.

Burt, R. S., \& Janicik, G. A. (1996). Social contagion and social structure. In D. Iacobucci (Hrsg.), Networks in Marketing (S. 32-49). Thousand Oaks: SAGE.

Cacioppo, J. T., Fowler, J. H., \& Christakis, N. A. (2009). Alone in the crowd: The structure and spread of loneliness in a large social network. Journal of Personality and Social Psychology, 97(6), 977-991.

Christakis, N. A., \& Fowler, J. H. (2007). The spread of obesity in a large social network over 32 years. The New England Journal of Medicine, 357, 370-379.

Coleman, J. S. (1988). Social capital in the creation of human capital. The American Journal of Sociology, 94, S95-S120.

Cornwell, B., \& Hoagland, E. (2015). Survey methods for social network research. In T. P. Johnson (Hrsg.), Health survey methods (S. 275-313). Hoboken: Wiley.

DiNicola, G., Julian, L., Gregorich, S. E., Blanc, P. D., \& Katz, P. P. (2013). The role of social support in anxiety for persons with COPD. Journal of Psychosomatic Research, 74(2), 110-115.

Elbing, E. (1991). Einsamkeit: Psychologische Konzepte, Forschungsbefunde und Treatmentansätze. Göttingen: Hogrefe.

Erickson, B. H. (1988). The relational basis of attitudes. In B. Wellman \& S. D. Berkowitz (Hrsg.), Social structures: A social network approach (S. 99-121). Cambridge: Cambridge University Press.

Festinger, L., Schachter, S., Back, K., Bauer, C., \& Woods, R. (1950). Social pressures in informal groups: A study of human factors in housing. New York: Harper.

Fletcher, A., Bonell, C., \& Sorhaindo, A. (2011). You are what your friends eat: Systematic review of social network analyses of young people's eating behaviours and bodyweight. Journal of Epidemiology and Community Health, 65(6), 548-555.

Fowler, J. H., \& Christakis, N. A. (2008). Dynamic spread of happiness in a large social network: Longitudinal analysis over 20 years in the Framingham Heart Study. British Medical Journal, 337, a2338.

Friedkin, N. E. (2001). Norm formation in social influence networks. Social Networks, 23(3), 167-189. 
Gleason, M. E. J., \& Iida, M. (2015). Social support. In M. Mikulincer, P. R. Shaver, J. A. Simpson, \& J. F. Dovidio (Hrsg.), APA handbook of personality and social psychology: Bd. 3. Interpersonal relations (S. 351-370). Washington: American Psychological Association.

Gore, S. (1978). The effect of social support in moderating the health consequences of unemployment. Journal of Health and Social Behavior, 19(2), 157-165.

Granovetter, M. S. (1974). Getting a job. A study of contacts and careers. Cambridge: Harvard University Press.

Guadagno, R. E. (2017). Compliance: A classic and contemporary review. In S. G. Harkins, K. D. Williams, \& J. M. Burger (Hrsg.), The Oxford handbook of social influence (S. 107-127). New York: Oxford University Press.

Hagel, C., Weidemann, F., Gauch, S., Edwards, S., \& Tinnemann, P. (2017). Analysing published global Ebola virus disease research using social network analysis. PLoS Neglected Tropical Diseases, 11(10), e0005747. https://doi.org/10.1371/journal. pntd.0005747.

Harkins, S. G., Williams, K. D., \& Burger, J. M. (2017). The Oxford handbook of social influence. New York: Oxford University Press.

Hatfield, E., Cacioppo, J. T., \& Rapson, R. L. (1994). Emotional Contagion. New York: Cambridge Press.

Heesacker, M. (2017). Social influence and clinical intervention. In S. G. Harkins, K. D. Williams, \& J. M. Burger (Hrsg.), The Oxford handbook of social influence (S. 261379). New York: Oxford University Press.

Hetherington, M. M., Anderson, A. S., Norton, G. N. M., \& Newson, L. (2006). Situational effects on meal intake: A comparison of eating alone and eating with others. Physiology \& Behavior, 88(4-5), 498-505.

Hill, A. L., Rand, D. G., Nowak, M. A., \& Christakis, N. A. (2010). Emotions as infectious diseases in a large social network: The SISa model. Proceedings of the Royal Society B: Biological Sciences, 277(1701), 3827-3835.

Hodges, B. H. (2017). Conformity and divergence in interactions, groups, and culture. In S. G. Harkins, K. D. Williams, \& J. M. Burger (Hrsg.), The Oxford handbook of social influence (S. 87-105). New York: Oxford University Press.

Huxhold, O., Mahne, K., \& Naumann, D. (2010). Soziale Integration. In A. Motel-Klingebiel, S. Wurm, \& C. Tesch-Römer (Hrsg.), Altern im Wandel. Befunde des Deutschen Alterssurvey (DEAS) (S. 215-233). Stuttgart: Kohlhammer.

Kawachi, I., \& Berkman, L. F. (2001). Social ties and mental health. Journal of Urban Health, 78(3), 458-467.

Klärner, A., \& Keim, S. (2019). Christakis/Fowler: The spread of obesity in a large social network over 32 years. In B. Holzer \& C. Stegbauer (Hrsg.), Schlüsselwerke der Netzwerkforschung (S. 111-113). Wiesbaden: Springer.

Klovdahl, A. (1985). Social networks and the spread of infectious diseases: The AIDS example. Social Science and Medicine, 21(11), 1203-1216.

Kouvonen, A., De Vogli, R., Stafford, M., Shipley, M. J., Marmot, M. G., Cox, T., Vahtera, J., Väänänen, A., Heponiemi, T., Singh-Manoux, A., \& Kivimäki, M. (2012). Social support and the likelihood of maintaining and improving levels of physical activity: The Whitehall II study. European Journal of Public Health, 22(4), 514-518. 
Laireiter, A.-R., \& Lettner, K. (1993). Belastende Aspekte sozialer Netzwerke und sozialer Unterstützung. In A.-R. Laireiter (Hrsg.), Soziales Netzwerk und soziale Unterstützung. Konzepte, Methoden und Befunde (S. 101-114). Bern: Huber.

Lin, N. (1999a). Building a network theory of social capital. Connections, 22(1), 28-51.

Lin, N. (1999b). Social networks and status attainment. Annual Review of Sociology, 25, 467-487.

Lippitt, R., Polansky, N., \& Rosen, S. (1952). The dynamics of power: A field study of social influence in groups of children. Human Relations, 5(1), 37-64.

Lois, D. (2013). Zur Erklärung von sozialer Ansteckung beim Übergang zur Elternschaft. Kölner Zeitschrift für Soziologie und Sozialpsychologie, 65(3), 397-422.

Lorant, V., Rojas, V. S., Robert, P.-O., Kinnunen, J. M., Kuipers, M. A. G., Moor, I., Roscillo, G., Alves, J., Rimpelä, A., Federico, B., Richter, M., Perelman, J., \& Kunst, A. E. (2017). Social network and inequalities in smoking amongst school-aged adolescents in six European countries. International Journal of Public Health, 62(1), 53-62.

Macdonald-Wallis, K., Jago, R., \& Sterne, J. A. C. (2012). Social network analysis of childhood and youth physical activity: A systematic review. American Journal of Preventive Medicine, 43(6), 636-642.

Marsden, P. V. (1987). Core discussion networks of Americans. American Sociological Review, 52(1), 122-131.

Marsden, P. V., \& Friedkin, N. E. (1993). Network studies of social influence. Sociological Methods \& Research, 22(1), 127-151.

Martin, L. R., \& DiMatteo, M. R. (2017). Social influence and health. In S. G. Harkins, K. D. Williams, \& J. M. Burger (Hrsg.), The Oxford handbook of social influence (S. 381394). New York: Oxford University Press.

McCarty, M. K., \& Karau, S. J. (2017). Social inhibition. In S. G. Harkins, K. D. Williams, \& J. M. Burger (Hrsg.), The Oxford handbook of social influence (S. 165-181). New York: Oxford University Press.

Miller, N. A., \& John Dollard, J. (1941). Social learning and imitation. New Haven: Yale University Press.

Mossong, J., Hens, N., Jit, M., Beutels, P., Auranen, K., Mikolajczyk, R., Massari, M., Salmaso, S., Tomba, G. S., Wallinga, J., Heijne, J., Sadkowska-Todys, M., Rosinska, M., \& Edmunds, W. J. (2008). Social contacts and mixing patterns relevant to the spread of infectious diseases. PLoS Medicine, 5(3), e74. https://doi.org/10.1371/journal. pmed.0050074.

Nezlek, J. B., \& Smith, C. V. (2017). Social influence and personality. In S. G. Harkins, K. D. Williams, \& J. M. Burger (Hrsg.), The Oxford handbook of social influence (S. 53-68). New York: Oxford University Press.

Nolan, J. M. (2017). Social norms and their enforcement. In S. G. Harkins, K. D. Williams, \& J. M. Burger (Hrsg.), The Oxford handbook of social influence (S. 147-164). New York: Oxford University Press.

Okamoto, J., Johnson, C. A., Leventhal, A., Milam, J., Pentz, M. A., Schwartz, D., \& Valente, T. W. (2011). Social network status and depression among adolescents: An examination of social network influences and depressive symptoms in a Chinese sample. Research in Human Development, 8(1), 67-88. 
Pescosolido, B. A. (2006). Of pride and prejudice: The role of sociology and social networks in integrating the health sciences. Journal of Health and Social Behavior, 47(3), 189-208.

Pescosolido, B. A., \& Levy, J. A. (2002): The role of social networks in health, illness, disease and healing. the accepting present, the forgotten past, and the dangerous potential for a complacen future. In J. A. Levy \& B. A. Pescosolido (Hrsg.), Social networks and health (S. 3-25). Amsterdam: JAI/Elsevier.

Popitz, H. (2006). Soziale Normen. Frankfurt a. M.: Suhrkamp.

Primomo, J., Yates, B. C., \& Woods, N. F. (1990). Social support for women during chronic illness: The relationship among sources and types to adjustment. Research in Nursing \& Health, 13(3), 153-161.

Read, J. M., Eames, K. T. D., \& Edmunds, W. J. (2008). Dynamic social networks and the implications for the spread of infectious disease. Journal of the Royal Society, Interface, 5(26), 1001-1007.

Röhrle, B., \& Strouse, J. (2009). Der Einfluss Sozialer Netzwerke auf den psychotherapeutischen Erfolg - Eine Meta-Analyse. In B. Röhrle \& A.-R. Laireiter (Hrsg.), Soziale Unterstützung und Psychotherapie (S. 277-296). Tübingen: DGVT.

Rogers, E. (2003). The diffusion of innovations (5. Aufl.). New York: Free Press.

Salvy, S.-J., Nitecki, L. A., \& Epstein, L. H. (2009). Do social activities substitute for food in youth? Annals of Behavioral Medicine, 38(3), 205-212.

Schwarzer, R., \& Knoll, N. (2007). Functional roles of social support within the stress and coping process: A theoretical and empirical overview. International Journal of Psychology, 42(4), 243-252.

Schwarzer, R., Jerusalem, M., \& Hahn, A. (1994). Unemployment, social support and health complaints: A longitudinal study of stress in East German refugees. Journal of Community \& Applied Social Psychology, 4(1), 31-45.

Seo, D.-C., \& Huang, Y. (2012). Systematic review of social network analysis in adolescent cigarette smoking behavior. Journal of School Health, 82(1), 21-27.

Shor, E., Roelfs, D. J., \& Yogev, T. (2013). The strength of family ties: A meta-analysis and meta-regression of self-reported social support and mortality. Social Networks, 35(4), 626-638.

Smith, K. P., \& Christakis, N. A. (2008). Social networks and health. Annual Review of Sociology, 34(1), 405-429.

Suls, J., \& Wheeler, L. (2017). On the trail of social comparison. In S. G. Harkins, K. D. Williams, \& J. M. Burger (Hrsg.), The Oxford handbook of social influence (S. 71-86). New York, NY, US: Oxford University Press.

Tay, L., Tan, K., Diener, E., \& Gonzalez, E. (2013). Social relations, health behaviors, and health outcomes: A survey and synthesis. Applied Psychology: Health and Well-Being, 5(1), 28-78.

Taylor, S. E. (2015). Health psychology (9. Aufl.). New York: McGraw-Hill.

Uchino, B. N. (2006). Social support and health: A review of physiological processes potentially underlying links to disease outcomes. Journal of Behavioral Medicine, 29(4), 377-387.

Valente, T. W. (2010): Social networks and health. Models, methods, and applications. Oxford: Oxford University Press. 
Valente, T. W. (2015). Social networks and health behavior. In K. Glanz, B. K. Rimer, \& K. V. Viswanath (Hrsg.), Health behavior: Theory, research, and practice (S. 205-222). San Francisco: Jossey-Bass.

Vonneilich, N., Jöckel, K.-H., Erbel, R., Klein, J., Dragano, N., Siegrist, J., \& von dem Knesebeck, O. (2012). The mediating effect of social relationships on the association between socioeconomic status and subjective health - Results from the Heinz Nixdorf Recall cohort study. BMC Public Health, 12, 285.

Wendt, V., Diewald, M., \& Lang, F. R. (2008). Interdependenzen zwischen verwandtschaftlichen und beruflichen Beziehungs-Netzwerken (IDUN). Entwicklung eines sparsamen Netzwerkinstrumentes und erste Ergebnisse. In M. Feldhaus \& J. Huinink (Hrsg.), Neuere Entwicklungen in der Beziehungs- und Familienforschung. Vorstudien zum Beziehungs- und Familienentwicklungspanel (PAIRFAM) (S. 457-479). Würzburg: Ergon.

Westaby, J. D. (2012). Dynamic network theory: How social networks influence goal pursuit. Washington: APA.

Open Access Dieses Kapitel wird unter der Creative Commons Namensnennung 4.0 International Lizenz (http://creativecommons.org/licenses/by/4.0/deed.de) veröffentlicht, welche die Nutzung, Vervielfältigung, Bearbeitung, Verbreitung und Wiedergabe in jeglichem Medium und Format erlaubt, sofern Sie den/die ursprünglichen Autor(en) und die Quelle ordnungsgemäß nennen, einen Link zur Creative Commons Lizenz beifügen und angeben, ob Änderungen vorgenommen wurden.

Die in diesem Kapitel enthaltenen Bilder und sonstiges Drittmaterial unterliegen ebenfalls der genannten Creative Commons Lizenz, sofern sich aus der Abbildungslegende nichts anderes ergibt. Sofern das betreffende Material nicht unter der genannten Creative Commons Lizenz steht und die betreffende Handlung nicht nach gesetzlichen Vorschriften erlaubt ist, ist für die oben aufgeführten Weiterverwendungen des Materials die Einwilligung des jeweiligen Rechteinhabers einzuholen.

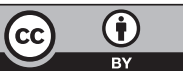




\title{
Negative Beziehungsaspekte und gesundheitliche Ungleichheiten
}

\author{
Philip Adebahr
}

\section{Überblick}

- Negative Beziehungsaspekte werden definiert als interpersonelle Verbindungen zwischen zwei Personen, die von Ego als belastend wahrgenommen werden. In der Forschung müssen handlungsorientierte, einstellungsorientierte und strukturorientierte Ansätze differenziert werden.

- Stress und Gewalt (körperlich), geringerer Selbstwert und Depression (psychisch) und verändertes Gesundheitsverhalten sind potenzielle gesundheitliche Folgen negativer Beziehungsaspekte. Ob negative Beziehungsaspekte zudem auch gesundheitsförderlich Effekte erzielen (salutogene Perspektive) und inwiefern die Gesundheit umgekehrt auch auf die Entstehung negativer Beziehungsaspekte Einfluss nimmt, bleibt Gegenstand zukünftiger Forschung.

- Es bestehen mehrere theoretische Konzeptionen, um den Zusammenhang zwischen sozioökonomischem Status (SES) und negativen Beziehungsaspekten zu erklären. In diesem Beitrag werden der Diskriminierungs-, der Ressourcen- und der Sozialisationsansatz aufgegriffen und mit empirischen Befunden unterlegt.

- Um den Zusammenhang aller drei Aspkete (zwischen SES, Gesundheit und negativen Aspekten sozialer Beziehungen) hinlänglich zu klären, bedarf es weiterer Forschung auch in Richtung einer salutogenen Perspektive und der Wirkrichtungen der Zusammenhänge.

P. Adebahr $(\bowtie)$

Chemnitz, Deutschland

E-Mail: philip.adebahr@soziologie.tu-chemnitz.de

A. Klärner et al. (Hrsg.), Soziale Netzwerke und gesundheitliche Ungleichheiten, https://doi.org/10.1007/978-3-658-21659-7_5 


\section{$1 \quad$ Negative Beziehungsaspekte - eine Einführung}

Während in der Netzwerkforschung bereits Konzepte für positive Beziehungen breit diskutiert sind, zu nennen wäre hier beispielsweise das Konzept des Sozialkapitals (siehe Kap. „Netzwerktheorie(n)“), gibt es in der Netzwerkforschung bis dato noch kein einheitliches Verständnis von negativen Beziehungen (negative ties). Diese Vielfalt spiegelt sich auch in den diversen Operationalisierungen wider. Labianca (2014, S. 241) fasst zusammen, dass negative Aspekte beispielsweise mit Begriffen wie ,distant relationships, difficult relationships, prefer to avoid, dislike, distrust, conflict, relationship conflict, task conflict, disrupts, excludes socially, being a political adversary, troubled relationships“ erhoben werden. Je nach Theorieposition (z. B. Konflikttheorien, Balancetheorie, Sozialkapitalansatz - näheres im folgenden Absatz) herrscht ein anderes Verständnis von negativen Beziehungsaspekten vor, wobei ein gewisser Konsens in folgenden drei Definitionskriterien vorzufinden ist (vgl. z. B. Borgatti et al. 2014, S. 9; Chauvac et al. 2014, S. 7; Heider 1946, S. 107; Labianca und Brass 2006, S. 597; Laireiter und Lettner 1993). Erstens existiert ein „tie“1 also eine Verbindung zwischen den Akteuren, zweitens weist die Verbindung interpersonelle Spannungen bzw. negative Aspekte (z. B. durch Konkurrenz um Ressourcen, verletzte Reziprozitätserwartungen, u. ä.) auf, welche von Ego als belastend wahrgenommen werden und mit Gefühlen der Abneigung z. B. Angst, Hass, Groll o. ä. verbunden sind. Drittens wird eine dyadische Perspektive eingenommen (Ego-Alter-Relation), welche die Analyse auf multipersoneller Ebene erlaubt, ohne die individuelle Perspektive zu vernachlässigen. Somit kann zwischen gegenseitigen und einseitigen Wahrnehmungen der Beziehung unterschieden und die Entstehung von Emergenz nachvollzogen werden.

Während die Frage der Verbindung (tie) und die dyadische Perspektive noch relativ leicht $\mathrm{zu}$ beantworten sind, existieren hingegen noch Differenzen in der Gegenstandsbestimmung: Was sind negative Verbindungen? Hier stehen sich drei Konzeptionen gegenüber, deren Unterschied primär im Aggregationsgrad der „Verbindung“ deutlich wird: Erstens, die handlungsorientierte Konzeption, in der

\footnotetext{
${ }^{1}$ Der Begriff Verbindung (engl. tie) wird hier vom Begriff Beziehung (engl. relationship) abgegrenzt. Nach Perry et al. (2018, S. 161) kann die Beziehung von Ego zu Alter in eine Zusammenstellung analytisch unterscheidbarer Verbindungen (ties) unterteilt werden. Beziehungen sind folglich das Aggregat der verbindenden und spannungsgeladenen Elemente (ties). In Anlehnung daran, wird im vorliegenden Beitrag von negativen Beziehungsaspekten gesprochen und nicht von negativen Beziehungen.
} 
die einzelnen konflikthaften Interaktionen und Interaktionsketten die Verbindung schaffen. Simmel ist mit seinen Ausführungen über den Streit einer der frühen Vertreter dieser Forschungsperspektive (vgl. Simmel 1908, S. 186-225). Mittlerweile ist der Terminus ,sozialer Konflikt“ weit verbreitet. Obgleich der Konfliktbegriff Anschlussfähigkeit zu vielen wissenschaftlichen Diskursen schafft (z. B. zur Aggressions- und Gewaltforschung), ist er aus analytischer Sicht problembehaftet. Einerseits, da in der soziologischen Konfliktforschung begrifflich weniger zwischen Auseinandersetzungen auf Mikro- (zwischen Einzelpersonen) und Makroebene (zwischen sozialen Gruppen) sowie zwischen den Ebenen (zwischen Einzelpersonen und Gruppen) unterschieden wird. Dies verdeutlicht folgende Definition. Soziale „Konflikte lassen sich [...] als soziale Tatbestände [definieren], an denen mindestens zwei Parteien (Einzelpersonen, Gruppen, Staaten etc.) beteiligt sind, die auf Unterschieden in der sozialen Lage und/oder auf Unterschieden in der Interessenkonstellation der Konfliktparteien beruhen" (Bonacker und Imbusch 2010, S. 69). Es gilt also weitaus trennschärfer zu differenzieren zwischen interpersonellem Konflikt als „Aufeinandertreffen von zwei miteinander unvereinbaren Handlungstendenzen [zwischen Personen]" und innerhalb einer Person (intrapersoneller Konflikt) sowie Intergruppenkonflikte (zwischen sozialen Gruppen) und Intragruppenkonflikte (innerhalb sozialer Gruppen) zu unterscheiden (vgl. Nolting 1998, S. 552). Andererseits ist der Terminus „,sozialer Konflikt“ im Kontext negativer Beziehungsaspekte problematisch, da negative Aspekte sozialer Beziehungen nicht zwangsläufig in Konflikten münden. Konflikthaftes Verhalten ist, neben Loyalität, Vermeidung und Beziehungsabbruch, eine von mehreren Coping-Strategien (dt. Bewältigungsstrategien) für den Umgang mit interpersonellen Spannungen (siehe voice, loyality, neglect, exit bei Rusbult und Zembrodt 1983). Nach diesem Verständnis gehen mit interpersonellen Konflikten logischerweise interpersonelle Spannungen einher, mit interpersonellen Spannungen aber nicht zwangsläufig interpersonelle Konflikte (gleiches gilt für Gewaltphänomene).

\section{Exkurs: Negative Beziehungsaspekte und Gewalt}

Streitbezogene Gewalt ist eine Spezialform konflikthafter Spannungsbewältigung. Der Zusammenhang zwischen negativen Aspekt sozialer Beziehungen und personenbezogener Gewalt ist vermittelt über Aggressivität, welche jedoch nicht zwangsläufig in aggressives, antisoziales Verhalten umgesetzt wird. Zudem gehen nicht jeder Gewalttat negative Beziehungsaspekte zum Opfer voraus (z. B. bei räuberischer Gewalt). Die Bedingungen zur Entstehung von Aggressionen und Gewalttaten weisen 
Schnittstellen mit negativen Aspekten sozialer Beziehungen auf. Beispielsweise ist im General Aggression Modell die Dimension externe „Person“ als Bedingungsfaktor aufgeführt (Allen et al. 2018). Einen Überblick zur Aggressions- und Gewaltforschung bieten Heitmeyer und Hagan (2002) und Bogerts und Möller-Leimkühler (2013). Bei häuslicher Gewalt besteht hingegen eine Verbindung zwischen den Personen (gemeinsames Wohnen), und auch wenn nicht immer eine Absicht unterstellt wird, wird die Tat dennoch als schädigend oder belastend erlebt. Damit erfüllt sie für das Opfer in der Regel die Definitionskriterien negativer Beziehungsaspekte.

Aggregierte Einstellungen bilden die zweite Konzeption von negativen Verbindungen. Danach sind weniger die Einzelsituationen von Bedeutung für die Beschreibung einer „Verbindung“, sondern vielmehr die Gesamtbewertung der Beziehung bzw. Egos Einstellung zu Alter. Einer Definition von Labianca und Brass zufolge werden negative Verbindungen dann als ein andauerndes, wiederkehrendes Set von negativen Bewertungen, Gefühlen und Verhaltensintentionen gegenüber Alter definiert (Labianca und Brass 2006, S. 597). ${ }^{2}$ Labianca und Brass argumentieren, dass Ego ähnlich einem Buchhaltungskonto eine Gesamteinschätzung (mögen/like oder ablehnen/dislike) entwickelt (ein sogenanntes „,negative person schema“; ebd.). Die Gesamtbewertung als ,negative Beziehung" ist bei näherer Betrachtung ebenfalls problembehaftet. Negative Aspekte sind in der Regel mit Ambivalenz verbunden bzw. mit einer Gleichzeitigkeit von positiven und negativen Beziehungsaspekten, da eine rein negative Beziehung nach Klein Ikkink und van Tilburg (1999) aufgrund fehlenden Nutzens in der Regel aufgelöst wird (siehe zu Ambivalenz auch Ajzen 2001; Coser 2009; Lüscher 2011; Simmel 1908, S. 186-225). Entsprechend der Gleichrangigkeit beider Beziehungsaspekte wird es den Individuen schwerfallen, eine ,positive oder negative" Gesamteinschätzung zu geben. $\mathrm{Zu}$ vermuten ist die Verzerrung zugunsten positiver Gesamtbewertungen, da Ego die Beziehung strategisch nutzt und so die positiven Aspekte in den Vordergrund stellt.

\footnotetext{
${ }^{2}$ Damit schließen Labianca und Brass an Heider und die Einstellungsforschung (engl. attitudes) an, die ebenfalls die kognitive, affektive und behaviorale Dimension aufgreifen vgl. Ajzen (2001); Banaji und Heiphetz (2010); Heider (1946), sowie an die, social ledger theorie‘ Labianca und Brass (2006).
} 
Die dritte Konzeption von negativen Verbindungen ist strukturorientiert. Demnach sind negativen Beziehungen jene, die den Zugang zu Ressourcen verhindern (Chauvac et al. 2014, S. 7) oder soziales Kapital reduzieren (Borgatti et al. 2014, S. 9). Die negative Verbindung besteht darin, dass Alter systematisch Verbindungsversuche von Ego blockiert oder zu unterbrechen versucht (zu sich und zu dritten). Die Verhinderung von Zugängen zu Ressourcen impliziert einen Zugangsversuch und somit eine interaktionistische Verbindung. Zusätzlich wird der Blick auf die Beziehungsdyade um die Beziehungstriade erweitert (siehe hierzu Heider 1946 und Kap. „Netzwerktheorie(n)“).

Obgleich der Verweis auf Stigmatisierung, Diskriminierung und Exklusion naheliegt und in der Forschung zu Mobbing (engl. Bullying) ebenfalls von ,negative ties" gesprochen wird (z. B. Kaur und Singh 2015, S. 24), ist die Verbindung zu dieser makrosoziologischen Perspektive nicht klar. Dies liegt daran, dass die Eindeutigkeit der mikrosoziologischen Definitionskriterien (Verbindung, Negativität, Dyaden-Perspektive) in der Abstraktion makrosoziologischer Betrachtung verloren geht. Zur Erläuterung: Das soziologische Begriffsinstrumentarium von Exklusion und Ausgrenzung ist nicht mit negativen Beziehungsaspekten gleichzusetzen. Einerseits kann Diskriminierung vom Forschenden beobachtet werden, aber zugleich den Individuen (Diskriminierender oder Diskriminierter) unbewusst bleiben (keine wahrgenommene Negativität). Andererseits verweist die Einführung der Beziehungstriade darauf, dass Diskriminierung stattfinden kann, obwohl Ego und Alter nicht in direkter Interaktion miteinander stehen. Der Austausch über die diskriminierte Personengruppe führt dazu, dass eine Interaktion mit dieser gar nicht erst in Erwägung gezogen wird (keine Verbindung).

Dass eine Verbindung zwischen Ego und Alter besteht, ist, wie oben dargelegt, ein zentrales Definitionskriterium. Es bedarf jedoch einer Erklärung, warum negative Verbindungen über längere Zeit fortbestehen können. Offer und Fischer (2018, S. 3-6) geben hier zwei Möglichkeiten vor. Erstens werden Beziehungen aus strategischen Kosten-Nutzen-Überlegungen aufrechterhalten. Beispielsweise kann die Beziehung zu einem Augenarzt von strategischem Nutzen sein, wenn Ego häufig Augenbeschwerden hat, die nächste Augenarztpraxis jedoch $50 \mathrm{~km}$ entfernt ist. Hier spart ein kurzes informelles Telefonat möglicherweise den aufwendigen Gang zum Augenarzt. Zweitens verfügt das Individuum nur über einen eingeschränkten Zugang zu einem Pool an Interaktionspartnern und ist daher nicht in der Lage, die belastete Interaktion zu beenden. Letztlich kann eine Beziehung so sehr von Nutzen sein, dass die Kosten, d. h. die negativen Aspekte der Beziehung, billigend in Kauf genommen werden. Beziehungen 
bestehen auch aufgrund schwierig begleichbarer Kosten, sogenannter externer und interner Barrieren, weiter (Hess 2000). Externe Barrieren entstehen außerhalb des Individuums und umfassen dabei die Bindung von Ego und Alter durch institutionelle Zugehörigkeit zu sozialen Gruppen (z. B. Kirche, Vereine, Verwandtschaft), finanzielle Verpflichtungen und Verträge (z. B. gemeinsame Kredite oder Verantwortung für Kinder und Wohnung) oder physische Nähe (z. B. durch Nachbarschaft und Arbeitsplatz) (Bushman und Holt-Lunstad 2009, S. 754; Hess 2003). Interne Barrieren hingegen bestehen nach Hess aus inneren Wünschen und Überzeugungen des Individuums, die zur Aufrechterhaltung einer Beziehung führen, auch wenn diese negative Aspekte beinhalten (Hess 2003). Zur Aufrechterhaltung interner Barrieren tragen demnach bei: Sogenannte self-identity goals, Ziele, welche in der Identität und dem Selbstbild des Individuums verankert sind. Zweitens, die damit teilweise einhergehenden Verantwortungs-, Pflicht- und Verbundenheitsgefühle (sense of commitment), und drittens auch Glaubenssätze und Überzeugungen z. B. von Nächstenliebe und Vergebung (religious beliefs). Hess fügt ergänzend subtile Ängste vor den Folgen der Beziehungsauflösung hinzu (z. B. die Angst, jemanden zu verletzen) (Hess 2000, 2003, 2016).

Zusammenfassend kann festgehalten werden, dass sich negative ties durch eine Verbindung (1) zwischen Ego und Alter (Dyadenperspektive (2)) auszeichnet, die von Ego als belastend wahrgenommen wird (3). Sie sind häufig mit schwer lösbaren Exit-Barrieren verbunden. Zudem bestehen Unterschiede darin, ob die negativen Aspekte als spannungsgeladene Einzelsituationen (interpersonelle Spannungen), als aggregierte Gesamteinschätzung (Einstellung), oder strukturell, als Zugangsbarrieren zu bestimmten Personen und Netzwerken, verstanden werden. Um den aktuellen Forschungsdiskurs in all seinen Facetten aufgreifen zu können, wird von negativen Aspekten im Allgemeinen gesprochen und sowohl Einzelsituationen als auch Gesamteinschätzungen betrachtet. Die zentrale Frage dieses Kapitels (Negative Beziehungsaspekte und gesundheitliche Ungleichheiten) besteht darin, den Forschungsstand über den Beitrag negativer Beziehung zur Reproduktion gesundheitlicher Ungleichheit zu eruieren. Nachdem in diesem Abschnitt dargelegt wurde, was unter negativen Beziehungen verstanden wird, erfolgt in Abschn. 2 die Darlegung des Zusammenhangs zwischen negativen Beziehungen und verschiedenen Gesundheitsparametern. Auf die Frage, inwiefern dieser Einfluss sozial ungleich verteilt ist, wird in Abschn. 3 eingegangen. Der Beitrag schließt in Abschn. 4 mit einer Zusammenfassung und einem Ausblick, in dem die wesentlichen Desiderata zur Forschung über negative Beziehungsaspekte und gesundheitlicher Ungleichheit angesprochen werden. 


\section{Negative Beziehungsaspekte und Gesundheit}

Obgleich negative Beziehungsaspekte seltener sind als positive (Labianca und Brass 2006; Offer und Fischer 2018), deuten empirische Befunde darauf hin, dass in bestimmten Fällen Belastungen aus sozialen Beziehungen einen größeren gesundheitsbezogenen Effekt erzeugen als positive Beziehungsaspekte (Rook 1998; Brooks und Dunkel Schetter 2011). Die Frage, wie häufig negative Verbindungen auftreten, wird unterschiedlich beantwortet. Je nach Sample und Operationalisierung, ergibt sich eine Prävalenz ,negativer Beziehung“ in persönlichen Netzwerken von bis zu 8 Prozent (Zusammengetragen von Labianca und Brass 2006, S. 597). Neuere Erkenntnisse weisen darauf hin, dass der Anteil in der allgemeinen Bevölkerung weitaus größer sein könnte. Offer und Fischer (2018, S. 1) berichten für die erste Welle der Studie UCNets (University of California Social Networks Study), dass $15 \%$ aller Beziehungen als ,,sometimes demanding or difficult" eingeschätzt werden. Untersucht wurden zwei Kohorten, 21- bis 30-Jährige und 50- bis 70-Jährige. Bezogen auf die Effekte weist Rook (1984) für ältere verwitwete Frauen nach, dass die Anzahl an belastenden Beziehungen das psychische Wohlbefinden stärker beeinflussen als die Anzahl unterstützender Beziehungen. Ähnliches bezeichnen Cacioppo und KollegInnen mit dem Begriff ,negativity bias", nachdem negativen Informationen im Gehirn größere Bedeutung zugeschrieben wird als positiven (Cacioppo und Gardner 1999; Ito et al. 1998).

\subsection{Negative Aspekte sozialer Beziehungen und körperliche Gesundheit}

Insofern negative Aspekte sozialer Beziehungen aufgrund starker Exit-Barrieren oft dauerhaft sind, kann hier von einem chronischen sozialen Stressor gesprochen werden. Dies führt zu wiederkehrender oder langanhaltender Aktivierung des Körpers durch die Stressreaktion. Das meint, der Körper wird in den ,fight-orflight"-Zustand versetzt (Cannon 1932). ${ }^{3}$ Es erfolgt eine Steigerung des Herzschlags und Blutdrucks, verstärkte Lungenventilation sowie Freisetzung von

\footnotetext{
${ }^{3}$ Mittlerweile ist bekannt, dass die Stressreaktion vom Kontext, seiner Wahrnehmung sowie von individuellen und sozialen Faktoren abhängt. Beispielsweise wird die weibliche Stressreaktion als ,tend-and-befriend'-Reaktion (deutsch: sich kümmern und Anfreunden) beschrieben (zuerst Taylor et al. 2000; vertiefend siehe Seidel et al. 2013).
} 
Fettsäuren und Glukose (Dawans und Heinrichs 2018). Zudem werden die Verdauung und Antikörperproduktion gehemmt (ebd.). Das dauerhafte Bestehen stressbedingter Prozesse im Körper wird als ,allostatic load“ bezeichnet. Dauerhaft als negativ empfundene Interaktionen stehen in Verbindung mit allostatischen Belastungen (Seeman et al. 2014). Die stressbedingte Krankheitsentstehung (,Allostase“) wurde bereits breit beforscht (z. B. Rensing 2013). Bekannt ist der Zusammenhang zwischen sozialem Stress und Herzkreislauferkrankungen z. B. Bluthochdruck (Sneed und Cohen 2014), koronaren Herzerkrankungen (Orth-Gomér 2007, 2009; Vogli et al. 2007) oder Schlaganfällen (Tanne et al. 2004). Auch das Endokrinsystem (Hormonhaushalt) wir durch negative Interaktionen verändert. Andauernde negative Interaktionen stehen z. B. in Verbindung mit hohem Cortisolspiegel, welcher das Immunsystem schwächt und die Anfälligkeit für Krankheiten erhöht (Dawans und Heinrichs 2018; Siegrist 2018). Auch die Wundheilung (Cytokine-Produktion, IL-6, TNF $\alpha$, IL-1 $\beta$ ) bzw. die damit verbundene Nachproduktion und Erneuerung von absterbenden Zellen wird von sozialem Stress gehemmt (Kiecolt-Glaser et al. 2005; Wright und Loving 2011). Als weitere körperliche Folge negativer Aspekte sozialer Beziehungen können körperliche Verletzungen aufgrund von physischer Gewalt angeführt werden. Wie in Abschn. 1 dargelegt, kann Gewalt eine Copingstrategie (Extremform konflikthaften Copings) für interpersonelle Spannungen sein. Laut einer Studie von Eggert et al. (2018, S. 8) erfahren beispielsweise elf Prozent der pflegenden Angehörigen körperliche Gewalt durch die Gepflegten in den letzten sechs Monaten. Wobei zwölf Prozent angaben, körperliche Gewalt gegen die pflegebedürftige Person ausgeübt zu haben (ebd.). Dabei wurde nur Gewalt erfasst, die beabsichtigt, also personengebunden ist sowie als schädigend erlebt wird und somit den Kriterien negativer Beziehungsaspekte entspricht (vgl. Eggert et al. 2018, S. 6).

\subsection{Negative Aspekte sozialer Beziehungen und mentale Gesundheit}

Psychische Gewalt ist im Vergleich zur körperlichen Gewalt in der häuslichen Pflege häufiger anzutreffen. $45 \%$ der pflegenden Angehörigen berichten laut Eggert et al. von psychischer Gewalt durch die Gepflegten in den letzten sechs Monaten (2018, S. 8). Wobei $32 \%$ angeben, selber psychische Gewalt gegen die pflegebedürftige Person ausgeübt zu haben (ebd.). An dieser Stelle sei auch auf die Gewalt zwischen Eltern und Kindern, zwischen Geschwistern sowie in der 
Partnerschaft als weitere Formen häuslicher Gewalt verwiesen (Lamnek et al. 2013). 2017 wurden laut Statistik des Bundeskriminalamtes 138.893 Personen Opfer partnerschaftlicher Gewalt (Bundeskriminalamt 2018, S. 28). Sowohl körperliche als auch psychische Gewalt haben zum Teil in Form von Psychotraumata Auswirkungen auf die mentale Gesundheit und spielen dann eine zentrale Rolle bei der Entstehung psychischer Störungen (Pape und Binder 2014).

Aber auch geringere soziale Belastung, wie kleine Streitereien und Auseinandersetzungen, können mit schlechter psychischer Gesundheit einhergehen. Einen Erklärungsansatz bietet die Soziometer-Theorie, nach welcher Selbstwert ein Indikator (Soziometer) für die eigene soziale Integration darstellt (Leary 2005). Der Soziometer-Theorie folgend, können interpersonelle Konflikte und Zurückweisungen die psychologischen Ressourcen (z. B. Selbstbewusstsein und Selbstwirksamkeitseinschätzung) herabsetzen (vgl. Leary 2005, 2012). Andererseits ist ebenfalls belegt, dass niedriger Selbstwert die Wahrscheinlichkeit interpersoneller Konflikte erhöht (Kiviruusu et al. 2016, S. 2). Zur kritischen Empirie-fokussierten Auseinandersetzung mit dieser Theorie siehe die Metaanalyse von Blackhart et al. (2009). Beide Ressourcen (Selbstbewusstsein und Selbstwirksamkeitseinschätzung) sind negativ mit Depression assoziiert. Stafford et al. (2011) finden auf Basis einer Panelstudie etwa Zusammenhänge zwischen negativen sozialen Interaktionen in engen Beziehungen (Familie, enger Freundeskreis) und Depressionen. Positiver Austausch ist hingegen nicht zwingend mit weniger Depression assoziiert (ähnlich siehe Lincoln et al. 2010).

\subsection{Negative Aspekte sozialer Beziehungen und Gesundheitsverhalten}

Ungünstige Gesundheitseffekte gehen nicht ausschließlich von der Stresssituation, d. h. den negativen Aspekten sozialer Beziehungen an sich, aus, sondern auch von Egos Reaktion (Verhalten) auf den negativen Beziehungsaspekt. Aus soziologischer Perspektive wirken die Individuen des sozialen Netzwerks als Kontrollinstanz, und negative Beziehungsaspekte bilden eine Form der Sanktionierung, die Personen $\mathrm{zu}$ einem bestimmten Verhalten veranlassen sollen (vgl. Peuckert 2006). Wie Personen mit Sanktionierung umgehen, hängt von der gewählten Bewältigungsstrategie (Copingstrategie) ab. Eine Systematisierung von Bewältigungsstrategien bietet beispielsweise das Dualaxiale Copingmodell 
(Hobfoll 1998). ${ }^{4}$ Darin wird zwischen aktivem/passiven sowie pro-/antisozialem Coping (Bewältigungsverhalten) unterschieden. Eine pauschale Antwort auf die Frage nach dem Zusammenhang der einzelnen Copingstrategien mit Gesundheit stößt, in Hinblick auf die vielen Einzelphänomene, schnell an seine Grenzen. Im Folgenden werden die vier Typen am Beispiel Fat-Shaming erläutert. Fat-Shaming bezeichnet die ,diskreditierende, meist öffentliche Äußerung gegenüber vermeintlich übergewichtigen Personen in Form von konkreter Kritik aufgrund des Gewichts, die als beleidigend gemeint oder verstanden wird" (Adebahr und Lehmann 2017, S. 2).

- Passiv prosoziales Coping besteht in vorsichtigem Handeln, z. B. in der Vermeidung des Kontakts mit dem Beleidigenden.

- Passives antisoziales Coping umfasst instinktives Handeln (passiv), bei der die spontane Reaktion negative Konsequenzen mit sich bringen kann (antisozial). Zum Beispiel sinkt durch das Fat-Shaming die Motivation der übergewichtigen Person, sich sportlich zu betätigen, Vorsorgeuntersuchungen in Anspruch zu nehmen, und es entsteht eine ablehnende Haltung zu Diäten (Alegria Drury und Louis 2002; Puhl und Brownell 2006; Sykes und McPhail 2008).

- Aktives prosoziales Coping besteht in der Suche nach Unterstützung und der Bildung von Koalitionen. Bei Fat-Shaming könnte das dem Anschluss an die Fat-Positive-Bewegung gleichkommen.

- Aktiv antisoziales Coping zeigt sich beispielsweise durch Gewalttaten (aktiv) mit entsprechenden Verletzungsabsichten (antisozial). Beispiele bilden das Beleidigen oder Schlagen des Fat-Shamers.

Copingstrategien können gesundheitsförderliches Verhalten verstärken. Die Teilnahme an einer Selbsthilfegruppe für Übergewichtige erhöht beispielsweise die Wahrscheinlichkeit der Gewichtsreduktion. Genauso könnten aber auch gesundheitshemmende Verhaltensweisen eingeleitet werden. So senkt Fat-Shaming beispielsweise die Wahrscheinlichkeit, sich sportlich zu betätigen (Sykes und McPhail 2008). Welches Verhalten gewählt wird, gilt es für jedes Phänomen mithilfe sozialer Handlungstheorien und empirischer Forschung einzeln zu erklären (beispielhaft siehe Rook et al. 2011).

\footnotetext{
${ }^{4}$ Das Multiaxiale Copingmodell enthält eine zusätzliche Achse (direkt vs. indirekt), welche primär kulturspezifische Unterschiede beim Coping abbildet (Hobfoll 1998). Kulturunterschiede stehen jedoch nicht im Fokus dieses Beitrags, weshalb das Dualaxiale Copingmodell vorgestellt wird.
} 
Negative Aspekte sozialer Beziehungen tragen zusammenfassend folgendermaßen zur Reproduktion gesundheitlicher Ungleichheit bei:

1. Auf körperlicher Ebene durch Stress und Verletzung aufgrund von Gewalt.

2. Auf psychischer Ebene durch verringerte mentale Gesundheit z. B. in Form von geringerem Selbstwert und höherem Depressionsrisiko.

3. In bestimmten Fällen kann der soziale Druck durch negative Beziehungsaspekte Veränderungen des (Gesundheits-)Verhaltens bewirken, wobei die gesundheitshemmenden oder -förderlichen Effekte von der Einzelsituation abhängen.

\section{Sozialer Status, negative Beziehungsaspekte und Gesundheit}

Inwiefern negative Aspekte sozialer Beziehungen, und somit auch die in Abschn. 2 angeführten gesundheitlichen Zusammenhänge, nach Dimensionen sozialer Ungleichheit variieren, ist die leitende Frage dieses Beitrags. Eine Studie, die systematisch den Einfluss negativer Aspekte sozialer Beziehungen auf den Zusammenhang zwischen sozioökonomischem Status (SES) und Gesundheitsparameter analysiert ist nicht bekannt. Aus diesem Grund wird in diesem Abschnitt der These nachgegangen, dass soziale Ungleichheiten mit negativen Aspekten sozialer Beziehungen zusammenhängen. Ziel ist es, durch Abschn. 2 und 3 die These $\mathrm{zu}$ untermauern, dass niedriger SES mit mehr negativen Beziehungsaspekten einhergeht und damit die niedrigere Gesundheit bei geringem SES zum Teil erklärt wird.

Krause et al. (2008, S. 1013) stellen anhand zweier Datensätze mit US-amerikanischen Senioren heraus, dass finanzielle Schwierigkeiten mit mehr negativen Interaktionen einhergehen (handlungsorientierte Konzeption, siehe Abschn. 1). Zudem finden sie über beide Datensätze keine Bildungseffekte im Zusammenhang mit negativen Interaktionen. Des Weiteren deuten ihre Ergebnisse darauf hin, dass die Auswirkungen persönlicher wirtschaftlicher Schwierigkeiten bei mehr negativer sozialer Interaktion stärker gesundheitshemmend wirken. Negative Interaktionen in Form von „,keine Hilfe bekommen, wenn sie erwartet wird“ verstärken zusätzlich den Effekt von finanziellen Spannungen auf die subjektive Gesundheit (ebd.).

Offer und Fischer (2018) fragen hingegen nach Personen, die als besonders schwierig wahrgenommen werden (gesamteinschätzungsorientierte Konzeption siehe Abschn. 1). Danach zeigen die Ergebnisse der California Social Network Study (UCNets) bei anderer Operationalisierung gegenläufige Effekte. Gegenüber dem eben berichteten Effekt finanzieller Spannungen, wird in der multivariaten 
Analyse von Offer und Fischer der Zusammenhang zwischen Einkommen und der Anzahl von als schwierig eingeschätzten Personen nicht signifikant, wohingegen Bildung einen signifikanten Zusammenhang mit als schwierig eingeschätzten Personen aufweist. In der Altersgruppe zwischen 50 und 70 Jahren haben Personen mit einem Bildungsabschluss unter Bachelor weniger Personen im Netzwerk, die sie als schwierig einschätzen, allerdings gleichzeitig mehr Personen, die sie als ambivalent wahrnehmen (Offer und Fischer 2018). ${ }^{5}$ Zusammenfassend korrelieren existenzielle finanzielle Schwierigkeiten unabhängig von der Bildung mit negativen Interaktionen, wohingegen die Anzahl als schwierig wahrgenommener Personen vom Bildungsgrad (unabhängig vom Einkommen) abhängt. Nach Vogli et al. (2007) sind zudem Personen in statusniedrigeren Beschäftigungsverhältnissen eher negativen Aspekten sozialer Beziehungen ausgesetzt als Personen in höheren Statusgruppen. Nachdem nun einige empirsche Befunde dargelegt sind, werden im Folgenden drei mögliche Erklärungsanätze umrissen.

Eine Argumentation, die den Zusammenhang zwischen finanziellen Problemen und negativen Aspekten sozialer Beziehungen zu erklären versucht, stammt von Krause et al. (2008). Sie argumentieren, dass die eingeschränkte Ressourcenausstattung (Erklärungsansatz 1) und Hilfsbedürftigkeit von Personen mit niedrigem sozioökonomischem Status (SES) die Erbringung einer adäquaten Gegenleistung erschweren, was letztlich eher zu Belastungen und sozialen Spannungen führt. Eng umgrenzte soziale Netzwerke tendieren zur Statushomogenität der Mitglieder (Belle 1983; Phan et al. 2009). ${ }^{6}$ Das bedeutet, dass im sozialen Netzwerk statusniedriger Personen eher Personen mit finanziellen Schwierigkeiten vorhanden sind, was wiederum die Wahrscheinlichkeit für das Auftreten sozialer Spannungen durch finanzielle Schwierigkeiten erhöht. Hobfoll (1998, S. 208) bezeichnet diesen tief greifenden Effekt als ,pressure cooker effect“" Wenn Personen selber zu wenig Ressourcen besitzen, um Probleme zu bewältigen, wird es ihnen schwerfallen, andere bei deren Problemen zu unterstützen (Krause et al. 2008). Empirisch untermauert wird dies durch die Beobachtung, dass die Unterstützung aus Netzwerken statusniedriger Personen oft geringer ausfällt, sporadisch, nicht verlässlich und von Spannungen geprägt ist (Offer 2012, S. 789).

Diesem Erklärungsansatz stehen andere entgegen. Im Sinne sozialisationstheoretischer Überlegungen (Erklärungsansatz 2) kann beispielsweise argumentiert werden, dass Personen niedriger sozialer Statusgruppen eher Konflikte

\footnotetext{
${ }^{5}$ Ergebnisse für die Altersgruppe 21-30 sind nicht signifikant bezogen auf die Bildung. ${ }^{6}$ Der Prozess, nachdem sich Personen nach gleichen Merkmalen in soziale Gruppen finden, wird in der Netzwerkforschung als Homophilie bezeichnet Lin (2000).
} 
vorgelebt bekommen. Sie versuchen deshalb auch häufiger, soziale Spannung durch konflikthaftes Verhalten zu lösen (weniger durch kooperatives Verhalten). Inwiefern drohender Ressourcenverlust in unteren sozialen Schichten als existenzbedrohender angesehen wird (als in höheren Schichten) und deshalb die Reaktion radikaler (anti- und prosozial) ausfällt, bleibt zu prüfen. Richtungsweisende Ergebnisse sind bei Greitemeyer und Sagioglou (2018) dargelegt. Sie zeigen, dass in vier von fünf betrachteten Studien niedriger SES mit aggressiverem Verhalten einhergeht. ${ }^{7}$

Aus der Schulforschung ist bekannt, dass Prozesse sozialer Schließung und Diskriminierung in Form von Mobbing sozial ungleich verteilt sind. Dies ist ein dritter Erklärungsansatz für den Zusammenhang von SES und negativen Aspekten sozialer Beziehungen. Demnach werden Personen mit niedrigem SES eher diskriminiert. Auch wenn SES ein schwacher Prädiktor für Mobbing in der Schule ist, zeigt die Metastudie von Tippett und Wolke (2014) einen signifikant positiven Zusammenhang zwischen niedrigem SES und der Wahrscheinlichkeit, Opfer von Mobbing zu sein auf. Ähnliches gilt für die Arbeitswelt. Tsuno et al. (2015) berichten einen signifikanten Zusammenhang zwischen hohem subjektivem sozioökonomischen Status und geringem Mobbing. Dieser Ansatz ist aus Netzwerkforschungsperspektive besonders interessant, da die Spannungen primär von den Alteri und nicht von den Egos ausgehen, was die Dyaden und sozialen Netzwerke stärker in den Blick nimmt.

Das ABC-X-Modell integriert alle genannten Perspektiven und fasst diesen Abschnitt zusammen (McCubbin und Patterson 1983). Die Belastung durch negative Beziehungsaspekte $(\mathrm{X})$ hängt demnach von der Art der Stressoren (A) (z. B. Diskriminierung, Ansatz 3), den bestehenden Ressourcen (B) (Ansatz 1) und der Interpretation des Stressors (C) (geprägt durch Sozialisation, Ansatz 2) ab (McCubbin und Patterson 1983).

\section{$4 \quad$ Fazit und Diskussion}

Ziel des Beitrags war es, den Forschungsstand über den Beitrag negativer Beziehung zur Reproduktion gesundheitlicher Ungleichheit zu eruieren. Hierzu wurden die Begriffe rund um „negative ties“ (negative Beziehungsaspekte)

\footnotetext{
${ }^{7}$ Zusätzlich deuten Studien an (z. B. Piff et al. 2010), dass niedriger SES ebenfalls mit stärkerem prosozialem Verhalten einhergeht. Diese Feststellung erweist sich mit Blick auf Greitemeyer und Sagioglou (2018) allerdings als eingeschränkt reliabel.
} 
erörtert, soziologische und psychologische Konzepte eingeführt sowie mögliche Zusammenhänge mit Gesundheit und sozialem Status aufgezeigt und anhand bestehender Theorien diskutiert. Es wurde herausgearbeitet, dass sich negative Beziehungsaspekte durch eine Verbindung (tie) von Ego und Alter (Dyade) auszeichnet, die interpersonelle Spannungen aufweist (Negativität). Sie gehen häufig mit nicht lösbaren Exit-Barrieren einher. Negative Aspekte sozialer Beziehungen wirken sich über Gewalttaten und Stress auf den Körper aus, mit entsprechenden Konsequenzen für die körperliche und mentale Gesundheit (niedrigerer Selbstwert und höheres Depressionsrisiko). Zudem beeinflussen sie, je nach gewählter Copingstrategie, das Gesundheitsverhalten (gesundheitshemmend oder förderlich). Einen integrierenden Erklärungsansatz für den Zusammenhang zwischen SES und negativen Beziehungsaspekten bietet das ABC-X-Modell (McCubbin und Patterson 1983). Auch wenn das Einkommen empirisch keinen signifikanten Zusammenhang mit als schwierig eingestuften Personen zeigt, sind finanzielle Spannungen mit mehr negativen Interaktionen assoziiert. Zudem geht niedriger SES (schwacher Prädiktor) mit einer erhöhten Wahrscheinlichkeit, Opfer von Mobbing zu werden und mehr aggressives Verhalten zu zeigen, einher. Eine Analyse des konkreten Zusammenhangs, also inwiefern negative Beziehungsaspekte die Korrelation zwischen SES und Gesundheit erklären, ist nicht bekannt. Die Ausführung in Abschn. 2 und 3 untermauern die These, dass der Einfluss von sozialem Status auf die Gesundheit zum Teil durch den Anteil negativer Beziehungen erklärt werden kann. Auf Basis der bisherigen Erkenntnisse wird dieser Erklärungsanteil allerdings vergleichsweise gering eingeschätzt.

In den bisherigen Ausführungen sind schon erhebliche Forschungslücken deutlich geworden, an dieser Stelle soll auf einige weitere interessante Aspekte und Limitationen eingegangen werden. In der Forschung zu negativen Aspekten sozialer Beziehungen gibt es eine Vielzahl verschiedener Begriffe und Messinstrumente, die alle ähnliche Aspekte bezeichnen, jedoch noch nicht systematisch zusammengeführt wurden. Wenn negative Aspekte sozialer Beziehungen als Sammelbegriff für viele unterschiedliche Phänomene verstanden werden, lohnt es sich, diese zu differenzieren und zu schauen, welche negativen Aspekte es gibt (z. B. Vermeidung, Konflikt, Gewalt) und wie sie im Einzelnen mit Gesundheit und sozialer Ungleichheit assoziiert sind. Besonders auf das Coping durch Vermeidung und dessen Gesundheitsfolgen wurde in diesem Beitrag kaum eingegangen.

An den dargelegten Ausführungen zum Zusammenhang zwischen negativen Beziehungsaspekten und Gesundheit können ausblickend vier Diskussionspunkte angemerkt werden. Der erste Diskussionspunkt besteht in der postulierten Wirkrichtung des Zusammenhangs. Soziale Spannungen wirken nicht nur auf die Gesundheit, sondern die Gesundheit wirkt auch auf soziale Spannungen. Dies 
wird in der Forschung wenig beachtet. In einer Studie mit Daten des SOEP der Wellen 2002 bis 2008 wurde beispielsweise herausgefunden, dass eine Verschlechterung der Gesundheit eine signifikante Verringerung der Zufriedenheit mit den sozialen Kontakten nach sich zieht (Kriwy und Nisic 2012). Zudem ist bekannt, dass der Gebrauch verschiedener Drogen (Alkohol, Kokain) Aggression fördert (Ntounas et al. 2018). Auch bezüglich des Zusammenhangs von negativen Beziehungsaspekten mit sozialer Ungleichheit konnte die Fokussierung der Argumentation auf eine Wirkrichtung festgestellt werden (soziale Ungleichheiten wirken demnach auf negative Beziehungsaspekte). Um zu ermitteln, inwiefern negative Aspekte sozialer Beziehungen zu sozialer Ungleichheit beitragen vice versa, sind zeitsensible Daten oder Experimentaldesigns notwendig.

Zweitens arbeiten, besonders was die Gesundheitseffekte betrifft, nur sehr wenige Studien mit dem methodischen Instrumentarium der Netzwerkanalyse, was weitere Erkenntnisse ermöglicht (zweiter Diskussionspunkt). Aus Netzwerkperspektive interessant ist die Frage, inwiefern negative Beziehungsaspekte zur Bildung von Gruppen und Netzwerkgrenzen beitragen, inwiefern sich Stress und negative Beziehungsaspekte in sozialen Netzwerken verbreiten (soziale Ansteckung) und inwiefern dadurch gestresste Gesamtnetzwerke oder negative-tie-Netzwerke entstehen. Besonders interessant vor der Prozessperspektive ist die These Cosers, dass Konflikte die Kontrahenten miteinander vertrauter machen, gemeinsame Normen entstehen lassen und damit den Aufbau von Netzwerken zwischen ihnen langfristig fördern können (Coser 2009, S. 144-154). Darüber hinaus sieht er Konflikte selbst als soziale Beziehung, insofern dadurch immer wieder Machtverhältnisse ausgehandelt werden (Coser 2009, S. 160-165).

Des Weiteren sieht Rook (2015) zukünftigen Forschungsbedarf bezüglich des Zusammenwirkens von positivem und negativem Austausch (dritter Diskussionspunkt). Zum Beispiel bezüglich der Frage, wie viele und welche positiven Aspekte einen negativen Beziehungsaspekt aufwiegen können.

In der Forschung zu sozialen Konflikten wird häufig deren Nutzen hervorgehoben (Bark 2012; Coser 2009; Simmel 1908), dies gilt es auch für negativen Beziehungsaspekte zu prüfen und mögliche gesundheitsförderliche Effekte zu eruieren (Diskussionspunkt vier). Inwiefern mit negativen Aspekten - z. B. durch Abgrenzung und Aufbau von Identität (Jetten et al. 2017), Aktivierung, Motivationssteigerung, oder die Ablenkung von chronischen Krankheiten gesundheitsförderliche Effekte bestehen, könnten Fragen einer solchen salutogenen Perspektive sein. Hierbei wird vermutlich dem individuellen Umdeutungsprozess von Disstress zu Eustress eine zentrale Rolle beikommen. Letztendlich gilt es, negative Beziehungsaspekte werturteilsfrei als Teil eines Prozesses interpersoneller Spannung und Entspannung zu verstehen, mit statischen und dynamischen Phasen (ähnlich siehe Bark 2012, S. 11; Rüssmann et al. 2015, S. 501). 


\section{Leseempfehlungen}

Bonacker, T. (Hrsg.) (2008): Sozialwissenschaftliche Konflikttheorien. Eine Einführung. ISBN 9783531161808. In diesem Sammelband werden die zentralen sozialwissenschaftichen Theorien der Soziologie, Psychologie und Politikwissenschaften verständlich aufgearbeitet und mit Anwendungsbeispielen versehen.

Laireiter, A.-R. \& Lettner, K. (1993), Belastende Aspekte sozialer Netzwerke und sozialer Unterstützung. In A.R. Laireiter (Hrsg.), Soziales Netzwerk und soziale Unterstuitzung. Konzepte, Methoden und Befunde. ISBN 3456824025. Hier werden erstmals die Belastenden Aspekte sozialer Unterstützung systematisch aufgearbeitet.

Rook, K. S. (2015), Social Networks in Later Life. Weighing Positive and Negative Effects on Health and Well-Being. Current directions in psychological science, https://doi.org/10.1177/0963721414551364. Dieser Beitrag bietet einen Überblick über die Forschung zu Gesundheitseffekten von positiven und negativen Aspekten sozialer Netzwerke.

\section{Literatur}

Adebahr, P., \& Lehmann, J. (2017). Die soziale Akzeptanz von „Fat Shaming“ als Akt der Stigmatisierung von Übergewichtigen. In S. Lessenich (Hrsg.), Geschlossene Gesellschaften. Verhandlungen des 38. Kongresses der Deutschen Gesellschaft für Soziologie in Bamberg 2016. http://publikationen.soziologie.de/index.php/kongressband_2016/ article/view/599/pdf_140. Zugegriffen: 28. Febr. 2019.

Ajzen, I. (2001). Nature and operation of attitudes. Annual Review of Psychology, 52, 27-58.

Alegria Drury, C. A., \& Louis, M. (2002). Exploring the association between body weight, stigma of obesity, and health care avoidance. Journal of the American Academy of Nurse Practitioners, 14(12), 554-561.

Allen, J. J., Anderson, C. A., \& Bushman, B. J. (2018). The general aggression model. Current Opinion in Psychology, 19, 75-80.

Banaji, M. R., \& Heiphetz, L. (2010). Attitudes. In S. T. Fiske, D. T. Gilbert, G. Lindzey, \& A. E. Jongsma (Hrsg.), Handbook of social psychology (S. 353-393). Hoboken: Wiley.

Bark, S. (2012). Zur Produktivität sozialer Konflikte. Wiesbaden: Springer VS.

Belle, D. E. (1983). The impact of poverty on social networks and supports. Marriage \& Family Review, 5(4), 89-103.

Blackhart, G. C., Nelson, B. C., Knowles, M. L., \& Baumeister, R. F. (2009). Rejection elicits emotional reactions but neither causes immediate distress nor lowers self-esteem. A meta-analytic review of 192 studies on social exclusion. Personality and Social Psychology Review, 13(4), 269-309. 
Bogerts, B., \& Möller-Leimkühler, A. M. (2013). Neurobiologische Ursachen und psychosoziale Bedingungen individueller Gewalt. Der Nervenarzt, 84(11), 1329-1344. https:// link.springer.com/content/pdf/10.1007/s00115-012-3610-x.pdf. Zugegriffen: 10. Jan. 2019.

Bonacker, T., \& Imbusch, P. (2010). Zentrale Begriffe der Friedens- und Konfliktforschung. Konflikt, Gewalt, Krieg, Frieden. In P. Imbusch \& R. Zoll (Hrsg.), Friedens- und Konfliktforschung. Eine Einführung (S. 67-142). Wiesbaden: VS.

Borgatti, S. P., Brass, D. J., \& Halgin, D. S. (2014). Social network research. Confusions, criticisms, and controversies. In D. J. Brass, G. Labianca, A. Mehra, D. S. Halgin, \& S. P. Borgatti (Hrsg.), Research in the sociology of organizations (Bd. 40, S. 1-29). Bradford: Emerald.

Brooks, K. P., \& Dunkel Schetter, C. (2011). Social negativity and health. Conceptual and measurement issues. Social and Personality Psychology Compass, 5(11), 904-918.

Bundeskriminalamt. (2018). Partnerschaftsgewalt. Kriminalstatistische Auswertung. Berichtsjahr 2017, Bundeskriminalamt. https://www.bka.de/SharedDocs/Downloads/ DE/Publikationen/JahresberichteUndLagebilder/Partnerschaftsgewalt/Partnerschaftsgewalt_2017.pdf?_blob=publicationFile\&v=2. Zugegriffen: 28. Febr. 2019.

Bushman, B. B., \& Holt-Lunstad, J. (2009). Understanding social relationship maintenance among friends. Why we don't end those frustrating friendships. Journal of Social and Clinical Psychology, 28(6), 749-778.

Cacioppo, J. T., \& Gardner, W. L. (1999). Emotion. Annual Review of Psychology, 50, 191214.

Cannon, W. B. (1932). The wisdom of the body. New York: Norton.

Chauvac, N., Cloutier, L., Defossez, A., Akermann, G., \& Federico, A. d. (2014). Negative ties, lost ties, latent ties. Bulletin of Sociological Methodology/Bulletin de Méthodologie Sociologique, 121(1), 5-9.

Coser, L. A. (2009). Theorie sozialer Konflikte. Wiesbaden: VS Verlag.

de Vogli, R., Chandola, T., \& Marmot, M. G. (2007). Negative aspects of close relationships and heart disease. Archives of Internal Medicine, 167(18), 1951-1957.

Eggert, S., Schnapp, P., \& Sulmann, D. (2018). Aggression und Gewalt in der informellen Pflege, Zentrum für Qualität in der Pflege. https://www.zqp.de/wp-content/uploads/ ZQP_Analyse_Gewalt_informelle_Pflege.pdf. Zugegriffen: 10. Jan. 2019.

Gleason, M. E. J., \& Iida, M. (2015). Social support. In M. Mikulincer, P. R. Shaver, J. A. Simpson \& J. F. Dovidio (Hrsg.), APA Handbook of Personality and Social Psychology, Volume 3: Interpersonal Relations (S. 351-370). Washington, DC: American Psychological Association.

Greitemeyer, T., \& Sagioglou, C. (2018). Does low (vs. high) subjective socioeconomic status increase both prosociality and aggression? Social Psychology, 49(2), 76-87.

Heider, F. (1946). Attitudes and cognitive organization. The Journal of Psychology, 21, $107-112$.

Heitmeyer, W., \& Hagan, J. (2002). Internationales Handbuch der Gewaltforschung. Wiesbaden: VS Verlag.

Hess, J. A. (2000). Maintaining nonvoluntary relationships with disliked partners. An investigation into the use of distancing behaviors. Human Communication Research, 26(3), 458-488. 
Hess, J. A. (2003). Maintaining undesired relationships. In D. J. Canary \& M. Dainton (Hrsg.), Maintaining realtionships through communication. Relational, contextual, and cultural variations (S. 103-124). Mahwah: Erlbaum.

Hess, J. A. (2016). Distance regulation in personal relationships. The development of a conceptual model and a test of representational validity. Journal of Social and Personal Relationships, 19(5), 663-683.

Hobfoll, S. E. (1998). Stress, culture, and community. The psychology and philosophy of stress (The Plenum series on stress and coping). New York: Plenum Press.

Ito, T. A., Larsen, J. T., Smith, N. K., \& Cacioppo, J. T. (1998). Negative information weighs more heavily on the brain. The negativity bias in evaluative categorizations. Journal of Personality and Social Psychology, 75(4), 887-900.

Jetten, J., Haslam, S. A., Cruwys, T., Greenaway, K. H., Haslam, C., \& Steffens, N. K. (2017). Advancing the social identity approach to health and well-being. Progressing the social cure research agenda. European Journal of Social Psychology, 47(7), 789-802.

Kaur, M., \& Singh, S. (2015). Analyzing negative ties in social networks. A survey. Egyptian Informatics Journal, 17(1), 21-43.

Kiecolt-Glaser, J. K., Loving, T. J., Stowell, J. R., Malarkey, W. B., Lemeshow, S., Dickinson, S. L., \& Glaser, R. (2005). Hostile marital interactions, proinflammatory cytokine production, and wound healing. Archives of General Psychiatry, 62(12), 1377-1384.

Kiviruusu, O., Berg, N., Huurre, T., Aro, H., Marttunen, M., \& Haukkala, A. (2016). Interpersonal conflicts and development of self-esteem from adolescence to mid-adulthood. A 26-year follow-up. PloS one, 11(10), e0164942.

Klein Ikkink, K., \& van Tilburg, T. (1999). Broken ties. Reciprocity and other factors affecting the termination of older adults' relationships. Social Networks, 21(2), 131-146.

Krause, N., Newsom, J. T., \& Rook, K. S. (2008). Financial strain, negative social interaction, and self-rated health. Evidence from two United States nationwide longitudinal surveys. Ageing and Society, 28(7), 1001-1023.

Kriwy, P., \& Nisic, N. (2012). Gesundheit als Ressource. In A. Knecht (Hrsg.), Ressourcen im Sozialstaat und in der Sozialen Arbeit. Ein Handbuch, (S. 89-101). Stuttgart: Kohlhammer.

Labianca, G. (2014). Negative Ties in Organizational Networks. In D. Brass, G. Labianca, A. Mehra, D. S. Halgin \& S. P. Borgatti (Hrsg.), Research in the Sociology of Organizations, (S. 239-259). Bradford, UK: Emerald.

Labianca, G., \& Brass, D. J. (2006). Exploring the social ledger. Negative relationships and negative asymmetry in social networks in organizations. Academy of Management Review, 31(3), 596-614.

Laireiter, A.-R., \& Lettner, K. (1993). Belastende Aspekte sozialer Netzwerke und sozialer Unterstützung. In A.-R. Laireiter (Hrsg.), Soziales Netzwerk und soziale Unterstützung. Konzepte, Methoden und Befunde (S. 101-114). Bern: Huber.

Lamnek, S., Luedtke, J., Ottermann, R., \& Vogl, S. (2013). Tatort Familie. Häusliche Gewalt im gesellschaftlichen Kontext. Wiesbaden: Springer VS.

Leary, M. R. (2005). Sociometer theory and the pursuit of relational value. Getting to the root of self-esteem. European Review of Social Psychology, 16(1), 75-111.

Leary, M. R. (2012). Sociometer theory. In A. W. Kruglanski, E. T. Higgins, \& P. A. M. van Lange (Hrsg.), Theories of social psychology (S. 141-159). Los Angeles: Sage. 
Lin, N. (2000). Social resources and social action. A theory of social capital. New York: Cambridge University Press.

Lincoln, K. D., Taylor, R. J., Bullard, K. M., Chatters, L. M., Woodward, A. T., Himle, J. A., \& Jackson, J. S. (2010). Emotional support, negative interaction and DSM IV lifetime disorders among older African Americans: Findings from the National Survey of American Life (NSAL). International Journal of Geriatric Psychiatry, 25(6), 612-621.

Lüscher, K. (2011). Über Ambivalenz. Forum der Psychoanalyse, 27(4), 323-327.

McCubbin, H. I., \& Patterson, J. M. (1983). The family stress process. The double ABCX model of adjustment and adoption. In H. I. McCubbin \& J. M. Patterson (Hrsg.), Social stress and the family (S. 7-37). New York: Haworth Press.

Nolting, H.-P. (1998). Konflikt. In S. Grubitzsch \& K. Weber (Hrsg.), Psychologische Grundbegriffe. Ein Handbuch (S. 552-554). Reinbek: Rowohlt.

Ntounas, P., Katsouli, A., Efstathiou, V., Pappas, D., Chatzimanolis, P., Touloumis, C., Papageorgiou, C., \& Douzenis, A. (2018). Comparative study of aggression - Dangerousness on patients with paranoid schizophrenia. Focus on demographic data, PANSS, drug use and aggressiveness. International Journal of Law and Psychiatry, 60, 1-11.

Offer, S. (2012). The burden of reciprocity. Processes of exclusion and withdrawal from personal networks among low-income families. Current Sociology, 60(6), 788-805.

Offer, S. \& Fischer, C. S. (2018). Difficult People. Who is percieved to be demanding in personal networks and why are they there? American Sociological Review, 83(1), 111-142.

Orth-Gomér, K. (2007). Psychosocial and behavioral aspects of cardiovascular disease prevention in men and women. Current Opinion in Psychiatry, 20(2), 147-151.

Orth-Gomér, K. (2009). Are social relations less health protective in women than in men? Social relations, gender, and cardiovascular health. Journal of Social and Personal Relationships, 26(1), 63-71.

Pape, J. C., \& Binder, E. B. (2014). Psychotrauma als Risiko für spätere psychische Störungen. Epigenetische Mechanismen. Der Nervenarzt, 85(11), 1382-1389.

Perry, B. L., Pescosolido, B. A., \& Borgatti, S. P. (2018). Egocentric network analysis. Foundations, methods, and models (Structural analysis in the social sciences, Bd. 44). Cambridge: Cambridge University Press.

Peuckert, R. (2006). Abweichendes Verhalten und soziale Kontrolle. In H. Korte \& B. Schäfers (Hrsg.), Einführung in Hauptbegriffe der Soziologie (S. 105-125). Wiesbaden: VS Verlag.

Phan, M. B., Blumer, N., \& Demaiter, E. I. (2009). Helping hands. Neighborhood diversity, deprivation, and reciprocity of support in non-kin networks. Journal of Social and Personal Relationships, 26(6-7), 899-918.

Piff, P. K., Kraus, M. W., Côté, S., Cheng, B. H., \& Keltner, D. (2010). Having less, giving more. The influence of social class on prosocial behavior. Journal of Personality and Social Psychology, 99(5), 771-784.

Puhl, R. M., \& Brownell, K. D. (2006). Confronting and coping with weight stigma. An investigation of overweight and obese adults. Obesity, 14(10), 1802-1815.

Rensing, L. (2013). Mensch im Stress. Psyche, Körper, Moleküle. Berlin: Springer VS.

Rook, K. S. (1984). The negative side of social interaction. Impact on psychological wellbeing. Journal of Personality and Social Psychology, 46(5), 1097-1108. 
Rook, K. S. (1998). Investigating the positive and negative sides of personal relationships. Through a glass darkly? In W. R. Cupach \& B. H. Spitzberg (Hrsg.), The dark side of close relationships (S. 369-393). New York: Routledge.

Rook, K. S. (2015). Social Networks in later life. Weighing positive and negative effects on health and well-being. Current Directions in Psychological Science, 24(1), 45-51.

Rook, K. S., August, K. J., Stephens, M. A. P., \& Franks, M. M. (2011). When does spousal social control provoke negative reactions in the context of chronic illness? The pivotal role of patients' expectations. Journal of Social and Personal Relationships, 28(6), 772-789.

Rusbult, C. E., \& Zembrodt, I. M. (1983). Responses to dissatisfaction in romantic involvements. A multidimensional scaling analysis. Journal of Experimental Social Psychology, 19(3), 274-293.

Rüssmann, K., Kopp, J., \& Hill, P. B. (2015). Macht, Arbeitsteilung, Konflikt, Konfliktstile und Gewalt in Partnerschaften. In P. B. Hill \& J. Kopp (Hrsg.), Handbuch Familiensoziologie (S. 487-527). Wiesbaden: Springer VS.

Seeman, T. E., Gruenewald, T. L., Cohen, S., Williams, D. R., \& Matthews, K. A. (2014). Social relationships and their biological correlates. Coronary Artery Risk Development in Young Adults (CARDIA) study. Psychoneuroendocrinology, 43, 126-138.

Seidel, E.-M., Kogler, L., Moser, E., Windischberger, C., Kryspin-Exner, I., Gur, R. C., Habel, U., \& Derntl, B. (2013). Weiblicher vs. männlicher Stresstyp? Ein aktueller Überblick zur neuropsychologischen Stressforschung. Zeitschrift für Psychiatrie, Psychologie und Psychotherapie, 61(2), 71-79.

Siegrist, J. (2018). Soziale Stressoren und stressbedingte Erkrankungen. In R. Fuchs \& M. Gerber (Hrsg.), Handbuch Stressregulation und Sport (S. 79-92). Berlin: Springer.

Simmel, G. (1908). Soziologie. Untersuchungen über die Formen der Vergesellschaftung. Kapitel IV: Der Streit. http://socio.ch/sim/soziologie/index.htm. Zugegriffen: 28. Febr. 2019.

Sneed, R. S., \& Cohen, S. (2014). Negative social interactions and incident hypertension among older adults. Health Psychology, 33(6), 554-565.

Stafford M., McMunn, A., Zaninotto, P., \& Nazroo, J. (2011). Positive and negative exchanges in social relationships as predictors of depression. Evidence from the English Longitudinal Study of Aging. Journal of Aging and Health, 23(4), 607-628.

Sykes, H., \& McPhail, D. (2008). Unbearable lessons. Contesting fat phobia in physical education. Sociology of Sport Journal - Special Issue on Social Construction of Fat, 25(1), 66-96.

Tanne, D., Goldbourt, U., \& Medalie, J. H. (2004). Perceived family difficulties and prediction of 23-year stroke mortality among middle-aged men. Cerebrovascular Diseases, 18(4), 277-282.

Taylor, S. E., Klein, L. C., Lewis, B. P., Gruenewald, T. L., Gurung, R. A., \& Updegraff, J. A. (2000). Biobehavioral responses to stress in females. Tend-and-befriend, not fightor-flight. Psychological Review, 107(3), 411-429.

Tippett, N., \& Wolke, D. (2014). Socioeconomic status and bullying. A meta-analysis. American Journal of Public Health, 104(6), e48-e59.

Tsuno, K., Kawakami, N., Tsutsumi, A., Shimazu, A., Inoue, A., Odagiri, Y., Yoshikawa, T., Haratani, T., Shimomitsu, T., \& Kawachi, I. (2015). Socioeconomic determinants of bullying in the workplace. A national representative sample in Japan. PloS one, 10(3), $\mathrm{e} 0119435$. 
Uchino, B. N. (2009). Understanding the Links Between Social Support and Physical Health. A Life-Span Perspective With Emphasis on the Separability of Perceived and Received Support. In Perspectives on Psychological Science, 4(3), 236-255.

von Dawans, B., \& Heinrichs, M. (2018). Physiologische Stressreaktion. In R. Fuchs \& M. Gerber (Hrsg.), Handbuch Stressregulation und Sport (S. 67-78). Berlin: Springer.

Wright, B. L., \& Loving, T. J. (2011). Health implications of conflict in close relationships. Social and Personality Psychology Compass, 5(8), 552-562.

Open Access Dieses Kapitel wird unter der Creative Commons Namensnennung 4.0 International Lizenz (http://creativecommons.org/licenses/by/4.0/deed.de) veröffentlicht, welche die Nutzung, Vervielfältigung, Bearbeitung, Verbreitung und Wiedergabe in jeglichem Medium und Format erlaubt, sofern Sie den/die ursprünglichen Autor(en) und die Quelle ordnungsgemäß nennen, einen Link zur Creative Commons Lizenz beifügen und angeben, ob Änderungen vorgenommen wurden.

Die in diesem Kapitel enthaltenen Bilder und sonstiges Drittmaterial unterliegen ebenfalls der genannten Creative Commons Lizenz, sofern sich aus der Abbildungslegende nichts anderes ergibt. Sofern das betreffende Material nicht unter der genannten Creative Commons Lizenz steht und die betreffende Handlung nicht nach gesetzlichen Vorschriften erlaubt ist, ist für die oben aufgeführten Weiterverwendungen des Materials die Einwilligung des jeweiligen Rechteinhabers einzuholen.

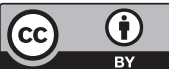




\title{
Netzwerkanalyse - eine methodische Annäherung
}

\author{
Markus Gamper
}

\section{Überblick}

- Netzwerke bestehen aus Akteuren, die durch Beziehungen miteinander verbunden sind und dessen Verbindungen sich $\mathrm{zu}$ unterschiedlichen sozialen Strukturen zusammensetzen.

- Man geht davon aus, dass soziale Netzwerke auf die Akteure wirken und Akteure wiederum die Netzwerke beeinflussen.

- Es findet sich eine Unterscheidung zwischen Gesamtnetzwerken und egozentrierten Netzwerken. Bei der Gesamtnetzwerkanalyse werden die jeweiligen Akteure und deren Relationen innerhalb vordefinierter Grenzen betrachtet. Bei egozentrierten Netzwerken steht die interpersonale Vernetzung eines bestimmten Akteurs im Zentrum der Analyse.

- Methodisch kann zwischen qualitativer - häufig bestehend aus visuellen Zugängen - und quantitativer Netzwerkforschung differenziert werden. Der Schwerpunkt in der Gesundheitsforschung liegt bisher eher auf den quantitativen Ansätzen.

- Getestete Verfahren der Netzwerkanalyse in der Gesundheitsforschung existieren so nicht. Forschungen müssen daher immer an den Gegenstand angepasst werden.

- Der zeitliche Aufwand für die Erhebung von Netzwerkdaten kann sehr hoch sein, daher sollten Netzwerkbefragungen im Pretest immer getestet werden.

M. Gamper $(\bowtie)$

Köln, Deutschland

E-Mail: m.gamper@uni-koeln.de 


\section{$1 \quad$ Was ist ein Netzwerk?}

„Netzwerke“ scheinen in modernen Gesellschaften omnipräsent zu sein (z. B. soziale Online-Netzwerke wie Facebook und Twitter oder auch kriminelle und terroristische Netzwerke), jedoch bleiben der Begriff und seine Bedeutung im Alltag häufig amorph. Um mit dem Konzept wissenschaftlich adäquat arbeiten zu können, werden in diesem Kapitel der Begriff, unterschiedliche Formen der Netzwerkanalyse sowie Erhebungs- und Auswertungsstrategien vorgestellt. Im Folgenden wird ein kurzer Überblick über verschiedene Verfahren und wichtige Literaturhinweise gegeben, auf die bei Bedarf vertiefend zurückgegriffen werden kann.

Das Axiom der Netzwerkforschung geht davon aus, dass Elemente sogenannte Knoten - mit anderen Elementen Beziehungen - sogenannte Kanten - eingehen können. Die kleinste Einheit solcher sozialen Beziehungen ist die Dyade, die Relation zwischen zwei Akteuren. Dyaden wiederum existieren nicht solitär, sondern verbinden sich zu größeren Netzwerken, wo sie auch bestimmte Strukturen ausbilden. Eine einheitliche Definition von (sozialen) Netzwerken existiert jedoch nicht. Wie ein Netzwerk definiert wird hängt auch vom zu untersuchenden Gegenstand ab.

In einer sehr allgemeinen Begriffsbestimmung kann ein Netzwerk als ,,[...] abgegrenzte Menge von Knoten oder Elementen und der Menge der zwischen ihnen verlaufenden sogenannten Kanten" verstanden werden (Jansen 2006, S. 58). Diese Definition kann sowohl auf soziale wie auch nicht-soziale, technische oder physisch-materielle Elemente wie z. B. Straßen- oder Stromnetzwerke angewandt werden. Neben dieser formalen Bestimmung von Netzwerken existieren Begriffsbestimmungen, die stärker soziales Handeln und den gegenseitigen Einfluss von Netzwerken und Handeln in den Fokus stellen. Als Beispiel kann hier Clyde Mitchell genannt werden, der Netzwerke definiert als ,[...] as a specific set of linkages among a defined set of persons, with the additional property that the characteristics of these linkages as a whole may be used to interpret the social behaviour of the persons involved" (Mitchell 1969, S. 2).

Netzwerke sind vom soziologischen Begriff der Gruppe zu unterscheiden, da deren Existenz durch Grenzziehungen, nicht durch prinzipiell offene Relationen, bestimmt wird: „,(A) fundamental part of the concept of a group is the existence of boundaries “ (Borgatti und Halgin 2011, S. 1169). Das Konzept unterscheidet somit zwischen In- und Outgroup. In einigen Fällen werden Gruppen aber auch als Netzwerke bezeichnet, obwohl soziale Beziehungen innerhalb der Gruppe nicht explizit auf dyadischer Ebene untersucht, sondern eher vermutet werden. Gruppen können damit auch als eine Unterkategorie von besonders dichten 
Netzwerken verstanden werden. „(U)nlike networks, [groups] depend upon the merging of social relations within a shared space and with a recognizable culture. Although groups are distinguished from networks through their boundaries, pasts, and identifications, groups are in some regards dense networks" (Fine 2012, S. 168).

Anders als bei klassischen sozialwissenschaftlichen Verfahren werden in der Netzwerkanalyse neben persönlichen Attributen (z. B. Geschlecht, Alter, Einkommen) noch relationale Attribute (z. B. Positionen von Akteuren in Netzwerken) in die Analyse einbezogen. Es wird damit davon ausgegangen, dass die Struktur der sozialen Netzwerke (z. B. Unterstützungsnetzwerke) und soziale Outcomes (z. B. Gesundheitsverhalten, Gesundheit) voneinander abhängig sind und sich gegenseitig beeinflussen.

Netzwerke bestehen also aus sogenannten Knoten (z. B. Personen oder kollektive Akteure) und Beziehungen, den sogenannten Kanten (z. B. Freundschaft, Küssen, Weitergabe von Viren), über welche die Knoten verbunden sind. ${ }^{1}$ Ziel der Netzwerkforschung ist es, Kausalaussagen zu der Wirkung von Beziehungen auf die Akteure (oder umgekehrt) zu treffen oder die Akteure und ihre Beziehungen beschreiben zu können.

\section{Idealtypen der Netzwerkforschung}

Auch wenn ein Netzwerk allgemein als Set aus Knoten und Kanten beschrieben werden kann, zeigen sich hinsichtlich des empirischen Vorgehens, bei der Erhebung wie auch der Auswertung, deutliche Unterschiede. Die Netzwerkforschung kann idealtypisch entlang zweier Dimensionen differenziert werden (Gamper und Schönhuth 2016): Entlang einer strukturellen Dimension lassen sich Gesamtnetzwerke und egozentrierte Netzwerke unterscheiden, entlang einer methodischen Dimension quantitative und qualitative Verfahren der Netzwerkforschung. In der empirischen Praxis kann von diesen Idealtypen selbstverständlich abgewichen werden. Beispielsweise findet man Forschungsarbeiten, die sowohl auf qualitative als auch quantitative Methoden gleichzeitig zurückgreifen und Daten durch triangulieren miteinander in Verbindung setzen (Dominguez und Hollstein 2014).

${ }^{1}$ Zur Unterscheidung zwischen Gruppe und Netzwerk siehe auch Borgatti und Halgin (2011) oder Fuhse (2006). 


\subsection{Gesamtnetzwerke und egozentrierte Netzwerke}

Bei der Gesamtnetzwerkanalyse werden die jeweiligen Knoten und deren Kanten innerhalb vordefinierter Grenzen betrachtet. Der Fokus liegt auf der internen Vernetzung der Akteure in diesem vorbestimmten Bereich (z. B. Sexpartner*innen in einer Schule, Weitergabe von Krankheiten in einem Dorf, Einfluss von Rauchverhalten in einem Verein). Im idealtypischen Fall werden die Relationen außerhalb dieser definierten Grenzen nicht in die Analyse miteinbezogen. Somit liegt der Forschungsschwerpunkt auf einer bestimmten Anzahl von Akteuren und deren ganz spezifischen Beziehungen (Jansen 2006). Die Grenzziehung sollte gut begründet und beschrieben werden, da jede Grenzziehung Auswirkung auf die Daten und Ergebnisse hat. Grenzen können z. B. aufgrund bestimmter Theorien oder auch empirischer Vorkenntnisse bestimmt werden. In der Forschung gibt es jedoch auch pragmatische Grenzziehungen, die dem Forschungsfeld geschuldet sind (vertiefend: Laumann et al. 1983). Meist werden Akteure (z. B. Schüler*innen) zu ihren Verbindungen zu anderen Personen (z. B. Mitschüler*innen) in einem vordefinierten Bereich (z. B. Schulklasse) befragt. Neben vorgefertigten Namenslisten, mit deren Hilfe die betreffenden Kontaktpersonen nur ausgewählt werden müssen, können die Befragten z. T. Namen der Kontaktpartner auch selbst bestimmen. Hierbei müssen diese Kontaktpersonen jedoch Teil der vordefinierten Menge (z. B. Schulklasse) sein. Neben den Beziehungsparametern (z. B. Freundschaftsbeziehungen, Liebesbeziehungen) werden den Interviewten weitere Fragen zur eigenen Person gestellt (z. B. Alter, Gesundheitsstand, BodyMass-Index). Alle erhobenen Beziehungen und Attribute werden dann in ein Gesamtnetzwerk überführt. In anderen Fällen, z. B. im Internet, liegen Daten über die Beziehungen (z. B. Twitter, Facebook) bereits digital vor. Ein eher selten angewendetes Verfahren zur Datenerhebung ist zudem die teilnehmende/ nicht-teilnehmende Beobachtung. Hier werden Beziehungen zwischen Akteuren auf Basis von Beobachtungen registriert und festgehalten wie etwa die Weitergabe von Zigaretten auf den Schulhof. In vielen Studien werden diese Ergebnisse visuell dargeboten bzw. abgebildet.

Ein prominentes Beispiel für eine Gesamtnetzwerkanalyse aus dem Bereich der Gesundheitsforschung ist die Untersuchung von Romantik- und Sexualnetzwerken in der „Jefferson High School“ in den USA (Bearman et al. 2004). Die Studie von 2004 nimmt das Ansteckungsrisiko von Geschlechtskrankheiten bei Jugendlichen und die Möglichkeit der Prävention in den Fokus. Hierbei wurde das Gesamtnetzwerk aus ca. 800 Schüler*innen der "Jefferson High School“ in einer Kleinstadt in den USA erhoben. Die Knoten sind in diesem Fall die Schüler*innen der Schule. Die Kanten bilden die Romantik- und Sexualbeziehungen während 


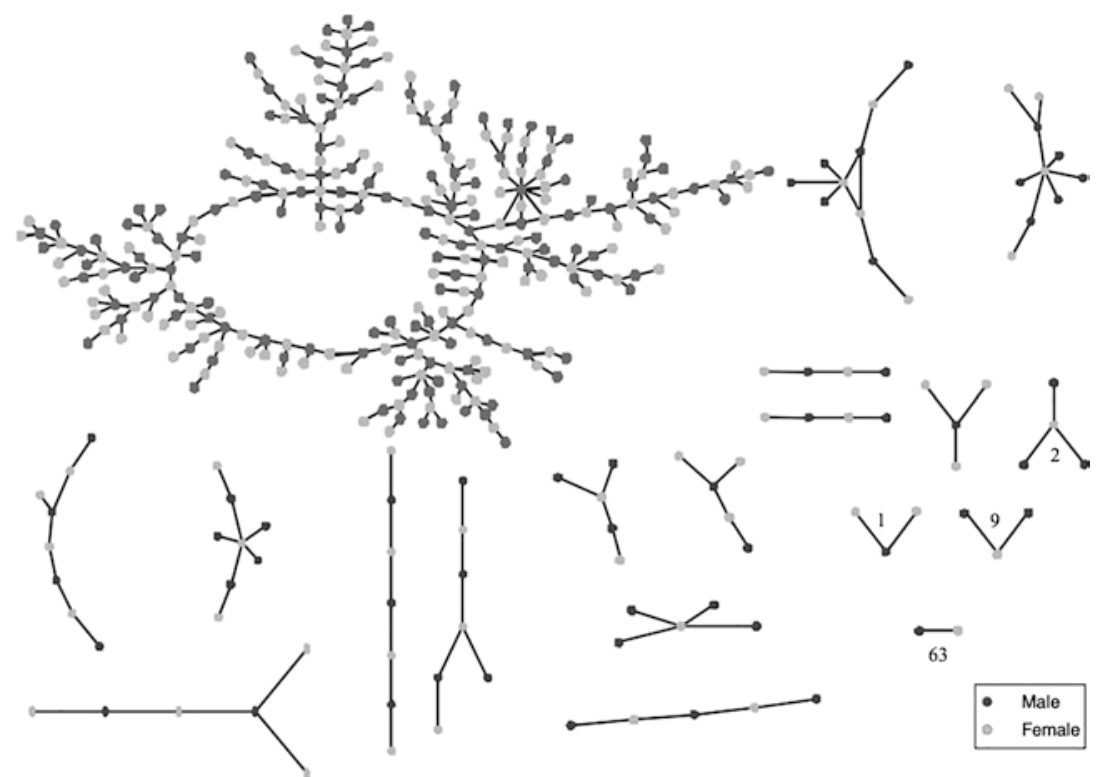

Abb. 1 Sexual- und Romantikbeziehungen von Schüler*innen innerhalb der Jefferson High School. (Quelle: Bearman et al. 2004, S. 58)

der letzten 18 Monate zwischen ihnen ab. Hierbei gaben 573 Schüler*innen an, eine solche oder mehrere solche Beziehungen eingegangen zu sein.

Durch unterschiedliche Möglichkeiten, Beziehungen mit anderen zu schließen, ergeben sich verschiedene Formen von Netzwerken. Diese reichen von einfachen Dyaden über Triaden bis hin zu einer großen Netzwerkkomponente mit vielen Akteuren, die auf unterschiedliche Weise miteinander verwoben sind (siehe Abb. 1). Durch den Vergleich mit zufällig erzeugten Netzwerken konnten die Forscher feststellen, ,that the observed structures differ radically from the randomly generated networks. Specifically, we find that real sexual and romantic networks are characterized by much longer contact chains and far fewer cycles." (Bearman et al. 2004, S. 44). Dies hat zur Folge, dass viele Personen (hier knapp $50 \%$ ) auf indirekten Weg miteinander verbunden sind und somit die Zahl der Sexualbeziehungen nicht in ihrer Gesamtheit überschauen können. Eine indirekte Beziehungskette ergibt sich zum Beispiel, wenn ein erkrankter Schüler A eine Beziehung mit Schülerin B hatte und diese dann eine weitere Beziehung mit Schüler C eingeht - wenn Schüler C nichts von der Beziehung zwischen A und 
B erfährt, ahnt C nichts davon, dass B die Erkrankungen von A an ihn übertragen könnte. Durch diese Art von Vernetzung kann sich eine Krankheit schnell übertragen und eine große Anzahl von Schüler*innen infizieren. Um Ansteckungen $\mathrm{zu}$ vermeiden, ist es daher wichtig, das große Cluster „auseinanderzubrechen“, sodass das Virus in seiner Verbreitung gestoppt werden kann. Hierzu muss das Verhalten einiger Schüler*innen geändert werden (z. B. durch den Einsatz von Verhütungsmitteln), da dann das Cluster in einzelne Ketten zerfällt und die Ansteckung dadurch reduziert wird.

Wie das Beispiel verdeutlicht, ist die Netzwerkegrenze sozusagen das „Schulgelände“ der Jefferson High School. Analysiert werden daher auch „nur“ die Romantik- und Sexualbeziehungen der Schüler*innen dieser Schule. Sexual- und Romantikbeziehungen zu Personen außerhalb der Schule, wie z. B. Schüler*innen in einer anderen Schule, werden hier nicht berücksichtigt. Hinzu kommt, dass andere Beziehungsarten (z. B. Freundschaft), jenseits der Sexual- und Romantikbeziehungen, nicht in die Analyse mit einfließen.

Die egozentrierte Netzwerkforschung unterliegt einer etwas anderen Logik. Hier steht die interpersonale Vernetzung eines bestimmten Akteurs, dem Ego, im Zentrum der Betrachtung. Aus der Sicht des Befragten (=Ego) werden bestimmte Personen und deren Beziehungen untereinander erfragt (Burt 1984; McCallister und Fischer 1978; Wellman 1979). Das egozentrierte Netzwerk besteht aus Beziehungen des befragten Akteurs (Ego) zu anderen Akteuren in seinem Netzwerk, den sogenannten Alteri, mit denen er direkt verwoben ist. Zum Teil wird Ego in den Studien auch nach zu Relationen zwischen den Alteri befragt.

Zuerst wird Ego zu seiner subjektiven Sicht auf seine Beziehungen interviewt. Hierbei muss er/sie Personen nennen, zu denen er bestimmte, meist vom Forscher vordefinierte Beziehungen (z. B. zusammen rauchen, Sexualbeziehung, Spritzenaustausch) unterhält. Diese Fragen werden auch Akteursgeneratoren (dazu gehören z. B. Namensgeneratoren, Ressourcengeneratoren, Positionsgeneratoren) genannt, da durch diese Netzwerkakteure generiert werden. Eine vorgegebene Liste von Namen, wie bei der Gesamtnetzwerkanalyse, existiert nicht. Dem Forscher sind die Namen der Kontaktpersonen vorab nicht bekannt und eine klare Grenzziehung des Netzwerks fehlt. Daran anknüpfend wird Ego aufgefordert, weitere Informationen zu den genannten Alteri (sogenannte Akteursinterpretatoren) und zu seiner eigenen Person zu nennen. Das können z. B. soziodemografische Angaben, Rauchverhalten oder der Gesundheitszustand sein. In vielen Studien werden Ego auch Fragen zu den Beziehungen zwischen den Alteri gestellt, z. B. inwieweit die Alteri in Kontakt untereinander stehen. Dies ist nicht unbedingt nötig, wenn bestimmte statistische Maßzahlen oder Fragestellungen nicht als essenziell für die eigene Fragestellung betrachtet werden 
(Herz 2012; Wolf 2006, 2010). Anders als bei der Gesamtnetzwerkanalyse, wo die Kontaktpersonen durch die Eingrenzung vorgegeben sind, ist hier der/die zu Befragende bei seiner/ihrer Nennung frei. Hinzu kommt, dass die Informationen über die Alteri (z. B. Geschlecht, Gesundheitszustand) von Ego stammen und nicht von den Alteri selbst.

Als Beispiel soll hier eine Längsschnittstudie von Perry und Pescosolido (2015) angeführt werden. Hierbei wurden ca. 171 Personen (Egos) nach ihren Alteri befragt, die im Falle von Krankheit, hier psychische Problemen, kontaktiert wurden. Das Forschungsinteresse galt der Aktivierung der Unterstützungsleistung durch die Alteri und welche Art von Netzwerken, die für Gesundheitsfragen in Anspruch genommen wird. Die Stichprobe bestand aus einer Gruppe von Patienten mit schweren psychischen Erkrankungen und einer Gruppe mit weniger schweren Störungen, die zum ersten Mal psychologisch behandelt wurden. In der Studie wurde folgender Akteursgenerator (hier speziell ein Namensgenerator) verwendet: „I'm interested in who, among all of the people in your life, you talk to about health problems when they come up. Who are the people that you discuss your health with or you can really count on when you have physical or emotional problems?" (Perry und Pescosolido 2015, S. 119). Anders als bei der Studie von Bearman et al. (2004) geht es hier nicht um die Verbindung der Akteure innerhalb einer gewissen Grenze und zwischen diesen Personen, sondern um den Effekt von Personen auf das gesundheitliche Wohlbefinden einzelner Egos vor dem Hintergrund ihrer ganz persönlichen Netzwerke. In anderen Worten: Welche Netzwerke können dem Einzelnen helfen, dass er/sie sich wohler fühlt. Ziel war es, generelle Aussagen zu treffen. Wie die Studie zeigt, spielen Netzwerke besonders vor dem Hintergrund der emotionalen Unterstuitzung und Informationsweitergabe eine wichtige Rolle:

„Social networks have the potential to serve as conduits of general emotional support and information. However, according to our findings, it is not these general support processes that drive recovery outcomes. Rather, the key factor appears to be activation of particular kinds of people for health discussion. This indicates that achieving a state of recovery may be facilitated by cultivating a social safety net that can provide targeted, health-related advice, affirmation, and instrumental aid that buoys the treatment process and permits gains in self-sufficiency and productivity “ (Perry und Pescosolido 2015, S. 126).

In der quantitativen egozentrierten Netzwerkforschung wird meist auf Visualisierungen verzichtet, da hier mehrere einzelne Netzwerke (in diesem Beispiel wären es 171 einzelne Netzwerke) visualisiert werden müssten und der Mehrwert eher als gering eingeschätzt werden kann. Anders ist dies bei der visuellen bzw. 
qualitativen egozentrierten Netzwerkforschung, auf die später noch eingegangen wird (siehe Abschn. 2.2).

Gesamt- und egozentrierte Netzwerkanalyse unterscheiden sich somit. Zwar ist es auch möglich, aus Gesamtnetzwerken einzelne egozentrierte Netzwerke zu isolieren, diese sind jedoch immer nur Subnetzwerke aus einem vordefinierten Bereich, der vom Forscher festgelegt wurde. Umgekehrt ist dieser Umwandlungsprozess nur schwer bis gar nicht möglich. Im Forschungsprozess sollte sich die Forscher*innen daher für eines der beiden Verfahren entscheiden. Diese Entscheidung ist essenziell, da beide Verfahren sich hinsichtlich ihrer jeweiligen Datenerhebung und zum Teil auch in der Datenanalyse unterscheiden, wie später nochmals detaillierter gezeigt wird (siehe Abschn. 2.2). Die Auswahl für eines der beiden Verfahren sollte stark an der Forschungsfrage orientiert sein und auch den Zugang zum Feld berücksichtigen.

Wenn die Forschungsfrage auf die interne Vernetzung von Akteuren abzielt, wie beispielsweise die Weitergabe von Zigaretten von Schülern und Schülerinnen einer Schule, ist die Gesamtnetzwerkanalyse das geeignetere Mittel. Bei Gesamtnetzwerken liegt der Fokus auf einer gut zu isolierenden Gruppe und deren interne Vernetzung. Setzt man den Schwerpunkt auf den Einfluss von Freunden und Freundinnen auf den Drogenkonsum von Obdachlosen, wäre die egozentrierte Netzwerkanalyse besser geeignet, da in diesem Fall die Grenze schwer zu ziehen ist und nicht nur die interne Verflechtung interessiert. Auch bezüglich der Auswertungsverfahren ergeben sich Differenzen. Beispielsweise sind nicht alle statistischen Messmethoden für die egozentrierte Netzwerkanalyse anwendbar (siehe Abschn. 2.2).

Es kann gelten:

- Immer wenn das Forschungsinteresse auf die interne Struktur eines Netzwerks gerichtet ist und die Verbindungen zwischen einer vorbestimmten Menge an Akteuren bekannt sind oder von Interesse, ist die Gesamtnetzwerkanalyse besonders gut geeignet (Schnegg und Lang 2002). Hier bestimmt der Forscher oder die Forscherin, wer in das Sample gehört und wer nicht.

- Die egozentrierte Netzwerkforschung kommt zum Einsatz, wenn die Beziehungen nicht nur zwischen Akteuren in einem bestimmten vordefinierten Raum analysiert werden sollen, sondern wenn das Interesse darüber hinaus reicht. Hier wird zwar das fokale Ego, durch ein Stichprobeverfahren ausgewählt, welche Personen (Alteri) von Ego genannt werden, ist jedoch offen und wird nicht vorgegeben. Gut geeignet ist das Verfahren besonders, wenn man eine bestimmte Gruppe in den Fokus stellt und deren allgemeine Einbettung in das soziale Umfeld betrachten möchte, ohne dieses zuvor definiert zu haben. 


\subsection{Quantitative und qualitative Netzwerkanalyse}

Neben der Unterscheidung von egozentrierten und Gesamtnetzwerkanalysen, kann auch eine Differenzierung auf dem Kontinuum zwischen offener/qualitativer und standardisierter/quantitativer Forschung vorgenommen werden. Während die soziale Netzwerkanalyse der letzten 40 Jahre überwiegend standardisiert und quantitativ geprägt war, werden zwischenzeitlich (wieder) häufiger weniger standardisierte Forschungsansätze für die soziale Netzwerkforschung (Hollstein und Straus 2006; Straus 2002) diskutiert sowie Konzeptionierungen von Netzwerkanalysen als Methodenkombinationen aus offenen und standardisierten Zugängen vorgelegt (Dominguez und Hollstein 2014; Hollstein und Straus 2006; Gamper et al. 2012).

Bei der standardisierten Netzwerkforschung stehen sogenannte statistische Strukturbeschreibungen oder Kausalzusammenhänge im Mittelpunkt des Interesses, dazu zählen: Verteilungseigenschaften von Merkmalen, die Prüfung von Hypothesen und Erklärungsmodellen, die Aufdeckung von Zusammenhängen und auch die Entwicklung alternativer Hypothesen und Erklärungsmuster. Anders als bei der klassischen Forschung, in denen Attribute (z. B. Alter, Geschlecht) und deren Zusammenhänge untersucht werden, werden hier auch Beziehungsaspekte in die Analyse einbezogen oder stehen sogar im Zentrum der Forschung. Mithilfe von strukturierten und standardisierten Daten werden vor allem Strukturmaße wie beispielsweise Netzwerkgröße, Zentralität, Heterogenität und Dichte berechnet (Jansen 2006; Wasserman und Faust 1994; Scott 2000). Zum Verständnis werden im nächsten Schritt einige Maßzahlen kurz erörtert. Auf eine mathematische Herleitung wird in dieser Einführung verzichtet. Gute Einführungsbücher gibt es z. B. von Wasserman und Faust (1994) oder von Scott (2000), die immer wieder aktualisiert und auf den neuesten Stand der Forschung gebracht werden.

Zuerst kann zwischen Netzwerkparametern, also Aspekten die das ganze Netzwerk umfassen, und Maßzahlen, die Akteure eines Netzwerkes betreffen, sogenannten Akteursparametern, unterschieden werden. Für die netzwerkbezogenen Maßzahlen können z. B. die Netzwerkgröße, Dichte oder auch Cliquenberechnungen angeführt werden. ${ }^{2}$ Die Netzwerkgröße ist wohl das einfachste Maß. Hier werden die Akteure in einem Netzwerk summiert. Unter der Dichte versteht man den Grad der Verbundenheit des Netzwerkes, welches sich

\footnotetext{
${ }^{2}$ Wie oben bereits erwähnt wurde, finden viele dieser Berechnungen hauptsächlich bei Gesamtnetzwerken Anwendung.
} 
aus den Verbindungen der einzelnen Akteure untereinander ergibt. Die maximale Dichte $^{3}$ ist bei einem Wert von 1 erreicht, d. h., wenn jeder mit jedem im Netzwerk verbunden ist (Seidmann 1983; Wasserman und Faust 1994). Der Wert 0 ist der Minimalwert und bedeutet, dass keine Beziehungen in einem Netzwerk existieren. Bereits Bott (1957) unterschied zwischen ,tightly-knitted“ und „loosely-knitted" Netzwerken und meint damit die Vernetzung der Netzwerkmitglieder untereinander. In einem dichten Netzwerk sind viele Akteure untereinander verwoben. Hier geht man davon aus, dass eine hohe Dichte beispielsweise zu einer starken Kontrolle führen kann oder sich Krankheiten (z. B. durch Viren) schneller verbreiten können. Als Beispiel kann die oben erwähnte Weitergabe von sexuell übertragbaren Infektionskrankheiten im Sexual- und Romantiknetzwerk der Jefferson High School angeführt werden.

Neben Maßzahlen, die sich auf das ganze Netzwerk beziehen, existieren auch solche, die den einzelnen Akteur betreffen. Zu nennen wären hier die sogenannten Zentralitäts- bzw. Zentralisierungsmaße $e^{4}$ diese gehen der Frage nach, wie zentral die jeweiligen Akteure in einem Netzwerk sind. Allerdings wurde bislang noch keine Einigkeit erreicht, wie Zentralität konzeptionell zu erfassen und wie sie zu messen ist: „There is certainly no unanimity on exactly what centrality is or on its conceptual foundations, and there is little agreement on the proper procedure for its measurement" (Freeman 1979, S. 217). Demzufolge gibt es unterschiedliche Formen und Berechnungsarten von Zentralität. Einige fokussieren Aspekte wie beispielsweise Kontrolle, Macht, Prestige, andere den Informationsfluss und wiederum andere nehmen die Erreichbarkeit von Personen in einem Netzwerk in den Fokus. Die einfachste Form ist die Degree-Zentralität. Hier ist der Akteur der zentralste, der die meisten Beziehungen zu anderen Akteuren im Netzwerk hat. Bei der Betweenness-Zentralität ist der Akteur zentral, der am häufigsten auf den kürzesten Wegen zwischen zwei Akteuren im Netzwerk liegt. Bei der Closeness-Zentralität hingegen ist der Knoten zentral, der die kürzesten Distanzen zu allen anderen Knoten hat. Bei der Eigenvektor-Zentralität ist der Akteur zentral, der Beziehungen zu Akteuren hat, die wiederum sehr zentral sind. ${ }^{5}$

\footnotetext{
${ }^{3}$ Hierbei muss darauf hingewiesen werden, dass die Netzwerkgröße und die Dichte miteinander korrelieren können. Siehe dazu auch Anderson et al. (1999).

${ }^{4}$ Diese können auch für das ganze Netzwerk berechnet werden.

${ }^{5}$ Einen weiten Überblick zu unterschiedlichen Zentralitätsmaßen und ihrer Berechnung finden sich auf http://schochastics.net/sna/periodic.html. Auf der Webseite befinden sich unterschiedliche Zentralitätsmaße und es wird direkt auf die Artikel verwiesen, in denen das Maß besprochen wird.
} 
Neben der Unterscheidung zwischen Netzwerkparametern und Akteursparametern kann auch (idealtypisch) zwischen strukturbeschreibenden und statistischen Modellen, die Kausalzusammenhänge prüfen, differenziert werden. Die strukturbeschreibenden Verfahren beschreiben die Struktur des ganzen Netzwerkes oder fokussieren wenige Teile eines Netzwerkes. Ein Verfahren wurde bereits vorgestellt, die sogenannte Dichte. Daneben existieren Maße wie z. B. Cliquenanalyse, Cluster- oder auch Komponentenanalyse, Blockmodellanalyse oder auch der Triadenzensus. Cliquen-, Cluster- und Komponentenverfahren versuchen aus einem Netzwerk Subgraphen herauszufiltern, deren interne Dichte höher ist als die Dichte des gesamten Netzwerks (Luce 1950; Moody und White 2003). Auch in diesem Fall existieren unterschiedliche Verfahren wie z. B. n-core, n-clan und n-cliques Verfahren. N-clique ist z. B. ein maximaler Subgraph bei dem die Pfaddistanz, also die Anzahl der Akteure über die alle Knoten im Netzwerk miteinander verbunden sind, nicht größer als ein vorher festgelegter Wert $n$ ist (Bron und Kerbosch 1973). Somit können Gruppen hierarchisch, je nach Distanz, herausgefiltert und unterschieden werden. Das Komponentenverfahren ist ähnlich. Unter Komponenten versteht man im Allgemeinen Subgraphen, also Teile eines Netzwerks, die aus Knoten bestehen und auch untereinander verwoben sind. Eine starke verbundene Komponente ist eine Gruppe von Knoten, in denen alle Knoten durch gerichtete Kanten (z. B. alle Personen in einem Teil des Netzwerks leihen sich Zigaretten) vernetzt sind. Es gibt auch schwach verbundene Komponenten, hier ist jeder Knoten durch genau einen Pfad verbunden. Für ungerichtete Netzwerke, bei denen die Richtung einer Beziehung nicht gegeben ist (z. B. ,Treffen Sie sich mit der Person XY gelegentlich?") gibt es keine stark oder schwach verbundene Komponente. Hier spricht man lediglich von verbundenen Komponenten (De Nooy et al. 2011, S. 77). Ein weiteres exploratives Verfahren, welches auf eine datenreduzierende Darstellung von Knoten und Kanten basiert, ist die Blockmodellanalyse. Bei der Blockmodellanalyse werden Akteure und Beziehungen zu Akteursgruppen und Beziehungsbündeln geclustert (Heidler 2008) und bilden somit ein reduziertes Abbild der Netzwerkstruktur. Durch Clusterung können Hierarchien, Zentrum-Peripherie-Gruppierungen oder auch Cliquen visuell dargeboten und analysiert werden. Hier wird zwischen a-posteriori Blockmodellen, in denen Akteure aufgrund ähnlicher Positionen im Netzwerk gruppiert werden, und a-priori Blockmodellen, in denen Akteure anhand von Eigenschaften gruppiert werden, unterschieden (Heidler 2008). Das statistische Verfahren des Triadenszensus geht auf Heider (1958) zurück (siehe auch Kap. „Netzwerktheorie(n)“). Dabei wird überprüft, wie häufig geschlossene Triaden - drei, jeweils direkt miteinander verbundene Akteure - in einem Netzwerk vorkommen. In einem gerichteten Netzwerk können je nach Beziehungsrichtung und Beziehungsart 16 verschiedene 


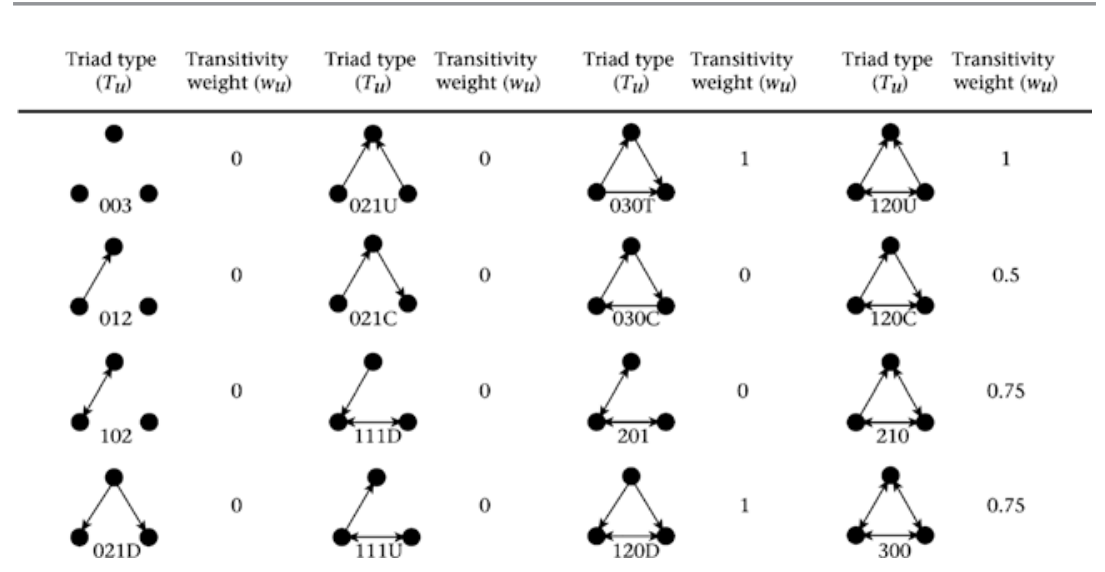

Abb. 2 Triadenszensus und das MAN-Schema (Mutual, Assymmetric, Null). (Quelle: Shizuka und McDonald 2012, S. 934)

Triadentypen (Isormophieklassen) differenziert werden (Holland und Leinhardt 1970). Die Beschriftung der Triadentypen basiert auf dem MAN-Schema: Mutual, d. h. eine wechselseitige Beziehung, Assymmetric, d. h. eine einseitige Beziehung und Null, d. h. keine Beziehung. Aus dem signifikant vermindert oder erhöhten Vorhandensein bestimmter Triadentypen kann auf spezifische Mikrostrukturmechanismen in sozialen Netzwerken geschlossen werden, z. B. ob ein Netzwerk eher hierarchisch oder flach strukturiert ist. In der Abb. 2 sieht man eine vollständige Triadenzählung, die alle 16 Triadenkonfigurationen zeigt. Hier wird das MAN-Schema angewandt. Sieben Dreieckskonfigurationen, in denen alle drei Knoten entweder durch asymmetrische oder gegenseitige Kanten verbunden sind, sind schwarz dargestellt. Der Gewichtungsfaktor $\left(\mathrm{w}_{\mathrm{u}}\right)$ für jede der sieben Dreieckskonfigurationsarten basiert auf der Wahrscheinlichkeit, dass das Dreieck transitiv ist, mit der Annahme, dass jedes Individuum in einer gegenseitigen Dyade die gleiche Wahrscheinlichkeit hat, dominant zu sein.

Hinsichtlich der stochastischen Verfahren, werden hier Exponential Random Graph Models (ERGMs) und SIENA vorgestellt (zum Vergleich der beiden Verfahren siehe auch Heidler und Gamper 2017). Exponential Random Graph Models sind stochastische Modelle von empirischen Netzwerken (Robins et al. 2007). Ziel ist es, mit wenigen lokalen Parametern strukturelle Zusammenhänge zu prüfen (Heidler und Gamper 2017). Es lässt sich ein multivariates Modell erstellen, in welchem Parameter, wie z. B. Reziprozität, Transitivität, Homophilie und Zentralität auf Signifikanz geprüft werden. Abhängige Variablen sind hierbei 
die Kanten, während die unabhängigen Variablen sowohl Attribute (z. B. Alter, Geschlecht) als auch Beziehungen (z. B. strong oder weak ties) sein können. Die Basis der ERGMs ist ein Markov-Chain-Monte-Carlo-Schätzprozess, mit dem eine Sequenz an Zufallsnetzwerken generiert wird, die schrittweise kleine Änderungen von unterschiedlichen Parametern beinhalten.

SIENA wurde für longitudinale Daten konstruiert und ist ein dynamisches Verfahren (Snijders et al. 2010). Hierbei werden Einfluss- oder auch Selektionseffekte (siehe Kap. „Netzwerktheorie(n)“) untersucht und getestet. Anders ausgedrückt: Inwieweit haben Attribute einen Effekt auf Relationen (Selektion), Relationen auf Relationen (Reziprozität), Attribute auf Attribute (Kontrollvariable) oder auch Relationen auf Attribute (Einfluss). Das Modell beruht auf vier Annahmen: Akteure haben Einfluss auf ausgehende Beziehungen, die Veränderung von Beziehungen erfolgt in sog. Microsteps (Akteure haben die Möglichkeit, eine Beziehung aufzulösen, einzugehen oder beizubehalten), die Änderung wird so erfolgen, dass die Änderung einen Nutzenanstieg für den Akteur beinhaltet (Rational-Choice-Ansatz) und die Nutzenfunktion beinhaltet neben einzelnen Effekten und ihren Parametern (objective function) eine Zufallskomponente.

Anzumerken ist noch, dass nicht alle Maßzahlen für egozentrierte und Gesamtnetzwerke in gleicher Weise Anwendungen finden. $\mathrm{Zu}$ nennen wären hier z. B. die unterschiedlichen Zentralitätsmaße, da diese erst bei einer großen Anzahl von Akteuren anwendbar sind. Egonetzwerke haben dafür oft zu wenige Akteure. Auch die Blockmodellanalyse, bei der Cluster vor dem Hintergrund der Beziehungsstruktur gebildet werden, findet man bei der egozentrierten Netzwerkanalyse so nicht.

Als Beispiel für eine quantitative Netzwerkstudie soll hier die Framingham Heart Study angeführt werden. Ab dem Jahr 1948 wurden in der Stadt Framingham in den USA regelmäßig Daten erhoben, um beispielsweise Ursachen und Gefahren von Herzerkrankungen sowie Arteriosklerose zu eruieren. Seit 1983 wurden auch Netzwerkdaten aufgenommen, auf die Fowler und Christakis (2008) zurückgreifen, um den Zusammenhang von „Glücklich-Sein“ und Einbettung in Netzwerken mithilfe einer Regression zu ergründen. Hierbei wurden von 1983 bis 20034739 Personen medizinisch begleitet. Die Ergebnisse zeigen, dass glückliche Menschen sich besonders im Zentrum des Netzwerkes befinden, also zentral sind und Cluster bilden (Abb. 3): Wer von vielen glücklichen Menschen umgeben ist, bei dem ist die Wahrscheinlichkeit hoch, dass er auch glücklich wird. Unglücklichere Akteure befinden sich eher in der Peripherie des Netzwerkes. Ferner zeigt sich, dass glückliche Menschen im Netzwerk einen großen Einfluss auf das Glücksgefühl von Ego besitzen, und dass sich dieser Einfluss über drei Kanten verbreiten kann. 


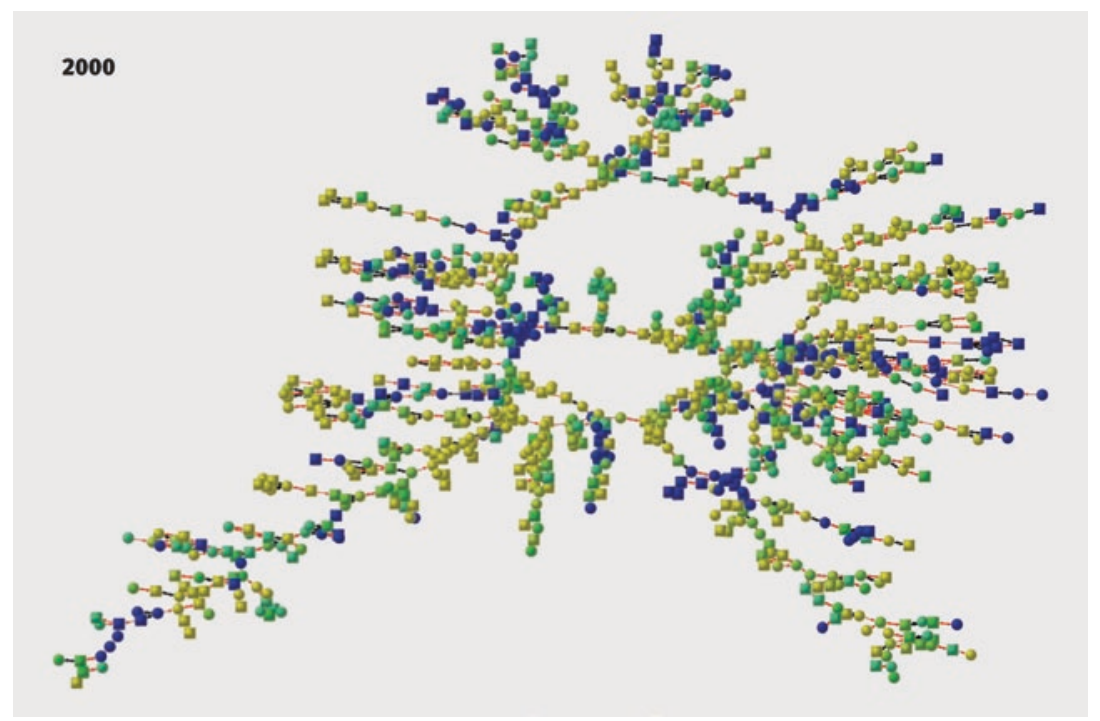

Abb. 3 Die Clusterung von glücklichen sowie weniger glücklichen Menschen in der Stadt Framingham. Die Linien zwischen den Knoten zeigen die Beziehung an (schwarz für Geschwister, rot für Freunde und Ehepartner). Die Knotenfarbe zeigt das Glücklich-Sein des Egos, wobei blaue Schattierungen am wenigsten glücklich, grün ein wenig glücklich und gelbe Schattierungen am glücklichsten bedeutet. (Quelle: Fowler und Christakis 2008, S. 3)

Als zweites Beispiel soll hier ein SIENA-Model angeführt werden. Anhand von Längsschnittdaten wurde das Rauchverhalten von Schüler*innen in Finnland untersucht. Hierbei eruierten Mercken et al. (2010) Selektions- und Einflussfaktoren zwischen der Schülerschaft. Sie gingen der Frage nach, inwieweit Rauchen unter Freunden „sozial ansteckend“ (Einfluss) ist oder sich Freundschaften aufgrund vom Interesse am Rauchen entwickeln (Selektion). Wie bei der Framingham Heart Study handelt es sich um eine Gesamtnetzwerkstudie. Neben den reinen Relationen innerhalb der Schule wurde auch gefragt, ob die eigenen Eltern oder auch Geschwister rauchen. Dabei konnte festgestellt werden, dass sowohl Schüler*innen ihre Freunde aufgrund des Rauchverhaltens auswählen. Bei Mädchen zeigt sich hingegen auch ein Einflussfaktor durch das Rauchverhalten in der "Clique“. Zudem wird ersichtlich, dass das Rauchverhalten der Eltern einen signifikanten Einfluss besitzt. Anders als bei der Studie Fowler und Christakis (2008) wurde hier auf eine Visualisierung verzichtet. 
Die qualitative Forschung ist innerhalb der Netzwerkanalyse eher unterrepräsentiert, hat in den letzten 20 Jahren aber deutlich an Bedeutung gewonnen. Im Gegensatz zu den quantitativen Ansätzen, stehen hier das Verstehen von Zusammenhängen bzw. Mechanismen und die subjektive Sichtweise der Akteure ihre Netzwerke im Fokus. Das Interesse liegt auf den Geschichten hinter den Beziehungen, da Netzwerke nach White (2008) keine gegebenen Wirklichkeiten darstellen, sondern phänomenologische Konstrukte sind, die durch die Akteure mit Sinn belegt werden (siehe auch Kap. „Netzwerktheorie(n)“). Als Substrat sozialer Netzwerke gelten hier die sogenannten „stories“ (Beschreibungen bzw. Sinndeutungen), die es ermöglichen, Ereignisse so zu strukturieren, dass sie als Teil einer Beziehungsgeschichte fungieren, welche den subjektiv-sozialen „Sinn“ der Beziehung beinhaltet. Um also das Entstehen von Netzwerken beziehungsweise die dynamische Veränderung von Netzwerken konstruieren zu können, müssen die Geschichten der Personen und die Handlungsmöglichkeiten im jeweiligen Kontext verstanden werden (White 2008; Schweizer 1996).

Die theoretische Diskussion um eine kulturelle bzw. konstruktivistische Öffnung (z. B. White 2008; Emirbayer 1997) der Netzwerkforschung geht einher mit dem Bedarf an weniger standardisierten bzw. qualitativ-methodischen Ansätzen (Hollstein und Straus 2006; Schönhuth et al. 2013). Das Vorgehen kann sehr unterschiedlich sein. Hier soll die sogenannte visuelle Netzwerkforschung (Gamper und Kronenwett 2012) vorgestellt werden, die in der qualitativen Netzwerkforschung dominierend ist. Seit den 1980er Jahren kommen sogenannte Netzwerkkarten (Kahn und Antonucci 1980; Kupfer 2018) und Netzwerkzeichnungen (z. B. Straus 2002; Schönhuth et al. 2013; Gamper und Kronenwett 2012) bei der Datenerhebung zum Einsatz, mit deren Hilfe subjektive Erfahrungen und Einstellungen der Akteure erhoben werden. Die offenste Form der visuellen Netzwerkforschung stellt die Netzwerkzeichnung dar. Durch einen Erzählstimulus zeichnet der/die Befragte sein individuelles Netzwerk auf ein nicht vorstrukturiertes Blatt oder rekonstruiert dieses mithilfe von eines Softwareprogramms (z. B. VennMaker). So werden innere Netzwerkbilder, ohne eine konkrete Vorgabe durch den Forscher bzw. die Forscherin, sichtbar gemacht. Die subjektive Sinnzuschreibung geschieht durch die Beforschten, wobei die Bewertung im Rahmen einer kommunikativen Validierung erfolgt. Durch die geführten Interviews fließen die Aussagen und Interpretationen in die Analyse mit ein (Heinze und Klusemann 1979; Mayring 2002).

Aufgrund der Offenheit der Netzwerkzeichnung und der Interviews ist eine quantitative Auswertung nicht möglich. Hingegen können Netzwerkkarten als Landkarten von sozialen Beziehungen beschrieben werden, mit deren Hilfe Individuen ihre sozialen Netzwerke visualisieren. Anders als bei Netzwerkzeichnungen 


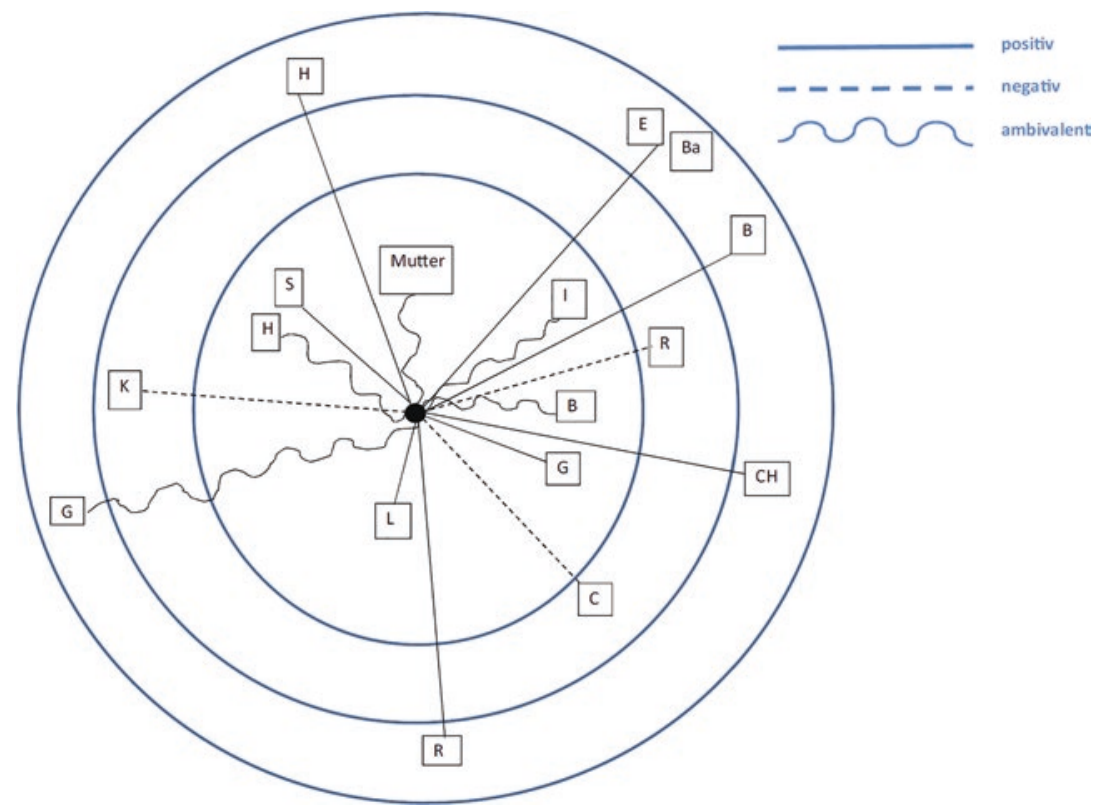

Abb. 4 Netzwerkkarte einer Patientin am Therapiebeginn. (Quelle: Weigl 2016, S. 238)

enthalten diese Strukturierungen (z. B. die Positionierung von Ego sowie Alter, oder auch andere Attribute wie Alter, Geschlecht) und Standardisierungen (Vereinheitlichung durch Wertzuweisung). Diese Attribute werden durch die Forschenden mehr oder weniger stark vorgegeben und die Freiheit des Interviewenden eingeschränkt. Hierfür werden die Netzwerkkarten teilstrukturiert oder strukturiert sowie halbstandardisiert oder standardisiert vom Forscher bzw. Forscherin bereits vordefiniert (Hollstein und Pfeffer 2010). Die Vorstrukturierung kann unterschiedlich ausfallen. Beliebte Formen sind z. B. konzentrische Kreise (z. B. Abb. 4) oder auch Sektoren. Bekommen die Vorgaben wie z. B. die konzentrischen Kreise um Ego oder auch die Sektoren keine diskreten Ausprägungen von Attributen zugewiesen, liegt hier eine Strukturierung, jedoch keine Standardisierung vor (Gamper et al. 2012). Bei einer Teilstandardisierung oder auch Vollstandardisierung werden diese visuellen Items teilweise oder auch in ihrer Gesamtzahl mit Merkmalsausprägungen belegt. Den konzentrischen Kreisen, die die Nähe (diese kann z. B. als Wichtigkeit, Erreichbarkeit definiert sein) zum Ego strukturieren, können demnach die Ausprägungen ,,sehr wichtig“, ,wichtig“ und ,weniger wichtig“ zugewiesen werden, um die Bedeutung 
der Alteri für Ego abzubilden. Die Zunahme von Strukturierung und Standardisierung geht mit dem Verlust der subjektiven Zuweisung durch den zu Befragenden einher. Jedoch können die gewonnenen standardisierten Daten mithilfe quantitativer Verfahren ausgewertet werden (Hollstein und Pfeffer 2010). Die visuelle Erhebung kann durch ein Paper-and-Pencil-Verfahren, Papier, Stifte und Bausteine-Verfahren oder auch mithilfe eines Computerprogramms (z. B. VennMaker) erhoben werden, die jeweils unterschiedliche Vor- und Nachteile besitzen (Gamper und Schönhuth 2016). Hinzu kommt, dass die visuelle Erhebungsmethode in Gruppeninterviews (z. B. Schönhuth und Kievelitz 1995) oder Einzelinterviews (z. B. Krumbein 1995) eingesetzt werden kann. Hinsichtlich der qualitativen Auswertung können sowohl die geführten Interviews als auch die Ergebnisse der unterschiedlichen Netzwerkkarten oder auch -zeichnungen im Fokus stehen. Hierbei können Aussagen der Interviews auf die Visualisierungen bezogen werden, indem zuerst die Interviews analysiert und dann erst im zweiten Schritt die Visualisierungen eruiert und in Zusammenhang gebracht werden. Eine andere Möglichkeit besteht darin, von den Karten bzw. Zeichnungen auszugehen und erst im Anschluss die Interviews für die Analyse heranzuziehen. Welches der beiden Vorgehen gewählt wird, hängt stark von der Forschungsfrage und dem Datenmaterial wie der Schwerpunktsetzung der Erhebung (eher visuell oder interviewbasiert) ab und kann daher nicht pauschal beantwortet werden. Qualitative Verfahren der Netzwerkforschung stellen somit Mechanismen, Verhaltensweisen oder auch individuelle Deutung in den Mittelpunkt und legen damit z. B. Handlungs- und Denkprozesse offen.

Auch hier sollen Beispiele präsentiert werden, die die qualitative Forschung nochmals konkretisieren. Das erste Beispiel kommt aus der Psychologie bzw. Psychotherapie und dem Bereich der Intervention und befasst sich mit den Auswirkungen von Netzwerkbeziehungen auf das psychische Wohlbefinden. Anhand dreier Fallbeispiele zeigt Silvia Weigl (2016), wie Netzwerkkarten eingesetzt werden, um die Auswirkungen von Beziehungen auf das Wohlbefinden der Probanden $\mathrm{zu}$ visualisieren und $\mathrm{zu}$ reflektieren. In Abb. 4 ist eine Netzwerkkarte abgebildet, in der eine Befragte die eigenen Beziehungen dargestellt und als positiv, negativ oder ambivalent bewertet hat (zur Bedeutung negativer Beziehungen siehe Kap. „Negative Beziehungsaspekte und gesundheitliche Ungleichheiten“). Die Klientinnen werden neben der Zeichnung noch zu ihren Beziehungen befragt, die in Netzwerkkarten visualisiert werden. In den Therapiesitzungen werden diese Relationen diskutiert, in den Lebensphasenkontext gestellt und ihr Einfluss auf das Wohlbefinden reflektiert.

Die Ergebnisse der Netzwerkkarten und die darauf folgende Netzwerkarbeit der zu Beratenden werden als positiv bewertet. Der Einsatz von Netzwerkkarten verdeutlicht die Lebenssituation der Befragten und den Stellenwert der eigenen 
Person im sozialen Netzwerk. Dadurch steigen die eigene Wertschätzung sowie die wahrgenommene Selbstwirksamkeit. Ferner wird eine Stabilisierung der eigenen Position erreicht. Es kommt auch zu unterschiedlichen Formen der Netzwerkarbeit durch die Betroffenen selbst, in dem an Beziehungen im Netzwerk gezielt und aktiv gearbeitet wird sowie zu einer Relativierung von idealisierten und abwertenden Betrachtungen sozialer Beziehung in der Vergangenheit. Wie das Beispiel zeigt, dienen Netzwerke somit nicht nur als wissenschaftliches Analysetool, sondern bieten unter dem Stichwort „Netzwerkarbeit“ auch ein Instrument bei der Intervention im Gesundheitssektor (vgl. Kupfer 2018).

Das zweite Beispiel behandelt einen Fall eines drogenabhängigen jungen Mannes (Mayrhofer 2016). Hier wird der Frage nachgegangen, welche Rolle soziale Beziehungen spielen und wie diese in Verbindung mit dem Drogenkonsum stehen. Mayrhofer stellt die Binnendynamik zwischen den Befragten und den Alteri in seinem Egonetzwerk deutlich heraus. Es zeigt sich, dass die Suchterkrankung die Beziehungen zu den Alteri drastisch stört und die Alteri eine Balance zwischen Unterstützung und Rückzug aus dem Netzwerk suchen. Auffällig ist weiter, dass das Netzwerk mit der Zeit von den Betroffenen dahin gehend gestaltet wird, dass die Alteri im Netzwerk so wenig Einfluss auf den Suchtkonsum haben wie möglich. Dies geschieht z. B. durch Verheimlichen oder das Bagatellisieren der Abhängigkeit. Der Verlust von Beziehungen geht auch mit dem Verlust von Rollenvielfalt einher und führt zu immer weniger „Selbstregie“. Mit anhaltender Dauer der Suchtkrankheit kommt es auch zu einer qualitativen wie auch quantitativen Reduzierung der Beziehungen und führt in einen ,Teufelskreis“. Das Fallbeispiel und der Prozess der Netzwerkveränderung wird wie in Abb. 5 dargestellt visualisiert.

\section{$3 \quad$ Fazit}

In diesem Kapitel wurde der Begriff des Netzwerks definiert und die unterschiedlichen Ansätze und Verfahren der Netzwerkforschung und -analyse vorgestellt. Anhand von Beispielen sollte gezeigt werden, welches Verfahren für welche Fragestellung herangezogen werden kann. Netzwerke sind demnach Zusammenschlüsse von Personen, Institutionen, kollektiven Akteuren - den sogenannten Knoten - die durch Beziehungen (z. B. Sexualbeziehung, Liebe) - den Kanten miteinander verwoben sind. Es wird davon ausgegangen, dass die Einbettung der Akteure Folgen für diese hat oder bestimmte Handlungen der Akteure sich auf die Beziehungen innerhalb eines Netzwerkes auswirken. 


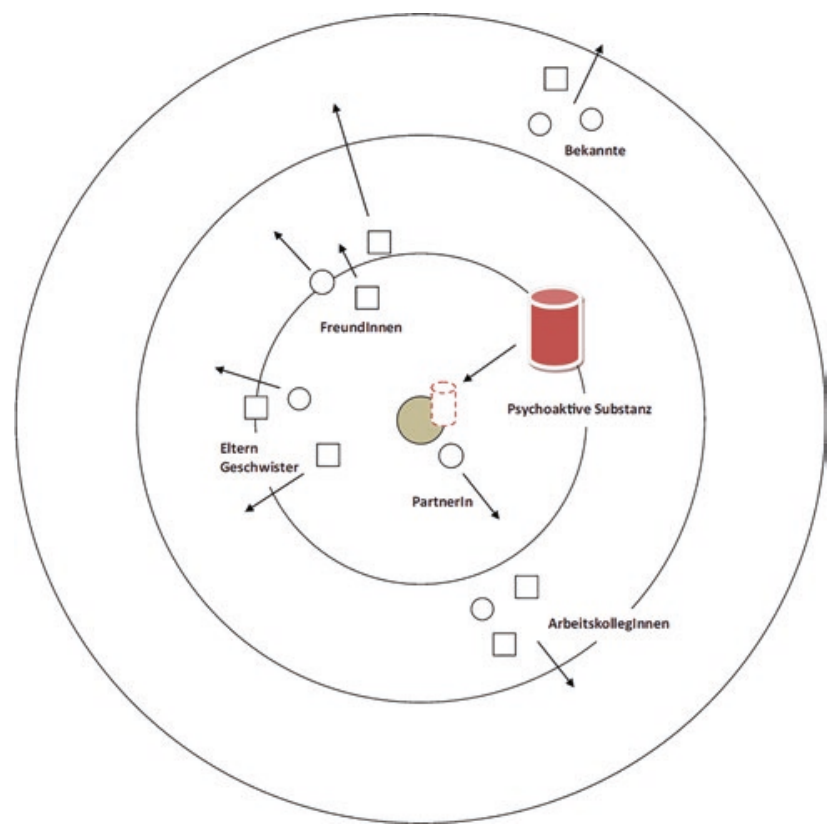

Abb. 5 Eine dynamische Netzwerkkarte eines jungen Drogenabhängigen. (Quelle: Mayrhofer 2016, S. 267)

Bei der Analyse können zwei Hauptunterscheidungen herauskristallisiert werden. Vor dem Hintergrund der Struktur des Netzwerkes kann zwischen Gesamtnetzwerken und egozentrierten Netzwerken differenziert werden. Die Gesamtnetzwerkanalyse fokussiert die Binnenstruktur von Personen innerhalb eines vordefinierten Bereichs. Dieser kann z. B. Schüler*innen in einer Schulklasse oder Menschen in einer Stadt umfassen. Hierbei werden nur die Beziehungen untereinander erfasst. Bei der egozentrierten Netzwerkforschung liegt das Interesse auf der Einbettung des Individuums in seine soziale Umgebung. Hierbei wird Ego zu seinen Beziehungen und den Personen (Alteri) und ihren Attributen in seinem persönlichen Netzwerk befragt. Wenn das Forschungsinteresse auf die interne Struktur einer Gruppe gelegt wird und die Grenzen von innen klar gegeben sind, dann ist eine Gesamtnetzwerkanalyse besonders gut geeignet. Die egozentrierte Netzwerkforschung hat ihre Vorteile, wenn Personen einer bestimmten Gruppe (z. B. Drogenabhängige, 
alte Menschen) und ihre allgemeine Einbettung, auch im Vergleich zu anderen Gruppen, untersucht werden sollen. Neben der methodischen Dimension kann auch zwischen quantitativer und qualitativer Netzwerkforschung unterschieden werden. Die standardisierte Netzwerkforschung kann zwischen strukturbeschreibenden Verfahren und Verfahren zur Analyse von Kausalzusammenhängen differenziert werden. Die strukturbeschreibenden Verfahren beschreiben das Netzwerk, hierzu gehören z. B. die Größe eines Netzwerkes oder auch die Dichte. Stochastische Verfahren, z. B. Exponential Random Graph Models (ERGMs) und SIENA, versuchen überzufällige Zusammenhänge aufzudecken. Beide Ausrichtungen können sowohl das ganze Netzwerk (z. B. Dichte, Netzwerkgröße) oder auch einzelne Knoten oder Kanten (z. B. Zentralitätsmaße) umfassen.

Hinsichtlich der qualitativen Netzwerkforschung wurden unterschiedliche visuelle Verfahren vorgestellt. Dabei wurde zwischen Netzwerkzeichnungen und Netzwerkkarten unterschieden. Netzwerkzeichnungen sind freie Visualisierungen, die keine Vorstrukturierung durch den Forscher bzw. die Forscherin beinhalten. Bei den Netzwerkkarten werden Vorgaben wie z. B. konzentrische Kreise getroffen. Hierbei können Strukturierungen auch durch Zuweisung von Werten standardisiert werden. Dadurch wird es auch möglich, die Daten quantitativ auszuwerten, während dies bei Netzwerkzeichnungen nicht möglich ist. Für die Kopplung von Interviews und die Visualisierungen gibt es kaum wissenschaftliche Handreichungen oder Standardwerke. Auf die qualitative Forschung sollte zurückgegriffen werden, wenn eher idiografische Konstrukte, wie Deutungsmuster, Sinnstrukturen oder subjektive Wahrnehmungen von Netzwerken und Beziehungen im Fokus stehen. Auch bei Phänomenen, die nicht oder nur wenig bekannt bzw. erforscht wurden, eignen sich qualitative Instrumente wegen ihrer thematischen Offenheit besser. Nicht selten werden in qualitativen Studien Hypothesen für die quantitative Netzwerkforschung generiert. Bei Kausalzusammenhängen oder wenn repräsentative Aussagen getroffen werden sollen, eignen sich die unterschiedlichen quantitativen Verfahren. Wichtig ist hier, dass die Erhebungsmethoden dem Forschungsfeld und der Forschungsfrage angepasst werden müssen. Besonders in der Gesundheitsforschung, gibt es z. B. bei den Namensgeneratoren kein einheitliches Vorgehen, und damit noch viel Spielraum für eigene Ideen.

Durch die wenigen Studien die im Bereich Netzwerkforschung und gesundheitliche Ungleichheiten existieren, sind getestete Akteursgeneratoren oder andere Vorarbeiten, auch im qualitativen Bereich, sehr selten. Daher müssen Forschungsfragen selbst konstruiert und getestet werden. Dies macht es notwendig z. B. eigene Akteursgeneratoren zu entwickeln oder bereits getestet Fragen der eigenen Forschung anzupassen. Zentral ist es, die eigenen Fragen, qualitativ wie quantitativ, an die theoretischen Konzepte (siehe Kap. „Netzwerktheorie(n)“) anzubinden. Hier 
eignen sich besonders Paradigmen wie der sozialen Unterstützung, der Diffusionsforschung und des Sozialkapitals, die mit Gesundheitsfragestellungen und Netzwerken gut kombiniert werden können. Grenzen zeigen sich im Allgemeinen hinsichtlich der Dauer der Befragungen. Qualitative und quantitative Verfahren der Netzwerkforschung sind sehr zeitaufwendig und nehmen in der Befragung viel Raum ein. Daher sollte im Vorhinein genau bedacht werden, welche Rolle Netzwerke für die Antwort der Forschungsfrage zur gesundheitlichen Ungleichheit essenziell sind. Darauf aufbauend sollte der Teil der Netzwerkanalyse getestet werden, um die Dauer der Befragung einschätzen zu können. Wie die wenigen Studien zeigen, ist ein Zusammenhang zwischen Gesundheit und Netzwerken in vielen Feldern (z. B. Weitergabe von Krankheiten, Gesundheitsverhalten) von großer Wichtigkeit und sollte noch viel stärker, auch methodisch, berücksichtigt werden.

\section{Leseempfehlungen}

Carrington, P. J., Scott, J., \& Wasserman, S. (Hrsg.) (2005). Models and methods in social network analysis. Cambridge University Press. Einführung in die Methoden der Netzwerkanalyse mit einem Fokus auf quantitative Verfahren.

Gamper, M., \& Schönhuth, M. (2016). Ansätze und Verfahren der Visuellen Netzwerkforschung. In K. Lobinger (Hrsg.), Handbuch Visuelle Kommunikationsforschung (S. 1-27). Wiesbaden: VS. Überblick über die unterschiedlichen visuellen Netzwerkforschungsverfahren in komprimierter Form.

De Nooy, W., Mrvar, A., \& Batagelj, V. (2011). Exploratory social network analysis with Pajek. Cambridge University Press. Englisches Handbuch für die Software Pajek, ein kostenloses Tool zur Analyse von Gesamtnetzwerken, mit dem die Berechnung einer Reihe von Maßzahlen möglich ist.

Heidler, R., \& Gamper, M. (2017). Ein Freund, ein guter Freund? Oder: Über blinde Flecken der stochastischen Modellierungsverfahren ERGM und SIENA am Beispiel von Freundschaften in Schulklassen. In M. Emirbayer \& H. Löwenstein (Hrsg.), Netzwerke, Kultur und Agency. Problemlösungen in relationaler Methodologie und Sozialtheorie (S. 355-380). Weinheim: Beltz. Kurze Hinführung zu den zwei wohl wichtigsten stochastischen Verfahren der Netzwerkforschung und deren blinde Flecken.

Domínguez et al. (Hrsg.) (2014). Mixed methods social networks research: Design and applications. Cambridge University Press. Englischer Sammelband über die Verbindung von qualitativen und quantitativen Verfahren in der Netzwerkforschung. 


\section{Literatur}

Anderson, B. S., Butts, C., \& Carley, K. (1999). The interaction of size and density with graph-level indices. Social Networks, 21(3), 239-267.

Bearman, P., Moody, J., \& Stovel, K. (2004). Chains of affection: The structure of adolescent romantic and sexual networks. American Journal of Sociology, 110, 44-91.

Borgatti, S. P., \& Halgin, D. S. (2011). On network theory. Organization Science, 22(5), $1168-1181$.

Bott, E. (1957). Family and social network (roles, norms and external relationships in ordinary urban families). Travistock Institute of Human Relations.

Bron, C., \& Kerbosch, J. (1973). Finding all n-cliques of an undirected graph. Communications of the ACM, 16, 575-577.

Burt, R. S. (1984). Network items and the general social survey. Social Networks, 6, 293-339.

De Nooy, W., Mrvar, A., \& Batagelj, V. (2011). Exploratory social network analysis with Pajek. Cambridge: Cambridge University Press.

Domínguez, S., \& Hollstein, B. (Hrsg.). (2014). Mixed methods social networks research: Design and applications. Cambridge: Cambridge University Press.

Emirbayer, M. (1997). Manifesto for a relational sociology. American Journal of Sociology, $103,281-317$.

Fine, G. A. (2012). Group culture and the interaction order: Local sociology on the meso-level. Annual Review of Sociology, 38, 159-179.

Fowler, J. H., \& Christakis, N. A. (2008). Dynamic spread of happiness in a large social network: Longitudinal analysis over 20 years in the Framingham Heart Study. BMJ, 337, a2338.

Freeman, L. C. (1979). Centrality in social networks: Conceptual clarification. Social Networks, 1, 215-239.

Fuhse, J. (2006). Gruppe und Netzwerk: Eine begriffsgeschichtliche Rekonstruktion. Berliner Journal für Soziologie, 16(2), 245-263.

Gamper, M., \& Kronenwett, M. (2012). Visuelle Erhebung von egozentrierten Netzwerken mit Hilfe digitaler Netzwerkkarten. In S. Kulin, K. Frank, D. Fickermann, \& K. Schwippert (Hrsg.), Soziale Netzwerkanalyse (S. 151-166). Münster: Waxmann.

Gamper, M., \& Schönhuth, M. (2016). Ansätze und Verfahren der Visuellen Netzwerkforschung. In K. Lobinger (Hrsg.), Handbuch Visuelle Kommunikationsforschung (S. 1-27). Wiesbaden: VS Verlag.

Gamper, M., Schönhuth, M., \& Kronenwett, M. (2012). Bringing qualitative and quantitative data together: Collecting and analyzing network data with the help of the software tool VennMaker. In M. Safar (Hrsg.), Social networking and community behavior modeling: Qualitative and quantitative measures (S. 193-213). Hershey: IGI Global.

Heider, F. (1958). The psychology of interpersonal relations. New York: Wiley.

Heidler, R. (2008). Zur Evolution sozialer Netzwerke: theoretische Implikationen einer akteursbasierten Methode. In C. Stegbauer (Hrsg.), Netzwerkanalyse und Netzwerktheorie (S. 359-372). Wiesbaden: VS Verlag.

Heidler, R., \& Gamper, M. (2017). Ein Freund, ein guter Freund? Oder: Über blinde Flecken der stochastischen Modellierungsverfahren ERGM und SIENA am Beispiel von Freundschaften in Schulklassen. In M. Emirbayer \& H. Löwenstein (Hrsg.), Netzwerke, Kultur und Agency. Problemlösungen in relationaler Methodologie und Sozialtheorie (S. 355-380). Weinheim: Beltz. 
Heinze, T., \& Klusemann, H. W. (1979). Ein biografisches Interview als Zugang zu einer Bildungsgeschichte. In D. Baacke \& T. Schulze (Hrsg.), Aus Geschichten lernen (S. 182-225). München: Juventa.

Herz, A. (2012). Erhebung und Analyse ego-zentrierter Netzwerke. In S. Kulin, K. Frank, D. Fickermann, \& K. Schwippert (Hrsg.), Soziale Netzwerkanalyse. Münster: Waxmann.

Holland, P. W., \& Leinhardt, S. (1970). A method for detecting structure in sociometric data. American Journal of Sociology, 76(3), 492-513.

Hollstein, B., \& Pfeffer, J. (2010). Netzwerkkarten als Instrument zur Erhebung egozentrierter Netzwerke. http://www.pfeffer.at/egonet/Hollstein\%20Pfeffer.pdf. Zugegriffen: 4. Febr. 2019.

Hollstein, B., \& Straus, F. H. (2006). Qualitative Netzwerkanalyse. Konzepte, Methoden, Anwendungen. Wiesbaden: VS Verlag.

Jansen, D. (2006). Einführung in die Netzwerkanalyse: Grundlagen, Methoden, Forschungsbeispiele. Wiesbaden: VS Verlag.

Kahn, R. L., \& Antonucci, T. C. (1980). Convoys over the life course: Attachment, roles and social support. Life Span Development, 3, 219-250.

Krumbein, S. (1995). Selbstbild und Männlichkeit. Rekonstruktion männlicher Selbst- und Idealbilder und deren Veränderung im Laufe der individuellen Entwicklung. München: Profil.

Kupfer, A. (2018). Netzwerkkarten als diagnostische Instrumente. In P. Buttner, S. B. Gahleitner, U. H. Freund, P. Pantuček, \& D. Röh (Hrsg.), Handbuch Soziale Diagnostik. Berlin: Lambertus.

Laumann, E. O., Marsden, P. V., \& Prensky, D. (1983). The boundary specification problem in network analysis. In R. S. Burt, M. J. Minor, \& R. D. Alba (Hrsg.), Applied network analysis: A methodological introduction (S. 18-34). Beverly Hills: Sage.

Luce, R. D. (1950). Connectivity and generalized cliques in sociometric group structure. Psychometrika, 15(2), 169-190.

Mayrhofer, D. (2016). Soziokulturelle Atome im Wandel der Suchtdynamik. Zeitschrift für Psychodrama und Soziometrie, 15(2), 261-273.

Mayring, P. (2002). Einführung in die qualitative Sozialforschung. Einführung in die qualitative Sozialforschung: Eine Anleitung zu qualitativem Denken. Weinheim: Beltz.

McCallister, L., \& Fischer, C. S. (1978). A procedure for surveying personal networks. Sociological Methods \& Research, 7(2), 131-148.

Mercken, L., Snijders, T. A., Steglich, C., Vertiainen, E., \& De Vries, H. (2010). Smoking-based selection and influence in gender segregated friendship networks: A social network analysis of adolescent smoking. Addiction, 105(7), 1280-1289.

Mitchell, J. C. (1969). Social networks in urban situations: Analyses of personal relationships in central African towns. Manchester: Manchester University Press.

Moody, J., \& White, D. (2003). Social cohesion and embeddedness: A hierarchical conception of social groups. American Sociological Review, 68, 1-25.

Perry, B. L., \& Pescosolido, B. A. (2015). Social network activation: The role of health discussion partners in recovery from mental illness. Social Science and Medicine, 125, 116-128.

Robins, G., Pattison, P., Kalish, Y., \& Lusher, D. (2007). An introduction to exponential random graph p models for social networks. Social Networks, 29(2), 173-191. 
Schnegg, M., \& Lang, H. (2002). Netzwerkanalyse. Eine praxisorientierte Einführung. https://www.researchgate.net/publication/275041134_Die_Netzwerkanalyse_Eine_ praxisorientierte_Einfuhrung. Zugegriffen: 4. Febr. 2019.

Schönhuth, M., \& Kievelitz, U. (1993). Partizipative Erhebungs- und Planungsmethoden in der Entwicklungszusammenarbeit. Wiesbaden: Universum.

Schönhuth, M., Gamper, M., Kronenwett, M., \& Stark, M. (Hrsg.). (2013). Visuelle Netzwerkforschung. Bielefeld: Transcript.

Schweizer, T. (1996). Muster sozialer Ordnung. Netzwerkanalyse als Fundament der Sozialethnologie. Berlin: Reimer.

Scott, J. (2000). Social network analysis: A handbook. London: Sage.

Shizuka, D., \& McDonald, D. B. (2012). A social network perspective on measurements of dominance hierarchies. Animal Behaviour, 83(4), 925-934.

Seidmann, S. (1983). Network structure and minimum degree. Social Networks, 5, 269287.

Snijders, T. A., Steglich, C., \& van de Bunt, G. (2010). Introduction to actor-based models for network dynamics. Social Networks, 32, 44-60.

Straus, F. (2002). Netzwerkanalysen. Gemeindepsychologische Perspektiven für Forschung und Praxis. Wiesbaden: Deutscher Universitätsverlag.

Wasserman, S., \& Faust, K. (1994). Social network analysis: Methods and applications. Cambridge: Cambridge University Press.

Weigl, S. (2016). Der Einsatz mehrerer sozialer Atome zu verschiedenen Lebenszeitpunkten in den unterschiedlichen Phasen des Therapieprozesses. Zeitschrift für Psychodrama und Soziometrie, 15(2), 231-243.

Wellman, B. (1979). The community question: The intimate networks of east Yorkers. The American Journal of Sociology, 84(5), 1201-1231.

White, H. C. (2008). Identity and control: How social formations emerge (2. Aufl.). Princeton: Princeton University Press.

Wolf, C. (2006). Egozentrierte Netzwerke. Erhebungsverfahren und Datenqualität. Kölner Zeitschrift für Soziologie und Sozialpsychologie, 44, 244-273.

Wolf, C. (2010). Egozentrierte Netzwerke. Datenerhebung und Datenanalyse. In C. Stegbauer \& R. Häußling (Hrsg.), Handbuch Netzwerkforschung (S. 471-483). Wiesbaden: VS Verlag.

PD Dr. Markus Gamper ist Akademischer Rat am Institut für vergleichende Bildungsforschung und Sozialwissenschaften der Universität zu Köln. 
Open Access Dieses Kapitel wird unter der Creative Commons Namensnennung 4.0 International Lizenz (http://creativecommons.org/licenses/by/4.0/deed.de) veröffentlicht, welche die Nutzung, Vervielfältigung, Bearbeitung, Verbreitung und Wiedergabe in jeglichem Medium und Format erlaubt, sofern Sie den/die ursprünglichen Autor(en) und die Quelle ordnungsgemäß nennen, einen Link zur Creative Commons Lizenz beifügen und angeben, ob Änderungen vorgenommen wurden.

Die in diesem Kapitel enthaltenen Bilder und sonstiges Drittmaterial unterliegen ebenfalls der genannten Creative Commons Lizenz, sofern sich aus der Abbildungslegende nichts anderes ergibt. Sofern das betreffende Material nicht unter der genannten Creative Commons Lizenz steht und die betreffende Handlung nicht nach gesetzlichen Vorschriften erlaubt ist, ist für die oben aufgeführten Weiterverwendungen des Materials die Einwilligung des jeweiligen Rechteinhabers einzuholen.

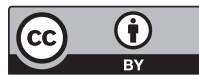


Lebenslauf 


\section{Soziale Netzwerke, familiales Sozialkapital und kindliche Gesundheit}

\section{Daniel Lois}

\section{Überblick}

- Soziale Kindernetzwerke bestehen im engsten Kreis vorwiegend aus Mitgliedern der Kernfamilie (Eltern, Geschwister) und im erweiterten Kreis aus weiteren Familienmitgliedern wie Großeltern und Freunden. Netzwerkgröße und Anteil der Freunde im Netzwerk steigen mit dem Alter.

- Ein Literaturüberblick zeigt, dass die kindliche Gesundheit sowohl direkt durch das soziale Netzwerk des Kindes beeinflusst wird als auch indirekt durch das soziale Netzwerk der Eltern.

- Von den verschiedenen theoretischen Mechanismen, die zur Erklärung dieser Befunde infrage kommen - z. B. soziale Unterstützung, soziale Ansteckung oder soziale Kontrolle -, ist der Unterstützungsmechanismus am besten empirisch bestätigt. Allerdings sind „echte“ Netzwerkstudien, in denen Familiennetzwerke namensbasiert aufgespannt werden, im hier betrachteten Altersbereich eher selten.

- Familiales Sozialkapital korreliert in westlichen Industrienationen positiv mit den sozioökonomischen Ressourcen der Eltern. Für Schwellenund Entwicklungsländer zeigt sich, dass die kindliche Gesundheit hier verstärkt vom Vorhandensein sozialer Unterstützung abhängig ist.

Der Autor bedankt sich bei den Herausgebern sowie Holger von der Lippe für ihre Unterstützung bei der Literaturrecherche sowie hilfreichen Anregungen.

D. Lois $(\bowtie)$

Neubiberg, Deutschland

E-Mail: daniel.lois@unibw.de

(C) Der/Die Herausgeber und der/die Autor(en) 2020

A. Klärner et al. (Hrsg.), Soziale Netzwerke und gesundheitliche Ungleichheiten, https://doi.org/10.1007/978-3-658-21659-7_7 


\section{$1 \quad$ Einleitung}

Seitdem sich Ende der 1980er Jahre das sogenannte Salutogenesemodell etabliert hat, suchen Forscher und Praktiker im Feld der Gesundheitsförderung nicht nur nach Faktoren, die krank machen, sondern auch nach Faktoren und dynamischen Wechselwirkungen, die zur Entstehung und Erhaltung von Gesundheit führen. Soziale Beziehungen gelten hierbei als hilfreich und unterstützend. Ihre Verbesserung ist ein Ziel der Gesundheitsförderung.

Der vorliegende Beitrag beschäftigt sich mit der Familie als einen Kernbereich sozialer Beziehungen und nimmt zudem die physische und mentale Gesundheit von Kindern (bis 13 Jahre) in den Blick. Familiale Einflüsse auf die kindliche Gesundheit sind vielfältig (vgl. Rattay et al. 2012): Von klein auf bis ins Jugendalter lernen Kinder in der Familie den Umgang mit ihrem Körper, mit Gesundheit, Krankheit sowie entsprechenden Bewältigungsstrategien. In der alltäglichen Interaktion in der Familie und durch die sozialen Kontexte, zu denen die Familie einen Zugang ermöglicht, erwerben Kinder und Jugendliche grundlegende Kenntnisse und Einstellungen, die zu ihrer Entwicklung in psychischer, körperlicher, sozialer und kognitiver Hinsicht beitragen. Die gesundheitsbezogene Sozialisation erfolgt

\footnotetext{
„insbesondere über familiale Alltagspraktiken wie die Gestaltung der Mahlzeiten, das Bewegungs- und Freizeitverhalten in der Familie, feste Tageszeiten für das Aufstehen und Ins-Bett-Gehen, die Inanspruchnahme von medizinischen Leistungen sowie über familiale Haltungen zum Beispiel zur Hygiene. Aber auch gesundheitsabträglichen Praktiken wie dem Konsum von Tabak und Alkohol sind Heranwachsende in ihrer Familie mehr oder weniger direkt ausgesetzt" (Rattay et al. 2012, S. 146).
}

In der Forschung wird zwischen protektiven Faktoren von Familie und Risikofaktoren unterschieden. $\mathrm{Zu}$ den Risikofaktoren zählen z. B. ungünstige materielle Bedingungen, niedrige Schulbildung der Eltern, Arbeitslosigkeit, beengte Wohnverhältnisse, familiale Konflikte, körperliche oder mentale Erkrankungen eines Elternteils, schlechte Verfügbarkeit primärer Bezugspersonen im Kleinkindalter, Vernachlässigung oder Gewalt (Tiber Egle et al. 2002).

Beim vorliegenden Beitrag handelt es sich um einen Literaturüberblick, der sich vorwiegend mit protektiven sozialen Faktoren beschäftigt, welche die kindliche Gesundheit beeinflussen. Im Mittelpunkt stehen dabei a) direkte Einflüsse des kindlichen sozialen Netzwerkes, z. B. die soziale Unterstützung durch die Eltern und b) indirekte Einflüsse des elterlichen Netzwerks auf das Kind, z. B. in Form von emotionaler oder instrumenteller Unterstützung der Eltern durch die Großeltern. 
Zunächst wird in Abschn. 2 besprochen, wie soziale Netzwerke von Kindern zusammengesetzt sind, welche Funktionen sie theoretisch erfüllen und welche Effekte auf die Gesundheit daraus resultieren könnten. In die Diskussion integriert wird hier der Begriff des ,family social capital“, der auf James S. Coleman zurückgeht. In Abschn. 3 wird dann als Ausgangspunkt kurz auf Studien eingegangen, die den sozioökonomischen Status der Familie als Prädiktor für den Gesundheitszustand des Kindes verwenden. Davon ausgehend wird in Abschn. 4 im Rahmen eines Literaturüberblicks auf Netzwerkeffekte eingegangen, die zudem in Abschn. 5 noch einmal speziell dahin gehend überprüft werden, inwiefern sie unabhängig von klassischen Ungleichheitsdimensionen auftreten bzw. wie sie mit diesen Dimensionen verknüpft sind. In Abschn. 6 erfolgt eine abschließende Diskussion der Befunde.

\section{Kindernetzwerke: Struktur, Funktionen und Effekte auf die Gesundheit sowie familiales Sozialkapital}

\subsection{Strukturen, Funktionen und Gesundheitseffekte von sozialen Netzwerken von Kindern}

Nestmann und Wehner (2008, S. 22-27) beschreiben, aufbauend auf Vaux (1988), in welchem Spektrum soziale Netzwerke die Gesundheit von Kindern beeinflussen können. Sie nehmen dabei eine entwicklungspsychologische Perspektive ein. Beim Kleinkind ermöglichen hiernach ein sicherer Halt und eine vertrauensvolle Bindung zu den engsten Bezugspersonen nach der Bindungstheorie (Bowlby 1975) eine Exploration neuer sozialer Beziehungen und Lebenssphären. Über die Mutter-Kind-Beziehung hinaus sollte jedoch schon früh ein Augenmerk auf eine mögliche Netzwerkperspektive gelegt werden, die neben anderen Kontaktpersonen der Kleinkinder (z. B. Väter, Geschwister, Großeltern, Pflegepersonen) auch die Einflüsse sogenannter Exosysteme (Bronfenbrenner 1981) aufgreift. Hiermit ist gemeint, dass Personen und Institutionen Kinder, vermittelt über ihre engsten Bezugspersonen, indirekt tangieren. Neben den sozialen Netzwerken der Kinder selbst sind demzufolge auch die Netzwerke der Eltern in die Analyse mit einzubeziehen (vgl. auch Cochran und Brassard 1979).

Im direkten Kontakt zu Netzwerkmitgliedern der Eltern erhalten die Kinder verschiedene kognitive und soziale Anregungen, die ihre Entwicklung stimulieren: andere Interaktionsstile und Zuwendungsformen, divergierende Interaktionsinhalte (z. B. Reden, Spielen, Vorlesen) und andere Interaktionssettings 
(z. B. der Haushalt der Großeltern). Neben diesen Anregungen erfahren die Kinder andere Formen der Unterstützung und Regulation. Mitglieder des elterlichen Netzwerks dienen zudem als Verhaltensmodelle (soziales Lernen) und bieten den Kindern Interaktionsgelegenheiten, die ihre Sozialkompetenz stärken.

Personen aus dem Netzwerk der Eltern wie Großeltern, Freunde oder Nachbarn können die Kinder auf verschiedene Weise indirekt beeinflussen: Sie geben den Eltern explizite oder implizite Rückmeldungen zur Kinderversorgung und Erziehung, unterstützen sie bei Erziehung und Versorgung (z. B. bei Notfällen und Krankheit), bestätigen die Eltern emotional in ihrer Elternrolle und geben Rückhalt. Zudem stellen Netzwerkpersonen Lernmodelle dar, die den Zugang zu einer größeren Bandbreite von Interaktionsstilen, Strategien der Alltagsführung oder Konfliktlösungskompetenzen bieten. Neben den aufgeführten positiven Impulsen sind jedoch entsprechend auch negative Einflüsse wie z. B. ungebetene Ratschläge, widersprüchliche Vorgaben oder negative Verhaltensbeispiele zu berücksichtigen.

Hieraus lassen sich bereits einige zentrale Mechanismen ableiten, durch die soziale Netzwerke des Kindes selbst oder elterliche Netzwerke die kindliche Gesundheit beeinflussen (zu theoretischen Mechanismen siehe Kap. „Soziale Beziehungen, soziales Kapital und soziale Netzwerke“ sowie Kap. „Wirkmechanismen in sozialen Netzwerken"). Heuristisch sind vier Aspekte differenzierbar:

- Soziale Unterstützung: Im Hinblick auf soziale Unterstützung unterscheiden Erhart und Ravens-Sieberer (2008) zwischen einer Abschirm-, Puffer- und Toleranzwirkung. Emotionale oder instrumentelle Unterstützung beugt Krisensituationen vor (1., Abschirmwirkung), kann in eingetretenen Krisensituationen negative Auswirkungen durch eine produktive Verarbeitung der Anforderungen reduzieren (2., Pufferwirkung) und stärkt Fähigkeiten, mit bereits eingetretenen Gesundheitsstörungen umzugehen (3., Toleranzwirkung). Beispiele für die Abschirmwirkung wären das warme Anziehen des Kindes im Winter oder eine vitaminreiche Ernährung. Stärken Netzwerkpersonen das Selbstwertgefühl und den Bewältigungsoptimismus in Stresssituationen, z. B. bei Schulstress des Kindes, wäre dies ein Beispiel für die Pufferwirkung. Wird ein krankes Kind von Netzwerkpersonen emotional unterstützt, zeigt sich hierin beispielhaft die Toleranzwirkung.

- Soziale Kontrolle: Eltern und auch Personen aus dem Netzwerk der Eltern (z. B. Großeltern) sind in Familien mit hoher Kohäsion durch (informelle) soziale Kontrolle eher in der Lage, Kinder z. B. vor „risk-fashion“ Aktivitäten 
oder gesundheitsgefährdenden Verhaltensweisen (etwa Drogenkonsum) fernzuhalten. Bei hoher Kohäsion kann der Gesundheitszustand des Kindes zudem besser überwacht und ggf. darauf reagiert werden (,monitoring“).

- Soziale Beeinflussung: Eltern haben in Familien mit hoher Kohäsion eher die Möglichkeit, beispielsweise das Essverhalten der Kinder im Rahmen von regelmäßigen gemeinsamen Mahlzeiten aktiv zu beeinflussen und auch das Wissen zu gesunder Ernährung zu fördern. Gleiches gilt für physische Aktivität (z. B. Sport) oder Medienkonsum. Enge familiale Sozialbeziehungen fördern außerdem soziale Gemeinschaft und eine positive Gemütslage. Dies vermeidet negative Isolationseffekte wie Depression oder Vernachlässigung von Ernährung oder Selbstpflege.

- Soziale Ansteckung: Die Eltern selbst, aber auch Personen aus dem sozialen Netzwerk der Eltern, stellen erstens für Kinder und Jugendliche Verhaltensmodelle dar, deren Einstellungen und Verhaltensweisen im Rahmen von sozialem Lernen (Bandura 1977) übernommen werden können. Zweitens besteht ein indirekter Mechanismus darin, dass Betreuungspersonen des Kindes selektiv Beziehungen zu Netzwerkpersonen aufbauen bzw. erhalten, die ähnliche Einstellungen und Verhaltensweisen im Bereich der Gesundheit aufweisen wie sie selbst (Homophilie; Kennedy-Hendricks et al. 2015).

Im nächsten Schritt stellt sich die Frage, welche Personen aus dem Netzwerk des Kindes bzw. aus dem elterlichen Netzwerk welche Funktionen übernehmen und ob es hier je nach Alter des Kindes Unterschiede gibt. Hinsichtlich der Struktur kindlicher Netzwerke verwenden Levitt et al. (1993) - in Anlehnung an Kahn und Antonucci (1980) - die Metapher der ziehenden Karawane, einer Idealtypik der strukturellen Netzwerkentwicklung über den Lebensverlauf. Hiernach durchzieht zunächst ein kleiner Konvoi der engsten Familie die frühe Kindheit, reichert sich anschließend schnell durch Verwandtschaft, Freundschaft und Nachbarschaft an und vergrößert sich in der späten Kindheit bzw. im Jugendalter, in denen die Peers und erste institutionelle Kontakte (Kindergarten, Schule) hinzutreten. Aufbauend auf diesem „,convoy model“ verwenden Levitt et al. (1993) konzentrische Kreisdiagramme, um Netzwerkpersonen der Kinder (hier zwischen 7 und 14 Jahre) voneinander abzugrenzen, die den innersten Zirkel des Netzwerks (größte Wichtigkeit für das Kind und Nähe zum Kind) oder den mittleren und äußeren Zirkel bilden. Es zeigt sich, dass der innerste Zirkel fast ausschließlich aus engen Familienmitgliedern (Eltern, Geschwister) bzw. anderen Familienmitgliedern wie Großeltern besteht. Der mittlere Zirkel ist heterogen zusammengesetzt (es überwiegen Familienmitglieder außerhalb der Kernfamilie aber auch Freunde 
gewinnen an Bedeutung) und im äußeren Zirkel stellen Freunde die größte Gruppe dar. Mit dem Alter der Kinder steigen die Netzwerkgröße, der Anteil der Freunde und das wahrgenommene Unterstützungspotenzial im Netzwerk (insbesondere durch Freunde; siehe auch Bost et al. 2004).

Boosman et al. (2002) zeigen ferner in einer differenzierten Studie zu sozialen Netzwerken von Kindern im Alter von 4-8 Jahren, welche Arten von Netzwerkeinflüssen (soziale Kontrolle, soziale Unterstützung und Kinderbetreuung) von welchen Netzwerkpersonen ausgehen. Dabei zeigt sich erwartungsgemäß, dass alle drei Funktionen allgemein am häufigsten von den Eltern erfüllt werden. Erfolgt jedoch eine Unterteilung nach Unterstützungsarten, zeigt sich ein differenzierteres Bild: Unterstützung, die sich in Form von Geselligkeit und Spielgelegenheiten äußert, wird am häufigsten von Peers zur Verfügung gestellt. Auch Konflikte werden mit Peers häufiger ausgetragen als mit den Eltern. Großeltern ähneln strukturell den Eltern - allerdings auf niedrigerem Niveau. Sie üben nach den Eltern relativ häufig soziale Kontrolle aus, sind relativ stark für die Kinderbetreuung (z. B. Essen, Anziehen) verantwortlich und bieten auch emotionale wie instrumentelle Unterstützung. Geschwister spielen nach den Eltern und den Peers ebenfalls eine wichtige Rolle im Bereich der Geselligkeit, das Konfliktniveau mit Geschwistern ist jedoch niedriger ausgeprägt als bei Peers. Lehrer werden etwas überraschend selten als signifikante Einflusspersonen benannt, sogar im Bereich „informational support“. Schließlich zeigt sich, dass auch Kuscheltiere und Puppen von den Kindern stellenweise als symbolische Netzwerkpersonen eingeordnet werden, z. B. im Bereich der emotionalen Unterstützung.

Nur selten wird in der Literatur diskutiert, welche Eigenschaften einzelne Ties bzw. das Netzwerk insgesamt aufweisen müssen, damit die oben diskutierten Mechanismen wirken. Erhart und Ravens-Sieberer (2008) deuten an, dass die Abschirm-, Puffer- und Toleranzwirkung sozialer Unterstützung vor allem dann zum Tragen kommt, wenn zum einen mehrere Unterstützer zur Verfügung stehen und Unterstützung zum anderen langfristig angelegt ist. In ähnlicher Weise erwarten Kana'iaupuni et al. (2005) in einer mexikanischen Studie, dass soziale Netzwerke, die entweder einen hohen Anteil von Blutsverwandten (Eltern und Geschwister) oder einen hohen Anteil von ,extended kin“ enthalten, mehr soziale Unterstützung bzw. eine besonders intensive Form der Unterstützung bereitstellen können. Unter „,extended kin“ werden dabei Vertrauenspersonen (,persons de confianza") in einem kulturell verankerten reziproken Unterstützungssystem sowie Paten der Kinder („Compadrazgo“) subsumiert. Zusätzlich wird erwartet, dass sich räumliche Nähe, Koresidenz und eine hohe Kontakthäufigkeit positiv 
auf das Unterstützungspotenzial auswirken. Somit kann vorsichtig vermutet werden, dass dichte Netzwerke mit hohem Verwandtenanteil, die entsprechend vorwiegend aus Strong Ties bestehen, besonders förderlich für die kindliche Gesundheit sein sollten.

\subsection{Der Ansatz des familialen Sozialkapitals von Kindern}

Anschlussfähig an die besprochene Netzwerkperspektive - zugleich aber breiter ist ferner der auf Coleman (1990) zurückgehende Begriff des ,family social capital". Hier wird postuliert, dass der familiäre Hintergrund eines Kindes aus drei Komponenten besteht:

- finanzielles Kapital (die finanziellen Ressourcen, die für den Haushalt insgesamt und das Kind zur Verfügung stehen),

- elterliches Humankapital (z. B. die kognitiven Fähigkeiten und Bildungsabschlüsse der Eltern),

- Sozialkapital (die Ressourcen, die im Rahmen von sozialen Beziehungen zur Verfügung stehen und für die kognitive und soziale Entwicklung von Kindern und Jugendlichen nützlich sind).

Das Sozialkapital stellt allgemein eine konzeptionelle Verbindung her zwischen den Eigenschaften individueller Akteure und ihren unmittelbaren sozialen Kontexten in Haushalt, Schule und Nachbarschaft - mithin also auch außerfamiliale Netzwerkbeziehungen. Das intra-familiale Sozialkapital bezieht sich auf die Eltern-Kind-Beziehung und manifestiert sich durch die Zeit und die Aufmerksamkeit, die Eltern aufbringen, indem sie mit ihren Kindern interagieren, soziale Kontrolle ausüben und ihr Wohlbefinden fördern. Operationalisiert wird familiales Sozialkapital in der Forschung über Indikatoren, die sich zwei Hauptdimensionen zuordnen lassen:

- die strukturelle Dimension (familiale Struktur): z. B. Kernfamilie (mit zwei biologischen Elternteilen im Haushalt) vs. Stieffamilie oder alleinerziehende Eltern; Anzahl der Geschwister oder

- die funktionale Dimension (das Vorhandensein förderlicher Interaktionen zwischen Eltern und Kindern). 
Tab. 1 Konzepte zur Messung von familialem Sozialkapital

\begin{tabular}{|c|c|c|}
\hline Konstrukt & Unterkonstrukt & Beispielitems \\
\hline \multirow[t]{4}{*}{ Familiale Kohäsion } & Kollektive Wirksamkeit & $\begin{array}{l}\text { Wahrnehmung, als Familie gut zu } \\
\text { funktionieren }\end{array}$ \\
\hline & Informelle Kontrolle & $\begin{array}{l}\text { Wie viele Stunden sind Kinder nach der } \\
\text { Schule ohne Eltern zu Hause? } \\
\text { Kennen Eltern Freunde des Kindes? } \\
\text { Erlauben Eltern dem Kind, mit ihnen } \\
\text { unbekannten Freunden auszugehen? } \\
\text { Überprüfen Eltern, ob Kinder ihre } \\
\text { Hausaufgaben erledigt haben? }\end{array}$ \\
\hline & Soziale Interaktion & $\begin{array}{l}\text { Häufigkeit gemeinsamer Eltern-Kind- } \\
\text { Aktivitäten wie z. B. Mahlzeiten, } \\
\text { Spiele, Gespräche, Feiern }\end{array}$ \\
\hline & $\begin{array}{l}\text { Gefühl der } \\
\text { Zugehörigkeit }\end{array}$ & $\begin{array}{l}\text { Respektieren sich Familienmitglieder } \\
\text { gegenseitig? } \\
\text { Empfinden sie gegenseitig Loyalität und } \\
\text { Vertrauen? }\end{array}$ \\
\hline \multirow[t]{3}{*}{$\begin{array}{l}\text { Familiale } \\
\text { Unterstützung }\end{array}$} & $\begin{array}{l}\text { Emotionale } \\
\text { Unterstützung }\end{array}$ & $\begin{array}{l}\text { Sprechen Familienmitglieder über } \\
\text { Sorgen? } \\
\text { Sind Verwandte verlässliche Personen, } \\
\text { die bei ernsten Problem helfen? } \\
\text { Wird Familienmitgliedern emotionale } \\
\text { Unterstützung, Empathie und Liebe } \\
\text { entgegengebracht? }\end{array}$ \\
\hline & $\begin{array}{l}\text { Instrumentelle } \\
\text { Unterstützung }\end{array}$ & Eltern helfen bei den Hausaufgaben \\
\hline & Konflikt & $\begin{array}{l}\text { Wie häufig kritisieren sich } \\
\text { Familienmitglieder? } \\
\text { Konfligieren persönliche Ziele mit } \\
\text { denen der Familie? }\end{array}$ \\
\hline \multirow[t]{2}{*}{$\begin{array}{l}\text { Soziales Netzwerk } \\
\text { (des Kindes bzw. der } \\
\text { Eltern) }\end{array}$} & Netzwerkstruktur & $\begin{array}{l}\text { Netzwerkgröße, -dichte und -zentralität; } \\
\text { Geschlechts- und Alterskomposition; } \\
\text { Reichweite des Familiennetzwerks } \\
\text { (Eltern, Geschwister, Schwiegereltern, } \\
\text { weitere Verwandte) }\end{array}$ \\
\hline & Beziehungsqualität & $\begin{array}{l}\text { Wohnortnähe und Kontakthäufigkeit, } \\
\text { emotionale Nähe }\end{array}$ \\
\hline
\end{tabular}

Quelle: Eigene Darstellung basierend auf Alvarez et al. 2017, S. 19 f 
Der Begriff des „family social capital“ leidet zum Teil unter seiner theoretischen Unschärfe und der Breite der Messindikatoren, die hier subsumiert werden. ${ }^{1}$ Dem Sozialkapital zugerechnet werden sowohl die familiale Kohäsion, die Qualität der Eltern-Kind-Beziehung (z. B. Kontakthäufigkeit, emotionale Nähe) als auch strukturelle Aspekte des kindlichen Netzwerks bzw. des Elternnetzwerks. Zu letzteren zählen z. B. Netzwerkgröße, -dichte und -zentralität (Alvarez et al. 2017).

Alvarez et al. (2017) haben hierzu auf Basis eines Literaturüberblicks eine Übersicht erstellt, die in Tab. 1 - etwas verkürzt - wiedergegeben wird. Die Bereiche der familialen Kohäsion und der familialen Unterstützung lassen sich als Ausdifferenzierungen der funktionalen Dimension nach Coleman verstehen und das Konstrukt des familialen Netzwerks als Repräsentanz der strukturellen Dimension.

$\mathrm{Zu}$ ergänzen bleibt, dass der Begriff der sozialen Kohäsion voraussetzungsvoller ist als der Begriff des Sozialkapitals, und vor allem in der Familienpsychologie als zentrales Kriterium familialer Funktionsfähigkeit beschrieben wird (z. B. Dilworth-Anderson et al. 2005). So ist es möglich, dass trotz eines ausgeprägten Sozialkapitals keine soziale Kohäsion besteht. Umgekehrt erscheint die Abwesenheit von Sozialkapital bei gegebener sozialer Kohäsion nur schwer denkbar.

\section{$3 \quad$ Soziale Ungleichheit und kindliche Gesundheit}

Eine umfangreiche Literatur widmet sich dem Zusammenhang zwischen sozialer Ungleichheit und (kindlicher) Gesundheit. Zugrunde liegt hier das Konzept des sozioökonomischen Status, d. h. die individuelle Position in einem durch

\footnotetext{
${ }^{1}$ Das Konzept des familialen Sozialkapitals von Coleman (1990) sowie die Operationalisierung des Konzepts in der Forschung sind in mehrfacher Hinsicht kritisiert worden (Alvarez et al. 2017; Morrow 1999). Es wird eingewendet, dass insbesondere Kinder und Jugendliche lediglich als Nutznießer des Sozialkapitals gesehen werden und dabei übersehen wird, wie sie selbst zu dessen Entstehung beitragen (Morrow 1999). Kritisch ist zudem anzumerken, dass der Begriff des ,,family) social capital“ durch die Vielzahl der in ihm vereinigten Konzepte unscharf wird. Er deckt sowohl strukturelle Aspekte ab (z. B. die Familienform) als auch konkrete Unterstützungsleistungen aus dem Netzwerk bis hin zu Zugehörigkeitsgefühlen, Interaktionsmustern oder der emotionalen Nähe zwischen Eltern und Kindern (Morrow 1999). Hier fehlt die konzeptionelle Abgrenzung zu anderen, zum Teil trennschärferen Begriffen wie z. B. dem Lebensstil (Wippermann 2009).
} 
Ungleichheit in der Verteilung von Privilegien und Wohlstand geprägten Gesellschaftsgefüge. Damit gehen Vor- und Nachteile bezüglich der Verfügbarkeit von verschiedenen Gütern einher. Zu diesen zählen zum einen klassische Güter wie Einkommen, Vermögen, Macht, Sozialprestige, Bildung oder Wissen und zum anderen - wie etwa im Konzept der sozialen Lage (Hradil 1987) - auch die soziokulturelle Teilhabe in den Lebensbereichen Arbeit, Ausbildung, Wohnen, Freizeit und Kultur.

Lampert und Schenk (2004) systematisieren in einem Mehrebenenmodell verschiedene theoretische Erklärungsansätze zum Zusammenhang zwischen sozialer Ungleichheit und kindlicher Gesundheit. Hiernach steht die soziale Lage des Haushaltes, gemessen z. B. über Schichtzugehörigkeit, Einkommenssituation und Familienform (Alleinerziehende) in einer Beziehung zu Lebensbedingungen und Teilhabechancen. Hierzu zählen etwa die materielle Versorgung, die Familiensituation, Wohnverhältnisse, das Freizeitverhalten und die Zusammensetzung der Peers sowie die gewählte Schule bzw. Kindertagesstätte. Lebensbedingungen und Teilhabechancen wirken sich wiederum zum einen auf das Gesundheitsverhalten aus (z. B. Ernährung, körperliche Aktivität, Alkohol- und Tabakkonsum, Mundhygiene) und zum anderen auf die Persönlichkeit, die etwa durch Selbstwertgefühl, Kontrollüberzeugungen, Optimismus oder Aggressivität zum Ausdruck kommt. Gesundheitsverhalten und Persönlichkeit, die sich auch wechselseitig bedingen, führen schließlich zu gesundheitlichen Ungleichheiten, die sich u. a. in Krankheiten, Behinderungen, Unfallverletzungen, subjektiver und psychischer Gesundheit oder Verhaltensauffälligkeiten äußern.

Zahlreiche empirische Studien belegen Zusammenhänge zwischen sozialer und gesundheitlicher Ungleichheit bei Kindern und Jugendlichen. Die entsprechenden Resultate werden hier auf Basis des Forschungsüberblicks von Lampert und Richter (2009), der stellenweise aktualisiert wurde, kurz zusammengefasst:

- Säuglingssterblichkeit: Die bisherige empirische Evidenz, die sich auf regionale Daten beschränkt, zeigt eine erhöhte Säuglingssterblichkeit in unteren sozialen Schichten. Dies gilt auch für Risikofaktoren wie niedrigeres Geburtsgewicht und angeborene Fehlbildungen (Mielck 1998).

- Entwicklungsstörungen: Nach jährlichen Schuleingangsuntersuchungen des Öffentlichen Gesundheitsdienstes (vgl. für das Land Brandenburg: Ellsäßer und Lüdecke 2015) sind Entwicklungsstörungen bei niedrigem Sozialstatus (gemessen über Bildung und Erwerbsstatus der Eltern) deutlich häufiger anzutreffen: Während z. B. Sprach- und Sprechstörungen bei Kindern mit niedrigem Sozialstatus in 43,9\% der Fälle diagnostiziert wurden, waren es bei 
Kindern mit hohem Sozialstatus nur 13,2\%. Ähnlich große Unterschiede zeigen sich z. B. auch bei Wahrnehmungs- und psychomotorischen Störungen, intellektuellen Entwicklungsverzögerungen, emotionalen und sozialen Störungen sowie psychischen Auffälligkeiten. Eine Ursache mag darin liegen, dass die U-Untersuchungen von sozial benachteiligten Bevölkerungsschichten etwas seltener in Anspruch genommen werden (Ellsäßer und Lüdecke 2015)

- Chronische Krankheiten: Chronische Krankheiten bei Kindern weisen ebenfalls einen sozialen Gradienten auf: Nach den Befunden der Brandenburger Einschulungsuntersuchung des Jahres 2015 (Ellsäßer und Lüdecke 2015) sind Kinder mit niedrigem sozialen Status in 23,7\% der Fälle chronisch krank. Beispiele sind somatische Erkrankungen (z. B. Sprach-, Seh- oder Hörstörungen) oder psychische Erkrankungen wie ADHS und emotionale soziale Störungen. Dieser Anteil liegt bei hohem sozialen Status mit 9,5\% deutlich niedriger.

- Unfallverletzungen: Daten zu Unfällen in der Schule, Kita, zu Hause, in der Freizeit und im Straßenverkehr wurden vereinzelt im Hinblick auf Zusammenhänge mit der sozialen Lage untersucht. Eine ältere Studie von Geyer und Peter (1998) zeigt, dass Kinder von un- und angelernten Arbeitern sowie von Facharbeitern häufiger unfallbedingt im Krankenhaus behandelt werden als Kinder von Angestellten und Personen in höheren beruflichen Personen.

- Psychosoziale Gesundheit: Befunde auf Basis der „Health Behaviour in School-aged Children“ (HBSC)-Studie (z. B. Richter et al. 2008) zeigen für Kinder und Jugendliche im Altersbereich 11-15 Jahre, dass die subjektive Gesundheit in Abhängigkeit des familialen Wohlstands besser beurteilt wird. Ähnliche soziale Unterschiede werden auch für psychosomatische Beschwerden wie Kopf-, Bauch- und Rückenschmerzen, Schlafstörungen oder Items zum emotionalen Befinden berichtet.

- Gesundheitsverhalten: Ebenfalls auf Basis der HBSC-Studien lassen sich schließlich statusabhängige Unterschiede z. B. in der Ernährung zeigen (Kinder aus sozial schlechter gestellten Familien essen z. B. seltener frisches Obst und Gemüse) sowie Unterschiede in der Häufigkeit des Tabak- und Alkoholkonsums, die mit dem sozialen Status abnimmt.

Lampert und Richter (2009) resümieren, dass der soziale Status zwar in der Forschungslandschaft sehr unterschiedlich operationalisiert wird (z. B. über die Bildung und die berufliche Stellung der Eltern aber auch über den Wohlstand der Familie), die verschiedenen Statusindikatoren jedoch in ihren Effekten weitgehend übereinstimmen. Sie schließen daraus, dass zwischen der sozialen und gesundheitlichen Lage der Heranwachsenden ein vergleichsweise 
enger Zusammenhang besteht (siehe auch Kap. „Soziale Netzwerke, Gesundheit und gesundheitliche Ungleichheiten im Jugendalter"). Im vorliegenden Beitrag ist nun von besonderem Interesse, inwieweit Netzwerkeffekte auf der einen Seite und Ungleichheitseffekte auf der anderen Seite zusammenhängen. So ist z. B. denkbar, dass die negativen Auswirkungen einer geringen Ausstattung mit sozioökonomischen Ressourcen schwächer ausfallen, wenn die Familie über Kompensatoren in Form von sozialer Unterstützung verfügt.

\section{Soziale Netzwerke, familiales soziales Kapital und kindliche Gesundheit: Ein Literaturüberblick}

Bei der Aufarbeitung des Forschungsstandes wird konzeptuell zwischen zwei Perspektiven unterschieden:

1. Wie wird der Gesundheitszustand der Kinder durch Mitglieder ihres unmittelbaren familialen Netzwerks beeinflusst (Abschn. 4.1)?

2. Welchen Einfluss üben die sozialen Netzwerke der Eltern indirekt auf die Gesundheit der Kinder aus (Abschn. 4.2)?

\subsection{Kindernetzwerke und kindliche Gesundheit}

In diesem Abschnitt liegt das Augenmerk in einem ersten Schritt auf Studien, die Effekte des sozialen Netzwerks des Kindes auf seine Gesundheit in den Blick nehmen und zudem eine Netzwerkmethodologie im engeren Sinne verwenden, d. h. egozentrierte Netzwerke aufspannen. Dieses Kriterium erfüllen die beiden entwicklungspsychologischen Studien von Levitt et al. (1993) sowie Levitt et al. (2005). Zweitens wird der Forschungsstand für Studien kurz zusammengefasst, die den breiteren Begriff des ,family social capital“ verwenden (Bala-Brusilow 2010; Berntsson et al. 2007; Erhart und Ravens-Sieberer 2008; Eriksson et al. 2012; Klocke 2004; Klocke und Lipsmeier 2008; Lau und Li 2011; Morgan und Haglund 2009; Rattay et al. 2012; Wu et al. 2010). Letztere werden größtenteils auch in einem aktuellen Literaturüberblick von Alvarez et al. (2017) besprochen.

Levitt et al. (1993) überprüfen auf Basis einer Stichprobe von N=333 amerikanischen Schulkindern im Altersbereich von 7-14 Jahren, wie affektiv-emotionale und instrumentelle soziale Unterstützung insgesamt und insbesondere soziale Unterstützung aus dem innersten Zirkel des kindlichen Netzwerks (,,convoy model“", siehe Abschn. 2.1) zwei Aspekte der psychischen Gesundheit 
beeinflusst: das positive Selbstkonzept und einen Index zur allgemeinen Gemütslage und Geselligkeit des Kindes. Soziale Unterstützung aus dem sozialen Netzwerk insgesamt, insbesondere aber aus dem innersten Zirkel, der überwiegend aus Mitgliedern der Kernfamilie (Eltern, Geschwister) besteht, üben mittelstarke positive Effekte auf beide Gesundheitsfaktoren aus.

In einer aktuelleren Studie (ebenfalls mit Schulkindern im Altersbereich 9-13 Jahre) erweitern Levitt et al. (2005) diese Befunde um einen typologischen Ansatz. Eine Clusteranalyse führt zu dem Ergebnis, dass es drei Strukturtypen von Kindernetzwerken zu geben scheint: Einen Typ, in dem soziale Unterstützung sowohl von Mitgliedern der Kernfamilie als auch von engen Freunden ausgeht (,close family/friend“), einen Typ mit Unterstützung ausschließlich durch die Familie (,close family“) und einen Typ mit vielfältiger Unterstützung seitens der Kernfamilie, der erweiterten Familie und auch tendenziell von Freunden (,close/extended family“). Wiederum werden mit dem positiven Selbstkonzept, Einsamkeit sowie internalisierten wie externalisierten Verhaltensproblemen (z. B. Gefühl der Wertlosigkeit, körperliche Gewalt) Aspekte des ,psychological adjustment" untersucht. Die Befunde zeigen, dass das Selbstkonzept der Kinder am positivsten, und die Einsamkeit am geringsten ausgeprägt ist, wenn ihre sozialen Netzwerke Unterstützung von mehreren Seiten zur Verfügung stellen, d. h. entweder sowohl von engen Familienmitgliedern und Freunden oder von Mitgliedern der engen und erweiterten Familie (z. B. Onkel, Tanten, Cousinen).

In den Studien, die sich unter dem Begriff des „family social capital“ subsumieren lassen, wird familiales Sozialkapital nicht - wie in den zuvor genannten Studien - über namensbasierte Netzwerkindikatoren, sondern über sogenannte Globalindikatoren erfasst. Hierzu zwei Beispiele: Erhart und Ravens-Sieberer (2008) decken die strukturelle Dimension nach Coleman durch die Familienform (Kernfamilie, Stieffamilie, alleinerziehende Eltern) ab und die funktionale Dimension über a) emotionale Unterstützung durch (Stief-)Eltern und ältere Geschwister und b) instrumentelle Unterstützung durch Eltern in der Schule. Morgan und Haglund (2009) operationalisieren familiales Sozialkapital - dem Kohäsions-Ansatz folgend - zum einen über gemeinsame Aktivitäten in der Familie, z. B. zusammensitzen und unterhalten oder besuchen von Freunden, und zum anderen über das Ausmaß sozialer Kontrolle durch die Eltern („How often does your mother or father try to control everything you do?").

Bei den verwendeten Gesundheitsindikatoren zeigt sich ein breites Spektrum. Abgedeckt werden psychische und psychosomatische Aspekte (z. B. Lebenszufriedenheit, schulischer Leistungsdruck, nervöse Magenprobleme), gesundheitsrelevantes Verhalten (z. B. physische Aktivität, Zähne putzen, gemeinsame Mahlzeiten in der Familie, TV-Konsum, Obst- und Gemüseverzehr, Tabak- und 
Alkoholkonsum), physische Gesundheit (Verletzungen, Übergewicht) und Globalindikatoren zur allgemeinen Gesundheit.

Methodisch werden die Effekte der Sozialkapitalindikatoren auf die Gesundheitsindikatoren in der Regel im Rahmen von hierarchischen Regressionsmodellen bestimmt, die ohne und mit Kontrolle von sozioökonomischen Variablen wie Bildung, Berufsprestige und Einkommen der Eltern geschätzt werden. Die Ergebnisse dieser Analysen führen zu dem Schluss, dass der Sozialkapitalansatz allgemein sehr viel Potenzial zur Erklärung der kindlichen Gesundheit hat. Es zeigt sich sehr konsistent, dass fast alle Sozialkapitalindikatoren die Gesundheitsindikatoren in der erwarteten Weise positiv beeinflussen und dies meist auch bei Kontrolle des sozioökonomischen Status.

Zwei Studien seien besonders hervorgehoben. Die Arbeit von Rattay et al. (2012) ist insofern aufschlussreich, da hier - ermöglicht durch eine relativ große Fallzahl getestet wird, ob die Effekte der Sozialkapitalindikatoren auf die kindliche Gesundheit vom Alter des Kindes bzw. Jugendlichen abhängen, wobei fünf Altersklassen gebildet werden (0-2 Jahre, 3-6 Jahre, 7-10 Jahre, 11-13 Jahre, 14-17 Jahre). Zum Beispiel zeigt sich, dass eine Skala zum Familienklima, die familiale Kohäsion misst, alters- und geschlechtsübergreifend erklärungskräftig ist: Kinder und Jugendliche werden bei einem besseren Familienklima durchgängig als signifikant gesünder eingestuft. Ein oder mehr Geschwisterteile beeinflussen dagegen lediglich die allgemeine Gesundheit von Jungen im Altersbereich 0-2 Jahre negativ, während sich für ältere Kindern und bei Mädchen keine Effekte zeigen.

Eine Besonderheit der Studie von Wu et al. (2010) ist, dass das familiale Sozialkapital im Rahmen von Strukturgleichungsmodellen analytisch als Mediator in eine Erklärungskette eingebettet wird. Exogene Variablen am Beginn dieser Kette sind das familiale Humankapital (elterliche Bildung) und das Familieneinkommen. Mediatoren bzw. intervenierende Variablen sind das familiale Sozialkapital (positive familiale Interaktion, soziale Kontrolle und Monitoring) und das „,community social capital“ (z. B. subjektiv als sicher empfundene Nachbarschaft, Anzahl der Freunde in der Nachbarschaft). Depression der Kinder stellt die Outcome-Variable dar. Im Rahmen von Pfadanalysen wird deutlich, dass das familiale Humankapital zum einen Depressivität direkt negativ beeinflusst und zum anderen indirekt negativ, da eine hohe Bildung der Eltern zu mehr familialem Sozialkapital führt, das seinerseits einen negativen Effekt auf die Depressivität der Kinder hat. Darüber hinaus führt auch ein höheres Sozialkapital in der Nachbarschaft zu einem stärker ausgeprägten familialen Sozialkapital und auf diese Weise zu einer geringeren Depressivität. Überraschenderweise haben gleichzeitig Familien mit höherem Familieneinkommen multivariat ein geringeres familiales Sozialkapital und sind auch etwas häufiger von Depressivität betroffen. 


\subsection{Elterliche soziale Netzwerke, familiales Sozialkapital und kindliche Gesundheit}

Die Literaturrecherche ergab vier Studien, die indirekte Effekte elterlicher sozialer Netzwerke in den Blick nehmen. Diese lassen sich wie folgt ordnen: Runyan et al. (1998) stützen ihre Analysen auf eine Stichprobe extremer Fälle, die durch spezielle Screening-Techniken gezogen wurde. Die Studien von Adams et al. (2002), Kennedy-Hendricks et al. (2015) sowie Kana'iaupuni et al. (2005) zeichnen sich zudem dadurch aus, dass hier eine Netzwerkmethodologie im engeren Sinne (hier: namensbasierte, egozentrierte Netzwerke) verwendet wird. Außerdem handelt es sich bei Adams et al. (2002) sowie Kana'iaupuni et al. (2005) um Studien, die nicht in westlichen Industrienationen durchgeführt wurden (Mali, Mexiko). In allen vier Fällen erscheint somit eine etwas ausführlichere Besprechung angemessen.

Runyan et al. (1998) verwenden eine Stichprobe (Longitudinal Studies on Child Abuse and Neglect, LONGSCAN), in der Kinder überrepräsentiert sind, die bereits seit ihrer Geburt besonderen gesundheitlichen Risiken ausgesetzt sind. Kriterien hierfür sind z. B. geringes Geburtsgewicht, alleinerziehendes Elternteil ohne familiale Unterstützung, geringes Alter der Mutter bei Geburt, Alkoholoder Drogenprobleme der Mutter, Misshandlung oder Wachstumsstörungen. Das kindliche Wohlbefinden wird über Indikatoren zu Entwicklungs- oder Verhaltensproblemen erfasst, z. B. Ängstlichkeit, Depression, körperliche Beschwerden, soziale Probleme, Konzentrations- und Schlafprobleme, regelverletzendes und aggressives Verhalten sowie motorische, adaptive, sprachliche und kognitive Fähigkeiten. Im Rahmen einer Fall-Kontroll-Studie werden Kinder, die auf dieser Basis als klinisch ,,auffällig“ klassifiziert werden, mit unauffälligen Kindern verglichen. Die Kinder sind im Mittel 4,5 Jahre alt.

Sozialkapital wird zum einen über die strukturelle Dimension nach Coleman (1990) (das Vorhandensein von zwei Eltern im Haushalt sowie die Geschwisteranzahl) gemessen. Zum anderen wird über sieben Globalindikatoren gemessen, inwieweit die primäre Betreuungsperson des Kindes über funktionale und emotionale Unterstützung aus ihrem sozialen Netzwerk verfügt (Beispiele: Ego kennt Personen, mit denen er über Probleme reden kann, erhält Einladungen, mit anderen auszugehen, erhält Liebe und Zuneigung, erhält Beratung zu wichtigen Lebensaspekten, wird bei eigener Krankheit unterstützt, kennt Personen, die sich darum kümmern, wie es ihm geht). Die so gemessene Form der sozialen Unterstützung wird einzeln betrachtet sowie mit anderen Sozialkapitalindikatoren (zwei Eltern im Haushalt, höchstens zwei Kinder, soziale Unterstützung aus der Nachbarschaft, regelmäßiger Kirchgang) zu einem Summenscore „Social Capital Index" verrechnet. Avancierte Netzwerkmaße werden nicht berichtet. 
Empirisch zeigt sich, dass die persönliche soziale Unterstützung der Eltern bei Kindern, die als auffällig klassifiziert werden, signifikant schwächer ausgeprägt ist als bei unauffälligen Kindern. Gleiches gilt für einen regelmäßigen Kirchgang und den Sozialkapitalindex insgesamt. Die strukturellen Indikatoren (zwei Eltern im Haushalt, nicht mehr als zwei Kinder) üben bivariat keinen signifikanten Einfluss aus. Der positive Effekt des Sozialkapitalindex auf die kindliche Entwicklung und Gesundheit bleibt auch in einem logistischen Regressionsmodell stabil, in dem für Bildung der Mutter, Familieneinkommen und mütterliche Depression kontrolliert wird.

Kennedy-Hendricks et al. (2015) zielen als einzige hier besprochene Studie auf Prozesse der sozialen Ansteckung ab. Die Stichprobe basiert auf eher benachteiligten Familien im Rahmen des sozialen Wohnungsbaus. Durch eine Erhebung namensbasierter egozentrierter sozialer Netzwerke der Eltern wird überprüft, inwiefern die Netzwerkpersonen (insbesondere in der Nachbarschaft) im Zusammenhang mit Gesundheitsaspekten positive Verhaltensmodelle für die Kinder darstellen, indem sie sich z. B. gesundheitsbewusst ernähren, physisch aktiv oder nicht übergewichtig sind. Empirisch zeigt sich, dass Kinder selbst sportlich aktiver und seltener übergewichtig sind, wenn sich in den Netzwerken der Eltern viele physisch aktive und nicht übergewichtige Personen befinden. Diese Ergebnisse unterstützen die unterstellten sozialen Lern- und Ansteckungsprozesse, auch wenn diese nicht direkt getestet werden.

Kana'iaupuni et al. (2005) zeigen mit Daten des Health und Migration Survey (HBS) für einige ausgewählte mexikanische Dörfer $(\mathrm{N}=620)$, dass sich das Ausmaß der emotionalen und finanziellen Unterstützung der Eltern durch ihre Netzwerkpersonen weniger mit der Anzahl der Blutsverwandten als mit der Anzahl der Personen (in unmittelbarer räumlicher Nähe) erhöht, die als erweiterte Verwandtschaft gelten. Hierzu zählen die oben bereits erwähnten Vertrauenspersonen und Paten der Kinder. Hoch interaktive soziale Netzwerke dieser Natur wirken sich zudem, vermittelt über emotionale und finanzielle Unterstützung, erwartungsgemäß positiv auf den allgemeinen Gesundheitszustand der Kinder aus insbesondere bei Familien, die über wenige materielle Ressourcen verfügen.

Adams et al. (2002) befragen $\mathrm{N}=1008$ Mütter in Mali aus zwei Volksstämmen (Bamanan, Fulbe). Durch einen Namensgenerator wird erfasst, wie groß spezifische soziale Teilnetzwerke sind, die für die Mutter materielle, praktische, kognitive und emotionale Unterstützung zur Verfügung stellen. Außerdem werden verschiedene Netzwerkcharakteristika relativ detailliert erhoben, z. B. die Geschlechts- und Alterskomposition, die räumliche Nähe der Netzwerkpersonen und der Beziehungsstatus zur Mutter (Verwandte, Freunde). Mithilfe einer Cox-Regression wird das Sterberisiko des Kindes in den ersten fünf Lebensjahren 
geschätzt. Die Sterbewahrscheinlichkeit des Kindes sinkt signifikant mit einer Zunahme der Netzwerkgröße sowie mit steigender Zahl von Personen, die praktische, kognitive und emotionale Unterstützung verfügbar machen. Dies gilt insbesondere für die Population der Fulbe, die besonders von Armut betroffen ist. Die verschiedenen strukturellen Netzwerkeigenschaften (z. B. Verwandtenanteil, Anteil der im Haushalt lebenden Netzwerkmitglieder) sind multivariat insignifikant.

\section{Familiales Sozialkapital, kindliche Gesundheit und soziale Ungleichheit}

In einem Zwischenkapitel werden nun das familiale Sozialkapital und die kindliche Gesundheit mit sozialer Ungleichheit in Verbindung gebracht, indem die referierten Studien aus diesem Blickwinkel kurz ausgewertet werden. Hierbei geht es um zwei Fragen:

1. Führt ein geringer sozioökonomischer Status der Eltern, vermittelt über eine geringe Ausstattung mit familialem Sozialkapital, zu einer schlechteren kindlichen Gesundheit? ${ }^{2}$

2. Besteht ein Interaktionseffekt zwischen dem sozioökonomischen Status und dem familialen Sozialkapital bei der Vorhersage der kindlichen Gesundheit? Wirkt sich also eine hohe Ausstattung mit Sozialkapital je nach sozialer Schicht anders auf die Gesundheit aus?

Zur ersten Frage ist zunächst festzustellen, dass insbesondere in den soziologischen Studien aus dem Bereich der familialen Sozialkapitalforschung multivariate Modelle berechnet werden, in denen sowohl die Sozialkapital-Indikatoren als auch Merkmale zur sozioökonomischen Lage (Bildung, Einkommen und Erwerbsstatus der Eltern) vertreten sind. Generell verdeutlichen die Befunde, dass das familiale Sozialkapital seine eigenständige Erklärungskraft auch bei Kontrolle der sozioökonomischen Indikatoren behält. Im Hinblick auf die erste zu beantwortende Frage bedeutet dies, dass das Sozialkapital nicht bloß eine Funktion der sozioökonomischen Situation ist, sondern eigenständige Effekte hat.

\footnotetext{
${ }^{2}$ Für eine ausführliche theoretische Diskussion des Zusammenhangs zwischen sozioökonomischen Status und Sozialkapital siehe Hartung (2013, S. 139-175).
} 
Gleichzeitig zeigen diejenigen Studien, die entweder hierarchische Regressionsmodelle oder - wie Wu et al. (2010) - Strukturgleichungsmodelle verwenden, dass das familiale Sozialkapital sowohl von anderen Sozialkapital-Subdimensionen (Schule, Nachbarschaft) als auch vom sozioökonomischen Status der Familie abhängig ist. Wu et al. (2010) differenzieren diese Abhängigkeit dahin gehend, dass vor allem Familien mit hoher elterlicher Bildung über mehr Sozialkapital (hier vor allem familiale Kohäsion) verfügen. Diese Befunde bestätigen die in Frage 1 formulierte Vermittlungshypothese. ${ }^{3}$

Eine allgemeine soziologische Erklärung besteht darin, dass sozio-ökonomische Benachteiligung nicht nur mit materiellen Einschränkungen einhergeht, sondern auch zu geringeren Partizipationschancen und schwächerer sozialer Integration führt: Sozial benachteiligte Menschen erweitern ihre sozialen Netzwerke in der Regel nicht, sondern ziehen sich auf verwandtschaftliche und enge Freundeskreise zurück, die jedoch häufig genauso ressourcenschwach sind wie die Betroffenen selbst (vgl. Hartung 2013, S. 73 ff). Wu et al. (2010) postulieren zudem, dass die sozioökonomische Lage der Familie auch über die Wohnstandortwahl entscheidet und damit gleichzeitig über die Ressourcen, die über nachbarschaftliche Beziehungen mobilisiert werden können. Nach Coleman (1990) ist darüber hinaus zu erwarten, dass wohlhabende Eltern besonders viel Ressourcen in die Qualität der Eltern-Kind-Beziehung investieren, da die Transmission der elterlichen Bildung und des finanziellen Wohlstands auf die Kinder intensive Eltern-Kind-Interaktionen voraussetzt. Die Befundlage stimmt ferner mit der Angleichungsthese von West (1997) überein. Hiernach werden in der frühen Kindheit Unterschiede in der Gesundheit relativ stark von der sozioökonomischen Position der Familie beeinflusst, die sich - nach den hier diskutierten Befunden - auch in einer spezifischen Ausstattung mit Sozialkapital niederschlägt. Im frühen Jugendalter verschwinden gesundheitsspezifische Unterschiede zwischen den verschiedenen sozialen Schichten dagegen weitgehend, da von Schule, Peergroup und Jugendkultur nivellierende Einflüsse ausgehen.

Zur zweiten Frage ist auf die Studie von Klocke (2004) einzugehen, die jedoch mit einem Altersbereich von 11-15 Jahren eher auf Jugendliche fokussiert. Hier wird ein Interaktionseffekt zwischen materiellen Ressourcen und Sozialkapital bei der Vorhersage der Gesundheit getestet. Die Befunde verdeutlichen, dass sich das gesundheitsrelevante Verhalten (hier: Rauchen) in allen sozialen

\footnotetext{
${ }^{3} \mathrm{Nach}$ Wu et al. (2010) ist dabei jedoch entscheidend, wie der sozioökonomische Status der Eltern operationalisiert wird. So erbringt die Studie den überraschenden Befund, dass die finanziellen Ressourcen der Eltern zu einer größeren Depressivität des Kindes führen. Erklärt wird dies dadurch, dass die Finanzressourcen ein indirekter Indikator für den Arbeitsumfang der Eltern sind, der die Zeit für gemeinsame Eltern-Kind-Interaktionen reduziert.
} 
Ungleichheitslagen mit steigender familialer Kohäsion und Unterstützung des Kindes durch die Eltern verbessert. Auch wenn geringe materielle Ressourcen oft mit niedrigem Sozialkapital einhergehen, so können hiernach Kinder und Jugendliche in allen Soziallagen von einer guten Sozialkapital-Ausstattung profitieren.

Auch wenn sich somit für dieses Beispiel aus Deutschland kein Interaktionseffekt zwischen sozioökonomischen Status und Sozialkapital bei der Vorhersage der Gesundheit zeigt (und Forschungsfrage 2 hier somit verneint werden muss), so ergeben die Studien zu nicht-westlichen Industrienationen (Adams et al. 2002; Kana'iaupuni et al. 2005) ein anderes Bild: Unter der Bedingung von stärkerer materieller Deprivation (Mexiko) bzw. extremer Armut (Mali) wird das Sozialkapital zu einem kompensierenden bzw. existenziellen Faktor für die Gesundheit bzw. das Überleben der Kinder. Auch innerhalb der beiden hier besprochenen Länder zeigt sich, dass die Kinder besonders armer Familien am meisten von sozialer Unterstützung profitieren, die den Eltern zur Verfügung steht.

\section{Abschließende Diskussion des Forschungsstands}

Zunächst ist allgemein festzustellen, dass die Netzwerkperspektive sowie der Ansatz des familialen Sozialkapitals bei der Erklärung kindlicher Gesundheit ein großes Potenzial haben. In fast allen Fällen zeigen sich die erwarteten positiven Korrelationen mit den Gesundheitsindikatoren.

Dennoch sind einige Aspekte kritisch zu diskutieren. Insbesondere die soziologischen Sozialkapitalstudien gehen explizit oder implizit davon aus, dass die Eltern die wesentlichen Netzwerkpersonen sind, durch die das Kind Zugriff auf wichtige Ressourcen wie Aufmerksamkeit oder Unterstützung erhält. Darüber hinaus werden gelegentlich noch Geschwister berücksichtigt. Weitere mögliche Mitglieder des Familiennetzwerks, wie z. B. Großeltern, Onkel oder Tanten und Paten, finden dagegen - im Gegensatz zum ausgereifteren Konvoy-Modell der Autorengruppe um Mary J. Levitt - keine Beachtung. ${ }^{4}$ Insgesamt sind Studien,

\footnotetext{
${ }^{4}$ Ein weiterer Vorschlag, um breitere Familienkonfigurationen zu erfassen, stammt von Widmer (2006). Bei der hier entwickelten „family network method“ handelt es sich im Wesentlichen um Namensgeneratoren, bei denen Ego gebeten wird, signifikante Familienmitglieder zu nennen, die zurzeit oder im letzten Jahr eine wichtige Rolle in seinem Leben gespielt haben. Dabei kann es sich sowohl um geliebte und respektierte Personen als auch um Personen handeln, mit denen Konflikte bestehen. Eine Befragung auf Basis einer Studentenpopulation, die auf dieser Methode aufbaut, führt zu verschiedenen Typen von familialen sozialen Netzwerken, die neben Blutsverwandten auch Stiefeltern und Freunde umfassen, die subjektiv als signifikante Familienmitglieder betrachtet werden (z. B. Taufpaten).
} 
die „echte“ Netzwerkanalysen (z. B. egozentrierte Studien) durchführen, im vorliegenden Kontext selten.

Bei einer Kausalinterpretation der referierten Befunde ist in einigen Fällen auf Alternativerklärungen hinzuweisen. So wird z. B. von Martin (2008) ausgeführt, dass der Zusammenhang zwischen dem Gewicht der Eltern und ihrer Kinder zu einem großen Anteil auf genetische Faktoren zurückzuführen ist - zum einen dadurch, dass sich die physiologischen Voraussetzungen für das Körpergewicht vererben und zum anderen auch dadurch, dass Prädispositionen für bestimmte Lebensstilmerkmale (z. B. physische Aktivität) zum Teil genetisch bedingt sind. Wird diese genetische Störgröße im Rahmen einer Zwillingsstudie ${ }^{5}$ statistisch kontrolliert, zeigt sich, dass sozial verursachte Lebensstilfaktoren sowohl an Erklärungskraft verlieren (Mediation) als auch an Bedeutung gewinnen können, d. h. durch genetische Faktoren bivariat verdeckt werden (Suppression). In den hier besprochenen Studien wird in der Regel nicht für genetische Faktoren kontrolliert, wodurch sich zum Teil Interpretationsprobleme ergeben.

Schultz et al. (2009) gehen ferner der Frage nach, ob die kindliche Gesundheit einen Effekt auf das Sozialkapital der Eltern hat. Ließen sich Hinweise auf eine derartige umgekehrte Kausalität finden, würde dies die referierten Befunde in ihrer bisherigen Lesart zum Teil in Zweifel stellen. Empirisch zeigt sich allerdings in einer Studie von Eltern, die ab Geburt in einem Dreijahreszeitraum beobachtet werden, dass mehr oder weniger ernsthafte gesundheitliche Probleme des Babys (z. B. geringes Geburtsgewicht, Behinderungen) im Sinne eines exogenen Schocks, der durch die elterlichen Verhaltensweisen nicht selbst herbeigeführt wurde, keinen Effekt auf verschiedene Sozialkapitalindikatoren (z. B. Häufigkeit des Besuchs bei Verwandten, Kirchgangshäufigkeit und Aktivität in Organisationen) haben.

Im Hinblick auf die theoretischen Mechanismen ist festzustellen, dass ein expliziter Test bisher am ehesten für den Mechanismus der sozialen Unterstützung erfolgt ist. Während das Unterstützungspotenzial aus dem Netzwerk in einer Reihe von Studien durch spezifische Indikatoren facettenreich erhoben wird, fehlen ausgereifte Messinstrumente und Forschungsdesigns für die Mechanismen der sozialen Kontrolle oder der sozialen Ansteckung weitgehend. Hier besteht weiterhin großer Forschungsbedarf.

Ein weiterer interessanter Aspekt betrifft schließlich das Wechselverhältnis zwischen informeller sozialer Unterstützung in sozialen Netzwerken und

\footnotetext{
${ }^{5}$ Mehrgruppenvergleiche in Strukturgleichungsmodellen mit monozygotischen und dizygotischen Zwillingen.
} 
professioneller Hilfe bei gesundheitlichen Problemen. So zeigen Martinez und Lau (2011) in einer US-amerikanischen Studie, dass Eltern, deren Kinder mentale Gesundheitsprobleme aufweisen, bei hoher wahrgenommener Unterstützung aus dem sozialen Netzwerk weniger dazu tendieren, professionelle Hilfsangebote in Anspruch zu nehmen. Dies ist teilweise darauf zurückzuführen, dass sich der Gesundheitszustand der Kinder bei hohem Unterstützungspotenzial tatsächlich über die Zeit verbessert.

\section{Leseempfehlungen}

Alvarez, E. C., Kawachi, I., \& Romani, J. R. (2017). Family social capital and health: A systematic review and redirection. Sociology of Health \& Illness, 39(1), S. 5-29. Altersübergreifender Überblick zur Forschung im Bereich des familialen Sozialkapitals

Morrow, V. (1999). Conceptualising social capital in relation to the wellbeing of children and young people: A critical review. Sociological Review, 47 (4), S. 744-765. Kritische Diskussion des Sozialkapital-Ansatzes

\section{Datensätze}

- Studie zur Gesundheit von Jugendlichen in Deutschland (KiGGS) Im Rahmen der vom Robert Koch-Institut durchgeführten KiGGS-Studie wurden 2003-2006 erstmals umfassende und bundesweit repräsentative Gesundheitsdaten für Kinder und Jugendliche erhoben. Seit 2009 wird KiGGS als Langzeitstudie fortgeführt. Mithilfe der Daten können sowohl die aktuelle gesundheitilche Lage von Kindern und Jugendlichen unter 18 Jahren als auch - aufgrund der Panelstruktur der Daten - zeitliche Entwicklungstrends und Veränderungen im Lebensverlauf analysiert werden. Familiales Sozialkapital lässt sich über verschiedene Globalindikatoren abbilden die z. B. familiale Kohäsion oder elterliche soziale Kontrolle messen.

Zugang über www.kiggs-studie.de

- Health Behaviour in School-Aged Children - WHO Collaborative Cross-National Survey (HBSC)

Die alle vier Jahre stattfindende Befragung HSBC wurde 1982 initiiert und wird derzeit in 48 Ländern (Europa und Nordamerika) durchgeführt. Das Ziel der Studie ist die Sammlung landesweit repräsentativer 
Daten über die Gesundheit, das familiäre und soziale Umfeld sowie das gesunheitsrelevante Verhalten von Jungen und Mädchen des 5. bis 9. Schuljahres, die in der Regel zwischen 11 und 15 Jahre alt sind. Familiales Sozialkapital wird über einige Globalindikatoren wie z. B. emotionale oder instrumentelle Unterstützung durch die Eltern operationalisiert.

Zugang über www.hbsc.org (international) bzw. hbsc-germany.de (Deutschland)

\section{Literatur}

Adams, A. M., Madhavan, S., \& Simon, D. (2002). Women's social networks an child survival in Mali. Social Science and Medicine, 54, 165-178.

Alvarez, E. C., Kawachi, I., \& Romani, J. R. (2017). Family social capital and health: A systematic review and redirection. Sociology of Health \& Illness, 39, 5-29.

Bala-Brusilow, C. (2010). A Study of the Associations between Childhood Obesity and three Forms of Social Capital. Wayne State University.

Bandura, A. (1977). Social Learning Theory. Englewood Cliffs: Prentice Hall.

Berntsson, L., Köhler, L., \& Vuille, J.-C. (2007). Health, economy and social capital in nordic children and their families: A comparison between 1984 and 1996. Child: Care. Health \& Development, 32, 441-451.

Boosman, K., van der Meulen, M., van Geert, P., \& Jackson, S. (2002). Measuring young children's perceptions of support, control, and maintenance in their own social networks. Social Development, 11(3), 386-408.

Bost, K. K., Vaughn, B. E., Boston, A. L., Kazura, K. L., \& O’Neal, C. (2004). Social support networks of African-American children attending head start: A longitudinal investigation of structural and supportive network characteristics. Social Development, 13(3), 393-412.

Bowlby, J. (1975). Bindung. Frankfurt: Fischer.

Bronfenbrenner, U. (1981). Die Ökologie der menschlichen Entwicklung. Natürliche und geplante Experimente. Stuttgart: Klett-Cotta.

Cochran, M. M., \& Brassard, J. A. (1979). Child development and personal social networks. Child Development, 50(3), 601-616.

Coleman, J. S. (1990). Foundations of the Social Theory. Cambridge: Harvard University Press.

Dilworth-Anderson, P., Burton, L. M., \& Klein, D. M. (2005). Contemporary and emerging theories in studying families. In V. L. Bengtson, A. C. Acock, K. R. Allen, P. DilworthAnderson, \& D. M. Klein (Hrsg.), Sourcebook of Family Theory and Research (S. 35-58). Thousand Oaks: Sage. 
Ellsäßer, G., \& Lüdecke, K. (2015). Einschuluntersuchung 2015. Zossen: Landesamt für Arbeitsschutz, Verbraucherschutz und Gesundheit des Landes Brandenburg.

Erhart, M., \& Ravens-Sieberer, U. (2008). Die Rolle struktureller Aspekte von Familie, innerfamiliärer Kommunikation und Unterstützung für die Gesundheit im Kindes- und Jugendalter. In M. Richter, K. Hurrelmann, A. Klocke, W. Melzer, \& U. Ravens-Sieberer (Hrsg.), Gesundheit, Ungleichheit und jugendliche Lebenswelten. Ergebnisse der zweiten internationalen Vergleichsstudie im Auftrag der Weltgesundheitsorganisation WHO (S. 190-230). Weinheim: Juventa.

Eriksson, U., Hochwälder, J., Carlsund, A., \& Sellström, E. (2012). Health outcomes among Swedish children: The role of social capital in the family, school and neighbourhood. Acta Paediatrica, 101, 513-517.

Geyer, S., \& Peter, R. (1998). Unfallbedingte Krankenhausaufnahme von Kindern und Jugendlichen in Abhängigkeit von ihrem sozialen Status - Befunde mit Daten einer nordrhein-westfälischen AOK. Gesundheitswesen, 60, 493-499.

Hartung, S. (2013). Sozialkapital und gesundheitliche Ungleichheit. Analyse des elterlichen Sozialkapitals in der schulischen Gesundheitsförderung. Wiesbaden: Springer VS.

Hradil, S. (1987). Sozialstrukturanalyse in einer fortgeschrittenen Gesellschaft. Opladen: Leske+Budrich.

Kahn, R. L., \& Antonucci, T. C. (1980). Convoys over the life course: Attachment, roles, and social support. In P. B. Baltes \& O. G. Brim (Hrsg.), Life-Span Development and Behaivor (S. 253-586). New York: Academic.

Kana'iaupuni, M. S., Donato, K. M., Thompson-Colón, T., \& Steinback, M. (2005). Counting on kin: Social networks, social support, and child health status. Social Forces, 83, 1137-1164.

Kennedy-Hendricks, A., Schwartz, H., Johnson Thornton, R., Griffin, B. A., Green, H. D., Jr., Kennedy, D. P., Burkhauser, S., \& Pollack, C. E. (2015). Intergenerational social networks and health behaviors among children living in public housing. American Journal of Public Health, 105, 2291-2297.

Klocke, A. (2004). Soziales Kapital als Ressource für Gesundheit im Jugendalter. In M. Jungbauer-Gans \& P. Kriwy (Hrsg.), Soziale Benachteiligung und Gesundheit bei Kindern und Jugendlichen (S. 85-96). Wiesbaden: Springer VS.

Klocke, A., \& Lipsmeier, G. (2008). Soziale Determinanten der Gesundheit im Kindesund Jugendalter: eine Mehrebenenanalyse. In M. Richter, K. Hurrelmann, A. Klocke, W. Melzer, \& U. Ravens-Sieberer (Hrsg.), Gesundheit, Ungleichheit und jugendliche Lebenswelten (S. 231-254). München: Juventa.

Lampert, T., \& Richter, M. (2009). Gesundheitliche Ungleichheit bei Kindern und Jugendlichen. In M. Richter \& K. Hurrelmann (Hrsg.), Gesundheitliche Ungleichheit. Grundlagen, Probleme, Perspektiven (S. 207-228). Wiesbaden: Springer VS.

Lampert, T., \& Schenk, L. (2004). Gesundheitliche Konsequenzen des Aufwachsens in Armut und sozialer Benachteiligung. In M. Jungbauer-Gans \& P. Kriwy (Hrsg.), Soziale Benachteiligung und Gesundheit bei Kindern und Jugendlichen (S. 57-83). Wiesbaden: Springer VS.

Lau, M., \& Li, W. (2011). The extent of family and school social capital promoting positive subjective well-being among primary school children in Shenzhen, China. Children and Youth Services Review, 33, 1573-1582. 
Levitt, M. J., Guacci-Franco, N., \& Levitt, J. L. (1993). Convoys of social support in childhood and early adolescence: Structure and function. Developmental Psychology, 29(5), 811-818.

Levitt, M. J., Levitt, J. L., Bustos, G. L., Crooks, N. A., Santos, J. D., Telan, P., Hodgetts, J., \& Milevsky, A. (2005). Patterns of social support in the middle childhood to early adolescent transition: Implications for adjustment. Social Development, 14(3), 398-420.

Martin, M. A. (2008). The intergenerational correlation in weight: How genetic resemblance reveals the social role of families. American Journal of Sociology, 114(Supplement), 67-105.

Martinez, J. I., \& Lau, A. S. (2011). Do social networks push families toward or away from youth mental health services?: A national study of families in child welfare. Journal of Emotional and Behavioral Disorders, 19, 169-181.

Mielck, A. (1998). Armut und Gesundheit bei Kindern und Jugendlichen: Ergebnisse der sozial-epidemiologischen Forschung in Deutschland. In A. Klocke \& K. Hurrelmann (Hrsg.), Kinder und Jugendliche in Armut: Umfang, Auswirkungen und Konsequenzen (S. 225-249). Wiesbaden: Westdeutscher Verlag.

Morgan, A., \& Haglund, B. J. A. (2009). Social capital does matter for adolescent health: Evidence from the English HBSC Study. Health Promotion International, 24, 363-372.

Morrow, V. (1999). Conceptualising social capital in relation to the well-being of children and young people: A critical review. Sociological Review, 47, 744-765.

Nestmann, F., \& Wehner, K. (2008). Soziale Netzwerke von Kindern und Jugendlichen. In F. Nestmann, J. Günther, S. Stiehler, K. Wehner, \& J. Werner (Hrsg.), Kindernetzwerke. Soziale Beziehungen und soziale Unterstützung in Familie, Pflegefamilie und Heim (S. 11-40). Tübingen: dgvt-Verlag.

Rattay, P., Lampert, T., Neuhauser, H., \& Ellert, U. (2012). Bedeutung der familialen Lebenswelt für die Gesundheit von Kindern und Jugendlichen. Ergebnisse des Kinderund Jugendgesundheitssurveys (KiGGS). Zeitchrift für Erziehungswissenschaft, 15, 145-170.

Richter, M., Hurrelmann, K., Klocke, A., Melzer, W., \& Ravens-Sieberer, U. (Hrsg.). (2008). Gesundheit, Ungleichheit und jugendliche Lebenswelten: Ergebnisse der zweiten internationalen Vergleichsstudie der Weltgesundheitsorganisation WHO. Weinheim: Juventa.

Runyan, D. K., Hunter, W. M., Socolar, R. R. S., Amaya-Jackson, L., English, D., Landsverk, J., Dubowitz, H., Browne, D. H., Bangdiwala, S. I., \& Mathew, R. M. (1998). Children who prosper in unfavorable environments: The relationship to social capital. Pediatrics, 101, 12-18.

Schultz, J., Corman, H., \& Reichman, N. E. (2009). Effects of child health on parents“ social capital. Social Science and Medicine, 69, 76-84.

Tiber Egle, U., Hardt, J., \& Ralf, N. (2002). Früher Streß und Langzeitfolgen für die Gesundheit - wissenschaftlicher Erkenntnisstand und Forschungsdesiderate. Zeitschrift für Psychosomatische Medizin und Psychotherapie, 4, 411-434.

Vaux, A. (1988). Social Support: Theory, Research and Intervention. New York: Praeger.

West, P. (1997). Health inequalities in the early years: Is there equalisation in youth? Social Science and Medicine, 27, 291-296.

Widmer, E. D. (2006). Who are my family members? Bridging and binding social capital in family configurations. Journal of Social and Personal Relationships, 23, 979-998. 
Wippermann, C. (2009). Lebensstile und Milieus: Einflüsse auf die Gesundheit. In V. Schumpelick \& B. Vogel (Hrsg.), Volkskrankheiten: Gesundheitliche Herausforderungen in der Wohlstandsgesellschaft (S. 143-156). Freiburg i.Br.: Herder.

Wu, Q., Xie, B., Chou, C.-P., Palmer, P. H., Gallaher, P. E., \& Jonson, A. C. (2010). Understanding the effect of social capital on the depression of urban Chinese adolescents: An integrative framework. American Journal of Community Psychology, 45, $1-16$.

Open Access Dieses Kapitel wird unter der Creative Commons Namensnennung 4.0 International Lizenz (http://creativecommons.org/licenses/by/4.0/deed.de) veröffentlicht, welche die Nutzung, Vervielfältigung, Bearbeitung, Verbreitung und Wiedergabe in jeglichem Medium und Format erlaubt, sofern Sie den/die ursprünglichen Autor(en) und die Quelle ordnungsgemäß nennen, einen Link zur Creative Commons Lizenz beifügen und angeben, ob Änderungen vorgenommen wurden.

Die in diesem Kapitel enthaltenen Bilder und sonstiges Drittmaterial unterliegen ebenfalls der genannten Creative Commons Lizenz, sofern sich aus der Abbildungslegende nichts anderes ergibt. Sofern das betreffende Material nicht unter der genannten Creative Commons Lizenz steht und die betreffende Handlung nicht nach gesetzlichen Vorschriften erlaubt ist, ist für die oben aufgeführten Weiterverwendungen des Materials die Einwilligung des jeweiligen Rechteinhabers einzuholen.

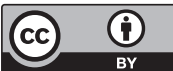




\title{
Soziale Netzwerke, Gesundheit und gesundheitliche Ungleichheiten im Jugendalter
}

\author{
Irene Moor, Laura Hoffmann, Martin Mlinarić \\ und Matthias Richter
}

\section{Überblick}

- Die soziale Netzwerkforschung ist im Jugendalter vergleichsweise weit fortgeschritten, aufgrund von schulbasierten Surveys die v. a. seit den 1960er Jahren durchgeführt wurden.

- Studien im Jugendalter fokussieren sich vornehmlich auf das Gesundheitsverhalten (insbesondere den Tabakkonsum aber auch Alkoholkonsum, Ernährung und körperliche Aktivität) als auch im geringeren Umfang auf die psychosoziale Gesundheit.

- Zur Erklärung der Homophilie von Peergroups im Jugendalter werden zwei verschiedene Mechanismen aufgeführt, die nur in längsschnittlichen Studien untersucht werden können:

- These des sozialen Einflusses: Die Freunde beeinflussen das (Gesundheits-)Verhalten und die Einstellungen der Jugendlichen und adaptieren diese.

I. Moor $(\varangle) \cdot$ L. Hoffmann $\cdot$ M. Mlinarić $\cdot$ M. Richter

Halle (Saale), Deutschland

E-Mail: irene.moor@medizin.uni-halle.de

L. Hoffmann

E-Mail: laura.hoffmann@medizin.uni-halle.de

M. Mlinarić

E-Mail: martin.mlinaric@medizin.uni-halle.de

M. Richter

E-Mail: m.richter@medizin.uni-halle.de 
- These des Selektionsmechanismus: Jugendliche suchen sich ihre Freunde danach aus, ob sie die gleichen Einstellungen und (Gesundheits-) Verhaltensweisen aufzeigen wie sie selbst.

- Beide Thesen konnten empirisch nachgewiesen werden.

- Lediglich vereinzelte Studien existierten, die eine Relevanz der Peergroup im Zusammenhang sozioökonomischer/bildungsspezifischer Ungleichheiten und Gesundheit identifizieren konnten.

- Forschungsbedarf besteht hinsichtlich der Rolle sozialer Netzwerke zur Erklärung gesundheitlicher Ungleichheiten (über den Tabakkonsum hinausgehend) in Deutschland als auch unter Nutzung von längsschnittlichen Forschungsdesigns.

\section{$1 \quad$ Einführung}

"People are connected, and so their health is connected"

(Christakis und Fowler 2008, S. 2257, The New England Journal of Medicine)

Der vorliegende Beitrag diskutiert die Bedeutung sozialer Netzwerke für die Gesundheit und das Gesundheitsverhalten mit Fokus auf gesundheitliche Ungleichheiten im Jugendalter. Das Jugendalter ist geprägt von vielfältigen Veränderungen, die sich in dieser Lebensphase ergeben. Adoleszenten sind mit Herausforderungen wie der eigenen Persönlichkeitsentfaltung, der Identitätsfindung und der Auseinandersetzung mit jugendtypischen Entwicklungsaufgaben konfrontiert. Eine zentrale Entwicklungsaufgabe ist die Ablösung vom Elternhaus und der gleichzeitige Aufbau von Beziehungen zu Gleichaltrigen (Havighurst 1974; Richter und Moor 2015), der zu großen Teilen im Schulkontext erfolgt. Für Heranwachsende ist die Freundesgruppe ein zentraler Kontext, da in diesen machtäquivalenten Beziehungen soziale Grundregeln wie Mutualität, Reziprozität oder Intimität erlernt werden können (Youniss und Jacqueline 1986). Freundschaften entstehen u. a. dann, wenn sich bestimmte Eigenschaften bzw. Verhaltensweisen in der Gruppe wiederfinden. Schon in den 1970er Jahren hat Kandel (1978) herausgefunden, dass beim Konsum von Marihuana eine sehr große Kongruenz im Freundeskreis besteht. Aus der Forschung ist folglich 
bekannt, dass ein Freundeskreis, der sich auflöst, weniger Gemeinsamkeiten beinhaltet als einer, der sich bildet. Diese Kongruenzorientierung wurde auch bei weiteren Merkmalen wie bei anderen illegalen Drogen oder der Wahl der politischen Partei festgestellt.

Die soziale Netzwerkforschung (SNA: social network analysis) ermöglicht es, beispielsweise den Zusammenhang zwischen kollektiven Normen und individuellem Verhalten innerhalb der Peergroup zu untersuchen. Fragen, die beantwortet werden können, sind etwa, ob sich Jugendliche eher jene Freunde suchen, die ein ähnliches Verhalten aufzeigen oder ob Jugendliche innerhalb bestimmter Netzwerke aufgrund des (schädlichen) Einflusses ihrer Freunde zu gesundheitsschädlichem Verhalten ,animiert“ werden (Hall und Valente 2007). Zudem kann analysiert werden, welche Rolle bzw. Position verschiedene Personen (Eltern, Freundeskreis, Geschwister) im Netzwerk einnehmen und inwieweit sich das auf die Gesundheit und das Gesundheitsverhalten der Jugendlichen auswirkt. Diese und weitere Fragen können in dem Ausmaß und der Detailliertheit vor allem mithilfe der SNA untersucht werden.

Von besonderem Forschungsinteresse ist die Bedeutung sozialer Netzwerke auch für die (Re-)Produktion gesundheitlicher Ungleichheiten. So zeigen zahlreiche nationale wie internationale Studien, dass Jugendliche mit einem geringem sozioökonomischen Status (SES) oder jene, die kein Gymnasium besuchen, sowohl eine schlechtere Gesundheit als auch ein ungünstigeres Gesundheitsverhalten angeben (Hölling et al. 2014; Inchley et al. 2016; Kuipers et al. 2016; Kuntz und Lampert 2013; Moor et al. 2012; Richter und Moor 2017). Der Zusammenhang zwischen sozialer Herkunft und Gesundheit bzw. Gesundheitsverhalten wurde in der Adoleszenz zwar oft untersucht, wenige Studien haben jedoch überprüft, inwieweit die sozialen Netzwerke der Jugendlichen diese Assoziation erklären.

Der folgende Übersichtsbeitrag befasst sich demnach mit SNA und der Gesundheit bzw. gesundheitlichen Ungleichheiten im Jugendalter. In einem ersten Schritt wird zunächst der Blick auf die bisherigen Forschungsarbeiten der SNA im Jugendalter gelegt (Abschn. 1.1). Im nächsten Schritt werden in Abschn. 2 theoretische Zusammenhänge der SNA (u. a. Homophilie, These des Einflusses und der Selektion) für die Gesundheit und das Gesundheitsverhalten vorgestellt. Im Anschluss wird der Zusammenhang zwischen gesundheitlicher Ungleichheit und Gesundheit erörtert (Abschn. 3) sowie die Bedeutung der SNA für die Gesundheit und dem Gesundheitsverhalten ausgeführt (Abschn.4), wobei der 
Fokus auf dem Tabakkonsum im Jugendalter liegt (Abschn. 4.3). Der Rolle des sozialen Netzwerks im Zusammenhang mit gesundheitlichen Ungleichheiten widmet sich Abschn. 5. Die Zusammenfassung erfolgt in Abschn. 6, welches Forschungslücken herausarbeiten und die Ergebnisse kritisch diskutieren wird.

\subsection{Soziale Netzwerkforschung im Jugendalter}

Die SNA ist ein international etabliertes Forschungsfeld (vgl. Scott 2011; Scott und Carrington 2011; Stegbauer und Häußling 2010). Dabei findet die SNA multidisziplinäre Anwendung, vor allem in der Soziologie, aber auch in der Psychologie, Ökonomie und Anthropologie (Valente et al. 2004). Die unterschiedlichen Disziplinen und Gegenstandsbereiche sind sich in einem Punkt einig: Netzwerke haben nachhaltige Auswirkungen auf Zugang und Inanspruchnahme von Lebenschancen in unserer Gesellschaft. Dies lässt sich anhand einer längsschnittlichen Studie illustrieren, die Selektionsmechanismen beobachten konnte. So zeigt sich, dass jene, die im Jugendalter über gute schulischen Leistungen verfügen, sich auch tendenziell eher leistungsstarke Freunde suchen (Flashman 2012).

Erste Erhebungen und Analysen von Netzwerken zwischen Jugendlichen wurden im Schulkontext bereits im 19. Jahrhundert durchgeführt (Heidler et al. 2014). Spätestens mit den 1960er Jahren (Coleman 1961) begann dann eine systematische Untersuchung im Kontext von Schulumfragen, die sich vor allem in den USA als führender Untersuchungsgegenstand der SNA etabliert haben (vgl. (Freeman 2004; Marsden 2011)). Auf internationaler Ebene wurden für das Jugendalter vielfältige Themen im Zusammenhang mit der sozialen Netzwerkforschung bearbeitet, jedoch steckt die deutschsprachige Debatte - insbesondere in Hinblick auf die Gesundheit und gesundheitliche Ungleichheiten - hierzu noch weitestgehend in den Kinderschuhen.

Gegenstandsbereiche der SNA im Jugend- und jüngeren Erwachsenenalter beziehen sich im Kern auf das individuelle Risikoverhalten und strukturell ungleich verteilte Risikoexpositionen, denn sozial benachteiligte Jugendliche sind im Vergleich zu Adoleszenten aus sozial privilegierten Familien einer größeren Anzahl von Risiken ausgesetzt (Alvin und Deschamps 1998; Friedman und Aral 2001). Querschnittliche Forschungsarbeiten zu Selbstmordversuchen unter Jugendlichen bieten deutliche Hinweise, dass die Wahrscheinlichkeit für das Planen von Suizid mit Eigenschaften der Peergroup wie etwa einem erhöhten Anteil an depressiven Freunden assoziiert ist (Fulginiti et al. 2016). Der häufige Kontakt im Netzwerk mit risikobehafteten oder depressiven Freunden zeigt sich für den US-amerikanischen Kontext besonders erschreckend im Feld jugendlicher 
Obdachlosigkeit, die innerhalb des Netzwerkes zudem mit fehlender Safer Sex-Praktik (Craddock et al. 2016; Kennedy et al. 2012) oder gestiegenem Substanz- und Drogenkonsum wie etwa von Crystal Meth (Barman-Adhikari et al. 2016; Martino et al. 2011) assoziiert ist, wie soziale Netzwerkstudien zeigen konnten.

Es lässt sich festhalten, dass die SNA für eine große Bandbreite an gesundheitlich relevanten Forschungsthemen genutzt wird. Themen aus der Public Health-Forschung umfassen etwa sexuell übertragbare Risiken (HIV) (Neaigus et al. 1995), körperliche Aktivität (Macdonald-Wallis et al. 2012; Simpkins et al. 2013), den Body-Mass-Index (Fletcher et al. 2011; Renna et al. 2008) oder auch der Konsum von Tabak, Alkohol und illegalen Drogen (Kandel 1978; Valente et al. 2004). Auf diese wird in den folgenden Abschnitten des vorliegenden Beitrags noch vertieft eingegangen.

\section{Theoretische Zusammenhänge}

Im Folgenden sollen der theoretische Hintergrund der Wirkmechanismen sozialer Netzwerke im Jugendalter und ihre Bedeutung für das Gesundheitsverhalten skizziert werden. Das Gesundheitsverhalten ist eingebettet in vielfältige soziale Kontexte. Folglich wird in der SNA davon ausgegangen, dass individuelle Verhaltensweisen von dem sozialen Netzwerk geprägt sind, in welchem sich die jeweilige Person befindet. In der SNA wird die Homophilie als ein zentraler Wirkmechanismus präsentiert (siehe auch Kap. „Netzwerkanalyse“). Homophilie meint, dass Menschen sich vorzugsweise mit jenen Menschen umgegeben, die sich in bestimmten Merkmalen ähneln. Das kann sowohl in Bezug auf demografische Merkmale der Fall sein oder sich auch auf bestimmte Verhaltensweisen beziehen (Daw et al. 2015). Hierzu werden die Annahmen des sozialen Einflusses und der Selektion beschrieben, die in der Konsequenz dazu führen, dass soziale Netzwerke homophile Gruppenmitglieder umfassen. Die Theorien werden anhand des Tabakkonsums beispielhaft erläutert.

\subsection{Sozialer Einfluss}

Über den Mechanismus des Einflusses der Freundesgruppe besteht in der Forschung Einigkeit darin, dass Jugendliche mit einer erhöhten Wahrscheinlichkeit anfangen zu rauchen, wenn im Freundeskreis auch geraucht wird. Ohne die SNA konnte bislang nur auf Angaben der Heranwachsenden, beispielsweise wie 
hoch die Rauchprävalenz in ihrem Freundeskreis ist, zurückgegriffen werden. Informationen bzw. Charakteristika von Freunden und deren Rauchverhalten blieben dabei unberücksichtigt (Hall und Valente 2007) - dies ist bei der SNA möglich. Denn problematisch ist, dass Jugendliche dazu tendieren, die Prävalenzen des Tabakkonsums im Freundeskreis zu überschätzen. Nachgewiesen wurde dies insbesondere für Mädchen und für ehemalige Raucherinnen und Raucher, die rauchende Freunde haben, als auch für Schülerinnen und Schüler ${ }^{1}$ mit niedrigerer Schulleistung (Kuipers et al. 2016). Bei der Anwendung der SNA muss daher nicht auf diese (oft) verzerrten Angaben zurückgegriffen werden, da das soziale Netzwerk erhoben wird und damit oftmals Angaben zu allen Netzwerkmitgliedern zur Verfügung stehen. Bei dem Einfluss der Peergroup wird zwischen „endogenem Effekt", „exogenem oder kontextuellem Effekt" und „korrelierendem Effekt" unterschieden (Ali und Dwyer 2009).

Endogener Effekt: Es wird angenommen, dass individuelles Verhalten das Verhalten der Peergroup widerspiegelt. Eine Person wird eher rauchen, wenn in ihrer Peergroup viele Raucher sind. Ändert sich das Verhalten einer Person in der Gruppe, kann dies als Multiplikatoren-Effekt fungieren, der dann auch das Verhalten der gesamten Peergroup verändern kann, deren Mitglieder sich wiederum auch in anderen Netzwerken befinden und damit die Änderung weitertragen können (Ali und Dwyer 2009).

Exogener oder kontextueller Effekt: Bei diesem Effekt wird davon ausgegangen, dass individuelles Verhalten von Merkmalen außerhalb der Peergroup abhängt. Wenn beispielsweise in einer kollektiven Gruppe viele Erwachsene rauchen, kann sich diese Exposition auch auf Jugendliche auswirken. So hat das Rauchen der Eltern mit erhöhter Wahrscheinlichkeit einen Einfluss auf das Rauchverhalten ihrer Kinder (Ali und Dwyer 2009).

Korrelierender Effekt: Dieser Effekt tritt auf, wenn sich Personen in einer Gruppe aufgrund ähnlicher - nicht im Fokus stehender bzw. unbeobachteter Merkmale ähnlich verhalten. Demnach werden Heranwachsende mit ähnlichem SES sich eher zu einer Gruppe zusammenfinden, die sich durch eine ähnliche Soziallage auszeichnet. Aus der Forschung ist zudem bekannt, dass sozial deprivierte Jugendliche häufiger rauchen als sozial besser gestellte Gleichaltrige. Selbst wenn aus dieser Gruppe jemand zum Beispiel mit dem Rauchen aufhören würde, würde das einen geringeren Effekt haben, da diese unbeobachteten Merkmale

\footnotetext{
${ }^{1}$ Zur sprachlichen Vereinfachung wird im Folgenden die maskuline Form verwendet, was jedoch nicht auf die Geschlechtsidentität der bezeichneten Personen schließen lässt.
} 
nach wie vor bestehen und diese zu einem höheren Risiko eines gesundheitsschädigendem Verhalten führen (Alexander et al. 2001; Ali und Dwyer 2009).

\subsection{Selektion}

Im Gegensatz zur These des sozialen Einflusses gibt es zur Selektion nicht so viele verschiedene Annahmen, die näherer Erläuterung bedürfen. Gemäß der Selektionsannahme entscheiden Heranwachsende selbst und treffen eine präferenzorientierte Auswahl, mit wem sie sich befreunden möchten. Dabei suchen sie sich mit höherer Wahrscheinlichkeit jene Freunde aus, die ähnliche Eigenschaften oder Vorstellungen haben oder analoge Verhaltensweisen zeigen. Die Selektionsthese beschreibt daher auch den Ausschluss von Freundschaften, d. h. welche Personen vom Freundeskreis exkludiert werden. Wenn Freunde bspw. das eigene Rauchverhalten nicht gutheißen, werden sich die Jugendlichen jenen zuwenden, die diese Verhaltensweisen teilen und das Rauchen normativ nicht abwerten. Oftmals sind es jedoch mehrere Eigenschaften und Verhaltensweisen, die diese Netzwerke entstehen bzw. bestehen lassen (Simons-Morton und Farhat 2010).

Für viele Verhaltensweisen, wurden beide Wirkrichtungen des Einflusses und der Selektion untersucht. Beide Mechanismen scheinen beispielsweise für das Rauchverhalten der Jugendlichen zentral zu sein und teilweise auch gleichzeitig zu wirken (Hall und Valente 2007; Schaefer et al. 2012). Insgesamt wird der Selektionsthese jedoch mehr Gewichtung beim Tabakkonsum zugesprochen (Mercken et al. 2009; Mercken et al. 2010; Mercken et al. 2012; Seo und Huang 2012). Es ist jedoch methodisch herausfordernd, in den Analysen zwischen diesen beiden Effekten zu unterscheiden. Nur in Längsschnittstudien können diese Mechanismen separat untersucht werden.

\section{Jugend, soziale Ungleichheit und Gesundheit}

Im Jugendalter sind es vor allem das Gesundheitsverhalten und die subjektive Einschätzung der Gesundheit, die Aufschluss über das Wohlbefinden und die gesundheitliche Lebensqualität der jungen Generation geben. Obwohl sich die Gesundheit und das gesundheitliche Verhalten insgesamt eher positiv über die Zeit entwickelt haben, was sich u. a. in einer höheren Einschätzung einer sehr guten Gesundheit (Cavallo et al. 2015), einem höherem Obst- und Gemüsekonsum (Vereecken et al. 2015), mehr physischer Aktivität (Kalman et al. 2015) und 
sinkenden Tabakprävalenzen (Kuntz et al. 2018; Moor et al. 2016) äußert, zeigt sich jedoch, dass nicht alle Jugendlichen im gleichen Maße von dieser Entwicklung profitieren. Nach wie vor ist der SES eine der wichtigsten Determinanten jugendlicher Gesundheit (Inchley 2017; Viner et al. 2012). Jugendliche mit einem geringen Sozialstatus zeigen häufiger eine ungesunde Ernährungsweise (Borrmann und Mensink 2015; Kuntz und Lampert 2011), sind seltener körperlich aktiv (Kuntz und Lampert 2011; Lämmle et al. 2012) und auch häufiger übergewichtig oder adipös im Vergleich zu Heranwachsenden mit einem höheren Sozialstatus (Krause und Lampert 2014). Sozial benachteiligte Kinder und Jugendliche geben weiter eine schlechtere Gesundheit an, zeigen häufiger ein erhöhtes Risiko für psychische Auffälligkeiten und psychosomatische Beschwerden sowie eine geringere Lebenszufriedenheit verglichen mit jenen, die eine höhere Schulbildung haben oder in einer sozial privilegierteren Familie leben (Elgar et al. 2015; Hölling et al. 2014; Moor et al. 2012; Moor et al. 2015).

Im Hinblick auf das Risikoverhalten sind die Ergebnisse nicht konsistent, zeigen jedoch überwiegend, dass sozial benachteiligte bzw. bildungsfernere Jugendliche häufiger rauchen (Kuntz et al. 2018; Moor et al. 2014; Moor et al. 2016; Orth 2016) und alkoholbedingte Rauscherfahrungen machen als sozial besser gestellte Heranwachsende bzw. jene mit einer höheren Schulbildung (Inchley 2017; Moor et al. 2016).

\section{$4 \quad$ Bedeutung der sozialen Netzwerke für die Gesundheit und das Gesundheitsverhalten}

Ungesunde und schädliche Verhaltensweisen, die starken Einfluss und Konsequenzen für die Gesundheit im Erwachsenenalter haben können, entwickeln sich während der Adoleszenz (Daw et al. 2015; Valente 2012). Dabei spielt das soziale Netzwerk eine entscheidende Rolle im Kontext der Gesundheit und des Gesundheitsverhaltens bei Jugendlichen. Verschiedene Studien zeigen zum Beispiel, dass soziale Netzwerke Einfluss auf die mentale Gesundheit (z. B. Baggio et al. 2017), den Alkoholkonsum (z. B. Deutsch et al. 2014), das Rauchverhalten (z. B. Lorant et al. 2017), die Ernährung, das Körpergewicht und die körperliche Aktivität (z. B. Barclay et al. 2013; Simpkins et al. 2013) sowie den Drogenkonsum (z. B. Pearson et al. 2006) von Jugendlichen haben. Daher soll sich das folgende Kapitel mit der Bedeutung sozialer Netzwerke für die Gesundheit und das Gesundheitsverhalten von Jugendlichen befassen und einen Überblick liefern. 


\subsection{Mentale Gesundheit}

Verschiedene Studien haben den Einfluss sozialer Netzwerke auf die mentale Gesundheit von Jugendlichen untersucht. Baggio et al. (2017) haben zum Beispiel erforscht, wie die mentale Gesundheit von Jugendlichen im Alter von 12 bis 14 Jahren und die Struktur des Netzwerkes zusammenhängen, und herausgefunden, dass Heranwachsende mit besserer mentaler Gesundheit eher mit denen befreundet sind, die über eine ähnlich gute mentale Gesundheit verfügen wie sie selbst. Jungen waren dabei eher mit Jungen befreundet und Mädchen eher mit Mädchen. Diese Ergebnisse decken sich auch mit Befunden anderer Studien (Schaefer et al. 2011). Pachucki et al. (2015) konnten mithilfe einer Längsschnittstudie aufzeigen, dass sich Jugendliche in der frühen Adoleszenz über einen untersuchten Zeitraum von drei Monaten bzgl. ihrer mentalen Gesundheit nicht ähnlicher wurden. Da es sich bei einem Zeitraum von nur drei Monaten jedoch um eine verhältnismäßig kurze Zeitspanne handelt, sollten diese Ergebnisse mit Vorsicht interpretiert werden. Baggio et al. (2017) konnten zudem zeigen, dass Jugendliche mit schlechterer mentaler Gesundheit ein höheres Risiko haben, weniger Freunde zu haben und im Netzwerk eher isoliert zu sein als Jugendliche mit besserer mentaler Gesundheit. Eine weitere Studie fand heraus, je mehr Freunde ein Jugendlicher im Netzwerk hat, desto geringer ist sein Risiko an einer Depression zu erkranken. Das bedeutet im Umkehrschluss für diejenigen Jugendlichen, die eher isoliert sind und wenig Verbindungen im Netzwerk haben, dass sie ein erhöhtes Risiko aufweisen von Depressionen betroffen zu sein (Okamoto et al. 2011).

\subsection{Gesundheitsverhalten}

\subsubsection{Körperliche Aktivität und Ernährung}

Körperliche Aktivität und Ernährung sind soziale Verhaltensweisen, die oftmals mit anderen geteilt und von ihnen beeinflusst werden. Mangelnde körperliche Aktivität und eine ungesunde Ernährungsweise kann dabei gesundheitliche Folgewirkungen wie Übergewicht hervorrufen (Cunningham et al. 2012; Shoham et al. 2012; Trogdon et al. 2008). So zeigt sich zum Beispiel, dass sich Jugendliche, die miteinander befreundet sind, in ihrem Body-Mass-Index (BMI) ähnlich sind hier zeigt sich die Homophilie der Freundschaften (Fletcher et al. 2011; Renna et al. 2008). In der Untersuchung von Renna et al. (2008) mit Daten der „National Longitudinal Study of Adolescent Health“ von über 20.000 Jugendlichen war 
der Einfluss der Freunde auf den BMI allerdings nur für Mädchen signifikant. Ein systematisches Review konnte hinsichtlich Selektions- und Isolationseffekten aufzeigen, dass sich befreundete Schulfreunde bezüglich ihres Körpergewichts und BMI ähneln (Fletcher et al. 2011). Außerdem weisen die Ergebnisse darauf hin, dass übergewichtige Jugendliche unbeliebter sind und weniger Freunde haben als Normalgewichtige in ihrer Altersklasse (Fletcher et al. 2011). Mädchen und insbesondere übergewichtige Jugendliche werden in Bezug auf ihr Körpergewicht stärker durch ihre Freunde beeinflusst (Trogdon et al. 2008). Der Einfluss der Freunde zeigt sich z. B. darin, dass das Risiko, in einem bestimmten Zeitraum übergewichtig zu werden, um $57 \%$ ansteigt, wenn einer der Freunde im selben Zeitraum auch übergewichtig wird (Nam et al. 2015). Wenig Evidenz gibt es jedoch zu der Art und Weise dieser Beeinflussung. Einerseits kann es sich hierbei um direkte Kommunikation der Freunde handeln, während der sich Jugendliche über unterschiedliche Ansichten und Meinungen austauschen und somit gemeinsame Normen ausbilden, andererseits können verschiedene Verhaltensweisen der Freunde, z. B. Ernährungsweisen oder körperliche (In-)Aktivitäten, Auswirkungen auf das Körpergewicht der Jugendlichen haben (Cunningham et al. 2012). Neben sozialem Einfluss, der die Ähnlichkeit von Freunden bzgl. des Körpergewichts erklären kann, spielen hier auch Selektionsprozesse eine Rolle (Nam et al. 2015; Shoham et al. 2012). Das heißt, Jugendliche suchen sich tendenziell Freunde mit ähnlichem Gewicht wie sie selbst (Nam et al. 2015). Insbesondere Jugendliche, die nicht übergewichtig sind, schließen eher Freundschaften mit Individuen mit ähnlichem Gewichtsstatus (Nam et al. 2015). Analoge Selektionseffekte zeigen sich auch in einer Längsschnittstudie für die körperliche Aktivität von ca. 1900 Jugendlichen (Simpkins et al. 2013). Insgesamt konnten verschiedene Studien nachweisen, dass sich Jugendliche, die miteinander befreundet bzw. in einer gemeinsamen Peergroup sind, bzgl. ihrer körperlichen Aktivität ähneln (Macdonald-Wallis et al. 2012; Simpkins et al. 2013). Ein Review konnte jedoch aufzeigen, dass zum Zusammenhang zwischen körperlicher Aktivität und der Auswahl der Freunde inkonsistente Ergebnisse existieren (Macdonald-Wallis et al. 2012). Einerseits existieren Ergebnisse, welche zeigen, dass körperlich aktive Jugendliche tendenziell mehr Freunde haben als weniger aktive Jugendliche, wohingegen andere Analysen keinen Zusammenhang nachweisen konnten (Macdonald-Wallis et al. 2012). Außerdem konnten geschlechtsspezifische Unterschiede festgestellt werden, denn befreundete Jungen ähneln sich bzgl. ihrer körperlichen Aktivität stärker als Mädchen (Macdonald-Wallis et al. 2012). La Haye et al. (2010) fanden heraus, dass sich weibliche Freunde ähnlicher in ihren Bildschirm-basierten Aktivitäten, wie zum Beispiel Fernsehen oder Computer spielen, sind, wohingegen Jungen sich stärker bzgl. ihres Konsums von hochkalorischer 
Nahrung, wie z. B. Fast Food, ähneln (La Haye et al. 2010). Barclay et al. (2013) zeigten zudem, dass die Wahrscheinlichkeit, dass ein Jugendlicher sich gesund ernährt und regelmäßig Sport treibt, höher ist, wenn seine Freunde dies auch tun. Je enger die Bindung bzw. die Freundschaft zwischen den Jugendlichen ist, desto größer ist auch die Wahrscheinlichkeit, dass sie sich in diesen Verhaltensweisen ähnlich sind. Ob diese Freundschaft zwischen Jugendlichen gleichen Geschlechts oder gleichem Migrationshintergrund besteht, beeinflusst diese Assoziationen nicht (Barclay et al. 2013).

\subsubsection{Alkohol und illegale Drogen}

Ergebnisse aus der Netzwerkforschung zum Substanzkonsum bei Jugendlichen weisen darauf hin, dass sich Jugendliche, die miteinander befreundet sind, tendenziell auch in ihrem Konsum verschiedener Substanzen ähneln (Kirke 2004; Valente et al. 2004). Wenn Jugendliche Substanzen, wie zum Beispiel Alkohol, konsumieren oder auch nur als Konsumenten dieser wahrgenommen werden, nehmen ihre Freunde diese mit höherer Wahrscheinlichkeit auch zu sich (Kirke 2004). Jugendliche, die zum Beispiel illegale Drogen konsumieren, haben demnach auch eher Freunde, die dies ebenfalls tun (Valente et al. 2004). Zudem ist die Anzahl an Freunden, die illegale Drogen konsumieren, positiv mit dem eigenen Drogenkonsum der Jugendlichen assoziiert (Valente et al. 2004). Verschiedene Studien erklären diese Ähnlichkeit im Konsumverhalten der Jugendlichen aufgrund von zwei Mechanismen - Selektion und/oder sozialem Einfluss, die bereits einleitend beschrieben wurden. Kirke (2004) und Valente et al. (2004) konnten mithilfe sozialer Netzwerkanalysen, in denen typische Parameter wie Zentralität (,centralization“), Dichte (,density“) und Transitivität (,transitivity“) untersucht wurden, aufzeigen, dass sowohl Selektionsprozesse als auch der Einfluss der Peergroup die Ähnlichkeit des Substanzkonsums bei Jugendlichen erklären und nicht nur ein einzelner Mechanismus zur Erläuterung herangezogen werden kann. Gerade der frühe Konsum von Alkohol stellt bei Jugendlichen ein großes gesundheitliches Problem dar. Auch hier spielen soziale Netzwerke eine entscheidende Rolle, denn sie nehmen Einfluss auf den Einstieg in den Alkoholkonsum bei Heranwachsenden. So zeigen die Ergebnisse der Studie von Mundt (2011), dass Jugendliche, die mit dem Trinken von Alkohol anfangen, tendenziell mehr Freunde und Freundesfreunde haben, die ebenfalls Alkohol konsumieren. Gleichzeitig haben sie engeren Kontakt zu beliebten Jugendlichen und tauschen sich ebenso mit mehr Freunden und Freundesfreunden aus als abstinente Gleichaltrige (Mundt 2011). Knecht et al. (2011) fanden mithilfe einer längsschnittlichen Multilevel-Netzwerkanalyse heraus, dass bei Jugendlichen im durchschnittlichen Alter von zwölf Jahren in Bezug auf den Konsum von Alkohol 
Selektionsprozesse eine größere Rolle spielen als sozialer Einfluss, d. h., die Jugendlichen suchen sich eher Freunde, die ähnliche Konsummuster haben wie sie (Knecht et al. 2011). Auch bei älteren Jugendlichen im Alter von 16 bis 17 Jahren spielen hier Selektionsprozesse eine Rolle (Kiuru et al. 2010). Parallel dazu ist, stärker als bei jüngeren Jugendlichen, aber auch der Einfluss der Peers in dieser Altersklasse wirksam und entscheidend; und der Konsum steigt tendenziell mit dem Alter an, wodurch der soziale Charakter des Alkohols bei Jugendlichen unterstrichen wird (Kiuru et al. 2010). Hier konnten zusätzlich Unterschiede zwischen den Geschlechtern nachgewiesen werden, denn weibliche Jugendliche ähneln sich in ihrem Trinkverhalten ihrer Peergroup stärker als männliche Jugendliche (Kiuru et al. 2010). Deutsch et al. (2014) kamen in ihrer prospektiven Multilevel-Netzwerkanalyse zu dem Ergebnis, dass die Innigkeit („Closeness“) der Freundschaften zwischen den Jugendlichen Auswirkungen auf ihr Trinkverhalten hat. So steigt der Einfluss auf das Trinkverhalten bei Jungen und Mädchen, wenn die Enge der Freundschaften zu männlichen Jugendlichen abnimmt (Deutsch et al. 2014). Die Innigkeit von Freundschaften zwischen Mädchen beeinflusst das Trinkverhalten dieser hingegen nicht (Deutsch et al. 2014). Eine Längsschnittuntersuchung von Huang et al. (2014) zeigte den Einfluss sozialer Medien, wie z. B. Facebook, auf den Alkoholkonsum von Jugendlichen. Heranwachsende, deren Freunde Fotos in sozialen Netzwerken hochladen, auf denen sie Alkohol trinken oder feiern, haben selbst ein höheres Risiko Alkohol zu konsumieren (Huang et al. 2014). Allerdings muss hierbei beachtet werden, dass lediglich egozentrierte Netzwerke erhoben und analysiert wurden.

\subsection{Bedeutung sozialer Netzwerke für den Tabakkonsum}

Besonders viele Forschungsarbeiten zur gesundheitlichen Bedeutung von sozialen Netzwerken im Jugendalter beschäftigen sich mit dem Tabakkonsum, daher soll im Folgenden ein Schwerpunkt des Beitrags im jugendlichen Tabakkonsum liegen und den bisherigen Forschungsstand skizzieren. Obwohl der Tabakkonsum im Jugendalter deutlich zurückgegangen ist (Inchley et al. 2016; Kuntz et al. 2018), finden das Experimentieren mit dem Rauchen und der Einstieg in den Konsum weiterhin vor allem im Jugendalter statt. Mit etwa 13 bis 14 Jahren greifen Jugendliche das erste Mal zu Tabak (Moor et al. 2016). Dabei steht ein frühes Einstiegsalter in den Substanzkonsum im Zusammenhang mit einem problematischen Konsumverhalten im Erwachsenenalter (Kendler et al. 2013). Zudem sind 
mit einem regelmäßigen Tabakkonsum auch (langfristige) gesundheitliche Risiken wie eine erhöhte Morbidität sowie frühzeitige Mortalität verbunden (Mons 2011; World Health Organization 2015). Da zum Tabakkonsum im Jugendalter viele soziale Netzwerkstudien durchgeführt wurden, werden im Folgenden vor allem diese herangezogen.

\subsubsection{Bedeutung verschiedener Netzwerkmitglieder}

Es wurde vielfach belegt, dass eine höhere Anzahl an Rauchern im Freundeskreis die Wahrscheinlichkeit erhöht, dass der Jugendliche selbst zur Zigarette greift (Ennett et al. 2008). Alexander et al. (2001) konnten anhand von logistischen Regressionsanalysen belegen, dass die Wahrscheinlichkeit selbst zu rauchen auf das Doppelte erhöht wird, wenn in dem Freundeskreis mindestens die Hälfte der Freunde rauchen, wenn ein oder zwei beste Freunde rauchen, und mit steigender Rauchprävalenz der besuchten Schule. Bislang weniger untersucht wurden andere Eigenschaften der Freunde bzw. der Freundesbeziehung im Zusammenhang mit dem jugendlichen Rauchverhalten. Darunter fallen z. B. die Anzahl der Freundschaften und die Enge der Freundschaft, die Qualität der Freundschaft (Reziprozität der Freundschaft, Unternehmungen außerhalb der Schule, Engagement der Freundschaft), die Stellung bzw. Position in der Peergroup (betweenness centrality, d. h. inwiefern Jugendliche verschiedene Freundesgruppen verbinden) oder das (weitere) Verhalten der Freunde, welches mit dem Rauchen im Zusammenhang stehen, wie in der längsschnittlichen Studie mit über 6.500 Jugendlichen im Alter von 11 bis 17 Jahren untersucht wurde (Ennett et al. 2008).

Simons-Morton und Farhat (2010) konnten in ihrem Review, welches längsschnittliche Netzwerkstudien zur Bedeutung der Freundesgruppe beim jugendlichen Tabakkonsum beinhaltete, herausstellen, dass der beste Freund einen größeren Einfluss auf den Tabakkonsum besitzt als andere Freunde. Allerdings kann dieser Einfluss verringert werden, wenn andere Freunde ein gegenteiliges Verhalten (z. B. Nichtrauchen) zeigen. Auch das Gruppenverhalten (soziale Normen) beeinflusst dabei das eigene (Rauch-)Verhalten. Der Einfluss der Freundesgruppe konnte gezeigt werden, jedoch wurden vor allem Selektionsprozesse identifiziert, da Jugendliche sich vermehrt Freunde mit ähnlichem Verhalten suchten. Darüber hinaus zeigte das Review, dass auch die Eltern eine wichtige Rolle einnehmen. Rauchen diese, rauchen auch häufiger ihre Kinder.

In der längsschnittlichen Studie Add Health haben Ali und Dwyer (2009) anhand von drei Erhebungswellen (1994, 1996 und 2002) die Bedeutung des Einflusses verschiedener Personen im Netzwerk auf das Rauchverhalten vom Jugendalter bis ins junge Erwachsenenalter hin untersucht. Dabei zeigte sich, dass 
auch nach Kontrolle für soziodemografische und elterliche Merkmale ein deutlicher Peer-Einfluss auf den Tabakkonsum besteht. Erhöht sich die Rauchprävalenz bei Mitschülern um $10 \%$, so erhöht sich die Wahrscheinlichkeit des eigenen Tabakkonsums um $3 \%$. Erhöht sich die Rauchprävalenz bei engen Freunden um $10 \%$, steigt die Wahrscheinlichkeit selbst zu rauchen dagegen um $5 \%$ an. Der Einfluss von engen Freunden bleibt auch bis ins Erwachsenenalter bestehen (Ali und Dwyer 2009). Auch mit der Add Health-Studie konnten Daw et al. (2015) zeigen, dass Geschwister, gefolgt von Freunden und Mitschülern, den größten Einfluss auf das Rauchen haben. Der Einfluss war größer, sofern eine Freundschaft reziprok angegeben wurde (Daw et al. 2015).

\subsubsection{Position im Netzwerk}

Heterogene Ergebnisse lassen sich bezogen auf die Stellung von Ego im Netzwerk und dem Rauchverhalten vorfinden. Einige Studien fanden heraus, dass Jugendliche in isolierten Positionen, d. h. wenn sie wenig oder keine Freunde bzw. Freundschaften zu Mitschülern angaben, eher rauchen (Ennett et al. 2008; Seo und Huang 2012; Valente et al. 2004). Dabei gibt es unterschiedliche Interpretationen. Seo und Huang (2012) interpretieren in ihrem systematischen Review sozialer Netzwerkanalysen zu jugendlichem Rauchverhalten, dass soziale Isolation dazu führen kann, dass Jugendliche zum Tabak greifen, um diesen emotionalen Stress abzumildern. Es ist aber auch eine andere Wirkungsrichtung denkbar, dass Jugendliche aufgrund ihres Tabakkonsums aus einer (früheren) Freundesgruppe ausgeschlossen wurden. Andere Studien kommen zu dem Schluss, dass Raucher im Freundeskreis eher beliebt sind (Lakon und Valente 2012; Moody et al. 2011; Schaefer et al. 2012). Jedoch kommt es auch darauf an, welcher Freundeskreis betrachtet wird. Raucher sind beliebter in Freundeskreisen, die viele Raucher aufweisen. Hier zeigt sich auch der Selektionsprozess mithilfe der Add Health-Studie, dass Raucher auch Raucher als Freunde benennen (Schaefer et al. 2012). Dabei könnte sowohl der soziale Druck von der Freundesgruppe (Seo und Huang 2012) als auch der Schulkontext eine Rolle spielen. So wurde berichtet, dass Raucher in jenen Schulen beliebter sind, in denen die Tabakprävalenzen allgemein höher sind und gleichzeitig in Schulen mit geringeren Rauchprälenzen beliebtere Schüler eher weniger rauchen. Dies sind erneut Ergebnisse der Add Health-Studie, hier wurde die Beliebtheit anhand der aufsummierten Freundschaftsnennungen der Schüler erhoben (in-degree centrality) (Alexander et al. 2001). 


\section{Sozioökonomische Ungleichheiten im Substanzkonsum: Die Rolle des sozialen Netzwerks}

Im Bereich „Gesundheit und Gesundheitsverhalten“ existieren derzeit nur wenige Studien, die mithilfe der SNA sozioökonomische Ungleichheiten bei Jugendlichen untersuchen. So fehlt es bislang zum Beispiel an Untersuchungen, die die mentale Gesundheit von Jugendlichen im Zusammenhang mit dem Netzwerk sowie dem SES betrachten. Auch die körperliche Aktivität und Ernährung bei Jugendlichen wurde dahin gehend noch wenig erforscht. Das folgende Kapitel will daher einen Überblick geben über bisherige Erkenntnisse im Bereich des Substanzkonsums - insbesondere des Tabakkonsums - bei Jugendlichen, und die Rolle sozialer Netzwerke in Kombination mit dem SES.

\subsection{Konsum von Alkohol und Drogen}

Etwa $10 \%$ der Jugendlichen im Alter von 12 bis17 Jahren trinken wöchentlich Alkohol (Kraus et al. 2012; Orth 2017). Jungen konsumieren mehr und häufiger Alkohol als Mädchen (European School Survey Project on Alcohol und other Drugs 2016; Inchley 2017; Moor et al. 2016). Dabei lassen sich auch bildungsspezifische Unterschiede erkennen, Gymnasiasten greifen im Vergleich zu Schülern anderer Schulformen seltener regelmäßig zu Alkohol (Moor et al. 2016; Orth 2017). Insgesamt gibt es nur wenige Studien, die mithilfe der sozialen Netzwerkanalyse sozioökonomische Unterschiede bei Jugendlichen im Bereich des Alkohol- und Drogenkonsums untersuchen. Eine Ausnahme stellt Pearson et al. (2006) dar, die mithilfe einer Untersuchung, in der 13- bis 15-Jährige befragt wurden, aufzeigen, dass Mädchen und Jugendliche mit höherem SES eher in Gruppen integriert und beliebter sind (friendship nominations received) sowie selbst mehr Freunde nominieren als Jungen oder Jugendliche mit niedrigem SES.

\subsection{Tabakkonsum}

Auffällig ist, dass Jugendliche aus unteren sozialen Statusgruppen häufiger rauchen als sozial besser gestellte Jugendliche (Kuntz et al. 2018). Insbesondere ist 
dies bei der Berücksichtigung des besuchten Schultyps erkennbar: Mädchen im Alter von 15 Jahren, die das Gymnasium besuchen, geben nur zu 4,4 \% an, regelmäßig, d. h. mindestens wöchentlich, zu rauchen (Jungen: 6,7 \%), jedoch 29,9\% der Mädchen, die eine Hauptschule besuchen (Jungen: 14\%), so das Ergebnis von Moor et al. (2016), die Daten der HBSC-Studie (,Health Behaviour in School-aged Children“) für Deutschland aus dem Jahr 2014 analysierten. Dieser bildungsspezifische Rückgang im Rauchen konnte neben der HBSC-Studie auch von der KiGGS-Studie (,Studie zur Gesundheit von Kindern und Jugendlichen in Deutschland“, der ESPAD-Studie (,the European School Survey Project on Alcohol and Other Drugs") als auch von der BZgA (Bundeszentrale für gesundheitliche Aufklärung) nachgewiesen werden (Kuntz et al. 2018). Ungeklärt bleibt an dieser Stelle, welche Mechanismen für das Rauchen verantwortlich sind bzw. für bildungsspezifische Ungleichheiten im Tabakkonsum. Bekannt ist, dass soziale Kontexte wie Familie, Schule und Peergroup für das Rauchverhalten im Jugendalter eine zentrale Rolle spielen (Piko und Kovacs 2010; Schaefer et al. 2012; Simetin et al. 2011; Simons-Morton und Farhat 2010), weniger wurde dies in Hinblick auf soziale Ungleichheiten untersucht.

$\mathrm{Zu}$ den wenigen Studien zum Rauchverhalten im Jugendalter, die sozioökonomische Ungleichheiten im Kontext der sozialen Netzwerkanalyse berücksichtigen, gehören die SILNE- (2013) („Tackling socioeconomic inequalities in smoking: learning from natural experiments by time trend analyses and cross-national comparisons“) und die SILNE-R-Studie (2016/2017) („Enhancing the Effectiveness of Programs and Strategies to Prevent Smoking by Adolescents"), die in sechs bzw. sieben Ländern der Europäischen Union (EU) bei 14 bis 16-Jährigen Schülern diesen Zusammenhang untersuchen (Lorant et al. 2015; Lorant et al. 2016; Lorant et al. 2017; Robert et al. 2018). Die Ergebnisse der ersten SILNE-Studie weisen darauf hin, dass sozial benachteiligte Heranwachsende häufiger rauchen und sich in ihrem schulischen Netzwerk mehr rauchende Schüler befinden als bei jenen mit einem höheren Sozialstatus. Das Rauchverhalten der Freunde und die Homophilie der Gruppe vermittelten den Zusammenhang zwischen SES und Tabakkonsum (Lorant et al. 2017). Lorant et al. (2017) schlagen ein Modell (vgl. Abb. 1) vor, welches sowohl das Rauchen von Freunden als auch soziale Homophilie berücksichtigt.

Nach diesem Modell, welches an DiMaggio und Garip (2011) angelehnt ist, müssen zwei Voraussetzungen erfüllt sein: Der Tabakkonsum muss ein interdependentes, d. h. ein von anderen abhängiges Verhalten sein und soziale Beziehungen müssen sozial homophil sein. Wie bereits ausgeführt, fangen Jugendliche 


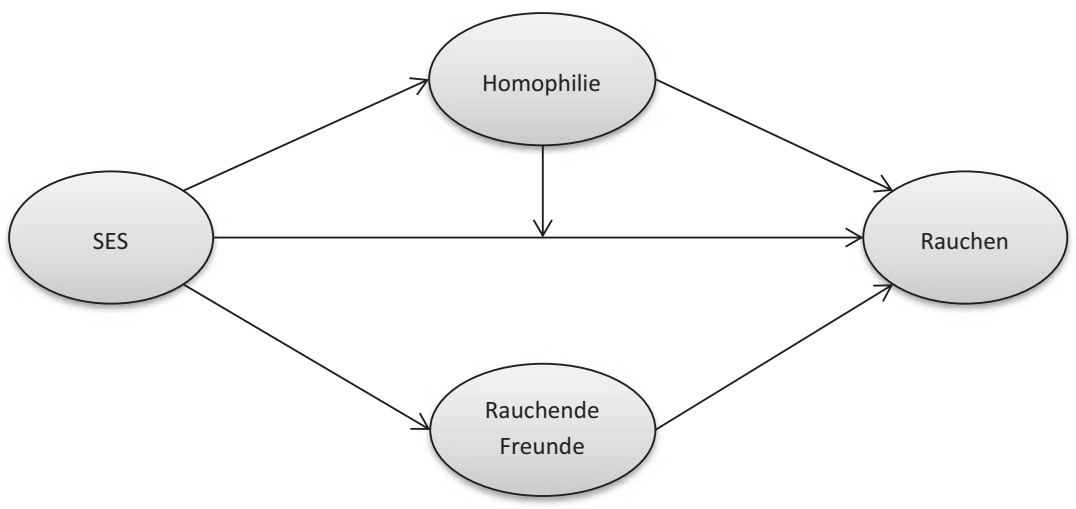

Abb. 1 Ungleichheiten im Tabakkonsum: Konzeptionelles Modell. (Quelle: Lorant et al. 2017)

eher an zu rauchen, wenn ihre Freunde ebenfalls rauchen und das Gleiche gilt für Nichtraucher. Der Tabakkonsum bzw. der Nichtkonsum definiert auch die Gruppe sowie deren soziale Kohäsion. Bezogen auf den zweiten Aspekt wurde ebenfalls beschrieben, dass soziale Beziehungen nicht zufällig entstehen, sondern Gruppen entstehen oder bestehen weiter, weil die Gruppenmitglieder verschiedene Merkmale miteinander teilen, wie z. B. das Geschlecht, den SES, Migration etc. (Lorant et al. 2017). Lorant et al. (2017) konnten das Modell auch empirisch belegen, der Zusammenhang zwischen einem niedrigem Sozialstatus und dem Rauchverhalten wurde sowohl durch (mehr) rauchende Freunde (enge und nicht so enge) als auch durch soziale Homophilie partiell erklärt. Der Effekt der Selektion oder des Einflusses konnte in dieser Studie jedoch nicht differenziert werden.

Pearson et al. (2006) konnten für den Tabakkonsum ebenfalls einen Zusammenhang mit dem Sozialstatus herstellen. In ihrer Studie zeigte sich, dass Mädchen und jene mit höherem schulischen SES (d. h. geringerer Anteil deprivierter Schüler in der Schule) häufiger in einer Gruppe integriert und beliebter sind sowie auch ein größeres Netzwerk besitzen. Raucher waren hier häufiger isoliert oder hatten nur ein kleines Netzwerk.

Evident ist zudem im Hinblick auf das Aufhören mit dem Rauchen im Erwachsenenalter, dass bei Freunden mit höherer Bildung der Einfluss untereinander höher ist als bei jenen mit geringerer Bildung (Christakis und Fowler 
2008). Dies konnte auch in Studien für das Jugendalter belegt werden, hier zeigte sich, dass die Homophilie nach dem Bildungsstand der Eltern unterschiedlich ausfällt. Die Homophilie in Freundschaften ist bei jenen Heranwachsenden höher, deren Eltern eine höhere Bildung angaben, im Vergleich zu jenen, die eine geringere Bildung aufweisen. Dieser Zusammenhang traf sowohl für das Rauchen als auch auf andere Verhaltensweisen wie Alkohol- und Fernsehkonsum als auch physische Aktivität zu (Daw et al. 2015). Ähnliche Ergebnisse konnte auch die Studie von Robert et al. (2018) mithilfe der SILNE Studie liefern. Jugendliche sind nicht nur homophil zu dem Rauchverhalten, sondern auch in Bezug auf die schulische Leistung. Schüler mit schlechteren schulischen Leistungen sind dabei eher befreundet als jene mit unterschiedlich guten Schulleistungen. Der Zusammenhang zwischen schulischer Leistung und dem Rauchverhalten konnte durch die Komposition und Homophilie der Freundschaften als auch durch den Schultyp teilweise erklärt werden.

Die Bedeutung der sozialen Netzwerke für das Rauchen unter Berücksichtigung des Schultyps als auch der elterlichen Bildung der Jugendlichen wurde zudem von Huisman und Bruggeman (2012) untersucht. Die Autoren führten eine Längsschnittstudie unter 13- bis 14-jährigen niederländischen Jugendlichen im Schuljahr 2008/2009 durch und analysierten die vermittelnde Rollte des sozialen Netzwerks. Dazu konnten die Schüler der jeweiligen Schulklasse bis zu 15 andere Schüler benennen, mit denen sie befreundet sind. Die Angaben zum Netzwerk wurden mittels SIENA ${ }^{2}$ analysiert. Da die soziale Herkunft der Eltern oftmals die schulische Bildung der Kinder prägt und die Schule ein besonderer Raum für soziale Kontakte darstellt, war die Frage, inwiefern die schulische Freundesgruppe eine Mediatorrolle zwischen dem Schultyp und dem Rauchverhalten einnimmt. Die Ergebnisse zeigen, dass der Effekt des Schultyps auf das Rauchen durch das soziale Netzwerk (rauchende Freunde) vermittelt wird, auch unter Kontrolle des eigenen Rauchverhaltens (Huisman und Bruggeman 2012). Das ist ein sehr wichtiges Ergebnis, da es aufzeigt, dass es (nicht) unbedingt die schulische Bildung des Jugendlichen ist, welche für das Rauchverhalten verantwortlich ist, sondern die (schulischen) Freunde, die rauchen und den Effekt zwischen Schultyp und Rauchen vermitteln.

\footnotetext{
${ }^{2}$ SIENA ist ein statisches Programm zur Analyse sozialer Netzwerke, welches insbesondere bei Längsschnittdaten eingesetzt wird (vgl. dazu auch Kapitel: Netzwerkanalyse).
} 


\section{Diskussion und Schlussfolgerungen}

\subsection{Zusammenfassung und kritische Reflexion}

Für das Jugendalter gibt es eine Bandbreite an Studien, die Einflussfaktoren auf die Gesundheit und das Gesundheitsverhalten in dieser Lebensphase analysiert haben. Dabei wird auch zunehmend der Fokus auf die sozialen Determinanten gelegt, da bereits im Jugendalter gesundheitliche Ungleichheiten zum Vorschein treten und die Gesundheit und das gesundheitliche Verhalten nachhaltig negativ beeinflussen. Weniger Aufmerksamkeit wurde jedoch der Rolle des sozialen Netzwerks für die (Re-)Produktion dieser gesundheitlichen Ungleichheiten gewidmet, obwohl die SNA hierfür vielversprechende Ansätze offenbart. Eine Ausnahme bildet der Schulkontext, dem in der sozialen Netzwerkforschung schon sehr früh eine starke Bedeutung zugesprochen wurde, sodass sich hier auf eine - im Vergleich zu anderen Lebensphasen - recht hohe Anzahl an Studien zurückgreifen lässt. Vor allem im Bereich des Rauchverhaltens und der Bedeutung des sozialen Netzwerks gibt es eine gute Studienlage, die das gesamte Klassennetzwerk - und damit das Gesamtnetzwerk - betrachtet. Weniger Netzwerkstudien wurden allerdings zur (psychischen) Gesundheit und zu anderen Verhaltensweisen durchgeführt, wobei auch hier die Zahl steigend ist.

\subsubsection{Methodische Herausforderungen}

Methodisch ist die SNA im Jugendalter eine große Herausforderung, da möglichst ganze Klassen befragt werden müssen, um Netzwerke vollständig zu erfassen - dies ist jedoch mit datenschutzrechtlichen Hürden versehen. Davon abgesehen müssen die vorliegenden Studien auch kritisch beleuchtet werden. Beispielsweise wurden in der Studie von Schaefer et al. (2012) Daten von 1994 bis 1996 bzw. in der Studie von Alexander et al. (2001) Daten von 1994/1995 ausgewertet. Die Frage ist, ob diese Ergebnisse heutzutage noch Gültigkeit besitzen. Die Rauchprävalenzen waren zu dieser Zeit deutlich höher und auch das Rauchen an sich gesellschaftlich akzeptierter sowie mit weniger Stigmatisierung versehen. Wenn in diesen Studien Raucher isoliert waren, hat dies möglicherweise eine andere Bedeutung als wenn heutzutage Raucher im Netzwerk isoliert werden, da sich gesellschaftliche Normen in Bezug auf das Rauchen verändert haben. Zum anderen könnten Studien, die nur das schulische Netzwerk betrachten und hier beispielsweise Raucher als isolierte Personen identifizieren, zu verzerrten Schlussfolgerungen kommen. Möglicherweise sind diese Schüler außerhalb der Schule in einem breiten Netzwerk eingebunden und dort nicht isoliert (Pearson 
et al. 2006). In schulbasierten Netzwerkstudien kann daher ein „blinder Fleck“ entstehen. Weiterhin wird häufig erhoben, ob Freunde, Familie und Mitschüler ein bestimmtes Merkmal aufweisen, weniger jedoch wie die Beziehungsqualität (z. B. Kontakthäufigkeit, positive/negative Beziehung) gestaltet ist. Eine wesentliche Frage der SNA ist sicherlich, ob nicht nur die Beziehung zu verschiedenen Personen Einfluss auf ein Verhalten hat, sondern ob auch dieser Einfluss bei unterschiedlichen Verhaltensweisen eine unterschiedliche Bedeutung hat. Einige Studien haben dies untersucht, jedoch ist die Forschung hier noch unzureichend. Für den Zusammenhang zwischen dem Rauchen und dem sozialen Netzwerk zeigten sich in einer Studie stärkere Zusammenhänge im Vergleich zu Alkohol, Fernsehkonsum oder körperlicher Bewegung (Daw et al. 2015). Weitere Untersuchungen - insbesondere auch qualitative Studien - sollten hier folgen, um die Wirkmechanismen verstehen zu können.

\subsection{Fazit und Forschungsdesiderata}

Der vorliegende Beitrag konnte aufzeigen, dass die SNA in einigen Bereichen noch deutliche Forschungslücken aufweist. So häufen sich Studien im Schulkontext, die vor allem den Tabakkonsum im Zusammenhang mit dem sozialen Netzwerk untersuchen, allerdings wurden nur wenige Studien zu anderen Gesundheitsverhaltensweisen und insbesondere zur (mentalen) Gesundheit durchgeführt. Ein weiteres Problem ist, dass meist nur das schulische Netzwerk erfasst werden kann und nicht auch weitere Netzwerke (außerschulische Freunde, familiäres Netzwerk etc.), was zu verzerrten Ergebnissen führen könnte. Viele Studien basieren auf querschnittlichen Betrachtungen, die keine kausale Aussage ermöglichen. Es fehlt an Längsschnittstudien, die die kausalen Wirkmechanismen genauer herausstellen können (mit Ausnahme für Untersuchungen zum Tabakkonsum, hier sind gehäuft Längsschnittstudien zu finden). Auffällig ist darüber hinaus, dass SNA überwiegend quantitativ bearbeitet wird. Es lassen sich für das Jugendalter kaum qualitative bzw. ego-zentrierte Studien vorfinden, obwohl hier insbesondere untersucht werden kann, wie und weshalb das soziale Netzwerk auf die Gesundheit und auf das gesundheitliche Verhalten wirkt. Hier könnten in diesem Zusammenhang auch die Normänderungen über die Zeit berücksichtigt werden. Insbesondere für den Zusammenhang zwischen dem Tabakkonsum und dem sozialem Netzwerk könnte die Position im Netzwerk Normänderungen statt Freundesbeziehungen widerspiegeln, da sich die gesellschaftliche Akzeptanz und die Tabakprävalenz über die Zeit verändert haben. Die höheren sozialen Schichten grenzen sich beispielsweise durch einen weitgehenden Rauchverzicht 
$\mathrm{ab}$, während in unteren sozialen Schichten noch zur Zigarette gegriffen wird, was mit einer zunehmenden sozial-normativen Entwertung und Stigmatisierung von rauchenden - und damit benachteiligten - Bevölkerungsgruppen einhergeht (Bell et al. 2010; Chapman und Freeman 2008; Reuband 2014).

Abschließend sei daher noch darauf verwiesen, dass ein deutlicher Mangel an SNA-Studien konstatiert werden kann, die vertikale und gesundheitliche Ungleichheiten berücksichtigen (auch hier ist die größte Studienlage bislang für den Tabakkonsum vorhanden). Die Evidenz ist jedoch insgesamt nur fragmentarisch in der Beantwortung der Frage, inwieweit das soziale Netzwerk gesundheitliche Ungleichheiten erklären kann. Einige wenige Forschungsarbeiten wiesen einen vermittelnden Effekt (Mediatoreffekt) nach (Huisman und Bruggeman 2012; Lorant et al. 2017). Auch ein Moderatoreffekt konnte nachgewiesen werden, da der Einfluss des sozialen Netzwerks in Hinblick auf das Aufhören mit dem Rauchen unter Freunden mit höherer Bildung stärker ausgeprägt ist als unter Freunden mit geringerer Bildung (Christakis und Fowler 2008). Weitere Studien, die dazu beitragen können, diese Forschungslücken auch für weitere Gesundheitsoutcomes zu schließen, sind dringend erforderlich.

\section{Leseempfehlungen}

Lorant, V., Rojas, V. S., Robert, P.-O., Kinnunen, J. M., Kuipers, M. A. G., Moor, I., Roscillo, G., Alves, J., Rimpela, A., Federico, B., Richter, M., Perelman, J., \& Kunst, A. E. (2017). Social network and inequalities in smoking amongst school-aged adolescents in six European countries. International Journal of Public Health. https://doi.org/10.1007/s00038016-0830-z. Ergebnisse der SILNE-Studie zur Bedeutung der sozialen Netzwerke für sozioökonomische Ungleichheiten im Tabakkonsum bei Heranwachsenden in sechs Ländern.

Ali, M. M., \& Dwyer, D. S. (2009). Estimating peer effects in adolescent smoking behavior: a longitudinal analysis. Journal of Adolescent Health. https://doi.org/10.1016/j.jadohealth.2009.02.004. Ergebnisse der längsschnittlichen Studie „AddHealth“ zur Bedeutung des Einflusses verschiedener Personen im Netzwerk auf das Rauchverhalten vom Jugendalter bis ins junge Erwachsenenalter.

Simons-Morton, B. G., \& Farhat, T. (2010). Recent findings on peer group influences on adolescent smoking. The Journal of Primary Prevention. https://doi.org/10.1007/s10935-010-0220-x. Übersichtsarbeit über 
Einfluss der Freunde auf das Rauchverhalten von Jugendlichen, Einschluss von längsschnittlichen SNA-Studien.

Mercken, L., Snijders, T. A. B., Steglich, C., Vertiainen, E., \& Vries, H. de. (2010). Smoking-based selection and influence in gender-segregated friendship networks: a social network analysis of adolescent smoking. Addiction. https://doi.org/10.1111/j.1360-0443.2010.02930.x. Längsschnittliche Studie zur Untersuchung der Mechanismen des Einflusses und der Selektion für den Tabakkonsum im Jugendalter.

Huisman, C., \& Bruggeman, J. (2012). The social network, socioeconomic background, and school type of adolescent smokers. International Journal of Behavioral Development. https://doi. org/10.1177/0165025412444078. Untersucht wurde mithilfe einer Längsschnittstudie die Bedeutung der sozialen Netzwerke für gesundheitliche Ungleichheiten im Rauchen von Jugendlichen.

\section{Datensätze}

- „SILNE“ (Tackling socioeconomic inequalities in smoking: learning from natural experiments by time trend analyses and cross-national comparisons)

SILNE ist ein durch die Europäische Kommission gefördertes Projekt, welches auf schulischen Netzwerkdaten beruht. Es werden Rauchverhalten- und Normen von Jugendlichen im Alter von ca. 14-16 Jahren auf familiärer, sozioökonomischer und schulischer Ebene in sechs europäischen Ländern (Belgien, Finnland, Deutschland, Italien, Niederlande und Portugal) untersucht.

http://silne.ensp.org/

- „SILNE-R“ (Enhancing the Effectiveness of Programs and Strategies to Prevent Smoking by Adolescents)

SILNE-R schließt eine quantitative Wiederholungsbefragung von SILNE zu schulischen Tabakkontrollpolitiken ein. Rauchinnovationen wie E-Zigaretten und die Gesundheitskompetenz von Jugendlichen wurden zudem ergänzt. Zusätzlich wurden qualitative Fokusgruppen mit Jugendlichen und Lehrpersonal erhoben, die mit den quantitativen Befunden verknüpft werden können.

http://silne-r.ensp.org/ 
- Add Health (National Longitudinal Study of Adolescent Health) Längsschnittliche Studie von Jugendlichen in Amerika der Jahrgangsklassen 7-12 u. a. zum Substanzkonsum. Die Studie bietet viele verschiedene Netzwerkparameter an und untersucht unterschiedliche Beziehungen (schulische und familiäre Beziehungen). https://www.cpc.unc.edu/projects/addhealth

- VOCL'99 (Longitudinal Cohort Studies on Secondary Education Cohort 1999)

Niederländische Längsschnittstudie. Schüler im Alter von durchschnittlich 13 Jahren wurden in die Studie aufgenommen. Die Studie untersucht die Stabilität jugendlicher Beziehungen im Peer-Kontext im Längsschnitt.

\section{Literatur}

Alexander, C., Piazza, M., Mekos, D., \& Valente, T. (2001). Peers, schools, and adolescent cigarette smoking. Journal of Adolescent Health, 29(1), 22-30.

Ali, M. M., \& Dwyer, D. S. (2009). Estimating peer effects in adolescent smoking behavior. A longitudinal analysis. Journal of Adolescent Health, 45(4), 402-408.

Alvin, P., \& Deschamps, J. P. (1998). Health, risks, and risk-taking behaviors in adolescents. Considerations on current priorities. Annales de Pediatrie, 45(5), 378-384.

Baggio, S., Luisier, V., \& Vladescu, C. (2017). Relationships between social networks and mental health an exponential random graph model approach among Romanian adolescents. Swiss Journal of Psychology, 76(1), 5-11.

Barclay, K. J., Edling, C., \& Rydgren, J. (2013). Peer clustering of exercise and eating behaviours among young adults in Sweden. A cross-sectional study of egocentric network data. BMC Public Health, 13(1), 784.

Barman-Adhikari, A., Begun, S., Rice, E., Yoshioka-Maxwell, A., \& Perez-Portillo, A. (2016). Sociometric network structure and its association with methamphetamine use norms among homeless youth. Social Science Research, 58, 292-308.

Bell, K., Salmon, A., Bowers, M., Bell, J., \& McCullough, L. (2010). Smoking, stigma and tobacco ,denormalization'. Further reflections on the use of stigma as a public health tool. A commentary on Social Science \& Medicine's Stigma, Prejudice, Discrimination and Health Special Issue (67: 3). Social Science and Medicine, 70(6), 795-799.

Borrmann, A., \& Mensink, G. B. M. (2015). Obst- und Gemüsekonsum von Kindern und Jugendlichen in Deutschland. Ergebnisse der KiGGS-Welle 1. Bundesgesundheitsblatt, 58(9), 1005-1014.

Cavallo, F., Dalmasso, P., Ottová-Jordan, V., Brooks, F., Mazur, J., Välimaa, R., Gobina, I., Gaspar de Matos, M., \& Raven-Sieberer, U. (2015). Trends in self-rated health in European and North-American adolescents from 2002 to 2010 in 32 countries. European Journal of Public Health, 25(Suppl 2), 13-15. 
Chapman, S., \& Freeman, B. (2008). Markers of the denormalisation of smoking and the tobacco industry. Tobacco Control, 17(1), 25-31.

Christakis, N. A., \& Fowler, J. H. (2008). The collective dynamics of smoking in a large social network. The New England Journal of Medicine, 358(21), 2249-2258.

Coleman, J. S. (1961). The adolescent society. The social life of the teenager and its impact on education. New York: Free Press on Glencoe.

Craddock, J. B., Rice, E., Rhoades, H., \& Winetrobe, H. (2016). Are parental relationships always protective? A social network analysis of black, latino, and white homeless youth and sexual risk-taking behaviors. Prevention Science, 17(8), 914-924.

Cunningham, S. A., Vaquera, E., Maturo, C. C., \& Narayan, K. M. V. (2012). Is there evidence that friends influence body weight? A systematic review of empirical research. Social Science and Medicine, 75(7), 1175-1183.

Daw, J., Margolis, R., \& Verdery, A. M. (2015). Siblings, friends, course-mates, club-mates. How adolescent health behavior homophily varies by race, class, gender, and health status. Social Science and Medicine, 125, 32-39.

de La Haye, K., Robins, G., Mohr, P., \& Wilson, C. (2010). Obesity-related behaviors in adolescent friendship networks. Social Networks, 32(3), 161-167.

Deutsch, A. R., Steinley, D., \& Slutske, W. S. (2014). The role of gender and friends“ gender on peer socialization of adolescent drinking. A prospective multilevel social network analysis. Journal of Youth and Adolescence, 43(9), 1421-1435.

DiMaggio, P., \& Garip, F. (2011). How network externalities can exacerbate intergroup inequality. American Journal of Sociology, 116(6), 1887-1933.

Elgar, F. J., Pförtner, T.-K., Moor, I., Clercq, B., Stevens, G. W. J. M., \& Currie, C. (2015). Socioeconomic inequalities in adolescent health 2002-2010. A time-series analysis of 34 countries participating in the Health Behaviour in School-aged Children study. The Lancet, 385(9982), 2088-2095.

Ennett, S. T., Faris, R., Hipp, J., Foshee, V. A., Bauman, K. E., Hussong, A., \& Cai, L. (2008). Peer smoking, other peer attributes, and adolescent cigarette smoking. A social network analysis. Prevention Science, 9(2), 88-98.

European School Survey Project on Alcohol and other Drugs. (2016). ESPAD report 2015. Results from the European school survey project on alcohol and other drugs. Luxembourg: Publications Office of the European Union.

Flashman, J. (2012). Academic achievement and its impact on friend dynamics. Sociology of Education, 85(1), 61-80.

Fletcher, A., Bonell, C., \& Sorhaindo, A. (2011). You are what your friends eat. Systematic review of social network analyses of young people's eating behaviours and bodyweight. Journal of Epidemiology and Community Health, 65(6), 548-555.

Freeman, L. C. (2004). The development of social network analysis. A study in the sociology of science. Vancouver: Empirical Press.

Friedman, S. R., \& Aral, S. (2001). Social networks, risk-potential networks, health, and disease. Journal of Urban Health, 78(3), 411-418.

Fulginiti, A., Rice, E., Hsu, H.-T., Rhoades, H., \& Winetrobe, H. (2016). Risky integration a social network analysis of network position, exposure, and suicidal ideation among homeless youth. Crisis, 37(3), 184-193.

Hall, J. A., \& Valente, T. W. (2007). Adolescent smoking networks. The effects of influence and selection on future smoking. Addictive Behaviors, 32(12), 3054-3059. 
Havighurst, R. J. (1974). Developmental tasks and education (3. Aufl.). New York: McKay. Heidler, R., Gamper, M., Herz, A., \& Eßer, F. (2014). Relationship patterns in the 19th century. The friendship network in a German boys' school class from 1880 to 1881 revisited. Social Networks, 37, 1-13.

Hölling, H., Schlack, R., Petermann, F., Ravens-Sieberer, U., \& Mauz, E. (2014). Psychische Auffälligkeiten und psychosoziale Beeinträchtigungen bei Kindern und Jugendlichen im Alter von 3 bis 17 Jahren in Deutschland. Prävalenz und zeitliche Trends zu 2 Erhebungszeitpunkten (2003-2006 und 2009-2012). Ergebnisse der KiGGS-Studie. Erste Folgebefragung (KiGGS Welle 1). Bundesgesundheitsblatt, 57(7), 807-819.

Huang, G. C., Unger, J. B., Soto, D., Fujimoto, K., Pentz, M. A., Jordan-Marsh, M., \& Valente, T. W. (2014). Peer influences The impact of online and offline friendship networks on adolescent smoking and alcohol use. Journal of Adolescent Health, 54(5), 508-514.

Huisman, C., \& Bruggeman, J. (2012). The social network, socioeconomic background, and school type of adolescent smokers. International Journal of Behavioral Development, 36(5), 329-337.

Inchley, J. (Hrsg.). (2017). Adolescent obesity and related behaviours. Trends and inequalities in the who european region, 2002-2014. Observations from the Health Behavior in School-aged Children (HBSC) WHO collaborative cross-national study. Copenhagen: World Health Organization.

Inchley, J., Currie, D., Young, T., Samdal, O., Torsheim, T., Augustson, L., Mathison, F., Aleman-Diaz, A. Y., Molcho, M., Weber, M. W., \& Barnekow, V. (2016). Growing up unequal. Gender and socioeconomic differences in young people's health and wellbeing. Health Behaviour in School-Aged Children (HBSC) Study. International report from the 2013/2014 survey. Copenhagen: World Health Organization.

Kalman, M., Inchley, J., Sigmundova, D., Iannotti, R. J., Tynjälä, J. A., Hamrik, Z., Haug, E., \& Bucksch, J. (2015). Secular trends in moderate-to-vigorous physical activity in 32 countries from 2002 to 2010. A cross-national perspective. European Journal of Public Health, 25(Suppl 2), 37-40.

Kandel, D. B. (1978). Homophily, selection, and socialization in adolescent friendships. American Journal of Sociology, 84(2), 427-436.

Kendler, K. S., Myers, J., Damaj, M. I., \& Chen, X. (2013). Early smoking onset and risk for subsequent nicotine dependence. A monozygotic co-twin control study. American Journal of Psychiatry, 170(4), 408-413.

Kennedy, D. P., Tucker, J. S., Green, Harold D., Jr., Golinelli, D., \& Ewing, B. (2012). Unprotected sex of homeless youth. Results from a multilevel dyadic analysis of individual, social network, and relationship factors. Aids and Behavior, 16(7), 2015-2032.

Kirke, D. M. (2004). Chain reactions in adolescents' cigarette, alcohol and drug use. Similarity through peer influence or the patterning of ties in peer networks? Social Networks, 26(1), 3-28.

Kiuru, N., Burk, W. J., Laursen, B., Salmela-Aro, K., \& Nurmi, J.-E. (2010). Pressure to drink but not to smoke. Disentangling selection and socialization in adolescent peer networks and peer groups. Journal of Adolescence, 33(6), 801-812.

Knecht, A. B., Burk, W. J., Weesie, J., \& Steglich, C. (2011). Friendship and alcohol use in early adolescence: A multilevel social network approach. Journal of Research on Adolescence, 21(2), 475-487. 
Kraus, L., Pabst, A., \& Piontek, D. (2012). Europäische Schülerstudie zu Alkohol und anderen Drogen 2011 (ESPAD). Befragung von Schülerinnen und Schülern der 9. und 10. Klasse in Bayern, Berlin, Brandenburg, Mecklenburg-Vorpommern und Thüringen. München: Institut für Therapieforschung.

Krause, L., \& Lampert, T. (2014). Statusspezifische Unterschiede im Auftreten von Übergewicht und Adipositas beim Übergang vom Kindes- in das Jugendalter. Ergebnisse des Kinder- und Jugendgesundheitssurveys (KiGGS). Gesundheitswesen, 76(6), 377-384.

Kuipers, M. A. G., Robert, P.-O., Richter, M., Rathmann, K., Rimpela, A. H., Perelman, J., Federico, B., Lorant, V., \& Kunst, A. E. (2016a). Individual and contextual determinants of perceived peer smoking prevalence among adolescents in six European cities. Preventive Medicine, $88,168-175$.

Kuipers, M. A. G., de Korte, R., Soto, V. E., Richter, M., Moor, I., Rimpela, A. H., Perelman, J., Federico, B., Kunst, A. E., \& Lorant, V. (2016b). School smoking policies and educational inequalities in smoking behaviour of adolescents aged 14-17 years in Europe. Journal of Epidemiology and Community Health, 70(2), 132-139.

Kuntz, B., \& Lampert, T. (2011). Potenzielle Bildungsaufsteiger leben gesünder. Prävention und Gesundheitsförderung, 6(1), 11-18.

Kuntz, B., \& Lampert, T. (2013). Wie gesund leben Jugendliche in Deutschland? Gesundheitswesen, 75(2), 67-76.

Kuntz, B., Waldhauer, J., Moor, I., Rathmann, K., Richter, M., Orth, B., Piontek, D., Kraus, L., Zeiher, J., \& Lampert, T. (2018). Zeitliche Entwicklung von Bildungsunterschieden im Rauchverhalten von Jugendlichen in Deutschland. Ergebnisse aus vier bevölkerungsweiten Studien. Bundesgesundheitsblatt, 61(1), 7-19.

Lakon, C. M., \& Valente, T. W. (2012). Social integration in friendship networks. The synergy of network structure and peer influence in relation to cigarette smoking among high risk adolescents. Social Science \& Medicine, 74(9), 1407-1417.

Lämmle, L., Worth, A., \& Bös, K. (2012). Socio-demographic correlates of physical activity and physical fitness in German children and adolescents. European Journal of Public Health, 22(6), 880-884.

Lorant, V., Soto, V. E., Alves, J., Federico, B., Kinnunen, J., Kuipers, M., Moor, I., Perelman, J., Richter, M., Rimpela, A., Robert, P.-O., Roscillo, G., \& Kunst, A. (2015). Smoking in school-aged adolescents. Design of a social network survey in six European countries. BMC Research Notes, 8(1), 91.

Lorant, V., Soto Rojas, V., Becares, L., Kinnunen, J. M., Kuipers, M. A. G., Moor, I., Roscillo, G., Alves, J., Grard, A., Rimpela, A., Federico, B., Richter, M., Perelman, J., \& Kunst, A. E. (2016). A social network analysis of substance use among immigrant adolescents in six European cities. Social Science and Medicine, 169, 58-65.

Lorant, V., Rojas, V. S., Robert, P.-O., Kinnunen, J. M., Kuipers, M. A. G., Moor, I., Roscillo, G., Alves, J., Rimpela, A., Federico, B., Richter, M., Perelman, J., \& Kunst, A. E. (2017). Social network and inequalities in smoking amongst school-aged adolescents in six European countries. International Journal of Public Health, 62(1), 53-62.

Macdonald-Wallis, K., Jago, R., \& Sterne, J. A. C. (2012). Social network analysis of childhood and youth physical activity. A systematic review. American Journal of Preventive Medicine, 43(6), 636-642.

Marsden, P. V. (2011). Survey methods for network data. In J. Scott \& P. J. Carrington (Hrsg.), The SAGE handbook of social network analysis (S. 370-388). London: Sage. 
Martino, S. C., Tucker, J. S., Ryan, G., Wenzel, S. L., Golinelli, D., \& Munjas, B. (2011). Increased substance use and risky sexual behavior among migratory homeless youth. Exploring the role of social network composition. Journal of Youth and Adolescence, 40(12), 1634-1648.

Mercken, L., Snijders, T. A. B., Steglich, C., \& de Vries, H. (2009). Dynamics of adolescent friendship networks and smoking behavior. Social network analyses in six European countries. Social Science \& Medicine, 69(10), 1506-1514.

Mercken, L., Snijders, T. A. B., Steglich, C., Vertiainen, E., \& de Vries, H. (2010). Smoking-based selection and influence in gender-segregated friendship networks. A social network analysis of adolescent smoking. Addiction, 105(7), 1280-1289.

Mercken, L., Steglich, C., Sinclair, P., Holliday, J., \& Moore, L. (2012). A longitudinal social network analysis of peer influence, peer selection, and smoking behavior among adolescents in British schools. Health Psychology, 31(4), 450.

Mons, U. (2011). Tabakattributable Mortalität in Deutschland und in den deutschen Bundesländern - Berechnungen mit Daten des Mikrozensus und der Todesursachenstatistik. Gesundheitswesen, 73(4), 238-246.

Moody, J., Brynildsen, W. D., Osgood, D. W., Feinberg, M. E., \& Gest, S. (2011). Popularity trajectories and substance use in early adolescence. Social Networks, 33(2), 101-112.

Moor, I., Pförtner, T. K., Lampert, T., Ravens-Sieberer, U., \& Richter, M. (2012). Sozioökonomische Ungleichheiten in der subjektiven Gesundheit bei 11- bis 15-Jährigen in Deutschland. Eine Trendanalyse von 2002-2010. Gesundheitswesen, 74, 49-55.

Moor, I., Lampert, T., Rathmann, K., Kuntz, B., Kolip, P., Spallek, J., \& Richter, M. (2014). Explaining educational inequalities in adolescent life satisfaction. Do health behaviour and gender matter? International Journal of Public Health, 59(2), 309-317.

Moor, I., Richter, M., Ravens-Sieberer, U., Ottová-Jordan, V., Elgar, F. J., \& Pförtner, T.-K. (2015). Trends in social inequalities in adolescent health complaints from 1994 to 2010 in Europe, North America and Israel. The HBSC study. European Journal of Public Health, 25(Suppl 2), 57-60.

Moor, I., Schumann, N., Hoffmann, L., Rathmann, K., \& Richter, M. (2016). Tabak-, Alkohol- und Cannabiskonsum im Jugendalter. In L. Bilz, G. Sudeck, J. Bucksch, A. Klocke, P. Kolip, W. Melzer et al. (Hrsg.), Schule und Gesundheit. Ergebnisse des WHOJugendgesundheitssurveys „Health Behaviour in School-aged Children“ (S. 65-83). Weinheim: Beltz Juventa.

Mundt, M. P. (2011). The impact of peer social networks on adolescent alcohol use initiation. Academic Pediatrics, 11(5), 414-421.

Nam, S., Redeker, N., \& Whittemore, R. (2015). Social networks and future direction for obesity research. A scoping review. Nursing Outlook, 63(3), 299-317.

Neaigus, A., Friedman, S. R., Goldstein, M., Ildefonso, G., Curtis, R., \& Jose, B. (1995). Using dyadic data for a network analysis of HIV infection and risk behaviors among injecting drug users. NIDA Research Monograph, 151, 20-37.

Okamoto, J., Johnson, C. A., Leventhal, A., Milam, J., Pentz, M. A., Schwartz, D., \& Valente, T. W. (2011). Social network status and depression among adolescents. An examination of social network influences and depressive symptoms in a Chinese sample. Research in Human Development, 8(1), 67-88. 
Orth, B. (2016). Die Drogenaffinitat Jugendlicher in der Bundesrepublik Deutschland 2015. Rauchen, Alkoholkonsum und Konsum illegaler Drogen. Aktuelle Verbreitung und Trends. BZgA-Forschungsbericht. Köln: Bundeszentrale für gesundheitliche Aufklärung.

Orth, B. (2017). Der Alkoholkonsum Jugendlicher und junger Erwachsener in Deutschland. Ergebnisse des Alkoholsurveys 2016 und Trends. Köln: Bundeszentrale für gesundheitliche Aufklärung.

Pachucki, M. C., Ozer, E. J., Barrat, A., \& Cattuto, C. (2015). Mental health and social networks in early adolescence. A dynamic study of objectively-measured social interaction behaviors. Social Science and Medicine, 125, 40-50.

Pearson, M., Sweeting, H., West, P., Young, R., Gordon, J., \& Turner, K. (2006). Adolescent substance use in different social and peer contexts. A social network analysis. Drugs: Education, Prevention and Policy, 13(6), 519-536.

Piko, B. F., \& Kovacs, E. (2010). Do parents and school matter? Protective factors for adolescent substance use. Addictive Behaviors, 35(1), 53-56.

Renna, F., Grafova, I. B., \& Thakur, N. (2008). The effect of friends on adolescent body weight. Economics and Human Biology, 6(3), 377-387.

Reuband, K.-H. (2014). Die Ausgrenzung des Tabakgebrauchs aus dem öffentlichen Raum. Die Einstellungen der Bürger zu Rauchverboten und die Entstehung neuer Konfigurationen sozialer Repräsentation. Soziale Probleme, 25(1), 5-51.

Richter, M., \& Moor, I. (2015). Die Bewältigung von Anforderungen und Stress im Kindesund Jugendalter. In W. Melzer (Hrsg.), Handbuch Aggression, Gewalt und Kriminalität bei Kindern und Jugendlichen (S. 99-103). Bad Heilbrunn: Klinkhardt.

Richter, M., \& Moor, I. (2017). Entwicklungen und Bedingungen des Aufwachsens. Ergebnisse der Health Behaviour in School-aged Children (HBSC) Studie 2013/2014. http:// www.dji.de/fileadmin/user_upload/bibs2017/15_KJB_Richter_Moor19_04_17zu.pdf. Zugegriffen: 27. Febr. 2019.

Robert, P.-O., Kuipers, M. A. G., Rathmann, K., Moor, I., Kinnunen, J. M., Rimpelä, A., Perelman, J., Federico, B., Richter, M., Kunst, A. E., \& Lorant, V. (2018). Academic performance. Academic performance and adolescent smoking in 6 European cities. The role of friendship ties, 24(1), 125-135.

Schaefer, D. R., Kornienko, O., \& Fox, A. M. (2011). Misery does not love company. Network selection mechanisms and depression homophily. American Sociological Review, 76(5), 764-785.

Schaefer, D. R., Haas, S. A., \& Bishop, N. J. (2012). A dynamic model of US adolescents“ smoking and friendship networks. American Journal of Public Health, 102(6), 8.

Scott, J. (2011). Social network analysis. Developments, advances, and prospects. Social Network Analysis and Mining, 1(1), 21-26.

Scott, J., \& Carrington, P. J. (Hrsg.). (2011). The SAGE handbook of social network analysis. London: Sage.

Seo, D.-C., \& Huang, Y. (2012). Systematic review of social network analysis in adolescent cigarette smoking behavior. Journal of School Health, 82(1), 21-27.

Shoham, D. A., Tong, L., Lamberson, P. J., Auchincloss, A. H., Zhang, J., Dugas, L., Kaufman, J. S., Cooper, R. S., \& Luke, A. (2012). An actor-based model of social network influence on adolescent body size, screen time, and playing sports. PLoS ONE, 7(6), e39795. 
Simetin, I. P., Kuzman, M., Franelic, I. P., Pristas, I., Benjak, T., \& Dezeljin, J. D. (2011). Inequalities in Croatian pupils' unhealthy behaviours and health outcomes. Role of school, peers and family affluence. European Journal of Public Health, 21(1), 122-128.

Simons-Morton, B. G., \& Farhat, T. (2010). Recent findings on peer group influences on adolescent smoking. The Journal of Primary Prevention, 31(4), 191-208.

Simpkins, S. D., Schaefer, D. R., Price, C. D., \& Vest, A. E. (2013). Adolescent friendships, BMI, and physical activity. Untangling selection and influence through longitudinal social network analysis. Journal of Research on Adolescence, 23(3), 537-549.

Stegbauer, C., \& Häußling, R. (Hrsg.). (2010). Handbuch Netzwerkforschung. Wiesbaden: Springer VS.

Trogdon, J. G., Nonnemaker, J., \& Pais, J. (2008). Peer effects in adolescent overweight. Journal of Health Economics, 27(5), 1388-1399.

Valente, T. W. (2012). Network interventions. Science, 337(6090), 49-53.

Valente, T. W., Gallaher, P., \& Mouttapa, M. (2004). Using social networks to understand and prevent substance use. A transdisciplinary perspective. Substance Use \& Misuse, 39(10-12), 1685-1712.

Vereecken, C., Pedersen, T. P., Ojala, K., Krølner, R., Dzielska, A., Ahluwalia, N., Giacchi, M., \& Kelly, C. (2015). Fruit and vegetable consumption trends among adolescents from 2002 to 2010 in 33 countries. European Journal of Public Health, 25(Suppl 2), $16-19$.

Viner, R. M., Ozer, E. M., Denny, S., Marmot, M., Resnick, M., Fatusi, A., \& Currie, C. (2012). Adolescence and the social determinants of health. The Lancet, 379(9826), 1641-1652.

World Health Organization. (2015). WHO global report on trends in prevalence of tobacco smoking. Geneva.

Youniss, J., \& Jacqueline, S. (1986). Adolescent relations with mothers, fathers, and friends. Chicago: University of Chicago Press.

Open Access Dieses Kapitel wird unter der Creative Commons Namensnennung 4.0 International Lizenz (http://creativecommons.org/licenses/by/4.0/deed.de) veröffentlicht, welche die Nutzung, Vervielfältigung, Bearbeitung, Verbreitung und Wiedergabe in jeglichem Medium und Format erlaubt, sofern Sie den/die ursprünglichen Autor(en) und die Quelle ordnungsgemäß nennen, einen Link zur Creative Commons Lizenz beifügen und angeben, ob Änderungen vorgenommen wurden.

Die in diesem Kapitel enthaltenen Bilder und sonstiges Drittmaterial unterliegen ebenfalls der genannten Creative Commons Lizenz, sofern sich aus der Abbildungslegende nichts anderes ergibt. Sofern das betreffende Material nicht unter der genannten Creative Commons Lizenz steht und die betreffende Handlung nicht nach gesetzlichen Vorschriften erlaubt ist, ist für die oben aufgeführten Weiterverwendungen des Materials die Einwilligung des jeweiligen Rechteinhabers einzuholen.

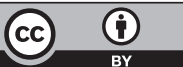




\section{Soziale Netzwerke und gesundheitliche Ungleichheiten im jungen und mittleren Erwachsenenalter}

\section{Holger von der Lippe und Olaf Reis}

\section{Überblick}

- Im Lebenslauf junger und mittlerer Erwachsener dürfte es enge Zusammenhänge zwischen sozialen und gesundheitlichen Ungleichheiten, biografischen Übergängen, sozialen Netzwerken und Gesundheitsverhalten geben. Viele dieser Zusammenhänge sind noch nicht hinreichend erforscht.

- Lebenslauftheorien der Entwicklung in sozialen Beziehungen Erwachsener werden berichtet und in ihrer Passung für Gesundheit und Gesundheitsverhalten diskutiert.

- Exemplarische Studien zur gesundheitlichen Bedeutung sozialer Netzwerke in biografischen Anpassungssituation junger und mittlerer Erwachsener (wie z. B. Paarbildung, Scheidung, Auszug der erwachsenen Kinder) werden vorgestellt.

- Nach aktueller Forschungslage ist ein Mediatoreffekt sozialer Netzwerke für den Einfluss sozialer Ungleichheiten auf Gesundheit wahrscheinlich.

- Die Forschungslage ist nicht gefestigt, weitere empirische wie theoretische Anstrengungen werden als notwendig erachtet.

H. von der Lippe $(\bowtie)$

Berlin, Deutschland

E-Mail: holger.vonderlippe@medicalschool-berlin.de

O. Reis

Rostock, Deutschland

E-Mail: olaf.reis@med.uni-rostock.de 
„Krankheit, Verlust des Gleichgewichts, meint nicht nur einen medizinischbiologischen Tatbestand, sondern auch einen lebensgeschichtlichen und gesellschaftlichen Vorgang. “

(Gadamer 1965)

\section{$1 \quad$ Einleitung: der thematische und paradigmatische Rahmen sozialer Netzwerke und gesundheitlicher Ungleichheiten im jungen und mittleren Erwachsenenalter}

$\mathrm{Zu}$ Beginn seiner einschlägigen Einführung in „Social Networks and Health“ formuliert Valente (2010) bereits ein zentrales Postulat, das auch für dieses Kapitel grundlegend sein wird. Er konstatiert, dass die wissenschaftliche Beschäftigung mit sozialen Beziehungsnetzen im Gesundheitskontext stets in einem interdisziplinären Zugang zum Gegenstand sowie unter Beachtung einer Entwicklungsbzw. Lebensspannenperspektive erfolgen müsse. Dies ist eine anspruchsvolle Forderung, bedeutet sie doch zum einen, dass man Netzwerke und Gesundheit zugleich als ein soziologisches Thema (z. B. ungleich verteilt, schichtabhängig), als ein psychologisches Thema (z. B. verhaltens- und persönlichkeitsabhängig) sowie unter einigen anderen disziplinären Perspektiven mehr (z. B. epidemiologisch, biologisch-physiologisch, gesundheitswissenschaftlich) verstehen kann und sollte (Interdisziplinarität des Gegenstandes). Und zum anderen bedeutet Valentes Postulat auch, dass die Frage nach Netzwerkeffekten im Gesundheitskontext kaum allgemein für „,den Menschen“ gestellt werden kann, sondern für unterschiedliche Altersphasen oder Lagen im Lebenslauf zu unterschiedlichen Ergebnissen kommen wird (Lebensspannenperspektive).

Auch wir werden in unserem Kapitel dieses sehr grundlegende Postulat Valentes aufgreifen und uns mit der Gesundheits- und Ungleichheitsrelevanz von Netzwerken aus einer psychologischen wie soziologischen Lebensspannenperspektive beschäftigen. Dabei richten wir ein besonderes Augenmerk auf wechselseitige Interaktionen zwischen Gesundheit, sozialer Ungleichheit und Netzwerken im Kontext biografischer Übergänge, welche den Lebenslauf Erwachsener entscheidend mitprägen (Lang et al. 2006), und fokussieren ausschließlich das junge und mittlere Erwachsenenalter - hier grob definiert als die Alterspanne von etwa 20 bis 60 Jahren. Einen zweiten Schwerpunkt unserer Darstellung wird die Entwicklungspsychologie der Lebensspanne ausmachen (Brandtstädter und Lindenberger 2007), deren konzeptuelles Verständnis von Netzwerken und Gesundheit bislang noch recht wenig Eingang in die Forschung gefunden hat. 
In diesem ersten Kapitel werden wir zunächst die bereits angedeuteten unterschiedlichen disziplinären Perspektiven und Paradigmen einführen, die sich mit dem Thema Netzwerke und gesundheitliche Ungleichheiten in dieser Lebensphase befassen. Hier werden zentrale Begriffe wie Lebenslauf und Transition, Beziehungen und Netzwerk, Gesundheits- und Risikoverhalten sowie soziale und gesundheitliche Ungleichheiten definiert. In Abschn. 2 werden dann Theorien dargestellt, die Wechselwirkungen zwischen den genannten Konzepten beschreiben. Hier legen wir einen Schwerpunkt insbesondere auf sozial- und entwicklungspsychologische Theorien, welche die genannten Konstrukte mit dem Erwachsenenalter als Lebensphase verknüpfen.

In den dann folgenden Abschnitten werden wir den Forschungsstand zu den Zusammenhängen zwischen sozialer und gesundheitlicher Ungleichheit (Abschn. 3), Netzwerken und Gesundheit (Abschn. 4) sowie Ungleichheit, Netzwerken und Gesundheit (Abschn. 5) zusammentragen. Um das junge und mittlere Erwachsenenalter als eigene Lebensphase anschaulich zu thematisieren, gehen wir auf drei Transitionen genauer ein: den Beginn einer festen Partnerschaft, Scheidungs- und Trennungsereignisse sowie den Auszug der Kinder aus dem Elternhaus. Diese biografischen Übergänge sind einerseits typische Übergänge der betrachteten Altersphase, und andererseits gibt es in der Literatur die Sichtweise, dass derartige normative oder nicht-normative Transitionen als vulnerable Zeiten individueller Entwicklung verstanden werden können, in denen mögliche Netzwerkeffekte auf Gesundheit besonders deutlich werden (Lang et al. 2006). Wir schließen mit einem Fazit und den Desiderata für zukünftige Forschung (Abschn. 6).

\subsection{Disziplinäre Perspektiven auf Netzwerke und gesundheitliche Ungleichheiten im jungen und mittleren Erwachsenenalter}

Die Altersspanne des jungen und mittleren Erwachsenenalters gilt aus einer soziologischen Ungleichheitsperspektive heraus seit jeher als eine sehr bedeutsame und dynamische Lebensphase fortwährender individueller Veränderung. Im Altersabschnitt zwischen 20 und 60 Jahren durchläuft der Einzelne verschiedene biografische Übergänge (sogenannte Transitionen wie z. B. Auszug aus dem Elternhaus, Umzüge, Heirat, berufliche Übergänge, Scheidung etc.), die allesamt das Potenzial haben, soziale, psychische und gesundheitliche Unterschiede zu vergrößern oder zu verkleinern. Eine Transition bezeichnet dabei den Wechsel einer Person von einer Lebenslage hin zu einer anderen mit einer markanten 
Vorher-nachher-Distinktion, die meist mit einem definierten Übergang im sozialen Status und/oder der sozialen Identität einhergeht. Solche Transitionen gehen besonders häufig mit Veränderungen in der Struktur und Funktion sozialer Beziehungen und Netzwerke einher.

Auch in der gesundheitswissenschaftlichen Forschung sind Verläufe von subjektiven wie objektiven Gesundheitsunterschieden im jungen und mittleren Erwachsenenalter zunehmend in das Blickfeld geraten. Aus der subjektiven Gesundheitsperspektive fällt die Altersspanne beispielsweise durch den U-förmigen Verlauf der Lebenszufriedenheit und des Wohlbefindens auf - mithin wichtigen Maßen des subjektiven Aspektes von seelischer Gesundheit (Stone et al. 2010). In der Analyse von sieben großen Datensätzen (Office for National Statistics Data für Großbritannien, BRFSS und GSS Data für die USA, Eurobarometer und ESS für Europa, ISSP Data für 45 Länder in sechs Erdteilen, Latino Barometer Data für Mittel- und Südamerika), gewonnen von über 1,3 Mio. TeilnehmerInnen aus der ganzen Welt, fanden Blanchflower und Oswald (2017) in den meisten Populationen eine konstante Abnahme der Lebenszufriedenheit bis hin zum Tiefpunkt zu Beginn der sechsten Lebensdekade, bevor dieses Maß bis zur achten Dekade wieder markant anstieg - auch dann, wenn der Einfluss verschiedener intermittierender Faktoren (z. B. Geschlecht, Bildungsstand, Erwerbsstatus, objektiver Gesundheitsstatus) statistisch kontrolliert wird.

Neben den subjektiven gibt es aber auch eine Reihe objektiver gesundheitlicher Veränderungen, die im Erwachsenenalter meist ab dem Beginn der vierten Lebensdekade stattfinden. Hierzu gehören das allmähliche Nachlassen der Seh- und Hörkraft, der Fertilität, der Verlust an Muskelmasse in der sechsten Lebensdekade sowie der Knochenstabilität. Geschlechtsunterschiede sind für viele dieser Rückgänge evident und Zusammenhänge mit hormonellen Regulationen nachgewiesen. Eine Liste dieser biologisch begründeten objektiven gesundheitlichen Veränderungen findet sich beispielsweise bei Riggs et al. (2008) oder Santrock (2015).

Interessanterweise bildete die Psychologie - hier vor allem die Persönlichkeits- und Entwicklungspsychologie - im Vergleich zu den beiden vorgenannten Disziplinen über viele Jahrzehnte einen gewissen Kontrast in der Betrachtung des jungen und mittleren Erwachsenenalters. Lange Zeit wurde diese Altersspanne als eine Lebensphase betrachtet, die vor allem durch hohe Stabilität individueller Merkmale charakterisiert sei: Es galt das auf William James (1842-1910) zurückgehende Verdikt, die individuelle Persönlichkeit sei mit dem Erreichen der Volljährigkeit quasi „set like plaster“, und es seien kaum noch relevante Veränderungen in Persönlichkeitsunterschieden zu verzeichnen, weder in der Kernpersönlichkeit (wie z. B. Extraversion oder Neurotizismus; Costa und McCrae 1994) noch in anderen gesundheitsbezüglichen Dispositionen des Einzelnen (wie z. B. seelische Gesundheit, Selbstwertgefühl, Depressivität; Becker 2006). 
Seit etwa drei Jahrzehnten wird nun aber auch in der Psychologie die Entwicklungsdynamik des jungen und mittleren Erwachsenenalters als eigenständiger Forschungsgegenstand entdeckt und das "Stabilitäts-Verdikt" hinterfragt (Baltes 1987; Lachman et al. 2015; Roberts und DelVecchio 2000; Specht et al. 2014; Van Dulmen 2013). Insbesondere biografische Transitionen haben nach aktuellem Forschungsstand das Potenzial, auf Persönlichkeitseigenschaften der Individuen differenziell einzuwirken, d. h. auf unterschiedliche psychische Bereiche bzw. Individuen je unterschiedlich. So berichten beispielsweise US-amerikanische Frauen, die zwischen 27 und 43 Jahren einen beruflichen Aufstieg erlebten, durchaus über Persönlichkeitsveränderungen wie etwa eine steigende Selbstwirksamkeit (die Autoren sprechen von agency) und gestiegene Normaffinität (norm adherence) im Vergleich mit Frauen, die derartige Aufstiege nicht erlebt hatten (Roberts 1997). Neyer und Asendorpf (2001) zeigten an einer studentischen Stichprobe, dass diejenigen Teilnehmer, die im Laufe von acht Jahren den Übergang vom Singleleben in eine feste Partnerschaft durchlebten, ihre emotionale Stabilität signifikant erhöhten - unabhängig davon, ob diese Partnerschaft aufrechterhalten wurde oder nicht. In solchen dynamischen Biografie-Persönlichkeits-Transaktionen scheint der Grad der Normativität (d. h. Erwartbarkeit) eines Übergangs ein bedeutsamer Faktor zu sein (siehe für eine Übersicht: Neyer et al. 2014). Durch solche und ähnliche Studien ist nun auch die Frage nach dem Zusammenhang zwischen sozialen Beziehungen, gesundheitsrelevanten Persönlichkeitsmerkmalen und dem individuellen Lebenslauf zu einem Forschungsthema der Psychologie geworden (Klauer und Greve 2005; Knoll und Schwarzer 2005; Weber 2005).

\subsection{Relevante Forschungsparadigmen zu Netzwerken und gesundheitlichen Ungleichheiten im jungen und mittleren Erwachsenenalter}

Der im Folgenden gegebene Überblick über den Forschungsstand zu sozialer Ungleichheit, Netzwerken und Gesundheit im jungen und mittleren Erwachsenenalter wird durch fünf übergreifende und interdisziplinäre Forschungsparadigmen gerahmt. Das erste, ursprünglich soziologische Paradigma des Lebenslaufs (1) (Mayer 2000; in der Psychologie häufig als Psychologie der Lebensspanne bezeichnet: Antonucci et al. 2010; Baltes und Smith 2004) betrachtet soziologische wie psychologische Phänomene in einem direkten konstitutiven Zusammenhang mit dem biologischen Alter, mit der Altersspanne, in der sich Individuen oder Bevölkerungsgruppen befinden, und mit der Sequenz bereits absolvierter bzw. zu absolvierender Übergänge. Das meint, dass 
das Lebensalter und die bisher erlebten Lebensübergänge hier nicht nur als Konkomitanten (begleitende Bedingungen), sondern als direkte Einflussfaktoren auf interessierende Phänomene mit betrachtet werden.

So beschreibt etwa Dragano (2007) die individuelle Abfolge biografischer Transitionen als einen zentralen Bestandteil der individuellen Belastungsbiografie. Diese stellt den biografischen Verlauf der Einwirkung patho- wie salutogener Faktoren dar, zu denen auch Netzwerkveränderungen gehören. In der Psychologie wird ein ähnlicher Ansatz im Ansatz der Kritischen Lebensereignisse verfolgt, in dem direkte und indirekte Belastungswirkungen nach dem Eintreffen unerwarteter oder unerwünschter Übergänge oder Widerfahrnisse erforscht werden (Klauer und Greve 2005). Gleichzeitig nimmt die Bedeutung individueller Bewältigungspotenziale für die Unterschiede in der Gesundheit mit steigendem Lebensalter zu, was die Notwendigkeit der Lebensspannenperspektive für Gesundheit und Netzwerke belegt (Lohaus und Klein-Heßling 2009; Wurm und Tesch-Römer 2005).

Weitere zentrale Paradigmen für dieses Kapitel beschreiben soziale Veränderungen in dieser Altersspanne, wobei entweder die sozialen Beziehungen (2) oder die sozialen Ungleichheiten (3) im Vordergrund stehen. Die meisten Forschungsarbeiten zur Veränderung von sozialen Beziehungen im jungen und mittleren Erwachsenenalter beziehen sich auf die spezifischen Veränderungen in einzelnen Beziehungsdomänen (soziale Bereiche), weniger auf die Veränderung von Netzwerken insgesamt (eine wichtige Ausnahme: Wrzus et al. 2013). Die Metaanalyse von Wrzus et al. (2013) über 243 Primärstudien, die meist im jungen und mittleren Erwachsenenalter die Größe des persönlichen Netzwerks untersuchten, zeigte einen Höhepunkt um das 30. Lebensjahr, zu dem sowohl Netzwerkgröße als auch der relative Anteil nicht-verwandter Personen am ausgeprägtesten sind, um danach kontinuierlich abzunehmen. Darüber hinaus ist zum Lebensspannenverlauf der Unterstützungs- und anderer Netzwerkeffekte im Hinblick auf Gesundheit (siehe Kap. ,Wirkmechanismen in sozialen Netzwerken“) wenig bekannt. Es ist bislang lediglich erforscht, dass Veränderungen in proximalen (d. h. engen, vertrauten) oder intimen Beziehungen (z. B. Liebesbeziehungen) immer mit systematischen Änderungen in den distalen Beziehungen (z. B. Freundes- und Bekanntennetzwerken) korrespondieren, etwa wenn die Auflösung einer Ehe mit dem Verlust des Kontaktes zu solchen Beziehungen des Ex-Partners einhergehen. Inwieweit sich soziale Beziehungen und soziale Ungleichheiten auch in gesundheitliche Ungleichheiten (4) übersetzen, wird in den folgenden Kapiteln erörtert.

Aus der Lebenslauf- oder Lebensspannenforschung ist weiterhin bekannt, dass sich das junge Erwachsenenalter als eine Hochphase des Ausprobierens verschiedener Gesundheits- und Risikoverhaltensweisen (5), aber auch als ein „Weichen-Alter“ für die Konsolidierung längerfristiger Gewohnheiten 
beschreiben lässt (Fooken und Kavšek 2012), deren Ausprägung eng an das erfolgreiche Erledigen phasenspezifischer Entwicklungsaufgaben und Transitionen gebunden ist. Unter Gesundheitsverhaltensweisen werden hierbei Handlungen verstanden, deren gesundheitsförderliche Effekte bekannt sind, wie z. B. eine ausgewogene Ernährung oder regelmäßiger Sport. Das Gegenteil davon sind Risikoverhaltensweisen, wie z. B. Tabak- oder Alkoholkonsum (Knoll et al. 2011). So diskutieren z. B. Sussman et al. (2011), dass gerade das junge Erwachsenenalter ein Risikoalter für gewohnheitsmäßigen Substanzkonsum darstellt und sich Ähnliches auch für andere Risiko- und Gesundheitsverhaltensweisen beobachten lässt. Somit wird gerade das junge Erwachsenenalter aus präventionsorientierter, gesundheitssoziologischer und psychologischer Sicht immer relevanter.

Für das Ende des jungen und mit Beginn des mittleren Erwachsenenalters (d. h. die Jahre um das 40. Lebensjahr herum) lässt sich in der gesundheitspsychologischen und sozialepidemiologischen Literatur ein weiterer Umschwung im individuellen Gesundheitsverhalten beobachten, der in einem markanten Anstieg im subjektiven Interesse an Gesundheits- und eine Aufgabe vieler wenngleich nicht aller - Risikoverhaltensweisen findet (Lachman et al. 2015). Dies wird auf die subjektive und sozial geteilte Wahrnehmung vieler Menschen in dieser Altersphase zurückgeführt, dass die Hochphase der physischen Kraft und Belastbarkeit an ein Ende gelangt und dass für das Bewahren der privaten wie beruflichen Leistungsfähigkeit ein neuer Fokus auf Gesundheit und Wohlbefinden notwendig ist.

Wir werden nun nach einem kurzen Aufgreifen einiger relevanter Theorien den jeweiligen Forschungsstand, das bisherige Wissen über die Zusammenhänge zwischen sozialer und gesundheitlicher Ungleichheit sowie sozialen Netzwerken und Gesundheit referieren. Dabei beziehen wir uns auf die genannten exemplarischen Transitionen des jungen und mittleren Erwachsenenalters als Motoren individueller Entwicklung und gesundheitlicher Ungleichheit.

\section{Spezielle psychologische Theorien der Lebenslauf- und Netzwerkentwicklung im Erwachsenenalter}

Im vorderen Teil dieses Bandes haben die Kapitel „Wirkmechanismen“ (siehe Kap. „Wirkmechanismen in sozialen Netzwerken“) und „Theorien“ (siehe Kap. „Soziale Beziehungen, soziales Kapital und soziale Netzwerke“) bereits wichtige theoretische Modelle vorgestellt, die hier nicht noch einmal wiederholt 
werden sollen. Wir möchten an dieser Stelle einige zusätzliche entwicklungs- und sozialpsychologische Theorien aus der Lebensspannenforschung heranziehen, da diese geeignet sind, den Zusammenhang von Netzwerkentwicklung und biografischen Transition zu plausibilisieren. ${ }^{1}$

Zwei sozial- und entwicklungspsychologische Theorien der Lebensspanne, die einen Zusammenhang von Transition und Beziehungsnetzen (und indirekt auch mit seelischer Gesundheit) im jungen und mittleren Erwachsenenalter beschreiben, sind einerseits die Theorie der Sozioemotionalen Selektivität (SST; Carstensen et al. 1999) und andererseits die Konvoi-Theorie nach Kahn und Antonucci (KT; Kahn und Antonucci 1980; Antonucci et al. 2011). Die Sozioemotionale Selektivitätstheorie geht von grundlegenden Entwicklungsaufgaben (Havighurst 1976) des Individuums aus, die eine Blaupause für die Konstruktion seiner sozialen Beziehungen abgeben. Entwicklungsaufgaben werden der Theorie zufolge durch das Individuum in Abhängigkeit von der subjektiv wahrgenommenen, verbleibenden Lebenszeit gewählt (,selegiert“). Während zu Beginn des Erwachsenenalters aufgrund einer subjektiv relativ „unbegrenzten“ Zukunftsperspektive vor allem Informationen gesammelt werden und Wirksamkeitsziele im Vordergrund stehen (Yeung et al. 2008), werden mit abnehmender subjektiver Lebenszeit Aufgaben der Emotionsregulation immer bedeutsamer. Bindungsmotive stehen dann im Vordergrund. Damit einhergehend werden der Theorie zufolge im jungen Erwachsenenalter tendenziell größere und loser gestrickte Netzwerke konstruiert, während im mittleren Erwachsenenalter persönliche Beziehungsnetze vermehrt derart umgestaltet werden, dass die proximalen (Familien-)Beziehungen intensiviert und distalere, z. B. kürzer bestehende und weniger vertraute Beziehungen, aufgegeben oder reduziert werden.

\footnotetext{
${ }^{1}$ Hier sei noch einmal auf die Abgrenzung von „Netzwerkeffekten“ zur bekannten „SocialSupport-Forschung“ hingewiesen. Während der enge Zusammenhang von wahrgenommener und geleisteter sozialer Unterstützung mit Gesundheit als allgemein bestätigt gelten kann (siehe z. B. die klassischen Meta-Analysen von Schwarzer und Leppin 1989; Smith et al. 1994), wird in der Netzwerkanalyse eine detaillierte Betrachtung der Zusammensetzung und Struktur von Beziehungsgesamtheiten verfolgt. In unsere Literaturrecherche wurden daher nur solche Studien ausgewählt, die konkrete Beziehungen zwischen Individuum und Netzwerkpartnern oder zumindest eine Gewichtung unterschiedlicher Netzwerksektoren (z. B. Familien- vs. Freundeskreise) berichteten. Erst ab dieser Tiefe in der Darstellung werten wir eine Studie als „Netzwerkstudie“ und beziehen sie in die Darstellung ein.
} 
Die Konvoi-Theorie geht wie die SST davon aus, dass Menschen nicht allein durch das Leben gehen, sondern sich fortwährend in einem relevanten Umfeld sozialer Beziehungen bewegen (engl. convoy $=$ Geleitzug). Dieser Convoy of Life gliedert sich der Theorie zufolge in proximale, eher stabile sowie distale, weniger stabile Beziehungen. Dabei konzipieren Antonucci et al. (2011) weniger die Veränderung der subjektiven Gewichtung beider Beziehungsarten über die Lebensspanne, sondern vielmehr eine fortwährende Relevanz beider. Der Unterschied besteht laut dieser Theorie vor allem darin, dass die distalen Beziehungen eher den Lebensumständen nach einem Übergang entsprechend umgebaut und angepasst werden müssen (z. B. indem nach einer Trennung oder einem Umzug neue Freundschaften eingegangen und alte de-intensiviert oder aufgegeben werden), während die proximalen (Kern-)Beziehungen des Netzwerks einen von diversen Transitionen relativ unabhängigen Bestand haben sollten.

Beide Theorien postulieren somit, dass proximale Beziehungen zu Familienmitgliedern und Freunden eher konstant über die Lebensspanne bleiben, während distale Beziehungen mit zunehmendem Alter aus intra-psychischen Gründen abnehmen (SST) bzw. von Lebensereignissen beeinflusst werden (KT). In einer Meta-Analyse zu beiden Ansätzen und der Veränderung der Netzwerkgröße über die Lebensspanne schließen Wrzus et al. (2013), dass sich empirisch Belege für beide Theorien finden lassen, sodass sich die Theorien eher in den zugrunde liegenden Mechanismen als in den Voraussagen zur Größe und Art der Netzwerke unterscheiden. Gleichwohl bleiben beide Netzwerktheorien bezüglich der Entwicklung von gesundheitlicher oder sozialer Ungleichheit defizitär, d. h. sie treffen keine unmittelbaren Vorhersagen hierzu.

Weitere Theorien der Netzwerkentwicklung im Erwachsenenalter sind eher struktureller Art oder fokussieren auf einzelne Domänen (soziale Bereiche). Die strukturorientierte Theorie der unterbrochenen Dyaden (dyadic withdrawal, Johnson und Leslie 1982) beispielsweise nimmt an, dass mit dem Übergang zur Partnerschaft, erst recht der Heirat, Freundesnetzwerke beider PartnerInnen kleiner werden. Hierbei kann es sein, dass verschiedene Dyaden, etwa die Partnerschaft und Freundschaftsbeziehungen, um die Ressourcen der Individuen konkurrieren (competition principle), womit die wachsende Zuwendung zu PartnerInnen oder Kindern Abstriche in den peripheren Beziehungen nach sich zieht. Neben der Konkurrenz sind im Sinne der Heider'schen Balancetheorie (siehe Kap. „Netzwerktheorie(n)“) jedoch auch ausgleichende bzw. harmonisierende Interaktionen von proximalen und distalen Beziehungen denkbar. Mit der Verkleinerung der individuellen Netzwerke gehen dann oft eine Homogenisierung und eine Überlappung der Freundesnetzwerke beider Partner einher (Kalmijn 2003), womit die Konkurrenz bzw. die Aufgabe von Freundesbeziehungen für 
eine Partnerschaft durch Balancierung - etwa die Konstruktion gemeinsamer Netzwerke - aufgefangen werden kann. Derartig verbundene Netzwerke (joint networks) gehören dann zum sozialen Kapital einer Partnerschaft oder Familie. Diese Form des sozialen Kapitals stabilisiert Paarbeziehungen und vertieft auch die Abhängigkeit der PartnerInnen voneinander (Kalmijn und Bernasco 2001). Über diesen Mechanismus können partnerschaftliche Netzwerke, ebenso wie der berufliche Erfolg, Persönlichkeitsmerkmale wie die bereits erwähnte Normaffinität (norm adherence) der PartnerInnen verstärken (Milardo und Allan 2000).

Die Theorie der Beziehungsturbulenz, (relational turbulence, Solomon und Knobloch 2004) zielt darauf ab, dass Transitionen und die mit ihnen einhergehenden Netzwerkveränderungen nicht ohne Auswirkung auf die proximalen Beziehungen - vor allem die Partnerschaft - bleiben. Viele Transitionen oder Ereignisse im Erwachsenenalter können Partnerbeziehungen gefährden, seien es berufliche Schwierigkeiten, ungewollte Kinderlosigkeit oder schwere Erkrankungen (Nagy und Theiss 2013). Derartige Herausforderungen an die Partnerschaft werden dann oft mit der Änderung von Beziehungsskripten (Normen und Routinen) bewältigt, die adaptiv (z. B. gesundheitsförderlich), aber auch maladaptiv (z. B. gesundheitsgefährdend) sein können. Mit der Theorie der Kritischen Lebensereignisse (KLE; Filipp und Aymanns 1987) lässt es sich genauer beschreiben, dass eine zentrale Aufgabe des Erwachsenenalters in der Bewältigung derartiger Turbulenzen und der Aufrechterhaltung einer relativen Stabilität in der Partnerschaft besteht. In der gesundheitswissenschaftlichen und sozialepidemiologischen Lebenslaufforschung wird gesehen, dass sich unbewältigte kritische Lebensereignisse langfristig negativ auf die Gesundheit auswirken können (Steptoe 1998, zit.n. Marmot 2000). Auch diese Theorien sind eher psychologischer Natur, d. h. es fehlt ihnen an Einbettung in den Kontext der Entwicklung gesundheitlicher Ungleichheit. Kritische Lebensereignisse allerdings variieren in Häufigkeit und Schweregrad in Abhängigkeit von der sozialen Herkunft.

Ausgehend von den genannten paradigmatischen Begriffen stehen für uns im Folgenden diejenigen biografischen Übergänge im Vordergrund, an denen die Veränderungen sozialer und gesundheitlicher Ungleichheiten sowie von Netzwerken im Erwachsenenalter illustriert und diskutiert werden können. Exemplarisch werden dafür der Übergang zur Partnerschaft/Heirat, die Scheidung/ Trennung und der Auszug der eigenen Kinder aus dem Elternhaus herausgegriffen. Diese Auswahl wird dadurch begründet, dass einerseits das Wechselspiel soziologischer und psychologischer Effekte gut verdeutlicht werden kann und dass diese Transitionen andererseits erhebliche Auswirkungen auf das Leben und die Gesundheit im Erwachsenenalter haben können. Andere relevante Transitionen des Erwachsenenalters, wie der Übergang in die Erwerbslosigkeit 
(siehe Kap. „Arbeitslosigkeit, soziale Netzwerke und gesundheitliche Ungleichheit") werden an anderen Stellen dieses Bandes behandelt. Während das Eingehen einer Partnerschaft und der Auszug der Kinder normative Transitionen darstellen, die für die Mehrheit der Erwachsenen erwartbar sind, bleibt Scheidung trotz relativ hoher Prävalenzen ein nicht-normatives Ereignis. Damit ist gemeint, dass es sich nicht - anders als die beiden erstgenannten - um einen Übergang handelt, der im individuellen Lebenslauf als fest erwartbar und erwünscht betrachtet werden kann, sondern zumeist als krisenhafte Widerfahrnis und aversiv erlebt wird (Filipp und Aymanns 1987).

\section{Ungleichheit (SES) und Gesundheit}

Der enge Zusammenhang zwischen sozialer und gesundheitlicher Ungleichheit im Erwachsenenalter ist in zahlreichen sozialepidemiologischen Studien aufgezeigt worden (für einen Überblick siehe z. B. Cutler und Lleras-Muney 2010; Hurrelmann und Richter 2013; Mielck 2005). So rauchen bildungsfernere Personen beispielsweise mehr, ernähren sich ungesünder und sterben früher als bildungsnähere (Hoffmann et al. 2018). Es gibt insgesamt eine besonders große gesundheitliche Belastung der unteren Statusgruppen, wobei dieser Effekt interessanterweise in einigen eher egalitären Gesellschaften wie den skandinavischen abgemildert scheint. In einer epidemiologischen Studie mit 1003 norwegischen Personen im mittleren Erwachsenenalter (46,3 Jahre) fanden Dalgard und Håheim (1998) beispielsweise, dass Einkommen keinen signifikanten Einfluss auf die Sterblichkeit im Verlauf von 17 Jahren hatte.

Für den deutschen Epidemiologen Mielck (2005) beispielsweise wird der für viele Länder typische, enge Zusammenhang zwischen sozialer und gesundheitlicher Ungleichheit dadurch erklärt, dass statusniedrige gesellschaftliche Gruppen deshalb weniger gesund sind als statushöhere, weil sie mehr Risiko- und weniger Gesundheitsverhalten zeigen. Zudem seien diese Gruppen statusbedingt mehr biografischen Belastungen (z. B. materiellen Entbehrungen, schlechteren Arbeitsbedingungen) ausgesetzt, erhielten weniger oder ineffektivere soziale Unterstützung und können oft weniger gut von der medizinischen Versorgung oder Vorsorge profitieren. Mit diesen Mechanismen wären etliche der in Abschn. 1.2 bezeichneten Zusammenhänge erklärt. Übertragen auf die biografischen Übergänge während des jungen und mittleren Erwachsenenalters würde dies bedeuten: Statusniedrige Personen erleben in dieser Alterspanne mehr Belastungen, u. a. mehr belastende Transitionen, erhalten bei diesen weniger oder ineffektivere soziale Unterstützung und können zudem bei der Bewältigung wenig gut als 
statushöhere Gruppen von professioneller (z. B. medizinisch-psychologischer) Gesundheitsfürsorge profitieren. Welche Belege lassen sich in der Literatur für diese Annahmen finden?

\section{1 Übergänge in Partnerschaften als Motor von gesundheitlichen Ungleichheiten}

Das vorherrschende Muster des Eingehens und Lösens von Partnerschaften junger Erwachsener in westlichen Industriegesellschaften ist als sequenzielle Monogamie bezeichnet worden (z. B. Morris und Kretzschmar 1995). Das bedeutet, dass sich zumeist mit einem Partner oder einer Partnerin verbunden wird, dabei aber mehrere Partnerschaften unterschiedlicher Dauer aufeinander folgen. Hier lassen sich deutliche interindividuelle Unterschiede darin finden, wann und $o b$ geheiratet oder ob eher unverheiratet als Paar zusammengelebt wird und wie viele Partnerschaften in dieser Altersspanne insgesamt eingegangen werden (Schneider und Rüger 2008). Beide Parameter hängen sowohl mit Ungleichheitsdimensionen wie auch mit Gesundheit zusammen.

Als empirisch gesichert gilt, dass stabile Partnerschaften positive Einflüsse auf das subjektive Wohlbefinden haben (Schütz und Wiesner 2000). Auch für körperliche Erkrankungen stellen sie einen häufig bestätigten Schutzfaktor dar, was insbesondere für Männer zu gelten scheint (healthy-marriage-hypothesis, Carr und Springer 2010; Lillard und Waite 1995; Dalgard und Håheim 1998; Soons et al. 2009). Bei Frauen sind Unterschiede im sexuellen Risikoverhalten zwischen ledigen und verheirateten Personen gefunden worden (Wayment et al. 2003). Somit lässt sich das diesem Abschnitt zugrunde liegende Thema in die Frage übertragen, inwieweit die Stabilität von Partnerschaften geeignet ist, zwischen sozialen und gesundheitlichen Ungleichheiten zu vermitteln.

In der aktuellen Forschung werden signifikante, aber numerisch nicht allzu große Unterschiede im Partnerschaftsverhalten der Bildungsschichten beschrieben: Statusniedrigere Personen heiraten früher als statushöhere, dafür sind ihre Ehen weniger stabil (Schwartz und Han 2014). Dieser Befund ist vor dem Hintergrund unserer Fragestellung dahin gehend interessant, dass häufiger wechselnde Partner als ein Risikofaktor für sexuell übertragbare Erkrankungen beschrieben werden (Millstein et al. 1994). Beide Prozesse (Stabilität und Wechsel) wären demnach geeignet, zu gesundheitlichen Ungleichheiten beizutragen, sofern sich ihre soziale Schichtung weiter belegen ließ. Hierzu gibt es unseres Wissens jedoch keine einheitliche Befundlage (vgl. etwa die widersprüchlichen Ergebnisse bei Kupek 2001; Rissel et al. 2014; Tanfer et al. 1995). 
Trennungen oder Scheidungen hingegen ${ }^{2}$ werden in der Literatur eindeutiger als Gesundheitsrisiko betrachtet, das sich insbesondere durch eine Zunahme von Risikoverhaltensweisen (z. B. Alkohol, Promiskuität) sowie von psychischer Belastung (z. B. geringeres Wohlbefinden, Zunahme von Depressivität) gesundheitlich auswirken kann (Leopold 2018). Dass eine Scheidung insbesondere dann zu psychologischem Stress und Anpassungsschwierigkeiten führt, wenn wahrgenommene ökonomische Ressourcen für ihre Bewältigung unzureichend sind, kann eine jüngere iranische Studie mit 800 geschiedenen Frauen (Durchschnittalter 38,8 Jahre, 1 - 2 Jahre nach der formalen Scheidung) zeigen (Esmaeili et al. 2015). In den Ergebnissen der querschnittlichen Regressionsanalyse erklärten Bildungsjahre (beta $=-.05$ ), Kinderzahl $($ beta $=.45)$ und geringer ökonomischer Status (beta $=.46)$ multivariat $63.6 \%$ der Varianz in der psychischen Symptomatik der Frauen. Hier gehen soziale und gesundheitliche Ungleichheiten Hand in Hand.

\subsection{Empty nest}

Einen weiteren biografischen Übergang im Erwachsenenalter stellt der Auszug der Kinder aus dem Elternhaus dar. Hierfür hat sich in der Forschung der Begriff der „empty nest-Situation“ eingebürgert ${ }^{3}$. Es ist schon längere Zeit bekannt, dass die Mehrheit der Eltern diesen Übergang ohne schwerwiegende emotionale, gesundheitliche oder ökonomische Probleme bewältigt (Harkins 1978), was auch ein Effekt des historisch veränderten Kindernutzens ist. Kinder, die in industrialisierten Wohlfahrtsgesellschaften das Elternhaus verlassen, entziehen diesem kaum noch ihre Arbeitskraft, und emotionale Nähe lässt sich auch nach dem Auszug herstellen - oft sogar besser als vorher (Papastefanu 2000).

Soziale Unterschiede werden deshalb nur dort mit dem Auszug der Kinder assoziiert, wo die Kinder mehr als emotionalen Nutzen für die Familie haben.

\footnotetext{
${ }^{2}$ Wir machen im Folgenden keinen Unterschied zwischen der Trennung verheirateter oder unverheirateter Paare oder zwischen dem Übergang zur faktischen Trennung vs. der rechtlichen Scheidung eines verheirateten Paares, und nutzen der Einfachheit halber nur den Begriff der Scheidung.

${ }^{3}$ In der Lebenslaufforschung herrscht Uneinigkeit, wie diese Transition korrekt benannt werden sollte. Einerseits ist das Familiennest nach dem Auszug der Kinder nicht „leer“, andererseits hören auch die Eltern mit dem Auszug ihrer Kinder nicht auf, Eltern zu sein (postparental period). Für eine Übersicht siehe Bouchard (2014).
} 
Dies betrifft insbesondere traditionelle und rurale Gesellschaften und ärmere soziale Schichten in industrialisierten Gesellschaften. Besondere Relevanz hat die empty nest-Situation daher beispielsweise in China, wo sie auch breit diskutiert wird (Wan et al. 2008). Dort sind Kinder nach wie vor eine wesentliche Quelle der Unterstützung Älterer und damit ihrer Gesundheit. Als Folge der jahrzehntelang verfolgten Ein-Kind-Politik und kaum vorhandener Wohlfahrt müssen zwei erwerbstätige Erwachsene die Kosten für vier Ältere und ein Kind erwirtschaften (eine sogenannte 4-2-1-Familienkonstellation; Wan et al. 2008). Darüber hinaus macht die massenhafte Abwanderung erwachsener Kinder in die Städte vor allem das Alter auf dem Lande zu einem gesundheitlichen Hochrisiko (Liu und Guo 2008).

In stärker industrialisierten Ländern hat sich hingegen der Zeitpunkt des Auszuges nicht nur nach hinten verlagert (Beaupré et al. 2006); es wird auch der Wiedereinzug erwachsener Kinder zunehmend diskutiert. In „crowded nests“ wohnen erwachsene Kinder neben ihren Eltern, wenn die Kinder beispielsweise aufgrund abnehmender Reallöhne oder zyklischer Wirtschaftskrisen nicht genug Ressourcen haben, einen eigenen Haushalt zu gründen. Hier treffen die „Boomers“ auf die „Boomerangers“" . Für Europa liegen hierzu nur wenige Daten vor, die jedoch zeigen, dass es neben kulturellen auch sozioökonomische Faktoren zu geben scheint, die einen Wiedereinzug erwachsener Kinder in das Elternhaus und verlängerten Elternnutzen wahrscheinlicher machen (Kleinepier et al. 2017). Sowohl Auszüge als auch Gründungen eigener Haushalte werden in Industriegesellschaften mit hoher Jugendarbeitslosigkeit und/oder hohen Heiratshürden zunehmend problematisch (Mínguez 2016; South und Lei 2015). Das Zusammenleben mit erwachsenen Kindern scheint der Lebenszufriedenheit wiederum eher abträglich zu sein und einen relevanten psychischen Stressor darzustellen (Pollmann-Schult 2011). Hier soll nur festgehalten werden, dass sozioökonomischer Wandel und finanzielle Ressourcen das Timing und die Art der Übergänge nachhaltig beeinflussen. Damit wird ein weiterer Mechanismus deutlich, über den sich soziale auf die gesundheitliche Ungleichheit auswirken kann.

\footnotetext{
${ }^{4}$ Dieses im angelsächsischen Sprachraum gebräuchliche Wortspiel meint, dass die Eltern aus der Baby-Boomer-Generation (in Deutschland die Mitte der 1950er bis Ende der 1960er Jahre geborenen Personen) ihre Kinder zunehmend häufiger und länger im elterlichen Haushalt behalten, oft als „Rückkehrer“ (boomerang) nach fehlgeschlagenen Auszugsversuchen.
} 


\section{$4 \quad$ Netzwerke und Gesundheit}

\subsection{Partnerschaftsübergänge als Motor von Netzwerkeffekten auf Gesundheit}

Weder das Eingehen noch das Auflösen von Partnerschaft findet außerhalb sozialer Kontexte oder auf einer „Insel“ statt. Diese Metapher wird in den grundlegenden Arbeiten von Felmlee (2001) und Sprecher et al. (2006) zur Bedeutung sozialer Netzwerke für Partnerschaften herangezogen. Die Autoren beschreiben mindestens drei grundlegende Mechanismen, über die soziale Beziehungsnetze auf partnerschaftliche Übergänge einwirken können. Zum einen stellen Netzwerke Möglichkeiten für das Kennenlernen von potenziellen Partnern dar und bestimmen somit durch ihre Zusammensetzung sowie Struktur die Wahrscheinlichkeit für das Eingehen einer Partnerschaft oder sexuellen Beziehung. Zum zweiten treffen Individuen in ihren Netzwerken stets auch auf unterschiedliche Ausmaße an Anerkennung vs. Ablehnung ihres partnerschaftlichen Handelns (z. B. Partnerwahl, Heirat, Trennung), wodurch der fragliche Übergang für das Individuum in unterschiedlichem Ausmaß auch wahrscheinlicher bzw. sozial unterstützt wird. Drittens stellen Netzwerke immer auch mehr oder weniger attraktive Beziehungsalternativen zur Verfügung und ver(un)wahrscheinlichen damit partiell eine Trennung - was sich dann wiederum auf individuelle gesundheitliche Merkmale auswirken kann.

In ihrer Darstellung des diesbezüglichen Forschungsstandes schließen Sprecher et al. (2006), dass unterstützende (approving) soziale Netzwerke als förderlich für das Eingehen und die Stabilität von Paarbeziehungen angesehen werden können und dass umgekehrt eine Scheidung oder Trennung mit einer signifikanten Abnahme des Verwandten- und Verheirateten-Anteils im Netzwerk sowie der Zunahme des Kollegen- und Singleanteils einhergeht. Aber nicht nur die Zusammensetzung, auch die Struktur des Netzwerkes scheint mit Paarstabilität einherzugehen, wie eine Arbeit von Widmer et al. (2004) zeigt: Paare mit individualisierten (individualized) oder sich einmischenden (interfering) Netzwerken berichteten über eine signifikant geringere Paarzufriedenheit sowie stärkere Trennungsgedanken als Paare mit überlappenden (overlapping) Netzwerken. Erste Pilotstudien zu diesem wichtigen Zusammenhang von Netzwerk und Paarstabilität und -zufriedenheit finden sich bereits z. B. bei Milardo (1989), Levitt et al. (1986), Hansen et al. (1991) oder Burger und Milardo (1995). Die Studie von Veiel et al. (1991) zeigte beispielsweise, dass sowohl die Ähnlichkeit als auch die Überlappung des partnerschaftlichen Netzwerks für die Bewältigung belastender Anforderungen funktional sein kann. 
Aber auch jenseits des Stabilitätseffektes sozialer Netzwerke finden sich in der Literatur Hinweise auf die direkte gesundheitliche Bedeutung nach einer erfolgten Scheidung. Die frühe Längsschnittstudie von Hughes et al. (1993) befragte 29 alleinerziehende US-Amerikanerinnen drei sowie acht Monate nach der juristischen Scheidung zu ihren Netzwerken und ihrer psychischen Gesundheit. Im zeitlichen Umfeld der Scheidung wurde über eine hohe Dynamik in den Freundesbeziehungen berichtet: Bereits in den Monaten um den Zeitpunkt der Scheidung herum waren den Studienteilnehmerinnen im Schnitt knapp fünf Freunde verloren gegangen, bis zum zweiten Interview waren es noch einmal vier weitere Freunde. Gleichzeitig kamen in diesem Zeitraum circa fünf neue Freunde dazu. Während die Anzahl der Unterstützungsleister im Netzwerk beim ersten sowie zweiten Interview meist positiv mit der psychischen Gesundheit beim zweiten Interview zusammenhing, sagte ein hoher Eltern- und geringer Freundes- sowie Geschwisteranteil im Netzwerk eher Anpassungsschwierigkeiten und eine geringere seelische Gesundheit bei den alleinerziehenden Frauen voraus. Auch die Ergebnisse von Stone (2002) zeigen anhand der Zusammensetzungs- und Unterstützungsmaße der Netzwerke von 101 geschiedenen Vätern, dass seelische Gesundheit positiv mit den nach der Scheidung neu ins Netzwerk hinzugekommenen Vertrauten und ihrer Unterstützung zusammenhängt.

Einen weiteren Zusammenhang zwischen der Zusammensetzung der sozialen Netzwerke und depressiven Symptomen nach einer Scheidung berichten Kincaid und Caldwell (1991). In ihrer Analyse von 56 geschiedenen Personen aus der Milwaukee Family Study zeigte sich, dass insbesondere diejenigen Personen, die die Scheidung selbst nicht initiiert hatten, von einem höheren Verwandtenanteil im Netzwerk zu profitieren schienen, indem sie signifikant geringere Depressionswerte berichteten. Bei den scheidungsinitiierenden Personen war der Zusammenhang schwach gegenläufig im Sinne eher marginal höheren Depressivität bei höherem Verwandtenanteil im Netz.

Die Ergebnisse in Bezug auf die sozialen Netzwerke von Geschiedenen sowie ihre Gesundheitseffekte sind also weiter uneinheitlich, was in der Literatur durchaus gesehen und diskutiert wird (Ertel et al. 2009; Kalmijn et al. 2005). Hier liegt ein vielversprechendes Feld für zukünftige Forschung.

Einen einzigartigen Einblick in den Zusammenhang von partnerschaftlichen Netzwerken und seelischer Gesundheit liefert die Studie von Murphy et al. (1998). Hier ging es um die Bewältigung eines anderen und seltenen traumatischen Familienübergangs, nämlich des gewaltsamen Todes des eigenen Kindes in dessen Jugend- oder jungen Erwachsenenalter. Die Daten von 261 trauernden Elternteilen zeigen, dass sich vertrauensvolle und unterstützende Netzwerkbeziehungen tendenziell positiv im Sinne einer geringeren psychischen und physischen Symptomatik sowie einer höheren Partnerschaftszufriedenheit auswirkten. 


\subsection{Empty-Nest als Motor von Netzwerkeffekten auf Gesundheit}

Kinder spielen in den Netzwerken von Eltern eine nicht unerhebliche Rolle für deren Gesundheit, wenn auch nicht klar ist, in welcher Funktion. Eltern partizipieren stärker als Kinderlose an der Gesellschaft, ob bürgerschaftlich, politisch oder religiös. Dieser „Kinder-Effekt“ geht mit dem Auszug derselben aus dem Elternhaus größtenteils verloren (Pollmann-Schult 2011). Die Eltern-KindDyaden werden mit dem Auszug der Kinder aber meist nicht unterbrochen, sondern auf andere Kommunikationskanäle verschoben. US-amerikanische Eltern beispielsweise erhöhten ihre elektronische Kommunikation mit den Kindern, nachdem diese ausgezogen waren für etwa zwei Jahre (Tanis et al. 2017). Vorläufer depressiver Erkrankungen, wie Gefühle der Einsamkeit und des Verlassenseins, konnten so erfolgreich reduziert werden. In einer chinesischen Studie wurde gezeigt, dass diese elektronische Art der Kommunikation für Ältere weniger befriedigend ist als die direkte Interaktion (Sun et al. 2016) - was allerdings wiederum von der Erreichbarkeit der Kinder abhing. Sind Kinder räumlich für den direkten Kontakt erreichbar, wird die digitale Kommunikation als weniger befriedigend empfunden.

Im Hinblick auf das erweiterte Netzwerk konnte Kalmijn (2003) für die Niederlande zeigen, dass sowohl die Anzahl der Freunde von Eltern als auch die Intensität des Kontaktes mit ihnen am geringsten ist, wenn die Kinder ausziehen. Allerdings spielte für diesen Effekt wahrscheinlich auch das Alter der Befragten eine Rolle, das in dieser Untersuchung nicht kontrolliert wurde. Verglichen mit dem Gründen eines gemeinsamen Haushalts, der eine sprunghafte Verkleinerung der Freundesnetzwerke zur Folge hatte, war der Auszug der Kinder aus dem Elternhaus für das Netzwerk weniger bedeutend. Wird jedoch der Anteil gemeinsamer Freunde beider Eltern betrachtet, hat das leere Nest einen eigenständigen Effekt. Die über die Lebensspanne kontinuierlich zunehmende Verflechtung der Freundesnetzwerke beider Eltern erfährt eine sichtbare Steigerung, sobald die Kinder das Elternhaus verlassen. Dabei schöpfen die Eltern aus dem Pool der sogenannten asymmetrischen Freundschaften, das heißt, es werden insbesondere solche Freunde in das gemeinsame Netzwerk aufgenommen, die vom Partner vor der Transition als Freunde des anderen benannt wurden - aber nicht von den Betroffenen (Kalmijn 2003). Direkte Effekte auf Gesundheit oder Partnerschaftszufriedenheit wurden in dieser Studie nicht berichtet.

Ein Mechanismus, über den das leere Nest mit Netzwerken und Gesundheit wechselwirken kann, führt über die Beeinflussung der elterlichen Partnerschaft. Wenn es im Sinne des Turbulenzmodells (siehe Abschn. 2) nicht gelingt, 
die elterliche Beziehung für diese Phase gewissermaßen „,neu zu erfinden“, beispielsweise in Form gemeinsamer Zeit mit dem partnerschaftlichen Netzwerk, werden Konflikte und Trennungen wahrscheinlicher. Auch die allgemein mit Scheidungen verbundenen ökonomischen Risiken werden durch den Zeitpunkt der Trennung moderiert, da mit zunehmenden Alter die Wahrscheinlichkeiten für Neuorientierungen, sei es auf dem Partner- oder dem Arbeitsmarkt, geringer werden. In Partnerbeziehungen kann der Auszug der Kinder deshalb Ängste vor Abhängigkeit generieren, insbesondere bei Frauen (Nagy und Theiss 2013), die offenbar dann stärker wirken können, wenn das Netzwerk wenig unterstützt. Zum direkten Einfluss dieser Effekte auf objektive Gesundheitsmaße liegen bislang allerdings keine Studien vor.

\section{$5 \quad$ Ungleichheit, Netzwerke und Gesundheit}

Während es für den Zusammenhang von sozialer Ungleichheit, wahrgenommener sozialer Unterstützung und Gesundheit zumindest einige Studien gibt, sind Arbeiten mit eigentlichen Netzwerkparametern seltener. Wir müssen daher unseren Fokus auf Partnerschaftsübergänge und Empty-Nest-Situation im jungen und mittleren Erwachsenenalter an dieser Stelle aufgeben (mit Ausnahme einiger Scheidungsfolgestudien am Ende dieses Abschnitts), um dennoch einige Studien berichten zu können.

Insgesamt ist vorwegnehmend bereits festzustellen, dass die überwiegende Zahl der Studien zu den interessierenden Zusammenhängen methodisch entweder einen Moderator- oder einen Mediatoransatz verfolgt. Während Mediatoranalysen einen eigenständigen Zusammenhang von sozialen Ungleichheiten (im Folgenden häufig mit SES abgekürzt für socio-economic status) mit sozialen Netzwerken annehmen, so ist dies bei Moderatormodellen nicht notwendig. Abb. 1 stellt diese beiden unterschiedlichen Ansätze, die auch in vielen anderen Beiträgen dieses Bandes thematisiert werden, grafisch dar.

Einen Mediatoreffekt von sozialen Netzwerken auf den Zusammenhang zwischen sozialer und gesundheitlicher Ungleichheit fand die Studie von Rubin et al. (2016). Hier hatten 316 australische Studierende im ersten Semester zunächst ihren SES anhand einer Skala entlang von Geld, Bildung und Berufstätigkeit im Vergleich mit anderen Menschen in Australien einzuschätzen. Dann beurteilten sie ihre mentale Gesundheit mit der Depression Anxiety Stress Scale und einer angepassten Version der Satisfaction with Life Scale sowie ihr soziales Netzwerk anhand der Anzahl aktueller Freunde an der Universität und der Häufigkeit 

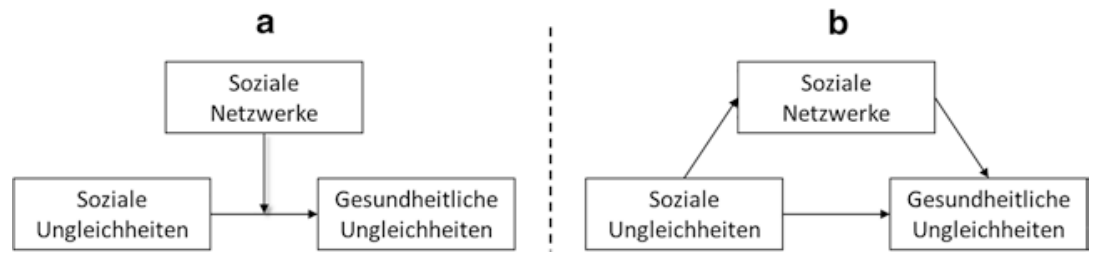

Abb. 1 Typische Designs von Moderator (a)- und Mediator (b)-Analysen zum Zusammenhang von SES, Netzwerken und Gesundheit. (Quelle: Eigene Darstellung)

der wöchentlichen Kommunikation mit diesen. Über einen kurzen Längsschnitt von einem Jahr fand sich zunächst der erwartete Effekt von initialem SES auf Gesundheitsmaße ein Jahr später, der partiell durch das individuelle Ausmaß sozialer Netzwerke mediiert wurde.

Cable et al. (2013) ermittelten dieselbe Mediation mithilfe von 3000 Teilnehmern der englischen NCDS-Studie. Als SES-Maß nutzte diese Studie die Bildung in Jahren. Für die Messung der Gesundheit wurde ein Mental Health-Inventar eingesetzt, während netzwerkseitig die Zahl der engen Familienmitglieder sowie die Zahl der Freunde erhoben wurde. Geringer gebildete Personen zeigten geringere Werte in seelischer Gesundheit und darüber hinaus größere Familienund kleinere Freundesnetzwerke. In der Mediationsanalyse konnten die Autoren einen eigenständigen Effekt dieser Netzwerkmaße auf die seelische Gesundheit zeigen: bei Männern wirkten sich größere Netzwerke (unabhängig vom Netzwerkbereich), bei Frauen lediglich Freundessektoren partiell mediierend auf den Zusammenhang von SES und Gesundheit aus.

Einen ähnlichen Mediationseffekt für soziale Netzwerke konnten Vonneilich et al. (2012) im Längsschnitt mit einer westdeutschen Stichprobe am Ende des mittleren Erwachsenenalters $(n=4146$ Teilnehmer; Mage =58,8 Jahre zum 2. Zeitpunkt des 5-Jahres-Längsschnitts) quantitativ beziffern. Die prospektiven und signifikante Effekte von Bildung, Einkommen und Berufsstatus auf den subjektiven Gesundheitsstatus der Teilnehmer reduzierten sich durch die Hinzunahme eines zusammengesetzten Indexes für die soziale Einbettung (SII nach Berkman, bestehend aus drei Indizes für die Anzahl enger Beziehungen, die Einbindung in Vereine oder anderen Gruppen sowie den Familienstand) signifikant. Dabei beliefen sich diese signifikanten Reduktionen der direkten Effekte durch die Hinzunahme des SII (plus zwei weiterer Unterstützungsmaße) bei der Gesamtstichprobe auf 19,0 \% für den Effekt von Bildung auf Gesundheit, auf 21,1\% für 
Berufsstatus und auf 26,6 \% für Einkommen. Die Autoren schließen zusammenfassend, dass die Ergebnisse einen deutlichen Hinweis auf die mediierende Wirkung sozialer Netzwerke für den Einfluss sozialer Ungleichheits- auf Gesundheitsvariablen darstellen.

Chappell und Funk (2010) wiederum konnten in einer Studie mit 916 kanadischen Teilnehmern einer Disadvantage Study diese Mediation in Bezug auf allgemeine Gesundheitsmaße jedoch nicht finden. Ungleichheit wurde hier über Einkommen und Bildung gemessen, Gesundheit über die RAND Health Survey Scale und Netzwerke über die egozentrierte Netzgröße sowie die Anzahl sozialer Vereine, in denen sich die Teilnehmer engagierten. In der Analyse zeigte sich der erwartete Effekt von Einkommen auf den Health Status, Netzwerkmaße trugen jedoch an keiner Stelle zu den statistischen Modellen der Analyse signifikant bei (keine Mediation).

\subsection{Scheidung, SES, Netzwerke und Gesundheit}

Die Studie von Steptoe und Marmot (2003) mit den Whitehall-2-Daten (227 Teilnehmer zwischen 47 und 59 Jahre alt) untersuchte den möglichen Zusammenhang zwischen SES, Scheidung, Netzwerken und Gesundheit sowie Gesundheitsverhalten. Ein aus den Indikatoren Netzwerkgröße, emotionale Unterstützung, berufliche, finanzielle und nachbarschaftliche Belastungen sowie persönliche Bewältigungsstile zusammengesetzter psychosozialer Belastungsindikator (PAVIX; hohe Werte stehen für die jeweiligen Risikoausprägungen der Indikatoren, wobei eine geringe Netzwerkgröße als Risikoausprägung gewertet wird) korrelierte zunächst negativ mit SES. Ein geringerer SES ging mit höheren psychosozialen Belastungen einher - ganz wie bereits in Abschn. 3 anhand der Studien von Mielck und anderen beschrieben wurde. Auch zeigten sich - analog der bereits berichteten "healthy-marriage-hypothesis“ - verheiratete Personen hinsichtlich dieser Indikatoren signifikant unbelasteter als nicht verheiratete (darunter auch Geschiedene). In einem Regressionsmodell, das all diese Maße für die Erklärung gesundheitlicher Indikatoren (z. B. Depression, Schlafstörungen, Hoffnungslosigkeit, subjektives Gesundheitsgefühl etc.) nutzte, verblieb nur noch der PAVIX als signifikanter Prädiktor. Weder SES noch der Familienstand sagten die Gesundheitsmaße nach Einschluss des PAVIX vorher. Dieselben Ergebnisse zeigten sich auch bei physiologischen Gesundheitsmaßen, nicht aber beim Gesundheitsverhalten selbst. Diese Befunde ließen sich als eine vollständige Mediation der bekannten Gesundheitseffekten von SES und Familienstand durch soziale (Netzwerk-)Ressourcen interpretieren, was von den Autoren 
als ein Argument für die Stärkung dieser Aspekte in der zukünftigen Gesundheitsforschung und -praxis gewertet wurde.

In einer niederländischen Studie (Terhell et al. 2004) konnten die persönlichen Netzwerke von 104 geschiedenen Männern und Frauen über einen Zeitraum von insgesamt durchschnittlich 11,7 Jahren beobachtet werden (von 4,2 Monaten [T1] und 1,1 Jahren [T2] bis 12,1 Jahren [T3] nach der Scheidung). Zusätzlich wurde retrospektiv nach dem Jahr vor der Scheidung [T0] gefragt. Die Autoren unterschieden clusteranalytisch vier verschiedene Muster der Netzwerkveränderungen in ihrer Stichprobe: eine signifikante und dauerhafte Verkleinerung des Netzwerks über alle Zeitpunkte hinweg (38,5\% der Befragten) eine Verkleinerung des Netzwerks im Jahr nach der Scheidung mit nachfolgender Erholung fast auf das Ausgangsniveau (28,8 \%) eine kurzfristige Erhöhung der Netzwerkgröße im Jahr nach der Scheidung mit nachfolgendem Absinken unter das Ausgangsniveau $(14,4 \%)$ sowie eine signifikanten und dauerhafte Vergrößerung des Netzwerks über alle Zeitpunkte hinweg (15,4\%). Interessant an den Ergebnissen dieser Studie für unsere Frage ist, dass sich weder Bildung noch seelische Gesundheit (operationalisiert über den Selbstwert und emotionale Stabilität) signifikant zwischen diesen vier Mustern unterschieden, sondern lediglich Geschlecht, Alter und Scheidungsmerkmale signifikant zwischen den Mustern differenzierten.

$\mathrm{Zu}$ etwas anderen Ergebnissen gelangen Symoens et al. (2014) mit Daten des European Social Survey (ESS3, $n=18.376$ jemals verheiratete 25- bis 60-Jährige). Symoens und Kollegen finden zunächst die erwarteten Unterschiede in seelischer Gesundheit zwischen Geschiedenen und Verheirateten $(d=0.28$, $p<.001$ ), können aber zeigen, dass diese Unterschiede sich halbieren, wenn die „Netzwerkmaße“ in die Regressionen einbezogen werden. Bildungsjahre als Indikator für den SES haben bereits einen Haupteffekt auf Depressivität (keine Daten in der Primärstudie berichtet), machen aber auch unter Einbezug der „Netzwerkmaße“ einen signifikanten Unterschied (beta $=-.26, p<.001$, in einer multiplen Regression von Depressivität auf verschiedene unabhängige Variablen). Für die seelische Gesundheit nach einer Scheidung scheinen somit Bildung und soziale Bindung gewichtige moderierende Faktoren zu sein: „The benefits of having a confidant and of regular social contact in terms of depressive feelings are also more pronounced in the divorced than in the continuously married population“ (S. 208). Auch wenn sich die dort betrachteten „Netzwerkmaße“ lediglich auf die subjektive Einschätzung der Einbettung in nachbarschaftliche Kontakte (,how close the respondent feels to people in the local area“, S. 203) sowie die Häufigkeit der Treffen mit Freunden, Verwandten oder Kollegen beziehen (,how often the respondent meets with friends, relatives, or colleagues", S. 203), so sind dies doch relevante Aspekte sozialer Netzwerke, die zum einen über die 
üblichen Supportfragen hinausweisen und zum anderen interessante ModeratorEffekte in Bezug auf sozioökonomischen Status und seelische Gesundheit zeigen.

\section{$6 \quad$ Fazit und Desiderata}

Die referierten Studien zeigen, dass es einerseits in der Forschung das Bemühen gibt, die black box „Netzwerke“ in ihrer Bedeutung für gesundheitliche Ungleichheiten genauer zu entschlüsseln, dass andererseits jedoch über die basale Unterscheidung von wahrgenommener Unterstützung oder der Größe von Familien- oder Freundschaftssektoren hinaus noch erheblicher Forschungsbedarf besteht. Es zeigte sich bislang kein einheitliches Bild zum Zusammenhang zwischen sozialen und gesundheitlichen Ungleichheiten sowie sozialen Netzwerke oder Transitionen im jungen und mittleren Erwachsenenalter.

Überwiegend bezieht sich die aktuelle empirische Forschung hierzu auf die oben in Abb. 1 skizzierten Moderator- oder Mediatormodelle. Dies erscheint uns auch vor dem Hintergrund der einleitenden Netzwerktheorien - als ein lohnenswerter und theoretisch gerechtfertigter Forschungsansatz, den es weiter zu verfolgen gilt. Denn in den meisten Theorien erfüllen Netzwerke genau dann ihre besten Aufgaben, wenn sie aus den passenden Netzwerkpartnern und -strukturen für eine spezifische Lebensphase oder Transition bestehen. Es lässt sich annehmen, dass womöglich diese Lebensphasen/Übergangs-Netzwerk-Passung den Ausschlag für das Eintreten (oder das Ausbleiben) gesundheitsförderlicher Effekte bildet. Einige Studien zeigten bereits, dass beispielsweise Freundes- oder Familiensektoren des Netzwerks ganz unterschiedliche Wirkungen auf Gesundheit haben können. Diese sektoralen Effekte gilt es weiter zu präzisieren und zu beforschen.

Dabei scheint die gesundheitliche Dynamik des Erwachsenenalters der Forschungsliteratur zufolge insgesamt weniger stark von eher langsamen biologischen Veränderungen herzurühren als aus einer Vielzahl zu bewältigender Übergänge, die sowohl mit ökonomischen (Ungleichheit) als auch sozialen Risiken (z. B. Netzwerkverkleinerung) verknüpft sind. In der Entwicklungspsychologie gibt es dazu eine Anzahl spezifischer Arbeiten, jedoch nur wenige übergreifende Theorien, die geeignet sind, diese Lebensphase als Ganzes zu beschreiben. Sowohl die Theorie der sozioemotionalen Selektivität als auch die Konvoi-Theorie (siehe Abschn. 2) gehen aber von einer übergreifenden Entwicklungsaufgabe aus - der Konstruktion von Lebensphasen-adäquaten sozialen Netzwerken. Das Gelingen dieser Konstruktion würde den Theorien zufolge eher mit einer günstigeren 
Prognose für (nicht nur seelische) Gesundheit einhergehen; das Misslingen eher mit einer ungünstigeren Prognose (z. B. Einsamkeit, schwache Unterstützung etc.). Ungleichheitsdimensionen werden hier allerdings oftmals nicht ausreichend berücksichtigt, ebenso wenig wie die Netzwerke hinreichend genau beschrieben werden.

Optimistisch für die weitere Forschung stimmt uns, dass die fraglichen Zusammenhäng in ihrer Komplexität zunehmend gesehen werden. So betonen Alwin et al. (2018a) in der Einleitung des aktuellen Bandes zu „Social Networks and the Life Course“, dass ,the understanding of social networks can improve the understanding of the life course, and vice versa." (S. 4). Dass diese wechselseitige Befruchtung auch Implikationen für gesundheitliche Ungleichheiten aufweist, wird jedoch nicht thematisiert. In der fast zeitgleich erschienenen Einleitung des Bandes „Life Course Health Development“ stellen Halfon et al. (2018a) das ,emerging field of life course health development“" (S. 2) vor, in dem wiederum gesundheitliche Ungleichheiten, nicht jedoch soziale Beziehungskontexte Erwähnung finden. Der Dreiklang aus Lebenslauf, Beziehungsnetzen und gesundheitlichen Ungleichheiten stellt somit eine logische Weiterentwicklung vorliegenden Wissens dar.

Studien, die diese komplexe Dynamik im Erwachsenenalter abbilden könnten, sollten daher verschiedenen Anforderungen genügen, von denen hier einige aufgelistet werden. Wir beginnen mit sieben methodischen Anforderungen, um dann auf die besprochenen Transitionen einzugehen.

1. Grundsätzlich ist zu bemängeln, dass sich kaum eine der vorgestellten Studien auf eine der hier ebenfalls vorgestellten Theorien bezieht. Jede der eingangs vorgestellten entwicklungspsychologischen Theorien hat unserer Meinung nach das Potenzial, Hypothesen bezüglich der diskutierten Zusammenhänge zu generieren. Alle Entwicklungstheorien sind ihrerseits in ein bio-psycho-soziales Modell eingebettet, in dem komplexe kausale Zusammenhänge gelten.

2. Daraus ergibt sich für uns, dass die Studien interdisziplinär in der Anlage sein sollten. Dabei gilt, dass alle Faktoren - auch biologische - veränderlich sein können und dementsprechend modelliert werden sollten. Beispielsweise sollten die Stichproben groß genug sein, um auch seltenere phasenspezifische gesundheitliche Übergänge (etwa Ansteckungen mit sexuell übertragbaren Krankheiten, etwa nach der Trennung einer Partnerschaft) so modellieren zu können, dass sich prämorbide oder distale Faktoren (z. B. Netzwerkveränderungen) hinreichend (im Vergleich zu getrennten Erwachsenen ohne Infektion) modellieren lassen. Hier ist die Zusammenarbeit von SoziologInnen und MedizinerInnen (ideal: wiederholte Reihenuntersuchungen) vonnöten. Bei der Planung der Messintervalle ist zu berücksichtigen, dass einige Faktoren in der Zeit nicht 
unmittelbar wirken, sondern ihre Wirkung erst nach einer gewissen Dauer entfalten. Beispielsweise wirkt sich allostatischer Stress durch den Verlust sozialer Beziehungen erst nach einiger Zeit und in Abhängigkeit von individuellen Bewältigungsmustern und Opportunitäten (etwa Nachbarschaftseffekte) aus.

3. Die Studien sollten vermehrt längsschnittlich angelegt sein, da nur auf diese Weise kausale Mechanismen im Zusammenhang von Ungleichheit, Netzwerk, Transition und Gesundheit analysiert werden können. Fragestellungen sollten grundsätzlich bidirektional und komplex gestellt werden, z. B. ob schlechte körperliche Gesundheit die Zugehörigkeit zu einer niedrigeren Einkommensklasse prädiziert oder vice versa. Netzwerke können in komplexen längsschnittlichen Modellen sowohl als Ursachen, Moderatoren oder Mediatoren, aber auch als abhängige Variable betrachtet werden.

4. Die Stichproben sollten groß genug sein, um ausreichend Varianz sowohl auf den Ungleichheitsdimensionen als auch in der Netzwerkentwicklung abbilden zu können. Proximale Faktoren, wie konstitutionelle physische Ressourcen ${ }^{5}$, Gesundheitsverhalten, Persönlichkeit oder elterliche Erziehungspraktiken erklären große Teile gesundheitlicher Ungleichheit, womit für den Nachweis der Wirkung eher distaler Faktoren Stichproben erforderlich sind, die MehrEbenen-Analysen erlauben. Um beispielsweise Einflüsse des Netzwerkes von denen sozialer Ungleichheit zu trennen, sind große Stichproben innerhalb einer Einkommensgruppe nötig, in denen die Netzwerkparameter hinreichend variieren, wobei andere Einflüsse kontrolliert werden sollten.

5. Da sich sozialer Wandel erheblich auf die Art und den Zeitpunkt der Übergänge auswirkt, sollte er Teil des Modells und der Stichprobenplanung sein. Letzteres wird durch cross-sequenzielle Designs erreicht, in denen unterschiedliche Alterskohorten für verschiedene Wandeleffekte stehen.

6. Studien zum Erwachsenenalter sollten möglichst genau den Zeitpunkt (damit auch die Sequenz) und den Kontext von Transitionen (als zeitabhängige Kovariaten) erfassen, ebenso wie den objektiven (beispielsweise den Einkommensverlust oder einen Wohnortwechsel) und subjektiven (beispielsweise Stress und Kausalattribution) Einfluss der Übergänge.

\footnotetext{
${ }^{5}$ Gemeint sind vor allem genetische Ressourcen. Deren Einbezug in interdisziplinäre Studien verlangt nach genetisch informativen Designs bei gleichzeitiger Erhebung klassischer soziologischer Indikatoren in großen Stichproben. Ein Beispiel für derartige Forschung in Deutschland ist die TwinLife Studie (http://www.twin-life.de/de), die bisher leider nicht das mittlere Erwachsenenalter untersucht.
} 
7. Soziale Netzwerke sollten hinreichend gründlich erfasst werden. Den hier besprochenen Studien ist gemein, dass entweder nur grobe Schätzer (beispielsweise zur Anzahl der Freunde, Kontaktintensitäten) oder nur bereichsspezifische Schätzer (beispielsweise nur egozentrierte Netzwerke) erhoben wurden. Die Frage, inwieweit sich mit den Übergängen des Erwachsenenalters auch Veränderungen im weiteren Netzwerk, etwa in den Beziehungen der Alteri untereinander, ergeben, konnte in keiner der referierten Studien beantwortet werden. Die Beziehungen im weiteren Netzwerk sollten jedoch als Teil des sozialen Kapitals einer Person betrachtet werden; auch unterbrochene Dyaden in Alteri-Beziehungen können transitionsbedingt gesundheitliche oder ökonomische Konsequenzen haben ${ }^{6}$. Hier gilt es, vorhandene theoretische Ansätze auf das gesamte Netzwerk auszuweiten.

Den Autoren ist bisher keine Studie bekannt, die all diese Anforderungen erfüllen könnte. Neben diesen allgemeinen Kritikpunkten gibt es zu den einzelnen Transitionen weitere offene Forschungsfragen, von denen einige angesprochen werden sollen.

Die Empty-Nest-Transition ist in ihrer Wirkung auf das Netzwerk bisher für Industriegesellschaften wenig differenziert dargestellt. Da beispielsweise in Deutschland gebildetere Mütter ihre Kinder in höherem Alter als bildungsfernere bekommen und dann aufgrund längerer Schulzeiten länger in der Familie halten, müssten sie älter sein, womit für sie seltener eine Phase der ,zweiten Jugend“ und der zugehörigen Netzwerkvergrößerung in Betracht kämen. Hier wird eine besondere Interaktion zwischen biologischem Alter, Bildungsstand und Transition deutlich, denn Individuen, die beispielsweise erst mit 40 Jahren Eltern werden, dürften die Empty-Nest-Situation erst um das sechzigste oder fünfundsechzigste Lebensjahr erleben (inkl. dem entsprechenden Risiko für späte Scheidungen). In diesem Lebensalter sind dann jedoch auch wiederum Lebensalter-spezifische Verkleinerungen des Netzwerkes eher erwartbar (siehe Kap., ,Soziale Netzwerke und gesundheitliche Ungleichheiten im Alter"). Auf der anderen Seite dürften finanzielle Ressourcen im Zuge des sozialen Wandels (Zunahme der Einkommensschere) für ärmere Nestflüchter geringer werden, womit hier

${ }^{6}$ Fällt beispielsweise der Auszug der Kinder mit der Trennung der Eltern zusammen, wird die Nutzung elterlicher „Beziehungen“ zu entfernten Netzwerkpersonen durch die ausziehenden Kinder, etwa für Ausbildung oder Wohnung, wohlmöglich weniger wahrscheinlich. Es ließe sich auch sagen, dass die Trennung der Eltern die Verfügbarkeit ihres „,second-hand social capital“ (Shah et al. 2018) für die Kinder verringert. 
crowding-in-Phänomene und unfreiwillig verlängerte Eltern-Kind-Phasen wahrscheinlicher werden. Inwieweit hier z. B. enttäuschte elterliche Erwartungen auf eine „Zweite Jugend“ (keine erneute Partnerschaft oder Elternschaft, da sich das Netzwerk ohne Auszug der Kinder nicht erweitert) gerade bei Ressourcenknappheit zu einer Verschärfung gesundheitlicher Probleme führt, bleibt eine der offenen Fragestellungen - auch in den ungleicher werdenden Industriegesellschaften. Diese hier nur angedeuteten und komplexen Wechselwirkungen zwischen den in Abschn. 1.2 skizzierten Themen soll hier nur eine von zahlreichen Forschungsdesiderata illustrieren.

Ein ähnlicher Präzisierungsbedarf in Bezug auf mögliche Wechselwirkungen lässt sich in Bezug auf Heirat und/oder Scheidung konstatieren. Während die Arbeiten der Forschungsgruppen um Felmlee (2001) und Sprecher et al. (2006) zeigen können, dass und in welcher Form Netzwerke das Paarleben fortwährend begleiten, so bleiben doch die Fragen unbeantwortet, ob hiermit stets auch soziale und gesundheitliche Ungleichheiten einhergehen. Spielen die sozialen Netzwerke von Ungebundenen, Paaren oder Geschiedenen für alle Formen der psychischen und physischen Gesundheit sowie für die Reproduktion von gesundheitlicher Ungleichheiten dieselbe Rolle oder lohnt sich hier der genauere Blick? Auch hierauf weiß die Forschung derzeit keine abschließende Antwort.

Aus der Ungleichheitsperspektive liegt für uns jedoch der Gedanke des Matthäus-Prinzips nahe: Individuen, die bereits zu Beginn ihrer Lebensspanne in gesünderen, beziehungszufriedeneren und ressourcenstärkeren Netzwerken leben, werden womöglich im Lebenslauf auch dadurch noch etwas gesünder, beziehungszufriedener und ressourcenstärker werden als andere. Für die weitere Untersuchung des Wechselspiels dieser Faktoren und für die Gesundheitsprävention sind dies allerdings relevante Ansatzpunkte.

\section{Leseempfehlungen}

Alwin, D. F., Felmlee, D. H., \& Kreager, D. A. (Hrsg.) (2018). Social Networks and the Life Course: Integrating the Development of Human Lives and Social Relational Networks. Cham, CH: Springer. Dieser aktuelle Sammelband stellt den Stand und die Perspektiven der innovativen Synthese aus Lebenslauf- und Netzwerkforschung in 22 Kapiteln vor.

Halfon, N., Forrest, C.B., Lerner, R.M. \& Faustman, E.M. (Hrsg.) (2018). Handbook of life course health development. Cham, CH: Springer Nature. Dieser aktuelle Sammelband stellt den Stand und die Perspektiven des neuen Forschungsbereichs LCHD (Life Course Health Development) in 26 Kapiteln vor. 
Kalmijn, M. (2003). Shared friendship networks and the life course: An analysis of survey data on married and cohabiting couples. Social Networks, 25, S. 231-249. Diese Studie erfüllt bereits viele der hier erhobenen Forderungen, denn sie ist orientiert am gesamten Lebenslauf des Erwachsenenalters und beschreibt acht verschiedene Transitionen in ihren Assoziationen mit dem Freundesnetzwerk an einer großen Stichprobe $(N=2977)$. Sie ist theoretisch orientiert (unterbrochene Dyaden, Balance-Prinzip) und berücksichtigt querschnittlich diverse sozioökonomische Variablen, ohne allerdings auf Gesundheit im engeren Sinne zu fokussieren. Damit kann sie keine Aussagen zu Veränderung gesundheitlicher Ungleichheit machen, gibt aber eine gute Orientierung für weitere Forschung.

Wrzus, C., Hänel, M., Wagner, J., \& Neyer, F. J. (2013). Social network changes and life events across the life span: A meta-analysis. Psychological Bulletin, 139 (1), S. 53-80. Eine maßgebliche Meta-Analyse der Veränderung egozentrierter Beziehungsnetze von der Kindheit bis zur Seneszenz mit einer großen Anzahl an Primärstudien $(k=243)$.

\section{Datensätze}

- „Allgemeine Bevölkerungsumfrage der Sozialwissenschaften“ (ALLBUS).

Seit 1980 werden in der Regel alle zwei Jahre repräsentative Daten über Einstellungen, Verhaltensweisen und Sozialstruktur der Bevölkerung in der Bundesrepublik Deutschland querschnittlich erhoben. Die Datenbank enthält einige Indikatoren zu sozialer Ungleichheit, Gesundheit und Gesundheitsverhalten, sozialen Netzwerken und sozialem Kapital. Weitere Informationen: http://www.gesis.org/allbus/allbus

- Studien aus dem Gesundheitsmonitoring des Robert-Koch-Instituts: „Studie zur Gesundheit Erwachsener in Deutschland“ (DEGS) und ,Gesundheit in Deutschland aktuell“" (GEDA)

In einer Kombination aus quer- und längsschnittlichen (DEGS) sowie querschnittlichen Daten (GEDA) werden seit 2008 in zweijährigem Rhythmus umfangreiche repräsentative Gesundheitsdaten der deutschen Wohnbevölkerung erhoben, die teilweise ärztliche Untersuchungsdaten umfassen. Es sind in unterschiedlichem Umfang verschiedene 
Indikatoren zur sozialen Ungleichheit sowie zur sozialen Unterstützung enthalten. Weitere Informationen: http://www.degs-studie.de und http:// www.geda-studie.de

- „Sozio-oekonomisches Panel“ (SOEP)

Jährliche, längsschnittliche Repräsentativbefragung der erwachsenen Bevölkerung Deutschlands (fortlaufend seit 1984 bzw. 1990 in Westbzw. Ostdeutschland). Fokussiert auf die soziale und ökonomische Situation der Bevölkerung, inkludiert aber regelmäßig auch psychologische und Netzwerk-Indikatoren in die Erhebung. Weitere Informationen: http//www.diw.de/de/soep

\section{Literatur}

Alwin, D. F., Felmlee, D. H., \& Kreager, D. A. (2018a). Together through time. Social networks and the life course. In D. F. Alwin, D. H. Felmlee, \& D. A. Kreager (Hrsg.), Social networks and the life course. Integrating the development of human lives and social relational networks (S. 3-26). Cham: Springer.

Alwin, D. F., Felmlee, D. H., \& Kreager, D. A. (Hrsg.). (2018b). Social networks and the life course. Integrating the development of human lives and social relational networks. Cham: Springer.

Antonucci, T. C., Fiori, K. L., Birditt, K., \& Jackey, L. M. H. (2010). Convoys of social relations: Integrating life-span and life-course perspectives. In M. E. Lamb, A. M. Freund, \& R. M. Lerner (Hrsg.), The handbook of life-span development (Bd. 2, S. 434473)., Social and emotional development Hoboken: Wiley.

Antonucci, T. C., Birditt, K. S., \& Ajrouch, K. (2011). Convoys of social relations. Past, present, and future. In K. L. Fingerman, C. A. Berg, J. Smith, \& T. C. Antonucci (Hrsg.), Handbook of life-span development (S. 161-182). New York: Springer.

Baltes, P. B. (1987). Theoretical propositions of life-span developmental psychology. On the dynamics between growth and decline. Developmental Psychology, 23(5), 611-626.

Baltes, P. B., \& Smith, J. (2004). Lifespan psychology. From developmental contextualism to developmental biocultural co-constructivism. Research in Human Development, 1(3), 123-144.

Beaupré, P., Turcotte, P., \& Milan, A. (2006). When is junior moving out? Transitions from the parental home to independence. Canadian Social Trends, 82, 9-15.

Becker, P. (2006). Gesundheit durch Bedürfnisbefriedigung. Göttingen: Hogrefe.

Blanchflower, D. G., \& Oswald, A. (2017). Do humans suffer a psychological low in midlife? Two approaches (with and without controls) in seven data sets. Cambridge: National Bureau of Economic Research. 
Bouchard, G. (2014). How do parents react when their children leave home? An integrative review. Journal of Adult Development, 21, 69-79.

Brandtstädter, J., \& Lindenberger, U. (Hrsg.). (2007). Entwicklungspsychologie der Lebensspanne. Stuttgart: Kohlhammer.

Burger, E., \& Milardo, R. M. (1995). Marital interdependence and social networks. Journal of Social and Personal Relationships, 12(3), 403-415.

Cable, N., Bartley, M., Chandola, T., \& Sacker, A. (2013). Friends are equally important to men and women, but family matters more for men's well-being. Journal of Epidemiology and Community Health, 67(2), 166-171.

Carr, D., \& Springer, K. W. (2010). Advances in families and health research in the $21 \mathrm{st}$ century. Journal of Marriage and Family, 72(3), 743-761.

Carstensen, L. L., Isaacowitz, D. M., \& Charles, S. T. (1999). Taking time seriously. A theory of socioemotional selectivity. American Psychologist, 54(3), 165-181.

Chappell, N. L., \& Funk, L. M. (2010). Social capital. Does it add to the health inequalities debate? Social Indicators Research, 99(3), 357-373.

Costa, P. J., \& McCrae, R. R. (1994). Set like plaster. Evidence for the stability of adult personality. In T. E. Heatherton \& J. L. Weinberger (Hrsg.), Can personality change?. Washington: American Psychological Association.

Cutler, D. M., \& Lleras-Muney, A. (2010). Understanding differences in health behaviors by education. Journal of Health Economics, 29(1), 1-28.

Dalgard, O. S., \& Håheim, L. (1998). Psychosocial risk factors and mortality. a prospective study with special focus on social support, social participation, and locus of control in Norway. Journal of Epidemiology and Community Health, 52(8), 476-481.

Dragano, N. (2007). Arbeit, Stress und krankheitsbedingte Frührenten. Zusammenhänge aus theoretischer und empirischer Sicht. Wiesbaden: Springer VS.

Ertel, K. A., Glymour, M. M., \& Berkman, L. F. (2009). Social networks and health: A life course perspective integrating observational and experimental evidence. Journal of Social and Personal Relationships, 26(1), 73-92.

Esmaeili, N. S., Yaacob, S. N., Juhari, R., \& Schoebi, D. (2015). Predictors of psychological distress among divorced women in Iran. Journal of Divorce \& Remarriage, 56(3), 248-259.

Felmlee, D. H. (2001). No couple is an island. A social network perspective on dyadic stability. Social Forces, 79(4), 1259-1287.

Filipp, S.-H., \& Aymanns, P. (1987). Die Bedeutung sozialer und personaler Ressourcen in der Auseinandersetzung mit kritischen Lebensereignissen. Zeitschrift für Klinische Psychologie, 16(4), 383-396.

Fooken, I., \& Kavšek, N. (2012). Entwicklungspsychologische Grundlagen. In E. Brähler \& B. Strau (Hrsg.), Grundlagen der Medizinischen Psychologie (S. 251-283). Göttingen: Hogrefe.

Halfon, N., Forrest, C. B., Lerner, R. M., Faustman, E. M., Tullis, E., \& Son, J. (2018a). Introduction to the handbook of life course health development. In N. Halfon, C. B. Forrest, R. M. Lerner, \& E. M. Faustman (Hrsg.), Handbook of life course health development (korr. Druck, S. 1-16). Cham: Springer Nature. 
Halfon, N., Forrest, C. B., Lerner, R. M., \& Faustman, E. M. (Hrsg.). (2018b). Handbook of life course health development. Cham: Springer Nature.

Hansen, F. J., Fallon, A. E., \& Novotny, S. L. (1991). The relationship between social network structure and marital satisfaction in distressed and nondistressed couples. A pilot study. Family Therapy, 18(2), 101-114.

Harkins, E. B. (1978). Effects of empty nest transition on self-report of psychological and physical well-being. Journal of Marriage and the Family, 40(3), 549-556.

Havighurst, R. J. (1976). Developmental tasks and education. New York: McKay.

Hoffmann, R., Kröger, H., \& Geyer, S. (2018). Social causation versus health selection in the life course. Does their relative importance differ by dimension of SES? Social Indicators Research, 141, 1341. https://doi.org/10.1007/a:112050181871.

Hughes, R., Good, E. S., \& Candell, K. (1993). A longitudinal study of the effects of social support on the psychological adjustment of divorced mothers. Journal of Divorce \& Remarriage, 19(1-2), 37-56.

Hurrelmann, K., \& Richter, M. (2013). Gesundheits- und Medizinsoziologie. Eine Einführung in sozialwissenschaftliche Gesundheitsforschung. Weinheim: Beltz Juventa.

Johnson, M. P., \& Leslie, L. (1982). Couple involvement and network structure. A test of the dyadic withdrawal hypothesis. Social Psychology Quarterly, 45(1), 34-43.

Kahn, R. L., \& Antonucci, T. C. (1980). Convoys over the life course. Attachment, roles and social support. In P. B. Baltes \& O. G. J. Brim (Hrsg.), Life-span development and behavior (Bd. 3, S. 253-286). New York: Academic.

Kalmijn, M. (2003). Shared friendship networks and the life course. An analysis of survey data on married and cohabiting couples. Social Networks, 25, 231-249.

Kalmijn, M., \& Bernasco, W. (2001). Joint and separated lifestyles in couple relationships. Journal of Marriage and Family, 63(3), 639-654.

Kalmijn, M., \& van Groenou, M. B. (2005). Differential effects of divorce on social integration. Journal of Social and Personal Relationships, 22(4), 455-476.

Kincaid, S. B., \& Caldwell, R. A. (1991). Initiator status, family support, and adjustment to marital separation. A test of an interaction hypothesis. Journal of Community Psychology, 19(1), 79-88.

Klauer, T., \& Greve, W. (2005). Kritische Lebensereignisse und Gesundheit. In R. Schwarzer (Hrsg.), Gesundheitspsychologie (S. 237-259). Göttingen: Hogrefe.

Kleinepier, T., Berrington, A., \& Stoeldraijer, L. (2017). Ethnic differences in returning home. Explanations from a life course perspective. Journal of Marriage and Family, 79, 1023-1040.

Knoll, N., \& Schwarzer, R. (2005). Soziale Unterstützung. In R. Schwarzer (Hrsg.), Gesundheitspsychologie (S. 333-349). Göttingen: Hogrefe.

Knoll, N., Scholz, U., \& Rieckmann, N. (2011). Einführung Gesundheitspsychologie. München: Reinhardt UTB.

Kupek, E. (2001). Sexual attitudes and number of partners in young British men. Archives of Sexual Behavior, 30(1), 13-27.

Lachman, M. E., Teshale, S., \& Agrigoroaei, S. (2015). Midlife as a pivotal period in the life course. Balancing growth and decline at the crossroads of youth and old age. International Journal of Behavioral Development, 39(1), 20-31.

Lang, F. R., Reschke, F. S., \& Neyer, F. J. (2006). Social relationships, transitions, and personality development across the life-span. In D. K. Mroczek \& T. D. Little (Hrsg.), Handbook of personality development (S. 445-467). Mahwah: Erlbaum. 
Leopold, T. (2018). Gender differences in the consequences of divorce. A study of multiple outcomes. Demography, 55(3), 769-797.

Levitt, M. J., Weber, R. A., \& Clark, M. C. (1986). Social network relationships as sources of maternal support and well-being. Developmental Psychology, 22(3), 310-316.

Lillard, L. A., \& Waite, L. J. (1995). Til death do us part. Marital disruption and mortality. American Journal of Sociology, 100(5), 1131-1156.

Liu, L.-J., \& Guo, Q. (2008). Life satisfaction in a sample of empty-nest elderly. A survey in the rural area of a mountainous county in China. Quality of Life Research, 17, $823-830$.

Lohaus, A., \& Klein-Heßling, J. (2009). Besondere Lebensabschnitte. In J. Bengel \& M. Jerusalem (Hrsg.), Handbuch der Gesundheitspsychologie und Medizinischen Psychologie (S. 164-171). Göttingen: Hogrefe.

Marmot, M. G. (2000). Multilevel approaches to understanding social determinants. In L. F. Berkman \& I. Kawachi (Hrsg.), Social epidemiology (S. 349-369). Oxford: University Press.

Mayer, K. U. (2000). Promises fulfilled? A review of 20 years of life course research. European Journal of Sociology, 41(2), 259-282.

Mielck, A. (2005). Soziale Ungleichheit und Gesundheit. Einführung in die aktuelle Diskussion. Bern: Huber.

Milardo, R. M. (1989). Theoretical and methodological issues in the identification of the social Networks of spouses. Journal of Marriage and Family, 51(1), 165-174.

Milardo, R. M., \& Allan, G. (2000). Social networks and marital relationships. In R. M. Milardo \& S. Duck (Hrsg.), Families as relationships (S. 117-134). New York: Wiley.

Millstein, S. G., Moscicki, A.-B., \& Broering, J. M. (1994). Female adolescents at high, moderate, and low risk of exposure to HIV. Differences in knowledge, beliefs, and behavior. Journal of Adolescent Health, 15(2), 133-141.

Mínguez, A. M. (2016). Late leaving of the parental home in Southern Europe. Lessons for Youth Policy. Comparative Sociology, 15(4), 485-507.

Morris, M., \& Kretzschmar, M. (1995). Concurrent partnerships and transmission dynamics in networks. Social Networks, 17(3-4), 299-318.

Murphy, S. A., Lohan, J., Dimond, M., \& Fan, J. (1998). Network and mutual support for parents bereaved following the violent deaths of their 12- to 28-year old children. A longitudinal prospective analysis. Journal of Personal \& Interpersonal Loss, 3(4), 303-333.

Nagy, M. E., \& Theiss, J. A. (2013). Applying the relational turbulence model to the empty-nest transition. Sources of relationship change, relational uncertainty and interference from partners. Journal of Family Communication, 13, 280-330.

Neyer, F. J., \& Asendorpf, J. B. (2001). Personality-relationship transaction in young adulthood. Journal of Personality and Social Psychology, 81(6), 1190-1204.

Neyer, F. J., Mund, M., Zimmermann, J., \& Wrzus, C. (2014). Personality-relationship transactions revisited. Journal of Personality, 82(6), 539-550.

Papastefanu, C. (2000). Der Auszug aus dem Elternhaus. Ein vernachlässigter Gegenstand der Entwicklungspsychologie. Zeitschrift für Soziologie der Erziehung und Sozialisation, 20(1), 55-69.

Pollmann-Schult, M. (2011). Soziale Integration und Lebenszufriedenheit kinderloser Frauen und Männer im mittleren und höheren Erwachsenenalter. Zeitschrift für Gerontologie und Geriatrie, 44, 411-416. 
Riggs, B. L., Melton, L. J., Robb, R. A., Camp, J. J., Atkinson, E. J., McDaniel, L., Amin, S., Rouleau, P. A., \& Khosla, S. (2008). A Population-based assessment of rates of bone loss at multiple skeletal sites. Evidence for substantial trabecular bone loss in young adult women and men. Journal of Bone and Mineral Research, 23(2), 205-214.

Rissel, C., Badcock, P. B., Smith, A. M. A., Richters, J., de Visser, R. O., Grulich, A. E., \& Simpson, J. M. (2014). Heterosexual experience and recent heterosexual encounters among Australian adults. The second Australian study of health and relationships. Sexual Health, 11(5), 416-426.

Roberts, B. W. (1997). Plaster or plasticity: Are adult work experiences associated with personality change in women? Journal of Personality, 65(2), 205-232.

Roberts, B. W., \& DelVecchio, W. F. (2000). The rank order consistency of personality from childhood to old age. A quantitative review of longitudinal studies. Psychological Bulletin, 126, 3-25.

Rubin, M., Evans, O., \& Wilkinson, R. B. (2016). A longitudinal study of the relations among university students' subjective social status, social contact with university friends, and mental health and well-being. Journal of Social and Clinical Psychology, 35(9), 722-737.

Santrock, J. W. (2015). Life-span development. New York: McGraw-Hill.

Schneider, N. F., \& Rüger, H. (2008). Beziehungserfahrungen und Partnerschaftsverläufe vor der Heirat. Eine empirische Analyse von Angehörigen der Eheschließungskohorte 1999-2005. Zeitschrift für Familienforschung, 20(2), 131-156.

Schütz, A., \& Wiesner, C. (2000). Partnerschaft und Gesundheitszustand. In P. Kaiser (Hrsg.), Partnerschaft und Paartherapie (S. 193-218). Göttingen: Hogrefe.

Schwartz, C. R., \& Han, H. (2014). The reversal of the gender gap in education and trends in marital dissolution. American Sociological Review, 79(4), 605-629.

Schwarzer, R., \& Leppin, A. (1989). Social support and health. A meta-analysis. Psychology \& Health, 3(1), 1-15.

Shah, N. P., Levin, D. Z., \& Cross, R. (2018). Secondhand social capital. Boundary spanning, secondhand closure, and individual performance. Social Networks, 52, 18-27.

Smith, C. E., Fernengel, K., Holcroft, C., \& Gerald, K. (1994). Meta-analysis of the associations between social support and health outcomes. Annals of Behavioral Medicine, $16(4), 352-362$.

Solomon, D. H., \& Knobloch, L. K. (2004). A model of relational turbulence. The role of intimacy, relational uncertainty, and interference from partners in appraisals of irritations. Journal of Social and Personal Relationships, 21(2), 795-816.

Soons, J. P. M., Liefbroer, A. C., \& Kalmijn, M. (2009). The long-term consequences of relationship formation for subjective well-being. Journal of Marriage and Family, 71(5), 1254-1270.

South, S. J., \& Lei, L. (2015). Failures-to-launch and boomerang kids. Contemporary determinants of leaving and returning to the parental home. Social Forces, 94(2), 863890.

Specht, J., Bleidorn, W., Denissen, J. J. A., Hennecke, M., Hutteman, R., Kandler, C., Luhmann, M., Orth, U., Reitz, A. K., \& Zimmermann, J. (2014). What drives adult personality development? A comparison of theoretical perspectives and empirical evidence. European Journal of Personality, 28(3), 216-230. 
Sprecher, S., Felmlee, D., Schmeeckle, M., \& Shu, X. (2006). No breakup occurs on an island. Social networks and relationship dissolution. In M. A. Fine \& J. H. M. E. Harvey (Hrsg.), Handbook of divorce and relationship dissolution (S. 457-478). Mahwah: Erlbaum.

Steptoe, A., \& Marmot, M. (2003). Burden of psychosocial adversity and vulnerability in middle age. Associations with biobehavioral risk factors and quality of life. Psychosomatic Medicine, 65(6), 1029-1037.

Stone, G. (2002). Nonresidential father postdivorce well-being. The role of social supports. Journal of Divorce \& Remarriage, 36(3-4), 139-150.

Stone, A. A., Schwartz, J. E., Broderick, J. E., \& Deaton, A. (2010). A snapshot of the age distribution of psychological well-being in the United States. PNAS Proceedings of the National Academy of Sciences of the United States of America, 107(22), 9985-9990.

Sun, K., Zuo, M., \& Kong, D. (2016). Communication with children for older adults' life satisfaction. Non-face-to-face and/or face-to-face? Gerontechnology, 14(4), 191-203.

Sussman, S., Lisha, N., \& Griffiths, M. (2011). Prevalence of the addictions. A problem of the majority or the minority? Evaluation \& the Health Professions, 34(1), 3-56.

Symoens, S., Van de Velde, S., Colman, E., \& Bracke, P. (2014). Divorce and the multidimensionality of men and women's mental health. The role of social-relational and socio-economic conditions. Applied Research in Quality of Life, 9(2), 197-214.

Tanfer, K., Cubbins, L. A., \& Billy, J. O. (1995). Gender, race, class and self-reported sexually transmitted disease incidence. Family Planning Perspectives, 27(5), 196-202.

Tanis, M., van der Louw, M., \& Buijzen, M. (2017). From empty nest to Social Networking Site. What happens in cyberspace when children are launched from the parental home? Computers in Human Behavior, 68, 56-63.

Terhell, E. L., Broese van Groenou, M. I., \& van Tilburg, T. (2004). Network dynamics in the long-term period after divorce. Journal of Social and Personal Relationships, 21(6), 719-738.

Valente, T. W. (2010). Social networks and health. Models, methods and applications. Oxford: University Press.

Van Dulmen, M. H. M. (2013). Emerging Adulthood. The Journal. Emerging Adulthood, $1(1), 3-4$.

Veiel, H. O., Crisand, M., Stroszeck-Somschor, H., \& Herrle, J. (1991). Social support networks of chronically strained couples. Similarity and overlap. Journal of Social and Personal Relationships, 8(2), 279-292.

Vonneilich, N., Jöckel, K.-H., Erbel, R., Klein, J., Dragano, N., Siegrist, J., \& von dem Knesebeck, O. (2012). The mediating effect of social relationships on the association between socioeconomic status and subjective health. Results from the Heinz Nixdorf Recall cohort study. BMC Public Health, 12, 285.

Wan, H., Yu, F., \& Kolanowski, A. (2008). Caring for aging chinese. Lessons learned from the United States. Journal of Transcultural Nursing, 19(2), 114-120.

Wayment, H. A., Wyatt, G. E., Tucker, M. B., Romero, G. J., Carmona, J. V., Newcomb, M., Solis, B. M., Riederle, M., \& Mitchell-Kernan, C. (2003). Predictors of risky and precautionary sexual behaviors among single and married white women. Journal of Applied Social Psychology, 33(4), 791-816.

Weber, H. (2005). Persönlichkeit und Gesundheit. In R. Schwarzer (Hrsg.), Gesundheitspsychologie (S. 129-147). Göttingen: Hogrefe. 
Widmer, E. D., Kellerhals, J., \& Levy, R. (2004). Types of conjugal networks, conjugal conflict and conjugal quality. European Sociological Review, 20(1), 63-77.

Wurm, S., \& Tesch-Römer, C. (2005). Alter und Gesundheit. In R. Schwarzer (Hrsg.), Gesundheitspsychologie (S. 71-90). Göttingen: Hogrefe.

Wrzus, C., Hänel, M., Wagner, J., \& Neyer, F. J. (2013). Social network changes and life events across the life span. A Meta-Analysis. Psychological Bulletin, 139(1), 53-80.

Yeung, D. Y., Fung, H. H., \& Lang, F. R. (2008). Self-construal moderates age differences in social network characteristics. Psychology and Aging, 23(1), 222-226.

Open Access Dieses Kapitel wird unter der Creative Commons Namensnennung 4.0 International Lizenz (http://creativecommons.org/licenses/by/4.0/deed.de) veröffentlicht, welche die Nutzung, Vervielfältigung, Bearbeitung, Verbreitung und Wiedergabe in jeglichem Medium und Format erlaubt, sofern Sie den/die ursprünglichen Autor(en) und die Quelle ordnungsgemäß nennen, einen Link zur Creative Commons Lizenz beifügen und angeben, ob Änderungen vorgenommen wurden.

Die in diesem Kapitel enthaltenen Bilder und sonstiges Drittmaterial unterliegen ebenfalls der genannten Creative Commons Lizenz, sofern sich aus der Abbildungslegende nichts anderes ergibt. Sofern das betreffende Material nicht unter der genannten Creative Commons Lizenz steht und die betreffende Handlung nicht nach gesetzlichen Vorschriften erlaubt ist, ist für die oben aufgeführten Weiterverwendungen des Materials die Einwilligung des jeweiligen Rechteinhabers einzuholen.

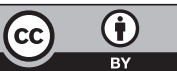




\title{
Soziale Netzwerke und gesundheitliche Ungleichheiten im Alter
}

\author{
Britta Müller und Lea Ellwardt
}

\section{Überblick}

- Gesundheit und soziale Netzwerke sind im Alter die zentralen Lebensbereiche.

- Es existieren drei Thesen zum Verlauf des sozialen Gradienten von Gesundheit im Alter: die Kontinuitäts-, die Divergenz- und die Konvergenzthese.

- Eine der wichtigsten Thesen zum sozialen Netzwerk im Alter ist die Aktivitätsthese. Sie besagt, dass gute Lebenszufriedenheit durch das Beibehalten von sozialen Interaktionen erreicht werden könne.

- Sterblichkeits-, Demenz- und Depressionsrisiko sind sowohl mit sozioökonomischem Status als auch mit sozialen Netzwerkmerkmalen assoziiert.

- Die Vermittlungsmechanismen von sozioökonomischem Status, Gesundheit und sozialem Netzwerk im Alter können durch vorliegende Studien noch nicht hinreichend erklärt werden.

- Mehrheitlich werden Netzwerkmerkmale indirekt durch Proxys erhoben. Etablierte quantitative und qualitative Verfahren der Netzwerkanalyse spielen in der gerontologischen Forschung bislang eine untergeordnete Rolle.

B. Müller $(\bowtie)$

Rostock, Deutschland

E-Mail: britta.mueller@med.uni-rostock.de

L. Ellwardt

Köln, Deutschland

E-Mail: ellwardt@wiso.uni-koeln.de 
- Forschungsdesigns, die sich lediglich auf qualitative oder quantitative Netzwerkmerkmale konzentrieren, unterschätzen systematisch den eigentlichen Effekt der sozialen Einbettung von Personen im Alter auf die Gesundheit.

\section{$1 \quad$ Einleitung}

Durch Verbesserungen des Lebensstandards und des Gesundheitsverhaltens sowie durch den medizinischen Fortschritt seit der zweiten Hälfte des 20. Jahrhunderts ist das Alter zu einer eigenständigen Lebensphase geworden. Diese wird in der Regel durch den Übergang vom Erwerbsleben in den Ruhestand eingeleitet (Kohli 2000). Sowohl die Chance, den Ruhestand zu erreichen, als auch die fernere Lebenserwartung nach Eintritt in den Ruhestand haben sich deutlich erhöht (Eisenmenger und Emmerling 2011). Die nachberufliche Lebensphase umfasst bei vielen Menschen inzwischen mehrere Jahrzehnte. Zudem sind Personen, die in den Ruhestand wechseln, erheblich gesünder als Gleichaltrige früherer Geburtsjahrgänge (Crimmins 2004). Die Ausweitung dieser Lebensphase ging mit einer Differenzierung alter Menschen hinsichtlich Gesundheit und Selbstständigkeit einher: zu ihr gehören gesunde und aktive Menschen genauso wie hilfe- und pflegebedürftige Personen. Diesem Umstand wird dadurch Rechnung getragen, dass zwischen Personen im höheren und hohen Alter unterschieden wird (Baltes 2007). Merkmale des höheren Alters sind das Fehlen nichtkompensierbarer gesundheitlicher Einschränkungen, die Selbstgestaltung vielfältiger Aktivitäten (z. B. Reisen, Hobbies, Ehrenamt) sowie eine gute soziale Einbindung. Die Anforderungen des Alters können in dieser Phase insgesamt gut bewältigt werden. Das hohe Alter ist durch eine Zunahme körperlicher und kognitiver Einbußen sowie Krankheiten gekennzeichnet. Fähigkeiten und Möglichkeiten der Kompensation von Defiziten werden geringer (Baltes 1997; Baltes und Smith 2003).

Gesundheit und soziale Netzwerke werden im Alter zu zentralen Lebensbereichen und weisen im Vergleich $\mathrm{zu}$ früheren Lebensphasen Besonderheiten auf. Das Risiko für Erkrankungen mit langsamen Verläufen, die sich oft nicht vollständig heilen lassen, steigt. Als Ursachen dafür werden die Zunahme altersphysiologischer Prozesse, die Kumulation von Risikofaktoren im Lebensverlauf, lange Latenzzeiten und Folgeerkrankungen von bereits im frühen Lebensalter ausgebrochenen Erkrankungen betrachtet (Tesch-Römer und Wurm 2009). Zudem tritt Multimorbidität, also das gleichzeitige Auftreten mehrerer 
chronischer Erkrankungen, mit zunehmendem Alter häufiger auf, wodurch die funktionale Gesundheit gefährdet wird (Müller et al. 2014). Weiterhin nimmt der Stellenwert subjektiver Gesundheit im Alter zu. Im Vergleich zur objektiven Gesundheit ist sie im Alter ein zuverlässigeres Maß für Lebensqualität, Lebenserwartung sowie für die Prognose von Krankheitsverläufen. Im Vergleich zu Krankheitsdiagnosen spiegelt die subjektive Gesundheit, in die neben der physischen und psychischen Gesundheit auch die Lebenssituation und der Lebensstil einfließen, den individuellen Gesundheitszustand umfassender wider (Spuling et al. 2017).

Die strukturellen und funktionalen Muster sozialer Netzwerke im Alter werden v. a. durch den Statusübergang vom Erwerbsleben in den Ruhestand und durch die Gesundheit der älteren Person selbst als auch durch die ihrer Netzwerkpartner geprägt. Insbesondere in der Bedeutung der Gesundheit für das soziale Netzwerk unterscheidet sich diese Lebensphase von früheren, wie dem jungen oder mittleren Erwachsenenalter (Hoogendijk et al. 2016). Der Tod wichtiger Netzwerkpersonen, funktionale Einschränkungen oder auch Pflegebedürftigkeit verändern das soziale Netzwerk im Alter bedeutsam. So beträgt beispielsweise die Abnahme der Netzwerkgröße ab dem Alter von 60 bis 65 Jahren schätzungsweise eine Kontaktperson pro Dekade (Wrzus et al. 2013).

\section{Theorien}

\subsection{Theorien zur gesundheitlichen Ungleichheit im Alter}

Annahmen zum Zusammenhang zwischen sozialer Ungleichheit und Gesundheit im Alter werden in drei Thesen diskutiert. Die Kontinuitätsthese geht von einer Konstanz gesundheitlicher Ungleichheit aus: das Ausmaß gesundheitlicher Ungleichheit im Alter entspricht dem früherer Lebensphasen (Atchley 1989). Sie unterstellt, dass sich die soziale Ungleichheit im Ruhestand aus der sozialen Ungleichheit der Erwerbsphase reproduziere (Kohli et al. 2000). Die sozioökonomische Position, die eine Person im Laufe ihres Lebens über das Beschreiten von Bildungs- und Berufspfaden erreicht, würde im Alter beibehalten werden. Das impliziert eine zeitliche Stabilität sozialer Ungleichheit innerhalb einer Kohorte bis in das hohe Alter (Status-Maintenance-Hypothesis) (Henretta und Campbell 1976). Angenommen wird weiter ein konstanter Effekt sozialer Ungleichheit auf den Gesundheitszustand. Die Divergenzthese geht davon aus, dass sich die gesundheitliche Ungleichheit im Alter vergrößert. Dies sei Folge 
einer zunehmenden Kumulation gesundheitlicher Risiken bei unteren Statusgruppen (Tews 1993). Weiterhin wird die Divergenz darauf zurückgeführt, dass im Falle eines schlechten Gesundheitszustandes Ressourcen (wie z. B. das Einkommen), die kompensatorisch genutzt werden können, soziostrukturell unterschiedlich verfügbar seien (Mayer und Wagner 2010). Dieser Prozess werde bei Kumulation materieller Ressourcen höherer Statusgruppen während des Lebensverlaufs (Cumulative-Advantage-Hypothesis) noch verstärkt (Lampert et al. 2017). Die gegenteilige Position vertritt die Konvergenzthese. Sie besagt, dass sich die gesundheitliche Ungleichheit im Alter verringere. Zur Begründung dieser These werden vier Argumente angeführt. Erstens wird auf die Universalität biologischer Alterungsprozesse verwiesen, durch die der Einfluss sozialer Faktoren auf Gesundheit und Lebenserwartung zunehmend in den Hintergrund trete (Age-As-Leveler-Hypothesis) (Lampert et al. 2017; Mayer und Wagner 2010). Zweitens könnten wohlfahrtsstaatliche Regelungen Unterschiede im sozioökonomischen Status reduzieren bzw. dessen Einfluss auf die Gesundheit verringern (von dem Knesebeck et al. 2003). Drittens wird die These damit begründet, dass Belastungen des mittleren Lebensalters (z. B. als Folge der Berufstätigkeit), die schichtspezifisch variieren und den Gesundheitszustand beeinflussen, im Ruhestand an Bedeutung abnehmen (House et al. 1992). Viertens schließlich wird die Konvergenztheorie mit sozial selektiver Mortalität begründet: Das Risiko, vor Erreichen des Rentenalters zu versterben, ist in unteren Statusgruppen größer als in höheren. Damit stellen die Überlebenden der unteren Statusgruppen eine positive Selektion im Hinblick auf den Gesundheitszustand dar (Markides und Machalek 1984; McMunn et al. 2008).

\subsection{Theorien zu sozialen Netzwerken im Alter}

Eine frühe soziologische Theorie zu sozialen Netzwerken im Alter ist die vom Strukturfunktionalismus geprägte Disengagement-Theorie (Cumming und Henry 1961). Ihr liegt die Annahme zugrunde, dass eine gute Anpassung an das Alter über den Weg des „Disengagements“, verstanden als Rückzug älterer Menschen aus sozialen Rollen und Beziehungen, zustande käme. Unterstellt wird eine funktionale Komplementarität zwischen Individuum und Gesellschaft. Der Wunsch nach Rückzug entspräche dem Bedürfnis der Gesellschaft, ihr fortlaufendes Funktionieren durch rechtzeitige Rollenübernahme zu gewährleisten. Der Prozess des Disengagements sei weder auf einen schlechten Gesundheitszustand noch auf Einkommenseinbußen im Alter zurückzuführen. Vielmehr setze er bereits bei Aufgabe der Berufsrolle oder mit der Verwitwung ein. Lebenszufriedenheit werde dadurch 
erlebt, dass durch den Rückzug die soziale Kontrolle, etwa durch Kollegen und Vorgesetzte, reduziert werde, was eine Befreiung von Alltagsnormen mit sich bringe. Nur in jenen Fällen, in denen keine alternativen sozialen Rollen wie z. B. in Form des Ehrenamtes zur Verfügung ständen, würde die Reduktion der Zahl oder der Unterschiedlichkeit sozialer Kontakte als Krise erlebt werden. Die empirische Evidenz dieser Theorie ist gering. Zwar entfallen mit dem Ende der Berufstätigkeit und durch Witwenschaft in der Tat wichtige soziale Rollen, dafür werden jedoch bestehende soziale Kontakte, etwa zu Kindern, Enkelkindern und Nachbarn nicht etwa gelockert, sondern im Gegenteil, häufig intensiviert. Ein freiwillig initiierter Rückzug aus sozialen Bindungen bei guter Gesundheit im Alter ist nicht typisch (Maddox und Eisdorfer 1972; Neugarten et al. 1969; Shanas et al. 1968).

Als Gegenentwurf zur Disengagement-Theorie kann die Aktivitätstheorie betrachtet werden. Sie besagt, dass eine gute Lebenszufriedenheit im Alter nur durch fortgesetzte soziale Aktivität, das Beibehalten von Interaktionen bzw. eines aktiven Lebensstils erreicht werden könne. Dem altersbedingten Wegfall sozialer Rollen (z. B. Berufstätigkeit) und sozialer Aktivitäten sei mit der Aufnahme neuer Aktivitäten (z. B. Ehrenamt) zu begegnen (Tartler 1961). Dieser Zusammenhang zwischen Aktivität und Zufriedenheit im Alter ist empirisch gut gesichert (Adams et al. 2011; Katz 1996; Lemon et al. 1972).

Nach der zur Rational Choice Theory gehörigen Theorie des sozialen Austauschs kommen Interaktionen durch den über Normen geregelten Austausch von sozialen Gütern (instrumentelle, emotionale und materielle) zustande. Als zentral wird die Reziprozitätsnorm betrachtet. Mit Bezug auf das Alter geht die Theorie davon aus, dass ältere Menschen zunehmend weniger Ressourcen wie soziale Position, Geld und Gesundheit aufwiesen und dadurch für potenzielle Tauschpartner an Attraktivität verlören (Bengtson und Dowd 1981). Auswege aus dem drohenden Ungleichgewicht zwischen Nehmen und Geben werden in der Konzentration auf jene Interaktionspartner gesehen, mit denen Reziprozität möglich ist, sei es durch gezielte Selektion bestehender oder Aufnahme neuer Beziehungen, was letztlich als positiv für das Wohlbefinden erachtet wird. Die Kritik gegenüber dieser Theorie richtet sich v. a. auf die Schwierigkeit, die Annahmen empirisch zu überprüfen, da ,soziale Güter“ individuell sehr Unterschiedliches bedeuten können. Zudem hängt die Interpretation von Reziprozität auch von der Qualität und Bedeutung sozialer Beziehungen ab. Diese aber bleiben in der Theorie des sozialen Austauschs unberücksichtigt (Tesch-Römer 2010).

Spezifisch auf die Beziehungen zwischen Eltern im höheren bzw. hohen Alter und ihren erwachsenen Kindern sind das Modell der intergenerationalen Solidarität (Bengtson und Roberts 1991) und das Modell der intergenerationalen Ambivalenz. (Lüscher 2000) ausgerichtet. Ersteres fokussiert die wechselseitige 
Unterstützung zwischen den Generationen einer Familie und beschreibt diese anhand von sieben Dimensionen: „Struktur“ (im Sinne von Opportunitätsstrukturen für Interaktionen), „Assoziation“ (Ausmaß an persönlichen Kontakten), „Affekt“ (Ausmaß an gegenseitiger Zuneigung), „Konsens“ (Ausmaß der Übereinstimmung von Werten und Einstellungen), ,normative Überzeugungen“ (Stärke der Verbindlichkeit), „funktionaler Austausch“ (Grad gegenseitiger Unterstützung) und „Konflikt“ (Häufigkeit von Konflikten). Zweiteres geht von einer Widersprüchlichkeit sozialer Beziehungen zwischen Eltern und erwachsenen Kindern aus und formuliert Annahmen darüber, wie diese aufgelöst werden kann.

Aussagen zur strukturellen Veränderung sozialer Netzwerke im Alter treffen explizit die sozio-emotionale Selektivitätstheorie (Carstensen 1993) und das Modell des sozialen Konvois (Antonucci et al. 1997). Erstere Theorie mutmaßt, dass Lebenszufriedenheit und positive Gefühle trotz kleiner werdender Netzwerke bis ins hohe Alter deshalb stabil bleiben, weil zunehmend eine Konzentration auf jene Interaktionspartner erfolge, die Quelle positiver Erfahrungen seien. Dieser Selektionsprozess wird als funktional für die psychische Gesundheit angesehen. Die zweite Theorie nimmt an, dass der innere Kern des Netzwerkes hierzu gehören Partner, Kinder, Eltern und enge Freunde - einen Menschen über den Lebenslauf begleitet, der äußere Kern - bestehend aus Nachbarn, Dienstleistern, Arbeitskollegen - jedoch von Substitution geprägt ist. Hier verkleinert sich das Netzwerk nicht per se, sondern es verändert sich vielmehr hinsichtlich seiner Zusammensetzung. So kann der Kontakt zu (ehemaligen) Arbeitskollegen abnehmen und der Kontakt zu Nachbarn und Pflegekräften zunehmen. Die Substitution ist u. a. Ausdruck sich wandelnder Opportunitäten und Bedürfnisse im hohen Alter. Laut des Modells des sozialen Konvois können somit auch entfernte, weniger emotional-regulierende Kontakte funktional für die körperliche und psychische Gesundheit im Alter sein bzw. werden.

\section{Soziale Ungleichheit und Gesundheit}

Während für das mittlere Erwachsenenalter Zusammenhänge zwischen sozioökonomischem Status und Gesundheit seit langem vielfach belegt sind, gilt das Alter diesbezüglich als vergleichsweise junges Forschungsgebiet (von dem Knesebeck und Vonneilich 2009). Die folgende Darstellung konzentriert sich auf drei Folgen sozialer Ungleichheit, die hauptsächlich im Alter relevant sind. Dies sind Unterschiede im Sterblichkeitsrisiko, in der altersbedingt abnehmenden kognitiven Funktionsfähigkeit und dem damit verbundenen Demenzrisiko sowie im Depressionsrisiko. 


\subsection{Sterblichkeitsrisiko}

Gemäß empirischer Ergebnisse aus dem Deutschen Alterssurvey (DEAS) hat der sozioökonomische Status auch im Alter einen fortbestehenden Einfluss auf die Gesundheit (Schöllgen et al. 2010; Spuling et al. 2017). Dies hängt wiederum potenziell mit sozioökonomischer Ungleichheit in der Sterblichkeit zusammen. So war laut Registerdaten 2003 das Sterblichkeitsrisiko bei männlichen deutschen Rentnern ab 65 Jahren im untersten sozioökonomischen Fünftel (Quintil) dreimal so hoch wie im obersten bzw. betrug die verbleibende Lebenserwartung 12,5 Jahre versus 20 Jahre (Shkolnikov et al. 2007). Yao und Robert (2008) fanden in ihrer US-amerikanischen Langzeitstudie ähnliche Disparitäten in einer älteren Population mit 1631 Menschen von mindestens 60 Jahren: Schwarze Ältere hatten eine schlechtere subjektive Gesundheit und ein höheres Sterblichkeitsrisiko als weiße Ältere. Dieser Unterschied ließ sich teilweise durch einen niedrigeren sozioökonomischen Status der schwarzen Älteren sowohl auf individueller als auch auf Nachbarschaftsebene erklären. Lleras-Muney (2005) zeigte mit US-amerikanischen Zensusdaten von 1960, 1970 und 1980 ebenfalls einen kausalen Zusammenhang auf: Mit jedem zusätzlichen Jahr Ausbildung sank die Sterblichkeitswahrscheinlichkeit bei Erwachsenen um 3,6\% innerhalb der nächsten zehn Jahre. Dieser Ungleichheitstrend ist nicht auf Deutschland und die USA beschränkt. Im internationalen Vergleich 22 europäischer Länder haben Mackenbach et al. (2008) eindrucksvoll gezeigt, dass Personen mit einem niedrigen sozioökonomischen Status systematisch einem höheren Sterblichkeitsrisiko ausgesetzt waren als Personen mit einem höheren Status. Der altersbereinigte statusbasierte Unterschied im Sterblichkeitsrisiko war in den osteuropäischen und baltischen Staaten besonders hoch; am niedrigsten war er in den südeuropäischen Staaten Italien und Spanien. Die Analyse bezog sich auf Sterberegisterdaten von knapp dreieinhalb Millionen verstorbener Menschen mit einem Mindestalter von 30 Jahren.

\subsection{Kognitive Verläufe und Demenzrisiko}

Konsens besteht darin, dass der Verlauf kognitiver Fähigkeiten - diese umfassen die Dimensionen „Sprachfähigkeit“, „Gedächtnis“, „Allgemeinbildung“, „Problemlösen“ und „Orientierung“ - im Alter eine hohe interindividuelle Variabilität aufweist (Christensen et al. 1994). Zudem gestaltet er sich in Abhängigkeit vom jeweiligen Leistungsbereich unterschiedlich. So sind altersbedingte Differenzen bei den Dimensionen „Problemlösen“ und „Gedächtnis“ 
deutlich ausgeprägter als bei der „Allgemeinbildung“ (Finkel et al. 2007; Reischies und Lindenberger 2010).

Wenn die Abnahme pathologisch verläuft, also über eine normale altersbedingte Abnahme der kognitiven Leistungsfähigkeiten hinausgeht, und medizinisch diagnostiziert ist, spricht man von Demenz. Demenz ist eine psychiatrische Kondition, die bei degenerativen und nichtdegenerativen Erkrankungen des Gehirns auftritt. Die Krankheit, die am häufigsten mit Symptomen der Demenz einhergeht, ist die Alzheimer-Krankheit. Charakteristisch für Demenz sind starke Beeinträchtigungen der Gedächtnisleistung (besonders des Kurzzeitgedächtnisses), der Sprache, der Motorik und manchmal der Persönlichkeitsstruktur. Das Demenzrisiko steigt mit dem Alter exponentiell an. So beträgt die Prävalenz der Demenz vom Alzheimertyp bei der Gruppe der 60-Jährigen schätzungsweise ein Prozent und verdoppelt sich danach alle fünf Jahre (Ferri et al. 2005). Ab dem 85. Lebensjahr ist das Risiko bereits drastisch erhöht und misst etwa $25 \%$. Die kognitiven Verläufe und das Risiko, an Demenz zu erkranken, eine mögliche, aber nicht zwingende Folge eines ungünstigen Verlaufs, sind durch eine Vielzahl sozialer und sozioökonomischer Faktoren bedingt (Müller und Kropp 2011, 2012).

Der diesbezüglich wohl stärkste Faktor ist Intelligenz bzw. intellektuelle Kapazität, in Surveys häufig gemessen am Bildungsabschluss. Die Hypothese der kognitiven Reserve (Liberati et al. 2012; Scarmeas und Stern 2003) geht davon aus, dass Personen mit einem höheren Bildungsabschluss über ein größeres Repertoire an Bewältigungsstrategien verfügen, die die Abnahme an kognitiven Funktionsfähigkeiten im Alter hinauszögern und abmindern, als Personen mit niedrigerem Bildungsabschluss. Dies beinhaltet, dass eher alternative Regionen im Gehirn aktiviert werden können, die bei Bedarf die Funktionen weniger leistungsfähiger, von Demenz oder Alzheimer betroffener Regionen übernehmen. Nicht Bildung per se, sondern das damit assoziierte intellektuelle Anregungspotenzial des sozialen und beruflichen Umfeldes werden als Erklärung dafür herangezogen (Gow et al. 2012; Lee und Chi 2016; Then et al. 2013; Wang et al. 2012).

Die Assoziation zwischen Bildung und Demenzrisiko ist empirisch vielfach belegt: Laut einer Metaanalyse über 69 Studien haben ältere Menschen mit einem niedrigen Bildungsabschluss ein 1,61-mal so hohes Risiko, an Demenz zu erkranken, wie ältere Menschen mit einer hohen Bildung (Meng und D'Arcy 2012). Ein interessanter Befund ist der sogenannte Hürdeneffekt: Größere kognitive Reserven zögern die Diagnose einer Demenz zwar hinaus, setzt die Demenz jedoch erst einmal ein, verläuft sie schneller als bei geringeren Reserven. Dies kommt dadurch, dass die kompensatorischen Prozesse der kognitiven Reserve die stattfindende Abnahme kognitiver Funktionen lange maskieren. Bis die 
Abnahme klinisch diagnostiziert ist, haben sich die pathologischen Prozesse aber womöglich schon länger manifestiert (Bruandet et al. 2008).

Die kognitive Reserve hängt eng mit einem stimulierenden sozialen Umfeld zusammen. Mehrere theoretische Ansätze postulieren daher explizit einen Zusammenhang zwischen sozialer Einbettung und kognitiver Funktionsfähigkeit. Allen voran konstatiert die Use-it-or-lose-it-Hypothese (Hultsch et al. 1999), dass das Gehirn - ähnlich einem Muskel - regelmäßig trainiert werden muss, um voll funktionsfähig zu bleiben. Soziale Beziehungen helfen dabei, indem sie den Menschen zu sozialen und körperlichen Aktivitäten stimulieren [körperliche Aktivität ist ein weiterer Prädiktor kognitiver Funktion (Fratiglioni et al. 2004)] und komplexen intellektuellen Input liefern (Schooler 1984). Die StressPuffer-Hypothese (Fratiglioni et al. 2004) unterstellt eine positive Wirkung emotional unterstützender Beziehungen in Krisenzeiten. Stress gilt als Alzheimer-fördernder Faktor, da er mit strukturellen Veränderungen im Hippocampus assoziiert ist (Wilson et al. 2003). Dieser Hypothese zufolge profitieren Menschen insbesondere von sogenannten funktionalen Netzwerken mit reichhaltigen Unterstützungsleistungen ungeachtet der eigentlichen Beziehungsanzahl bzw. Netzwerkgröße. Die Haupteffekt-Hypothese (Cohen 2004) vermutet, dass stark integrierte Menschen über mehr Motivation (auch: Normen und sozialen Druck), Wissen und Ressourcen für einen gesunden Lebensstil verfügen. Bei dieser Hypothese besitzen auch sogenannte strukturelle Aspekte Relevanz, wie die Einbettung in komplexe und diverse Beziehungsgeflechte. Alle drei Hypothesen sind in ihren Aussagen komplementär, da sie sich auf unterschiedliche Mechanismen konzentrieren, die prinzipiell parallel wirksam sein können.

\subsection{Depression}

Depressive Störungen sind durch einen über einen längeren Zeitraum anhaltenden Zustand deutlich gedrückter Stimmung, Interesselosigkeit und Antriebsminderung gekennzeichnet. Im Alter sind Depressionen die häufigste psychische Störung überhaupt. Luppa und Kollegen (2012) berichten als Ergebnis ihrer Metaanalyse über älteren Menschen ab 75 Jahren Punktprävalenzen von $17 \%$ für eine depressive Symptomatik und von $7 \%$ für eine Major Depression. Depressionen im Alter erhöhen die suizidale Mortalität, gehen mit Einbußen der subjektiven und funktionalen Gesundheit einher und beeinträchtigen häufig das Behandlungsergebnis bei somatischen Erkrankungen. Sie sind Risikofaktor für die koronare Herzkrankheit (Carney und Freedland 2017). Es bestehen Zusammenhänge zwischen Depressionen und neurodegenerativen Erkrankungen wie Alzheimer-Demenz und 
Parkinson (Mourao et al. 2016, den Brok et al. 2015). Chronische Schmerzen im Alter erhöhen das Risiko einer Depression (Zis et al. 2017). Lorant et al. (2003) fanden in ihrer Metaanalyse, die auch Personen im Alter einschloss, überzeugende Belege dafür, dass ein geringer sozioökonomischer Status mit einem höheren Risiko für depressive Erkrankungen assoziiert ist. Obwohl in den eingeschlossenen Studien beide Richtungen des Zusammenhangs (der sozioökonomische Status beeinflusst das Depressionsrisiko im Sinne der Verursachungsthese; Depression bedingt den sozioökonomischen Status im Sinne der Driftthese) auftreten, sprechen die meisten Befunde dieser Metaanalyse für die Verursachungsthese. Aktuelle Studien zum Alter bestätigen den Befund eines sozialen Gradienten bei Depression (Domènech-Abella et al. 2018; Han et al. 2018; Lei et al. 2014; McEniry et al.2018). Besonders interessant ist das Ergebnis einer japanischen Studie, in der die Autoren die späte Wirkung früher Lebenserfahrungen nachweisen konnten: Personen, die in Familien mit einem geringen sozioökonomischen Status aufgewachsen waren, hatten Jahrzehnte später - im Alter - ein um 44 \% höheres Risiko, an einer Depression zu erkranken als jene, deren Eltern einen hohen sozioökonomischen Status aufgewiesen hatten (Tani et al. 2016).

\section{$4 \quad$ Soziale Netzwerke und Gesundheit}

In der Forschung werden eine Vielzahl von Gesundheitsparametern in ihrem Bezug zu sozialen Netzwerken im Alter untersucht, wobei - den Besonderheiten des Alters entsprechend - der Fokus besonders häufig auf dem Sterblichkeitsrisiko, kognitiven Verläufen und Depression liegt. Zu diesen drei Schwerpunkten werden im Folgenden ausgewählte Studien dargestellt.

\subsection{Sterblichkeitsrisiko}

Die Einbettung in soziale Netzwerke ist mit dem Sterblichkeitsrisiko assoziiert. $\mathrm{Zu}$ dieser Schlussfolgerung kam die Forschergruppe um Holt-Lunstad in ihrer Metaanalyse von 70 Studien zu subjektiver und objektiver sozialer Isolation (Holt-Lunstad et al. 2015): Einsamkeit sowie Alleinleben korrespondierten in ähnlicher Assoziationsstärke mit einem erhöhten Sterblichkeitsrisiko (26\% und $32 \%$ ). Dieses Ergebnis knüpft an eine frühere Metaanalyse derselben Erstautorin an: Über 148 Studien hinweg fand sie eine um $50 \%$ höhere Sterbewahrscheinlichkeit für schwach im Vergleich zu stark eingebetteten Personen (Holt-Lunstad et al. 2010). Einbettung wurde über funktionale (bspw. Erhalten sozialer Unterstützung, Einsamkeit) und strukturelle Netzwerkmaße (bspw. Anzahl sozialer 
Beziehungen, Haushaltsgröße) gemessen. Dieser Unterschied in der Sterbewahrscheinlichkeit, welcher in etwa mit dem Gesundheitsrisiko des Rauchens und der Adipositas dritten Grades vergleichbar ist, zeigte sich konsistent über Altersgruppen, Geschlecht, ursprünglichen Gesundheitszustand, Todesursache und Beobachtungszeitraum der Studien hinweg. Interessante Differenzen stellten sich dabei bezüglich der verwendeten Netzwerkmaße heraus: Der Zusammenhang zwischen Einbettung und Sterblichkeit war am größten, wurden funktionale und strukturelle Maße von Netzwerken kombiniert.

\subsection{Kognitive Verläufe und Demenzrisiko}

Einige Metaanalysen haben bereits die beeindruckende Vielzahl an Studien zu sozialer Integration und kognitiver Funktion zusammenfassend aufgearbeitet. In einer Metaanalyse von Kuiper et al. (2015) zeigten drei von 43 Studien einen signifikanten Zusammenhang zwischen kognitiver Funktionsabnahme und Netzwerkgröße. Ältere Menschen mit kleineren Netzwerken verzeichneten eine stärkere Abnahme im Beobachtungszeitraum als ältere Menschen mit größeren Netzwerken (Chi und Chou 2000; Holtzman et al. 2004; Hughes et al. 2008). Diese Assoziation war stärker als für funktionale Aspekte wie geringe soziale Aktivität.

In einer weiteren Übersicht zu 19 Längsschnittstudien fanden Kuiper und Kollegen (2015) einen positiven Zusammenhang zwischen Demenzrisiko und geringer sozialer Teilhabe, geringer Kontakthäufigkeit und hoher Einsamkeit. Die Autoren verglichen die Effektstärken mit denen einer geringen Bildung, geringer körperlicher Aktivität und der Altersdepression. Ergebnisse zu Netzwerkgröße und Zufriedenheit mit dem Netzwerk blieben hingegen inkonsistent, sodass hierfür kein signifikanter Zusammenhang gefunden wurde: Nur zwei der acht Studien, die Netzwerkgröße berücksichtigten, zeigten eine erhöhte Demenzwahrscheinlichkeit von älteren Menschen mit kleinen Netzwerken (James et al. 2011; Saczynski et al. 2006).

$\mathrm{Zu}$ einem ähnlichen Ergebnis kommen Fratiglioni und Kollegen (2004) in ihrer Metaanalyse von 13 Studien. Drei von sechs Studien, die soziale Netzwerke analysierten, fanden ein vermindertes Demenzrisiko für stark sozial integrierte Personen (Fratiglioni et al. 2000; Scarmeas et al. 2001; Wang et al. 2002). Fünf von sieben Studien fanden eine geringere Abnahme kognitiver Funktionsfähigkeiten. Darüber hinaus ist auch der umgekehrte Kausalzusammenhang belegt: Nehmen kognitive Fähigkeiten mit dem Alter stark ab, verkleinert sich infolgedessen oft auch das soziale Netzwerk der Betroffenen (Aartsen et al. 2004), da sich ihr sozialer und physischer Aktionsradius verringert. Die zunehmenden kognitiven Beeinträchtigungen können so einen Rückzug in familiäre Beziehungsnetzwerke begünstigen. 


\subsection{Depression}

In ihrem systematischen Review analysierten Schwarzbach et al. (2014) insgesamt 37 Studien, die Zusammenhänge zwischen sozialen Netzwerken und Depression bei älteren Menschen untersucht hatten. Während die Befunde zu funktionalen Netzwerkaspekten insgesamt sehr konsistent sind (wenig soziale Unterstützung und geringe Beziehungsqualität sind mit Depression assoziiert), fielen die zu strukturellen Netzwerkaspekten (wie Familienstand, Netzwerkgröße und Kontakthäufigkeit) mehrheitlich heterogen aus. Übereinstimmend zeigte sich hingegen, dass Alleinlebende kein höheres Risiko für depressive Symptome aufwiesen. Teilweise werden die Zusammenhänge durch den kulturellen Kontext moderiert. So war in östlichen Kulturen wie China und Japan eine hohe Kontaktfrequenz mit einem geringeren Depressionsrisiko assoziiert. Für westliche Kulturen hingegen konnte dieser Zusammenhang nicht bestätigt werden. Antonucci et al. (1997) fanden in ihrer Analyse Belege dafür, dass funktionale und strukturelle Netzwerkaspekte je eigenständige Wirkungen auf depressive Symptome im Alter haben. Der Bedeutung sozialer Netzwerke für die Beziehung zwischen funktionalen Beeinträchtigungen und depressiven Symptomen gingen Litwin und Stoeckel (2016) in ihrer Arbeit nach. Es zeigte sich, dass funktional beeinträchtigte Personen mehr depressive Symptome aufweisen, wenn sie über keinerlei soziales Netzwerk verfügten im Vergleich zu jenen mit Netzwerkpartnern.

\section{$5 \quad$ Soziale Ungleichheit, soziale Netzwerke und Gesundheit}

Studien, die Beziehungen zwischen sozialer Ungleichheit, sozialen Netzwerken und Gesundheit im Alter analysieren, sind vergleichsweise rar. Sie berücksichtigten sowohl funktionale (also v. a. Unterstützungsformen) als auch strukturelle (also v. a. Größe, Häufigkeit der Kontakte) Aspekte. Die Darstellung vorliegender Befunde strukturiert sich entlang dreier Hypothesen:

1. Merkmale sozialer Netzwerke mediieren den Zusammenhang von sozioökonomischem Status und Gesundheit, d. h. der sozioökonomische Status wirkt sich über soziale Netzwerke auf den Gesundheitszustand aus.

2. Merkmale sozialer Netzwerke moderieren den Zusammenhang von sozioökonomischem Status und Gesundheit, d. h. Netzwerkmerkmale beeinflussen die Stärke des Zusammenhangs zwischen sozioökonomischem Status und Gesundheitszustand. 
3. Der sozioökonomische Status moderiert den Zusammenhang von sozialem Netzwerk und Gesundheit, d. h. der sozioökonomische Status beeinflusst die Stärke des Zusammenhangs zwischen Netzwerkmerkmalen und Gesundheitszustand.

\subsection{Soziales Netzwerk als Mediator}

An einer deutschen Stichprobe von im eigenen Haushalt lebenden Personen im Alter $\geq 60$ Jahretestete von dem Knesebeck (2005) die Hypothese, dass soziale Netzwerke den Zusammenhang von sozioökonomischem Status und Gesundheit mediieren. Abhängige Variablen waren die subjektive Gesundheit, depressive Symptome und funktionale Einschränkungen. Der sozioökonomische Status wurde mittels Bildung, Einkommen und Beruf erfasst. Zur Abbildung des sozialen Netzwerkes wurden die beiden Proxys „Kontakthäufigkeit mit Freunden/Bekannten“ und „Kontakthäufigkeit mit Familienmitgliedern“ sowie die wahrgenommene Verfügbarkeit, Inanspruchnahme und Adäquatheit emotionaler Unterstützung verwandt. Im Ergebnis zeigte sich, dass die vermittelnden Effekte sozialer Netzwerke auf den sozialen Gradienten von Gesundheit insgesamt nur schwach sind: Bei Kontrolle der Items „Kontakthäufigkeit mit Freunden/Bekannten“, „Kontakthäufigkeit mit Familienmitgliedern“ und „Verfügbarkeit emotionaler Unterstützung" verringern sich die positiven Zusammenhänge zwischen Einkommenshöhe und subjektiver sowie funktionaler Gesundheit bzw. der negative Zusammenhang zwischen Einkommenshöhe und Depressivität nur leicht und bleiben im signifikanten Bereich. Eine Verstärkung zeigt sich gar bei den Zusammenhängen zwischen Bildung bzw. Beruf und den drei Gesundheitsindikatoren, wenn die Netzwerkmerkmale kontrolliert werden (von dem Knesebeck 2005). Depressive Symptome wurden auch in der koreanischen Studie von Han et al. (2018) untersucht. Sie konnten zeigen, dass der Grad der Reziprozität des sozialen Austauschs den Zusammenhang von Haushaltseinkommen und Depression mediiert. Die subjektive Gesundheit untersuchten Vonneilich et al. (2012) im Rahmen der deutschen Heinz Nixdorf Recall Studie. Die analysierten Daten stammen aus der Baseline-Untersuchung und dem Fünf-Jahres-Follow-up (4146 Männer und Frauen im Alter 45 bis 75 Jahre). Strukturelle Merkmale wurden mit dem „Social Integration Index“ (SNI) erhoben (Berkman et al. 2004). Funktionale Merkmale wurden mit dem „New Haven Established Population for Epidemiologic Studies of the Elderly Questionnaire“ (EPESE) gemessen (Seeman und Berkman 1988). Es konnte gezeigt werden, dass sowohl strukturelle als auch funktionale Netzwerkmerkmale Zusammenhänge zwischen 
dem sozioökonomischen Status und der subjektiven Gesundheit vermitteln. Im Gegensatz dazu traten in der prospektiven Follow-up-Studie (Beobachtungszeitraum drei Jahre) von Nilsson et al. (2010) keine Mediatoreffekte des sozialen Netzwerkes auf den Zusammenhang von sozioökonomischem Status (gemessen über das finanzielle Vermögen) und der funktionalen Gesundheit (gemessen über die Anzahl von Mobilitätsaktivitäten, die ohne fremde Hilfe ausgeführt werden können) auf. Eingesetzte Netzwerkindikatoren bezogen sich auf Kohabitation, soziale Teilhabe, Netzwerkdiversität und Zufriedenheit mit sozialen Kontakten (Nilsson et al. 2010). Auch die Ergebnisse von Yan et al. (2013) auf der Grundlage einer Follow-up Studie, die einen Beobachtungszeitraum von 11,5 Jahren umfasste, stützen die Mediatorhypothese nicht. Die amerikanische Stichprobe bestand aus 64- bis 100-jährigen Personen. Untersucht wurde die Häufigkeit eines ischämischen Schlaganfalls in Abhängigkeit vom sozioökonomischen Status des Wohnviertels (,Neighbourhood socioeconomic status“). Netzwerkmerkmale wurden mit der „Interpersonal Support Evaluation List“ (Cohen et al. 1985), die die wahrgenommene Verfügbarkeit von sozialer Unterstützung erfasst, und der „Lubben Social Network Scale“ (Lubben 1988), ein speziell für die ältere Bevölkerung entwickeltes Instrument, das neben der emotionalen und instrumentellen Unterstützung auch die tatsächliche Größe des Netzwerkes erfragt, erhoben.

In der Zusammenschau geben die referierten Befunde keine eindeutige Antwort auf die Frage nach einem Mediatoreffekt struktureller Netzwerkmerkmale im höheren Lebensalter.

\subsection{Soziales Netzwerk als Moderator}

Mit Daten der vierten Welle der SHARE-Studie (Survey of Health, Ageing and Retirement in Europe) untersuchten Olofsson et al. (2018) Moderatoreffekte sozialer Netzwerke. Die Stichprobe umfasste 54.751 Personen im Alter $\geq$ 50 Jahre aus 16 europäischen Ländern. Zentrale Indikatoren waren Bildung und subjektive Gesundheit. Der Erhebung von Netzwerkgröße und -zufriedenheit lag ein Netzwerkgenerator zugrunde. Als Ergebnis wird ein moderierender Effekt der Netzwerkzufriedenheit bei Männern und Frauen Nordeuropas berichtet: Bei hoher Zufriedenheit ist der Zusammenhang zwischen sozioökonomischem Status und Gesundheit stärker, bei geringer Zufriedenheit schwächer ausgeprägt. Die Autoren argumentieren, dass insbesondere Personen mit geringerer Bildung bei schlechter Gesundheit Hilfe im sozialen Netzwerk finden, was mit hoher Zufriedenheit einhergeht. Darüber hinaus wird vermutet, dass eine geringe Zufriedenheit mit Netzwerkkontakten Folge emotional belastender Beziehungen 
sein könne, die das Wohlbefinden schwäche und den sozialen Gradienten verringere (Olofsson et al. 2018).

Das Ergebnis dieser Studie stützt die Hypothese vom Moderatoreffekt sozialer Netzwerke auf den sozialen Gradienten von Gesundheit. Der soziale Gradient ist bei hoher Zufriedenheit mit dem sozialen Netzwerk stärker ausgeprägt.

\subsection{Sozioökonomischer Status als Moderator}

Mittels längsschnittlicher Daten der MacArthurStudy of Successful Aging untersuchten Unger et al. (1999) die Rolle des sozioökonomischen Status (erhoben über Einkommen) bezüglich des Einflusses sozialer Netzwerke auf Veränderungen funktionaler Gesundheit im Zeitraum von sieben Jahren. Die Stichprobe umfasste Personen im Alter von 70-79 Jahren. Die Netzwerk-Items bezogen sich auf strukturelle und funktionale Merkmale. Es zeigte sich, dass bei Personen mit einem größeren sozialen Netzwerk funktionale Beeinträchtigungen geringer ausfielen als bei Personen mit kleinem Netzwerk. Dieser Zusammenhang war bei Männern besonders ausgeprägt. Das Einkommen indes erwies sich nicht als Moderatorvariable. In der bereits erwähnten Studie von von dem Knesebeck (2005) wurden neben Mediatoreffekten auch Moderatoreffekte getestet. Diese fielen in Abhängigkeit von Gesundheitsindikator und Netzwerkmerkmal inkonsistent aus. Während die positiven Korrelationen zwischen Netzwerkmerkmalen (Kontakthäufigkeit mit Freunden; Kontakthäufigkeit mit Familie) und subjektiver Gesundheit bzw. funktionaler Gesundheit bei mittleren Statusgruppe schwächer als bei niedrigen und hohen Statusgruppen waren, erwies sich die negative Korrelation zwischen Kontakthäufigkeit und Depressivität bei Personen mit hohem Status am stärksten: Personen mit seltenen Kontakten zu Freunden und Familie und defizitärer sozialer Unterstützung hatten, wenn sie der hohen Statusgruppe angehörten, ein höheres Risiko, an Depression zu erkranken als Personen mit geringerem Status. Auch in der Heinz-Nixdorf Recall Studie (Vonneilich et al. 2011) zeigten sich nur wenige statistisch signifikante Interaktionseffekte von sozioökonomischem Status und sozialem Netzwerk auf die subjektive Gesundheit bzw. Depression, die zudem zwischen Männern und Frauen variierten.

Die berichteten Befunde unterstützen nur partiell die Annahme, dass der sozioökonomische Status die empirisch vielfach belegten Zusammenhänge zwischen strukturellen Netzwerkmerkmalen und Gesundheit im höheren Lebensalter moderiert. 


\section{Zusammenfassung und kritische Reflexion}

Der Beitrag konnte zeigen, dass auch im höheren Lebensalter Zusammenhänge zwischen sozioökonomischem Status und Sterblichkeits-, Demenz- und Depressionsrisiko bestehen. Die dargestellten Befunde geben jedoch keine eindeutige Antwort auf die Frage nach dem Verlauf gesundheitlicher Ungleichheit im Lebenslauf. Die referierten Studien bestätigen sowohl die Kontinuitäts- als auch die Divergenzthese. So deuten einerseits die Studien zum Sterblichkeitsrisiko darauf hin, dass sich im Lebensverlauf statusbedingte Unterschiede im Sterberisiko fortsetzen (Kontinuitätsthese). Das höhere Risiko von Personen mit geringerem sozioökonomischen Status, im Alter an Demenz und Depression zu erkranken, kann andererseits die gesundheitliche Ungleichheit vergrößern (Divergenzthese). Die Uneindeutigkeit der Befunde, bezogen auf den Verlauf gesundheitlicher Ungleichheit, wurde in der Forschungsliteratur häufig konstatiert. Dies ist auch den unterschiedlichen Operationalisierungen der sozioökonomischen Indikatoren (Bildung, Berufsstatus, Einkommen) und den verschiedenen Gesundheitsdimensionen geschuldet. Fraglich ist darüber hinaus, ob die herkömmlichen Indikatoren überhaupt geeignet sind, Unterschiede in den akkumulierten sozioökonomischen Bedingungen im Alter hinreichend $\mathrm{zu}$ erfassen (Ausbildung und Beruf liegen lange zurück, sind für Männer und Frauen nur bedingt vergleichbar, Eigentumsverhältnisse geben mehr Aufschluss über Anhäufung von Ressourcen) (Clemens 2008; von dem Knesebeck und Schäfer 2009; Kohli et al. 2000; Leopold und Engelhardt 2011). Für Eltern im hohen Alter ist z. B. denkbar, dass die gesundheitliche Ungleichheit auch auf ungleiche, sozioökonomisch bedingte Ressourcen ihrer erwachsenen Kinder (wie z. B. Ausmaß der Unterstützung bei Pflegeleistungen; Wissen über Diagnose- und Behandlungsmöglichkeiten) beeinflusst wird (Rueda und Artazcoz 2009; Saraceno 2010). Wie zudem am Beispiel der Depression gezeigt werden konnte, kann darüber hinaus auch der erlebte elterliche sozioökonomische Status in der Kindheit für die Gesundheit im Alter eine nicht zu unterschätzende Rolle spielen (Brandt et al. 2012; Pakpahan et al. 2017). Für weitere Forschungen kann es lohnend sein, neben der sozioökonomischen Position der Person im Alter auch die ihrer Eltern und erwachsenen Kinder stärker in den Blick zu nehmen.

Studienbefunde zu den Wechselwirkungen zwischen strukturellen Netzwerkmerkmalen und Sterblichkeits-, Demenz- und Depressionsrisiko stützen die Aktivitätstheorie: Die Pflege von sozialen Interaktionen auch im Ruhestand erweist sich als wichtiger Schutzfaktor für die Gesundheit. Es scheint, dass es dabei weniger auf die Netzwerkgröße als vielmehr auf das Ausmaß sozialer Einbettung ankommt. Diese kann, entsprechend der sozioemotionalen 
Selektivitätstheorie, auch bei abnehmender Netzwerkgröße erlebt werden. Eine Erklärung dafür könnte in der Stabilität der Netzwerkpersonen, die, gemäß der Theorie des sozialen Konvois, zum inneren Kern zählen, liegen. Für eine abschließende Diskussion ist jedoch mehr Forschung hinsichtlich Anzahl und Rollendiversität sozialer Beziehungen (Ellwardt et al. 2015), aber auch anderer struktureller Netzwerkcharakteristika wie Netzwerkdichte und Brückenbeziehungen erforderlich. Deutlich wurde zudem, dass bei der Analyse der Zusammenhänge zwischen sozialem Netzwerk und Gesundheit der kulturelle Kontext berücksichtigt werden muss (Li und Zhang 2015; Schwarzbach et al. 2014). Wichtig ist, dass sowohl funktionale als auch strukturelle Merkmale je eigenständige Beiträge zur Varianzaufklärung gesundheitlicher Parameter im Alter leisten können (Antonucci et al. 1999). Darüber hinaus wurde sichtbar, dass die Zusammenhänge mit Gesundheit v. a. dann groß waren, wenn komplexe Maße analysiert worden sind (z. B. sowohl Lebensform als auch Netzwerkintegration und Erleben der Netzwerkbeziehung). Dies bedeutet, dass Forschungsdesigns, die sich lediglich auf qualitative oder quantitative Netzwerkmerkmale konzentrieren, den eigentlichen Effekt der sozialen Einbettung potenziell systematisch unterschätzen können. Es sollten also mehrere Indikatoren parallel getestet (Ellwardt et al. 2015) oder aber kombiniert werden, z. B. in Form von Netzwerktypologien (Ellwardt et al. 2016). Bei der Bildung einer Typologie werden Personen anhand verschiedener Merkmale ihrer Netzwerke klassifiziert, z. B. in Gruppen mit großen funktionalen versus kleinen wenig funktionalen Netzwerken. Diese Personengruppen können in einem weiteren Schritt hinsichtlich ihrer Gesundheit verglichen werden. Kritisch anzumerken ist ferner, dass häufig lediglich Proxys zur Operationalisierung von sozialen Netzwerken herangezogen werden, wie z. B. die Häufigkeit sozialer Kontakte oder die Haushaltszusammensetzung. Dabei liegen durchaus Hinweise zum Mehrwert echter Netzwerkanalysen für die Erklärung von Gesundheit im Alter vor (Li und Zhang 2015; Schwarzbach et al. 2014; Youm et al. 2014). Längsschnittliche Analysen fokussieren bislang vor allem die Testung von Netzwerkeffekten auf Gesundheit. Forschungslücken bestehen bezüglich der Frage nach einer gegenteiligen Wirkrichtung, dem Einfluss gesundheitlicher Verschlechterungen auf soziale Netzwerke.

Vorliegende Analysen zu Zusammenhängen der drei Bereiche ,sozioökonomischer Status“, „Gesundheit“ und ,,soziales Netzwerk“ konzentrieren sich v. a. auf Depression sowie funktionale und subjektive Gesundheit. Das Sterblichkeitsrisiko und Demenzerkrankungen sind hingegen weitgehend unerforscht. Die Vermittlungsmechanismen von sozioökonomischem Status, Gesundheit und sozialem Netzwerk im Alter können durch bisherige Studien nicht hinreichend erklärt werden. Nach bisherigem Kenntnisstand erscheinen Moderatoreffekte von 
Netzwerkmerkmalen auf die gesundheitliche Ungleichheit im Alter am wahrscheinlichsten.

Aus der bisherigen Forschung wird folgendes deutlich: Erstens liegt der Fokus der Studien auf in der eigenen Häuslichkeit lebenden Personen. Weitgehend unklar ist, inwieweit vorliegende Befunde auch auf in Pflegeeinrichtungen lebende Personen übertragbar sind. Diese Forschungslücke gilt es zu schließen. Zweitens hat sich gezeigt, dass Designs, die komplexe Merkmale von sozialen Netzwerken erheben, für die Untersuchung der Beziehung ,,sozioökonomischer Status“, „Gesundheit" und „soziales Netzwerk" besser geeignet sind als Instrumente, die nur quantitative oder nur qualitative Merkmale erheben. Drittens werden Netzwerkmerkmale in der gerontologischen Forschung mehrheitlich nur indirekt, durch Proxys, gemessen. Etablierte quantitative und qualitative Verfahren der Netzwerkanalyse spielen bei der Erforschung von alten Menschen bislang eine untergeordnete Rolle. Ihr Potenzial sollte für zukünftige Forschung wesentlich stärker genutzt werden.

\section{Leseempfehlungen}

Vonneilich, N., Jöckel, K.-H., Erbel, R., Klein, J., Dragano, N., Siegrist, J., \& von Dem Knesebeck, O. (2012). The mediating effect of social relationships on the association between socioeconomic status and subjective health-results from the Heinz Nixdorf Recall cohort study. BMC Public Health. https://doi.org/10.1186/1471-2458-12-285 Die Studie ist eine der ersten, die den Effekt des SES auf die Beziehung zwischen sozialen Beziehungen und Gesundheit untersucht (Durchschnittsalter der Stichprobe: 60 Jahre). Es zeigen sich nur wenige statistisch signifikante Interaktionseffekte von sozioökonomischem Status und sozialem Netzwerk auf die subjektive Gesundheit bzw. Depression, die zudem zwischen Männern und Frauen variieren.

Ellwardt, L., van Tilburg, T., Aartsen, M., Wittek, R., \& Steverink, N. (2015). Personal networks and mortality risk in older adults: a twenty-year longitudinal study. PloS one. https://doi.org/10.1371/journal.pone.0116731 Mittels Daten aus der Longitudinal Aging Study Amsterdam (LASA) werden Beziehungen zwischen der Sterblichkeit und Netzwerkmerkmalen, die sowohl strukturelle als auch funktionale Aspekte abbilden, berichtet.

Goldman, A. W., \& Cornwell, B. (2015). Social network bridging potential and the use of complementary and alternative medicine in later life.Social Science \& Medicine. https://doi.org/10.1016/j.socscimed.2015.07.003 Die Studie testet mit Daten der 1. Welle des National 
Social Life, Health, and Aging Project (NSHAP) die Hypothese, dass Personen, die ansonsten unverbundene Gruppen miteinander verbinden, also eine Brückenfunktion innehaben, häufiger als andere Netzwerkmitglieder komplementäre Medizin in Anspruch nehmen.

\section{Datensätze}

- „SHARE“ (The Survey of Health, Ageing and Retirement in

\section{Europe)}

Die Studie begann 2004 als repräsentative Befragung der Bevölkerung im Alter 50+. An der Baseline-Untersuchung nahmen 11 europäische Länder (Belgien, Dänemark, Deutschland, Frankreich, Griechenland; Italien, Niederlande, Österreich, Schweiz, Schweden, Spanien) teil. Es liegen quer- und längsschnittliche Daten aus sechs Erhebungswellen und Teilnehmern aus 27 europäischen Ländern sowie Israel vor. In der vierten und sechsten Welle wurde das soziale Netzwerk über Namensgeneratoren erfragt.

www.share-project.org

\section{- „Heinz Nixdorf Recall Studie““}

Es handelt sich um eine bevölkerungsbasierte Kohortenstudie. Die Stichprobenteilnehmer leben in der Metropole Ruhr und waren zur Baseline-Untersuchung 2000-2003 45-75 Jahre alt. Eine zweite Welle fand 2006-2008, eine dritte 2010-2013 statt. Untersucht werden insbesondere kardiovaskuläre Erkrankungen. Eingesetzte Netzwerkinstrumente sind der "Social Integration Index“ (SII) und die deutsche Adaption des „New Haven Established Population for Epidemiologic Studies of the Elderly (EPESE) Questionnaire“. https://www.uni-due.de/recall-studie

\section{- „LASA“ (Longitudinal Aging Study Amsterdam)}

Die Studie fokussiert physische, emotionale und soziale Alternsprozesse anhand einer niederländischen Stichprobe. Zur Baseline-Untersuchung 1992 waren die Teilnehmer der Studie im Alter von 55-85 Jahren. Follow-Up-Untersuchungen erfolgen alle drei Jahre; in jeder Welle werden Daten zum persönlichen Netzwerk erhoben.

https://www.lasa-vu.nl/ 


\section{- „HRS“ (The Health and Retirement Study)}

Die Ausgangsstichprobe dieser amerikanischen Längsschnittstudie bildeten 1931 bis 1941 Geborene. Sie wurden erstmals 1992 untersucht. Erneute Untersuchungen finden alle zwei Jahre statt. Indikatoren zum sozialen Netzwerk erfassen dessen Zusammensetzung, die Anzahl enger Beziehungen sowie die Kontakthäufigkeit. https://hrs.isr.umich.edu/about

- „NSHAP“ (National Social Life, Health, and Aging Project)

Die Baseline-Untersuchung dieser amerikanischen Studie fand 20052006 statt; die Stichprobenteilnehmer waren im Alter von 57 bis 85 Jahren. 2010-2011 wurde eine zweite Welle realisiert. Über Namensgeneratoren werden egozentrierte Netzwerke erhoben.

http://www.norc.org/Research/Projects/Pages/national-social-life-health-and-aging-project.aspx

\section{Literatur}

Aartsen, M. J., Van Tilburg, T., Smits, C. H., \& Knipscheer, K. C. (2004). A longitudinal study of the impact of physical and cognitive decline on the personal network in old age. Journal of Social and Personal Relationships, 21(2), 249-266.

Adams, K. B., Leibbrandt, S., \& Moon, H. (2011). A critical review of the literature on social and leisure activity and wellbeing in later life. Ageing \& Society, 31(4), 683-712.

Antonucci, T. C., Fuhrer, R., \& Dartigues, J.-F. (1997). Social relations and depressive symptomatology in a sample of community-dwelling French older adults. Psychology and Aging, 12(1), 189.

Antonucci, T. C., Ajrouch, K. J., \& Janevic, M. (1999). Socioeconomic status, social support, age, and health. Annals of the New York Academy of Sciences, 896(1), 390-392.

Atchley, R. C. (1989). A continuity theory of normal aging. The Gerontologist, 29(2), 183-190.

Baltes, P. B. (1997). Die unvollendete Architektur der menschlichen Ontogenese: Implikation für die Zukunft des vierten Lebensalters. Psychologische Rundschau, 48, 191-210.

Baltes, P. B. (2007). Alter (n) als Balanceakt: Im Schnittpunkt von Fortschritt und Würde. In P. Gruss (Hrsg.), Die Zukunft des Alterns: Die Antwort der Wissenschaft (S. 15-34). München: Beck.

Baltes, P. B., \& Smith, J. (2003). New frontiers in the future of aging: From successful aging of the young old to the dilemmas of the fourth age. Gerontology, 49(2), 123-135.

Bengtson, V. L., \& Dowd, J. J. (1981). Sociological functionalism, exchange theory and life-cycle analysis: A call for more explicit theoretical bridges. The International Journal of Aging and Human Development, 12(1), 55-73. 
Bengtson, V. L., \& Roberts, R. E. (1991). Intergenerational solidarity in aging families: An example of formal theory construction. Journal of Marriage and the Family, 53(4), 856-870.

Berkman, L. F., Melchior, M., Chastang, J.-F., Niedhammer, I., Leclerc, A., \& Goldberg, M. (2004). Social integration and mortality: A prospective study of French employees of Electricity of France-Gas of France: The GAZEL Cohort. American Journal of Epidemiology, 159(2), 167-174.

Brandt, M., Deindl, C., \& Hank, K. (2012). Tracing the origins of successful aging: The role of childhood conditions and social inequality in explaining later life health. Social Science and Medicine, 74(9), 1418-1425.

Bruandet, A., Richard, F., Bombois, S., Maurage, C., Masse, I., Amouyel, P., \& Pasquier, F. (2008). Cognitive decline and survival in Alzheimer's disease according to education level. Dementia and Geriatric Cognitive Disorders, 25(1), 74-80.

Carstensen, L. L. (1993). Motivation for social contact across the life span: A theory of socioemotional selectivity. Paper presented at the Nebraska symposium on motivation.

Chi, I., \& Chou, K. (2000). Depression predicts cognitive decline in Hong Kong Chinese older adults. Aging \& Mental Health, 4(2), 148-157.

Christensen, H., Mackinnon, A., Jorm, A., Henderson, A., Scott, L., \& Korten, A. (1994). Age differences and interindividual variation in cognition in community-dwelling elderly. Psychology and Aging, 9(3), 381.

Clemens, W. (2008). Zur ,ungleichheitsempirischen Selbstvergessenheit "der deutschsprachigen Alter (n) ssoziologie. In H. Künemund \& K. R. Schroeter (Hrsg.), Soziale Ungleichheiten und kulturelle Unterschiede in Lebenslauf und Alter (S. 17-30). Wiesbaden: Springer VS.

Cohen, S. (2004). Social relationships and health. American Psychologist, 59(8), 676.

Cohen, S., Mermelstein, R., Kamarck, T., \& Hoberman, H. M. (1985). Measuring the functional components of social support social support. In I. G. Sarason \& B. Sarason (Hrsg.), Social support: Theory, research, and applications (S. 73-94). The Hague: Springer Martinus Nijhoff.

Crimmins, E. M. (2004). Trends in the health of the elderly. Annual Revue of Public Health, 25, 79-98.

Cumming, E., \& Henry, W. E. (1961). Growing old, the process of disengagement. New York: Basic Books.

den Brok, M. G., van Dalen, J. W., van Gool, W. A., Moll van Charante, E. P., de Bie, R. M., \& Richard, E. (2015). Apathy in Parkinson's disease: a systematic review and metaanalysis. Movement Disorders, 30(6), 759-769.

Domènech-Abella, J., Mundó, J., Leonardi, M., Chatterji, S., Tobiasz-Adamczyk, B., Koskinen, S., \& Haro, J. M. (2018). The association between socioeconomic status and depression among older adults in Finland, Poland and Spain: A comparative cross-sectional study of distinct measures and pathways. Journal of Affective Disorders, 241, 311-318.

Eisenmenger, M., \& Emmerling, D. (2011). Amtliche Sterbetafeln und Entwicklung der Sterblichkeit. Wirtschaft und Statistik, 3(2011), 219-238.

Ellwardt, L., van Tilburg, T., \& Aartsen, M. (2015a). The mix matters: Complex personal networks relate to higher cognitive functioning in old age. Social Science and Medicine, 125, 107-115. 
Ellwardt, L., van Tilburg, T., Aartsen, M., Wittek, R., \& Steverink, N. (2015b). Personal networks and mortality risk in older adults: A twenty-year longitudinal study. PLoS ONE, 10(3), e0116731.

Ellwardt, L., Aartsen, M., \& van Tilburg, T. (2016). Types of non-kin networks and their association with survival in late adulthood: A latent class approach. Journals of Gerontology. Series B, Psychological Sciences and Social Sciences, 72(4), 694-705.

Ferri, C. P., Prince, M., Brayne, C., Brodaty, H., Fratiglioni, L., Ganguli, M., \& Huang, Y. (2005). Global prevalence of dementia: A Delphi consensus study. The Lancet, 366(9503), 2112-2117.

Finkel, D., Reynolds, C. A., McArdle, J. J., \& Pedersen, N. L. (2007). Age changes in processing speed as a leading indicator of cognitive aging. Psychology and Aging, 22(3), 558.

Fratiglioni, L., Wang, H. X., Ericsson, K., Maytan, M., \& Winblad, B. (2000). Influence of social network on occurrence of dementia: A community-based longitudinal study. The Lancet, 355(9212), 1315-1319.

Fratiglioni, L., Paillard-Borg, S., \& Winblad, B. (2004). An active and socially integrated lifestyle in late life might protect against dementia. The Lancet Neurology, 3(6), 343-353.

Gow, A. J., Mortensen, E. L., \& Avlund, K. (2012). Activity participation and cognitive aging from age 50 to 80 in the Glostrup 1914 cohort. Journal of the American Geriatrics Society, 60(10), 1831-1838.

Han, K.-M., Han, C., Shin, C., Jee, H.-J., An, H., Yoon, H.-K., \& Kim, S.-H. (2018). Social capital, socioeconomic status, and depression in community-living elderly. Journal of Psychiatric Research, 98, 133-140.

Henretta, J. C., \& Campbell, R. T. (1976). Status attainment and status maintenance: A study of stratification in old age. American Sociological Review, 41, 981-992.

Holt-Lunstad, J., Smith, T. B., \& Layton, J. B. (2010). Social relationships and mortality risk: A meta-analytic review. PLoS Med, 7(7), e1000316.

Holt-Lunstad, J., Smith, T. B., Baker, M., Harris, T., \& Stephenson, D. (2015). Loneliness and social isolation as risk factors for mortality: A meta-analytic review. Perspectives on Psychological Science, 10(2), 227-237.

Holtzman, R. E., Rebok, G. W., Saczynski, J. S., Kouzis, A. C., Doyle, K. W., \& Eaton, W. W. (2004). Social network characteristics and cognition in middle-aged and older adults. Journals of Gerontology Series B-Psychological Sciences and Social Sciences, 59(6), 278-284.

Hoogendijk, E. O., Suanet, B., Dent, E., Deeg, D. J., \& Aartsen, M. J. (2016). Adverse effects of frailty on social functioning in older adults: Results from the Longitudinal Aging Study Amsterdam. Maturitas, 83, 45-50.

House, J. S., Kessler, R. C., \& Herzog, A. R. (1990). Age, socioeconomic status, and health. The Milbank Quarterly, 68(3), 383-411.

House, J. S., Kessler, R. C., Herzog, A. R., Mero, R. P., Kinney, A. M., \& Breslow, M. J. (1992). Social stratification, age, and health. In K. W. Schaie, D. Blazer, J. S. House, \& J. A. House (Hrsg.), Aging, health behaviors, and health outcomes (S. 1-32). Hillsdale, NJ: Erlbaum Associates.

Hughes, T. F., Andel, R., Small, B. J., Borenstein, A. R., \& Mortimer, J. A. (2008). The association between social resources and cognitive change in older adults: Evidence from the Charlotte County Healthy Aging Study. Journals of Gerontology Series B-Psychological Sciences and Social Sciences, 63(4), 241-244. 
Hultsch, D. F., Hertzog, C., Small, B. J., \& Dixon, R. A. (1999). Use it or lose it: Engaged lifestyle as a buffer of cognitive decline in aging? Psychology and Aging, 14(2), 245-263.

James, B. D., Boyle, P. A., Buchman, A. S., Barnes, L. L., \& Bennett, D. A. (2011). Life space and risk of Alzheimer disease, mild cognitive impairment, and cognitive decline in old age. The American Journal of Geriatric Psychiatry, 19(11), 961-969.

Katz, S. (1996). Disciplining old age: The formation of gerontological knowledge: Charlottesville: University of Virginia Press.

Kohli, M. (2000). Der Alters-Survey als Instrument wissenschaftlicher Beobachtung. In M. Kohli \& H. Künemund (Hrsg.), Die zweite Lebenshälfte (S. 10-32). Wiesbaden: Springer VS.

Kohli, M., Künemund, H., Motel, A., \& Szydlik, M. (2000). Soziale Ungleichheit. In M. Kohli \& H. Künemund (Hrsg.), Die zweite Lebenshälfte (S. 318-336). Wiesbaden: Springer VS.

Kuiper, J. S., Zuidersma, M., Voshaar, R. C. O., Zuidema, S. U., van den Heuvel, E. R., Stolk, R. P., \& Smidt, N. (2015). Social relationships and risk of dementia: A systematic review and meta-analysis of longitudinal cohort studies. Ageing Research Reviews, 22, 39-57.

Lampert, T., Hoebel, J., Kuntz, B., Fuchs, J., \& Nowossadeck, E. (2017). Gesundheitliche Ungleichheit im höheren Lebensalter. Paper presented at the Public Health Forum.

Lee, Y., \& Chi, I. (2016). Do cognitive leisure activities really matter in the relationship between education and cognition? Evidence from the aging, demographics, and memory study (ADAMS). Aging and Mental Health, 20(3), 252-261.

Lei, X., Sun, X., Strauss, J., Zhang, P., \& Zhao, Y. (2014). Depressive symptoms and SES among the mid-aged and elderly in China: Evidence from the China Health and Retirement Longitudinal Study national baseline. Social Science and Medicine, 120, 224-232.

Lemon, B. W., Bengtson, V. L., \& Peterson, J. A. (1972). An exploration of the activity theory of aging: Activity types and life satisfaction among in-movers to a retirement community. Journal of Gerontology, 27(4), 511-523.

Leopold, L., \& Engelhardt, H. (2011). Bildung und Gesundheitsungleichheit im Alter: Divergenz, Konvergenz oder Kontinuität? Kölner Zeitschrift für Soziologie und Sozialpsychologie, 63(2), 207-236.

Li, T., \& Zhang, Y. (2015). Social network types and the health of older adults: Exploring reciprocal associations. Social Science and Medicine, 130, 59-68.

Liberati, G., Raffone, A., \& Belardinelli, M. O. (2012). Cognitive reserve and its implications for rehabilitation and Alzheimer's disease. Cognitive Processing, 13(1), 1-12.

Litwin, H., \& Stoeckel, K. J. (2016). Social network, activity participation, and cognition: A complex relationship. Research on Aging, 38(1), 76-97.

Lleras-Muney, A. (2005). The relationship between education and adult mortality in the United States. The Review of Economic Studies, 72(1), 189-221.

Lorant, V., Deliège, D., Eaton, W., Robert, A., Philippot, P., \& Ansseau, M. (2003). Socioeconomic inequalities in depression: A meta-analysis. American Journal of Epidemiology, 157(2), 98-112.

Lubben, J. E. (1988). Assessing social networks among elderly populations. Family \& Community Health: The Journal of Health Promotion \& Maintenance, 11(3), 42-52.

Luppa, M., Sikorski, C., Luck, T., Ehreke, L., Konnopka, A., Wiese, B., ... \& Riedel-Heller, S. G. (2012). Age-and gender-specific prevalence of depression in latest-life-systematic review and meta-analysis. Journal of affective disorders, 136(3), 212-221. 
Lüscher, K. (2000). Die Ambivalenz von Generationenbeziehungen - eine allgemeine heuristische Hypothese. In M. Kohli \& M. Szydlik (Hrsg.), Generationen in Familie und Gesellschaft (S. 138-161). Opladen: Leske+Buderich.

Mackenbach, J. P., Stirbu, I., Roskam, A.-J. R., Schaap, M. M., Menvielle, G., Leinsalu, M., \& Kunst, A. E. (2008). Socioeconomic inequalities in health in 22 European countries. New England Journal of Medicine, 358(23), 2468-2481.

Maddox, G. L., \& Eisdorfer, C. (1972). Zusammenhänge zwischen Aktivität und Stimmung bei älteren Menschen. Altern - Probleme und Tatsachen. Frankfurt a. M.: Akademische Verlagsgesellschaft.

Markides, K. S., \& Machalek, R. (1984). Selective survival, aging and society. Archives of Gerontology and Geriatrics, 3(3), 207-222.

Mayer, K. U., \& Wagner, M. (2010). Lebenslagen und soziale Ungleichheit im hohen Alter. In U. Lindenberger, J. Smith, \& P. B. Baltes (Hrsg.), Die Berliner Altersstudie (S. 275299). Berlin: Akademie.

McEniry, M., Samper-Ternent, R., Flórez, C. E., Pardo, R., \& Cano-Gutierrez, C. (2018). Patterns of SES health disparities among older adults in three upper middle-and two high-income countries. The Journals of Gerontology: Series B, gby050.

McMunn, A., Nazroo, J., \& Breeze, E. (2008). Inequalities in health at older ages: A longitudinal investigation of the onset of illness and survival effects in England. Age and Ageing, 38(2), 181-187.

Meng, X., \& D'Arcy, C. (2012). Education and dementia in the context of the cognitive reserve hypothesis: A systematic review with meta-analyses and qualitative analyses. PLoS ONE, 7(6), e38268.

Mourao, R. J., Mansur, G., Malloy-Diniz, L. F., Castro Costa, E., \& Diniz, B. S. (2016). Depressive symptoms increase the risk of progression to dementia in subjects with mild cognitive impairment: systematic review and meta-analysis. International journal of geriatric psychiatry, 31(8), 905-911.

Müller, B., \& Kropp, P. (2011). Aktivität und Kognition im höheren Lebensalter - Befunde aus der ILSE: oder: Wie bleibt das Gehirn möglichst lange frisch? In J. Höppner, D. Schläfke, \& J. Thome (Hrsg.), Impulse für Psychiatrie, Psychotherapie und Psychosomatik in der Lebensspanne (S. 215-228). Berlin: Medizinisch Wissenschaftliche Verlagsgesellschaft.

Müller, B., \& Kropp, P. (2012). Freizeit im höheren Lebensalter. Ein Bereich aktiver Lebensgestaltung. Befunde aus der Interdisziplinären Längsschnittstudie des Erwachsenenalters (ILSE). In M. Kumlehn \& A. Kubik (Hrsg.), Konstrukte gelingenden Alterns (S. 207-228). Stuttgart: Kohlhammer.

Müller, B., Nienaber, C. A., Reis, O., Kropp, P., \& Meyer, W. (2014). Sexuality and affection among elderly German men and women in long-term relationships: results of a prospective population-based study. PLoS ONE, 9(11), e111404.

Neugarten, B., Havighurst, R., Munnichs, J., \& Thomae, H. (1969). Adjustment to retirement. Assen, The Netherlands: Van Gorcum.

Nilsson, C. J., Avlund, K., \& Lund, R. (2010). Social inequality in onset of mobility disability among older Danes: The mediation effect of social relations. Journal of Aging and Health, 22(4), 522-541.

Olofsson, J., Padyab, M., \& Malmberg, G. (2018). Health disparities in Europe's ageing population: The role of social network. Global Health Action, 11(1), 1445498. 
Pakpahan, E., Hoffmann, R., \& Kröger, H. (2017). The long arm of childhood circumstances on health in old age: Evidence from SHARELIFE. Advances in Life Course Research, 31, 1-10.

Reischies, F. M., \& Lindenberger, U. (2010). Grenzen und Potentiale kognitiver Leistungsfähigkeit im Alter. In U. Lindenberger, J. Smith, \& P. B. Baltes (Hrsg.), Die Berliner Altersstudie (S. 375-401). Berlin: Akademie.

Rueda, S., \& Artazcoz, L. (2009). Gender inequality in health among elderly people in a combined framework of socioeconomic position, family characteristics and social support. Ageing \& Society, 29(4), 625-647.

Saczynski, J. S., Pfeifer, L. A., Masaki, K., Korf, E. S., Laurin, D., White, L., \& Launer, L. J. (2006). The effect of social engagement on incident dementia: The Honolulu-Asia Aging Study. American Journal of Epidemiology, 163(5), 433-440.

Saraceno, C. (2010). Social inequalities in facing old-age dependency: A bi-generational perspective. Journal of European Social Policy, 20(1), 32-44.

Scarmeas, N., Levy, G., Tang, M.-X., Manly, J., \& Stern, Y. (2001). Influence of leisure activity on the incidence of Alzheimer's disease. Neurology, 57(12), 2236-2242.

Scarmeas, N., \& Stern, Y. (2003). Cognitive reserve and lifestyle. Journal of Clinical and Experimental Neuropsychology, 25(5), 625-633.

Schöllgen, I., Huxhold, O., \& Tesch-Römer, C. (2010). Socioeconomic status and health in the second half of life: findings from the German ageing survey. European Journal of Ageing, 7(1), 17-28.

Schooler, C. (1984). Psychological effects of complex environments during the life span: A review and theory. Intelligence, 8(4), 259-281.

Schwarzbach, M., Luppa, M., Forstmeier, S., König, H. H., \& Riedel-Heller, S. G. (2014). Social relations and depression in late life-a systematic review. International Journal of Geriatric Psychiatry, 29(1), 1-21.

Seeman, T. E., \& Berkman, L. F. (1988). Structural characteristics of social networks and their relationship with social support in the elderly: Who provides support. Social Science and Medicine, 26(7), 737-749.

Shanas, E., Townsend, P., Wedderburn, D., Friis, H. K., Milhoj, P., \& Stehouwer, J. (1968). Old people in three industrial societies. New York: Atherton.

Shkolnikov, V. M., Scholz, R., Jdanov, D. A., Stegmann, M., \& Von Gaudecker, H.-M. (2007). Length of life and the pensions of five million retired German men. European Journal of Public Health, 18(3), 264-269.

Spuling, S. M., Wurm, S., Wolff, J. K., \& Wünsche, J. (2017). Heißt krank zu sein sich auch krank zu fühlen? Subjektive Gesundheit und ihr Zusammenhang mit anderen Gesundheitsdimensionen. In K. Mahne, J. K. Wolff, J. Simonson, C. Tesch-Römer \& Deutsches Zentrum für Altersfragen (Hrsg.), Altern im Wandel: zwei Jahrzehnte Deutscher Alterssurvey (DEAS) (S. 157-170). Wiesbaden: Springer VS.

Tani, Y., Fujiwara, T., Kondo, N., Noma, H., Sasaki, Y., \& Kondo, K. (2016). Childhood socioeconomic status and onset of depression among Japanese older adults: the JAGES prospective cohort study. The American Journal of Geriatric Psychiatry, 24(9), 717-726.

Tartler, R. (1961). Das Alter in der modernen Gesellschaft. Stuttgart: Enke.

Tesch-Römer, C. (2010). Soziale Beziehungen alter Menschen. Stuttgart: Kohlhammer. 
Tesch-Römer, C., \& Wurm, S. (2009). Theoretische Positionen zu Gesundheit und Alter. In K. Böhm, C. Tesch-Römer, \& T. Ziese (Hrsg.), Gesundheit und Krankheit im Alter (S. 7-21). Berlin: RKI.

Tews, H. P. (1993). Neue und alte Aspekte des Strukturwandels des Alters. In H. P. Tews (Hrsg.), Lebenslagen im Strukturwandel des Alters (S. 15-42). Opladen: Springer Westdeutscher Verlag.

Then, F. S., Luck, T., Luppa, M., Thinschmidt, M., Deckert, S., Nieuwenhuijsen, K., \& Riedel-Heller, S. G. (2013). Systematic review of the effect of the psychosocial working environment on cognition and dementia. Occupational and Environmental Medicine, oemed-2013-101760.

Unger, J. B., McAvay, G., Bruce, M. L., Berkman, L., \& Seeman, T. (1999). Variation in the impact of social network characteristics on physical functioning in elderly persons: MacArthur Studies of Successful Aging. The Journals of Gerontology Series B: Psychological Sciences and Social Sciences, 54(5), 245-251.

von dem Knesebeck, O. (2005). Die Bedeutung sozialer Beziehungen für den Zusammenhang zwischen sozialer Ungleichheit und Gesundheit im Alter. Sozial-und Präventivmedizin, 50(5), 311-318.

von dem Knesebeck, O., \& Schäfer, I. (2009). Gesundheitliche Ungleichheit im höheren Lebensalter. In M. Richter \& K. Hurrelmann (Hrsg.), Gesundheitliche Ungleichheit (S. 253-265). Wiesbaden: Springer VS.

von dem Knesebeck, O., \& Vonneilich, N. (2009). Gesundheitliche Ungleichheit im Alter. Zeitschrift für Gerontologie und Geriatrie, 42(6), 459-464.

von dem Knesebeck, O., Lüschen, G., Cockerham, W. C., \& Siegrist, J. (2003). Socioeconomic status and health among the aged in the United States and Germany: A comparative cross-sectional study. Social Science and Medicine, 57(9), 1643-1652.

Vonneilich, N., Jöckel, K.-H., Erbel, R., Klein, J., Dragano, N., Weyers, S., \& von dem Knesebeck, O. (2011). Does socioeconomic status affect the association of social relationships and health? A moderator analysis. International Journal for Equity in Health, 10(1), 43.

Vonneilich, N., Jöckel, K.-H., Erbel, R., Klein, J., Dragano, N., Siegrist, J., \& von Dem Knesebeck, O. (2012). The mediating effect of social relationships on the association between socioeconomic status and subjective health - Results from the Heinz Nixdorf Recall cohort study. BMC Public Health, 12(1), 285.

Wang, H.-X., Karp, A., Winblad, B., \& Fratiglioni, L. (2002). Late-life engagement in social and leisure activities is associated with a decreased risk of dementia: A longitudinal study from the Kungsholmen project. American Journal of Epidemiology, 155(12), 1081-1087.

Wang, H.-X., Jin, Y., Hendrie, H. C., Liang, C., Yang, L., Cheng, Y., \& Murrell, J. R. (2012). Late life leisure activities and risk of cognitive decline. Journals of Gerontology Series A: Biomedical Sciences and Medical Sciences, 68(2), 205-213.

Wilson, R., Evans, D., Bienias, J., De Leon, C. M., Schneider, J., \& Bennett, D. (2003). Proneness to psychological distress is associated with risk of Alzheimer's disease. Neurology, 61(11), 1479-1485.

Wrzus, C., Hänel, M., Wagner, J., \& Neyer, F. J. (2013). Social network changes and life events across the life span: a meta-analysis. Psychological Bulletin, 139(1), 53. 
Yan, T., Escarce, J. J., Liang, L. J., Longstreth, W. T., Merkin, S. S., Ovbiagele, B., \& Brown, A. F. (2013). Exploring psychosocial pathways between neighbourhood characteristics and stroke in older adults: The cardiovascular health study. Age and Ageing, 42(3), 391-397.

Yao, L., \& Robert, S. A. (2008). The contributions of race, individual socioeconomic status, and neighborhood socioeconomic context on the self-rated health trajectories and mortality of older adults. Research on Aging, 30(2), 251-273.

Youm, Y., Laumann, E. O., Ferraro, K. F., Waite, L. J., Kim, H. C., Park, Y. R., \& Lee, J. A. (2014). Social network properties and self-rated health in later life: comparisons from the Korean social life, health, and aging project and the national social life, health and aging project. BMC Geriatrics, 14, 102.

Zis, P., Daskalaki, A., Bountouni, I., Sykioti, P., Varrassi, G., \& Paladini, A. (2017). Depression and chronic pain in the elderly: links and management challenges. Clinical interventions in aging, 12, 709.

Open Access Dieses Kapitel wird unter der Creative Commons Namensnennung 4.0 International Lizenz (http://creativecommons.org/licenses/by/4.0/deed.de) veröffentlicht, welche die Nutzung, Vervielfältigung, Bearbeitung, Verbreitung und Wiedergabe in jeglichem Medium und Format erlaubt, sofern Sie den/die ursprünglichen Autor(en) und die Quelle ordnungsgemäß nennen, einen Link zur Creative Commons Lizenz beifügen und angeben, ob Änderungen vorgenommen wurden.

Die in diesem Kapitel enthaltenen Bilder und sonstiges Drittmaterial unterliegen ebenfalls der genannten Creative Commons Lizenz, sofern sich aus der Abbildungslegende nichts anderes ergibt. Sofern das betreffende Material nicht unter der genannten Creative Commons Lizenz steht und die betreffende Handlung nicht nach gesetzlichen Vorschriften erlaubt ist, ist für die oben aufgeführten Weiterverwendungen des Materials die Einwilligung des jeweiligen Rechteinhabers einzuholen.

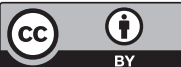


Ungleichheitsdimensionen 


\title{
Sozialer Status, soziale Beziehungen und Gesundheit
}

\author{
Nico Vonneilich
}

\section{Überblick}

- Die Hypothese der differenziellen Exposition geht davon aus, dass der Zusammenhang von sozialem Status und Gesundheit auch deswegen besteht, weil untere Statusgruppen über weniger soziale Kontakte und geringere soziale Unterstützung verfügen.

- Die Hypothese der differenziellen Vulnerabilität geht davon aus, dass sich gerade in unteren sozialen Statusgruppen fehlende soziale Beziehungen stärker gesundheitlich auswirken.

- Bisherige Studienergebnisse können mehrheitlich die Hypothese der differenziellen Exposition bestätigen (Mediator-Effekt sozialer Beziehungen).

- Der Forschungsstand zur Hypothese der differenziellen Vulnerabilität ist eher uneinheitlich, es finden sich wenige Hinweise für einen moderierenden Effekt des sozialen Status auf den Zusammenhang von sozialen Beziehungen und Gesundheit.

\footnotetext{
N. Vonneilich $(\bowtie)$

Institut für Medizinische Soziologie, Universitätsklinikum Hamburg-Eppendorf, Hamburg, Deutschland

E-Mail: n.vonneilich@uke.de
} 


\section{$1 \quad$ Einführung}

Das vorliegende Kapitel möchte einen Überblick über die Forschung zu den Zusammenhängen zwischen sozialen Beziehungen, sozialem Status und Gesundheit bieten. Soziale Beziehungen werden im vorliegenden Beitrag als übergeordneter Begriff verstanden, unter dem sich unterschiedliche Aspekte sozialer Beziehungen wiederfinden. In kaum einer Studie lassen sich umfangreiche Indikatoren sozialer Netzwerke identifizieren (siehe Kap. „Netzwerkanalyse“). In den Studien zum Themengebiet reichen die verwendeten Indikatoren von quantitativen Aspekten wie sozialer Integration, der Anzahl sozialer Kontakte über qualitative Aspekte sozialer Beziehungen wie soziale Unterstützung und sozialem Kapital gemessen auf kleinräumiger Ebene. Einige Studien verwenden nur einzelne Indikatoren, in anderen werden mehrere verwendet. Dieser Vielfalt entsprechend wird soziale Beziehung als Oberkategorie verwendet.

Im Rahmen dieses Kapitels wird der Forschungsstand zu zwei zentralen Fragestellungen aufbereitet:

- Mediator-Effekt von sozialen Beziehungen: Gibt es Studien, die einen Beitrag von sozialen Beziehungen zur Erklärung der Zusammenhänge zwischen sozialem Status und Gesundheit finden konnten?

- Moderator-Effekt des sozialen Status: Inwiefern konnten bereits Hinweise darauf gefunden werden, dass sozialer Status den Zusammenhang zwischen sozialen Beziehungen und Gesundheit moderiert, also der Zusammenhang zwischen sozialen Beziehungen und Gesundheit in verschiedenen Statusgruppen variiert?

Die erste Fragestellung zielt darauf ab, dass sich sozialer Status auf die Gesundheit auswirkt, gerade weil verschiedene Statusgruppen mit unterschiedlichen sozialen Beziehungen ausgestattet sind (siehe Abb. 1). Diese sogenannte Hypothese der differenziellen Exposition (differential exposure hypothesis) geht davon aus, dass der Zusammenhang zwischen sozialem Status und Gesundheit erklärt werden kann, weil untere Statusgruppen über weniger soziale Kontakte und geringere soziale Unterstützung verfügen und sich deshalb die gesundheitlichen Risiken eines niedrigen sozialen Status stärker ausprägen (Krause 2001). Die sozialen Beziehungen könnten so zu einer Erklärung gesundheitlicher Ungleichheiten beitragen, da sie als Mediator zwischen sozialem Status auf der einen und Gesundheit auf der anderen Seite fungieren. 


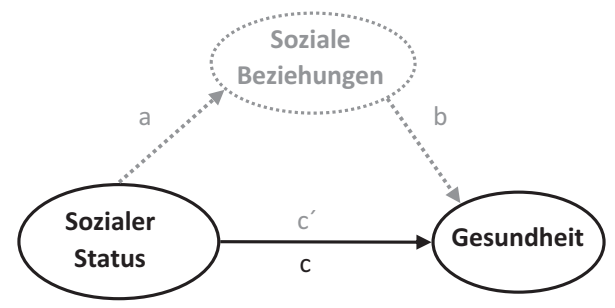

Abb. 1 Erklärungsbeitrag der sozialen Beziehungen zum Zusammenhang zwischen sozialen Beziehungen und Gesundheit (c-c') (These der statusspezifischen Exposition). (Quelle: Eigene Darstellung)

Die zweite Fragestellung basiert auf der Annahme, dass die Zusammenhänge zwischen sozialen Beziehungen und Gesundheit je nach Statusgruppe variieren (siehe Abb. 2). Demnach besteht insbesondere in unteren Statusgruppen eine höhere gesundheitliche Vulnerabilität gerade aufgrund unzureichender sozialer Kontakte und sozialer Unterstützung. Diese Annahme findet sich in der Hypothese der differenziellen Vulnerabilität (differential vulnerability hypothesis) wieder (Krause 2001). Daraus lässt sich ableiten, dass sich insbesondere in unteren Statusgruppen ein stärkerer Zusammenhang zwischen sozialen Beziehungen und Gesundheit finden lässt, der soziale Status den Zusammenhang demzufolge moderiert.

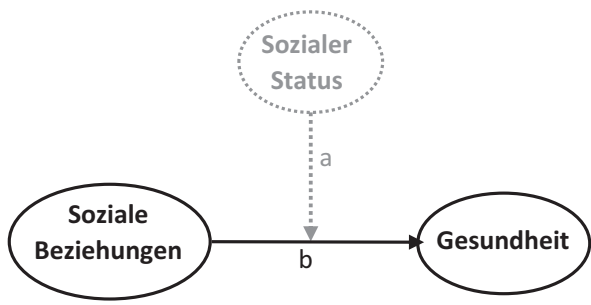

Abb. 2 Moderierender Effekt des sozialen Status (a) auf die Assoziationen zwischen sozialen Beziehungen und Gesundheit (b) (These der statusspezifischen Vulnerabilität). (Quelle: Eigene Darstellung) 


\section{$2 \quad$ Stand der Forschung}

\subsection{Mediator-Effekt der sozialen Beziehungen}

Dass verschiedene Aspekte sozialer Beziehungen eine Mediatorfunktion für die Zusammenhänge zwischen sozioökonomischem Status und Gesundheit einnehmen können, findet sich im sogenannten Pfad-Modell von Berkman und Krishna wieder (siehe dazu Abb. 3, Berkman und Krishna 2014). Im Modell werden die möglichen Pfade von u. a. sozioökonomischen Faktoren auf unterschiedliche Aspekte sozialer Beziehungen und schließlich auf die Gesundheit dargestellt. Die Mediatorfunktion von sozialen Beziehungen, die Frage also, inwiefern soziale Beziehungen den Zusammenhang zwischen sozialem Status und Gesundheit erklären können, wurde bereits in verschiedenen Studien untersucht.

Cohen und Kollegen untersuchten die Zusammenhänge zwischen sozialer Unterstützung, sozialem Status und subjektiver Gesundheit (Cohen et al. 1999). Nachdem sie zeigen konnten, dass soziale Unterstützung sowohl mit höherem sozialem Status als auch mit wahrgenommener Gesundheit positiv assoziiert ist, wurde der Erklärungsbeitrag von sozialer Unterstützung untersucht. Der Erklärungsbeitrag sozialer Beziehungen war in den untersten Statusgruppen am stärksten ausgeprägt (Cohen et al. 1999).

Gorman und Sivaganesan fanden keine Hinweise auf einen vollständigen Mediatoreffekt von sozialen Beziehungen. Jedoch zeigten ihre Subgruppenanalysen, dass die Zusammenhänge zwischen einzelnen Statusindikatoren und subjektiver Gesundheit sich verringern, nachdem für soziale Beziehungen kontrolliert wurde. Insbesondere Arbeitslose schienen hinsichtlich ihrer subjektiven Gesundheit von sozialer Integration zu profitieren, da hier der negative Effekt auf die Gesundheit durch soziale Integration deutlich abgemildert werden konnte (Gorman und Sivaganesan 2007).

Dahl und Malmberg-Heimonen fanden in ihren Analysen auf der Grundlage querschnittlicher, repräsentativer Daten aus Norwegen keinen Mediatoreffekt für soziale Beziehungen in Bezug auf den Zusammenhang zwischen sozioökonomischem Status und Gesundheit (Dahl und Malmberg-Heimonen 2010). Soziale Beziehungen wurden insbesondere auf der Ebene des sozialen Kapitals erfasst, wobei als Indikatoren sowohl emotionale als auch instrumentelle Unterstützung als auch die Anzahl persönlicher Kontakte verwendet wurden. Es zeigte sich jedoch, dass keiner der verwendeten Indikatoren zu einer signifikanten Verringerung des Zusammenhangs zwischen sozialem Status und Gesundheit 


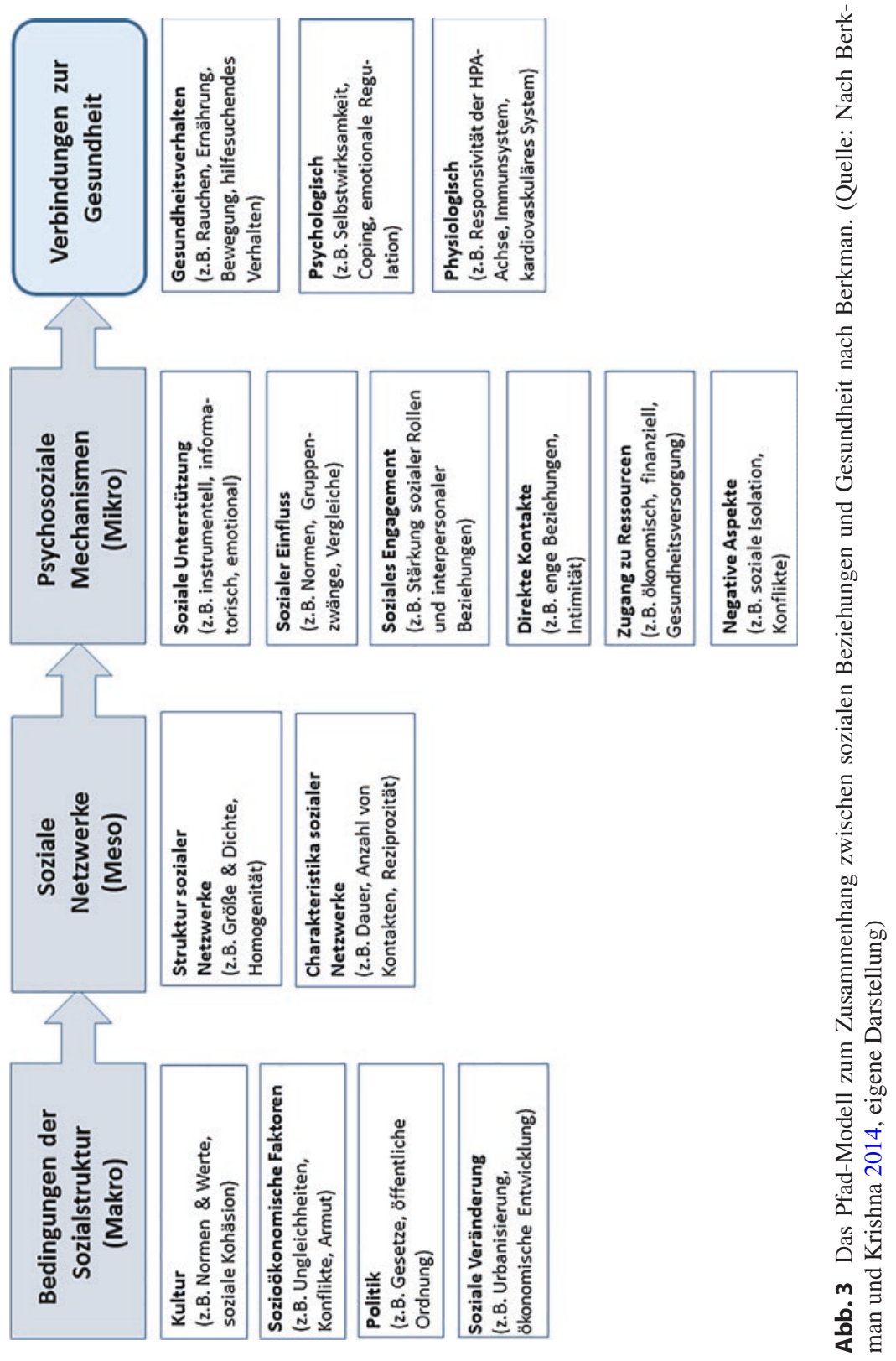


beitrug. Als Gesundheitsindikatoren wurden in der Studie subjektive Gesundheit sowie Angaben zu chronischen Erkrankungen verwendet (Dahl und Malmberg-Heimonen 2010).

Von dem Knesebeck und Geyer (2007) untersuchten ebenfalls, inwiefern soziale Unterstützung möglicherweise zur Erklärung der Zusammenhänge zwischen sozialem Status, gemessen anhand der Bildung, und subjektiver Gesundheit beiträgt. Sie beschränkten sich in ihrer Analyse auf emotionale Unterstützung. Auf Grundlage von Auswertungen des European Social Survey aus dem Jahr 2003 fanden die Autoren wenige Hinweise, dass emotionale Unterstützung zur Erklärung gesundheitlicher Ungleichheiten beitragen kann. In der länderspezifischen Auswertung fanden sich nur für einzelne Staaten Erklärungsbeiträge der emotionalen Unterstützung, die mehr als $10 \%$ des Zusammenhangs zwischen sozialem Status und subjektiver Gesundheit betrugen. Auch fanden sich keine Hinweise, dass die Hinzunahme von emotionaler Unterstützung zu unterschiedlichen Erklärungsbeiträgen zu gesundheitlicher Ungleichheit zwischen Männern und Frauen führt.

Kroll und Lampert (2011) fanden einen Effekt von sozialer Unterstützung auf den Zusammenhang zwischen Erwerbslosigkeit und gesundheitlichen Beeinträchtigungen. Es zeigte sich, dass insbesondere diejenigen Erwerbslosen, welche ausreichend soziale Unterstützung angaben, höhere Wahrscheinlichkeiten für geringe gesundheitliche Beeinträchtigungen hatten als diejenigen, die über wenig soziale Unterstützung verfügen konnten. Dies ergaben die Analysen auf Grundlage einer querschnittlichen, repräsentativen, telefonischen Befragung in Deutschland.

Huurre et al. (2007) fanden in ihrer Studie, basierend auf Daten aus einer finnischen Kohortenstudie, keine Hinweise darauf, dass soziale Unterstützung zur Aufklärung des Zusammenhangs zwischen sozioökonomischem Status und Depressionen bei jungen Erwachsenen beitragen kann.

Einen weiteren Hinweis, dass möglicherweise soziale Beziehungen gerade für ältere Menschen die Zusammenhänge zwischen sozialem Status und Gesundheit abfedern können, lieferten Aida et al. (2011). Anhand ihrer Analyse auf der Basis eines Querschnitts aus einer laufenden japanischen Kohortenstudie konnten die Autoren zeigen, dass für die untersuchte Population insbesondere soziales Kapital auf Gemeindeebene, wie etwa die Anzahl an Vereinsmitgliedschaften sowie ein generelles Vertrauen in der Gemeinde, zu einer Verringerung des Zusammenhangs zwischen sozialem Status und subjektiver Gesundheit beitragen konnte. Jedoch fanden sich keine Beiträge zur Erklärung für Indikatoren des sozialen Kapitals auf Individualebene. 
In Analysen hinsichtlich der Zusammenhänge zwischen sozialer Ungleichheit, sozialer Kohäsion und mentaler Gesundheit konnten Fone et al. (2007) zeigen, dass nicht allein der sozioökonomische Status die Wahrscheinlichkeit schwächerer mentaler Gesundheit beeinflusst, sondern dass gerade das Zusammenspiel zwischen niedrigem Status und gleichzeitig schwacher sozialer Kohäsion innerhalb der Nachbarschaft die Wahrscheinlichkeit schlechter mentaler Gesundheit deutlich erhöhten.

Insgesamt finden sich unterschiedliche Hinweise auf den Erklärungsbeitrag von sozialen Beziehungen zu gesundheitlichen Ungleichheiten. Je nach verwendeten Gesundheitsindikatoren oder erfassten Aspekten von sozialen Beziehungen variieren die gefundenen Erklärungsanteile, zudem spielt die Auswahl der Zielpopulation eine wichtige Rolle, wie etwa die Forschungsarbeiten zu sozialen Beziehungen im höheren Lebensalter zeigen. In einem Review bezüglich der Frage, inwiefern materielle, psychosoziale oder verhaltensbezogene Aspekte einen größeren Beitrag zur Erklärung gesundheitlicher Ungleichheiten liefern, kommen Moor et al. (2017) nach Analyse der Literatur zu dem Schluss, dass insbesondere materielle Aspekte zur Erklärung beitragen. Jedoch betonen die Autoren, dass Effekte materieller Aspekte auch indirekt über psychosoziale und verhaltensbezogene Aspekte auf gesundheitliche Ungleichheit wirken.

\subsection{Moderator-Effekt des sozioökonomischen Status}

Hinweise darauf, dass der sozioökonomische Status die Zusammenhänge zwischen sozialen Beziehungen und Gesundheit moderiert, finden sich auf Grundlage einer französischen Querschnittstudie (Heritage et al. 2008). Die Autoren konnten zeigen, dass insbesondere in unteren Statusgruppen die Assoziationen zwischen schwachen sozialen Beziehungen und schlechter subjektiver Gesundheit am stärksten sind, während sich in oberen Statusgruppen die Zusammenhänge weniger deutlich zeigten.

Gorman und Sivaganesan finden deutliche Unterschiede im Zusammenhang zwischen Bluthochdruck und sozialer Integration - gemessen anhand der Kontakte zu Familien und Freunden in den letzten zwei Wochen vor der Befragung zwischen verschiedenen Statusgruppen (Gorman und Sivaganesan 2007). Gemessen anhand des Bildungsgrads ergab sich, dass diejenigen ohne qualifizierten Schulabschluss mit steigender sozialer Integration auch höhere Risiken für Bluthochdruck zeigten. Dieses Bild wandelt sich jedoch komplett, wenn man die Ergebnisse der Studie für höhere Bildungsgruppen betrachtet: Hier gilt, dass mit steigender sozialer Integration auch die Wahrscheinlichkeit für Bluthochdruck 
abnimmt (Gorman und Sivaganesan 2007). In Bezug auf subjektive Gesundheit zeigte sich, dass insbesondere in höheren Statusgruppen mit steigender sozialer Kontaktfrequenz auch eine höhere Wahrscheinlichkeit für gute subjektive Gesundheit einherging. Auch diese Analysen beruhen jedoch auf Querschnittsanalysen.

Eine Analyse auf Grundlage von Daten aus der französischen GAZELKohortenstudie lieferte Hinweise darauf, dass sozioökonomischer Status den Zusammenhang zwischen sozialen Beziehungen und Gesundheit moderiert (Melchior et al. 2003). Jedoch fanden sich hier unterschiedliche Ergebnisse zwischen den Geschlechtern. Insbesondere für Männer in höheren beruflichen Positionen zeigten sich die stärksten Assoziationen zwischen sozialen Beziehungen und subjektiver Gesundheit: Ein geringes Ausmaß an sozialer Unterstützung führte zu einem deutlich höheren Risiko einer schlechten subjektiven Gesundheit als in den anderen untersuchten Berufsgruppen. Für Frauen zeigten sich über die verschiedenen Berufsgruppen hinweg sehr ähnliche Zusammenhänge (Melchior et al. 2003).

Auf Basis einer für die ältere Bevölkerung (60 Jahre und älter) repräsentativen telefonischen Befragung in Deutschland aus dem Jahr 2001 konnte eine weitere Studie zeigen, dass sozialer Status den Zusammenhang zwischen sozialen Beziehungen und Gesundheit auch in der älteren Bevölkerung moderiert. Es fanden sich insbesondere in der höchsten Statusgruppe signifikante Zusammenhänge von sozialen Beziehungen und den verwendeten Gesundheitsindikatoren (subjektive Gesundheit, funktionale Einschränkungen, Depressivität). Auch fanden sich, wie bereits oben angedeutet, Hinweise auf geschlechtsspezifische Unterschiede, jedoch in konträrer Form zu den oben genannten: Insbesondere für Frauen zeigten sich deutliche Unterschiede zwischen den Statusgruppen (Knesebeck 2005).

Auch in einer finnischen Kohortenstudie an Jugendlichen und Heranwachsenden fanden sich Hinweise darauf, dass die Stärke des Zusammenhangs zwischen sozialen Beziehungen und Gesundheit je nach sozialem Status variiert (Huurre et al. 2007). Als Gesundheitsoutcome wurde Depression verwendet. Soziale Beziehungen wurden durch Angaben zu sozialer Unterstützung und zur Größe des persönlichen Netzwerks erfasst. Es zeigte sich, dass insbesondere in Familien, deren Haupteinkommensbezieher in manueller Tätigkeit arbeitete, der Zusammenhang zwischen Depression und Indikatoren von sozialen Beziehungen stärker ausgeprägt war als in Familien, deren Haupteinkommensbezieher in nicht-manueller Tätigkeit arbeitete (Huurre et al. 2007). 


\section{Diskussion und Bedeutung sozialer Netzwerke}

\subsection{Mediator}

Der Erklärungsanteil von sozialer Integration verweist auf das soziale Umfeld, auf den sozialen Raum, in dem Interaktionen stattfinden. Und der soziale Raum meint auch die unterschiedlichen Strukturen, in denen diese Handlungen vollzogen werden, aber auch die Kontexte, in denen diese stattfinden und welche Interaktionen diese beeinflussen. Denn Maßnahmen, welche die Interaktion von Individuen in einem bestimmten Raum positiv verändern sollen, stellen auch eine Veränderung des Kontextes dar. Die Bedeutung von Kontexten für die Entstehung von Krankheit, aber auch für das Fortbestehen gesundheitlicher Ungleichheiten, rückt zunehmend die Struktur und weniger individuelle Faktoren in den Mittelpunkt (Frohlich et al. 2001). Zentral ist hierbei die Frage, welche Kontexte dafür sorgen, dass sich eben solch individuelle Unterschiede etablieren und dauerhaft halten können, wie sie sich in der gesundheitlichen Ungleichheit widerspiegeln. Ein Beitrag von sozialer Integration zur Abmilderung gesundheitlich negativer Effekte von geringem sozialen Status verweist auf Umstände, die weniger mit den einzelnen Individuen, als vielmehr mit dem sozialen Umfeld und den darin stattfindenden sozialen Beziehungen verknüpft sind. Hierzu schreiben Frohlich und Kollegen: „Consequently, material/structural factors in health inequalities research are frequently studied as proxies for social structure and each variable is not understood in terms of its relation to other elements in the system, nor in terms of how it is manifested in and reinforced by social practices" (Frohlich et al. 2001, S. 781). Der Verweis auf die sozialen Praktiken deutet an, dass eben die Bedeutung von sozialen Beziehungen für die Erklärung gesundheitlicher Ungleichheit auf mehr verweist, als auf die bloße Existenz individueller Risikofaktoren. Hier geht es darum, auf Strukturen innerhalb von Gesellschaften $\mathrm{zu}$ verweisen, welche individuelles Verhalten beeinflussen. Und zu diesen zählt ganz sicherlich auch das soziale Umfeld. Der Kontext individueller Handlungen resultiert aus dem Zusammenspiel von Einschränkungen und Möglichkeiten, individuelles Handeln wird so auf einer strukturellen Ebene erklärbar. Gleichzeitig wird aber auch der Kontext durch individuelle Handlungen verändert und neu interpretiert. Diese Mechanismen der Rekursivität zwischen Kontext und Individuum sorgen aus Sicht der Autoren dafür, dass individualisierende Konzepte wie das der „Lifestyles“ nicht zu einer Erklärung kollektiver sozialer Praktiken beitragen können, insbesondere nicht, wie und wodurch sich diese Praktiken und Lebensstile verändern (Frohlich et al. 2001). Da die Ergebnisse dieser Arbeit 
darauf hinweisen, dass soziale Beziehungen, hier insbesondere soziale Integration, zu einer Erklärung der Zusammenhänge zwischen sozialem Status und subjektiver Gesundheit beitragen können, so verweist dies auch auf die Rolle der vermittelnden Faktoren (,agency“), welche soziale Integration spielt und welche möglicherweise mit der Entwicklung und Aufrechterhaltung von bestimmten sozialen Praktiken innerhalb begrenzter sozialer Räume assoziiert ist.

Es wurden auch bereits Ansätze zur Intervention in soziale Beziehungen diskutiert, um so auch gesundheitliche Ungleichheiten reduzieren zu können. Diese reichen von einer Anpassung der Lebensumgebung (Eriksson und Emmelin 2013) bis zu einer Beeinflussung des gesundheitsrelevanten Verhaltens und damit einhergehend der Verstärkung sozialer Kontrolle (Conklin et al. 2014). Wenn der Effekt sozialer Beziehungen auf die Gesundheit genutzt werden kann, dann spielt die Qualität der unmittelbaren Lebensumgebung, in denen soziale Interaktionen stattfinden, eine wichtige Rolle. Kawachi und Berkman haben in ihrer Übersichtsarbeit bereits dargelegt, dass soziale Integration und ein hohes Maß an sozialer Interaktion eher zu gesundheitsförderlichem Verhalten und der Entwicklung gesundheitsförderlicher Normen beiträgt. Zudem kann angenommen werden, dass innerhalb gut organisierter Nachbarschaften und Gemeinden der Zugang zu gesundheitlicher Versorgung und auch zu gesundheitsrelevantem Wissen erleichtert wird (Kawachi und Berkman 2001). Wie bereits erwähnt, sind qualitative Merkmale von Wohn- und Lebensverhältnissen, welche die Integration und Interaktion fördern oder hemmen können, eng mit sozioökonomischen Ressourcen, insbesondere dem Einkommen, verknüpft, und diese strukturellen Unterschiede wirken sich in den Lebensbedingungen auch auf die Nutzbarmachung protektiver Faktoren der Wohnbedingungen aus. Nicht jeder hat die Möglichkeiten, von günstigen Wohnbedingungen zu profitieren. Ungünstige Wohnbedingungen innerhalb von sozioökonomisch benachteiligten Nachbarschaften und Gemeinden wirken sich negativ auf die Gesundheit aus, wie einige Studien bereits zeigen konnten (Dragano et al. 2007; Mujahid, et al. 2008; Dragano et al. 2009).

Gerade vor dem Hintergrund einer komplexeren Erfassung sozialer Beziehungen und den daraus resultierenden unterschiedlichen Erklärungsbeiträgen von Indikatoren des sozialen Netzwerks oder der qualitativen Aspekte sozialer Beziehungen ergeben sich auch unterschiedliche Möglichkeiten der Intervention. Während ein höherer Erklärungsbeitrag von sozialer Unterstützung deutlicher auf Ressourcen innerhalb von sozialen Beziehungen hinweist, so verweist ein größerer Mediator-Effekt von sozialen Netzwerkindikatoren stärker auf 
die mögliche Verbesserung von sozialen Interaktionsmöglichkeiten in der jeweils untersuchten Population. Zu ähnlichen Einschätzungen kamen auch schon vorhergehende Forschungsarbeiten. In ihrer querschnittlichen Untersuchung zeigten Salonna et al. (2011), dass nicht alle Aspekte sozialer Beziehungen per se zu einer Erklärung gesundheitlicher Ungleichheiten beitragen können. Ihre Publikation enthält die Aufforderung an zukünftige Forschungsarbeiten zum Thema, soziale Beziehungen möglichst differenziert zu erfassen. Im Sinne der hier gefundenen Ergebnisse kann diesem Appell nur zugestimmt werden. Darüber hinaus sollten weitere Forschungsarbeiten neben den quantitativen und qualitativen Aspekten sozialer Beziehungen auch weitere Facetten sozialer Beziehungen untersuchen: Dauerhafte Konflikte, die Reichweite sozialer Netzwerke und auch die zunehmende Bedeutung virtueller sozialer Netzwerke sollten zukünftige Forschungsarbeiten berücksichtigen.

Soziale Beziehungen können auch nicht per se als positiv bewertet werden (siehe dazu auch Kap. „Negative Beziehungsaspekte und gesundheitliche Ungleichheiten"). Nicht jede Form von sozialer Unterstützung oder sozialer Kontakte kann dazu beitragen, die negativen gesundheitlichen Effekte eines niedrigen sozialen Status abzumildern. Für die hier präsentierten Ergebnisse bedeutet dies, dass eine zukünftige ausführliche Berücksichtigung negativer Aspekte wie beispielsweise soziale Isolation oder Konflikte innerhalb sozialer Beziehungen einen Einfluss auf den ermittelten Erklärungsbeitrag sozialer Beziehungen zu gesundheitlichen Ungleichheiten haben könnte. Möglich ist, dass insbesondere statusschwächere Individuen und Gruppen aufgrund von Exklusionsprozessen weniger Zugang zu Ressourcen innerhalb von Gemeinschaften haben und dadurch letztlich auch gesundheitlich vulnerabler sein können (Portes 1998; Abel 2012; Uphoff 2013). Soziale Prozesse, welche die Exklusion von statusniedrigen Gruppen fördern und somit deren Zugang zu sozialem Kapital innerhalb von Gemeinschaften hemmen, haben häufig auch entsprechende gesundheitliche Konsequenzen (Subramanian et al. 2002; Uphoff et al. 2013). Daher erscheint es aus dieser Perspektive wichtig, dass zukünftige Forschungsprojekte zum Thema negative Aspekte sozialer Beziehungen miterfassen und in die Analysen einbeziehen. Auch Überforderung innerhalb sozialer Netzwerke kann gesundheitlich negative Konsequenzen haben. Personen, die besonders aktiv in sozialen Beziehungen partizipieren, können dies auch als Überforderung wahrnehmen, wenn nicht genügend Zeit bleibt, die entsprechenden sozialen Rollen innerhalb dieser Netze auch in einem zufriedenstellenden Rahmen auszufüllen (Macinko und Starfield 2001; Mansyur et al. 2008; Gorman und Sivaganesan 2007). 


\subsection{Moderator}

Insgesamt stellen sich die Ergebnisse der bisherigen Studienlage hinsichtlich eines moderierenden Effekts des sozialen Status auf die Zusammenhänge zwischen sozialen Beziehungen und Gesundheit weitgehend uneinheitlich dar. Die gefundenen Studien zum Thema variierten erheblich hinsichtlich der verwendeten Status- und Beziehungsindikatoren, auch zeigten sich unterschiedliche Ergebnisse je nach verwendeten Gesundheitsindikatoren. In einem Review zum Thema zeigen Uphoff et al. (2013) eine Übersicht zu Studien, die den moderierenden Effekt des sozialen Status auf den Zusammenhang von sozialem Kapital und Gesundheit untersuchen. Einige der Studien, die in den Review eingeschlossen wurden, kommen zu dem Ergebnis, dass insbesondere Personen aus unteren Statusgruppen von Effekten des sozialen Kapitals gesundheitlich profitieren. In Studien, die diese Zusammenhänge bestätigen, finden sich deutlich stärkere Assoziationen zwischen sozialem Kapital und Gesundheit in unteren als in oberen Statusgruppen. Jedoch sind die Ergebnisse einiger der aufgeführten Studien hinsichtlich ihrer gewählten Populationen und ihrer gewählten Gesundheitsoutcomes kaum zu verallgemeinern.

Auf der Grundlage seiner Ausführungen zu den verschiedenen Formen von Kapital erörterte Bourdieu auch die gegenseitige Bedingtheit der drei wesentlichen Kapitalformen (Bourdieu 1983). Demnach können soziale Beziehungen und das in ihnen enthaltene soziale Kapital erst dann richtig genutzt und eingesetzt werden, wenn auch entsprechend ökonomisches und kulturelles Kapital zur Verfügung steht, welches wiederum den Zugang zu sozialen Kontakten und deren Aufrechterhaltung ermöglicht. Im Umkehrschluss würde dies bedeuten, dass Personen aus unteren Statusgruppen über weniger soziales Kapital verfügen und dies auch weniger effektiv für ihre Gesundheit einsetzen können, sie also von den möglichen positiven Effekten nicht profitieren können (Uphoff et al. 2013). Dies muss nicht zwangsläufig im Kontrast zu den bisherigen Forschungsergebnissen stehen: Personen in unteren Statusgruppen mögen insbesondere von bindendem sozialen Kapital (bonding social capital) profitieren, jedoch fehlt ihnen das überbrückende soziale Kapital (bridging social capital). Eine weitere Annahme zum Zusammenhang zwischen sozialen Beziehungen und Gesundheit lautet hier, dass es innerhalb von sozialen Gemeinschaften mit ausreichend sozialem Kapital auch Menschen gibt, die hiervon nicht profitieren. Wenn soziales Kapital insbesondere denjenigen mit höherem sozialem Status zur Verfügung steht, so kann es Exklusionsprozesse beschleunigen und zu dauerhaftem Ausschluss anderer Personen führen. Dies trifft insbesondere auf kontextuelles soziales Kapital zu, also solches, welches innerhalb von sozialen Gemeinschaften verfügbar, aber eben doch nicht jedem innerhalb der Gemeinschaft gleichermaßen 
zugänglich ist. Insofern kann ein solcher Prozess auch zur Verstärkung gesundheitlicher Ungleichheit beitragen, da dauerhafter Ausschluss sich auch negativ auf die Gesundheit auswirken kann (Uphoff et al. 2013).

Zudem konnte gezeigt werden, dass ein moderierender Effekt des sozialen Status nicht für alle Aspekte sozialer Beziehungen gleichermaßen auftritt, sondern dass zwischen quantitativen und qualitativen Aspekten differenziert werden sollte, da diese auch vor dem Hintergrund des sozialen Status unterschiedlich mit Gesundheit assoziiert sein können (Knesebeck 2005).

\section{$4 \quad$ Zusammenfassung und Fazit}

Es konnte gezeigt werden, dass bereits eine große Vielfalt an Studien zu den verschiedenen Zusammenhängen zwischen sozialem Status, sozialen Beziehungen und Gesundheit existiert. Jedoch lässt diese Vielfalt, insbesondere aufgrund der jeweils verwendeten Indikatoren, eine Vergleichbarkeit der Ergebnisse nur bedingt zu. Dies bezieht sich vor allem auf die unterschiedlichen Indikatoren für soziale Beziehungen, trifft aber auch auf Gesundheits- und mit gewissen Einschränkungen auch auf die Statusindikatoren zu. Mit den moderierenden Effekten des sozialen Status sowie der Frage nach einem möglichen Erklärungsbeitrag sozialer Beziehungen zu gesundheitlichen Ungleichheiten lassen sich zwei große Forschungsstränge identifizieren, deren Hauptergebnisse im vorliegenden Kapitel dargestellt wurden. $\mathrm{Zu}$ beiden Forschungsfragen sind die Studienlagen eher heterogen, für einen moderierenden Effekt des sozialen Status finden sich insgesamt gesehen eher weniger Hinweise als für einen Erklärungsbeitrag sozialer Beziehungen zu gesundheitlichen Ungleichheiten. Für Letzteren finden sich stärkere Belege, auch auf Basis von Längsschnittanalysen. Jedoch bleibt der Erklärungsbeitrag in den meisten Fällen eher gering und bleibt im Vergleich zu anderen Erklärungsansätzen eher zurück. Hinsichtlich der Frage, wie die einzelnen Erklärungsansätze gesundheitlicher Ungleichheiten einander gegenseitig bedingen und wie diese zusammen hängen, gibt es nach wie vor noch Forschungsbedarf (siehe auch Moor et al. 2017).

Eine komplexere Erfassung von sozialen Beziehungen könnte in Bezug auf beide Forschungsstränge positive Effekte haben. Mit einer komplexeren und multidimensionalen Erfassung sozialer Netzwerke, welche unterschiedliche Aspekte sozialer Beziehungen umfassen, könnte eine bessere Vergleichbarkeit der Ergebnisse über verschiedene Netzwerk- und Beziehungsindikatoren hinweg erreicht werden. Zudem können mit einer Erfassung engerer sozialer Netzwerke auch Aussagen über das soziale Umfeld gemacht werden, welche über den bisherigen Standard der egobasierten Befragung hinausgehen. In welcher Beziehung 
stehen die Netzwerkmitglieder untereinander, wie genau sind Ressourcen innerhalb der Netzwerke verteilt und welchen Einfluss haben solche Aspekte auf die Gesundheit? Diese Fragen könnten dann auch mit Bezug auf den sozioökonomischen Status sowohl der Befragten als auch der Netzwerkmitglieder konkreter beantwortet werden. Inwiefern dies aber tatsächlich zu einer besseren Beantwortung der zwei zentralen Forschungsfragen in diesem Bereich führt, bleibt abzuwarten. Mit den steigenden technischen Möglichkeiten, verbesserten Erhebungsinstrumenten und komplexeren Analysemethoden wäre es jedoch wünschenswert, wenn dies in Zukunft versucht werden würde.

\section{Leseempfehlungen}

Berkman, L. F., \& Krishna, A. (2014). Social network epidemiology. In L. F. Berkman \& I. Kawachi (Hrsg.), Social Epidemiology (S. 234-289). Oxford: University Press. Ausführlicher und systematischer Überblick zu den Zusammenhängen von sozialen Netzwerken und Gesundheit.

Uphoff, E.P., Pickett, K.E., et al. (2013). A systematic review of the relationships between social capital and socioeconomic inequalities in health: a contribution to understanding the psychosocial pathway of health inequalities. International Journal for Equity in Health, 12, S. 54. Eine der sehr wenigen systematischen Übersichtsarbeiten im Feld, die sowohl Aspekte sozialer Beziehungen, sozialen Status und Gesundheit berücksichtigt.

Moor, I., Spallek, R., Richter, M. (2017) Explaining socioeconomic inequalities in self-rated health: a systematic review of the relative contribution of material, psychosocial and behavioural factors. Journal of Epidemiology \& Community Health, 71, S. 565-575. Aktuelle Übersichtsarbeit zur Frage, wie sich gesundheitliche Ungleichheiten erklären lassen und welche Aspekte besonders zu einer Erklärung beitragen.

\section{Literatur}

Abel, T., \& Frohlich, K. L. (2012). Capitals and capabilities: Linking structure and agency to reduce health inequalities. Social Science and Medicine, 74(2), 236-244.

Aida, J., Kondo, K., et al. (2011). Income inequality, social capital and self-rated health and dental status in older Japanese. Social Science and Medicine, 73, 1561-1568.

Berkman, L. F., \& Krishna, A. (2014). Social network epidemiology. In L. F. Berkman \& I. Kawachi (Hrsg.), Social Epidemiology (S. 234-289). Oxford: University Press. 
Bourdieu, P. (1983). Ökonomisches Kapital, kulturelles Kapital, soziales Kapital. In R. Kreckel (Hrsg.), Soziale Ungleichheiten (S. 183-198). Göttingen: Schwartz.

Cohen, S., Kaplan, G. A., et al. (1999). The role of psychological characteristics in the relationship between socioeconomic status and perceived health. Journal of Applied Social Psychology, 29(3), 445-468.

Conklin, A. I., Forouhi, N. G., et al. (2014). Social relationships and healthful dietary behaviour: Evidence from over-50s in the EPIC cohort, UK. Social Science and Medicine, 100, 167-175.

Dahl, E., \& Malmberg-Heimonen, I. (2010). Social inequality and health: The role of social capital. Sociology of Health \& Illness, 32(7), 1102-1119.

Dragano, N., Bobak, M., et al. (2007). Neighbourhood socioeconomic status and cardiovascular risk factors: A multilevel analysis of nine cities in the Czech Republic and Germany. BMC Public Health, 7, 255-267.

Dragano, N., Hoffmann, B., et al. (2009). Subclinical coronary atherosclerosis and neighbourhood deprivation in an urban region. European Journal of Epidemiology, 24(1), 25-35.

Eriksson, M., \& Emmelin, M. (2013). What constitutes a health-enabling neighborhood? A grounded theory situational analysis addressing the significance of social capital and gender. Social Science and Medicine, 97, 112-123.

Fone, D., Dunstan, F., et al. (2007). Does social cohesion modify the association between area income deprivation and mental health? A multilevel analysis. International Journal of Epidemiology, 36(2), 338-345.

Frohlich, K. L., Corin, E., et al. (2001). A theoretical proposal for the relationship between context and disease. Sociology of Health \& Illness, 23(6), 776-797.

Gorman, B. K., \& Sivaganesan, A. (2007). The role of social support and integration for understanding socioeconomic disparities in self-rated health and hypertension. Social Science and Medicine, 65(5), 958-975.

Heritage, Z., Wilkinson, R. G., et al. (2008). Impact of social ties on self-reported health in France: Is everyone affected equally? BMC Public Health, 8, 243.

Huurre, T., Eerola, M., et al. (2007). Does social support affect the relationship between socioeconomic status and depression? A longitudinal study from adolescence to adulthood. Journal of Affective Disorders, 100(1-3), 55-64.

Kawachi, I., \& Berkman, L. (2001). Social cohesion, social capital, and health. In L. F. Berkman \& I. Kawachi (Hrsg.), Social Epidemiology (S. 174-190). Oxford: Oxford University Press.

Knesebeck, O.v.d. (2005). The importance of social relationships for the association between social inequality and health among the aged. Sozial- und Präventivmedizin, 50(5), 311-318.

Knesebeck, O.v.d, \& Geyer, S. (2007). Emotional support, education and self-rated health in 22 European countries. BMC Public Health, 7, 272.

Krause, N. (2001). Social Support. In R. H. Binstock \& L. K. George (Hrsg.), Handbook of Aging and the Social Sciences (S. 273-294). San Diego: Academic.

Kroll, L. E., \& Lampert, T. (2011). Unemployment, social support and health problems: Results of the GEDA study in Germany, 2009. Deutsches Ärzteblatt International, 108(4), 47-52.

Macinko, J., \& Starfield, B. (2001). The utility of social capital in research on health determinants. Milbank Quarterly, 79(3), 387-427. 
Mansyur, C., Amick, B. C., et al. (2008). Social capital, income inequality, and self-rated health in 45 countries. Social Science and Medicine, 66(1), 43-56.

Melchior, M., Berkman, L. F., et al. (2003). Social relations and self-reported health: A prospective analysis of the French Gazel cohort. Social Science and Medicine, 56(8), 1817-1830.

Moor, I., Spallek, R., \& Richter, M. (2017). Explaining socioeconomic inequalities in self-rated health: A systematic review of the relative contribution of material, psychosocial and behavioural factors. Journal of Epidemiology \& Community Health (JECH), $71,565-575$.

Mujahid, M. S., Diez Roux, A. V., et al. (2008). Neighborhood characteristics and hypertension. Epidemiology, 19(4), 590-598.

Portes, A. (1998). Social capital: Its origins and applications in modern sociology. Annual Review of Sociology, 24, 1-24.

Salonna, F., Geckova, A. M., et al. (2011). Does social support mediate or moderate socioeconomic differences in self-rated health among adolescents? International Journal of Public Health, 57(3), 609-617.

Subramanian, S. V., Kim, D. J., et al. (2002). Social trust and self-rated health in US communities: A multilevel analysis. Journal of Urban Health, 79(4 Suppl 1), 21-34.

Uphoff, E. P., Pickett, K. E., et al. (2013). A systematic review of the relationships between social capital and socioeconomic inequalities in health: A contribution to understanding the psychosocial pathway of health inequalities. International Journal for Equity in Health, 12, 54.

Open Access Dieses Kapitel wird unter der Creative Commons Namensnennung 4.0 International Lizenz (http://creativecommons.org/licenses/by/4.0/deed.de) veröffentlicht, welche die Nutzung, Vervielfältigung, Bearbeitung, Verbreitung und Wiedergabe in jeglichem Medium und Format erlaubt, sofern Sie den/die ursprünglichen Autor(en) und die Quelle ordnungsgemäß nennen, einen Link zur Creative Commons Lizenz beifügen und angeben, ob Änderungen vorgenommen wurden.

Die in diesem Kapitel enthaltenen Bilder und sonstiges Drittmaterial unterliegen ebenfalls der genannten Creative Commons Lizenz, sofern sich aus der Abbildungslegende nichts anderes ergibt. Sofern das betreffende Material nicht unter der genannten Creative Commons Lizenz steht und die betreffende Handlung nicht nach gesetzlichen Vorschriften erlaubt ist, ist für die oben aufgeführten Weiterverwendungen des Materials die Einwilligung des jeweiligen Rechteinhabers einzuholen.

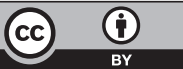




\title{
Geschlecht und gesundheitliche Ungleichheiten - Soziale Netzwerke im Kontext von Gesundheit und Gesundheitsverhalten
}

\author{
Markus Gamper, Julia Seidel, Annett Kupfer, \\ Sylvia Keim-Klärner und Andreas Klärner
}

\section{Überblick}

- Es gibt deutliche Unterschiede hinsichtlich der Morbidität (Krankheitshäufigkeit) und der Mortalität (Sterblichkeit) zwischen Männern*1 und Frauen*.

\footnotetext{
${ }^{1}$ Mit der Verwendung des ,*“ weisen die Autor*innen zum einen auf den Konstruktionscharakter der Kategorie Geschlecht hin und sie möchten zum anderen aufzeigen, dass es sich bei der Geschlechtsidentität und dem Geschlechtsausdruck nicht um abgeschlossene
}

M. Gamper $(\bowtie)$

Köln, Deutschland

E-Mail: m.gamper@uni-koeln.de

J. Seidel · A. Kupfer

Dresden, Deutschland

E-Mail: julia.seidel4@tu-dresden.de

A. Kupfer

E-Mail: annett.kupfer@tu-dresden.de

S. Keim-Klärner · A. Klärner

Braunschweig, Deutschland

E-Mail: sylvia.keim-klaerner@thuenen.de

A. Klärner

E-Mail: andreas.klaerner@thuenen.de 
- Bis zur Pubertät weisen männliche* Jugendliche häufiger gesundheitliche Probleme auf.

- Während der Pubertät leiden Mädchen* an chronischen und psychischen Erkrankungen und männliche* Heranwachsende eher an akuten und lebensbedrohlichen Krankheiten (z. B. HIV).

- Jungen* und Männer* haben ein riskanteres Gesundheitsverhalten.

- Das Forschungsfeld bezieht sich hauptsächlich auf die Binarität der Geschlechter Mann und Frau. Studien zu trans ${ }^{* 2}$ und queren ${ }^{3}$ Personen sind in diesem Bereich selten.

- Netzwerke haben einen geschlechtsspezifischen Effekt auf das Risikoverhalten.

- Frauen* leisten mehr und zeitintensivere soziale Unterstützung, auch im Krankheitsfall.

- Nach der Verwitwung haben Netzwerke sowohl negative wie auch positive Effekte. Diese sind geschlechtsspezifisch.

Kategorien handelt, sondern auch, jenseits der Binarität von weiblich* und männlich* bzw. Frau* und Mann*, eine Vielfalt existiert und es Menschen gibt, die sich nicht eindeutig der dualistischen Geschlechterordnung zuordnen wollen oder können. Mittlerweile gibt es zwar eine wachsende Zahl an Studien speziell zu trans* Personen, das Geschlecht wird aber in der Mehrheit der allgemeinen Studien als dichotome Variable (,männlich“/ „weiblich“) abgefragt (Döring 2013). Wir fokussieren uns in diesem Aufsatz auf Studien mit dichotomen Geschlechtervariablen, lassen aber wenn möglich auch Befunde aus der Forschung zu trans* Personen einfließen. Zum anderen weist das ,"* darauf hin, dass bei Bezeichnungen von Personengruppen, ausdrücklich sowohl weibliche als auch männliche Personen gemeint sind sowie alle Menschen, die sich nicht eindeutig der dualistischen Geschlechterordnung zuordnen wollen oder können.

${ }^{2}$ Die (Selbst-)Bezeichnung trans* stellt einen Oberbegriff für verschiedene, mit „Trans“ beginnende Bezeichnungen dar, zum Beispiel Transgender, Transidentität und Transsexualität usw. Zudem nimmt das , ${ }^{*}$ “ die Rolle eines*einer Platzhalter*in für vielfältige (Selbst-)Bezeichnungen ein (Gerede e. V. 2018).

${ }^{3}$ Queer bezeichnet vor allem Personen, die sich nicht mit traditionellen Geschlechterrollen und -stereotypen identifizieren und eine behauptete Zweigeschlechtlichkeit infrage stellen. Queer steht aber auch für Menschen, die durch ihre Selbstdefinition (trans*, multisexuell, lesbisch etc.) Heteronormativität ablehnen (i-Päd 2019). 


\section{$1 \quad$ Geschlecht als Ungleichheitskategorie}

Geschlecht gehört mittlerweile zu einer der wichtigsten Kategorien im sozialwissenschaftlichen Diskurs. Die Geschlechtskategorie durchzieht und prägt alle gesellschaftlichen Lebensbereiche und nimmt in der Funktion einer horizontalen Ungleichheitsdimension eine bedeutungsvolle Rolle als soziale Ordnungs- und gesellschaftliche Positionierungskategorie ein (Babitsch 2009; Rose 2015). Sowohl für das weibliche* als auch für das männliche* Geschlecht ,existieren geschlechtsspezifische Normalitätsvorstellungen, Verhaltensstandards und Inszenierungsskripte, mit denen sie sich im Laufe ihres Lebens unentwegt arrangieren" müssen (Rose 2015, S. 63). In unserem Alltagswissen wird die Zweigeschlechtlichkeit des Menschen sowie die von Geburt (und größtenteils Schwangerschaft) an festgelegte Geschlechtszugehörigkeit und die dazu implizierte Heterosexualität meist als selbstverständlich und als naturgegeben akzeptiert sowie praktiziert (Wetterer 2004).

Jedoch handelt es sich bei der Geschlechtskategorie um ein sozialstrukturelles und sozial konstruiertes sowie historisch und gesellschaftlich gewachsenes Phänomen, das in sozialen und alltäglichen Interaktionen sowie Handlungen (re)produziert wird (doing gender). Geschlecht ordnet Individuen in zwei unterschiedliche Gruppen, die sowohl auf einer biologisch gebundenen Zuordnung, als auch auf gesellschaftlichen Zuschreibungsprozessen beruhen (Winker und Degele 2010).

Als wichtiger Schritt in der Betrachtung und Analyse des Geschlechts gilt die Trennung in die zwei Komponenten sex (das bei der Geburt aufgrund biologischer Merkmale zugewiesene Geschlecht) und gender (als soziale, kulturelle Dimension und Geschlechtsidentität) und die damit verbundene Möglichkeit „die mit dem biologischen Geschlecht verbundene Vorstellung von naturgegebenen Unterschieden zwischen Frauen und Männern in Frage zu stellen und im Kontext der gesellschaftlichen Herstellungsmodi zu reflektieren“ (Babitsch 2009, S. 284). Die geschlechtsspezifischen Verhaltensweisen unterliegen somit einer sozialen Prägung und sind zudem abhängig von den jeweiligen kulturellen, historischen und gesellschaftlichen Bedingungen. Des Weiteren können die existierenden gesellschaftlichen Geschlechterungleichheiten nicht alleine durch die biologischen Geschlechterdifferenzen begründet werden (Babitsch 2009; Degele 2010).

\subsection{Geschlecht und Gesundheit}

Seit den 1970er Jahren hat das Thema Geschlecht und dessen Einfluss auf die Gesundheit sowohl in der Forschung als auch in der medizinischen Praxis an 
Einfluss gewonnen (Babitsch 2009; Kuhlmann 2016). Durch eine Vielzahl an Studien kann ein mitunter stark ausgeprägter Geschlechterunterschied bezüglich des Gesundheitsgeschehens nachgewiesen werden, d. h., in der Morbidität (Krankheitshäufigkeit) und der Mortalität (Sterberate), in den Entstehungsprozessen von Krankheiten sowie den Krankheitsverläufen und im Gesundheitsverhalten scheinen Männer* und Frauen* sich signifikant zu unterscheiden (z. B. Robert-Koch-Institut 2015). Studien zu Trans*-Personen sind eher selten. Meist umfassen vorliegende Forschungen die ganze Gruppe LGBT*I*Q: „Lesbian, Gay, Bisexual, Transgender, Intersexual and Queer".

\section{Lebenserwartung und Mortalität}

Weltweit lässt sich in den meisten Ländern ein homogenes Muster hinsichtlich der Lebenserwartung ausmachen: die Lebenserwartung der Frauen* ist in der Regel höher als die der Männer* (Kolip und Hurrelmann 2002). ${ }^{4}$ Auch in Deutschland liegt die mittlere Lebenserwartung von Frauen* bei der Geburt derzeit bei 83,1 Jahren, jene von Männern* bei 78,3 Jahren (Robert-Koch-Institut 2015; Statistisches Bundesamt 2019e). Dabei nähern sich die Geschlechterdifferenzen in den letzten Jahren zugunsten des männlichen* Geschlechts an (Kolip und Hurrelmann 2002; Lampert et al. 2017), was auf den Anstieg gesundheitsriskanten Verhaltens unter Frauen* (z. B. steigende Anzahl rauchender Frauen*) zurückgeführt wird. Die kürzere Lebenserwartung des männlichen* Geschlechts besteht jedoch weiter fort. So zeigen weltweit auch männliche* Säuglinge ein höheres Sterberisiko als weibliche* Säuglinge (WHO 2019). Die ungünstige Sterblichkeitsstatistik des männlichen* Geschlechts setzt sich auch im weiteren Lebenslauf fort und wird im Alter zwischen 25 bis 65 Jahren besonders deutlich. In Deutschland starben 2016 fast doppelt so viele Männer* (86.654) im mittleren Lebensalter wie Frauen* (46.815) (Statistisches Bundesamt 2019a). Als Ursache für den Geschlechtsunterschied bzgl. der Übersterblichkeit wird häufig ein gesundheitsriskanteres Verhalten der Männer* angeführt (Hurrelmann und Quenzel 2011; Kolip und Hurrelmann 2002; Sieverding 2005; Robert-KochInstitut 2015). Babitsch (2009) führt ergänzend dazu aus, dass eine Vielzahl an

\footnotetext{
${ }^{4}$ Für die Jahre 2015-2020 konnten die Vereinten Nationen exemplarisch folgende Lebenserwartungen, in Jahren gemessen, ermitteln: Afghanistan (Männer*( $\left.\mathbf{M}^{*}\right)$ : 62,7; Frauen* (F*): 65,6); Brasilien (M*: 72,2; $\left.\mathrm{F}^{*}: 79,4\right)$; Japan (M*: 80,7; $\left.\mathrm{F}^{*}: 87,1\right)$; Canada (M*: 80,7; $\left.F^{*}: 84,4\right)$; Estland $\left(M^{*}: 73,01 ; F^{*}: 81,9\right)$; Kenia $\left(M^{*}: 64,9 ; F^{*}: 69,6\right)$; Neuseeland (M*: 80,4; F*: 83,7) (UNdata 2017).
} 
Studien auf größere sozioökonomisch bedingte Unterschiede in der Lebenserwartung von Frauen* und Männern* hindeuten.

Auch bei den diversen Todesursachen ergeben sich deutliche Unterschiede der Geschlechter. Frauen* sterben häufiger an Herz-Kreislauf-Erkrankungen. Jedoch sterben sie seltener an bösartigen Neubildungen. ${ }^{5}$ Bei Atmungs- oder Verdauungssystemerkrankungen findet man nur geringfügige Geschlechtsdifferenzen (Robert-Koch-Institut 2015). Ein enormer geschlechtsspezifischer Unterschied kann für die Suizidrate bestätigt werden. Im Jahr 2016 beendeten 9838 Menschen ihr Leben, wobei der Anteil der Männer* mit $75 \%$ dreimal so hoch war wie der Anteil der Frauen* mit 25 \% (Statistisches Bundesamt 2019b, c).

\section{Morbidität im Lebenslauf}

Auch bei der Morbidität werden geschlechtsspezifische Differenzen sichtbar. Hurrelmann und Quenzel (2011) konstatierten, dass bereits im Kindesalter, d. h. vom ersten Lebensjahr bis zum Eintreten der Geschlechtsreife im Alter von etwa zwölf Jahren, gesundheitliche Unterschiede zwischen den Geschlechtern auftreten: Jungen* schneiden in den meisten Gesundheitsindikatoren schlechter ab als Mädchen*. Folglich wurden im Jahr 2017 bis zu dem Alter von 15 Jahren mehr Jungen* (4598) als Mädchen* (3659) wegen gesundheitlicher Störungen von ärztlichem Fachpersonal untersucht (Hurrelmann und Quenzel 2011; Robert-Koch-Institut 2015; Statistisches Bundesamt 2019a). Auch in der Krankheitshäufigkeit können geschlechtsspezifische Unterschiede im Kindesalter aufgezeigt werden (Hurrelmann und Quenzel 2011; Kolip und Hurrelmann 2002). Exemplarisch erkrankten laut dem Statistisches Bundesamt (2019a) im Jahr 2017 Jungen* im Alter von 1-15 Jahren häufiger als Mädchen* an Leukämie, an Epilepsie, an chronischen Krankheiten der unteren Atemwege, wie zum Beispiel Asthma bronchiale, und leiden häufiger an Übergewicht sowie Schlafstörungen. Eine größere Anfälligkeit der männlichen* Geschlechter wird sich ebenfalls im Bereich der psychischen Krankheiten konstatiert (Statistisches Bundesamt 2019a; Robert-Koch-Institut 2015; Hurrelmann und Quenzel 2011).

Erst mit dem Einsetzen der Pubertät verändert sich diese Situation innerhalb weniger Jahre. Mädchen* im Alter ab 15 Jahren erkranken signifikant häufiger

\footnotetext{
${ }^{5}$ Auch bei der Art der bösartigen Neubildungen zeigen sich Geschlechtsdifferenzen. Laut dem Statistischen Bundesamt (2019i) kann für das Jahr 2016 für die männlichen* Geschlechter Lungen- und Bronchialkrebs als die häufigste Krebserkrankung mit Todesfolge aufgeführt werden, mit 29.305 von 125.128 Fällen. Bei den Frauen* ist es mit 18.570 von 105.597 Fällen der Brustkrebs.
} 
als Jungen* an psychosomatischen und physiologischen Beschwerden (Kolip und Hurrelmann 2002): Mädchen* im Alter von 15-18 Jahren leiden beispielsweise öfter als Jungen* an Kopfschmerzen, an Bauch- und Beckenschmerzen, an Schwindel und Taumel und an Essstörungen (Statistisches Bundesamt 2019a). Mit Beginn der Pubertät ändert sich zudem die Inanspruchnahme von ärztlicher Konsultation und Behandlung, die nun mehr Mädchen* als Jungen* in Anspruch nehmen (Hurrelmann und Quenzel 2011; Statistisches Bundesamt 2019a).

Die Pubertät kennzeichnet zwar eine Kehrtwende sowohl in der Inanspruchnahme von medizinischen Hilfeleistungen als auch im Gesundheits- und Krankheitsgeschehen, die geschlechtsspezifische Tendenz setzt sich jedoch im Erwachsenenalter (18-65 Jahre) fort (Kolip und Hurrelmann 2002). Diesbezüglich konstatieren das Robert-Koch-Institut (2015), Lampert et. al (2017) sowie Babitsch (2009) einen geschlechtsspezifischen Unterschied in der subjektiven Selbsteinschätzung der Gesundheit. 72,9\% aller Frauen* im mittleren Alter bewerten ihre Gesundheit als gut oder sehr gut, hingegen sind es bei den Männern* 76,6 \% (Robert-Koch-Institut 2015).

Das Vorhandensein einer oder mehrerer chronischer Erkrankungen führt ebenfalls zu einer geschlechtsspezifischen Differenz. Kolip und Hurrelmann (2002), Sieverding (2005) und Regitz-Zagrosek (2018) heben hervor, dass das weibliche* Krankheitsprofil eher durch chronische Erkrankungen sowie durch psychosomatische und psychische Beeinträchtigungen (z. B. Schilddrüsenerkrankungen, Depression, Essstörungen, Migräne, Hypertonie, Gallenblasenerkrankungen, Arthrose, Osteoporose, koronare Herzerkrankungen) geprägt ist; das männliche* hingegen durch akute und lebensbedrohliche Krankheiten (z. B. HIV-Infektion, bösartige Neubildungen der Verdauungsorgane sowie der Lungen und Bronchien, Lungenemphysem, Leberzirrhose, koronare Herzerkrankungen). Eine Metaalanalyse zu Trans*-Personen weist darauf hin, dass insbesondere Trans*männer ${ }^{6}$ stark von HIV/AIDS betroffen sind. Hierbei gibt es auch Zusammenhänge mit anderen Risikofaktoren wie beispielsweise Prostitution oder Diskriminierung (Herbst et al. 2008). Insgesamt zeigt sich bei LGBT*I*Q-Personen ein hohes Risiko für Darmerkrankungen (z. B. Giardien, Amöben), Hepatitis A und B, Humane Papillomviren ${ }^{7}$ und Analkarzinom (Analkrebs) (Dean et al. 2000).

\footnotetext{
${ }^{6}$ Personen, die sich als überwiegend männlich identifizieren, welche aber bei der Geburt dem weiblichen Geschlecht zugeordnet wurden (Gerede e. V. 2018).

${ }^{7}$ Diese Viren können Haut sowie verschiedener Schleimhäute infizieren und ein unkontrolliertes tumorartiges Wachstum hervorrufen.
} 
Eine besondere Bedeutung in Bezug auf geschlechtsspezifische Differenzen hinsichtlich der Morbidität nehmen zudem die koronaren Herzerkrankungen (KHK) ein, der nach Kuhlmann (2016) unter dem Geschlechtsaspekt beste untersuchte Bereich. Laut Kuhlmann (2016) und Regitz-Zagrosek (2017, 2018) existieren geschlechtsspezifische Unterschiede in fast jedem Studium einer KHK. So führt Regitz-Zagrosek (2017) beispielsweise Differenzen bei den Risikofaktoren an. ${ }^{8}$ Weitere Beispiele bringt Kuhlmann (2016) ein und bezieht sich auf deutsche und internationale Studien. Demnach werden „Frauen mit KHK seltener evidenzbasiert behandelt [...], [erhalten] seltener invasive Diagnostik, [werden] seltener und anders über präventive Maßnahmen (z. B. Raucherentwöhnungsprogramme) aufgeklärt" (Kuhlmann 2016, S. 189).

Auch in Bezug auf psychische Erkrankungen können Differenzen zwischen den Geschlechtern verzeichnet werden. Laut den Daten des Robert Koch-Instituts (2015) liegt die Prävalenz für Angststörungen bei Frauen* mit 21,3 \% höher als bei Männern* mit 9,3\%. Ein ähnliches Bild zeigt sich bei den depressiven Störungen und bei chronischem Stress (Hapke et al. 2013). Auch wenn es insgesamt kaum Forschungen zu vollendetem Selbstmord sowie Suizidgefahren unter Trans*-Personen gibt, kann das sehr ausführliche Review von Haas et al. (2010) eine erhöhte Suizidgefahr wie auch eine erhöhte Anzahl an vollendeten Selbstmorden für trans*-Personen nachweisen. Dies gilt wohl besonders für junge Heranwachsende (Mustanski et al. 2010). Trans*-Menschen weisen zudem im Vergleich zur Allgemeinbevölkerung höhere Prävalenzraten u. a. für Depressionen und Angsterkrankungen auf (Nieder et al. 2016).

Bezüglich Alkoholabhängigkeit scheinen Männer* stärker als Frauen* betroffen zu sein. Pabst et al. (2013) konstatieren für das Jahr 2012 eine Alkoholabhängigkeit bei 2,0 \% der Frauen* und 4,8 \% der Männer* in Deutschland. Im Jahr 2017 registrierte die Krankenhausdiagnosestatistik bei Frauen* 85.283 und bei Männern* 228.928 stationäre Behandlungsfälle aufgrund psychischer und Verhaltensstörungen durch Alkohol (Statistisches Bundesamt 2019a).

\footnotetext{
${ }^{8}$ Geschlechtsspezifische Unterschiede im Zusammenhang mit Risikofaktoren existieren bei dem Einfluss von Diabetes mellitus, der bei Frauen* stärker ausgeprägt ist als bei Männern*. Laut Regitz-Zagrosek (2017) erhöht Diabetes mellitus das Auftreten einer KHK bei Frauen* um das 5- bis 7-fache und bei Männern* um das 3- 4-fache. Die klassischen Risikofaktoren wie Hypertonie, Zigarettenrauchen, Hypercholesterinämie haben bei dem weiblichen* Geschlecht hingegen eine ähnliche Auswirkung auf das KHK-Risiko wie bei dem männlichen* Geschlecht.
} 
Im hohen Alter ist kaum ein genereller Geschlechterunterschied zu erkennen. Hinsichtlich der Multimorbidität schneidet das weibliche* Geschlecht signifikant schlechter ab, d. h., Frauen* leiden mit zunehmendem Alter öfter als Männer* unter multiplen chronischen Erkrankungen, z. B. Osteoporose, Osteoarthrose und Herzinsuffizienz. Bei dem männlichen* Geschlecht treten auch im hohen Alter eher lebensbedrohliche Erkrankungen, wie Herzinfarkte und chronisch obstruktive Lungenerkrankungen auf (Iller und Wienberg 2012; Statistisches Bundesamt 2019a).

Auch im Hinblick auf die subjektive Beurteilung des eigenen Gesundheitszustandes können weiterhin Geschlechtsunterschiede belegt werden: Männer* sind im Allgemeinen zufriedener; mit zunehmenden Alter sinkt die Gesundheitszufriedenheit jedoch schneller ab (Iller und Wienberg 2012).

Für Trans*- Personen fassen Graham et al. (2011) einzelne Aspekte in den verschiedenen Lebensphasen zusammen, können aber nach eigenen Angaben kaum Ergebnisse liefern.

\subsection{Geschlecht und Gesundheitsverhalten}

Laut Kuhlmann (2016) beeinflussen kulturelle und soziale Faktoren die Inanspruchnahme von gesundheitlichen Leistungen und führen teilweise $\mathrm{zu}$ signifikanten Geschlechterdifferenzen in fast allen Bereichen des gesundheitlichen Versorgungssystems. Beispielsweise nehmen mehr Frauen* an Gesundheitskursen der Volkshochschule und der Krankenkassen teil (Kuhlmann 2016; Robert-Koch-Institut 2015), die allerdings vermutlich auch primär auf die Bedürfnisse der Frauen* abzielen und somit Männer* benachteiligen (Kuhlmann 2016).

Auch bei der Inanspruchnahme von ambulanter ärztlicher Versorgung kann laut Prütz und Rommel (2017) teilweise ein erheblicher Unterschied, aber auch eine deutliche Angleichung der Geschlechter mit zunehmendem Lebensalter verzeichnet werden. Ein Geschlechtsunterschied zeigt sich insbesondere im jungen Erwachsenenalter: So nahmen von den 18- bis 29-jährigen Frauen* 90,4 \% und lediglich 78,4 \% der Männer* in den letzten zwölf Monaten eine Leistung in Anspruch. Bei den 65-Jährigen und älteren Personen sind jedoch kaum mehr Unterschiede feststellbar. Neuere Studien sowie differenzierte Analysen widerlegen zudem laut Kuhlmann (2016) die Annahme, dass sich Männer* weniger um ihre Gesundheit kümmern.

Die Inanspruchnahme von psychiatrischen und psychotherapeutischen Leistungen nimmt im Kontext der Geschlechterdifferenzen eine besondere Stellung 
ein. Laut Barry und Yuill (2012) und Rommel et al. (2017) zeigen Männer* hier besonders große Zurückhaltung bei der Konsultation bzw. Meldung einer psychischen Krankheit, was die Autor*innen auf das vorherrschenden gesellschaftlichen Geschlechterstereotypen zurückführen (Barry und Yuill 2012).

Rauchverhalten ist einer der bedeutenden Risikofaktoren für Gesundheit und die führende Ursache vorzeitiger Sterblichkeit. Im Geschlechtervergleich zeigt sich laut Zeiher et al. (2017) und hier den Daten der GEDA-Studie 2014/2015-EHIS ein leicht stärkeres (gelegentliches) Rauchverhalten bei Männern* $(27,0 \%)$ als bei Frauen* (20,8\%). Laut der Robert-Koch-Stiftung (2015) hat sich die Rauchquote der Geschlechter durch die Zunahme weiblicher* Raucherinnen in den letzten 20 Jahren jedoch angenähert. Als Erklärungsursache für den Anstieg der weiblichen* Rauchquote werden veränderte Geschlechterrollen und-stereotypen angenommen (Sieverding 2005; Kolip und Hurrelmann 2016; Bartley 2017, s. u.).

Alkoholkonsum weist als Risikofaktor erhebliche geschlechtsspezifische Ungleichheiten in allen Lebensaltern auf: So berichten Orth und Töppich (2015), dass im Jahre 2014 8,5\% der Mädchen* im Alter von 12 bis 17 Jahren und 14,9\% der Jungen* im selben Alter in den letzten zwölf Monaten mindestens einmal wöchentlich riskante Mengen an Alkohol konsumiert haben. Auch im Erwachsenenalter zeigt sich diese Geschlechtsdifferenz (Lange et al. 2017). Dabei ist ein signifikanter Einfluss von sozialen Unterschieden und dem Alkoholkonsum auf die Geschlechter nachweisbar (Lange et al. 2017). So weisen Frauen* der oberen Bildungsgruppe in allen Altersgruppen eine höhere Prävalenz für riskanten Alkoholkonsum auf als Frauen* aus unteren Bildungsgruppen; bei dem männlichen Geschlecht* trifft ähnliches zu.

Kaum eine Forschung hat den Substanzkonsum bei trans*-Jugendlichen und -Heranwachsenden untersucht. Meist beziehen sich vorhandene Studien - wie bereits erwähnt - auf die Gruppe der LGBT*I*Q-Personen. Eine Studie über junge LBT*I*Q-Frauen* in San Francisco zeigt allerdings, dass Substanzkonsum bei trans*weiblichen ${ }^{9}$ Jugendlichen sehr verbreitet ist und dies signifikant mit psychosozialen Risikofaktoren in Verbindung steht (Rowe et al. 2015). Eine Langzeitstudie in den USA konnte daran anschließend nachweisen, dass der Alkoholkonsum im Laufe der Zeit linear zunahm. Bei männlichen* LGBT*I*Q-Jugendlichen* konnte hierbei eine tendenziell schnellere Zunahme verzeichnet werden als bei den weiblichen* Jugendlichen (Newcomb et al. 2012).

\footnotetext{
${ }^{9}$ (Selbst-)Bezeichnung von Personen, die sich als überwiegend weiblich identifizieren, aber bei der Geburt dem männlichen Geschlecht zugeordnet wurden (Gerede e. V. 2018).
} 
Der Missbrauch von verschreibungspflichtigen Opioiden und Beruhigungsmitteln zeigt sich bei LGBT*I*Q-Jugendliche schon in jungen Jahren (Kecojevic et al. 2012). Daran anknüpfend finden sich in einer weiteren US-Studie Belege, dass der Missbrauch von verschreibungspflichtigen Medikamenten relativ häufig bei LGBT*I*Q-Erwachsenen vorkommt und stark mit emotionaler Belastung in Verbindung steht (Benotsch et al. 2013).

\subsection{Ausgewählte Erklärungsansätze im Kontext geschlechtsspezifischer Gesundheitsunterschiede}

So klar wie die geschlechtsspezifischen Gesundheitsunterschiede aufgezeigt werden konnten, so schwierig gestaltet sich die Ursachenfindung. Viele Fragen konnten in diesem Zusammenhang noch nicht geklärt werden. Von den verschiedenen, aktuell diskutierten Erklärungsansätzen werden im Folgenden drei vorgestellt.

\section{Geschlechtsspezifische Rollenvorstellungen und -stereotype}

Der Einfluss gesellschaftlicher Konstruktionen von Geschlecht auf die Gesundheit werden in wissenschaftlichen Diskursen bereits seit längerem ausführlich diskutiert (Kolip und Hurrelmann 2016; Kuhlmann 2016; Sieverding 2005; Babitsch 2009; Barry und Yuill 2012; Bartley 2017; Regitz-Zagrosek 2017, 2018 u. a.). Es besteht laut Sieverding (2005) weitestgehend ein Konsens darüber, ,dass die Geschlechterunterschiede in physischer Gesundheit und Krankheit am stärksten durch Geschlechtsunterschiede in gesundheitsrelevanten Verhalten, insbesondere im höheren Risikoverhalten von Männern, begründet sind" (Sieverding 2005, S. 57). Das gesundheitsrelevante Verhalten wird wiederum durch eine große Anzahl an soziokulturellen Faktoren beeinflusst. In diesem Kontext werden gesellschaftlichen Geschlechterrollen und -stereotypen eine Schlüsselfunktion beigemessen (Sieverding 2005). Beispielsweise wird dem weiblichen* Geschlecht im Zusammenhang mit Gesundheit immer noch eine eher sorgende und gesundheitsbewusstere Rolle zugesprochen. Dahingegen basiert die Konstruktion männlichen* Geschlechts weiterhin darauf, gesundheitliche Probleme selbstständig und ohne fremde Hilfe lösen bzw. ertragen zu können oder zu müssen, um somit die Kontrolle der eigenen Leistungsfähigkeit wahren zu können (Kolip und Hurrelmann 2002).

\section{Diskriminierung}

Gesellschaftliche Geschlechterstereotype und -rollen wirken sich auch auf die Beurteilung anderer Personen aus. Es wird vermutet, dass Patient*innen von 
ärztlichem Fachpersonal je nach Geschlechtszugehörigkeit abweichend wahrgenommen und auch behandelt werden. Studien weisen darauf hin, dass ärztliches Fachpersonal männliche* Beschwerden ernster nehmen. Dagegen werden bei dem weiblichen* Geschlecht anscheinend häufiger psychisch bedingte Leiden vermutet und die Behandlung dementsprechend ausgerichtet (Kolip und Hurrelmann 2002; Sieverding 2005; Kuhlmann 2016). Eine qualitative Studie zeigt, dass Klinikpersonal auf die gesundheitlichen Bedürfnisse von Trans*-Patientinnen* oft mit Unsicherheit reagiert, welche sich dann in Stigmatisierung ausdrücken kann. Dies führt bei Trans*-Personen wiederum zur Ansicht, dass sie mit ihren Bedürfnissen nicht verstanden werden (Poteat et al. 2013). Ein Review von 17 Artikeln über die Einstellung von Pflegekräften zu LGBT*I*Q-Patienten bestätigte das Ergebnis der Benachteiligung (Dorsen 2012, zur Diskriminierung siehe auch Grant et al. 2011).

\section{Armut und soziale Ungleichheit}

Armut und soziale Ungleichheit haben zentrale Auswirkungen auf die Gesundheit und Lebenserwartung der Geschlechter und führen zugleich zu geschlechtsspezifischen Unterschieden. Immer noch bekommen Frauen* im Durchschnitt $21 \%$ weniger Gehalt als Männer*, arbeiten mit $49 \%$ fast doppelt so häufig in Teilzeitbeschäftigung wie Männer* mit $11 \%$ und sind weiterhin öfter von Armut betroffen als Männer* (WSI 2017). Diese geschlechtsspezifischen Ungleichheiten haben einen deutlichen Einfluss auf das Gesundheitsgeschehen.

Kuhlmann (2016) bezieht sich in diesem Zusammenhang beispielsweise auf das deutsche Gesundheitssystem, welches sich durch hohe Qualitätsstandards und eine hohe Versorgungsdichte sowie niedrige Zugangsbarrieren auszeichnet. Dennoch existieren systembedingte Barrieren, die zu Unterschieden in den Zugangschancen von Männern* und Frauen* führen. Als Beispiel nennt Kuhlmann (2016) die steigenden finanziellen Belastungen der Nutzer*innen im Zusammenhang mit dem zu erbringenden Eigenanteil bei den Krankenkassenbeiträgen. Der Eigenanteil beträgt aktuell in Deutschland 14,3\%, 2010 lag er noch bei $13 \%$ (WHO 2010; Bundesversicherungsamt 2017). Es ist also eine leichte Steigung zu verzeichnen. „Hier liegt es auf der Hand, dass Frauen als Gruppe aufgrund der Einkommensdifferenzen häufiger und stärker als Männer von einem steigenden Eigenanteil an den gesundheitsbezogenen Kosten betroffen sind" (Kuhlmann 2016, S. 188). Dies gilt noch stärker für die Gruppe der älteren Frauen*, da Frauen* mit durchschnittlich 643 EUR im Monat eine niedrigere Rente beziehen als Männer* (1154 EUR) und somit öfter von Altersarmut betroffen sind (ebd., WSI-Gender Daten Portal 2018). Eine US-amerikanische Studie ergab, dass die Arbeitslosenquote bei Trans*-Personen, im Vergleich zur Allgemeinbevölkerung, 
doppelt so hoch ist. Damit sinkt für sie die Wahrscheinlichkeit, zum einen krankenversichert und zum anderen von einem Unternehmen allgemein versichert zu sein (Grant et al. 2011).

\section{Gender und soziale Netzwerke - Ein Überblick}

Historisch zurückgeblickt ging man in den 1970er Jahren davon aus, dass Frauen* und Männern* unterschiedliche Einstellungen zu sozialen Kontakten besitzen (z. B. Miller 1976), ohne dass bis dahin Netzwerkstudien mit großen Stichproben vorlagen ${ }^{10}$, die diese These unterstützten. Erst in den 1980er Jahren kam es vermehrt zu quantitativen wie qualitativen Forschungsarbeiten mit einer expliziten Genderausrichtung, und Geschlecht gewann auch in der Netzwerkforschung immer mehr an Bedeutung. So ist Geschlecht mittlerweile eine Ungleichheitsvariable, die im Vergleich zu den meisten anderen hier im Band dargebotenen Merkmalen sehr gut untersucht ist. Aufgrund der großen Anzahl an Studien und auch weil Geschlecht innerhalb der quantitativen Netzwerkforschung häufig als eine Kontrollvariable herangezogen wird, kann die vorliegende Aufzählung nicht repräsentativ sein, sondern lediglich einen kurzen Ausschnitt der Forschung wiedergeben und auf empirische Herangehensweisen und Lücken hinweisen. Dabei ist einschränkend anzumerken, dass die Suche nach Unterschieden bis heute primär auf einem binären Differenzschema von Mann*/Junge* vs. Frau*/Mädchen* basiert und dadurch Geschlechtsidentitäten wie z. B. transgender oder queer bisher kaum berücksichtigt werden.

\subsection{Soziale Netzwerke und Lebensalter}

Geschlecht, so die Freundschafts- und Schulforschung, ist für Freundschaftsbildungen eine wichtige Variable. Schon für Vorschulkinder können Martin et al. (2013) zeigen, dass die Wahl der Spielpartner*innen überproportional auf gleichgeschlechtliche Kinder fällt. Auch bezüglich der Netzwerke von

\footnotetext{
${ }^{10}$ Einer der ersten Netzwerkforschungen zu Geschlecht ist die qualitative ethnographische Studie von Bott (1957). Sie untersuchte inwieweit häusliche Arbeitsteilung in Beziehungen von Männern* und Frauen* und deren soziale Netzwerke zusammenhängen. Sie stellte fest, dass nicht etwa Schichtzugehörigkeit oder das Wohngebiet, sondern vielmehr die Unterschiede in den persönlichen Netzwerken einen Effekt auf die traditionelle oder gemeinsame Arbeitsteilung innerhalb der 20 untersuchten Paarbeziehungen hatten.
} 
jungen Heranwachsenden (McPherson et al. 2001) und in den ersten Jahren der Sekundarschule (Lubbers und Snijders 2007) zeigt sich noch eine sehr starke Trennung zwischen den Geschlechtern (hohe Gender-Homophilie), welche in den Jahren zwar abnimmt, aber dennoch erhalten bleibt. Mit dem Älterwerden lösen sich diese homogenen Netzwerke langsam auf und es bilden sich geschlechtsheterogenere Gruppen heraus (Feiring 1999). Studien von Lubbers und Snijders (2007) zeigen ferner einen geringen Anteil an Liebesbeziehungen oder Sexualbeziehungen in der Sekundarstufe, während diese in der High-School (Bearman et al. 2004) stärker ausgeprägt sind. In beiden Studien sind diese Sexual- oder auch Beziehungsnetzwerke vornehmlich heterosexuell geprägt und erhöhen damit den Anteil gegengeschlechtlicher Alteri im Netzwerk.

Für ältere Menschen, und hier beispielhaft in den Familiennetzwerken älterer Mexikaner*innen, zeigen sich in der Studie von Fuller-Iglesias und Antonucci (2016) keine Geschlechterunterschiede (Nähe, Anteile im Netzwerk). Gegensätzlich dazu finden Schwartz und Litwin (2018) anhand des europaweiten Längsschnittsurvey „Health, Ageing, and Retirement in Europe“ $(\mathrm{n}=13,938)$ für über 65-Jährige vor allem für Frauen* eine Zunahme an Netzwerkbeziehungen über die Zeit, die parallel dazu weniger in Familiennetzwerken involviert sind.

\subsection{Lebenszyklus und die Zusammensetzung der sozialen Netzwerke}

Hinsichtlich des Lebenszyklus zeichnen unterschiedliche Forschungsergebnisse folgendes Bild. In der Studie von Fischer und Oliker aus dem Jahr 1983 finden sich einige wenige Unterschiede zwischen den Geschlechtern nach der Jugendphase. So sind Frauen* mehr mit Verwandten in Kontakt, während Männer* mehr Mitarbeiter*innen und Kolleg*innen als Netzwerkpartner*innen benennen. Ein größerer Zusammenhang wird hinsichtlich der Lebenszyklusphasen deutlich. Bei einer frühen Heirat und Elternschaft schrumpfen die Freundschaftsnetzwerke bei Frauen* im Vergleich zu den Männern* stärker. Nach der Geburt verkleinern sich diese im Vergleich zu den Frauen* vor allem bei den Männern*. „Further evidence suggests that this interaction effect can be explained by both structural and dispositional factors, the former working to reduce women's friendships relative to men's in the earlier period and the latter expanding their friendships later on " (ebd., S. 132). Hierbei stellten Munch et al. (1997) fest, dass gesellschaftliche Normen hinsichtlich der Kindererziehung in westlichen Ländern Auswirkungen auf die Netzwerkstrukturen haben. Während die Geburt eines Kindes keinen statistisch signifikanten Einfluss auf die Größe des Netzwerks der Männer* hatte, 
war aber ein signifikanter negativer Einfluss auf die Größe des Netzwerks der Frauen* festzustellen.

\subsection{Geschlechterunterschiede in den Netzwerkstrukturen mit Blick auf die Allgemeinbevölkerung}

Neben Studien zum Thema Lebensphasen existieren seit den 1980er Jahren unterschiedliche Studien, die der Frage nach Geschlechterunterschieden hinsichtlich der sozialen Netzwerke in der Allgemeinbevölkerung nachgehen. $\mathrm{Zu}$ nennen ist hier die vielzitierte Studie von Fischer (1982) „To Dwell Among Friends - Personal Networks in Town and City“, die einen Effekt von Geschlecht auf die Netzwerke herausstellt. „Women tend to be involved in networks with more relatives and to have more intimate ties than did otherwise similar man. Young women, particular mothers, were more constricted in various ways, such as in the number of the "just friend" they had [...]" (Fischer 1982, S. 253).

Hingegen, und im Widerspruch zu Fischer (1982), fanden Gillespie et al. (2015) keine wesentlichen geschlechtsspezifischen Unterschiede in der Anzahl der Freund*innen, der Anzahl der Alteri, mit denen man Geburtstage feiert, intime Angelegenheiten (z. B. Sexualleben) oder Problemen spät in der Nacht diskutiert. Die Anzahl der Freundschaften variierte jedoch erheblich nach Familienstand, Alter und Elternstatus (s. o.). Auffällig ist, dass jede*r der Befragten mindestens eine*n enge*n Freund*in nennen kann.

Weitere Studien mit der gleichen Schwerpunktsetzung griffen auf die Daten des General Social Survey (GSS) aus den USA zurück, um herauszufinden wie die Netzwerke in der US-amerikanischen Bevölkerung beschrieben werden können. Die Untersuchung von Marsden (1987) geht der Frage von Unterschieden hinsichtlich der Variablen Alter, Bildung, „race“, Geschlecht und Größe des Wohnortes etc. nach. Im Ergebnis scheinen die Netzwerke von jungen, gut ausgebildeten und großstädtischen Bewohner*innen am größten. Geschlechtsunterschiede findet man in erster Linie in der Zusammensetzung des Netzwerks aus Verwandten und Nicht-Verwanden; so ist der Anteil der Familienangehörigen bei Frauen* größer. Ähnliche Ergebnisse zeigen sich in einer etwas älteren Untersuchung von Moore (1990). Selbst nach Kontrolle der Variablen in Bezug auf Beschäftigung, sozialen Strukturpositionen, Familie und Alter besaßen Frauen* einen größeren Anteil an Verwandtschaftsbeziehungen und einen kleineren Anteil an Bekanntschaftsbeziehungen im Netzwerk sowie eine größere Vielfalt an Verwandtenbeziehungen als Männer*. Diese Unterschiede werden auf 
unterschiedliche strukturelle Beziehungskontexte bzw. -orte zurückgeführt, die bestimmte Möglichkeiten für und Beschränkungen auf die Formierung von engen sozialen Beziehungen ausüben. Die Geschlechterunterschiede in der Netzwerkzusammensetzung und -struktur verschwinden nämlich, wenn Beschäftigungsund Familienstatus sowie das Alter statistisch kontrolliert werden. Gleichwohl bleibt als empirischer Befund, dass die Netzwerke von Frauen* eine höhere Anzahl, einen höheren Anteil und eine größere Diversität von Verwandtschaftsbeziehungen enthalten als die Netzwerke von Männern*.

Eine Studie in Singapur zeigt zudem, dass Männer* und Frauen* eher auf berufliche Kontakte treffen, die von der jeweils eigenen Geschlechtszugehörigkeit (bipolar: Mann* oder Frau*) dominiert werden. Beispielsweise treffen Frauen* eher auf Krankenpfleger*innen, da sie in der Pflege überrepräsentiert sind, wobei unterschiedliche Lebensphasen darauf Einfluss haben. Ab der Geburt eines Kindes kommen Frauen* dann auch in Kontakt mit Berufsgruppen, in denen sie unterrepräsentiert sind wie z. B. Lehrer*innen, was sich wiederum auf die Zusammensetzung des Netzwerkes auswirkt (Chua et al. 2016).

Der Geschlechter-Aspekt scheint in den letzten Jahren in seiner Wirkung auf die Unterschiede der Netzwerkbildung an Kraft verloren zu haben. Während Frauen* noch etwas größere Netzwerke als Männer* besitzen und mehr Gespräche über wichtige Angelegenheiten mit Verwandten führen, besitzen sie jetzt auch immer mehr Beziehungen außerhalb der Familie. Frauen* haben somit nicht mehr ein deutlich verwandtschaftsorientiertes Diskussionsnetzwerk als Männer* und sind nicht mehr so häufig sozial isoliert (McPherson et al. 2006). Dies wird auch durch Fuller-Iglesias und Antonucci (2016) für 18- bis 99-jährige Mexikaner*innen bestätigt.

Ob wirklich Unterschiede hinsichtlich der Netzwerke existieren, ist mit Blick auf die widersprüchlichen Forschungsergebnisse fraglich. So weisen einige Kritiker*innen bspw. auf den starken Interviewer*in-Effekt bei der Erhebung des GSS hin (Fischer 2009), andere wiederum stellen die verwendeten Namensgeneratoren infrage und merken bspw. an, dass Frauen* vielleicht mehr wichtige Dinge zu besprechen haben als Männer* und daher ggf. auch ein größeres Netzwerk besitzen (Bearman und Parigi 2004).

\subsection{Netzwerkressourcen und Geschlechterunterschiede}

Neben der Strukturbeschreibung gehen viele Studien der Frage nach, welche Ressourcen die Netzwerke zur Verfügung stellen können. Dies geschieht auf unterschiedlichen Ebenen: 
1. Auf einer allgemeinen gesellschaftlichen Ebene. Hier wird versucht zu eruieren, inwieweit sich die Ressourcenverteilung in der allgemeinen Bevölkerung zwischen den Geschlechtern unterscheidet.

2. Auf der Ebene der Organisationen wird untersucht, inwieweit die Einbindung in soziale Netzwerke den - meist beruflichen - Erfolg beeinflusst.

\section{Soziale Unterstützung und Ressourcenverteilung}

Gillespie et al. (2015) zeigen, dass Männer* wie Frauen* gleichermaßen auf emotionale Unterstützung zurückgreifen können. Ähnliches zeigt sich auch bei Moore (1990). Bearman und Parigi (2004) weisen allerdings darauf hin, dass vor dem Hintergrund ,wichtige Dinge zu besprechen“ Frauen* mehr Personen angeben als Männer*. Die Studie zur sozialen Unterstützung von Turner und Marion (1994) stützt sowohl einen Lebenszyklus- als auch einen Gendereffekt: Frauen* geben an, mehr soziale Unterstützung von Mitarbeiter*innen, Verwandten und Freund*innen zu erhalten als Männer*. Widersprüchlich dazu zeigen sich bei Vyncke et al. (2014) bezogen auf das verfügbare Sozialkapital von Frauen* und Männern*. Männer* können signifikant mehr Ressourcen im Netzwerk aktivieren, berichten von mehr potenziellen Unterstützungsbeziehungen und mehr Netzwerkpartner*innen, die gesunde Lebensweisen fördern. Hobfoll und Vaux (1993) schlussfolgern dagegen anhand verschiedener Studien, dass Frauen* stärker in soziale Unterstützungsinteraktionen eingebunden sind, sie geschickter in Supportprozessen agieren und deswegen auch häufig mehr und intimere Beziehungen sowie größere Unterstützungsnetzwerke besitzen. Frauen* verbringen mehr Zeit in sozialen Interaktionen, teilen eher Gefühle und persönliche Sorgen und berichten häufiger von erhaltener sozialer Unterstützung.

Walen und Lachman (2000) stellen in ihrer Untersuchung an 2348 in Zweierbeziehungen eingebundenen Erwachsenen (25-75 Jahren) fest, dass Frauen* von mehr Unterstützung durch Familie und Freund*innen berichten, wohingegen Männer* häufiger Unterstützung von ihrer Partnerin* erhalten. Daneben hält Diewald (1991) anhand der Auswertung fünf repräsentativer Bevölkerungsumfragen fest, dass Frauen* in den meisten Lebensformen mehr Ansprechpartner*innen zur Verfügung haben als Männer*. Dies traf vor allem für ledige, alleinerziehende, geschiedene und verwitwete Frauen* zu. Frauen* suchen, so auch Barker et al. (1990), eher als Männer* Unterstützung von nahen und weiter entfernten Verwandten sowie Freund*innen und Nachbar*innen.

Wen dabei Frauen* und Männer* bei der Hilfeinanspruchnahme bevorzugen, scheint widersprüchlich. Belegen Antonucci et al. (1998) und Lenz (2003), dass jeweils das eigene Geschlecht bei der Supportsuche favorisiert wird, zeigen andere Wissenschaftler*innen auch gegenteilige Erkenntnisse. Zwar berücksichtigen 
Frauen* tendenziell häufiger innerfamiliäre Helferinnen*, wie die Schwester*, oder außerfamiliäre weibliche* Helferinnen, wie die Nachbarin* (Nestmann und Schmerl 1992), - allerdings sind Frauen* generell die zentralen „Geberinnen*“. So werden in der Studie von Veiel und Herrle (1991) sowohl von Studierenden als auch depressiven Patient*innen und Eltern krebskranker Kinder durchschnittlich häufiger Frauen* als Männer* als Unterstützer*innen genannt.

Am eindeutigsten zeigt sich die geschlechtsspezifische Arbeitsteilung zudem hinsichtlich der Hilfe im Krankheitsfall. Sowohl von männlichen* als auch von weiblichen* Befragten wurden Frauen* um ein Vielfaches häufiger als Männer* als Quellen sozialer Unterstützung genannt. Ebenso bedeutsame Unterstützerinnen* sind sie bei Niedergeschlagenheit, Ratschlägen bezüglich wichtiger Lebensveränderungen und Problemen mit dem Partner*/der Partnerin* (Diewald 1991). Auch bei Nestmann und Schmerl (1992) werden Frauen* häufiger als Helferinnen* genannt. Sowohl Männer* als auch Frauen* erhalten den Autor*innen zufolge mehr Hilfe von weiblichen* Helferinnen als von männlichen* Helfern (Mutter* häufiger als Vater*, Tochter* vor Sohn*, Schwester* vor Bruder* genannt). Frauen*, und vor allem Mütter*, gelten deshalb als die zentralen Unterstützungsinstanzen für ihre Familie (ebd.). Unter anderem bei Barker et al. (1990) nahmen Männer* in belastenden Situationen signifikant häufiger ihre Partnerin* als Unterstützerin* in Anspruch. Das Angewiesen-Sein des Mannes* auf die Partnerin* ist zudem bei älteren, über 60-Jährigen besonders ausgeprägt (Diewald 1991).

Frauen* fungieren dabei aber nicht nur für ihre Männer* häufiger als Unterstützer*in, sondern bieten der Studienübersicht Schmids (2014) zufolge häufiger und auch zeitintensiveren Support als Väter* für ihre erwachsenen Kinder. Stehen sie vor allem im Haushalt und bei der Kinderbetreuung hilfreich zur Seite, unterstützen Väter* ihre erwachsenen Kinder eher mit Einkäufen, Reparaturen oder Gartenarbeiten. Mit Blick auf die intergenerationellen Beziehungen sind auch aufseiten der Unterstützungsleistungen der Kinder Geschlechterunterschiede festzuhalten. So pflegen Töchter* häufigeren Kontakt mit ihren Eltern als Söhne*, übernehmen Töchter* in vielen Ländern häufiger körperlich anspruchsvolle und zeitintensive Pflegeleistungen und unterstützen insgesamt mehr. Söhne* helfen ihren Eltern vor allem bei administrativen Aufgaben, Reparaturen oder finanziellen Fragen. Allerdings, so Schmid (2014), finden diese Unterschiede in der Generationenforschung bislang wenig Beachtung, weshalb die „Ursachen geschlechtsspezifischer Unterstützungsmuster noch immer unzureichend erforscht [sind]" (ebd., S. 17)

Netzwerk- wie Support-Studien zu den Lebenswelten von Trans*-Personen sind kaum zu finden. Beispielhaft findet sich jedoch bei Pflum et al. (2015) 
ein bedeutsamer Zusammenhang zwischen sozialer Unterstützung und psychischer Gesundheit für Trans*-Personen: Sowohl für die Teilnehmer*innen des trans*-männlichen Spektrums (TMS) als auch des trans*-femininen Spektrums (TFS) ist die allgemeine soziale Unterstützung signifikant negativ mit Symptomen von Angst und Depression verbunden - d. h., mit zunehmender sozialer Unterstützung nahmen Gefühle der Angst und depressiven Verstimmungen ab. Der negative Zusammenhang zwischen trans*gemeinschaftlicher Verbundenheit und Symptomen der psychischen Gesundheit war jedoch nur für TFS-Teilnehmer*innen signifikant.

\section{Soziale Beziehungen von Männern* und Frauen* in Organisationen}

Neben dem allgemeinen Nutzen der Netzwerke vor dem Hintergrund der Sozialkapital- und sozialen Unterstützungstheorien, existieren Forschungsarbeiten über den Unterschied der „Verwertung“ von sozialen Beziehungen zwischen Männern* und Frauen* in Organisationen wie z. B. Wirtschaftsbetrieben oder Universitäten. Hierbei wird davon ausgegangen, dass der berufliche „Erfolg“ nicht nur von Kompetenzen, sondern auch von Netzwerken abhängig ist. Besonders Frauen* scheinen in diesem Fall - u. a. durch Prozesse der Stereotypisierung (Oehlendieck 2003) - benachteiligt zu sein (Lyness und Thompson 2000). Der größte Teil dieser Forschungen verdeutlicht, dass Männer* größere arbeitsbezogene Netzwerke haben, mit größeren Clustern verbunden sind und mehr Vorteile aus diesen Beziehungen ziehen, da Männer* höhere Positionen in hierarchischen Strukturen einnehmen (McGuire 2000).

Im Gegensatz dazu scheinen Frauen* in kleinere und weniger vielfältige Netzwerke eingebettet zu sein, die kaum Ressourcen zur Verfügung stellen. Diese weisen eine weibliche* Homophilie auf und sind vor allem durch Personen aus niedrigeren hierarchischen Positionen besetzt. Da die Subcluster ebenfalls tendenziell homogener sind, gibt es Überlappungen der Ressourcen, was zu einer Sozialkapitalbenachteiligung und Reproduktion der Positionen innerhalb des Netzwerkes führen kann (Lin 2000). Dabei schlussfolgern Scheidegger und Osterloh (2003) kontrastierend dazu, dass überwiegend Männer* (als Personen mit starker Legitimation) aus strukturellen Löchern Karrierevorteile ziehen würden und Frauen* für einen Aufstieg innerhalb der Organisation eher kohäsive, redundante Netzwerke benötigten. Zugleich sind Frauen*, solange nur wenige weibliche* Personen in zentralen statushöheren Positionen vertreten sind, aus ressourcenökonomischen Gründen auf Netzwerkkontakte mit höherrangigen Männern* angewiesen und müssen daher ihre Netzwerkkontakte differenzieren - mit entsprechenden Kosten. In einem Studienüberblick zeigen sie zudem die starke Homophilie der jeweiligen Netzwerke (Manager*innen, Mitarbeiter*innen 
aus Medienunternehmen), wobei v. a. für Männer* galt, dass ihre Netzwerke vorrangig aus ,same sex ties“ bestanden. Es wird deshalb davon ausgegangen, dass Frauen* eher auf ihre individuellen Kompetenzen statt auf das Sozialkapital fokussieren (Poole und Bornholt 1998), während Männer* stärker auf Netzwerke setzen und die Ressourcen besser nutzen (Van Emmerik 2006).

\section{Geschlecht, soziale Netzwerke und gesundheitliche Ungleichheiten}

\subsection{Wirkung von Sozialkapital und sozialer Unterstützung auf gesundheitliche Ungleichheiten}

Die Bedeutung von Geschlecht in der Forschung zu gesundheitlichen Ungleichheiten ist in der letzten Zeit wiederholt hervorgehoben worden und wird in der Regel zentral mit dem Konzept des sozialen Kapitals bzw. der sozialen Unterstützung als einer zentralen Funktion und wichtigem Wirkmechanismus sozialer Netzwerke verknüpft (vgl. den Beitrag: Soziale Beziehungen, soziales Kapital und soziale Netzwerke und den Beitrag: Wirkmechanismen in sozialen Netzwerken). Der Begriff des Netzwerkes wird dann, wenn er überhaupt vorkommt, als Metapher für unterstützende oder für ,Rückhalt“ bietende Beziehungen verwendet.

Es gibt zahlreiche Hinweise darauf, dass dieses soziale Kapital und die Verfügbarkeit sozialer Unterstützung zwischen Männern* und Frauen* ungleich verteilt und dass auch die Wirkung geschlechtsspezifisch zu unterscheiden ist. Dies wurde im vorangegangenen Kapitel bereits zum Teil erörtert (siehe oben). Auf Basis mehrerer Studien geht Underwood (2005) davon aus, dass Frauen* bei Krankheiten (Bypass-Operation, Myokardinfarkt) generell mehr Unterstützung erhalten als Männer*. Sie empfangen oft über einen längeren Zeitraum mehr emotionale, jedoch nicht unbedingt materielle Unterstützung (ebd., siehe auch Hobfoll und Vaux 1993). Die Wirkung wird dagegen unterschiedlich bewertet. In einer finnischen Studie wurde etwa ein positiver Zusammenhang zwischen Vertrauen (trust) bei Frauen* sowie Freizeitaktivitäten mit anderen bei Männern* und einer niedrigeren Mortalität festgestellt. Basierend auf dänischen Survey-Daten berichten Ejlskov et al. (2014) einen statistisch signifikanten Geschlechterunterschied bezüglich des Zusammenhangs von sozialem Kapital und Mortalität. Die Ergebnisse zeigen, auch nach Kontrolle von sozioökonomischem Status, Alter, Gesundheitsstatus und Gesundheitsverhalten, dass für Frauen* ein höheres Niveau an sozialem Kapital mit einem geringeren 
Mortalitätsrisiko (all-cause mortality) verbunden war. Ein weiterer theoretisch sehr bedeutsamer Befund der Studie ist der für Frauen* positive Zusammenhang zwischen der Kontakthäufigkeit mit Freund*innen und einem niedrigeren Sterblichkeitsrisiko. Auf negative Effekte des Sozialkapitals weisen auch Kawachi und Berkman (2001) hin. Demnach werden Frauen* durch ihr soziales Engagement mental stärker belastet und zeigen entsprechende Krankheitssymptome, wenn Personen mit denen sie verbunden sind, (gesundheitliche) Probleme bekommen. Daran anschließend berichten Sarason et al. (1997) und Antonucci et al. (1998), dass Frauen* stärker in soziale Beziehungen eingebunden sind und insbesondere, wenn sie über größere Netzwerke verfügen und viele enge Beziehungen pflegen, eher Stress und negative Effekte auf die allgemeine Lebenszufriedenheit erleben. Walen und Lachman (2000) zufolge mag dies daran liegen, dass Frauen*, die stärker in soziale Beziehungen eingebettet sind, auch eher negativen Ereignissen in ihrem sozialen Umfeld ausgesetzt sind (z. B. eine*n Freund*in bei Verlust einer geliebten Person unterstützen). Sie nehmen eher Hilfebedürfnisse anderer wahr, reagieren darauf und fungieren als Unterstützerinnen* in Krisen (Hobfoll und Vaux 1993; Nestmann und Schmerl 1992). Generell steht das Wohlbefinden der befragten Frauen* mehr mit positiven und negativen Aspekten der Ehe- und Freundschaftsbeziehungen in Verbindung als bei Männern* (Antonucci et al. 2001).

\subsection{Netzwerke und Geschlechterunterschiede mit Blick auf die Gesundheit}

Über diese Forschung zu sozialem Kapital hinausgehend, gibt es auch einige Studien, in denen eine dezidierte Netzwerkperspektive im Mittelpunkt steht und Geschlechterunterschiede eine wichtige oder zentrale Rolle einnehmen. Diese konzentrieren sich oft auf bestimmte Lebensphasen und dort insbesondere auf die netzwerkanalytisch schon vergleichsweise gut erforschte Jugendphase (siehe dazu auch den Beitrag: „Soziale Netzwerke, Gesundheit und gesundheitliche Ungleichheiten im Jugendalter") sowie auf die Phase des höheren Alters (siehe dazu auch den Beitrag: „Soziale Netzwerke und gesundheitliche Ungleichheiten im Alter"). Im Folgenden sollen einige neuere Befunde aus diesen Forschungsbereichen vorgestellt werden.

Ein wichtiges Thema im Jugendalter ist das Risikoverhalten, wie z. B. Tabakoder Alkoholkonsum. Hier finden sich sowohl Querschnitt- als auch Längsschnittstudien, die Geschlechterunterschiede beleuchten und sich dabei v. a. auf Netzwerke in Schulklassen fokussieren. Die Netzwerkforschung kann hier 
zeigen, dass spezifische Netzwerkeigenschaften, wie z. B. Homophilie, dafür sorgen, dass sich spezifisches Gesundheitsverhalten wie auch Interventionen zur Verbesserung des Gesundheitsverhaltens mehr oder weniger gut verbreiten können (Valente 2012).

So untersuchten beispielsweise Grard et al. (2018) in einer Querschnittsstudie Geschlechterunterschiede im Zigaretten-, Alkohol- und Cannabiskonsum bei 14bis 16-jährigen Jungen* und Mädchen* an 50 europäischen Schulen. Sie zeigen, dass Mädchen* eine geringere Prävalenz im Substanzkonsum haben als Jungen*. Aber auch das Geschlecht der Freund*innen spielt eine Rolle: Wenn Mädchen* in ihren Netzwerken mehr Freund*innen des anderen Geschlechts haben (other sex friendships, OSF), konsumieren sie eher eine der drei erhobenen Substanzen als Mädchen*, die mehr mit Mädchen* befreundet sind (same sex friendhips, SSF). Jungen* in OSF rauchen eher als Jungen* in SSF. Bei Alkohol- und Cannabiskonsum gehen bei Jungen* allerdings SSF eher mit dem Konsum dieser Substanzen einher. Auch die Geschlechterzusammensetzung an der Schule ist von Bedeutung: In Schulen, die männlich* dominiert sind, ist das Risiko des Substanzkonsums für Jungen* und Mädchen* höher.

Im Unterschied dazu finden Deutsch et al. (2014a) in ihrer Analyse basierend auf den Daten der National Longitudinal Study of Adolescent Health (Add Health) aus den USA ein Jahr später keinen Einfluss der Geschlechterzusammensetzung der Freundschaftsnetzwerke auf das Trinkverhalten. So bestätigt sich zwar die Hypothese der Autor*innen, dass der durchschnittliche Alkoholkonsum im peer-Netzwerk einen Einfluss auf den Alkoholkonsum von Ego hat, allerdings wird dies nicht vom Geschlecht (gender) moderiert. Die Autor*innen vermuten hier Selektionseffekte: Mädchen* suchen sich demnach peers, die ein ähnliches Trinkverhalten wie sie selbst aufweisen. Auch für das Geschlechterverhältnis in einer peer group konnte kein Einfluss auf den Alkoholkonsum von Ego nachgewiesen werden: Höhere Anteile von männlichen* Jugendlichen im Netzwerk führten entgegen der Annahme weder bei Jungen* noch bei Mädchen* zu einem höheren Alkoholkonsum. Überraschender Weise erwies sich allerdings die Nähe der Beziehungen als relevant auf den Alkoholkonsum: Sowohl bei Jungen* (SSF) als auch bei Mädchen* (OSF) ging eine geringere freundschaftliche Nähe zu männlichen* Freunden mit einem stärken Einfluss dieser Freunde auf den Alkoholkonsum ein Jahr später einher. Die Nähe zu Freundinnen* wurde auf diese Weise allerdings nur für Jungen* (OSF) bedeutsam. Die Autor*innen schließen aus ihren Befunden, dass die Rolle des Geschlechts bei der Sozialisation mit Alkohol viel komplexer ist als bisher angenommen, und fordern die Untersuchung einer Vielzahl von Beziehungen innerhalb eines Netzwerkes, auch solcher, die weniger eng oder nicht reziprok sind. Zudem müssten die Kontexte in 
denen Jugendliche trinken und ihre Motive für den Alkoholkonsum näher untersucht werden.

Den Effekt von Selektions- bzw. Einflussfaktoren, d. h. inwiefern sich Jugendliche ihre Peers nach ihren Vorlieben und Bedürfnissen auswählen oder durch diese in ihren Verhaltensweisen beeinflusst werden, gehen Studien mit Längsschnittdaten nach. Hierfür werden in vielen Fällen sogenannte SIENA-Modelle (Simulation Investigation for Empirical Network Analysis) verwendet. Die Forschungen fokussieren vor allem die Aspekte Alkohol-, Zigaretten und Cannabiskonsum bei Schüler*innen (z. B. Knecht et al. 2011; Osgood et al. 2013; Pearson et al. 2006). Hier sollen einige Beispielstudien angeführt werden: Bezüglich des Rauchverhaltens sind es bei finnischen Schüler*innen der Sekundärstufe eher Selektionsfaktoren die den Ausschlag für Freundschaftsbeziehungen geben. Beim Alkoholverhalten sind es sowohl Selektions- als auch Einflussfaktoren. Die Ergebnisse unterschieden sich nicht durchgängig in Bezug auf das Geschlecht (Kiuru et al. 2010). Auch Daw et al. (2015) können zeigen, dass Jungen* wie Mädchen* in den USA (7. Klasse) ihre gleichgeschlechtlichen Freund*innen nach Ähnlichkeit im Rauchverhalten auswählen. Ein Einfluss von Freundinnen* auf das Rauchverhalten konnte nur für Mädchen* nachgewiesen werden. Bezüglich des Alkoholkonsums stellen Burk et al. (2012) fest, dass die Ähnlichkeit zwischen dem Trinkverhalten von Freund*innen in der 6. Klasse beginnt, ihren Höhepunkt in der 8. Klasse erreicht und während der späten Adoleszenz wieder abnimmt. Jugendliche in allen drei Altersgruppen wählten Peers mit ähnlichem Trinkverhalten, wobei die Effekte bei frühjugendlichen Männern* und bei spätjugendlichen Frauen* am stärksten sind. Hinsichtlich des Einflusses gibt es keinen Unterschied zwischen den Geschlechtern (Burk et al. 2012). Bezüglich des Marihuanakonsums in High-Schools in den USA stellen die Autor*innen fest, dass auch der Freundeskreis nach Alter und Marihuanakonsum ausgesucht wird. Der Faktor Einfluss wurde nur an einer High-School festgestellt. Das Geschlecht, „race“ oder die Anzahl der Freund*innen außerhalb der Schule sagten jedoch nicht signifikant die Häufigkeit des Marihuanakonsums voraus. Ebenfalls gab es nur minimale Hinweise darauf, dass Peer-Effekte durch persönliche, schulische oder familiäre Risikofaktoren moderiert werden (De La Haye et al. 2013).

Für das Jugendalter lassen sich ferner Netzwerkstudien zu Geschlechterunterschieden und depressiven Erkrankungen finden. Ähnlich wie die Studie von Rosenquist et al. (2011) unter Erwachsenen, die zu dem Ergebnis kommt, dass Depressionen insbesondere für Frauen* sozial ansteckend sind, zeigen Conway et al. (2011) für das Jugendalter, dass bei Mädchen* das Auftreten von Depressionen im Freundeskreis mit einem verstärkten Auftreten eigener depressiver Symptome ein Jahr später einhergeht. 
Weitere Studien untersuchen sehr spezifische Netzwerkparameter und können zeigen, dass gleiche Netzwerkparameter für Mädchen* und Jungen* auf völlig unterschiedliche Weise mit depressiven Erkrankungen in Verbindung stehen. So leiden Jungen* eher an depressiven Erkrankungen, wenn sie Angst vor negativen Bewertungen durch ihre Peers erhalten und eine geringere Popularität in ihrem Netzwerk haben. Für Mädchen*, die Angst vor negativen Bewertungen haben, trifft dies eher zu, wenn sie eine hohe Popularität in ihren Netzwerken aufweisen (Kornienko und Santos 2014). Eine Studie von Falci und McNeely (2009) untersucht die Größe und Dichte von Netzwerken und zeigt, dass Mädchen*, wenn sie in sehr große, fragmentierte Netzwerke (d. h., nur wenige Netzwerkmitglieder kennen einander) eingebunden sind, eher von depressiven Symptomen betroffen sind als Mädchen*, die zwar in große aber kohäsive Netzwerke eingebunden sind. Bei Jungen* hingegen sind die Zusammenhänge genau umgekehrt: Sind sie in große und wenig kohäsive Netzwerke eingebunden, so sind sie weniger von depressiven Symptomen betroffen als Jungen*, die in große und kohäsive Netzwerke eingebettet sind.

Netzwerkstudien findet man auch in der Phase des hohen Alters. Eine Studie über ältere Menschen (über 60 Jahre) in den USA untersucht die Auswirkungen von unterschiedlichen idealtypischen Netzwerken (diverses Netzwerk, Netzwerk mit hohem gesellschaftlichem Engagement, Netzwerk mit geringem gesellschaftlichem Engagement und eingeschränkte Netzwerk) auf das Wohlbefinden. Männer*, die in eingeschränkte Netzwerke eingebunden sind, zeigen ein besonders niedriges Wohlbefinden. Im Allgemeinen bewerten Frauen*, in unterschiedlichen Netzwerktypen, ihre Gesundheit viel besser als Männer* (Fiori und Fuller 2017).

Ein wichtiges gesundheitsrelevantes Thema im höheren Alter ist auch der biografische Übergang der Verwitwung. Der Tod des*/der Partner*in kann negative Einflüsse auf die psychische Gesundheit haben und etwa zu depressiven Symptomen führen. Die Netzwerkmechanismen soziale Unterstützung, soziales Engagement und soziale Integration werden in diesem Zusammenhang als Faktoren genannt, die o. g. Symptome lindern und einen positiven Einfluss auf Gesundheit haben (vgl. den Beitrag: Soziale Netzwerke und gesundheitliche Ungleichheiten im Alter). Es gibt in diesem Zusammenhang einige Hinweise auf relevante geschlechtsspezifische Unterschiede (vgl. Monserud und Wong 2015): Ältere Männer* verlassen sich eher auf ihre Frauen*, wenn es um emotionale Unterstützung, die Haushaltsführung und das Pflegen sozialer Kontakte geht (siehe auch Lee et al. 2001; Umberson et al. 1992) und Frauen* befinden sich eher in ökonomischer Abhängigkeit von ihrem Mann* und können daher bei Verwitwung finanziellem Stress ausgesetzt sein (Arber 2004; Umberson et al. 1992). Zudem steht ausschließlich bei älteren Frauen* eine als gering wahrgenommene 
soziale Unterstützung und nur bei älteren Männern* eine geringere Netzwerkeinbindung in Beziehung zu einer schlechteren selbstberichteten Gesundheit (Caetano et al. 2013). Hieraus könnten sich unterschiedliche Anforderungen an die sozialen Beziehungsnetzwerke ergeben, die diese nicht immer erfüllen können.

Für Mexiko, ein Land, in dem institutionelle Hilfesysteme weniger ausgebaut und private, familiäre Unterstützungsstrukturen daher wichtiger sind, finden Monserud und Wong (2015) in einer Längsschnittstudie etwa, dass verheiratete Männer* weniger depressive Symptome angaben als alle anderen nach Geschlecht differenzierten Statusgruppen (verheiratet/bereits in Welle 1 verwitwet/in Welle 2 verwitwet). Allerdings gab es bei den kürzlich (seit Welle 2) verwitweten Personen keine statistisch signifikanten Geschlechterunterschiede bezüglich depressiver Symptomatiken. Die Ergebnisse zum Einfluss sozialer Unterstützung sind uneinheitlich bzw. die Effekte müssen differenziert betrachtet werden: Unabhängig vom Familienstand hängt ein höherer Wert bei emotionaler Unterstützung mit niedrigeren Zunahmen depressiver Symptome zusammen, während der Empfang finanzieller oder praktischer Unterstützung - bei kürzlich verwitweten Männern* ausgeprägter als bei kürzlich verwitweten Frauen* - mit einer stärkeren Zunahme dieser Symptome verbunden ist. Dies könnte damit zusammenhängen, dass die Angewiesenheit auf diese Form der Unterstützung Gefühle der Abhängigkeit auslösen, mit der Wahrnehmung einer eingeschränkten Autonomie und einer Umkehr der Rollen in den Eltern-Kind-Beziehungen verbunden sein könnte und damit Stress hervorruft (siehe dazu auch den Beitrag „Negative Beziehungsaspekte und gesundheitliche Ungleichheiten“). Eine stärkere Integration in ein soziales Netzwerk, die über Ko-Residenz mit Kindern, Verwandten oder Freund*innen sowie der Teilnahme an Gemeinschaftsaktivitäten operationalisiert wurde, hat ebensolche differenziert $\mathrm{zu}$ betrachtenden Effekte: Allgemein ist Ko-Residenz mit Verwandten mit einer höheren Zunahme depressiver Symptome verbunden, während Ko-Residenz mit anderen (Kindern, Freund*innen) eine geringere Zunahme depressiver Symptome bedeutet. Bei kürzlich verwitweten Männern* und bei seit längerem verwitweten Frauen* hängt Ko-Residenz mit Kindern mit einer geringeren Zunahme depressiver Symptome zusammen, während für kürzlich verwitwete Männer* die Ko-Residenz mit anderen Personen mit einer stärkeren Zunahme einhergeht. Soziale Integration in Gemeinschaftsaktivitäten liefert allgemein keinen Erklärungsbeitrag für die Veränderung bei depressiven Symptomen zwischen den beiden Wellen. Bei kürzlich verwitweten Frauen* hängt der Kirchenbesuch mit einem stärkeren Anstieg zusammen, während freiwillige Arbeit in Gemeinschaftsaktivitäten bei seit längerem verwitweten Frauen* mit einem niedrigeren Anstieg assoziiert ist. Es gibt also deutliche Hinweise darauf, dass soziale Unterstützung und soziale 
Integration für die Geschlechter eine unterschiedliche Bedeutung haben und dass hierbei Rollenbilder und eine ungleiche Verteilung von Aufgaben im Haushalt und der Partnerschaft eine Rolle spielen. Nach der Theorie des Sozialkapitals stellen soziale Netzwerke auch für ältere Trans*-Personen ein Vehikel für soziale Ressourcen dar, die für ein erfolgreiches Altern und Wohlbefinden von Vorteil sein können: „Controlling for background characteristics, network size was positively associated with being female, transgender identity, employment, higher income, having a partner or a child, identity disclosure to a neighbor, engagement in religious activities, and service use. Controlling in addition for network size, network diversity was positively associated with younger age, being female, transgender identity, identity disclosure to a friend, religious activity, and service use“" (Erosheva et al. 2016, S. 98).

\section{$4 \quad$ Fazit}

Zusammenfassend lässt sich sagen, dass die Kategorie Geschlecht, im Vergleich $\mathrm{zu}$ den anderen vorgestellten Kategorien in diesem Buch, relativ gut untersucht sind. Dennoch wird der Begriff des Netzwerkes häufig als Metapher anstatt einer Methode oder Theorie verwendet. Der Fokus liegt vor allem auf Schulklassenstudien und älteren Menschen.

Studien weisen u. a. darauf hin, dass Frauen* länger leben als Männer*. Auch bezüglich der Morbidität existieren gesundheitliche Unterschiede zwischen den Geschlechtern. Besonders im Jugendalter schneiden Jungen* in den meisten gesundheitsbedingten Indikatoren (z. B. Leukämie, Epilepsie, chronische Krankheiten) schlechter ab als Mädchen*. In der Pubertät scheinen Mädchen* eher an psychosomatischen und physiologischen Beschwerden zu leiden. Das weibliche* Krankheitsprofil ist ab diesen Zeitpunkt eher durch chronische Erkrankungen sowie durch psychosomatische und psychische Beeinträchtigungen (z. B. Schilddrüsenerkrankungen, Depression, Essstörungen) gekennzeichnet; das männliche* hingegen durch akute und lebensbedrohliche Krankheiten (z. B. HIV-Infektion, bösartige Neubildungen der Verdauungsorgane sowie der Lungen und Bronchien). Im hohen Alter ist kaum ein genereller Geschlechterunterschied zu erkennen. Hinsichtlich des Risikoverhaltens zeigen Forschungen, dass Männer* sowohl mehr rauchen als auch mehr Alkohol zu sich nehmen als Frauen*. Während bis ins Erwachsenenalter hinein Männer* seltener psychiatrische und psychotherapeutische sowie ambulante ärztliche Leistungen in Anspruch nehmen, gleicht sich dies im hohem Alter wieder an. 
Netzwerkstudien stellen Differenzen zwischen Männern* und Frauen* fest. Es kann behauptet werden, dass Frauen* größere Netzwerke besitzen, die ihrerseits mehr familiäre und verwandtschaftliche Diversität aufweisen. Neuere Studien gehen jedoch davon aus, dass sich die Netzwerke beider Geschlechter langsam angleichen. Mit Blick auf die aus den sozialen Beziehungen gewonnenen Ressourcen finden sich Belege, dass Hilfe im Krankheitsfall häufiger von Frauen* geleistet wird. Mütter* übernehmen auch den zeitintensiveren Support, und Frauen* scheinen mehr Ansprechpartner*innen für Probleme zu besitzen als Männer*. Wer bei der Hilfeinanspruchnahme bevorzugt wird, Männer* oder Frauen*, scheint hingegen widersprüchlich, wobei sich in mehr Studien ein Hang zu weiblichen* Helferinnen zeigt. Bei beruflichen Netzwerkbeziehungen zeigt sich folgendes Bild: Männer* haben größere arbeitsbezogene Netzwerke, sie sind anderen Subnetzwerken verbunden und ziehen mehr Vorteile aus diesen Beziehungen, da Männer* höhere Positionen in beruflichen Netzwerken einnehmen. Frauen* scheinen sich eher auf ihre individuellen Kompetenzen statt auf das Sozialkapital zu fokussieren, während Männer* stärker auf Netzwerke setzen und die Ressourcen besser nutzen.

Studien über den Zusammenhang von Netzwerken und Sozialkapital oder sozialer Unterstützung vor dem Hintergrund gesundheitlicher Ungleichheiten zeigen eine ungleiche Verteilung zwischen den Geschlechtern. Frauen* scheinen mehr und zeitaufwendigere soziale Unterstützungsaufgaben zu übernehmen. Sie besitzen mehr Ansprechpartner*innen für Probleme als Männer*. Daneben leiden sie wohl auch häufiger unter negativen Aspekten von sozialen Beziehungen. Es wird davon ausgegangen, dass Frauen* durch ihr stärkeres soziales Engagement höheren gesundheitlichen Belastungen ausgesetzt sind als Männer*.

Im Allgemeinen rücken die Gesundheit sowie das Gesundheitsverhalten von Schüler*innen und älteren Menschen in den Fokus der Netzwerkforschung. Bei Jugendlichen und Heranwachsenden untersuchen Netzwerkstudien häufig den Zigaretten-, Alkohol- und Cannabiskonsums. Neben den Querschnittstudien gehen neuere Längsschnittstudien den Einfluss- bzw. Selektionsfaktoren nach. Sie untersuchen die Frage, inwieweit sich Jugendliche ihre Freund*innen nach ihren Vorlieben und Bedürfnissen auswählen oder durch diese in ihren Verhaltensweisen beeinflusst werden. Hier scheint die Forschungslage, vielleicht auch aufgrund der unterschiedlichen Datensätze und Länderfokussierung, doch eher heterogen. Es wird allerdings deutlich, dass Mädchen* oder junge Frauen* im geringeren Maße leichte Drogen zu sich nehmen als ihre männlichen* Altersgenossen und soziale Netzwerke einen großen Effekt auf das Gesundheitsverhalten besitzen. Inwieweit es bei den Netzwerkeffekten Geschlechtsunterschiede 
gibt, bleibt jedoch noch offen. Auch zwischen depressiven Erkrankungen und sozialen Netzwerken zeigt sich ein Zusammenhang, der allem Anschein nach geschlechtsspezifischen Faktoren unterliegt.

Im Alter stehen vor allem die Phase der Verwitwung und die damit zusammenhängenden Netzwerkeffekte im Blickpunkt. Es scheint so zu sein, dass Netzwerke einen positiven Einfluss auf Gesundheit besitzen. Dennoch zeigen sich auch negative Seiten von Netzwerken. Hier gibt es Hinweise auf Geschlechtsunterschiede. Beispielsweise verlieren Männer* durch den Tod ihrer Frau* eher emotionale Unterstützung und Teile der sozialen Kontakte, während Frauen* durch die ökonomische Abhängigkeit von ihrem Mann* finanziellem Stress ausgesetzt sein können.

Die sehr wenigen Studien zu Trans*-Personen zeigen, dass viele Trans*Personen am Rande der Gesellschaft leben und mit Stigmatisierung, Diskriminierung, Ausgrenzung, Gewalt und schlechter Gesundheit konfrontiert sind (Winter et al. 2016).

Als Fazit möchten wir noch kurz auf die Desiderata eingehen. Trotz einer Anzahl an wissenschaftlichen Untersuchungen sind bisher noch viele Fragen ungeklärt. Vor allem wollen wir darauf hinweisen, dass intergeschlechtliche Personen $^{11}$ in den Studien (fast) nie Berücksichtigung finden. Ferner spielt bei der Analyse zum Nutzen von sozialer Unterstützung oder Sozialkapital Netzwerkforschung bisher eine untergeordnete Rolle. Aber auch konkrete Fragen bleiben kaum berücksichtigt. Während bei Risikoverhalten der Einfluss von Netzwerken bereits sehr gut erforscht ist, stellt sich die Frage, welche positiven Aspekte soziale Netzwerke auf das Gesundheitsverhalten wie z. B. Sporttreiben oder auch das Entsagen von bestimmten Drogen haben. Auch bei den Erklärungsmustern hinsichtlich der Erkrankung und dem Verlauf von Krankheiten, sollte die Frage nach den Effekten von Schicht, Geschlecht und sozialen Netzwerkverbindungen noch stärker in den Blickpunkt genommen werden und dies nicht nur mit neueren Verfahren der quantitativen sondern auch der qualitativen Netzwerkforschung. Zudem wäre es hier wichtig, das Konzept der Intersektionalität noch besser mit der Netzwerkforschung zu verbinden.

\footnotetext{
${ }^{11}$ Menschen, deren körperliche Merkmale sich nicht der weiblichen oder männlichen Geschlechternorm zuordnen lassen (Gerede e. V. 2018).
} 


\section{Leseempfehlungen}

Kolip, P. \& Hurrelmann, K. (2016). Handbuch Geschlecht und Gesundheit: Männer und Frauen im Vergleich. Bern: Hogrefe. Das Handbuch bietet einen aktuellen und umfassenden Überblick über den wissenschaftlichen Forschungsstand und interdisziplinäre Diskurse im Kontext von Geschlecht und Gesundheit.

Barry, A.-M. \& Yuill, C. (2012). Understanding the sociology of health: An introduction. 3. Aufl. Los Angeles, CA: Sage. Der Abschnitt zu Gender and Health (S. 129-144) bietet den Leser*innen eine gut verständliche und auf internationalen Daten basierende Einführung in die Zusammenhänge von Gesundheit und Geschlecht.

Bradford, J., Reisner, S. L., Honnold J. A. \& Xavier, J. (2013). Lesbian, gay, bisexual, and transgender health: Findings and concerns. Journal of the Gay and Lesbian Medical Association, 4 (3), S. 102-151. Ein dichter und guter englischer Überblicksartikel zum Thema LGBT und Gesundheit.

Moore, G. (1990). Structural determinants of men's and women's personal networks. American Sociological Review, 55 (5), S. 726-735. Ältere, aber beispielhafte repräsentative Studie aus den USA, die mit quantitativen Daten des General Social Survey (GSS, 1985) zu starken Beziehungen arbeitet.

Schwartz, E. \& Litwin, H. (2018). Social network changes among older Europeans: The role of gender. European Journal of Ageing, 15 (4), S. 359-367. Aktuelle, quantitative Längsschnittstudie, die mithilfe des europaweit angelegten Survey of Health, Ageing, and Retirement in Europe $(\mathrm{n}=13,938)$ nach Geschlechterdifferenzen in den sozialen Netzwerken älterer Menschen (65+) fragt.

\section{Literatur}

Antonucci, T. C., Akiyama, H., \& Lansford, J. E. (1998). Negative effects of close social relations. Family Relations, 47(4), 379-384.

Arber, S. (2004). Gender, marital status, and ageing: Linking material, health, and social resources. Journal of Aging Studies, 18(1), 91-108.

Babitsch, B. (2009). Die Kategorie Geschlecht: Theoretische und empirische Implikationen für den Zusammenhang zwischen sozialer Ungleichheit und Gesundheit. In M. Richter \& K. Hurrelmann (Hrsg.), Gesundheitliche Ungleichheit. Grundlagen, Probleme, Perspektiven (2., aktualisierte Aufl., S. 283-299). Wiesbaden: VS. 
Barker, C., Pistrang, N., Shapiro, D. A., \& Shaw, I. (1990). Copig and help-seeking in the UK adult population. British Journal of Clinical Psychology, 29(3), 271-285.

Barry, A.-M., \& Yuill, C. (2012). Understanding the sociology of health. An introduction (3. Aufl.). Los Angeles: SAGE.

Bartley, M. (2017). Health inequality. An introduction to concepts, theories and methods (2. Aufl.). Cambridge: Polity.

Bearman, P. S., Moody, J., \& Stovel, K. (2004). Chains of affection: The structure of adolescent romantic and sexual networks. American Journal of Sociology, 110(1), 44-91.

Bearman, P., \& Parigi, P. (2004). Cloning headless frogs and other important matters: Conversation topics and network structure. Social Forces, 83(2), 535-557.

Benotsch, E. G., Zimmerman, R., Cathers, L., McNulty, S., Pierce, J., Heck, T., \& Snipes, D. (2013). Non-medical use of prescription drugs, polysubstance use, and mental health in transgender adults. Drug and Alcohol Dependence, 132(1-2), 391-394.

Bott, E. (1957). Family and social network: Roles, norms and external relationships in ordinary urban families. London: Tavistock.

Bradford, J., Reisner, S. L., Honnold, J. A., \& Xavier, J. (2013). Lesbian, gay, bisexual, and transgender health: Findings and concerns. Journal of the Gay and Lesbian Medical Association, 4(3), 102-151.

Bundesversicherungsamt. (2017). Tätigkeitsbericht 2017. https://www.bundesversicherungsamt.de/fileadmin/redaktion/Presse/epaper2017/index.html\#0. Zugegriffen: 28. März 2019.

Burk, W. J., Van Der Vorst, H., Kerr, M., \& Stattin, H. (2012). Alcohol use and friendship dynamics: Selection and socialization in early-, middle-, and late-adolescent peer networks. Journal of Studies on Alcohol and Drugs, 73(1), 89-98.

Caetano, S. C., Silva, C. M. F. P., \& Vettore, M. V. (2013). Gender differences in the association of perceived social support and social network with self-rated health status among older adults: A population-based study in Brazil. BMC Geriatrics, 13, 122.

Chua, V., Mathews, M., \& Loh, Y. C. (2016). Social capital in Singapore: Gender differences, ethnic hierarchies, and their intersection. Social Networks, 47, 138-150.

Conway, C. C., Rancourt, D., Adelman, C. B., Burk, W. J., \& Prinstein, M. J. (2011). Depression socialization within friendship groups at the transition to adolescence: The roles of gender and group centrality as moderators of peer influence. Journal of Abnormal Psychology, 120(4), 857-867.

Daw, J., Margolis, R., \& Verdery, A. M. (2015). Siblings, friends, course-mates, club-mates: How adolescent health behavior homophily varies by race, class, gender, and health status. Social science \& medicine, 1982(125), 32-39.

De La Haye, K., Green, H. D., Kennedy, D. P., Pollard, M. S., \& Tucker, J. S. (2013). Selection and influence mechanisms associated with marijuana initiation and use in adolescent friendship networks. Journal of Research on Adolescence, 23(3), 474-486.

Dean, L., Meyer, I. H., Robinson, K., Sell, R. L., Sember, R., Silenzio, V. M., \& Dunn, P. (2000). Lesbian, gay, bisexual, and transgender health: Findings and concerns. Journal of the Gay and Lesbian Medical Association, 4(3), 102-151.

Degele, N. (2008). Gender/Queer Studies. Eine Einführung. Paderborn: Wilhelm Fink.

Deutsch, A. R., Steinley, D., \& Slutske, W. S. (2014). The role of gender and friends' gender on peer socialization of adolescent drinking: A prospective multilevel social network analysis. Journal of Youth and Adolescence, 43(9), 1421-1435. 
Diewald, M. (1991). Soziale Beziehungen: Verlust oder Liberalisierung? Soziale Unterstützung in informellen Netzwerken. Berlin: Edition Sigma.

Döring, N. (2013). Zur Operationalisierung von Geschlecht im Fragebogen: Probleme und Lösungsansätze aus Sicht von Mess-, Umfrage-,Gender- und Queer-Theorie. Gender, 5(2), 94-113.

Dorsen, C. (2012). An integrative review of nurse attitudes towards lesbian, gay, bisexual, and transgender patients. Canadian Journal of Nursing Research, 44(3), 18-43.

Ejlskov, L., Mortensen, R. N.; Overgaard, C., Christensen, L. R. B. U., Vardinghus-Nielsen, H., Kræmer, S. R. J., Wissenberg, M., ... Hansen, C. D. (2014). Individual social capital and survival: A population study with 5-year follow-up. BMC Public Health, 14(1025).

Erosheva, E. A., Kim, H. J., Emlet, C., \& Fredriksen-Goldsen, K. I. (2016). Social networks of lesbian, gay, bisexual, and transgender older adults. Research on Aging, 38(1), 98-123.

Falci, C. D., \& McNeely, C. (2009). Too many friends: Social integration, network cohesion and adolescent depressive symptoms. Social Forces, 87(4), 2031-2062.

Feiring, C. (1999). Other-sex friendship networks and the development of romantic relationships in adolescence. Journal of Youth and Adolescence, 28(4), 495-512.

Fiori, K. L., \& Fuller, H. R. (2017). Social network typologies and health in late life: The moderating role of gender. Innovation in Aging, 1(Suppl. 1), 941.

Fischer, C. S., \& Oliker, S. J. (1983). A research note on friendship, gender, and the life cycle. Social Forces, 62, 123-133.

Fischer, C. S. (1982). To dwell among friends: Personal networks in town and city. Chicago, IL: University of Chicago Press.

Fischer, C. S. (2009). The 2004 GSS finding of shrunken social networks: An artifact? American Sociological Review, 74(4), 657-669.

Fuller-Iglesias, H. R., \& Antonucci, T. C. (2016). Familism, social network characteristics, and well-being among older adults in Mexico. Journal of Cross-Cultural Gerontology, 31(1), 1-17.

Gerede e. V. (2018). Trans* - Eine Informationsbroschüre zum Thema Transidentität für betroffene Menschen, Angehörige und Interessierte. https://gerede-dresden.de/index. php/infomaterial.html. Zugegriffen: 13. Mai 2019.

Gillespie, B. J., Lever, J., Frederick, D., \& Royce, T. (2015). Close adult friendships, gender, and the life cycle. Journal of Social and Personal Relationships, 32(6), 709-736.

Graham, R., Berkowitz, B., Blum, R., Bockting, W., Bradford, J., de Vries, B., \& Makadon, H. (2011). The health of lesbian, gay, bisexual, and transgender people: Building a foundation for better understanding. Washington, DC: Institute of Medicine.

Grant, J. M., Mottet, L., Tanis, J. E., Harrison, J., Herman, J., \& Keisling, M. (2011). Injustice at every turn: A report of the national transgender discrimination survey. Washington, DC: National Center for Transgender Equality.

Grard, A., Kunst, A., Kuipers, M., Richter, M., Rimpela, A., Federico, B., \& Lorant, V. (2018). Same-sex friendship, school gender composition, and substance use: A social network study of 50 European schools. Substance Use \& Misuse, 53(6), 998-1007.

Grunow, D., Breitkopf, H., Dahme, H.-J., Engfer, R., Grunow-Lutter, V., \& Paulus, W. (1983). Gesundheitsselbsthilfe im Alltag. Ergebnisse einer repräsentativen Haushaltsbefragung über gesundheitsbezogene Selbsterfahrungen und -potentiale. Stuttgart: Ferdinand Enke. 
Haas, A. P., Eliason, M., Mays, V. M., Mathy, R. M., Cochran, S. D., D’Augelli, A. R., Silverman..., M. M., \& Clayton, P. J. (2010). Suicide and suicide risk in lesbian, gay, bisexual, and transgender populations: Review and recommendations. Journal of Homosexuality, 58(1), 10-51.

Hapke, U., Maske, U. E., Scheidt-Nave, C., Bode, L., Schlack, R., \& Busch, M. (2013). Chronischer Stress bei Erwachsenen in Deutschland. Ergebnisse der Studie zur Gesundheit Erwachsener in Deutschland (DEGS1). Bundesgesundheitsblatt, 56(5/6), 749-775.

Herbst, J. H., Jacobs, E. D., Finlayson, T. J., McKleroy, V. S., Neumann, M. S., Crepaz, N., \& HIV/AIDS Prevention Research Synthesis Team. (2008). Estimating HIV prevalence and risk behaviors of transgender persons in the United States: A systematic review. AIDS and Behavior, 12(1), 1-17.

Hobfoll, S. E., \& Vaux, A. (1993). Social support: Social resources and social context. In L Goldberg \& S. Breznitz (Hrsg.), Handbook of stress. Theoretical and clinical aspects (2. Aufl., S. 685-705). New York: Free Press.

House, J. S., Umberson, D., \& Landis, K. R. (1988). Structures and processes of social support. Annual Review of Sociology, 14(1), 293-318.

Hurrelmann, K., \& Quenzel, G. (2011). Geschlecht und Gesundheit. Public Health Forum, 19(2), 2-3.

Iller, C., \& Wienberg, J. (2012). Altern und Geschlecht. Gesundheit und Wohlbefinden im Alter in einer geschlechterdifferenziellen Perspektive. In V. Moser \& B. Rendtorff (Hrsg.), Riskante Leben? Geschlechterordnungen in der Reflexiven Moderne (S. 83-92). Opladen: Budrich.

i-Päd - Initiative intersektionale Pädagogik. (2019). Glossar. http://www.i-paed-berlin.de/ de/Glossar/\#queer. Zugegriffen: 13. Mai 2019.

Kawachi, I., \& Berkman, L. F. (2001). Social ties and mental health. Journal of Urban Health, 78(3), 458-467.

Kecojevic, A., Wong, C. F., Schrager, S. M., Silva, K., Bloom, J. J., Iverson, E., \& Lankenau, S. E. (2012). Initiation into prescription drug misuse: Differences between lesbian, gay, bisexual, transgender (LGBT) and heterosexual high-risk young adults in Los Angeles and New York. Addictive Behaviors, 37(11), 1289-1293.

Kiuru, N., Burk, W. J., Laursen, B., Salmela-Aro, K., \& Nurmi, J. E. (2010). Pressure to drink but not to smoke: Disentangling selection and socialization in adolescent peer networks and peer groups. Journal of Adolescence, 33(6), 801-812.

Knecht, A. B., Burk, W. J., Weesie, J., \& Steglich, C. (2011). Friendship and alcohol use in early adolescence: A multilevel social network approach. Journal of Research on Adolescence, 21(2), 475-487.

Kolip, P., \& Hurrelmann, K. (2002). Geschlecht-Gesundheit-Krankheit: Eine Einführung. In: Hurrelmann, K. \& Kolip, P. (Hrsg.). Geschlecht, Gesundheit und Krankheit. Männer und Frauen im Vergleich. 1. Aufl. Bern, Göttingen, Toronto, Seattle: Huber (Verlag Hans Huber, Programmbereich Gesundheit), S. 13-31.

Kolip, P., \& Hurrelmann, K. (2016). Geschlecht und Gesundheit: eine Einführung. In P. Kolip \& K. Hurrelmann (Hrsg.), Handbuch Geschlecht und Gesundheit. Männer und Frauen im Vergleich (2. Aufl., S. 8-18). Bern: Hogrefe.

Kornienko, O., \& Santos, C. (2014). The effects of friendship network popularity on depressive symptoms during early adolescence: Moderation by fear of negative evaluation and gender. Journal of Youth and Adolescence, 43(4), 541-553. 
Kuhlmann, E. (2016). Gendersensible Perspektiven auf Gesundheit und Gesundheitsversorgung. In M. Richter \& K. Hurrelmann (Hrsg.), Soziologie von Gesundheit und Krankheit (S. 183-196). Wiesbaden: Springer VS.

Lampert, T., Hoebel, J., Kuntz, B., Müters, S., \& Kroll, L. E. (2017), Gesundheitliche Ungleichheit in verschiedenen Lebensphasen. Gesundheitsberichterstattung des Bundes. https://www.rki.de/DE/Content/Gesundheitsmonitoring/Gesundheitsberichterstattung/GBEDownloadsB/gesundheitliche_ungleichheit_lebensphasen.pdf. Zugegriffen: 20. März 2019.

Lange, C., Manz, K., \& Kuntz, B. (2017). Alkoholkonsum bei Erwachsenen in Deutschland: Riskante Trinkmengen. https://www.rki.de/DE/Content/Gesundheitsmonitoring/ Gesundheitsberichterstattung/GBEDownloadsJ/FactSheets/JoHM_2017_02_Alkoholkonsum_Erwachsene.pdf. Zugegriffen: 20. März 2019.

Lee, G. R., DeMaris, A., Bavin, S., \& Sullivan, R. (2001). Gender differences in the depressive effect of widowhood in later life. The Journals of Gerontology: Series B, 56(1), S56-S61.

Lenz, K. (2003). Zur Geschlechtstypik persönlicher Beziehungen - Eine Einführung. In K. Lenz (Hrsg.), Frauen und Männer. Zur Geschlechtstypik persönlicher Beziehungen (S. 7-51). Weinheim: Juventa.

Lepore, S. J. (1992). Social conflict, social support, and psychological distress: Evidence of cross-domain buffering effects. Journal of Personality and Social Psychology, 63(5), $857-867$.

Lin, N. (2000). Inequality in social capital. Contemporary Sociology, 29(6), 785-795.

Lubbers, M. J., \& Snijders, T. A. (2007). A comparison of various approaches to the exponential random graph model: A reanalysis of 102 student networks in school classes. Social Networks, 29(4), 489-507.

Lyness, K. S., \& Thompson, D. E. (2000). Climbing the corporate ladder: Do female and male executives follow the same route? Journal of Applied Psychology, 85(1), 86-101.

Marsden, P. V. (1987). Core discussion networks of Americans. American Sociological Review, 52(1), 122-131.

Martin, C. L., Kornienko, O., Schaefer, D. R., Hanish, L. D., Fabes, R. A., \& Goble, P. (2013). The role of sex of peers and gender-typed activities in young children's peer affiliative networks: A longitudinal analysis of selection and influence. Child Development, 84(3), 921-937.

McGuire, G. M. (2000). Gender, race, ethnicity, and networks: The factors affecting the status of employees' network members. Work and Occupations, 27(4), 501-524.

McPherson, M., Smith-Lovin, L., \& Brashears, M. E. (2006). Social isolation in America: Changes in core discussion networks over two decades. American Sociological Review, 71(3), 353-375.

McPherson, M., Smith-Lovin, L., \& Cook, J. M. (2001). Birds of a feather: Homophily in social networks. Annual Review of Sociology, 27(1), 415-444.

Mercken, L., Snijders, T. A. B., Steglich, C., Vertiainen, E., \& de Vries, H. (2010). Smoking-based selection and influence in gender-segregated friendship networks: A social network analysis of adolescent smoking. Addiction, 105(7), 1280-1289.

Miller, J. B. (1976). Toward a new psychology of women. Boston: Beacon.

Monserud, M. A., \& Wong, R. (2015). Depressive symptoms among older Mexicans: The role of widowhood, gender, and social integration. Research on Aging, 37(8), 856-886.

Moore, G. (1990). Structural determinants of men's and women's personal networks. American Sociological Review, 55(5), 726-735. 
Munch, A., McPherson, J. M., \& Smith-Lovin, L. (1997). Gender, children, and social contact: The effects of childrearing for men and women. American Sociological Review, 62(2), 509-520.

Mustanski, B. S., Garofalo, R., \& Emerson, E. M. (2010). Mental health disorders, psychological distress, and suicidality in a diverse sample of lesbian, gay, bisexual, and transgender youths. American Journal of Public Health, 100(12), 2426-2432.

Nestmann, F., \& Schmerl, C. (1992). Wer hilft im Alltag? Gruppendynamik, 23(2), 161-179.

Newcomb, M. E., Heinz, A. J., \& Mustanski, B. (2012). Examining risk and protective factors for alcohol use in lesbian, gay, bisexual, and transgender youth: A longitudinal multilevel analysis. Journal of Studies on Alcohol and Drugs, 73(5), 783-793.

Nieder, T.O., Briken, P., \& Güldenring, A. K. (2016). Eine aktuelle Übersicht zur Diagnostik und Behandlung. Geschlechtsinkongruenz, -dysphorie und Trans*-Gesundheit. InFo Neurologie und Psychatrie, 18(12), 38-49.

Oehlendieck, L. (2003). Gender Trouble in Organisationen und Netzwerken. In U. Pasero \& C. Weinbach (Hrsg.), Frauen, Männer, Gender Trouble: Systemtheoretische Essays (S. 171-185). Frankfurt a. M.: Suhrkamp.

Orth, B., \& Töppich, J. (2015). Der Alkoholkonsum Jugendlicher und junger Erwachsener in Deutschland 2014. Ergebnisse einer aktuellen Repräsentativbefragung und Trends. Köln: Bundeszentrale für gesundheitliche Aufklärung.

Osgood, D. W., Ragan, D. T., Wallace, L., Gest, S. D., Feinberg, M. E., \& Moody, J. (2013). Peers and the emergence of alcohol use: Influence and selection processes in adolescent friendship networks. Journal of Research on Adolescence, 23(3), 500-512.

Pabst, A., Kraus, L., Gomes de Matos, E., \& Piontek, D. (2013). Substanzkonsum und substanzbezogene Störungen in Deutschland im Jahr 2012. Sucht, 59(6), 321-331.

Paik, A., \& Sanchagrin, K. (2013). Social isolation in America: An artifact. American Sociological Review, 78(3), 339-360.

Pearson, M., Steglich, C., \& Snijders, T. (2006). Homophily and assimilation among sport-active adolescent substance users. Connections, 27(1), 47-63.

Pflum, S. R., Testa, R. J., Balsam, K. F., Goldblum, P. B., \& Bongar, B. (2015). Social support, trans community connectedness, and mental health symptoms among transgender and gender nonconforming adults. Psychology of Sexual Orientation and Gender Diversity, 2(3), 281-286.

Poole, M., \& Bornholt, L. (1998). Career development of academics: Cross-cultural and lifespan factors. International Journal of Behavioral Development, 22(1), 103-126.

Poteat, T., German, D., \& Kerrigan, D. (2013). Managing uncertainty: A grounded theory of stigma in transgender health care encounters. Social Science \& Medicine, 84, 22-29.

Prütz, F., \& Rommel, A. (2017). Inanspruchnahme von Krankenhausbehandlungen in Deutschland. https://www.rki.de/DE/Content/Gesundheitsmonitoring/Gesundheitsberichterstattung/GBEDownloadsJ/FactSheets/JoHM_04_2017_Krankenhausbehandlungen.pdf. Zugegriffen: 20. März 2019.

Regitz-Zagrosek, V. (2017). Geschlecht und Herz-Kreislauf-Erkrankungen: Warum wir Gendermedizin brauchen. Der Internist, 58(4), 336-343.

Regitz-Zagrosek, V. (2018). Gesundheit, Krankheit und Geschlecht. Aus Politik und Zeitgeschichte, 68(24), 19-24.

Robert-Koch-Institut (2015). Gesundheit in Deutschland. Gesundheitsberichterstattung des Bundes. http://www.gbe-bund.de/pdf/GESBER2015.pdf. Zugegriffen: 25. März 2019. 
Rommel, A., \& Prütz, F. (2017). Inanspruchnahme physiotherapeutischer Leistungen in Deutschland. https://www.rki.de/DE/Content/Gesundheitsmonitoring/Gesundheitsberichterstattung/GBEDownloadsJ/FactSheets/JoHM_04_2017_Physiotherapeutische_Leistungen.pdf?_blob=publicationFile. Zugegriffen: 20.03.2019.

Rose, L. (2015). Geschlecht als soziale Unterscheidungskategorie in unserer Lebenswelt. In B. Bretländer, M. Köttig, \& T. Kunz (Hrsg.), Vielfalt und Differenz in der sozialen Arbeit. Perspektiven auf Inklusion (S. 63-73). Stuttgart: W. Kohlhammer.

Rosenquist, J. N., Fowler, J. H., \& Christakis, N. A. (2011). Social network determinants of depression. Molecular Psychiatry, 16(3), 273-281.

Rowe, C., Santos, G. M., McFarland, W., \& Wilson, E. C. (2015). Prevalence and correlates of substance use among trans* female youth ages 16-24 years in the San Francisco Bay Area. Drug and Alcohol Dependence, 147, 160-166.

Sarason, B. R., Sarason, I. G., \& Gurung, R. A. R. (1997). Close personal relationships and health outcomes: A key to the role of social support. In S. Duck (Hrsg.), Handbook of personal relationships: Theory, research and interventions (S. 547-573). Hoboken: Wiley.

Schmid, T. (2014). Generation, Geschlecht und Wohlfahrtsstaat. Intergenerationelle Unterstützung in Europa. Wiesbaden: Springer VS.

Schwartz, E., \& Litwin, H. (2018). Social network changes among older Europeans: The role of gender. European Journal of Ageing, 15(4), 359-367.

Sheridan, A. (2002). What you know and who you know: "Successful" women's experiences of accessing board positions. Career Development International, 7(4), 203-210.

Sieverding, M. (2005). Geschlecht und Gesundheit. In R. Schwarzer \& N. (Hrsg.), Gesundheitspsychologie (S. 55-70). Göttingen: Hogrefe.

Statistisches Bundesamt (2019a). Genesis-Online-Datenbank. https://www-genesis.destatis. de/genesis/online. Zugegriffen: 22. März 2019.

Statistisches Bundesamt (2019b). Anzahl der Suizide nach Altersgruppen. https://www. destatis.de/DE/Themen/Gesellschaft-Umwelt/Gesundheit/Todesursachen/Tabellen/sterbefaelle-suizid-erwachsene-kinder.html. Zugegriffen: 24. März 2019.

Statistisches Bundesamt (2019c). Zahl der Todesfälle im Jahr 2016 um 1,5 \% gesunken. https://www.destatis.de/DE/Themen/Gesellschaft-Umwelt/Gesundheit/Todesursachen/ todesfaelle-2016.html. Zugegriffen: 24. März 2019.

Straus, F., Höfer, R., Nuchholz, W., \& Gmür, W. (1987). Die Bewältigung familiärer Probleme im sozialen Netzwerk. Überlegungen zur Praxisrelevanz der Netzwerkperspektive in der Familienarbeit. In H. Keupp \& B. Röhrle (Hrsg.), Soziale Netzwerke (S. 178-198). New York: Campus.

Turner, R. J., \& Marino, F. (1994). Social support and social structure: A descriptive epidemiology. Journal of Health and Social Behavior, 35(3), 193-212.

Umberson, D., Wortman, C. B., \& Kessler, R. C. (1992). Widowhood and depression: Explaining long-term gender differences in vulnerability. Journal of Health and Social Behavior, 33(1), 10-24.

UNdata. (2017). Life expectancy. http://data.un.org/Search.aspx?q=life+expectancy. Zugegriffen: 27. März 2019.

Underwood, P. W. (2005). Sozialer Rückhalt: Versprechen und Wirklichkeit. In V. Hill Rice, (Hrsg.), Stress und Coping. Lehrbuch für Pflegepraxis und -wissenschaft (S. 419-444). Bern: Hans Huber.

Valente, T. (2012). Network interventions. Science, 337(6090), 49-53. 
Van Emmerik, I. H. (2006). Gender differences in the creation of different types of social capital: A multilevel study. Social Networks, 28(1), 24-37.

Veiel, H. O. F., \& Herrle, Johannes. (1991). Geschlechtsspezifische Strukturen sozialer Unterstützungsnetzwerke. Zeitschrift für Soziologie, 20(3), 237-245.

Vyncke, V., Hardyns, W., Peersman, W., Pauwels, L., Groenewegen, P., \& Willems, S. (2014). How equal is the relationship between individual social capital and psychological distress? A gendered analysis using cross-sectional data from Ghent (Belgium). BMC Public Health, 14, 960.

Walen, H. R., \& Lachman, M. E. (2000). Social support and strain from partner, family, and friends: Costs and benefits for men and women in adulthood. Journal of Social and Personal Relationships, 17(1), 5-30.

Wetterer, A. (2004). Konstruktion von Geschlecht: Reproduktionsweisen der Zweigeschlechtlichkeit. In R. Becker \& B. Kortendiek (Hrsg.), Handbuch Frauen- und Geschlechterforschung (S. 122-131). Wiesbaden: VS.

WHO. (2019). Probability of dying per 1000 live births Data by WHO region. http://apps. who.int/gho/data/view.main.CM1300R?lang=en. Zugegriffen: 25. Apr. 2019.

Winker, G., \& Degele, N. (2010). Intersektionalität. Zur Analyse sozialer Ungleichheiten (2. Aufl.). Bielefeld: Transcript.

Winter, S., Diamond, M., Green, J., Karasic, D., Reed, T., Whittle, S., \& Wylie, K. (2016). Transgender people: Health at the margins of society. The Lancet, 388(10042), 390-400.

Wirtschafts- und Sozialwissenschaftliches Institut (WSI) (2017). Verdienstabstand nach Erwerbsumfang und beruflicher Position 2017. https://www.boeckler.de/52852.htm. Zugegriffen: 28. März 2019.

Wirtschafts- und Sozialwissenschaftliches Institut (WSI) (2018). Frauen in Deutschland. https://www.boeckler.de/wsi_38957.htm. Zugegriffen: 28. März 2019.

Zeiher, J., Kuntz, B., \& Lange, C. (2017). Rauchen bei Erwachsenen in Deutschland. https://www.rki.de/DE/Content/Gesundheitsmonitoring/Gesundheitsberichterstattung/ GBEDownloadsJ/FactSheets/JoHM_2017_02_Rauchen_Erwachsene.pdf. Zugegriffen: 26. März 2019.

Open Access Dieses Kapitel wird unter der Creative Commons Namensnennung 4.0 International Lizenz (http://creativecommons.org/licenses/by/4.0/deed.de) veröffentlicht, welche die Nutzung, Vervielfältigung, Bearbeitung, Verbreitung und Wiedergabe in jeglichem Medium und Format erlaubt, sofern Sie den/die ursprünglichen Autor(en) und die Quelle ordnungsgemäß nennen, einen Link zur Creative Commons Lizenz beifügen und angeben, ob Änderungen vorgenommen wurden.

Die in diesem Kapitel enthaltenen Bilder und sonstiges Drittmaterial unterliegen ebenfalls der genannten Creative Commons Lizenz, sofern sich aus der Abbildungslegende nichts anderes ergibt. Sofern das betreffende Material nicht unter der genannten Creative Commons Lizenz steht und die betreffende Handlung nicht nach gesetzlichen Vorschriften erlaubt ist, ist für die oben aufgeführten Weiterverwendungen des Materials die Einwilligung des jeweiligen Rechteinhabers einzuholen.

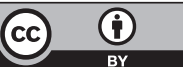




\title{
Arbeitslosigkeit, soziale Netzwerke und gesundheitliche Ungleichheiten
}

\author{
Gerhard Krug, Stefan Brandt, Markus Gamper, \\ André Knabe und Andreas Klärner
}

\section{Überblick}

- Arbeitslosigkeit führt zu Beeinträchtigungen der physischen und psychischen Gesundheit.

- Es existieren zwei wichtige Thesen zur Rolle sozialer Netzwerke für diesen Zusammenhang.

- These 1: Arbeitslosigkeit verändert soziale Netzwerke so, dass sie ihre positive Funktion für die Gesundheit nicht mehr erfüllen (Mediatorthese).

G. Krug $(\bowtie)$

Nürnberg, Deutschland

E-Mail: gerhard.krug@iab.de

S. Brandt

Berlin, Deutschland

E-Mail: brandt@tu-berlin.de

M. Gamper

Köln, Deutschland

E-Mail: m.gamper@uni-koeln.de

A. Knabe

Rostock, Deutschland

E-Mail: andre.knabe@uni-rostock.de

A. Klärner

Braunschweig, Deutschland

E-Mail: andreas.klaerner@thuenen.de 
- These 2: Arbeitslosigkeit lässt soziale Netzwerke unverändert und Personen mit ressourcenreichen Netzwerken leiden weniger unter Gesundheitseinbußen durch Arbeitslosigkeit (Moderatorthese).

- Zu beiden Thesen existiert bisher nur wenig empirische Evidenz.

- Die wenigen quantitativen Analysen messen Netzwerke nur indirekt und sind durch fehlende Längsschnittdaten in ihrer Aussagekraft stark eingeschränkt.

- Qualitative Studien würden davon profitieren, Netzwerkeinflüsse stärker zu systematisieren und sie dadurch quantitativen Analysen zum Test zugänglich zu machen.

\section{$1 \quad$ Einleitung}

Der Verlust der Erwerbstätigkeit stellt für viele Betroffene ein Ereignis dar, das in ihren Lebenslauf eingreift, dadurch Stress auslöst (Pearlin 1989) und infolgedessen die Gesundheit negativ beeinflussen kann. Metaanalysen zeigen, dass Arbeitslose einen schlechteren Gesundheitszustand und ein um wenigstens 1,6fach höheres Mortalitätsrisiko aufweisen als beschäftigte Personen (Herbig et al. 2013; Norström et al. 2014; Roelfs et al. 2011). Dabei zeigt sich, dass Arbeitslosigkeit vor allem mit einer geringeren psychischen, aber auch physischen Gesundheit sowie teilweise mit einem riskanteren Gesundheitsverhalten (insbesondere bezüglich des Tabakkonsums) einhergeht (Freyer-Adam et al. 2011; Khlat et al. 2004; Paul und Moser 2009; McKee-Ryan et al. 2005).

Auswertungen der Studien „Gesundheit in Deutschland aktuell“ von 2010 und 2012 (Kroll et al. 2016) und aktuelle Krankenkassendaten (Knieps und Pfaff 2016) zeigen, dass psychische Probleme (Depressionen, Angststörungen etc.) bei Arbeitslosen gehäuft auftreten, diese ihren Gesundheitszustand deutlich schlechter einschätzen sowie dass sie häufiger rauchen und seltener Sport treiben als Erwerbstätige. Während internationale Studien eher auf einen höheren Alkoholkonsum bei Arbeitslosen hinweisen (Henkel 2011), gibt es diesbezüglich für Deutschland keine nennenswerten Unterschiede: Arbeitslose Frauen konsumieren sogar seltener Alkohol in gesundheitlich bedenklichem Ausmaß (vgl. dazu auch Eggs et al. 2014).

Arbeitslosigkeit beeinflusst auch den Konsum von angemessenen und gesunden Lebensmitteln wie frisches Obst und Gemüse und einer warmen Mahlzeit am Tag negativ. In der internationalen Forschung wird dies als 
„food insecurity“ bezeichnet. In den USA wurden etwa in einer Studie zu den Auswirkungen der Rezession von 2007-2009 gezeigt, dass Arbeitslosigkeit und „food insecurity“ stark korrelieren (Huang et al. 2016). Auswertungen des sozio-ökonomischen Panels (SOEP) zeigen, dass der Anteil der Ausgaben für Lebensmittel am Haushaltsbudget mit 19,2 \% bei Arbeitslosen deutlich höher, die absolute Summe von 205 EUR aber im Vergleich zu Erwerbstätigenhaushalten (13,7\% und 362 EUR) erheblich geringer ist (Pfeiffer et al. 2016).

Eine Reihe theoretischer Analysen geht davon aus, dass soziale Netzwerke für die gesundheitlichen Auswirkungen der Arbeitslosigkeit eine wichtige Rolle spielen. Dabei geht ein Teil der Literatur davon aus, dass Arbeitslosigkeit Auswirkungen auf das Netzwerk hat und diese Veränderung im Netzwerk sich wiederum auf die Gesundheit auswirkt (Mediatoreffekt, siehe z. B. Jahoda 1981; Warr 1987). Ein anderer Teil nimmt an, dass Netzwerke die negativen Folgen des durch Arbeitslosigkeit entstehenden Stresses auf die Gesundheit verringern (Moderatoreffekt, siehe z. B. Cassel 1976; Cobb 1976; Atkinson et al. 1986).

Der vorliegende Beitrag liefert einen Überblick über empirische Analysen zum Thema Netzwerke und Arbeitslosigkeit. Im Allgemeinen wird sowohl in der Alltagssprache als auch in der Wissenschaft mit dem Begriff Arbeitslosigkeit das Fehlen von Erwerbsarbeit bezeichnet (vgl. zum Folgenden auch Ludwig-Mayerhofer 2018). Damit können auch Personen, die einer aus individueller und gesellschaftlicher Sicht produktiven Arbeit nachgehen (z. B. im Haushalt oder im Ehrenamt) in diesem Sinne arbeitslos sein. In Deutschland werden sogar gemäß der sozialrechtlichen Definition der Bundesagentur für Arbeit Personen als arbeitslos in der amtlichen Statistik geführt, die einer Erwerbstätigkeit nachgehen, dies aber im Umfang von weniger als 15 Wochenstunden tun.

Eine Alternative wäre der Begriff Erwerbslosigkeit, der einerseits genau auf das Fehlen einer entlohnten Tätigkeit rekurriert. Andererseits wird der Begriff aber auch vom Statistischen Bundesamt verwendet, um damit ein alternatives, international vergleichbares Messkonzept zu bezeichnen. Dieses orientiert sich am Labour-ForceKonzept der International Labour Organization (ILO) und bezeichnet Personen als erwerbslos, die weniger als eine Stunde pro Woche einer Erwerbsarbeit nachgehen.

Im Folgenden wird - auch im Anschluss an die von uns referierte Literatur meist von Arbeitslosigkeit gesprochen, wobei der Begriff Erwerbslosigkeit damit weitgehend synonym verwendet wird. Damit ist explizit keine bewertende Aussage zu nicht entlohnten Arbeiten verbunden.

Zunächst wird in Abschn. 2 der Forschungsstand zum Thema Arbeitslosigkeit und Gesundheit referiert. In Abschn. 3 wird dann die konkrete Bedeutung sozialer Netzwerke in Bezug auf Arbeitslosigkeit und Gesundheit thematisiert. In Abschn. 3.1 werden empirische Forschungsergebnisse zur Rolle der Netzwerke 
als Mediator und in Abschn. 3.2 die Forschung zur Rolle als Moderator zusammenfasst. Abschn. 4 schließt mit einer Zusammenfassung und Bewertung des Forschungsstandes.

\section{Arbeitslosigkeit und Gesundheit}

Der negative Zusammenhang zwischen Arbeitslosigkeit und Gesundheit wurde vielfach belegt. Gewöhnlich wird der These der Verursachung gesundheitlicher Probleme durch Arbeitslosigkeit die These der Selektion von Personen mit schlechterer Gesundheit entgegengesetzt. Der Großteil der Literatur geht allerdings von der Verursachungsthese aus (Kroll et al. 2016; Brand 2015; Wanberg 2012).

In ihrer Metaanalyse berichten Paul und Moser (2009), dass sich die meisten Forschungsarbeiten zum Thema Arbeitslosigkeit und Gesundheit mit den Auswirkungen auf mentale oder allgemeine Gesundheit befassen. Physische Gesundheit spielt hier eher eine untergeordnete Rolle. Dies gilt auch noch, wenn man sich auf Analysen mit explizit kausalanalytischem Design beschränkt.

Cygan-Rehm et al. (2017) berichten negative Effekte auf die mentale Gesundheit bei den Befragten in den USA, Großbritannien, Australien und Deutschland. Die Ergebnisse von Mandemakers und Monden (2013) zeigen zudem, dass der negative Effekt auf die mentale Gesundheit vom Bildungsniveau abhängt. Dabei leiden höher gebildete Arbeitslose weniger unter Gesundheitseinbußen, da ihre Aussichten auf Wiederbeschäftigung besser sind. Zwar berichten Mandemakers und Monden (2013) von einem negativen Gesundheitstrend vor der Arbeitslosigkeit, interpretieren diese aber nicht als Beleg für Gesundheitsselektion, sondern als negative Folgen der Antizipation von Arbeitslosigkeit. Auch Young (2012) kann negative Auswirkungen auf die mentale Gesundheit für die USA aufzeigen. Diese lassen sich weder durch den arbeitslosigkeitsbedingten Einkommensverlust noch durch die (nicht) Verfügbarkeit einer Krankenversicherung erklären. Zudem kehrt der Gesundheitszustand, gemessen anhand einer Depressionsskala, auch nach erneuter Erwerbsaufnahme nicht auf das Niveau vor der Arbeitslosigkeit zurück.

Für Italien können Minelli et al. (2014) dagegen keine kausale Arbeitslosigkeitseffekte finden. Sie beziehen sich jedoch auf die selbsteingeschätzte Gesundheit. Bezogen auf Finnland finden Böckerman und Ilmakunnas (2009) ebenfalls keine kausalen Auswirkungen von Arbeitslosigkeit auf die selbsteingeschätzte Gesundheit, sie zeigen aber, dass Personen, die irgendwann arbeitslos werden, bereits vorher einen schlechteren Gesundheitszustand aufwiesen. Sie 
interpretieren dies als Beleg für die These der direkten Selektion. Tøge und Blekesaune (2015) berichten hingegen einen starken negativen kausalen Effekt der Arbeitslosigkeit auf die selbsteingeschätzte Gesundheit in 28 Staaten der EU, der mit der Dauer der Arbeitslosigkeit zunimmt. Da sie jedoch keine gleichzeitigen negativen Gesundheitstrends vor Eintritt in Arbeitslosigkeit finden, schließen sie die Selektionsthese aus. Nach Pearlman (2015) beeinflusst Arbeitslosigkeit in Folge von Firmenschließung selbsteingeschätzte Gesundheit negativ, während Arbeitslosigkeit aus anderen Gründen die Gesundheit nicht beeinflusst. Gebel und Voßemer (2014) finden zwar statistisch negative Auswirkungen auf die Lebenszufriedenheit, aber keine Effekte auf die Gesundheitszufriedenheit der Befragten in Deutschland. Sie interpretieren ihre Ergebnisse als Beleg für negative Kausaleffekte auf die psychische und nicht auf die physische Gesundheit. Dem entgegenstehend findet Schmitz (2011) zunächst negative gesundheitliche Folgen der Arbeitslosigkeit auf Gesundheitszufriedenheit, mentale Gesundheit und Krankenhausaufenthalte, aber nicht für Arbeitslose, die ihre Arbeit aufgrund einer Betriebsschließung verloren haben. Da diese Gruppe von Arbeitslosen im Gegensatz zu den anderen Arbeitslosen keine gesundheitlichen Auswirkungen zeigt, deutet dies für den Autor auf reine Selektion krank gewordener Beschäftigter in die Arbeitslosigkeit hin und nicht auf negative Gesundheitseffekte der Arbeitslosigkeit selbst. Zu ähnlichen Ergebnisse kommt auch Salm (2009) für die USA. Er findet für durch Betriebsschließungen arbeitslos gewordene Arbeitnehmer keine Auswirkungen auf die physische oder mentale Gesundheit und schließt daraus gegen das Vorliegen kausaler Effekte der Arbeitslosigkeit.

Auf Basis von norwegischen Daten können Black et al. (2012) physische Gesundheit, hier Koronarerkrankungen, herausarbeiten. Korpi (2001) analysiert schwedische Daten und berichtet unter Verwendung kausalanalytischer Verfahren zwar keine Auswirkungen der aktuellen Arbeitslosigkeit auf die Gesundheit, wohl aber negative Auswirkungen der vergangenen Arbeitslosigkeitsdauer. In einer weiteren Analyse, die jedoch keine Kontrolle unbeobachteter Drittvariablen ermöglicht, kann der Autor einen Zusammenhang zwischen schlechter Gesundheit und dem erhöhten Risiko, arbeitslos zu werden, finden. Damit bestätigt er nach eigener Aussage sowohl die Kausations- als auch die Selektionsthese.

Weitere Arbeiten befassen sich mit Gesundheitsverhalten, welches sich letztendlich auf die physische Gesundheit auswirken kann. Marcus (2014) findet signifikante positive Auswirkungen der Arbeitslosigkeit auf den Zigarettenkonsum und den Body-Mass-Index in Deutschland. Dem widersprechen jedoch die Analysen von Schunck und Rogge (2012), die ebenfalls die Auswirkungen der 
Arbeitslosigkeit auf das Rauchverhalten in Deutschland untersuchen, jedoch keinen signifikanten Effekt der Arbeitslosigkeitsdauer finden.

Qualitative Forschungsarbeiten fokussieren vornehmlich auf den Umgang der Betroffenen mit der Situation, arbeitslos zu sein. Basierend auf den Ergebnissen ihrer Analyse von Gruppendiskussionen mit Langzeitarbeitslosen beschreibt Morgenroth (2002, 2003) Erwerbslosigkeit etwa als Trauerprozess aus dem depressive Zirkel resultieren können. Ausgangspunkt der Entstehung dieser Zirkel ist, dass die emotionale Besetzung von Erwerbsarbeit als verlorenem Objekt nicht aufgegeben wird. An die Stelle einer konstruktiven Trauerarbeit im Umgang mit dem Verlust des Arbeitsplatzes treten stattdessen als ,pathologische Entgleisung“ Formen der Verarbeitung, durch die diese emotionale Besetzung aufrechterhalten wird und die sich als Teufelskreise depressiver Reaktionen selbst beständig verstärken (vgl. Morgenroth 2003, S. 23).

In seiner qualitativen Untersuchung von Handlungs- und Deutungspraktiken im Kontext von und bezogen auf Erwerbslosigkeit stellt Rogge (2013) dar, wie Menschen Erwerbslosigkeit auf unterschiedliche Weise erfahren. Basierend auf einer identitätstheoretischen Heuristik beschreibt Rogge Wirkungsweisen von Erwerbslosigkeit als Zusammenspiel kontextueller und individueller Prozesse (ebd., S. 64 ff.). Diese Wirkungsweisen fasst Rogge in fünf biografischen Identitätsmodi zusammen (,Umstellung des Selbst“, „Befreiung des Selbst“, „Kampf um das Selbst“, „Verfall des Selbst“, „Transformation des Selbst“), wobei die psychische Belastung von Erwerbslosigkeit mit dem jeweiligen Modus variieren kann. Vor allem im Rahmen des „Kampf um das Selbst“ kommt es zu einer grundlegenden Erschütterung des Selbstbildes durch Inkongruenzempfinden und Wertlosigkeitsgefühle, während im Modus „Verfall des Selbst“ Arbeitslosigkeit als schädigend erfahren wird und irreversible Wirkungen hervorbringen kann. Entscheidend für den Modus, in dem Menschen Erwerbslosigkeit durchleben, sind neben Lebensformen, sowie der Ausstattung mit ökonomischen Ressourcen und kulturellem Kapital nicht zuletzt Bezugspersonen im sozialen Beziehungsnetzwerk Erwerbsloser. Mit dem Auftrennen ,in Personen, die einerseits Arbeitslosigkeit (unterstelltermaßen) stigmatisieren, und andererseits Personen, die sie (vermeintlich) entstigmatisieren, normalisieren oder alternative und solidarische Deutungen vertreten“ (ebd. S. 272), beschreibt Rogge eine normative Spaltung persönlicher Beziehungsnetzwerke. Aus dieser Spaltung resultiert nicht nur eine selektive Hinwendung zu bzw. Abwendung von Beziehungspartnerinnen und -partnern, sondern Rogge schätzt diese Spaltung als „höchst relevant für die psychische Gesundheit von Arbeitslosen“ (ebd.) ein. 


\section{$3 \quad$ Die Rolle von Netzwerken für den Zusammenhang zwischen Arbeitslosigkeit und Gesundheit}

Der Großteil der Literatur geht davon aus, dass Arbeitslosigkeit die Gesundheit negativ beeinflusst. Netzwerken können in diesem Zusammenhang zwei unterschiedliche Rollen zukommen, die in der Literatur oft nicht deutlich voneinander getrennt werden. Zum einen können Netzwerke einen der kausalen Pfade darstellen, über den sich Arbeitslosigkeit negativ auf die Gesundheit auswirkt. Jahoda (1981) führt etwa eine Reihe von Funktionen von Erwerbsarbeit an, deren Verlust zu gesundheitlichen Einbußen führt. Sie benennt das Einkommen als die manifeste Funktion von Arbeit und eine Reihe von latenten Funktionen: die Strukturierung des Tagesablaufes, die Teilhabe an kollektiven Zielen, Aktivität, Status und Identität und schließlich soziale Kontakte. In diesem Fall würden Netzwerke dazu beitragen die Gesundheitsauswirkungen von Arbeitslosigkeit hervorzubringen. Man spricht auch davon, dass Netzwerke den Zusammenhang von Arbeitslosigkeit und schlechtem Gesundheitszustand vermitteln und damit einen Mediator darstellen (siehe Abb. 1). Werden die Netzwerke geschwächt, so können Sie ihre gesundheitsförderliche Funktion nicht mehr erfüllen und damit kommt es zu einer schlechteren Gesundheit der Arbeitslosen.

Zum andern können Netzwerke auch helfen, die negativen Effekte der Arbeitslosigkeit abzumildern. Diese These der Abschwächung negativer Auswirkungen geht im Gegensatz zur Hervorbringungsthese davon aus, dass die Netzwerke grundsätzlich unverändert bleiben. Sie besagt, dass Arbeitslose mit einem

Mediatorthese

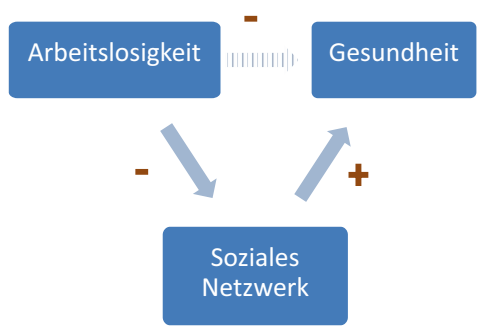

Puffer- bzw. Moderatorthese

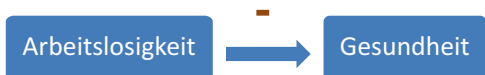

Soziales

Netzwerk

Abb. 1 Arbeitslosigkeit, Netzwerke und Gesundheit - Mediator- und Moderatorthese. (Quelle: eigene Darstellung) 
ressourcenstarken Netzwerk die negativen Auswirkungen wie Einkommens- oder Sinnverlust besser kompensieren können. Das Netzwerk liefert danach soziale, materielle, emotionale oder instrumentelle Unterstützung zur Bewältigung der Arbeitslosigkeit. Die These der Abschwächung wird auch oft als Puffer- oder Moderatorthese (siehe Abb. 1) bezeichnet (siehe auch Kap. „Sozialer Status, soziale Beziehungen und Gesundheit").

In den folgenden beiden Abschnitten wird die Literatur zu den jeweiligen Thesen dargeboten. Dabei wird deutlich, dass sich die empirische Forschung $\mathrm{zu}$ gesundheitlichen Ungleichheiten bisher selten mit dem Test beider Thesen beschäftigt hat, obwohl zumindest die These der Hervorbringung eine der theoretischen Grundlagen der Forschung zu Arbeitslosigkeit und Gesundheit darstellt.

\subsection{Mediatorthese: Netzwerkveränderung als Ursache für Gesundheitseffekte}

Die Mediatorthese geht von einer Kausalkette aus, bei der sich Arbeitslosigkeit im ersten Schritt negativ auf den Bestand und die Zusammensetzung des Netzwerkes auswirkt. Die veränderten Netzwerke wirken sich dann im zweiten Schritt der Kausalkette negativ auf die Gesundheit aus. Zwar nimmt die Mediatorthese eine prominente Stelle in der Erklärung negativer Gesundheitseffekte ein, indem soziale Kontakte als eine der latenten Funktionen der Arbeit beschrieben werden, die durch Arbeitslosigkeit beeinträchtigt werden. Dennoch lassen sich nur sehr wenige Arbeiten finden, welche die These einem direkten empirischen Test unterziehen.

Paul et al. (2009) berichten, dass der negative Effekt der Arbeitslosigkeit auf die mentale Gesundheit vollkommen durch Deprivation hinsichtlich der latenten Funktionen der Beschäftigung zu erklären ist. Die Autoren und Autorinnen liefern jedoch keine Analysen zur Relevanz der Deprivation im Teilbereich der „sozialen Kontakte“. Janlert und Hammarström (2009) untersuchen eine Reihe von theoretischen Konzepten zum Zusammenhang von Arbeitslosigkeit und Gesundheit, darunter auch soziale Unterstützung und Netzwerkumfang. Sie finden für keines der beiden nennenswerte Effekte. Ähnlich sind die Ergebnisse bei Creed und Macintyre (2001), sie finden unter Arbeitslosen keine Korrelation der sozialen Kontakte mit der psychischen Gesundheit, wohl aber signifikante Korrelationen der psychischen Gesundheit mit finanziellen Belastungen (manifeste Funktion) und den latenten Funktionen kollektiver Ziele, Zeitstruktur und Status. In einer 
Studie von Krug und Eberl (2018) wurden Paneldatenanalysen unter Berücksichtigung unbeobachteter Heterogenität und potenziell umgekehrter Kausalrichtungen durchgeführt. Es ergaben sich weder für die Zahl der engen Freunde (starke Kontakte) noch für die Mitgliedschaft in mindestens einem Verein (schwache Kontakte) Hinweise auf Mediationseffekte, ebenso wenig für das Haushaltseinkommen. Stattdessen wurde ein Teil der negativen Gesundheitseffekte über den geringeren subjektiven sozialen Status der Arbeitslosen vermittelt.

Während nur wenige Arbeiten sich mit der in der Mediatorthese angenommenen vollständigen Kausalkette zwischen Arbeitslosigkeit, Netzwerken und Gesundheit befassen, existieren weitaus mehr Arbeiten, welche zumindest einen Teil dieses Prozesses untersuchen. Neben dem Zusammenhang zwischen Netzwerken und Gesundheit ist dies der Einfluss von Arbeitslosigkeit auf soziale Netzwerke. So finden sich in der Literatur eine Reihe von Analysen der Veränderung von Größe und Struktur der Netzwerke von Arbeitslosen. Klärner und Knabe (2016) zeigen beispielsweise, dass der Übergang in die Arbeitslosigkeit mit dem Verlust der Gelegenheitsstruktur des Arbeitsplatzes zur Aufnahme und Pflege sozialer Beziehungen verbunden ist. Diewald (2007) berichtet, dass sich die Zahl der Freunde zwischen Kurzzeit- und Langzeitarbeitslosen unterscheidet. Dabei erleben Kurzzeitarbeitslose einen leichten Anstieg, während bei Langzeitarbeitslosen ein Rückgang der Freundeszahlen erfolgt. Atkinson et al. (1986) analysieren die sozialen Beziehungsnetzwerke von ca. 80 männlichen Arbeitsmarktteilnehmern. Sie berichten von keinem Einfluss der Arbeitslosigkeit auf die Netzwerkgröße, zeigen aber eine - nicht näher beschriebene - Veränderung der Zusammensetzung der Netzwerkmitglieder auf. Russel (1999) zeigt, dass die Netzwerke von Arbeitslosen zu einem hohen Anteil ebenso aus Arbeitslosen bestehen. Dies wirkt sich negativ auf die Verfügbarkeit sozialer Unterstützung und Hilfe bei der Stellenfindung aus. Lindsay (2009) kann auf Basis einer standardisierten Befragung unter Arbeitslosen in Glasgow nachweisen, dass Langzeitarbeitslose bei der Stellensuchende seltener auf ehemalige Arbeitskollegen zurückgreifen als andere Arbeitslose, aber ebenso häufig über den nahen Familien- und Freundeskreis suchen. In einer Analyse männlicher Arbeitsloser zeigt sich laut Jackson (1988) im Verlauf der Arbeitslosigkeit, dass sich das nicht-familiäre Netzwerk verkleinert, wodurch der Anteil familiärer Bindungen im Netzwerk steigt. In einer auf nur 60 Lehrern beruhenden, aber im Hinblick auf Netzwerke umfassenden Analyse berichten Röhrle und Hellmann (1989) von nur geringen Unterschieden hinsichtlich der Größe des Netzwerkes bei Lehrern mit zum Befragungszeitpunkt kürzerer, längerer oder keiner Arbeitslosigkeit. 
Ein weiterer Strang der Literatur untersucht die Auswirkungen von Arbeitslosigkeit auf das Ausmaß der sozialen Unterstützung und auf Kontakthäufigkeit mit Netzwerkmitgliedern. Laut Atkinson et al. (1986) sinkt durch Arbeitslosigkeit sowohl die familiäre Unterstützung als auch die Kontakthäufigkeit zu Bekannten und Freunden. Dabei zeigt eine getrennte Analyse nach Berufsstatus (Arbeiter vs. Angestellte), dass die Kontakthäufigkeit nur bei den Arbeitern nachlässt. Die Tatsache, dass Arbeiter stärker als Angestellte von finanziellen Einschränkungen durch Arbeitslosigkeit betroffen sind, kann laut den Autoren diesen Befund nicht vollständig erklären. Auch Gallie et al. (2001) belegen mit Daten aus mehreren Ländern, dass sich Arbeitslose insgesamt häufig mit Freunden und Bekannten treffen, dabei aber mit geringerer Wahrscheinlichkeit spezielle Unterstützungsleistungen erhalten, als Erwerbstätige. Röhrle und Hellmann (1989) berichten in ihrer bereits erwähnten Analyse bei Lehrern weder von Effekten der Arbeitslosigkeit auf die Häufigkeit noch auf die Intensität des Kontaktes. Dagegen waren arbeitslose Lehrer mit ihrem Netzwerk zufriedener und erhielten mehr soziale Unterstützung als ihre erwerbstätigen Kollegen.

Auch qualitative Analysen zeichnen das Auflösen oder das Wegfallen von Beziehungen zu Kolleginnen und Kollegen bzw. Freundinnen und Freunden aus der Arbeitswelt und die Reduktion auf den homogenen des Netzwerkes aus den engsten (meist familiären) Alteri nach (Cattell 2001; Stead et al. 2001). Als Ursache für die Verkleinerung und Homogenisierung von Netzwerken in Folge von Arbeitslosigkeit wird die gesellschaftliche Stigmatisierung und Abwertung von Arbeitslosen genannt (vgl. Knabe et al. 2017; Hirseland und Lobato 2014; Stead et al. 2001).

Die bezeichneten Prozesse der Verkleinerung und Homogenisierung von Netzwerken können sich negativ auf die Gesundheit auswirken. So beschreibt etwa Cattell (2001) die gesundheitlichen Folgen dieser Strukturveränderungen im Netzwerk auf Basis von 100 qualitativen Interviews mit von Arbeitslosigkeit und Armut betroffenen Bewohnerinnen und Bewohnern Londons: Unter den Befragten befinden sich viele Personen mit psychischen Erkrankungen und sehr geringem Selbstbewusstsein, darunter viele Frauen, die sich in materieller Abhängigkeit zu ihren Partnern befinden. Verkleinerung und Homogenisierung der Netzwerke infolge von Arbeitslosigkeit befördern den Mangel an sozialer Unterstützung, soziale Abhängigkeit und sozialen Druck. Gesundheitliche Probleme werden in Anbetracht dieser Dynamiken eher verschärft als abgemildert. Insbesondere die fehlende Einbindung in Erwerbsarbeit führt zu einem negativen Wohlbefinden aufgrund fehlender moralischer Unterstützung und fehlender sozialer Gelegenheiten zum Aufbau von Selbstvertrauen. 
Allerdings sind Netzwerke nicht nur Ursache von Problemen, sie können auch unterstützend bei der Bewältigung der negativen und gesundheitlich belastenden psychischen Folgen von Arbeitslosigkeit wirken. Den negativen Folgen der Arbeitslosigkeit auf ihre sozialen Netzwerke können von den Akteuren selbst Handlungsstrategien entgegengebracht werden, die auf eine Erweiterung von Handlungsspielräumen durch die Verlagerung der sozialen Aktivitäten auf soziale Kreise jenseits des Arbeitsmarktes zielen, z. B. in Nachbarschaften oder politischen Gruppen (vgl. Marquardsen 2012). Die Verfügbarkeit von Gelegenheitsstrukturen für derartige Handlungsstrategien jenseits des Arbeitsmarktes sowie die soziale und institutionelle Anerkennung alternativer sozialer Rollen zu der des Erwerbstätigen, erhöht die individuellen Handlungsmöglichkeiten zur Aneignung bzw. Verteidigung einer anerkennungswürdigen Identität, indem die eigene Persönlichkeit so inszeniert wird, dass die Arbeitslosigkeit in den Hintergrund rückt und stattdessen positiv besetzte soziale Rollen im Netzwerk betont werden (Knabe et al. 2017).

\subsection{Moderatorthese: Netzwerke als Schutz vor negativen Gesundheitseffekten der Arbeitslosigkeit}

Die These der Pufferfunktion beruht auf der Annahme, dass durch Netzwerke vermittelte soziale Unterstützung die negativen materiellen und emotionalen Folgen kritischer Lebensereignisse wie Arbeitslosigkeit reduziert und somit die Widerstandsfähigkeit zur Bewältigung der Arbeitslosigkeit stärkt (Cassel 1976; Cobb 1976; zusammengefasst z. B. bei Sattler und Diewald 2010).

So hat die Homogenisierung sozialer Beziehungen nicht nur negative Auswirkungen auf die Gesundheit. Netzwerke aus überwiegend arbeitslosen Personen können einen Schutzraum vor Stigmatisierung bieten und eine wichtige Quelle emotionaler Unterstützung sein. Stead et al. (2001) weisen in diesem Zusammenhang auf Ambivalenzen gesundheitsförderlicher und gesundheitsschädigender Mechanismen in sozialen Netzwerken hin. Sie analysieren die soziale Einbindung in benachteiligte Communities in Glasgow anhand von acht Gruppendiskussionen mit insgesamt 53 Teilnehmenden. Die Netzwerke der Befragten werden als relativ homogen in Bezug auf den sozialen Status, ressourcenarm und teilweise mit starken gruppeninternen Normen gesundheitsschädlichen Verhaltens (,pro-smoking community norms") bei gleichzeitiger Abgrenzung von übergeordneten gesellschaftlichen Werten (,,isolation from wider 
social norms") charakterisiert. Arbeitslosigkeit bildet in den Netzwerken der Teilnehmenden eher die Regel als die Ausnahme. Zwar bieten die so erforschten Beziehungsstrukturen Identifikationsmöglichkeiten und praktische Hilfe und haben somit eine Pufferfunktion für negative (psychische) Folgen von Langzeitarbeitslosigkeit, gleichzeitig wurden die Befragten in ihren Netzwerken jedoch eher zum Rauchen ermuntert, als beim Aufhören unterstützt.

Mit Blick auf verfügbare Quellen sozialer Unterstützung zeigt sich, dass soziale Netzwerke eine der ersten und wichtigsten Anlaufstellen bieten, um negative Folgen der Arbeitslosigkeit abzumildern, meist durch praktische Hilfen in Notfällen (z. B. Übernahme von ärztlichen Behandlungskosten durch Angehörige) sowie emotionalen Rückhalt (Edin und Lein 1997; Hill und Kauf 2001).

Heflin et al. (2011) untersuchen die Bewältigung von Notlagen in Familien mit geringem Einkommen auf Basis von qualitativen Interviews mit 50 Frauen aus den USA und stellen fest, dass Kosten für medizinische Notfälle in Ermangelung von staatlichen Hilfen und bereits ausgeschöpften individuellen Strategien (andere, weniger wichtige Rechnungen nicht zahlen, Schulden anhäufen etc.) insbesondere durch den Rückgriff auf soziale Netzwerke bewältigt werden. So können die Notlagen manchmal durch die finanziellen Ressourcen aus dem Netzwerk abgemildert werden. Die Hilfe bleibt jedoch unsicher und häufig auch uneffektiv und wenig nachhaltig. Noch weniger sind Netzwerke geeignet, kontinuierliche Bedarfe abzudecken. Die Folge sind Gesundheitsrisiken durch Verzicht auf Medikamente und Behandlungen wie z. B. Schmerzmittel, Kontrazeptiva und Asthmamittel oder Behandlungen beim Haus- oder Zahnarzt. Hill und Kauf (2001) beschreiben sehr detaillierte Mechanismen der Inanspruchnahme sozialer Unterstützung auf Basis einer Analyse von 16 unstrukturierten qualitativen Einzelinterviews mit erwerbstätigen und erwerbslosen Müttern, die in Haushalten mit sehr geringem Einkommen (unter 500 \$) in städtischen und ländlichen Regionen von Iowa (USA) leben. Viele der befragten Frauen leihen sich nur sehr ungern Geld. Wesentlich beliebter sind hingegen informelle Arbeitsgelegenheiten wie z. B. Babysitting für Verwandte, Freunde und Nachbarn. Soziale Unterstützung erscheint in der Analyse als wichtige Ressource im Netzwerk. Insbesondere aus dem Kreis der Familie werden von fast allen interviewten Müttern kleinere Geldgeschenke, Kleidung und Spielsachen für die Kinder oder Lebensmittel bezogen. Soziale Unterstützung von Nachbarinnen und Nachbarn sowie Freundinnen und Freunden erscheint seltener materiell als alltagspraktisch, z. B. in Form von Kinderbetreuung, Transport und Weitergabe von Kinderbekleidung. Soziale Unterstützung aus dem alläglichen Beziehungsnetzwerk wird häufiger in Anspruch genommen als institutionelle Angebote. Dennoch ist diese Form der Unterstützung häufig nur in geringem Maße verfügbar, da die Netzwerkpartner 
oft ebenfalls nur über beschränkte Ressourcen verfügen. Darüber hinaus reduziert sich das Ausmaß der aus dem Netzwerk empfangenen Unterstützung dadurch, dass sie oft nicht abgerufen wird, um sich ein Gefühl der Selbstwirksamkeit zu bewahren und nicht zu abhängig von dieser eher unzuverlässigen Form der Unterstützung zu werden. Premji und Shakya (2017) zeigen auf Basis von 30 Interviews mit Migrantinnen, dass soziale Isolation einen zentralen Mechanismus gesundheitlicher Beeinträchtigung durch Arbeitslosigkeit darstellt, neben intensivierten Suchbemühungen und verstärkten Haushalts- und Erziehungsaufgaben. Zusätzlich verweisen sie darauf, dass Arbeitslose mit höherer Wahrscheinlichkeit auf Stellen mit geringer Beschäftigungsqualität wieder in den Arbeitsmarkt zurückfinden.

Wie bereits im Fall der Mediatoreffekte sozialer Netzwerke existieren auch nur wenige quantitative Studien, die sich explizit den Moderatoreffekten sozialer Netzwerke im Fall der Arbeitslosigkeit widmen.

Atkinson et al. (1986) berichten, dass der negative Einfluss von Arbeitslosigkeit auf die psychische Gesundheit durch familiäre Unterstützung abgemildert wird. Für Netzwerkgröße und Kontakthäufigkeit liefern sie keine entsprechenden Analysen. Sie betonen aber die höhere Relevanz der Analyse außerfamiliärer Netzwerke, da im Bereich der Kernfamilie die gleichzeitige Betroffenheit von Arbeitslosigkeit die Frage nach der Unterstuitzungsfunktion hinfällig macht. Gore (1978) untersucht bei 100 Männern aus zwei Firmenschließungen, wie deren Gesundheitsentwicklung mit sozialer Unterstützung zusammenhängt. Diejenigen, die laut eigener Angaben auf soziale Unterstützung zurückgreifen konnten, wiesen mit geringerer Wahrscheinlichkeit Symptome physischer Krankheiten auf als andere Arbeitslose. Axelsson und Ejlertsson (2002) vergleichen in einer Querschnittsstudie die mentale Gesundheit bei arbeitslosen und erwerbstätigen jungen Erwachsenen. Dabei hängt Arbeitslosigkeit negativ mit der Gesundheit zusammen, wobei dieser Zusammenhang durch soziale Unterstützung abgeschwächt wird. Schwarzer et al. (1994) untersuchen mehr als 200 Übersiedler von Ost- nach Westdeutschland. Sie zeigen, dass diejenigen, die auf soziale Unterstützung zurückgreifen konnten, weniger körperliche Beschwerden aufwiesen. Dabei verweisen sie aber auch auf die negative Auswirkung von Krankheit auf die Verfügbarkeit sozialer Unterstützung. Die Studie von Milner et al. (2016) ist die einzige uns bekannte, die auf Basis einer Bevölkerungsstichprobe und mithilfe kausalanalytischer Methoden den Moderatoreffekt untersucht. Im Fokus steht die Auswirkung sozialer Unterstützung auf die mentale Gesundheit. Die Autoren verwenden die Panelstudie Household, Income and Labour Dynamics in Australia (HILDA) und bestätigen in Fixed-Effects-Analysen den Moderatoreffekt. Soziale Unterstützung wird anhand eines aus zehn 
Items bestehenden Mittelwertes gemessen, der dann allerdings zur weiteren Analyse - aus nicht näher bezeichneten Gründen - in eine polytome Variable mit den Ausprägungen niedrige, mittlere und hohe soziale Unterstützung vergröbert wird. Es zeigt sich, dass der negative Effekt der Arbeitslosigkeit auf die mentale Gesundheit durch hohe soziale Unterstützung abgeschwächt wird, jedoch nicht ganz vermieden werden kann.

\section{$4 \quad$ Zusammenfassung und Bewertung des Forschungsstandes}

Für die Betroffenen kann Arbeitslosigkeit mit einer Verschlechterung der physischen, vor allem aber auch der psychischen Gesundheit einhergehen. Dabei wird debattiert, inwiefern Arbeitslosigkeit hierbei auch ursächlich für einen schlechten Gesundheitszustand verantwortlich ist. Zur Beantwortung dieser Frage sind zum einen Forschungsdesigns nötig, die für Kausalanalysen besonders gut geeignet sind. Hier lässt sich in den quantitativen Analysen der letzten Jahre ein deutlicher Fortschritt beobachten, etwa die häufigere Verwendung von Längsschnittdaten und die Anwendung statistischer Verfahren zur Kontrolle unbeobachtbarer Drittvariablen. Zum anderen braucht es allerdings auch Analysen der kausalen Mechanismen, durch die Arbeitslosigkeit gesundheitliche Beeinträchtigungen hervorbringt. Einer dieser hypothetischen Mechanismen basiert auf der Vorstellung, dass soziale Netzwerke eine hohe Relevanz für gesundheitliche Ungleichheiten haben. In dem Maße, wie sich dieser Mechanismus nicht nur theoretisch explizieren, sondern auch empirisch bestätigen lässt, dient die Forschung hierzu auch als Beitrag zur übergeordneten Diskussion um den kausalen Einfluss der Arbeitslosigkeit im Unterschied zu Selektionseffekten.

Daher erstaunt zunächst die vergleichsweise geringe Zahl empirischer Forschungsarbeiten, die sich mit der Rolle sozialer Netzwerke für den Zusammenhang zwischen Arbeitslosigkeit und Gesundheit befassen. Es verwundert umso mehr, als die Literatur zur Begründung erwarteter negativer Zusammenhänge fast routineartig Jahodas (1981) Konzept des Verlusts latenter Funktionen der Arbeit rekurriert, zu denen auch die soziale Integration gehört. Der theoretisch behauptete hohe Stellenwert sozialer Netzwerke spiegelt sich aber weder in einer entsprechenden Zahl von Forschungsarbeiten, die sich mit diesem Mediatoreffekt, noch von Forschungsarbeiten, die sich mit dem angrenzendem Thema der Moderatoreffekte von Netzwerken beschäftigen, wider.

Die Forschung zu Moderator- und Mediatoreffekten sozialer Netzwerke bleibt allerdings nicht nur mengenmäßig hinter der Forschung zu Netzwerken und 
Gesundheit einerseits und Arbeitslosigkeit und Gesundheit andererseits zurück. Im Gegensatz zur Forschung zu Arbeitslosigkeit und Gesundheit spielen explizit kausalanalytische Forschungsdesigns kaum eine Rolle. So basieren viele Analysen auf sehr kleinen und vermutlich sozial selektiven Stichproben, es wird keine erwerbstätige Vergleichsgruppe herangezogen und es werden keine Paneldaten und damit verbundene statistische Verfahren der Kausalanalyse verwendet. Sicherlich kann dies vor allem älteren Arbeiten keinesfalls zum Vorwurf gemacht werden, doch fehlt es mit Ausnahme von Milner et al. (2016) und Krug und Eberl (2018) an neuern Arbeiten, welche die aktuellen Möglichkeiten der statistischen Datenanalyse für das Thema nutzbar machen.

Im Gegensatz zur Forschung zu sozialen Netzwerken und Gesundheit fällt zudem auf, dass kaum solche MessInstrumente eingesetzt werden, die zu einer adäquaten Erfassung von Netzwerken und ihren Strukturen geeignet wären. Der Grund hierfür liegt wohl größtenteils darin, dass vor allem die Literatur zu Moderatoreffekten weniger über die tatsächlichen Netzwerke, ihre Strukturen und die darüber vermittelten Ressourcen argumentiert. Vielmehr wird auf das Konzept der „sozialen Unterstützung“, oft sogar auf die lediglich „,wahrgenommene soziale Unterstützung" Bezug genommen wird. Hinzu kommt, dass der Aufwand für die Erhebung von egozentrierten Netzwerken sehr hoch ist und daher in Umfragen kaum Anwendung findet. Hier müsste ein spezielles Netzwerkerhebungsverfahren konstruiert und getestet werden - welches auf Gesundheitsaspekte zugeschnitten ist. Hier besteht große Handlungsrelevanz national wie auch international.

Erste qualitative Studien zeigen mögliche Mechanismen der Einflussnahme sozialer Beziehungsnetzwerke auf den Zusammenhang zwischen Arbeitslosigkeit und Gesundheit auf. Eine systematische Kategorisierung von Netzwerkeinflüssen auf den Zusammenhang zwischen Arbeitslosigkeit und Gesundheit fehlt bislang. Die hier vorgeschlagene Einteilung in Mediator- und Moderatoreffekte bleibt angesichts der wenigen empirischen Studien in der Literatur noch sehr fragmentarisch und thesenartig.

\section{Leseempfehlungen}

Cattell, V. (2001). Poor people, poor places, and poor health: the mediating role of social networks and social capital. Social Science and Medicine, 52 (10), S. 1501-1516. Vielzitierter Aufsatz, in dem auf Grundlage qualitativer Untersuchungen die Dynamiken von Armut und Exklusion, des Wohnumfeldes sowie von Gesundheit und Wohlbefinden unter Berücksichtigung der Rolle sozialer Netzwerk und sozialen Kapitals erörtert werden. 
Jahoda, M. (1981). Work, employment, and unemployment. Values, theories, and approaches in social research. American Psychologist, 36(2), S. 184-191. Der Aufsatz bietet eine grundlegende Übersicht zu sozialpsychologischen Theorien zu (Erwerbs-)Arbeit und Arbeitslosigkeit und betont insbesondere die latenten Funktionen der Erwerbsarbeit.

Krug, Gerhard; Eberl, Andreas (2018): What explains the negative effect of unemployment on health? An analysis accounting for reverse causality. Research in Social Stratification and Mobility, 55, S. 25-39. Eine der wenigen Arbeiten zum Mediatoreffekt, deren Analyse sich auf Paneldatenregressionen stützt. Netzwerke werden allerdings nur als einer von mehreren Mediatoren betrachtet. Als Netzwerkeigenschaften wird zudem lediglich der Umfang starker und schwacher Kontakte betrachtet.

Milner, A., Krnjacki, L., Butterworth, P., \& LaMontagne, A. D. (2016). The role of social support in protecting mental health when employed and unemployed: A longitudinal fixed-effects analysis using 12 annual waves of the HILDA cohort. Social Science and Medicine, 153, S. 20-26. Eine der wenigen Arbeiten zum Moderatoreffekt unter Verwendung von Paneldatenregressionen, der Fokus liegt aber auf sozialer Unterstützung und nicht auf netzwerktheoretischen Überlegungen.

\section{Datensätze}

- Panel Arbeitsmarkt und soziale Sicherung (PASS): jährliche Längsschnittbefragung des Instituts für Arbeitsmarkt- und Berufsforschung (IAB), seit 2007, mit Fokus auf die soziale und ökonomische Situation Arbeitsloser und Erwerbstätiger; regelmäßig Befragungsschwerpunkte zu sozialen Netzwerken sowie Gesundheit. Weitere Informationen: http://www.iab.de/de/befragungen/iab-haushaltspanel-pass.aspx

- Sozio-oekonomisches Panel (SOEP): jährliche Längsschnittbefragung des Deutschen Instituts für Wirtschaftsforschung (DIW), seit 1984 für Westdeutschland und 1990 für Ostdeutschland, mit Fokus auf die soziale und ökonomische Situation Arbeitsloser und Erwerbstätiger, regelmäßig Befragungsschwerpunkte zu sozialen Netzwerken sowie Gesundheit. Weitere Informationen: http://www.diw.de/de/soep

- Panel Armutsdynamik und Arbeitsmarkt: bundesweite qualitative Langezeituntersuchung zu Veränderungen der Lebenswege und Lebensumstände von Bezieher*innen der Grundsicherung für Arbeitssuchende 
im Zusammenhang mit Aktivierungsstrategien. Narrative Interviews u. a. zu den Einflüssen des Hilfesystems auf Lebenszusammenhänge in Mehrpersonen-Bedarfsgemeinschaften und auf Überwindung oder Verfestigung von Integrationsproblemen von Leistungsbeziehern mit Migrationshintergrund. Weitere Informationen: http://www.iab.de/138/ section.aspx/Projektdetails/k140110309

\section{Literatur}

Atkinson, T. H., Liem, J. H., \& Liem, R. (1986). The social costs of unemployment: Implications for social support. Journal of Health and Social Behavior, 27, 317-331.

Axelsson, L., \& Ejlertsson, G. (2002). Self-reported health, self-esteem and social support among young unemployed people. A population-based study. International Journal of Social Welfare, 11(2), 111-119.

Black, S. E., Devereux, P. J., \& Salvanes, K. G. (2012). Losing heart? The effect of job displacement on health. ILR Review, 68(4), 833-861.

Böckerman, P., \& Ilmakunnas, P. (2009). Unemployment and self-assessed health: Evidence from panel data. Health Economics, 18(2), 161-179.

Brand, J. E. (2015). The far-reaching impact of job loss and unemployment. Annual Review of Sociology, 41, 359-375.

Cassel, J. (1976). The contribution of the social environment to host resistance: The Fourth Wade Hampton Frost Lecture. American Journal of Epidemiology, 104(2), 107-123.

Cattell, V. (2001). Poor people, poor places, and poor health: The mediating role of social networks and social capital. Social Science and Medicine, 52(10), 1501-1516.

Cobb, S. (1976). Social support as a moderator of life stress. Psychosomatic Medicine, 38(5), 300-314.

Creed, P. A., \& Macintyre, S. R. (2001). The relative effects of deprivation of the latent and manifest benefits of employment on the well-being of unemployed people. Journal of Occupational Health Psychology, 6(4), 324-331.

Cygan-Rehm, K., Kuehnle, D., \& Oberfichtner, M. (2017). Bounding the causal effect of unemployment on mental health: Nonparametric evidence from four countries. Health Economics, 26(12), 1844-1861.

Diewald, M. (2007). Arbeitsmarktungleichheiten und die Verfügbarkeit von Sozialkapital. Die Rolle von Gratifikationen und Belastungen. Kölner Zeitschrift für Soziologie und Sozialpsychologie, 47, 183-210.

Edin, K., \& Lein, L. (1997). Making Ends Meet. How Single Mothers Survive Welfare and Low-Wage Work. New York: Russell Sage.

Eggs, J., Trappmann, M., \& Unger, S. (2014). Grundsicherungsempfänger und Erwerbstätige im Vergleich. ALG-II-Bezieher schätzen ihre Gesundheit schlechter ein. IAB-Kurzbericht, 23.

Freyer-Adam, J., Gaertner, B., Tobschall, S., \& John, U. (2011). Health risk factors and self-rated health among job-seekers. BMC Public Health, 11, 659. 
Gallie, D., Kostova, D., \& Kuchar, P. (2001). Social consequences of unemployment. An east-west Comparison. Journal of European Social Policy, 11(1), 39-54.

Gebel, M., \& Voßemer, J. (2014). The impact of employment transitions on health in Germany. A difference-in-differences propensity score matching approach. Social Science and Medicine, 108, 128-136.

Gore, S. (1978). The effect of social support in moderating the health consequences of unemployment. Journal of Health and Social Behavior, 19(2), 157-165.

Heflin, C., London, A. S., \& Scott, E. K. (2011). Mitigating material hardship. The strategies low-income families employ to reduce the consequences of poverty. Sociological Inquiry, 81(2), 223-246.

Henkel, D. (2011). Unemployment and substance use: A review of the literature (19902010). Current Drug Abuse Reviews, 4(1), 4-27.

Herbig, B., Dragano, N., \& Angerer, P. (2013). Health in the long-term unemployed. Deutsches Ärzteblatt International, 110(23-24), 413-419.

Hill, H., \& Kauff J. (2001). Living on little. Case studies of Iowa families with very low incomes. Mathematica Policy Research. https://www.mathematica-mpr.com/our-publications-and-findings/publications/living-on-little-case-studies-of-iowa-families-withvery-low-incomes. Zugegriffen: 18. Febr. 2019.

Hirseland, A., \& Ramos Lobato, P. (2014). "Die wollen ja ein bestimmtes Bild vermitteln". Zur Neupositionierung von Hilfeempfängern im aktivierenden Sozialstaat. SWS-Rundschau, 54(2), 181-200.

Huang, J., Kim, Y., \& Birkenmaier, J. (2016). Unemployment and household food hardship in the economic recession. Public Health Nutrition, 19(3), 511-519.

Jackson, P. R. (1988). Personal networks, support mobilization and unemployment. Psychological Medicine, 18(2), 397-404.

Jahoda, M. (1981). Work, employment, and unemployment. Values, theories, and approaches in social research. American Psychologist, 36(2), 184-191.

Khlat, M., Sermet, C., \& Le Pape, A. (2004). Increased prevalence of depression, smoking, heavy drinking and use of psycho-active drugs among unemployed men in France. European Journal of Epidemiology, 19(5), 445-451.

Klärner, A., \& Knabe, A. (2016). Soziale Netzwerke als Ressource für den Umgang mit Langzeitarbeitslosigkeit. WSI-Mitteilungen, 5, 354-363.

Knabe, A., Fischer, H., \& Klärner, A. (2017). Armut als relationales Konstrukt: Die (Re-) Produktion sozialer Ungleichheiten durch Stigmatisierung und Kontrollversuche in sozialen Netzwerken. In L. Behrmann, F. Eckert, A. Gefken, \& P. A. Berger (Hrsg.), ,Doing Inequality“ - Prozesse sozialer Ungleichheit im Blick qualitativer Sozialforschung (S. 167-190). Wiesbaden: Springer VS.

Knieps, F., \& Pfaff, H. (Hrsg.). (2016). Gesundheit und Arbeit. Zahlen, Daten, Fakten; mit Gastbeiträgen aus Wissenschaft, Politik und Praxis. Berlin: Medizinisch Wissenschaftliche Verlagsgesellschaft.

Korpi, T. (2001). Accumulating disadvantage. Longitudinal analyses of unemployment and physical health in representative samples of the Swedish population. European Sociological Review, 17(3), 255-273.

Kroll, L. E., Müters, S., \& Lampert, T. (2016). Arbeitslosigkeit und ihre Auswirkungen auf die Gesundheit. Ein Überblick zum Forschungsstand und zu aktuellen Daten der Studien GEDA 2010 und GEDA 2012. Bundesgesundheitsblatt, Gesundheitsforschung, Gesundheitsschutz, 59(2), 228-237. 
Krug, G., \& Eberl, A. (2018). What explains the negative effect of unemployment on health? An analysis accounting for reverse causality. Research in Social Stratification and Mobility, 55, 25-39.

Lindsay, C. (2009). In a lonely place? Social networks, job seeking and the experience of long-term unemployment. Social Policy \& Society, 9(1), 25.

Ludwig-Mayerhofer, W. (2018). Arbeitslosigkeit. In M. Abraham \& T. Hinz (Hrsg.), Arbeitsmarktsoziologie (3. Aufl., S. 155-192). Wiesbaden: VS.

Mandemakers, J. J., \& Monden, C. W. S. (2013). Does the effect of job loss on psychological distress differ by educational level? Work, Employment \& Society, 27(1), 73-93.

Marcus, J. (2014). Does job loss make you smoke and gain weight? Economica, 81(324), $626-648$.

Marquardsen, K. (2012). Aktivierung und soziale Netzwerke. Die Dynamik sozialer Beziehungen unter dem Druck der Erwerbslosigkeit. Wiesbaden: VS.

McKee-Ryan, F., Song, Z., Wanberg, C. R., \& Kinicki, A. J. (2005). Psychological and physical well-being during unemployment: A meta-analytic study. The Journal of Applied Psychology, 90(1), 53-76.

Milner, A., Krnjacki, L., Butterworth, P., \& LaMontagne, A. D. (2016). The role of social support in protecting mental health when employed and unemployed: A longitudinal fixed-effects analysis using 12 annual waves of the HILDA cohort. Social Science and Medicine, 153, 20-26.

Minelli, L., Pigini, C., Chiavarini, M., \& Bartolucci, F. (2014). Employment status and perceived health condition: Longitudinal data from Italy. BMC Public Health, 14, 946.

Morgenroth, C. (2003). Arbeitsidentität und Arbeitslosigkeit - Ein depressiver Zirkel. Aus Politik und Zeitgeschichte, 6-7, 17-24.

Morgenroth, C. (2002). Depressive Dynamik in der Arbeitslosigkeit. In T. Darmstädter (Hrsg.), Transformation der Arbeit (S. 135-152). Frankfurt a. M.: Neue Kritik.

Norström, F., Virtanen, P., Hammarström, A., Gustafsson, P. E., \& Janlert, U. (2014). How does unemployment affect self-assessed health? A systematic review focusing on subgroup effects. BMC Public Health, 14, 1310.

Paul, K. I., \& Moser, K. (2009). Unemployment impairs mental health. Meta-analyses. Journal of Vocational Behavior, 74(3), 264-282.

Paul, K. I., Geithner, E., \& Moser, K. (2009). Latent deprivation among people who are employed, unemployed, or out of the labor force. The Journal of Psychology, 143(5), 477-491.

Pearlin, L. I. (1989). The sociological study of stress. Journal of Health and Social Behavior, 30(3), 241-256.

Pearlman, J. (2015). The consequences of job displacement for health: Moderating influences of economic conditions and educational attainment. Social Science Research, 52, 570-587.

Pfeiffer, S., Oestreicher, E., \& Ritter, T. (2016). Hidden and neglected: Food poverty in the Global North: The case of Germany. World Review of Nutrition and Dietetics, 115, 16-23.

Premji, S., \& Shakya, Y. (2017). Pathways between under/unemployment and health among racialized immigrant women in Toronto. Ethnicity \& Health, 22(1), 17-35.

Röhrle, B., \& Hellmann, I. (1989). Characteristics of social networks and social support among long-term and short-term unemployed teachers. Journal of Social and Personal Relationships, 6, 463-473.

Roelfs, D. J., Shor, E., Davidson, K. W., \& Schwartz, J. E. (2011). Losing life and livelihood: A systematic review and meta-analysis of unemployment and all-cause mortality. Social Science and Medicine, 72(6), 840-854. 
Rogge, B. (2013). Wie uns Arbeitslosigkeit unter die Haut geht. Identitätsprozess und psychische Gesundheit bei Statuswechseln. Konstanz: UVK.

Russell, H. (1999). Friends in low places. Gender, unemployment and sociability. Work, Employment and Society, 13(2), 205-224.

Salm, M. (2009). Does job loss cause ill health? Health Economics, 18(9), 1075-1089.

Sattler, S., \& Diewald, M. (2010). Wechselwirkungen zwischen Arbeitslosigkeit und dem sozialen Netzwerk. In C. Stegbauer \& R. Häußling (Hrsg.), Handbuch Netzwerkforschung (S. 701-713). Wiesbaden: VS.

Schmitz, H. (2011). Why are the unemployed in worse health? The causal effect of unemployment on health. Labour Economics, 18(1), 71-78.

Schunck, R., \& Rogge, B. G. (2012). No causal effect of unemployment on smoking? A German panel study. International Journal of Public Health, 57(6), 867-874.

Schwarzer, R., Jerusalem, M., \& Hahn, A. (1994). Unemployment, social support and health complaints. A longitudinal study of stress in East German refugees. Journal of Community \& Applied Social Psychology, 4(1), 31-45.

Stead, M., MacAskill, S., MacKintosh, A. M., Reece, J., \& Eadie, D. (2001). 'It's as if you're locked in": qualitative explanations for area effects on smoking in disadvantaged communities. Health \& Place, 7(4), 333-343.

Tøge, A. G., \& Blekesaune, M. (2015). Unemployment transitions and self-rated health in Europe: A longitudinal analysis of EU-SILC from 2008 to 2011. Social Science \& Medicine, 143, 171-178

Wanberg, C. R. (2012). The individual experience of unemployment. Annual Review of Psychology, 63, 369-396.

Warr, P. (1987). Work, unemployment, and mental health. New York: Oxford University Press. Young, C. (2012). Losing a job. The nonpecuniary cost of unemployment in the United States. Social Forces, 91(2), 609-634.

Open Access Dieses Kapitel wird unter der Creative Commons Namensnennung 4.0 International Lizenz (http://creativecommons.org/licenses/by/4.0/deed.de) veröffentlicht, welche die Nutzung, Vervielfältigung, Bearbeitung, Verbreitung und Wiedergabe in jeglichem Medium und Format erlaubt, sofern Sie den/die ursprünglichen Autor(en) und die Quelle ordnungsgemäß nennen, einen Link zur Creative Commons Lizenz beifügen und angeben, ob Änderungen vorgenommen wurden.

Die in diesem Kapitel enthaltenen Bilder und sonstiges Drittmaterial unterliegen ebenfalls der genannten Creative Commons Lizenz, sofern sich aus der Abbildungslegende nichts anderes ergibt. Sofern das betreffende Material nicht unter der genannten Creative Commons Lizenz steht und die betreffende Handlung nicht nach gesetzlichen Vorschriften erlaubt ist, ist für die oben aufgeführten Weiterverwendungen des Materials die Einwilligung des jeweiligen Rechteinhabers einzuholen.

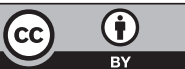




\title{
Soziale Netzwerke und die Gesundheit von Alleinerziehenden
}

\author{
Sylvia Keim-Klärner
}

\section{Überblick}

- Alleinerziehende verfügen über eine schlechtere psychische und physische Gesundheit als verheiratete Eltern.

- Die Relevanz sozialer Beziehungen und sozialer Unterstützung für das Wohlbefinden und die Gesundheit Alleinerziehender wurde vielfach belegt.

- Auch die Relevanz sozialer Netzwerke und ihrer Charakteristika konnte in einigen wenigen Studien aufgezeigt werden. Insgesamt sind spezifisch netzwerkanalytische Studien zur Gesundheit Alleinerziehender selten.

- Netzwerkstudien zur Gesundheit Alleinerziehender sind aber besonders relevant, weil

- wir wenig über den Zusammenhang zwischen spezifischen Netzwerkstrukturen und der Gesundheit Alleinerziehender wissen,

- sie über das Konzept der sozialen Unterstützung hinausgehen und auch andere Wirkmechanismen einbeziehen,

- sie auch negative und ambivalente Beziehungsinhalte einbeziehen und damit der Komplexität sozialer Beziehungsgeflechte in besonderem

S. Keim-Klärner $(\bowtie)$

Braunschweig, Deutschland

E-Mail: sylvia.keim-klaerner@thuenen.de

(C) Der/Die Herausgeber und der/die Autor(en) 2020

A. Klärner et al. (Hrsg.), Soziale Netzwerke und gesundheitliche Ungleichheiten, https://doi.org/10.1007/978-3-658-21659-7_14 
Maße gerecht werden und dazu beitragen, das Zusammenspiel von unterstützenden und konfliktbehafteten Beziehungen näher zu untersuchen,

- wir noch wenig darüber wissen, unter welchen Umständen und inwieweit welche Arten von sozialen Netzwerken in der Lage sind, soziale Ungleichheiten zu kompensieren, sodass diese nicht gesundheitsrelevant werden.

\section{$1 \quad$ Einleitung}

Einelternfamilien, das heißt Mütter oder Väter, die zusammen mit ihren Kindern, aber ohne einen Partner oder eine Partnerin im selben Haushalt leben, sind keine Seltenheit mehr. Die Lebensform „Alleinerziehend“ hat sich in Deutschland im Verlauf der letzten Jahrzehnte etabliert. Mittlerweile gibt es 1,6 Mio. Alleinerziehende mit Kindern unter 18 Jahren und rund jede fünfte Familie mit minderjährigen Kindern ist eine Einelternfamilie (Statistisches Bundesamt 2018, S. 55, 59). Alleinerziehende sind zumeist Frauen, nur etwa $12 \%$ der Alleinerziehenden sind Männer (Statistisches Bundesamt 2018, S. 55).

Auch wenn diese Lebensform häufiger auftritt und nicht mehr so stark gesellschaftlich stigmatisiert wird wie in früheren Zeiten, sind mit ihr doch ganz spezifische Risiken verbunden: So sind 2014 rund ein Drittel aller Alleinerziehenden von Armut bedroht, während dies nur für etwa ein Zehntel der Paarhaushalte mit zwei Kindern zutrifft (Statistisches Bundesamt 2018, S. 234). Während unter alleinerziehenden Müttern $28 \%$ und unter alleinerziehenden Vätern $20 \%$ ein monatliches Nettoeinkommen von unter 1300 EUR aufweisen, sind dies bei Ehepaaren nur $2 \%$ (Statistisches Bundesamt 2018, S. 61). Auch die Gesundheit Alleinerziehender ist schlechter als die von Eltern, die in einer Partnerschaft leben. Das im Vergleich zu anderen Lebensformen besonders hohe Armutsrisiko und die stärkere gesundheitliche Gefährdung macht diese Lebensform für die Erforschung sozialer und gesundheitlicher Ungleichheiten interessant. Mit Blick auf diese spezielle Gruppe stellt sich die Frage, wie sich das hohe Armutsrisiko und die gesundheitlichen Risiken erklären lassen.

Vor dem Hintergrund der diesen Band leitenden Fragestellung, welche Rolle die soziologische Netzwerkforschung für die Analyse gesundheitlicher Ungleichheiten spielen kann, soll hier am Beispiel der Studien zur Lebensform 
„,alleinerziehend“ verdeutlicht werden, inwieweit die Netzwerkforschung hier eine Rolle spielt und zur Erklärung gesundheitlicher Ungleichheiten beitragen kann. Zunächst wird dafür der aktuelle Forschungsstand zur Gesundheit von Alleinerziehenden präsentiert. Anschließend wird aufgearbeitet, was über deren soziale Integration, soziale Beziehungen und soziale Netzwerke bekannt ist, und welche Forschungslücken hier ggf. noch bestehen. Im darauffolgenden Abschnitt werden dann die Wechselwirkungen zwischen sozialen Netzwerken und der Gesundheit Alleinerziehender analysiert. Den Abschluss bilden ein Fazit und Forschungsdesiderata.

\section{Die Gesundheit Alleinerziehender}

Die Gesundheit Alleinerziehender wurde in den letzten Jahrzehnten häufiger untersucht. Im Fokus stehen dabei wegen des geringen Anteils alleinerziehender Väter in der Bevölkerung zumeist alleinerziehende Mütter. Nur wenige Studien beziehen alleinerziehende Väter ein oder stellen sie gar in den Mittelpunkt. Das Bild, das diese Studien seit Jahrzehnten für Deutschland wie für andere westliche Staaten zeigen, erscheint eindeutig: Alleinerziehende sind weniger gesund als Mütter und Väter, die in anderen Lebensformen leben. Dies gilt sowohl für die körperliche als auch für die seelische Gesundheit. So schätzen z. B. alleinerziehende Mütter ihre Gesundheit schlechter ein als Mütter, die in einer Partnerschaft leben (Chiu et al. 2016; Helfferich et al. 2003; Rousou et al. 2013; Sperlich et al. 2011; Van de Velde et al. 2014).

Alleinerziehende Mütter geben häufiger körperliche Beschwerden an, aber auch psychische wie Angst und Depressivität (Franz et al. 2003; Helfferich et al. 2003; Sperlich et al. 2011; Van de Velde et al. 2014). Auch weisen sie ein geringeres Wohlbefinden und eine geringere Lebenszufriedenheit auf als Eltern in Paarbeziehungen (Helfferich et al. 2003; Kohler et al. 2005; Osborne et al. 2012; Vignoli et al. 2014; Winkelmann und Winkelmann 1998). Das Gesundheitsverhalten alleinerziehender Mütter gilt als risikoreicher, so ist der Anteil der regelmäßigen Raucherinnen unter den alleinerziehenden Müttern fast doppelt so hoch (46\%) wie unter den verheirateten Müttern (24\%) (Helfferich et al. 2003, S. 16), auch achten alleinerziehende Mütter weniger auf eine gesunde Ernährung und sind etwas weniger sportlich aktiv als verheiratete Mütter (ebd.). Ähnliche Befunde zur subjektiven Gesundheit, zu körperlichen wie psychischen Beschwerden wie auch zum Rauchverhalten finden sich auch für alleinerziehende Väter (Benzeval 1998; Chiu et al. 2016; Cooper et al. 2008; Sperlich et al. 2011; 
Westin und Westerling 2006), wenngleich bei Vätern gelegentlich auch kein Unterschied zu Vätern in Partnerschaft gemessen werden kann (Domanska et al. 2013; Helfferich et al. 2003).

\section{Theoretische Erklärungsansätze für die schlechtere Gesundheit Alleinerziehender}

Wenn wir danach fragen, wie die höhere gesundheitliche Belastung Alleinerziehender erklärt werden kann, finden wir häufig Ansätze, die auf die schlechteren sozioökonomischen Lebensbedingungen von Alleinerziehenden (geringeres Einkommen, schlechtere materielle Ausstattung, Arbeitslosigkeit) verweisen (Benzeval 1998). Dies scheint auch insbesondere für alleinerziehende Väter eine wichtige Rolle zu spielen (Chiu et al. 2016). In vielen dieser Studien wird aber auch deutlich, dass der Blick auf sozioökonomische Faktoren allein nicht ausreicht (Benzeval 1998), oder dass andere Faktoren einen stärkeren Erklärungsgehalt bieten (Cairney et al. 2003). Dazu gehören zum Beispiel 1) Stress während des Prozesses der Trennung/Scheidung/Verwitwung oder das stärkere Erleben von Stress generell (Cairney et al. 2003), 2) gesellschaftliche Stigmatisierung der Einelternschaft (Evans et al. 1994), und 3) Selektionseffekte, d. h., dass erkrankte Personen oder Personen mit geringerem Wohlbefinden eher alleinerziehend werden als gesunde (Gerstel et al. 1985; Riessman und Gerstel 1985).

Verbreitet sind auch Erklärungsansätze, die soziale Beziehungen einbeziehen, z. B. das Fehlen eines Vertrauten, einer intimen Bezugsperson oder einer physisch im Haushalt präsenten unterstützenden Person (Anson 1989; Brown et al. 1993; Brown und Harris 1993) oder auch Kontakte zu und die Unterstützung von anderen Personen allgemein. Auf solche Forschungsarbeiten, die soziale Kontakte und die soziale Unterstützung Alleinerziehender in den Mittelpunkt stellen, wird im folgenden Kapitel näher eingegangen.

\section{Soziale Beziehungen Alleinerziehender}

Soziale Beziehungen und soziale Unterstützung sind schon seit einigen Jahrzehnten wichtige Faktoren im Rahmen der Erforschung der Auswirkungen von Scheidung und Trennung. Studien zu Alleinerziehenden, die ggf. nie verheiratet waren oder nie in einer Partnerschaft lebten, und anders als Geschiedene per Definition immer Kinder im Haushalt haben, sind eher jüngeren Datums. 
Die Scheidungsforschung zeigt v. a., dass eine Trennung einen Verlust sozialer Kontakte und ihrer positiven Auswirkungen mit sich bringt. So verändert der Verlust eines Partners oder einer Partnerin nicht nur die Alltagsorganisation, da ein Mitstreiter oder eine Mitstreiterin in allen anfallenden Aufgaben fehlt, auch geht damit eine wichtige Quelle für emotionale Unterstützung und soziale Wertschätzung verloren (z. B. Gerstel et al. 1985; Myers et al. 1975). Mit der Trennung kommt es auch zum Verlust weiterer Kontakte (Milardo 1987), z. B. weil gemeinsame Freunde Loyalitätskonflikte erleben und die Freundschaft nur zu einem der beiden Partner aufrecht erhalten (Terhell et al. 2004), ebenso ist es für viele Eltern schwierig, nach der Trennung den Kontakt zu der Schwiegerfamilie aufrecht zu erhalten (Dearlove 1999). Häufig gilt daher seit langem soziale Isolation als wesentliche Folge einer Scheidung (Jauch 1977), und damit verbunden auch ein Verlust an sozialer Unterstützung. Die aktuelleren empirischen Befunde $\mathrm{zu}$ sozialer Unterstützung nach einer Trennung sind jedoch nicht konsistent: Einige Studien finden, dass geschiedene Eltern verstärkte Unterstützung durch die eigenen Eltern erhalten und weiterhin Unterstützung durch die Schwiegereltern, während andere einen Rückgang sozialer Unterstützung konstatieren (Harknett und Knab 2007). Relevant ist hierbei auch, wie viel Zeit seit der Trennung vergangen ist. So zeigen neuere Längsschnittstudien ein differenzierteres Bild, was die längerfristigen Folgen einer Trennung angeht: Zwar kommt es zu Kontaktverlusten kurz nach der Scheidung, etwa die Hälfte der Befragten kompensiert diese Verluste jedoch in den folgenden Jahren. Im Zeitverlauf geht die Anzahl der Verwandten zurück (wahrscheinlich durch den Verlust der Schwiegerfamilie), der Kontakt zu Freundinnen und Freunden nimmt zu, für Männer auch die Unterstützung von Freundinnen und Freunden sowie Bekannten (Terhell et al. 2004).

Da eine Scheidung nicht der einzige Weg in die Einelternschaft ist, und geschiedene Elternteile auch nicht notwendigerweise mit ihren Kindern zusammenleben, können die Ergebnisse der Scheidungsforschung nicht unbedingt auf Alleinerziehende übertragen werden. So ist beispielsweise bekannt, dass Frauen nach einer Verwitwung mehr Unterstützung von Verwandten, Freunden und Nachbarn erhalten als nach einer Trennung (Kalmijn 2012) und dass sich die sozialen Netzwerke und der Erhalt von Unterstützung bei geschiedenen und nie verheirateten Alleinerziehenden unterscheiden (Nestmann und Stiehler 1998). Studien, die die sozialen Beziehungen Alleinerziehender differenziert nach ihrem Weg in die Einelternschaft untersuchen, liegen jedoch kaum vor.

Vergleicht man die sozialen Beziehungen von Alleinerziehenden mit denen von Eltern in Paarbeziehungen so zeigt sich in vielen Bereichen ein reduzierter Umfang: Alleinerziehende haben weniger Kontakte zu Verwandten als Eltern in Partnerschaften (Cairney et al. 2003; Cochran et al. 1990), weniger Kontakte 
zur Schwiegerfamilie (Dearlove 1999) und weniger Kontakte zu Freunden (Cairney et al. 2003). Auch sind sie seltener in Vereinen oder Organisationen aktiv als Eltern in Partnerschaften (ebd.). Die Befunde zur sozialen Unterstützung sind uneinheitlich (Lye 1996): So zeigen manche Studien, dass Alleinerziehende weniger Unterstützung als Eltern in Partnerschaften erhalten (Cairney et al. 2003; Reeves et al. 1994; Targosz et al. 2003); andere Studien zeigen, dass v. a. alleinerziehende Mütter nach einer Scheidung mehr Unterstützung erhalten (Hogan et al. 1990; Marks und McLanahan 1993). Alleinerziehende können allerdings in besonderem Maße von sozialer Unterstützung profitieren (Balaji et al. 2007; Harknett 2006), denn v. a. Unterstützung bei der Kinderbetreuung ermöglicht es für viele Alleinerziehende, einer Erwerbstätigkeit nachzugehen, und Familienarbeit und Erwerbstätigkeit zu vereinbaren, und damit im besten Fall einer Armutslage zu entgehen (Ciabattari 2007; Cook 2012).

Während sich die Unterstützungsforschung v. a. mit der Wahrnehmung und dem Erhalt bestimmter Formen sozialer Unterstützung beschäftigt, nimmt die soziale Netzwerkforschung eine erweiterte Perspektive ein, indem sie die Bedeutung sozialer Beziehungen betrachtet und dabei auch die strukturellen Eigenschaften der Beziehungsnetzwerke einbezieht (Smith und Christakis 2008). Die Netzwerke Alleinerziehender sind sehr heterogen in Struktur und Funktion: es gibt große und kleine, dichte und weniger dichte, unterstützende und weniger unterstützende (Campbell et al. 2016; Keim 2018; Lumino et al. 2016; Niepel 1994). Sozial weitgehend isolierte Personen finden sich eher selten, aber besonders in Armutslagen (ebd.). Durch die Trennung verlorene Kontakte werden häufig durch neue oder die Intensivierung bereits bestehender Beziehungen ersetzt (Niepel 1994).

Zur Zusammensetzung der Netzwerke finden sich widersprüchliche Befunde. Einigkeit besteht weitgehend darüber, dass Frauen unter den Personen, die Unterstützung leisten, dominieren (Attree 2005; Keim 2018; Niepel 1994). Während manche Studien eine Dominanz von Verwandten aufzeigen (Lumino et al. 2016), präsentieren andere Studien eine Dominanz von Freundschaften (Niepel 1994). In jedem Fall wird deutlich, dass die Netzwerke häufig sehr heterogen in ihrer Zusammensetzung sind und dass die Variationsbreite unterschiedlicher Netzwerkstrukturen und Kompositionen groß ist. Interessant sind daher Studien, die Netzwerktypologien entwickeln. Davon gibt es bisher allerdings recht wenige, es konnten in den letzten fast 40 Jahren nur drei solcher Studien in Deutschland und den USA gefunden werden. Diese stützen sich zudem auf sehr kleine und sehr unterschiedliche Samples, was sie kaum vergleichbar macht: 45 weiße geschiedene, zumeist erwerbstätige Mütter in den USA (McLanahan et al. 1981), 
20 erwerbstätige und erwerbslose Alleinerziehende in Bielefeld (Niepel 1994), 26 erwerbslose Alleinerziehende in Mecklenburg-Vorpommern (Keim 2018).

McLanahan et al. (1981) identifizieren in ihrer Studie über geschiedene Mütter drei Netzwerktypen: 1) „Rückkehr in die Herkunftsfamilie“, recht klein und dicht, dominiert von Verwandten, 2) ,erweitertes Netzwerk“, recht groß, wenig dicht und heterogen in der Zusammensetzung und 3) „Aufrechterhaltung oder Neugründung einer conjugalen Beziehung mit dem Ex-Partner oder einem neuen Partner", enthält Verwandte und Freunde, kann unterschiedlich groß und dicht sein. Niepel (1994) unterscheidet in ihrem Sample weiblicher Alleinerziehender 1) „Freundschaftsnetzwerke“, relativ kleine und wenig dichte Netzwerke, in denen Freunde dominieren, von 2) „Familien- und Freundschaftsnetzwerken“, große Netzwerke, in denen beide Rollenbeziehungen häufig vorkommen, und 3) „Familiennetzwerke“, kleine und dichte Netzwerke, in denen Verwandtschaftsbeziehungen dominieren. Keim (2018) unterscheidet in ihrer Studie über erwerbslose weibliche Alleinerziehende 1) „Familienorientierte“ und 2) „Conjugale Netzwerke", die vor allem verwandtschaftliche Beziehungen enthalten, sei es zu eigenen Verwandten oder zu Angehörigen des Partners, 3) „Erweiterte Netzwerke", die groß und wenig dicht sind und sich aus unterschiedlichen Beziehungstypen zusammensetzen, und 4) „Eingeschränkte Netzwerke“, die sehr klein sind und einen hohen Anteil an institutionellen Helfern aufweisen. Gemeinsam haben die drei Typologien, dass die Variationsbreite der Netzwerke Alleinerziehender hoch ist, von besonders großen und wenig dichten Netzwerken („Erweitertes Netzwerk“ bei McLanahan und Keim und „Familien- und Freundschaftsnetzwerk" bei Niepel) bis zu kleinen, dichten und verwandtschaftsdominierten Netzwerken. Allein die „Eingeschränkten Netzwerke“ bei Keim (2018) zeugen von einer gewissen sozialen Isolation. In diesen Netzwerken finden sich aber oft institutionelle Helfer, die wichtige Unterstützungsfunktionen übernehmen. Die Entwicklung einer Typologie basierend auf einem größeren Sample steht noch aus.

Fazit: Ob es um soziale Kontakte, soziale Beziehungen, soziale Unterstützung oder soziales Kapital geht, die vorgestellten Studien machen deutlich, dass Alleinerziehende über eine andere soziale Einbettung verfügen als verheiratete Eltern. Konzepte wie soziale Unterstützung werden dabei häufiger untersucht, netzwerkanalytische Studien sind eher selten. Auffällig ist, dass der Begriff „Netzwerke“ hier häufig als Metapher genutzt wird („Unterstützungsnetzwerke“) und für eine Vielzahl sozialer Beziehungen und Unterstützungsformen stehen kann. Seltener wird in diesen Studien, die von „Unterstützungsnetzwerken“ sprechen, auch tatsächlich die Struktur dieser Beziehungen genauer untersucht und netzwerkanalytische Instrumente angewandt. 


\section{$5 \quad$ Welche Rolle spielen soziale Beziehungen für die Gesundheit Alleinerziehender?}

Viele Studien konnten in den letzten Jahrzehnten zeigen, dass soziale Beziehungen bedeutsam für das Wohlbefinden, die Gesundheit und das Gesundheitsverhalten sind. Dies gilt auch für Alleinerziehende. Recht gut erforscht ist das Konzept der sozialen Unterstützung: Alleinerziehende profitieren davon, dass soziale Unterstützung dazu beiträgt, stressreiche Lebenssituationen abzumildern und damit positiv auf das Wohlbefinden wirkt (Campbell et al. 2016; Ciabattari 2007; Harknett 2006). Soziale Unterstützung korreliert auch negativ mit konkreten Krankheitsbildern: So geht eine geringere wahrgenommene soziale Unterstützung mit einem häufigeren Auftreten von depressiven Symptomen (Cairney et al. 2003; Harknett 2006) und anderen psychischen Erkrankungen (Franz et al. 2003) einher. Im Vergleich zu Müttern in Paarbeziehungen sind alleinerziehende Mütter nicht nur vermehrt Stressoren ausgesetzt, sondern verfügen auch über weniger Unterstützung (Cairney et al. 2003) und das Zusammenspiel aus geringerem sozialen Status, höherer Anzahl von Stressoren und geringerer Unterstützung kann die Unterschiede in der Depressionsneigung zwischen Müttern, die mit einem Erwachsenen im Haushalt zusammenleben, und Alleinerziehenden fast vollständig erklären (Targosz et al. 2003).

Ein differenzierteres Bild ergibt sich, wenn man die Zusammenhänge zwischen sozialem Status und sozialer Unterstützung genauer analysiert. Für Personen mit geringerem sozialen Status kann soziale Unterstützung deutlich entlastend wirken, so verringert der Zugang zu sozialer Unterstützung Konflikte in der Vereinbarung von Familie und Beruf für unverheiratete Mütter, v. a. für solche mit niedrigerem sozialen Status (Ciabattari 2007). Soziale Beziehungen generieren aber auch Kosten. Erhaltene Unterstützung muss häufig erwidert werden, was besonders für Personen mit geringerem sozialen Status, wie z. B. für erwerbslose Alleinerziehende, schwierig sein kann. Die Reziprozitätserwartungen üben sozialen Druck aus und belasten dann nicht nur das Wohlbefinden, sondern können längerfristig auch zu Kontaktabbrüchen und dem Verzicht auf soziale Unterstützung führen (Andreotti 2006; Cook 2012). Ob aktiver Verzicht auf Unterstützung oder mangelnder Zugang zu Unterstützungsmöglichkeiten, individuelle Benachteiligung wird durch solche Beziehungseffekte verstärkt: Für Alleinerziehende mit geringer Bildung, in prekärer Beschäftigung und Armutslagen, die Unterstützung am meisten benötigen, ist sie am wenigsten verfügbar (Brown und Moran 1997; Harknett 2006). Dieser Mangel an Unterstützung wiederum steht in enger Beziehung mit psychischen Erkrankungen (Simons et al. 1993). 
Soziologische Netzwerkstudien, die sich mit den Beziehungsstrukturen und ihren Auswirkungen beschäftigen und dabei soziale Wirkmechanismen betrachten, die über soziale Unterstützung hinausgehen (vgl. Berkman und Glass 2000), sind in der Alleinerziehendenforschung noch sehr selten. Dennoch finden sich Studien, die zeigen, dass soziale Netzwerke für die Gesundheit Alleinerziehender oder Geschiedener besonders relevant sind. So zeigt beispielsweise die Studie von Gerstel et al. (1985), dass die Charakteristika sozialer Netzwerke den Zusammenhang zwischen Familienstand (Geschieden oder Verheiratet) und psychischer Gesundheit zu einem hohen Grad erklären kann: für Männer $60 \%$ und für Frauen $57 \%$ der Unterschiede in der psychischen Gesundheit zwischen Verheirateten und Geschiedenen (ebd., S. 95). Dabei finden sich bedeutsame Unterschiede zwischen Männern und Frauen. Während für Frauen neben Netzwerkcharakteristika vor allem materielle Faktoren (v. a. das Einkommen) eine protektive Wirkung haben, ist es bei Männern vor allem die Struktur und Zusammensetzung des Netzwerks. Für beide Geschlechter vermindern Netzwerke, die nicht als Belastung empfunden werden und keine Einsamkeitsgefühle aufkommen lassen, das Risiko einer psychischen Erkrankung (ebd.).

Befunde für die genaue Wirkung spezifischer Netzwerkstrukturmaße auf die Gesundheit Alleinerziehender sind rar und meist uneinheitlich. So sind einerseits bei Geschiedenen große Netzwerke mit Glück und Wohlbefinden assoziiert, unabhängig davon, welche Inhalte in diesen Netzwerken ausgetauscht werden (Gerstel et al. 1985), bei Frauen stehen zudem große Netzwerke mit psychischer Gesundheit in Zusammenhang (ebd.). Andererseits bieten kleinere Netzwerke aus der Sicht von alleinerziehenden Müttern mehr und bessere Unterstützung als größere (Malo 1994), was Gesundheitseffekte haben kann. Wichtig ist festzuhalten, dass es sich bei den genannten Studien um Querschnittuntersuchungen handelt, die keine Aussagen über Ursache und Wirkung treffen können. Denkbar ist daher sowohl, dass große Netzwerke protektiv wirken, als auch, dass gesundheitlich weniger belastete Frauen eher in der Lage sind, größere Netzwerke zu unterhalten.

Hinsichtlich der Netzwerkdichte zeigen erste Befunde, dass gängige theoretische Überlegungen zur Rolle der Netzwerkdichte und der sozialen Unterstützung nicht notwendigerweise auf Alleinerziehende zutreffen. Allgemein wird angenommen, dass dichte Netzwerke eher instrumentelle und emotionale Unterstützung leisten als weniger dichte, diese stehen vielmehr in einem positiven Zusammenhang mit dem Zugang zu Informationen und neuen sozialen Kontakten (Granovetter 1973; Mitchell 1969). Nach einer Studie von McLanahan, Wedemyer und Adelberg von 1981 empfinden Alleinerziehende die Unterstützung durch Verwandte (die meist dichte Netzwerke bilden) als weniger befriedigend 
als die Unterstützung durch Freunde in einem Netzwerk mit geringer Dichte. Ein dichtes Netzwerk mit vielen Verwandten geht bei Alleinerziehenden mit einer geringeren Lebensqualität einher (Leslie und Grady 1985). Auch können weniger dichte Netzwerke flexiblere Unterstützung leisten und daher dabei helfen, besser mit einer neuen Situation zurechtzukommen (Gerstel et al. 1985), auf diesem Weg schützen sie vor allem Männer vor psychischen Erkrankungen nach einer Scheidung (ebd.).

Die Netzwerkforschung öffnet nicht nur den Blick für komplexe Beziehungsgeflechte, sondern auch für negative oder ambivalente Beziehungsinhalte. So können soziale Beziehungen nicht nur unterstützend, sondern auch konflikthaft, gelegentlich auch beides gleichzeitig sein. Im Kontext von Trennungs- und Scheidungsprozessen sind negative oder ambivalente Beziehungen besonders relevant, da konfliktbehaftete Beziehungen zu den ehemaligen Partnerinnen und Partnern aber auch deren Eltern, Verwandten oder Freunden nicht ohne Weiteres gekappt werden können, da sie oft wichtige Bezugspersonen für die eigenen Kinder sind. Studien über Alleinerziehende, die negative Beziehungsinhalte einbeziehen, sind rar. Die Studie von Gerstel et al. (1985) fragt neben einzelnen Unterstützungsdimensionen auch danach, ob soziale Beziehungen als Belastung empfunden werden. Die Analyse zeigt, dass Netzwerke, die nicht als Belastung empfunden werden, mit einem geringeren Risiko einer psychischen Erkrankung im Zusammenhang stehen (Gerstel et al. 1985). Auch die Studie von Samuelsson (1994) zeigt, dass Konflikte und negative Kontakte die psychische Gesundheit belasten. Empirisch wissen wir nicht nur bei Alleinerziehenden wenig über das Zusammenspiel von Unterstützung und Konflikten in ihren gesundheitlichen Folgen. Neuere Forschung zeigt, dass bei Studierenden, die ein hohes Maß an Unterstützung erhalten, soziale Konflikte nicht mit ihrem Wohlbefinden korrelieren, während für Personen, die wenig Unterstützung erhalten, soziale Konflikte das Wohlbefinden negativ beeinflussen (Abbey et al. 2010). Hier besteht weiterer Forschungsbedarf.

Eine besonders differenzierte Analyse von Netzwerkstrukturen und ihrer Wirkung auf das individuelle Wohlbefinden von geschiedenen Müttern legten McLanahan, Wedemeyer und Adelberg (1981) vor. Sie haben eine Netzwerktypologie gebildet, in der jeder der vier Netzwerktypen auf seine spezifische Weise mit der Gesundheit Alleinerziehender im Zusammenhang steht. Wesentlich dafür, ob die Netzwerkstruktur als gesundheitsförderlich oder -hinderlich erlebt wird, ist dabei nicht die Struktur selbst, sondern ob sie zur Rollenorientierung der Geschiedenen passt. Geschiedene Mütter, die die sozialen Rollen, die sie vor der Scheidung 
hatten, beibehalten möchten, fühlen sich am besten durch dichte Netzwerke unterstützt, während Mütter, die mit der Scheidung auch ihre sozialen Rollen verändern möchten, sich am besten von weniger dichten Netzwerken unterstützt fühlen. Sind diese Frauen in gänzlich anders strukturierte Netzwerke eingebettet, so geht das mit einem geringeren Wohlbefinden einher. Die Autoren plädieren deshalb dafür, dass spezifische Netzwerkstrukturen und Unterstützungsmöglichkeiten nicht per se für alle die gleiche gesundheitsförderliche oder -hinderliche Wirkung entfalten, sondern dass es auf die Unterstützungsbedarfe ankommt.

Keim (2018) zeigt hingegen, dass es unter erwerbslosen Alleinerziehenden zwei Netzwerkstrukturtypen gibt, die generell mit besonders hohem, respektive geringem Wohlbefinden einhergehen. Dabei handelt es sich zum einen um große und wenig dichte ,Erweiterte Netzwerke“, die eine hohe Heterogenität aufweisen. Personen, die in diese Art von Netzwerk eingebunden sind, erhalten vielfältige soziale Unterstützungsleistungen und sind auch selbst in der Lage, ihre Netzwerkpartner zu unterstützen und damit reziproke Beziehungen zu pflegen. Das Wohlbefinden von Personen, die diesen Netzwerktyp eingebunden sind, ist sehr hoch. Auch hier finden sich Wechselwirkungen zwischen Wohlbefinden und Netzwerkstruktur. Die als hilfreich bewertete Unterstützung fördert das Wohlbefinden, aber das hohe Wohlbefinden und der geringe Stresslevel tragen auch dazu bei, reziproke Unterstützungsbeziehungen zu pflegen, Konflikte konstruktiv anzugehen und den Aufbau neuer Beziehungen zu wagen. In starkem Kontrast dazu stehen zum anderen ,Eingeschränkte Netzwerke“, kleine Netzwerke mit einem hohen Anteil an institutionellen Helfern. Befragte, die in diese Netzwerke eingebettet sind, können oft nur durch den Einsatz der institutionellen Helfer als hilfreich bewertete Unterstützung erhalten, die Unterstützung kann die empfundenen Belastungen aber nur teilweise und kurzfristig abpuffern, das Wohlbefinden ist im Vergleich zu den anderen befragten Alleinerziehenden stark eingeschränkt. Eine aktive Netzwerkpflege, zum Beispiel auch durch das Leisten von Unterstützung, oder der Aufbau neuer Kontakte ist kaum möglich. Zwischen diesen beiden Polen liegen zwei Netzwerktypen, in denen verwandtschaftliche Kontakte zu der Herkunftsfamilie oder der Familie des alten/neuen Partners dominieren. Hier treten häufiger Belastungslagen auf als bei Personen mit erweiterten Netzwerken, diese können aber meist recht gut durch die Unterstützung in den Netzwerken abgepuffert werden, es bleibt genug Zeit und Kraft für die Pflege der bestehenden, und den Aufbau neuer Beziehungen. 


\section{$6 \quad$ Fazit und Forschungsdesiderate}

Mittlerweile gibt es einige Studien, die die Rolle der sozialen Einbettung Alleinerziehender für ihre Gesundheit und ihr Wohlbefinden in den Blick nehmen und die zeigen können, dass spezifische Netzwerkstrukturen einen bedeutsamen Einfluss haben. Es besteht aber noch weiterer Forschungsbedarf, der im Folgenden zusammengestellt werden soll:

1. Die Wege in die Einelternschaft sind vielfältig, Befunde aus der Scheidungsforschung sowohl zu Gesundheit wie auch zu sozialen Beziehungen lassen sich daher nicht unbedingt auch auf Alleinerziehende übertragen, hier sind weitere Studien spezifisch zur Lebensform "Alleinerziehend“ notwendig. Dabei sollte auch das Sorge- und Umgangsrecht berücksichtigt werden, so bieten Wechselmodelle (das Kind lebt zeitweise jeweils bei Mutter und Vater) sicherlich andere Vorteile und Herausforderungen als das alleinige Sorge- und Umgangsrecht, und sind mit anderen Formen der sozialen Einbindung verknüpft.

2. Studien, die die Rolle soziale Beziehungen für die Gesundheit Alleinerziehender in den Mittelpunkt stellen, beschäftigen sich zumeist mit Konzepten wie sozialer Unterstützung, strukturelle Netzwerkanalysen sind selten. Hier besteht noch Forschungsbedarf. Zu fragen ist:

a. Wie verändern sich die Netzwerkstrukturen mit dem Übergang in ein Leben als Alleinerziehende?

b. Welche Rolle spielen spezifische Netzwerkstrukturen für die Gesundheit? Gibt es neben einzelnen be- und entlastenden Beziehungen auch Strukturen des gesamten Netzwerks, die eine besonders be- oder entlastende Wirkung haben?

c. Welche Wirkmechanismen neben sozialer Unterstützung sind relevant?

3. Die Rolle sozialer Netzwerke für die Reproduktion oder Kompensation sozialer und gesundheitlicher Ungleichheiten ist für Alleinerziehende noch kaum erforscht. Die empirische Forschung weist in zwei Richtungen: Zum einen gehen ökonomische Mangellagen häufig mit einem kleineren Netzwerk einher, das in geringerem Maße Unterstützung bereitstellen kann. Da sich sowohl ein Mangel an ökonomischen als auch an sozialen Ressourcen negativ auf die Gesundheit auswirken kann, eine schlechte Gesundheit wiederum die Ausstattung mit Ressourcen negative beeinflusst, deutet sich eine Abwärtsspirale an, in der sich Ressourcenausstattung und Gesundheit stetig weiter verschlechtern. Zum anderen zeigen empirische Studien aber auch, dass sowohl 
Kontaktverluste durch eine Trennung kompensiert werden können als auch, dass soziale Ressourcen einen Mangel an ökonomischen Ressourcen kompensieren können. Damit könnten soziale Netzwerke von Alleinerziehenden eine gesundheitsförderliche Wirkung haben, indem sie negative Gesundheitseffekte von Trennung, Armut und sozialer Ungleichheit abpuffern. Unklar ist jedoch, inwieweit und unter welchen Bedingungen sie das tun oder sich eine negative Spirale entwickelt.

a. Besonders wünschenswert wären hier Längsschnittstudien, die kurz- und längerfristige Veränderungen in der Lebensform, im sozialen Status, in sozialen Netzwerken und der Gesundheit in ihren Bedingungen und Konsequenzen analysieren.

b. Sinnvoll sind aber auch Querschnittserhebungen z. B. unter Alleinerziehenden mit unterschiedlichem sozialen Status oder unterschiedlicher Verweildauer in der Lebensform, die zeigen können, inwieweit sich diese Gruppen in ihrer Netzwerkstruktur und Gesundheit unterscheiden.

c. Qualitative Studien können die Bedeutung sozialer Beziehungen und spezifischer Netzwerkstrukturen für die Alleinerziehenden näher beleuchten und aufzeigen, auf welche Weise, durch welche Mechanismen, unter welchen Bedingungen und in welchen Kontexten soziale Netzwerke zu einer Reproduktion sozialer Ungleichheiten beitragen oder soziale Ungleichheiten kompensieren können. Auch fehlen vertiefende qualitative Studien, die deutlich machen können, wie Personen aus unterschiedlichen sozialen Schichten mit einer Trennung umgehen, und was dies für ihre sozialen Beziehungen bedeutet. Diese können auch in den Mittelpunkt rücken, wie Alleinerziehende ihre sozialen Kontakte bewerten. So muss ein kleineres Netzwerk nicht unbedingt mit einer geringeren sozialen Unterstützung einhergehen, vielleicht wird es auch als positiv erlebt, da Kontakte wegfallen, für deren Pflege vorher Zeit und Mühe investiert werden musste.

d. Häufig werden soziale Beziehungen nur in ihren vorteilhaften Auswirkungen untersucht, sie können jedoch Konflikte beinhalten und Stress auslösen (Gräbe 1991). Gerade für Alleinerziehende mit niedrigerem sozialen Status kann die Annahme von Unterstützung belastend sein (Cook 2012). Diese negativen Aspekte von sozialen Beziehungen werden noch viel zu selten in Netzwerkstudien einbezogen, daher ist zu fragen: Wie lässt sich das komplexe Zusammenspiel von Unterstützung und Konflikten in sozialen Netzwerken fassen, und welche Rolle spielen hierfür konkrete Netzwerkstrukturen? 
4. Unterstützungsnetzwerke sind nicht nur privater Natur, auch von institutioneller Seite wird Unterstützung für Alleinerziehende bereitgestellt, die nicht nur in das persönliche Netzwerk Alleinerziehender integriert werden kann (Familienhelfer etc.), sondern auch selbst netzwerkförmig organisiert sein kann (siehe Bundesministerium für Familie, Senioren, Frauen und Jugend 2013). Auch bezüglich des Zusammenwirkens privater und institutionalisierter Unterstützung besteht Forschungsbedarf. So wirft sich hier die Frage auf, ob institutionalisierte Unterstützung private Unterstützung verdrängt und damit das soziale Gefüge und die Verfügbarkeit von Ressourcen weiter schwächt, oder ob sie nicht gerade besonders in schweren Belastungslagen Unterstützung überhaupt erst ermöglicht, da einzelne Unterstützter nun nicht mehr durch die notwendige Unterstützung überlastet werden.

\section{Leseempfehlungen}

Gerstel, N., Kohler Riessman, C., \& Rosenfield, S. (1985): Explaining the Symptomatology of Separated and Divorced Women and Men: The Role of Material Conditions and Social Networks. Social Forces 64 (1), S. 84-101. Diese US-amerikanische Studie aus den 1980er Jahren interessiert sich dafür, wodurch Ehen gesundheitsprotektiv wirken. Die Autorinnen analysieren Daten der Northern California Community Study zur Gesundheit von Verheirateten und Geschiedenen/getrennt Lebenden. Dabei handelt es sich um eine frühe Studie mit netzwerkanalytischer Perspektive, die auch gezielt Netzwerkstrukturen untersucht. Sie zeigt die Erklärungskraft sozialer Netzwerke für Unterschiede zwischen Verheirateten und Geschiedenen und eine gesundheitsprotektive Wirkung von Netzwerken geringerer Dichte.

Harknett, Kristen (2006): The Relationship Between Private Safety Nets and Economic Outcomes Among Single Mothers. Journal of Marriage and Family, 68 (1), S. 172-191. Die Autorin zeigt anhand US-amerikanischer Daten, dass Alleinerziehende mit geringer Bildung, in prekärer Beschäftigung und Armutslagen zwar am meisten Unterstützung benötigen, diese aber am wenigsten verfügbar haben. Damit verstärken ihres Erachtens Benachteiligungen auf der Meso-Ebene der sozialen Beziehungen Benachteiligungen auf der individuellen Ebene.

Mc Lanahan, Wedemeyer, Adelberg (1981), Niepel (1994) und Keim (2018), siehe Literaturverzeichnis. Dabei handelt es sich um drei 
methodenintegrative netzwerkanalytische Studien (aus den USA und Deutschland), die sehr differenziert die Strukturen und Funktionen sozialer Netzwerke von Alleinerziehenden/Geschiedenen analysieren und deren Auswirkungen auf Wohlbefinden und Gesundheit untersuchen. Dies mündet jeweils in der Entwicklung einer Typologie sozialer Netzwerke.

\section{Literatur}

Abbey, A., Abramis, D. J., \& Caplan, R. D. (2010). Effects of different sources of social support and social conflict on emotional well-being. Basic and Applied Social Psycho$\log y, 6(2), 111-129$.

Andreotti, A. (2006). Coping strategies in a wealthy city of northern Italy. International Journal of Urban and Regional Research, 30(2), 328-345.

Anson, O. (1989). Marital status and women's health revisited: The importance of a proximate adult. Journal of Marriage and Family, 51(1), 185-193.

Attree, P. (2005). Parenting support in the context of poverty: A meta-synthesis of the qualitative evidence. Health and Social Care in the Community, 13(4), 330-337.

Balaji, A. B., Claussen, A. H., Smith, D. C., Visser, S. N., Morales, M. J., \& Perou, R. (2007). Social support networks and maternal mental health and well-being. Journal of women's health, 16(10), 1386-1396.

Benzeval, M. (1998). The self-reported health status of lone parents. Social Science and Medicine, 46(10), 1337-1353.

Berkman, L. F., \& Glass, T. (2000). Social integration, social networks, social support, and health. In L. F. Berkman \& I. Kawachi (Hrsg.), Social epidemiology (S. 137-173). New York: Oxford University Press.

Brown, G. W., \& Harris, T. O. (1993). Aetiology of anxiety and depressive disorders in an inner-city population: Early adversity. Psychological Medicine, 23(1), 143-154.

Brown, G. W., Harris, T. O., \& Eales, M. J. (1993). Aetiology of anxiety and depressive disorders in an inner-city population: Comorbidity and adversity. Psychological Medicine, 23(1), 155-165.

Brown, G. W., \& Moran, P. M. (1997). Single mothers, poverty and depression. Psychological Medicine, 27(1), 21-33.

Bundesministerium für Familie, Senioren, Frauen und Jugend. (2013). Handbuch Unterstützungsnetzwerke Alleinerziehende, Berlin. https://www.bmfsfj.de/bmfsfj/service/publikationen/handbuch-unterstuetzungsnetzwerke-alleinerziehende/111890. Zugegriffen: 18. Jan. 2019.

Cairney, J., Boyle, M., Offord, D. R., \& Racine, Y. (2003). Stress, social support and depression in single and married mothers. Social Psychiatry and Psychiatric Epidemiology, 38(8), 442-449. 
Campbell, M., Thomson, H., Fenton, C., \& Gibson, M. (2016). Lone parents, health, wellbeing and welfare to work: A systematic review of qualitative studies. BMC Public Health, 16, 188-195.

Chiu, M., Rahman, F., Kurdyak, P., Cairney, J., Jembere, N., \& Vigod, S. (2016). Self-rated health and mental health of lone fathers compared with lone mothers and partnered fathers: A population-based cross-sectional study. Journal of Epidemiology and Community Health, 71(5), 417-423.

Ciabattari, T. (2007). Single mothers, social capital, and work-family conflict. Journal of Family Issues, 28(1), 34-60.

Cochran, M., Larner, M., Riley, D., Gunnarsson, L., \& Henderson, C. R. (1990). Extending families: The social networks of parents and their children. Cambridge: Cambridge University Press.

Cook, K. E. (2012). Social support in single parents' transition from welfare to work: Analysis of qualitative findings. International Journal of Social Welfare, 21(4), 338-350.

Cooper, C., Bebbington, P. E., Meltzer, H., Bhugra, D., Brugha, T., Jenkins, R., Farrell, M., \& King, M. (2008). Depression and common mental disorders in lone parents: Results of the 2000 National Psychiatric Morbidity Survey. Psychological Medicine, 38(3), 335-342.

Dearlove, J. (1999). Lone or alone? A qualitative study of lone mothers on low income with reference to support in their everyday lives. Thesis, University of Warwick. http:// wrap.warwick.ac.uk/36376/1/WRAP_THESIS_Dearlove_1999.pdf. Zugegriffen: 16. Jan. 2015.

Domanska, O., Rattay, P., \& von der Lippe, E. (2013). Sind Alleinerziehende öfter von Rückenschmerzen betroffen als in Partnerschaft lebende Mütter und Väter? Ergebnisse der GEDA-Studie 2009/10. Gesundheitswesen, 75(8/9), A189.

Evans, R. G., Hodge, M., \& Pless, I. B. (1994). If not genetics, then what? Biological pathways and population health. In R. G. Evans, M. L. Barer, \& T. R. Marmor (Hrsg.), Why are some people healthy and others not? The determinants of health populations (S. 161-188). New York: Gruyter.

Franz, M., Lensche, H., \& Schmitz, N. (2003). Psychological distress and socioeconomic status in single mothers and their children in a German city. Social Psychiatry and Psychiatric Epidemiology, 38(2), 59-68.

Gerstel, N., Kohler Riessman, C., \& Rosenfield, S. (1985). Explaining the symptomatology of separated and divorced women and men: The role of material conditions and social networks. Social Forces, 64(1), 84-101.

Gräbe, S. (1991). Reziprozität und Stress in ,Support'-Netzwerken. Neue Perspektiven in der familiensoziologischen Netzwerkforschung. Kölner Zeitschrift für Soziologie und Sozialpsychologie, 43(2), 344-356.

Granovetter, M. (1973). The strength of weak ties. American Journal of Sociology, 78(6), $1360-1380$.

Harknett, K. (2006). The relationship between private safety nets and economic outcomes among single mothers. Journal of Marriage and Family, 68(1), 172-191.

Harknett, K., \& Knab, J. (2007). More kin, less support: Multipartnered fertility and perceived support among mothers. Journal of Marriage and Family, 69(1), 237-253.

Helfferich, C., Hendel-Kramer, A., \& Klindworth, H. (2003). Gesundheit alleinerziehender Mütter und Väter. Gesundheitsberichterstattung des Bundes, 14. http://www.gbe-bund. de/pdf/Heft14.pdf. Zugegriffen: 13. Apr. 2018. 
Hogan, D. P., Hao, L.-X., \& Parish, W. L. (1990). Race, kin networks, and assistance to mother-headed families. Social Forces, 68(3), 797-812.

Jauch, C. (1977). The one-parent family. Journal of Clinical Child Psychology, 6(2), 30-32.

Kalmijn, M. (2012). Longitudinal analyses of the effects of age, marriage, and parenthood on social contacts and support. Advances in Life Course Research, 17(4), 177-190.

Keim, S. (2018). Are lone mothers also lonely mothers? Social networks of unemployed lone mothers in eastern Germany. In L. Bernardi \& D. Mortelmans (Hrsg.), Lone parenthood in the life course (S. 111-140). Cham: Springer Open.

Kohler, H.-P., Behrman, J. R., \& Skytthe, A. (2005). Partner + children=happiness? The effects of partnerships and fertility on well-being. Population and Development Review, 31(3), 407-445.

Leslie, L. A., \& Grady, K. (1985). Changes in mothers' social networks and social support following divorce. Journal of Marriage and Family, 47(3), 663-673.

Lumino, R., Ragozini, G., \& Vitale, M. P. (2016). Investigating social support patterns of single mothers from a social network perspective. International Review of Social Research, 6(4), 182-194.

Lye, D. N. (1996). Adult child-parent relationships. Annual Review of Sociology, 22(1), 79-102.

Malo, C. (1994). Ex-partner, family, friends, and other relationships: Their role within the social network of long-term single mothers. Journal of Applied Social Psychology, 24(1), 60-81.

Marks, N. F., \& McLanahan, S. S. (1993). Gender, family structure, and social support among parents. Journal of Marriage and Family, 55(2), 481-493.

McLanahan, S. S., Wedemeyer, N. V., \& Adelberg, T. (1981). Network structure, social support, and psychological well-being in the single-parent family. Journal of Marriage and the Family, 43(3), 601-618.

Milardo, R. M. (1987). Changes in social networks of women and men following divorce. A review. Journal of Family Issues, 8(1), 78-96.

Mitchell, C. J. (1969). The concept and use of social networks. In C. J. Mitchell (Hrsg.), Social networks in urban situations. Manchester: Manchester University Press.

Myers, J. K., Lindenthal, J. J., \& Pepper, M. P. (1975). Life events, social integration and psychiatric symptomatology. Journal of Health and Social Behavior, 16(4), 421-427.

Nestmann, F., \& Stiehler, S. (1998). Wie allein sind Alleinerziehende? Soziale Beziehungen alleinerziehender Frauen und Männer in Ost und West. Opladen: Leske \& Budrich.

Niepel, G. (1994). Soziale Netze und soziale Unterstützung alleinerziehender Frauen. Opladen: Leske \& Budrich.

Osborne, C., Berger, L. M., \& Magnuson, K. (2012). Family structure transitions and changes in maternal resources and well-being. Demography, 49(1), 23-47.

Reeves, J., Kendrick, D., Denman, S., \& Roberts, H. (1994). Lone mothers: Their health and lifestyle. Health Education Journal, 53, 291-299.

Riessman, C. K., \& Gerstel, N. (1985). Marital dissolution and health: Do males or females have greater risk? Social Science and Medicine, 20(6), 627-635.

Rousou, E., Kouta, C., Middleton, N., \& Karanikola, M. (2013). Single mothers' self-assessment of health. A systematic exploration of the literature. International Nursing Review, 60(4), 425-434. 
Samuelsson, M. A. K. (1994). Associations between the mental health and social networks of children and parents in single-parent families. Acta Psychiatrica Scandinavica, 90(6), 438-445.

Simons, R. L., Beaman, J., Conger, R. D., \& Chao, W. (1993). Stress, support, and antisocial behavior trait as determinants of emotional well-being and parenting practices among single mothers. Journal of Marriage and Family, 55(2), 385-394.

Smith, K. P., \& Christakis, N. A. (2008). Social networks and health. Annual Review of Sociology, 34(1), 405-429.

Sperlich, S., Arnhold-Kerri, S., \& Geyer, S. (2011). Soziale Lebenssituation und Gesundheit von Müttern in Deutschland. Ergebnisse einer Bevölkerungsstudie. Bundesgesundheitsblatt, Gesundheitsforschung, Gesundheitsschutz, 54(6), 735-744.

Statistisches Bundesamt. (2018). Datenreport 2018. Ein Sozialbericht für die Bundesrepublik Deutschland. Bonn.

Targosz, S., Bebbington, P., Lewis, G., Brugha, T., Jenkins, R., Farrell, M., \& Meltzer, H. (2003). Lone mothers, social exclusion and depression. Psychological Medicine, 33(4), $715-722$.

Terhell, E. L., Broese Van Groenou, M. I., \& van Tilburg, T. G. (2004). Network dynamics in the long-term period after divorce. Journal of Social and Personal Relationships, 21(6), 719-738.

Van de Velde, S., Bambra, C., Van der Bracht, K., Eikemo, T. A., \& Bracke, P. (2014). Keeping it in the family: The self-rated health of lone mothers in different European welfare regimes. Sociology of Health \& Illness, 36(8), 1220-1242.

Vignoli, D., Pirani, E., \& Salvini, S. (2014). Family constellations and life satisfaction in Europe. Social Indicators Research, 117(3), 967-986.

Westin, M., \& Westerling, R. (2006). Health and healthcare utilization among single mothers and single fathers in Sweden. Scandinavian Journal of Public Health, 34(2), 182-189.

Winkelmann, L., \& Winkelmann, R. (1998). Why are the unemployed so unhappy? Evidence from panel data. Economica, 65, 1-15.

Open Access Dieses Kapitel wird unter der Creative Commons Namensnennung 4.0 International Lizenz (http://creativecommons.org/licenses/by/4.0/deed.de) veröffentlicht, welche die Nutzung, Vervielfältigung, Bearbeitung, Verbreitung und Wiedergabe in jeglichem Medium und Format erlaubt, sofern Sie den/die ursprünglichen Autor(en) und die Quelle ordnungsgemäß nennen, einen Link zur Creative Commons Lizenz beifügen und angeben, ob Änderungen vorgenommen wurden.

Die in diesem Kapitel enthaltenen Bilder und sonstiges Drittmaterial unterliegen ebenfalls der genannten Creative Commons Lizenz, sofern sich aus der Abbildungslegende nichts anderes ergibt. Sofern das betreffende Material nicht unter der genannten Creative Commons Lizenz steht und die betreffende Handlung nicht nach gesetzlichen Vorschriften erlaubt ist, ist für die oben aufgeführten Weiterverwendungen des Materials die Einwilligung des jeweiligen Rechteinhabers einzuholen.

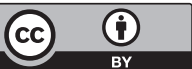




\section{Soziale Netzwerke und Behinderung - Zugang und Stabilisierung der Einbindung in den allgemeinen Arbeitsmarkt}

\section{Stefan Zapfel, Nancy Reims und Mathilde Niehaus}

\section{Überblick}

- Die arbeitsmarktbezogene Behinderungs- und Rehabilitationsforschung verzichtet bisher weitestgehend auf die Verwendung von Netzwerktheorien. Ihr Analyse- und Erklärungspotenzial wurde daher auf diesem Gebiet bei weitem noch nicht ausgeschöpft.

- Behinderungen stehen jedoch in engem Zusammenhang mit Genese und Stabilität von Netzwerken, die ihrerseits mit Zugang und Kontinuität von Beschäftigungsverhältnissen korrespondieren.

- Wohlfahrtsstaatliche Regelungen und Institutionen (z. B. Schwerbehindertenvertretung, Betriebliches Eingliederungsmanagement, Zentrale Auslands- und Fachvermittlung der Bundesagentur für Arbeit, Einrichtungen der beruflichen Rehabilitation) bieten Menschen mit Behinderung die Möglichkeit, Netzwerkkontakte (wieder) aufzubauen oder zu erweitern und Anschluss an den Arbeitsmarkt zu finden bzw. diesen aufrechtzuerhalten.

S. Zapfel $(\bowtie) \cdot$ N. Reims

Nürnberg, Deutschland

E-Mail: stefan.zapfel@ifes.uni-erlangen.de

N. Reims

E-Mail: nancy.reims@iab.de

M. Niehaus

Köln, Deutschland

E-Mail: mathilde.niehaus@uni-koeln.de 
- Inwiefern eine Eingliederung ins Erwerbssystem gelingt, hängt wesentlich von der Zugänglichkeit solcher Hilfen, dem Engagement sozialstaatlicher Akteure, deren Zusammenarbeit, der Teilnahmemotivation behinderter Menschen sowie dem individuellen Bildungshintergrund und sozialen Rückhalt ab.

\section{$1 \quad$ Einleitung}

Sozialwissenschaftliche Studien und amtliche Statistiken belegen immer wieder die vergleichsweise ungünstigen Beschäftigungsaussichten von Menschen mit Behinderung in Deutschland (Eichhorst et al. 2010, S. 7; Engels et al. 2017, S. 166 ff.; von Kardorff et al. 2013, S. 7 ff.; Pfaff 2012, S. 235 f.; Rauch 2005, S. 28 ff.). Menschen mit Behinderung profitieren deswegen auch in geringerem Umfang von den materiellen und latenten Funktionen, die Erwerbsarbeit leistet (Jahoda 1983). Zu den materiellen Funktionen gehören vor allem die Aneignung finanzieller Mittel und der Zugang zum Sozialversicherungssystem. Die latenten Funktionen umfassen u. a. vorgegebene zeitliche Strukturen, das Vorliegen einer gemeinschaftlichen Zielsetzung, die Zuweisung von sozialem und beruflichem Prestige, die Ausübung einer als sinnhaft erfahrenen Tätigkeit sowie die Herstellung und Aufrechterhaltung sozialer Kontakte. Zugangsdefizite zu den latenten Funktionen von Erwerbsarbeit zählen zu den wesentlichen Erklärungsfaktoren für die durchschnittlich schlechtere Gesundheitsverfassung von Arbeitslosen (Batinic et al. 2010; Jahoda 1982).

Angesichts der schwierigen Beschäftigungslage behinderter Menschen existiert in Deutschland eine Vielzahl arbeitsmarktpolitischer Maßnahmen, die das Ziel haben, die Erwerbssituation von Menschen mit Behinderung zu verbessern, $\mathrm{zu}$ erhalten oder zu stabilisieren. Neben allgemeinen Leistungen der Arbeitslosenversicherung im Bereich der Berufsberatung und Arbeitsvermittlung, die auch Menschen ohne Behinderung zustehen (Schröder et al. 2009, S. 13; Wuppinger und Rauch 2010, S. 8), gehören hierzu u. a. die Beschäftigungsquote von fünf Prozent ab einer Betriebsgröße von 20 Personen (§ 154 SGB IX, 2018), der erweiterte Kündigungsschutz ( $\$ 168-175$ SGB IX, 2018), Eingliederungszuschüsse, die Arbeitgebern gegebenenfalls für die Anstellung behinderter Menschen gewährt werden ( $\$ 88$ SGB III), Leistungen zur Teilhabe ( $\$ 50$ SGB IX, 2018), die Bereitstellung von Arbeitsassistenzen (§ 185 SGB IX), Unterstützte 
Beschäftigung ( 55 SGB IX, 2018), die Probebeschäftigung ( $\$ 46$ SGB III), das betriebliche Eingliederungsmanagement (BEM; § 167 SGB IX, 2018) oder auch Bildungsmaßnahmen der beruflichen Rehabilitation (Niehaus et al. 2012, S. 50 ff.; Weber und Weber 2015, S. 265 f.). Letztgenannte werden danach unterschieden, ob sie sich speziell an junge Berufsanfänger (Ersteingliederung) (Reims et al. 2016, S. 1) oder berufserfahrene Menschen mit Behinderung (Wiedereingliederung) richten (Reims et al. 2017).

Manche dieser Leistungen erfordern das Vorliegen einer Behinderung nach $\S 2$ SGB IX (2018), der auch diesem Beitrag als Definitionsgrundlage dient und nach der Menschen dann als behindert gelten, wenn sie ,[...] körperliche, seelische, geistige oder Sinnesbeeinträchtigungen haben, die sie in Wechselwirkung mit einstellungs- und umweltbedingten Barrieren an der gleichberechtigten Teilhabe an der Gesellschaft mit hoher Wahrscheinlichkeit länger als sechs Monate hindern können“ (§ 2 SGB IX, 2018). Andere Leistungen setzen eine amtlich anerkannte Schwerbehinderung (oder rechtliche Gleichstellung) voraus (SBG IX, Teil 3, $\S 151 \mathrm{ff}$., 2018), obwohl der amtlich verbürgte Behinderungsgrad nur bedingt für das Ausmaß der gesellschaftlichen Teilhabeeinschränkung aussagekräftig ist (Benitez-Silva et al. 2004; Rohrmann 2012, S. 475).

Die Bereitstellung wohlfahrtsstaatlicher Leistungen kann neben der Erzeugung von Inaktivitätsfallen (Famira-Mühlberger et al. 2015, S. 18) dazu beitragen, die unter Arbeitslosen in der Regel stärker in Mitleidenschaft gezogene Widerstandsfähigkeit gegen Erkrankungen zu erhöhen, geeignete Coping-Strategien zu entwickeln, wenn bereits eine Behinderung oder Erkrankung vorliegt (Potts 2005), und den Zugang zu Erwerbsarbeit zu erleichtern (Granovetter 1973). Soziale Netzwerke von Personen, Gruppen und Institutionen (Borgatti et al. 2018, S. 2) können ähnliche Wirkungen entfalten, aber trotz ihrer Bedeutung für Gesundheit, Bildung und Beschäftigung werden sie in der behinderungsbezogenen Gesundheits- und Rehabilitationsforschung bisher noch relativ selten berücksichtigt. Das gilt auch für die Methoden und Theorien der Netzwerkforschung (von Kardorff 2010).

Ziel des Beitrags ist es, diese Lücke in der Fachdiskussion einzugrenzen, indem er theoretisch und empirisch Ansatzpunkte für die Anwendung von Netzwerk- und Sozialkapitalansätzen auf dem Gebiet der Arbeitsmarkteingliederung behinderter Menschen aufzeigt und kritisch die bestehenden Forschungsdefizite in diesem Feld offenlegt. Im Fokus stehen dabei formale, informelle und institutionelle Beziehungsgeflechte, die aus ihnen resultierenden Unterstützungskapazitäten sowie mögliche Netzwerkänderungen durch einen Behinderungseintritt und die Auswirkungen, die solche Netzwerktransformationen auf die Beschäftigungssituation und die Erwerbschancen haben. 


\section{$2 \quad$ Behinderung und Arbeitsmarktintegration}

Für Deutschland wurden die vergleichsweise ungünstigen Bildungs- und Beschäftigungschancen von Menschen mit Behinderung bereits vielfach belegt (Eichhorst et al. 2010; Engels et al. 2017; Pfaff 2012; Rauch 2005; von Kardorff und Ohlbrecht 2013). Behinderte Menschen erreichen in der Bundesrepublik ein insgesamt niedrigeres Bildungsniveau als Personen, die keine Behinderung haben. Das gilt speziell für diejenigen, die schon frühzeitig im Förderschulbereich segregiert werden, der seinerseits häufig keinen Hauptschulabschluss bereithält (Klemm 2015). Jugendliche in Förderschulen verlassen deshalb ihre Bildungseinrichtung oft ohne Hauptschulabschluss, wodurch sich die Chancen auf einen Ausbildungsplatz entsprechend reduzieren (Niehaus et al. 2012). Sofern sie dennoch Zugang zum Ausbildungssystem erhalten, werden sie in der Regel weiterhin in Sonderbereichen mit geringer betrieblicher Anbindung (weiter-) qualifiziert (Reims et al. 2016). Im Verbund mit einer Reihe weiterer, vor allem stigmatisierungsbedingter Faktoren (Einstellungsvorbehalte auf Arbeitgeberseite, Verdacht auf Leistungsminderung, Angst vor hohen Fehlzeiten, erschwerte Kündigung, aber auch Mobilitätseinschränkungen u.ä.m.) (z. B. Niehaus und Bauer 2013, S. 12 f.; von Kardorff et al. 2013, S. 37; Rauch 2005, S. 32; Wansing und Westphal 2014, S. 41), schmälert diese bildungsinstitutionelle Streckenführung die Beschäftigungsaussichten, die Menschen mit Behinderung in Deutschland haben. Diese dokumentieren sich in niedrigeren Erwerbs- und höheren Arbeitslosenquoten als bei Menschen ohne Behinderung, selbst in Phasen wirtschaftlichen Aufschwungs (Bundesagentur für Arbeit 2018; Niehaus und Bauer 2013, S. 32), längeren Arbeitslosigkeitsepisoden, geringeren Löhnen und der häufigeren Besetzung von Berufspositionen, die sich unter dem erreichten Qualifikationsniveau befinden (Weller 2017).

Diverse arbeitsmarktpolitische Instrumente haben die Aufgabe, Benachteiligungen behinderter Menschen auf dem Arbeitsmarkt zu bekämpfen und zu kompensieren. Hierzu gehören alle schon genannten Maßnahmen, die in Bezug auf das Verhältnis zwischen Arbeitgebern und Menschen mit Behinderung entweder eine beziehungsgenerierende oder eine beziehungsstabilisierende Funktion übernehmen (sollen) und damit Netzwerkrelevanz haben. Unter den speziell auf Menschen mit Behinderung zugeschnittenen Instrumenten wirken die Beschäftigungsquote ab 20 Mitarbeitern, die Probebeschäftigung sowie Leistungen der beruflichen Rehabilitation im Wesentlichen beziehungsgenerierend, während der erweiterte Kündigungsschutz und das Betriebliche Eingliederungsmanagement in erster Linie beziehungsfestigend sind. Arbeitsplatzanpassungen, 
die Bereitstellung von Arbeitsassistenzen und Unterstützte Beschäftigung fördern beide Bereiche, indem sie sowohl die Beschäftigungsaufnahme als auch die Verstetigung von Arbeitsverhältnissen erleichtern.

\section{Soziale Netzwerke von Menschen mit Behinderung}

Verschiedene Studien, darunter auch der Teilhabebericht der Bundesregierung über Lebenslagen von Menschen mit Beeinträchtigungen, zeigen, dass behinderte Menschen häufig weniger soziale Kontakte aufweisen als andere Gruppen (Engels et al. 2017; Forrester-Jones et al. 2006; Morgan et al. 1984; Pfaff 2012, S. 234; Schröttle et al. 2014, S. 24). Sie haben kleinere Netzwerke und gehen seltener neue lebensweltliche Beziehungen ein (Forrester-Jones et al. 2006; Schröttle et al. 2014). Darüber hinaus kann der Eintritt einer Behinderung von einem Verlust an Beziehungen und Netzwerken begleitet werden (von Kardorff 2010). Er kann einerseits dazu führen, dass die bisherige Tätigkeit im Erwerbssystem nicht mehr ausgeübt werden kann und sich parallel dazu die bisherigen Kontakte in die Arbeitswelt lockern oder auflösen (Lang 2003, S. 181). Andererseits kann ein Behinderungseintritt auf lebensweltliche Beziehungen erodierend wirken, zumal er unter Umständen neue Belastungen auch für den sozialen Nahkreis mit sich bringt und bestehende Hilfebedarfe partiell die in der Privatsphäre verfügbaren Unterstützungskapazitäten übersteigen (von Kardorff 2010). Gefährdet sind vor allem bereits losere, emotional weniger stark unterfütterte Bindungen. Gleichzeitig kann der Aufbau neuer Kontakte aus Barrieregründen oder stigmatisierungsbedingt erschwert sein (Pfaff 2012; Schröttle et al. 2013, S. 24), sodass das soziale Isolationsrisiko steigt (Morgan et al. 1984, S. 495), mit dem aber wiederum die Zugangschancen zu professionellen Unterstützungsangeboten sinken (von Kardorff 2010). Frauen mit Schwerbehinderung sind hiervon besonders bedroht ${ }^{1}$ (Niehaus 1993; Niehaus und Bauer 2013).

Allerdings kommt es wegen einer Behinderung bei weitem nicht immer $\mathrm{zu}$ einer Auflösung von lebensweltlichen Beziehungen. Häufig bleibt es bei einer Änderung in den Beziehungsverhältnissen, die jedoch gravierend sein

\footnotetext{
${ }^{1}$ In der behinderungsbezogenen Inklusions- und Teilhabeforschung werden kumulative, an unterschiedliche soziale Merkmale gebundene Benachteiligungen intensiv unter dem Begriff Intersektionalität behandelt. Sie meint eine Exklusionswirkung, die aus der negativen Bewertung mehrerer personenbezogener Merkmale wie Geschlecht, Behinderung oder ethnischer Zugehörigkeit hervorgeht (Weinbach 2014).
} 
können. Solche Transformationen reichen von Verschiebungen in der familialen Arbeitsteilung und der Umstellung von Routinen und Zeitplänen in der Alltagsbewältigung über neue soziale Anforderungen an Mobilität und Affektivität bis hin zu erweiterten finanziellen Bedarfen (von Kardorff 2010). Netzwerkschrumpfungen gehen manchmal mit einer höheren Dichte des verbleibenden Netzwerks einher, wie empirische Arbeiten über kognitiv beeinträchtigte und schwerbehinderte Menschen zeigen (Forrester-Jones et al. 2006).

Mit den bisherigen Ausführungen ist bereits angedeutet, dass Netzwerke behinderter Menschen in Art und Qualität erheblich divergieren und mitunter spezifischen Charakter haben (Engels et al. 2017). Unterschiede bestehen etwa im Hinblick auf den Institutionalisierungsgrad (informell oder formal), ihre gesellschaftliche Verortung (z. B. Lebens- oder Arbeitswelt), den Entstehungskontext (etwa vor oder nach Behinderungseintritt oder Entstehungszweck), die Funktion (emotional, instrumental, informationsbezogen) oder die jeweiligen Unterstützungskapazitäten (Chronister et al. 2008).

Informelle Netzwerke bieten in der Regel informelle Hilfen. Sie ergeben sich einerseits aus der lebensweltlichen Einbettung in Familien, Freundschafts- und Bekanntenkreisen und entstehen großteils außerhalb von Erwerbszusammenhängen. Andererseits gehen informelle Beziehungen auch aus dem Erwerbssystem hervor und erzeugen soziale Bindungen zu Vorgesetzten, Untergebenen und Kollegen in unterschiedlicher Intensität (Knox und Parmenter 1993). Die Beziehungen können sowohl aus vertikalen Strukturen, die sich als hierarchische Struktur und somit zwischen den Mitarbeitern und ihren direkten Vorgesetzten verläuft, beschreiben lassen, als auch aus der horizontalen Struktur, welche die sozialen Beziehungen der Mitarbeiter untereinander beschreibt, entstehen (Badura 2008). Aus beiden Bereichen ergeben sich Ressourcen sozialer Unterstützung, die auch die Eingliederung in den Arbeitsmarkt und Möglichkeiten gesellschaftlicher Teilhabe begünstigen können (Granovetter 1995, S. 48). Allerdings kann ein mit Behinderung in Zusammenhang stehender erhöhter Unterstützungsbedarf zugleich neue (informelle) Abhängigkeiten erzeugen, die dem Selbstbestimmungsversprechen für Menschen mit Behinderung, wie es etwa in der UN-Behindertenrechtskonvention (UN-BRK), im Behindertengleichstellungsgesetz oder im Bundesteilhabegesetz zum Ausdruck kommt (vgl. z. B. Kastl 2017, S. 229; Lewicki 2014, S. 12; Welti 2005, S. 23 ff.), zuwiderlaufen (Bundesministerium für Arbeit und Soziales [BMAS] 2011, S. 53; Schröttle et al. 2013, S. 75).

Neben informellen Beziehungen sind auch formale, zum Teil rechtlich vorgeschriebene und regulierte Beziehungen zum Arbeitgeber bzw. im Betrieb (etwa durch das Betriebliche Eingliederungsmanagement oder die Schwerbehindertenvertretung (SBV)) wesentlich für den Zugang und die Aufrechterhaltung von 
Beschäftigungsverhältnissen. Gleiches gilt für Verbände und andere Interessensvertretungen von Menschen mit Behinderung oder Einrichtungen der beruflichen Rehabilitation (Bundesagentur für Arbeit, Rentenversicherung, Berufsförderungswerke usw.), die Beschäftigungsmöglichkeiten für behinderte Menschen schaffen, stärken oder sichern sollen. Anders als in lebensweltlichen Zusammenhängen ist der Eintritt einer Behinderung dort kein Ereignis, das das Risiko von Beziehungsverlusten erhöht, sondern im Gegenteil gerade ausschlaggebend für den Aufbau von Kontakten zu solchen Einrichtungen und Gruppen, die Hilfe bieten (vgl. Borgatti et al. 2018, S. 4).

Eine der normativen Grundanforderungen, die in Deutschland sowohl in Bezug auf informelle als auch im Hinblick auf formale Unterstützung zur Aufnahme und Aufrechterhaltung von Beschäftigungsverhältnissen behinderter Menschen gestellt werden, besteht hierbei darin, den Wünschen und Ansprüchen der Unterstützungsempfänger Rechnung zu tragen und autoritäre Abhängigkeiten zu vermeiden (Chronister et al. 2008).

\section{Die Rolle sozialer Netzwerke bei der Arbeitsmarktintegration von Menschen mit Behinderung}

Soziale Beziehungen und Netzwerke sind sowohl informell als auch institutionell für die Eingliederung in den Arbeitsmarkt von Bedeutung (Brucker 2015). Das gilt auch für Menschen mit Behinderung. Zugang und Nutzung sind dabei sehr unterschiedlich. Inwiefern die beiden Varianten auf die Einbindung behinderter Menschen ins Erwerbssystem Einfluss nehmen und welche Rolle sie sozial- und arbeitsmarktpolitisch spielen, wird im Folgenden erläutert.

\subsection{Informelle Beziehungen zur Förderung der Teilhabe am Arbeitsleben}

Die Arbeitsmarktforschung hat wiederholt auf die Bedeutung lebensweltlicher und beruflicher Beziehungen und Netzwerke für den Zugang zu Erwerbsarbeit und Karriere hingewiesen (Granovetter 1973, S. 1371 ff.; Granovetter 1995, S. 4 ff.). Dabei wird meist auf die „Unvollkommenheit“ von Arbeitsmärkten Bezug genommen (z. B. Lin 2009, S. 20): Entgegen den verbreiteten Annahmen der neoklassischen Arbeitsmarkttheorie besäßen weder Arbeitgeber noch (potenzielle) Arbeitnehmer alle relevanten Informationen, die bei der Stellen- bzw. 
Bewerbersuche benötigt werden (Hinz und Abraham 2008, S. 51 ff.). Netzwerke übernähmen in diesen Zusammenhang die Funktion, bestehende Informationslücken informell zu schließen. Da sich aber Zugang und Qualität der Netzwerke voneinander unterschieden, seien die Möglichkeiten hierfür ungleich verteilt. Die Beschäftigungschancen und Karriereaussichten gestalteten sich umso besser, je größer und heterogener die Netzwerke etwa im Hinblick auf Berufszugehörigkeiten oder den sozialen Status seien (Diewald und Sattler 2010; Granovetter 1995, S. 12 ff.). Mit Größe und divergenter Zusammensetzung steige die verfügbare Informationsvielfalt, jedoch nehme gleichzeitig die Zahl schwacher sozialer Bindungen im Netzwerk zu; schwache Bindungen kämen dem arbeitsmarktbezogenen Informationsgehalt zugute, enge Bindungen begünstigten hingegen Unterstützungsmöglichkeiten bei der Alltagsbewältigung und Coping (Potts 2005).

Nun stehen Gesundheit, Erwerbsarbeit, Behinderung, gesellschaftliche Teilhabe sowie die Verfügbarkeit und Einbindung in Netzwerke miteinander in engem Zusammenhang (Niehaus 1993). Da Menschen mit Behinderung in der Regel kleinere Netzwerke mit größerer Dichte aufweisen und seltener als in anderen Gruppen neue Kontakte dazukommen, bieten ihnen ihre vorhandenen Beziehungen weniger Gelegenheiten zur (Re-)Integration ins Erwerbssystem. Hinzu kommt im Falle einer im Lebenslauf auftretenden Behinderung bei gleichzeitigem Arbeitsplatzverlust, dass bestehende Kontakte ins Arbeitsleben verloren gehen und damit wichtige Informations- und Unterstützungskanäle entfallen, die den Wiedereintritt in den Arbeitsmarkt erleichtern könnten. Informelle Beziehungen helfen demnach Menschen mit Behinderung insgesamt in geringerem Umfang beim Arbeitsmarktzugang und Karrierewegen als es bei nicht-behinderten Menschen der Fall ist. Anders gestaltet sich die Situation bei institutionellen Beziehungen und Netzwerken.

\subsection{Institutionelle Beziehungen zur Förderung der Teilhabe am Arbeitsleben}

Institutionelle Netzwerke und Beziehungen von und für Menschen mit Behinderung sind in Deutschland vielfältig und wurden zum Teil bewusst eingerichtet, um behinderte Menschen bei der Eingliederung in den Arbeitsmarkt zu unterstützen. Andere wurden zu nicht-arbeitsbezogenen Zwecken geschaffen, helfen dem Personenkreis aber nichtsdestoweniger, Zugang ins Erwerbsleben zu finden oder bestehende Beschäftigungsverhältnisse zu stabilisieren. 
Von besonderer Bedeutung sind in diesem Zusammenhang Interessenverbände und Vereine behinderter Menschen, wohlfahrtsstaatliche Bestimmungen, die die Einbindung von schwerbehinderten Menschen im Betrieb betreffen (etwa Schwerbehindertenvertretung oder Betriebliches Eingliederungsmanagement), und sozialstaatliche Einrichtungen der beruflichen Rehabilitation und Arbeitsvermittlung, die speziell Menschen mit Behinderung bei der Arbeitsmarkteinbindung helfen. Letztgenannte Institutionen nutzen gezielt professionelle Netzwerke, um entsprechende Programme und Maßnahmen der Arbeitsmarktintegration umzusetzen.

\subsubsection{Interessenverbände und Vereine}

Behindertenorganisationen sind zentrale Akteure der Interessensvertretung von Menschen mit Behinderung und bieten ihren Mitgliedern in unterschiedlicher Weise Unterstützung in Alltag und Lebensführung. Sie sind nicht speziell auf die Eingliederung behinderter Menschen in den Arbeitsmarkt gerichtet, fördern aber durch Beratungsangebote und die Verbreitung von Stellenanzeigen beispielsweise per Newsletter die Beschäftigungsaufnahme ihrer Mitglieder.

Neben den etablierten Verbänden gibt es diverse Selbsthilfezusammenschlüsse für bestimmte Behinderungsarten und Erkrankungen, die sich in ihrem Organisationsgrad erheblich voneinander unterscheiden. Die BAG Selbsthilfe ist die Dachorganisation von 113 Organisationen behinderter und chronisch kranker Menschen und ihren Angehörigen. Sie vertritt als bundesweiter Zusammenschluss unabhängig von parteipolitischen oder konfessionellen Bindungen die Interessen der Gesamtheit der behinderten und chronisch kranken Menschen als freier Verband. Unter ihrem Dach haben sich auch die in den 1990er Jahren gegründeten Netzwerke von und für Frauen mit Behinderung organisiert, die den spezifischen Belangen von Mädchen und Frauen mit Behinderung mehr Gehör verschaffen wollen (Niehaus 2001). Ihre Aktivitäten und Forderungen sind u. a. in die Gesetzgebung zum Neunten Sozialgesetzbuch eingeflossen, unterstützen ihre Mitglieder also nicht nur individuell, sondern auch politisch durch Einflussnahme auf die Bundes- und Landesgesetzgebung.

Um die politischen Interessen behinderter Menschen durchzusetzen, streben Behindertenorganisationen in Deutschland Konsens- und Kompromissbildungen an. Dabei gehen sie Bündnisse mit Gewerkschaften und Verbänden der Freien Wohlfahrtspflege ein, mit denen sie ihre Durchsetzungschancen zu verbessern suchen (Hammerschmidt 1992). Die Betätigungsfelder sind unterschiedlich und betreffen neben Bildung auch die politische Teilhabe, Fragen der sozialen Sicherung, Arbeit und Beschäftigung u.a.m. (Engels et al. 2017). 
Allerdings wirken Behindertenorganisationen in zweierlei Weise selektiv (Bengtsson und Datta Gupta 2017): Zum einen sind sie häufig auf bestimmte Gruppen von Menschen mit Behinderung und chronischen Erkrankungen ausgerichtet, zum anderen sind es vorzugsweise höher gebildete Menschen mit Behinderung, die in diesen Verbänden organisiert sind und Zugang zu Informationen und Hilfen erhalten. So wichtig die Behindertenorganisationen also für die Gestaltung der Sozialpolitik und den Beschäftigungszugang in der Bundesrepublik auch sind, ihr Wirkungsradius sollte in einer objektiven Analyse nicht überschätzt werden.

\subsubsection{Schwerbehindertenvertretung (SBV)}

Die SBV ist eine gewählte Interessenvertretung der schwerbehinderten und ihnen gleichgestellten Menschen in Betrieben der Privatwirtschaft und Verwaltungen des öffentlichen Dienstes und in Deutschland fester Bestandteil des betrieblich-formalen Struktur- und Beziehungsgefüges. Sie hat Einfluss auf die betriebliche Beschäftigungskontinuität behinderter Menschen und deren soziale Einbettung in diesen Organisationen. Die Grundlagen der SBV-Arbeit sind in $\S \S$ 178 ff. SGB IX verankert und legen konkrete Rechte und Pflichten im Betriebsgeschehen fest. Die SBV ist auch für die Unterstützung von Beschäftigten zuständig, die nicht schwerbehindert, jedoch von Behinderung bedroht sind, etwa chronisch kranke Personen.

Die SBV unterstützt mit ihrer Expertise auf dem Gebiet betrieblicher Teilhabe bei Behinderung und chronischer Erkrankung den Betriebsrat und den Arbeitgeber bei Fragen der (Wieder-)Eingliederung. Sie hat durch ihre umfangreichen sozialrechtlichen Kenntnisse, die Bereitstellung vertrauensvoller Ansprechpartner, die Übernahme koordinierender Vermittlungsaufgaben und die proaktive Anbahnung betrieblicher Gesundheitsmaßnahmen eine Lotsenfunktion bei Fragen der betrieblichen Inklusion und Prävention (Kohl und Niehaus 2014). Informell trägt sie dazu bei, mögliche Arbeitgebervorbehalte bei der Einstellung behinderter Menschen (Verdacht auf verminderte Leistungsfähigkeit, auf Mobilitäts- und Flexibilitätseinschränkungen u. Ä.) abzubauen.

Die SBV fördert durch persönliche Beratung und Belegschaftsnähe auch das Vertrauensverhältnis zwischen den verschiedenen Akteuren im Betrieb (behinderte und chronisch kranke Menschen, Betriebsrat, Arbeitgeber, Betriebsarzt) (Deutsche Gesetzliche Unfallversicherung e. V. [DGUV] 2014). Vernetzung, Kooperation und Vertrauen zwischen den genannten Akteuren und zu den zuständigen Sozialversicherungsträgern sind zentrale Voraussetzungen für 
die erfolgreiche Durchführung des BEM und eine gelungene betriebliche Teilhabe (Niehaus und Vater 2014). Die Schwerbehindertenvertretungen sind somit wichtige Netzwerkpartner an der Schnittstelle zwischen behinderten Mitarbeitern, betrieblichen Organen (z. B. Betriebsrat), Arbeitgeberbeauftragten und externen Akteuren, zu denen auch Sozialversicherungsträger wie die Rentenversicherung oder die Krankenkassen gehören.

Durch die Unterzeichnung der Behindertenrechtskonvention der Vereinten Nationen (UN-BRK 2008) hat sich Deutschland mit der Ratifizierung 2008 dazu verpflichtet, die volle und wirksame Teilhabe von Menschen mit Behinderungen in allen gesellschaftlichen Bereichen herzustellen. Die entsprechend der UN-BRK definierte Zielvision eines inklusiven Arbeitsmarktes erweitert auch die Aufgaben der Vertrauenspersonen der schwerbehinderten Beschäftigten. Diese gehen zunehmend über Kenntnisse arbeitsrechtlicher Vorgaben hinaus und erstrecken sich immer mehr auch auf querschnittliche Beratungsfunktionen, die Vernetzung und Wissensmanagement in sehr unterschiedlichen Bereichen erfordern (Kohl et al. 2015). Dadurch stehen die Schwerbehindertenvertretungen in der betrieblichen Prävention und Inklusion vor neuen Herausforderungen, die sich u. a. aus großräumigen gesellschaftlichen Veränderungen wie Digitalisierung und demografischem Wandel ergeben. Das Tätigkeitsspektrum der SBV sowie innerbetriebliche und externe Allianzen, die zum Erhalt der Beschäftigungsfähigkeit und Teilhabe beitragen können, sind Mittelpunkt der aktuellen Diskussion. Netzwerkanalytische Untersuchungen gibt es hierzu bisher nicht. Diese könnten jedoch klären, ob und wie die SBV Menschen mit Behinderung unter diesen neuen Voraussetzungen bei der Eingliederung unterstützt und welche Rolle Vernetzungen der SBV in diesem Zusammenhang spielen.

\subsubsection{Betriebliches Eingliederungsmanagement (BEM)}

Mit dem BEM nach $\S 167$ Abs. 2 SGB IX (2018) hat der Gesetzgeber eine Vorschrift geschaffen, die Arbeitgeber seit 2004 dazu verpflichtet, bei Beschäftigten, die innerhalb eines Jahres insgesamt länger als sechs Wochen erkrankt sind, zu klären, inwiefern die Arbeitsunfähigkeit überwunden, erneuter Arbeitsunfähigkeit vorgebeugt und der Arbeitsplatz erhalten werden kann. Gemeinsam mit der zuständigen Interessenvertretung - bei Vorliegen einer Schwerbehinderung mit der SBV - und soweit erforderlich mithilfe des Werk- oder Betriebsarztes, wird geprüft, welche Maßnahmen hierfür zu ergreifen sind. Weitere in das BEM einbezogene Akteure können die Rehabilitationsträger und gegebenenfalls das Integrationsamt sein. Die Teilnahme der Arbeitnehmer am BEM ist freiwillig. 
Kleinere und mittelständische Unternehmen setzen aus Mangel an Ressourcen und an betrieblichen Stellenalternativen seltener das BEM um als gröBere Betriebe (Niehaus et al. 2008). $\mathrm{Zu}$ regionalen Anwendungsdifferenzen, verwendeten BEM-Standards und zur Rolle von Netzwerken beim Zugang zum BEM liegen bisher keine repräsentativen Forschungsbefunde vor.

\subsubsection{Zentrale Auslands- und Fachvermittlung und Peer- Beratung}

Die Zentrale Auslands- und Fachvermittlung der Bundesagentur für Arbeit (ZAV) unterstützt sowohl Akademiker mit Schwerbehinderung bei der Suche nach einer qualifikationsadäquaten Beschäftigung als auch Arbeitgeber bei der Stellenbesetzung mit schwerbehinderten Hochschulabsolventen (Deutsches Studentenwerk 2013, S. 201). Sie übernimmt als hierfür eingerichtete Organisation eine wichtige Vermittlungsfunktion schwerbehinderter Menschen mit Hochschulabschluss in Beschäftigung und versucht zu diesem Zweck gezielt Kontakte mit diesem Personenkreis und zwischen schwerbehinderten Menschen und Arbeitgebern herzustellen.

Parallel dazu werden Selbsthilfeaktivitäten bei Fragen der beruflichen Teilhabe von Menschen mit Behinderung zunehmend unter der Perspektive des Stellenwertes von Peer-Beratungen (Beratung von geschulten Betroffenen für Betroffene) diskutiert. Hintergrund dafür ist, dass Peer-Beratung als Bestandteil professioneller Beratungsangebote durch Anhebung der Reha-Motivation und den stärkeren Selbstbestimmungsbezug in der Entscheidungsfindung nachweislich zu einer verbesserten beruflichen Teilhabe beitragen kann. In Deutschland werden Forderungen nach mehr Peer-Beratung zur beruflichen Teilhabe nicht zuletzt durch Aktionspläne zur Umsetzung der UN-BRK der Bundesländer und der Gesetzlichen Unfallversicherung gestützt, in denen Peer-Counseling bereits als Maßnahme aufgenommen ist (Niehaus und Saupe-Heide 2012).

Im Bundesteilhabegesetz kommt seit 2018 der Peer-to-Peer-Beratung als ergänzende unabhängige Teilhabeberatung besondere Bedeutung zu. Die gesetzliche Verankerung fußt u. a. auf den Erkenntnissen der wissenschaftlichen Fachgruppe RehaFutur, die hervorhebt, dass berufliche Teilhabechancen verbessert werden, wenn die Selbstbestimmung und Selbstverantwortung von Menschen mit Behinderung aktiv genutzt und durch entsprechende Strukturen gestärkt werden (Riedel et al. 2009). Ob die Peer-to-Peer-Beratung als qualitatives Merkmal von Netzwerkstrukturen von Menschen mit Behinderung bessere Handlungsmöglichkeiten bereithält als eine Beratung durch nicht-behinderte Personen oder das Fehlen einer solchen Beratung, bleibt für die Forschung noch zu klären. 


\subsubsection{Rehabilitationsspezifische Institutionen}

Eine weitere Art sozialer Netze behinderter Menschen ist rehabilitationsspezifisch und entspringt den institutionellen und professionalisierten Unterstützungsformen, die dazu dienen, die Wiedereingliederung behinderter Menschen in den Arbeitsmarkt zu erleichtern oder zu verfestigen. In diesem Zusammenhang werden (ähnlich wie im Fall der ZAV) nach sozialrechtlichen und verwaltungsspezifischen Vorgaben bewusst formale Beziehungen zwischen Menschen mit Behinderung auf der einen Seite und Rehabilitationsberatung, Arbeitsvermittlung, Fallmanagement und potenziellen Arbeitgebern auf der anderen geknüpft. Die Rehabilitationsträger (Bundesagentur für Arbeit, Rentenversicherung, Gesetzliche Unfallversicherung etc.), Integrationsfachdienste und Leistungserbringer stellen hierbei durch (Fremd-)Investitionen in Sozialkapital (Bourdieu 2005, S. 65) Netzwerke her, die Menschen mit Behinderung dabei helfen sollen, wieder in Beschäftigung zu kommen oder in Erwerbsarbeit zu bleiben. Absicht der hieran professionell beteiligten Akteure ist es, eine Brückenfunktion (,,bridging“) (Putnam 2000, S. 411) zu übernehmen, mit deren Hilfe behinderten Menschen eingliederungsrelevante Netzwerkkontakte zur Verfügung gestellt werden, die bis ins Beschäftigungssystem hineinreichen (von Kardorff 2010).

Der Zugang zu beruflicher Rehabilitation und den dort vorhandenen Netzwerkstrukturen ist allerdings beschränkt und steht nur denjenigen offen, die einen förmlichen Antrag auf Leistungen zur Teilhabe am Arbeitsleben (LTA) gestellt haben und auch als Rehabilitand anerkannt wurden (Reims et al. 2017). Die Maßnahmeplanung erfolgt in enger Abstimmung zwischen Leistungserbringern, Kostenträgern und Rehabilitanden. Die Leistungserbringer von Maßnahmen der beruflichen Rehabilitation sind flexibel in der Maßnahmegestaltung und zeichnen sich durch eine breite Palette an Unterstützungs- und Netzwerkstrukturen aus. Sie bieten unterschiedliche Berufsbildungsmöglichkeiten an, sind teilweise auf bestimmte Behinderungsarten spezialisiert, stellen reha-begleitend in unterschiedlichen Ausprägungen sozialpädagogische oder medizinische bzw. therapeutische Zusatzangebote bereit, ermöglichen oft eine stationäre Unterbringung und sind in vielfältiger Weise mit Betrieben und potenziellen Arbeitgebern vernetzt. Aus den Unterschieden in der Netzwerkstruktur der Leistungserbringer können sich auch Divergenzen im Reha-Erfolg ergeben. So erscheinen kleinere, zentral organisierte und in Bezug auf das Arsenal an Leistungserbringern diversifizierte Netze integrationsförderlicher als größere, dezentral organisierte und homogene Netzwerke, während die Betreuungskontinuität eher in letztgenannter Konstellation gewährleistet werden kann (Lorant et al. 2017). 
Nach Beendigung der Qualifizierungsphase folgt häufig eine Übergangsbetreuung. Sie dient dazu, den Bewerbungsprozess zu begleiten und die Integration in den neuen Beruf zu erleichtern. Liegt eine Schwerbehinderung (oder eine Gleichstellung) vor, kann auch der Integrationsfachdienst hinzugezogen werden, der sowohl den Betrieben als auch Menschen mit Behinderung beratend und unterstützend zur Seite steht (von Kardorff 2010).

Es gibt also in Deutschland bereits ein breites institutionelles und professionelles Netzwerk, an dem unterschiedliche Akteure beteiligt sind. Dennoch werden nach wie vor erweiterte Vernetzungsbedarfe in der Leistungserbringerlandschaft angemahnt, mit deren Behebung fortbestehende Schnittstellenprobleme beseitigt, die Zugänglichkeit zu den Leistungen verbessert, Koordinationslücken geschlossen, Versorgungskosten reduziert und Wiedereingliederungserfolge erhöht werden sollen (von Kardorff 2010).

Im Prozess der beruflichen Rehabilitation sind nicht nur institutionelle Netzwerke von Bedeutung. Häufig spielen auch informelle, lebensweltliche Beziehungen der Rehabilitanden eine wichtige Rolle, die in der Maßnahmeplanung berücksichtigt werden (Chronister et al. 2008). Hintergrund hierfür ist einerseits die prominent in der International Classification of Functioning, Disability and Health (ICF) entwickelte Vorgabe, den personenbezogenen Gesamtzusammenhang bei der Planung der beruflichen Re-Integration zu berücksichtigen (Escorpizo et al. 2011), andererseits der in zahlreichen Studien belegte Umstand, dass der Rückhalt und der Kontakt mit Familie und Freunden während der Teilnahme an Teilhabeleistungen am Arbeitsleben das Rehabilitationsergebnis maßgeblich beeinflussen (Chronister et al. 2008; McKenna und Power 2000; Potts 2005). Der Effekt kann sowohl positiv als auch negativ sein, je nachdem, ob soziale Unterstützung und Rückhalt gegeben sind oder fehlen (Zapfel 2015, S. 242).

\section{$5 \quad$ Fazit, Desiderate}

Mit dem Eintritt einer Behinderung steigt das Risiko, informelle und Teile der formalen Netzwerke zu verlieren, gleichzeitig aber auch die Chance, andere - vor allem professionelle - Netzwerkpartner zu gewinnen. Wohlfahrtsstaatliche Regelungen und Institutionen wie die SBV, das BEM, die ZAV oder Einrichtungen der beruflichen Rehabilitation bieten Menschen mit Behinderung die Möglichkeit, Netzwerkkontakte neu aufzubauen oder zu erweitern und wieder Anschluss an den Arbeitsmarkt zu finden bzw. diesen aufrechtzuerhalten. Inwiefern das und eine erfolgreiche Eingliederung ins Erwerbssystem gelingt, 
hängt von verschiedenen Faktoren - vor allem der formalen Zugänglichkeit, dem Engagement sozialstaatlicher Akteure und ihrer Zusammenarbeit, der Inklusionsbereitschaft der Arbeitgeber, der Teilnahmemotivation behinderter Menschen, deren Bildungshintergrund sowie dem lebensweltlichen Rückhalt - ab.

In der arbeitsmarktbezogenen Behinderungs- und Rehabilitationsforschung wird bisher weitestgehend auf die Anwendung von Netzwerkansätzen verzichtet. Das gilt sowohl in Bezug auf informelle Zugangswege zum Arbeitsmarkt als auch im Hinblick auf die Rolle von Interessenverbänden behinderter Menschen, innerbetriebliche Organisationseinheiten und Abläufe (wie SBV und BEM), die Bedeutung der ZAV, Angebote der Peer-to-Peer-Beratung und Einrichtungen der beruflichen Rehabilitation. Aufgabe dieses Beitrags ist es, mögliche Ansatzpunkte hierfür aufzuzeigen, dabei relevantes empirisches Material miteinzubeziehen, entsprechende Forschungslücken zu verdeutlichen und Anregungen für künftige Forschungsaktivitäten auf diesem Gebiet zu geben.

\section{Leseempfehlungen}

Chronister, J., Chou, C. C., Frain, M. \& da Silva Cardoso, E. (2008). The relationship between social support and rehabilitation related outcomes: A meta-analysis. Journal of Rehabilitation, 74 (2), S. 16-32. https://www. questia.com/library/journal/1G1-182034960/the-relationship-between-social-support-and-rehabilitation. Zugegriffen: 04. April 2018. Der Artikel behandelt die Rolle sozialer Unterstützung zunächst generell in Bezug auf Erkrankungsrisiken und im weiteren Verlauf hinsichtlich der Erfolgsaussichten rehabilitativer Maßnahmen. Er gibt einen ausführlichen Überblick über psychologische, sozial- und gesundheitswissenschaftliche Veröffentlichungen im englischsprachigen Raum zu diesem Thema.

von Kardorff, E., Ohlbrecht, H. \& Schmidt, S. (2013). Zugang zum allgemeinen Arbeitsmarkt für Menschen mit Behinderungen. Expertise im Auftrag der Antidiskriminierungsstelle des Bundes. Berlin: Antidiskriminierungsstelle des Bundes. Die Expertise gibt einen fundierten Überblick über die Situation behinderter Menschen am Arbeitsmarkt in Deutschland und benennt vorhandene Unterstützungsmöglichkeiten. Verwendet wurden überwiegend qualitative Methoden empirischer Sozialforschung.

Lorant et al. 107 Study Group (2017). Optimal Network for Patients with Severe Mental Illness: A Social Network Analysis. Administration and Policy in Mental Health, 44 (6), S. 877-887. Der Beitrag behandelt 
Netzwerkstrukturen in der Gesundheitsversorgung und untersucht den Einfluss unterschiedlicher Strukturmerkmale von Netzwerken (etwa Zusammensetzung, Größe, Zentralität) in Bezug auf die Ermöglichung von Versorgungskontinuitäten und sozialer Integration in Belgien. Datengrundlage ist eine Befragung von 954 in Belgien lebenden Patientinnen und Patienten.

Morgan, M., Patrick, D. L. \& Charlton, J. R. (1984). Social networks and psychosocial support among disabled people. Social Science \& Medicine, 19 (5), S. 489-97. Der Artikel befasst sich in erster Linie mit dem Einfluss von Netzwerkeigenschaften (Netzwerkgröße und Netzwerktypus) auf die Zugänglichkeit psychosozialer Unterstützung in London von Menschen mit physischer Behinderung. Er behandelt überdies Netzwerkdifferenzen nach Grad der Behinderung, wohnortanhängige Netzwerkunterschiede behinderter Menschen sowie die Bedeutung familialer Bindungen für die Verfügbarkeit emotionaler Unterstützung.

\section{Datensätze}

In Deutschland sind nur wenige Datensätze verfügbar, die Informationen über Behinderung und Erwerbsarbeit bereithalten und sich zugleich nicht nur auf wenige Basisangaben über soziale Kontakte beschränken. Erwähnenswerte Ausnahmen sind „Gesundheit in Deutschland aktuell“ (GEDA) und die „Repräsentativbefragung zur Teilhabe von Menschen mit Behinderung“.

- GEDA ist eine seit 2008 vom Robert Koch-Institut regelmäßig durchgeführte, repräsentative Querschnittsbefragung. In der letzten Erhebungswelle 2014/15 wurden 20.000 Personen in Deutschland ab 15 Jahre befragt. Enthalten sind u. a. Fragen über Behinderung, die Beschäftigungssituation, die Nutzung von Gesundheitsdiensten und über soziale Kontakte mit verschiedenen Personenkreisen und Vertrauensverhältnisse.

Weitere Informationen: https://www.rki.de/DE/Content/Gesundheitsmonitoring/Studien/Geda/Geda_node.html

- Die „Repräsentativbefragung zur Teilhabe von Menschen mit Behinderung“ wird von 2018 bis 2020 vom Institut für angewandte 
Sozialwissenschaft unter 27,000 Menschen durchgeführt. Sie beinhaltet Fragen zu Behinderung, zu Beschäftigung und Erwerbserfahrungen, zur Nutzung verschiedener wohlfahrtsstaatlicher Einrichtungen sowie zu sozialen Beziehungen und Kontakten mit Menschen mit und ohne Behinderung.

Weitere Informationen: https://www.bmas.de/DE/Service/Medien/Publikationen/Forschungsberichte/Forschungsberichte-Teilhabe/fb-492-repraesentativbefragung-behinderung.html

\section{Literatur}

Badura, B. (2008). Sozialkapital: Grundlagen von Gesundheit und Unternehmenserfolg. Berlin: Springer.

Batinic, B., Selenko, E., Stiglbauer, B., \& Paul, K. (2010). Are workers in high-status jobs healthier than others? Assessing Jahodas latent benefits of employment in two working populations. Work and Stress, 24, 73-87.

Bengtsson, S., \& Datta Gupta, N. (2017). Identifying the effects of education on the ability to cope with a disability among individuals with disabilities. PLOS ONE, 12(3), e0173659.

Benitez-Silva, H., Buchinsky, M., Chan, H. M., Rust, J., \& Cheidvasser, S. (2004). How large is the bias in self-reported disability? Journal of Applied Econometrics, 19(6), 649-670.

Borgatti, S. P., Everett, M. G., \& Johnson, J. C. (2018). Analyzing social networks. London: Sage.

Bourdieu, P. (2005). Die verborgenen Mechanismen der Macht. Hamburg: VSA.

Brucker, D. L. (2015). Social capital, employment and labor force participation among persons with disabilities. Journal of Vocational Rehabilitation, 43, 17-31.

Bundesagentur für Arbeit, Statistik/Arbeitsmarktberichterstattung. (2018). Situation schwerbehinderter Menschen. Nürnberg: Bundesagentur für Arbeit. https://statistik. arbeitsagentur.de/Navigation/Statistik/Arbeitsmarktberichte/Personengruppen/Personengruppen-Nav.html. Zugegriffen: 13. Febr. 2019.

Bundesministerium für Arbeit und Soziales [BMAS]. (2011). Übereinkommen der Vereinten Nationen über Rechte von Menschen mit Behinderungen. Erster Staatenbericht der Bundesrepublik Deutschland. Vom Bundeskabinett beschlossen am 3. August 2011. https://www.bmas.de/SharedDocs/Downloads/DE/staatenbericht-2011.pdf?__blob=publicationFile. Zugegriffen: 13. Febr. 2019.

Chronister, J., Chou, C. C., Frain, M., \& da Silva Cardoso, E. (2008). The relationship between social support and rehabilitation related outcomes: A meta-analysis. Journal of Rehabilitation, 74(2), 16-32. 
Deutsche Gesetzliche Unfallversicherung e.V. [DGUV]. (2014). Leitfaden zum Betrieblichen Eingliederungsmanagement - Praxishilfe für die Beratung der UV-Träger in den Betrieben. http://publikationen.dguv.de/dguv/pdf/10002/12263.pdf. Zugegriffen: 04. April 2018.

Diewald, M., \& Sattler, S. (2010). Soziale Unterstützungsnetzwerke. In C. Stegbauer (Hrsg.), Netzwerkforschung (S. 689-799). Wiesbaden: Springer VS.

Deutsches Studentenwerk. (2013). Studium und Behinderung - Informationen für Studierende und Studieninteressierte mit Behinderungen und chronischen Krankheiten. Berlin: Bundesministerium für Bildung und Forschung. https://www.studentenwerke.de/ sites/default/files/37_handbuch_studium_und_behinderung_7_auflage.pdf. Zugegriffen: 13. Febr. 2019.

Eichhorst, W., Kenzia, M. J., Knudsen, J. B., Hansen, M. O., Vandeweghe, B., Vanhoren, I., Rückert, E., \& Schulte, B. (2010). The Mobility and Integration of People with Disabilities into the Labour Market. IZA Research Report, 29. http://legacy.iza.org/en/webcontent/publications/reports/report_pdfs/iza_report_29.pdf. Zugegriffen: 13. Febr. 2019.

Engels, D., Engel, H. \& Schmitz, A. (2017). Teilhabebericht der Bundesregierung über die Lebenslagen von Menschen mit Beeinträchtigungen. Köln: ISG Institut für Sozialforschung und Gesellschaftspolitik. http://www.bmas.de/SharedDocs/Downloads/ DE/PDF-Publikationen/a125-16-teilhabebericht.pdf?__blob=publicationFile\&v=9. Zugegriffen: 13. Febr. 2019.

Escorpizo, R., Reneman, M. F., Ekholm, J., Fritz, J., Krupa, T., \& Marnetoft, S.-U. (2011). A conceptual definition of vocational rehabilitation based on the ICF: Building a shared global model. Journal of Occupational Rehabilitation, 21, 126-133.

Famira-Mühlberger, U., Huemer, U., \& Mayrhuber, C. (2015). Der Einfluss der sozialen Sicherungssysteme auf die Beschäftigungsquote Älterer in traditionellen Wohlfahrtsstaaten, WIFO Working Papers, No. 499, Austrian Institute of Economic Research (WIFO), Vienna.

Forrester-Jones, R., Carpenter, J., Coolen-Schrijner, P., Cambridge, P., Tate, A., Beecham, J., \& Wooff, D. (2006). The social networks of people with learning disabilities living in the community twelve years after resettlement from long-stay hospitals. Journal of Applied Research in Intellectual Disabilities, 19, 285-295.

Granovetter, M. (1973). The strength of weak ties. American Journal of Sociology, 6, 1360-1380.

Granovetter, M. (1995). Getting a job. A study of contacts and careers. Chicago: The University of Chicago Press.

Hammerschmidt, M. (1992). Behindertenverbände im sozialpolitischen Entscheidungsprozeß. Frankfurt a. M.: New York Campus.

Hinz, T. \& Abraham, M. (2008). Theorien des Arbeitsmarktes: Ein Überblick. In M. Abraham \& T. Hinz (Hrsg.), Arbeitsmarktsoziologie. Probleme, Theorien, empirische Befunde. Wiesbaden. Springer VS.

Jahoda, M. (1982). Employment and unemployment: a social-psychological analysis. Cambridge: Cambridge University Press.

Jahoda, M. (1983). Wieviel Arbeit braucht der Mensch?. Weinheim: Beltz.

Kastl, J. M. (2017). Einführung in die Soziologie der Behinderung. Wiesbaden: Springer VS. 
Klemm, K. (2015). Inklusion in Deutschland. Daten und Fakten. Gütersloh: Bertelsmann Stiftung.

Knox, M., \& Parmenter, Trevor R. (1993). Social networks and support mechanisms for people with mild intellectual disability in competitive employment. International of Rehabilitation Research, 16, 1-12.

Kohl, S., \& Niehaus, M. (2014). Inklusive Gestaltung betrieblicher Gesundheitsmaßnahmen für junge und ältere Mitarbeiterinnen und Mitarbeiter durch die Schwerbehindertenvertretung als proaktiver betrieblicher Initiator. In e.V. GfA, (Hrsg.), 60. Kongress der Gesellschaft für Arbeitswissenschaft (GfA) e.V. Gestaltung der Arbeitswelt der Zukunft (S. 647-649). Dortmund: GfA-Press.

Kohl, S., Niehaus, M., \& Baumann, A. (2015). Die UN-Behindertenrechtskonvention und die Folgen für die Arbeit mit Schwerbehindertenvertretungen (SBV) in Betrieben und Dienststellen. In A. Leonhardt (Hrsg.), Die UN-Behindertenrechtskonvention und ihre Umsetzung. Beiträge zur interkulturellen und international vergleichenden Heil- und Sonderpädagogik (S. 572-579). Bad Heilbrunn: Klinkhardt.

Lang, F. R. (2003). Die Gestaltung und Regulation sozialer Beziehungen im Lebenslauf: Eine entwicklungspsychologische Perspektive. Berliner Journal für Soziologie, 13(2), $175-195$.

Lewicki, A. (2014). Allgemeines Gleichbehandlungsgesetz: Zwischenbilanz eines brüchigen Konsenses. Aus Politik und Zeitgeschichte, 13-14, 21-27.

Lin, N. (2009). Social Capital. A Theory of Social Structure and Action. Cambridge: Cambridge University Press.

Lorant, V., Nazroo, J., Nicaise, P., Title107 Study Group. (2017). Optimal network for patients with severe mental illness: A social network analysis. Administration and Policy in Mental Health, 44(6), 877-887.

McKenna, M. A., \& Power, P. W. (2000). Engaging the African American family in the rehabilitation process: An intervention model for rehabilitation counselors. Journal of Applied Rehabilitation Counseling, 31, 12-18.

Morgan, M., Patrick, D. L., \& Charlton, J. R. (1984). Social networks and psychosocial support among disabled people. Social Science and Medicine, 19(5), 489-497.

Niehaus, M. (1993). Behinderung und sozialer Rückhalt. Zur sozialen Unterstützung behinderter Frauen. Frankfurt a. M.: Campus.

Niehaus, M. (2001). Geschlechtsspezifische Ansätze in der Rehabilitationsforschung. Zur Partizipation von Frauen mit Behinderungen. In A. Kämmerer \& A. Franke (Hrsg.), Klinische Psychologie der Frau. Ein Lehrbuch (S. 737-749). Göttingen: Hogrefe.

Niehaus, M., Marfels, B., Vater, G., Magin, J., \& Werkstetter, E. (2008). Betriebliches Eingliederungsmanagement: Studie zur Umsetzung des Betrieblichen Eingliederungsmanagements nach § 84 Abs. 2 SGB IX. Köln: Forschungsbericht 374 Sozialforschung. http://www.bmas.de/SharedDocs/Downloads/DE/PDF-Publikationen/f374-forschungsbericht.pdf?_blob=publicationFile. Zugegriffen: 13. Febr. 2019.

Niehaus, M., Kaul, T., Friedrich-Gärtner, L., Klinkhammer, D., \& Menzel, F. (2012). Zugangswege junger Menschen mit Behinderung in Ausbildung und Beruf. Bonn: Bundesministerium für Bildung und Forschung. https://www.fachportal-paedagogik.de/ literatur/vollanzeige.html?FId=988603\#vollanzeige. Zugegriffen: 13. Febr. 2019.

Niehaus, M., \& Saupe-Heide, M. (2012). Selbstbestimmung in der beruflichen Rehabilitation: Rechtlich verankert - In der Praxis vernachlässigt? Forum D - Entwicklungen und Reformvorschläge. Diskussionsbeitrag 15/2012. Heidelberg: Deut- 
sche Vereinigung für Rehabilitation. http://www.reha-recht.de/fileadmin/download/ foren/d/2012/D15-2012_Selbstbestimmung_in_beruflicher_Reha.pdf. Zugegriffen: 13. Febr. 2019.

Niehaus, M. \& Bauer, J. (2013). Chancen und Barrieren für hochqualifizierte Menschen mit Behinderung. Übergang in ein sozialversicherungspflichtiges Beschäftigungsverhältnis. Aktion Mensch. https://promi.uni-koeln.de/wp-content/uploads/2014/03/ Niehaus-Bauer-2013-Chancen-und-Barrieren-fuer-hochqualifizierte-Menschen-mit-Behinderung-Abschlussbericht.pdf. Zugegriffen: 13. Februar 2019.

Niehaus, M., \& Vater, G. (2014). Psychische Erkrankungen und betriebliche Wiedereingliederung. WSI Mitteilungen, 7, 374-377.

Pfaff, H. (2012). Lebenslagen der behinderten Menschen - Ergebnisse des Mikrozensus 2009. Wirtschaft und Statistik. Wiesbaden: Statistisches Bundesamt. https://www. destatis.de/DE/Publikationen/WirtschaftStatistik/Sozialleistungen/Lebenslagenbehinderte032012.pdf?_blob=publicationFile. Zugegriffen: 13. Februar 2019.

Potts, B. (2005). Disability and employment: Considering the importance of social capital. Journal of Rehabilitation, 71(3), 20-25.

Putnam, R. D. (2000). Bowling alone. The collapse and revival of American community. New York: Simon \& Schuster.

Rauch, A. (2005). Behinderte Menschen auf dem Arbeitsmarkt. In R. Bieker (Hrsg.), Teilhabe am Arbeitsleben. Wege der beruflichen Integration von Menschen mit Behinderung (S. 25-43). Stuttgart: Kohlhammer.

Reims, N., Nivorozhkin, A. \& Tophoven, S. (2017). Personen mit gesundheitlichen Einschränkungen - Berufliche Rehabilitation zielt auf Prävention und passgenaue Förderung. IAB-Kurzbericht, 25. http://doku.iab.de/kurzber/2017/kb2517.pdf. Zugegriffen: 04. April 2018.

Reims, N., Tisch, A., \& Tophoven, S. (2016). Junge Menschen mit Behinderung: Reha-Verfahren helfen beim Berufseinstieg. IAB-Kurzbericht, 7. http://doku.iab.de/kurzber/2016/ kb0716.pdf. Zugegriffen: 04. Apr. 2018.

Riedel, H.-P., Schmidt, C., Ellger-Rüttgard, S., Karbe, H., Niehaus, M., Rauch, A., Schian, H.-M., Schmid, S., Schott, T., Schröder, H., Spijkers, W., \& Wittwer, U. (2009). Die Zukunft der beruflichen Rehabilitation Erwachsener gestalten: Acht Handlungsfelder als Ausgangspunkt für einen akteursübergreifenden Innovationsprozess. Die Rehabilitation, 48(6), 375-382.

Rohrmann, E. (2012). Zwischen selbstbestimmter sozialer Teilhabe und fürsorglicher Ausgrenzung: Lebenslagen und Lebensbedingungen von Menschen, die wir behindert nennen. In E.-U. Huster, J. Boeckh, \& H. Mogge-Grotjahn (Hrsg.), Handbuch Armut und soziale Ausgrenzung (S. 619-642). Wiesbaden: Springer VS.

Schröder, H., Knerr, P. \& Wagner, M. (2009). Vorstudie zur Evaluation von Maßnahmen zur Förderung der Teilhabe behinderter Menschen und schwerbehinderter Menschen am Arbeitsleben. Bonn: infas.

Schröttle, M., Hornberg, C., Glammeier, S., Sellach, B., Kavemann, B., Puhe, H., \& Zinsmeister, J. (2013). Lebenssituation und Belastungen von Frauen mit Behinderungen und Beeinträchtigungen in Deutschland. Berlin: Bundesministerium für Familie, Senioren, Frauen und Jugend. 
Schröttle, M., Hornberg, C., Zapfel, S., Wattenberg, I., Vogt, K., Kellermann, G., \& Becker, J. (2014). Vorstudie für eine Repräsentativbefragung zur Teilhabe von Menschen mit Behinderung(en). Berlin: Bundesministerium für Arbeit und Soziales. http://www.bmas. de/SharedDocs/Downloads/DE/PDF-Publikationen/forschungsbericht-vorstudie-repraesentativbefragung-zur-teilhabe-von-menschen-mit-behinderung.pdf?_blob=publicationFile. Zugegriffen: 13. Febr. 2019.

von Kardorff, E. (2010). Soziale Netzwerke in der Rehabilitation und im Gesundheitswesen. In C. Stegbauer \& R. Häußling (Hrsg.), Handbuch Netzwerkforschung (S. 715724.). Wiesbaden: Springer VS.

von Kardorff, E., Ohlbrecht, H. \& Schmidt, S. (2013). Zugang zum allgemeinen Arbeitsmarkt für Menschen mit Behinderungen. Expertise im Auftrag der Antidiskriminierungsstelle des Bundes. https://www.antidiskriminierungsstelle.de/SharedDocs/ Downloads/DE/publikationen/Expertisen/Expertise_Zugang_zum_Arbeitsmarkt.pdf? blob=publicationFile. Zugegriffen: 13. Februar 2019.

UN-Behindertenrechtskonvention [UN-BRK]. (2008). Gesetz zu dem Übereinkommen der Vereinten Nationen vom 13. Dezember 2006 über die Rechte von Menschen mit Behinderungen sowie zu dem Fakultativprotokoll vom 13. Dezember 2006 zum Übereinkommen der Vereinten Nationen über die Rechte von Menschen mit Behinderungen. Bundesgesetzblatt Teil II Nr. 35. http://www.un.org/depts/german/uebereinkommen/ar61106-dbgbl.pdf. Zugegriffen: 13. Febr. 2019.

Wansing, G. \& Westphal, M. (2014). Behinderung und Migration. Kategorien und theoretische Perspektiven. In G. Wansing \& M. Westphal (Hrsg.), Behinderung und Migration. Inklusion, Diversität, Intersektionalität (S. 17-47). Wiesbaden: Springer VS.

Weber, A., \& Weber, U. (2015). Älter, hörbeeinträchtigt und... erwerbstätig! Journal of Labour Market Research, 48(3), 263-270.

Weinbach, C. (2014). Von personalen Kategorien zu Sozialstrukturen. In G. Wansing \& M. Westphal (Hrsg.), Behinderung und Migration - Inklusion, Diversität, Intersektionalität (S. 73-82). Wiesbaden: Springer VS.

Weller, S. I. (2017). Tätigkeiten Erwerbstätiger mit Behinderung - Eine empirische Anwendung des tätigkeitsbasierten Ansatzes für die Beschreibung von Arbeitsplätzen von Erwerbstätigen mit Behinderung in Deutschland. Berichte zur beruflichen Bildung. Bonn: Bundesinstitut für Berufsbildung.

Welti, F. (2005). Behinderung und Rehabilitation im sozialen Rechtsstaat. Freiheit, Gleichheit und Teilhabe behinderter Menschen. Tübingen: Mohr Siebeck.

Wuppinger, J. \& Rauch, A. (2010). Wiedereingliederung in den Arbeitsmarkt im Rahmen beruflicher Rehabilitation: Maßnahmeteilnahme, Beschäftigungschancen und Arbeitslosigkeitsrisiko. IAB-Forschungsbericht. http://doku.iab.de/forschungsbericht/2010/ fb0110.pdf. Zugegriffen: 13. Febr. 2019.

Zapfel, S. (2015). Berufliche Rehabilitation und Return to Work von Personen mit Migrationshintergrund. In A. Weber, L. Peschkes, \& W. de Boer (Hrsg.), Return to WorkArbeit für alle: Grundlagen der beruflichen Reintegration (S. 239-246). Stuttgart: Genter. 
Open Access Dieses Kapitel wird unter der Creative Commons Namensnennung 4.0 International Lizenz (http://creativecommons.org/licenses/by/4.0/deed.de) veröffentlicht, welche die Nutzung, Vervielfältigung, Bearbeitung, Verbreitung und Wiedergabe in jeglichem Medium und Format erlaubt, sofern Sie den/die ursprünglichen Autor(en) und die Quelle ordnungsgemäß nennen, einen Link zur Creative Commons Lizenz beifügen und angeben, ob Änderungen vorgenommen wurden.

Die in diesem Kapitel enthaltenen Bilder und sonstiges Drittmaterial unterliegen ebenfalls der genannten Creative Commons Lizenz, sofern sich aus der Abbildungslegende nichts anderes ergibt. Sofern das betreffende Material nicht unter der genannten Creative Commons Lizenz steht und die betreffende Handlung nicht nach gesetzlichen Vorschriften erlaubt ist, ist für die oben aufgeführten Weiterverwendungen des Materials die Einwilligung des jeweiligen Rechteinhabers einzuholen.

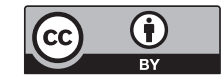




\title{
Migration als gesundheitliche Ungleichheitsdimension? Natio- ethno-kulturelle Zugehörigkeit, Gesundheit und soziale Netzwerke
}

\author{
Annett Kupfer und Markus Gamper
}

\section{Überblick}

- Ethnische und migrationsbedingte Differenzen werden zunehmend als Determinante gesundheitlicher Ungleichheit beforscht, diesbezügliche empirische Ergebnisse sind jedoch zum Teil widersprüchlich.

- Studien zu „Migration und Gesundheit bzw. gesundheitlichen Ungleichheiten“ und zu „Migration und Netzwerken“ liegen vor.

- Studien, die alle drei Bereiche gemeinsam umfassen, sind sehr selten und betrachten 1) fast immer nur eine Bevölkerungsgruppe ohne 2) den Blick zusätzlich auf vertikale Ungleichheitsdimensionen wie Einkommen oder Bildung zu weiten. Die meisten Studien benutzen 3) den Begriff des Netzwerks eher als Metapher, Synonym für Gruppe oder Sozialkapital oder sie beforschen ausschließlich soziale Unterstützung als zentrale Funktion sozialer Netzwerke.

- Es bleibt zu fragen, inwieweit die mit dem Begriff Migration assoziierten Phänomene tatsächlich migrationsspezifisch sind, d. h., beispielsweise

\footnotetext{
A. Kupfer $(\bowtie)$

Dresden, Deutschland

E-Mail: annett.kupfer@tu-dresden.de

M. Gamper

Köln, Deutschland

E-Mail: m.gamper@uni-koeln.de
} 
verbunden mit einem konkreten Migrationsprozess sind, oder ob nicht im Sinne der Intersektionalität andere soziale Gruppenzugehörigkeiten wie Klasse oder Geschlecht (höheren) Erklärungsgehalt für gesundheitliche Ungleichheiten besitzen.

\section{Die Gesundheit Migrationsanderer - Migration und Gesundheit}

Migration bzw. ein sogenannter Migrationshintergrund kann aus sozialwissenschaftlicher Sicht ein bedeutsamer Faktor für die Beschreibung gesundheitlicher Ungleichheit einer Bevölkerung sein, und so rücken in letzter Zeit „ethnische und migrationsbedingte Differenzen als Determinante gesundheitlicher Ungleichheit zunehmend in den Blickwinkel epidemiologischer Forschung" (Schenk 2007, S. 87). „Migranten sind - wie Empirie und Erklärungsmodelle zeigen - in einer besonderen gesundheitlichen Situation [...] Migration beeinflusst die Gesundheit und die Gesundheit beeinflusst, wer migriert" (Spallek und Razum 2016, S. 163). „Macht Migration krank?" fragen dazu Knipper und Bilgin (2009) und werten in ihrer sekundäranalytischen Studie eine Fülle an wissenschaftlicher Literatur zum Thema „Migration und Gesundheit“ aus. Zusammengefasst, so die Autoren, finden sich hier sehr unterschiedliche und teilweise sogar widersprüchliche Aussagen, insgesamt ist jedoch der "Gesundheitszustand der in Deutschland lebenden Bevölkerung mit Migrationshintergrund [...] nicht grundsätzlich besser oder schlechter als derjenige der Bevölkerung ohne Migrationshintergrund. [...] Viele Studien beschreiben den Gesundheitszustand von Migranten im statistischen Mittel sogar als besser" (Knipper und Bilgin 2009, S. 3; vgl. auch Sting 2010). Gesundheitschancen und Krankheitsrisiken differieren jedoch innerhalb der Migrant_ innenpopulation stark und ändern sich im Verlauf des Aufenthalts im Zielland.

Eine Herausforderung und immer wieder benannte Schwierigkeit innerhalb der Forschung zur Gesundheit von Migrationsanderen ${ }^{1}$ bildet aufgrund

\footnotetext{
${ }^{1}$ Mit dem Begriff „Migrationsandere“ kommen Prozesse und Phänomene der Konstruktion, Bewältigung, Bewahrung und Veränderung natio-ethno-kultureller Differenz unter bestimmten Bedingungen in den Blick. Probleme der Pauschalisierung Migrant_in vs. Nichtmigrant_in sowie die über Hierarchisierung und machtvolle Unterscheidung hergestellte Differenz zwischen „Anderen“ und „Nicht-Anderen“ werden hieran verdeutlicht (Mecheril 2010).
} 
der Heterogenität der Gruppe die Operationalisierung in Studien. Zum einen ist unklar, welche Kriterien - Nationalität, Muttersprache, Ethnie der Großeltern, Geburtsort, Migrationsort sowie Migrationsregime etc. - zur Bestimmung ,der Migrant_innen" herangezogen werden, was die Vergleichbarkeit der Studien erschwert (Kirkcaldy et al. 2006), zum anderen ist die Gruppe der Menschen mit Migrationsgeschichte bezogen auf andere Differenzlinien, wie soziales Milieu, Geschlecht, aber auch Herkunftsland, Migrationsgrund und -zeitpunkt in sich sehr heterogen, womit die gesundheitliche Situation der sogenannten Migrant_ innen sehr unterschiedlich und nicht verallgemeinernd beschreibbar ist (Knipper und Bilgin 2009; Spallek und Razum 2016).

\subsection{Gesundheit von Migrant_innen - Studienergebnisse ${ }^{2}$}

Vor dem Hintergrund der erwähnten Operationalisierungs- und Erfassungsprobleme, möchten wir eingangs Studien über den Zusammenhang von Migration und Gesundheit vorstellen. Einige dieser Ergebnisse fassen wir im Folgenden schlaglichtartig zusammen.

\subsubsection{Subjektiver Gesundheitszustand von Migrant_innen}

Erfasst werden hier Selbstangaben zur subjektiven Gesundheit: die Einschätzung des Wohlbefindens, der Funktionsfähigkeit und der Anfälligkeit für Krankheiten (Stenzel 2016). Nach Elkeles und Seifert (1996) finden sich in einer allgemeinen Gegenüberstellung keine erheblichen Unterschiede zwischen der Bevölkerung mit und ohne sogenannten Migrationshintergrund. Erst bei einem nach sozialen Merkmalen differenzierten Blick zeigen sich innerhalb der Gruppe der Arbeitslosen diesbezügliche Unterschiede in der Gesundheitszufriedenheit. So bewerten arbeitslose Migrant_innen ihre Gesundheitszufriedenheit negativer als die deutsche Vergleichsgruppe. Zudem nimmt die Zufriedenheit mit der eigenen Gesundheit mit steigendem Alter bei ,Deutschen“ wie Zuwanderer_innen ab, wobei für türkische

\footnotetext{
${ }^{2}$ Zum Gesundheitsverhalten von Migrant_innen finden sich laut Stenzel (2016) nur wenige Studien. Bekannt ist häufigeres Übergewicht bei Kindern und Jugendlichen mit sogenanntem Migrationshintergrund, das sich auch im Erwachsenenalter fortsetzt und das Risiko für Bluthochdruck, koronarer Herzkrankheit, Typ-2-Diabetes und orthopädische Erkrankungen erhöht. Bezüglich des Alkohol- und Drogenkonsums kann nicht von einem generell höheren oder niedrigeren Konsum bei Migrant_innen gesprochen werden (vgl. für differenziertere Ergebnisse Kirkcaldy et al. 2006; Razum et al. 2011).
} 
Zuwanderer und Zuwanderinnen die Abnahme stärker ausgeprägt ist als bei ,Deutschen' und Zuwanderer_innen aus anderen Herkunftsländern (Razum et al. 2011). Neben Alter und Geschlecht beeinflussen auch sozioökonomische Faktoren wie Bildungsstatus, Einkommen und Beschäftigungsstatus die Zufriedenheit mit der eigenen Gesundheit. Inwieweit sich für Migrant_innen der sozioökonomischen Status auf den subjektiven Gesundheitszustand auswirkt, bleibt aufgrund der heterogenen Studienlage dazu allerdings unklar (Stenzel 2016).

\subsubsection{Beeinträchtigungen der psychischen Gesundheit durch Migration, psychosomatische und psychiatrische Erkrankungen}

Bei selbst berichteten psychischen Erkrankungen fanden sich keine Unterschiede zwischen Migrant_innen und ,Einheimischen“. Innerhalb des Bundesgesundheitssurvey berichteten jedoch geschlechtsspezifisch Migrantinnen bezüglich ihrer gesundheitsbezogenen Lebensqualität einen schlechteren Gesundheitszustand und hatten ein schlechteres psychisches Wohlbefinden als ,deutsche“ Frauen (Kirkcaldy et al. 2006). Laut Kirkcaldy und Kolleg_innen (ebd.) sind psychosomatische und psychische Störungen bei Menschen mit sogenanntem Migrationshintergrund im Durchschnitt häufiger zu finden als in der übrigen Bevölkerung. Die Trennung von der Familie, schwierige Lebensumstände im Gastland (Erfahrungen mangelnder sozialer, kultureller und wirtschaftlicher Teilhabe, Identitätskonflikte etc.) sowie die Anpassung an neue gesellschaftliche und kulturelle Situationen bei geringer oder fehlender wirtschaftlicher und rechtlicher Absicherung aber auch Diskriminierungserfahrungen können direkte Auswirkungen auf die psychische aber auch physische Gesundheit haben.

$\mathrm{Zu}$ den psychischen Störungen, die häufig in Verbindung mit Migration auftreten, zählen Depressionen, psychosomatische Beschwerden, Somatisierung und posttraumatische Belastungen (Kirkcaldy et al. 2006). Im deutschsprachigen Raum liegen jedoch kaum epidemiologische Untersuchungen zur psychischen Belastung unterschiedlicher Migrant_innengruppen vor (ebd.). Nach Knipper und Bilgin (2009) ist die Häufigkeit psychischer Erkrankungen bei Menschen mit sogenanntem Migrationshintergrund schwer zu quantifizieren und die Studienlage unbefriedigend. Bekannt ist der starke Einfluss von traumatischen Ereignissen, wie Folter und Kriegserfahrungen, die in besonderer Weise gesundheitsbelastend sein können und vor allem beim Fortdauern der instabilen Lebenssituation in der posttraumatischen Phase (langwierige Asylverfahren etc.) massive Gesundheitsgefährdungen und Traumatisierung nach sich ziehen können (Sting 2010; Kutalek 2009). So leiden besonders Asylsuchende häufig an psychischen Störungen (posttraumatische Belastungsstörung) (Kirkcaldy et al. 2006; BPtK 2015). Jedoch 
dürfen „Migrationserfahrungen [...] nicht unkritisch und pauschal mit gesundheitlichen und insbesondere psychischen Belastungen gleichgesetzt werden. Nur bei einem Teil der entsprechenden Studien können Unterschiede zwischen der psychischen Gesundheit von Migranten und Einheimischen nachgewiesen werden“ (Kirkcaldy et al. 2006, S. 877).

\subsubsection{Beeinträchtigung der physischen Gesundheit bei Migrant_innen}

Kinder mit Migrationshintergrund in Deutschland leiden seltener an Bronchitis, Allergien, atopischen Erkrankungen (Überempfindlichkeitsreaktionen und Neigung zu allergischen Erkrankungen), Asthma, Magen-Darm-Infektionen und Mittelohrentzündungen und häufiger an Anämie, Tuberkulose, Karies und Übergewicht (Knipper und Bilgin 2009; Razum et al. 2011). Als Grund für diese Symptome werden jedoch weniger migrations-, sondern eher milieuspezifisch (soziale Schicht - Bildung, Berufsstatus etc.) schwächere „psychosoziale Schutzfaktoren“ (z. B. positives Familienklima, emotionale Stabilität, unterstützendes soziales Umfeld usw.) gesehen (Knipper und Bilgin 2009).

Auch im Erwachsenenalter sind Menschen mit sogenanntem Migrationshintergrund von bestimmten Erkrankungen anders betroffen als der Bevölkerungsdurchschnitt in Deutschland (Knipper und Bilgin 2009). So leiden türkischstämmige Menschen häufiger an Herz-Kreislauf-Erkrankungen, Diabetes und Hepatitis und Aussiedler_innen aus der ehemaligen Sowjetunion sterben im Vergleich zum Bevölkerungsdurchschnitt seltener an Krebs und Herz-Kreislauf-Erkrankungen obwohl hier Risikofaktoren wie Übergewicht, Bewegungsmangel, hohe Blutfettwerte etc. häufiger anzutreffen sind. Beide Gruppen zeigen ein erhöhtes Risiko für Lungen- und Magenkrebs sowie für chronische Magenerkrankungen. Um diese Befunde zu erklären (und auch, da sich Ergebnisse verschiedener Studien teilweise widersprechen) ist weitere Forschung dringend notwendig.

Internationale und nationale Ergebnisse liefern des Weiteren Hinweise, dass Migrant_innenpopulationen bzw. ethnische Minderheiten in einigen Bereichen größeren gesundheitlichen Risiken unterliegen als Personen ohne sogenannten Migrationshintergrund (siehe hierzu zitierte Studien in Schenk 2007). Bezüglich übertragbarer Infektionskrankheiten mit Folgekrankheiten werden z. B. chronische Hepatitis B, Helicobacter pylori ${ }^{3}$ oder Tuberkulose genannt, für die

\footnotetext{
${ }^{3}$ Das Helicobacter pylori, welches im menschlichen Magen vorgefunden werden kann. Dieses wird für Entzündungen und Tumore verantwortlich gemacht.
} 
Migrant_innen in ihren Herkunftsländern höheren Prävalenzraten ausgesetzt sind. Knipper und Bilgin (2009) weisen ferner darauf hin, dass die teilweise in Sammelunterkünften für Flüchtlinge herrschenden prekären Lebensumstände, eine schlechte Ernährung und ein unzureichender Zugang zu Gesundheitsversorgung zu den typischen Risikofakten für Tuberkulose zählen.

In Bezug auf chronische Erkrankungen ist bisher eine stärkere Belastung der einheimischen Bevölkerung festzustellen. Allerdings deuten verschiedene Studien darauf hin, dass eine lange Aufenthaltsdauer im Zielland durch die allmähliche Übernahme eines „westlichen Lebensstils“ negative Effekte auf die Gesundheit von Migrant_innen hat, indem z. B. Adipositas, Herzerkrankungen und Erkrankungen der Atmungsorgane zunehmen (Krämer und Baune 2004; Stenzel 2016, s. u.). In anderen Bereichen, z. B. bezüglich Asthma (seltener), Neurodermitis und Heuschnupfen, Sterblichkeit an koronarer Herzkrankheit (geringer), sind Migrant_innen genauso oder weniger gefährdet (Schenk 2007). Einige genetisch bedingte Erkrankungen, wie etwa Sichelzellanämie, das familiäre Mittelmeerfieber und seltene Stoffwechselerkrankungen treten - entsprechend ihrer Verbreitung in den Herkunftsländern - auch bei einigen Migrant_innengruppen in Deutschland häufiger auf (Knipper und Bilgin 2009). Weiterhin bekannt ist die höhere, aber kontinuierlich sinkende Müttersterblichkeit ${ }^{4}$ unter ausländischen Frauen (bis Mitte der 1990er Jahre rund 1,5-mal so hoch wie unter deutschen Frauen, Razum et al. 2011).

\subsection{Ausgewählte Erklärungsansätze zum Zusammenhang von Migration und Gesundheit und gesundheitlicher Ungleichheit}

Während im ersten Schritt der Gesundheitszustand von Migrant_innen empirisch diskutiert wurde, möchten wir im zweiten Schritt Erklärungsansätze vorstellen. Hierbei greifen wir auf Konzepte zurück, die zur Deutung bestehender Unterschiede im Gesundheitsverhalten, der körperlichen wie auch psychischen Gesundheit herangezogen werden.

\footnotetext{
${ }^{4}$ Müttersterblichkeit gilt als empfindlicher Indikator für gesundheitliche Ungleichheiten hinsichtlich des Zugangs zu und Nutzung von Gesundheitsdiensten (Razum et al. 2011).
} 


\subsubsection{Migration und Stress - Migrationsstresshypothese}

„Migration wird weitgehend übereinstimmend als ein kritisches Lebensereignis beschrieben, das die bis dahin erworbenen Anpassungsfähigkeiten, Bewältigungsund Problemlösungsstrategien überlasten kann“" (Kirkcaldy et al. 2006, S. 874). Migrations- und Akkulturationsprozesse, bringen - auch ohne das Vorliegen einer Fluchtgeschichte oder gar Traumatisierung - besondere Belastungen für Migrant_ innen mit sich und können damit die psychische Gesundheit sowie das Entstehen psychischer und körperlicher Krankheiten beeinflussen (Kutalek 2009; Schenk 2007). Unter der Migrationsstresshypothese werden unterschiedliche Stressoren, wie unsichere Lebensbedingungen/Wohnverhältnisse, gesetzliche Aufenthaltsrechte, chronische berufliche Belastung, (drohende) Arbeitslosigkeit, Stigmatisierung, Isolation aufgrund anhaltender Trennung und sich verändernder Netzwerkbeziehungen, eheliche und intergenerationale Normen- und Rollenkonflikte etc. (Nestmann 1999; Kirkcaldy et al. 2006) als gesundheitsrelevant benannt.

\subsubsection{Wirtschaftliche und berufliche Belastungen als Struktureffekt - Theorie der Unterprivilegierung}

Bisherige Untersuchungen verweisen laut Schenk (2007) auf einen sehr komplexen Zusammenhang zwischen Migration und Gesundheit. So leben Migrant_innen häufiger in sozial benachteiligten Schichten und überproportional oft in prekären Erwerbs- und Einkommenssituationen (auch in Sting 2010). Sie sind oft materiell schlechter ausgestattet, erhalten weniger (gute) Ausbildung(splätze), werden im Durchschnitt schlechter bezahlt und sind häufiger arbeitslos als die Mehrheitsbevölkerung (Spallek und Razum 2016). Diese soziale Benachteiligung schlägt sich auch innerfamiliär für die Kinder und Jugendlichen mit sogenannten Migrationshintergrund beispielsweise über die Bildungssituation nieder, wenn migrantische Jugendliche häufiger einen niedrigen oder gar keinen Schulabschluss besitzen (Schenk 2007). Soziale und berufliche Abstiegsprozesse, gesundheitsschädigende Wohn- und Arbeitsbedingungen und berufliche und ökonomische Unsicherheit zeigen ebenso wie Fremdenfeindlichkeit, Diskriminierung, mangelnde soziale Anerkennung und Informationsdefizite einen starken Zusammenhang mit psychischer Gesundheit und Wohlbefinden für Migrant_innen wie Nicht-Migrant_innen (Schenk 2007; Spallek und Razum 2016; Sting 2010). „Migranten mit schlechten Jobs haben auch mehr Gesundheitsprobleme" (Kirkcaldy et al. 2006, S. 874). Gesundheitliche Risiken von Migrant_innen können dann als Folge sozialer Benachteiligung gesehen werden (Schenk 2007). Allerdings erklärt der niedrige Sozialstatus nicht allein die gesundheitlichen Ungleichheiten zwischen Migrant_innen und Nicht-Migrant_innen. Bei der Betrachtung von 
Personen derselben Sozialschicht bildet der Migrationshintergrund einerseits einen zusätzlichen Risikofaktor und bringt andererseits in bestimmten Bereichen günstigere Gesundheitsaussichten mit sich, weshalb weitere erklärende Faktoren - wie ein anderer kultureller Hintergrund, die gesundheitliche und soziale Lage im Herkunftsland oder spezielle Zugangsbarrieren zum Gesundheitssystem - Beachtung finden müssen (Schenk 2007).

\subsubsection{Healthy-Migrant-Effect - Theorie der positiven Selektion}

„Migranten sind oftmals gesünder, als es ihr niedriger sozioökonomischer Status vermuten ließe - verglichen mit der Bevölkerung des Ziellandes der Migration“ (Razum et al. 2011, S. 568). Studien zufolge sind Einwanderer_innen bei der Ankunft häufig psychisch gesünder als Einheimische ${ }^{5}$ (Kirkcaldy et al. 2006), wobei die Gründe dafür noch nicht ausreichend erklärt sind (Knipper und Bilgin 2009). Möglicherweise finden sich unter den aus eigenem Antrieb Auswandernden wohlhabendere, robustere und belastbarere Menschen, die körperlich und psychisch widerstandsfähiger sind (Kirkcaldy et al. 2006; Schenk 2007; Knipper und Bilgin 2009). Auch der Wechsel in eine günstigere Lebensumgebung mit geringeren psychopathologischen Risiken könnte entscheidend sein (Kirkcaldy et al. 2006). Oder aber das junge Alter und damit niedrigere Risiken, z. B. für Herz-Kreislauferkrankungen oder die häufigere Remigration im hohen Alter oder/und bei Krankheit erklären den Healthy-Migrant-Effect (dann als statistisches Artefakt: Migrant_innen sind nicht „,gesünder“, sondern die Erkrankten werden aufgrund demografischer und soziologischer Faktoren vergleichsweise schlechter erfasst) (Knipper und Bilgin 2009; Razum et al. 2011).

Über den Zeitverlauf nehmen allerdings psychische Krankheiten wie beispielsweise Depressionen zu und die Morbidität steigt. Diese Gesundheitsverschlechterung kann aus der Übernahme des ungünstigen Gesundheitsverhaltens und nachteiligen Lebensstils der westlichen industrialisierten Welt bei gleichzeitiger Vernachlässigung von Ressourcen wie sozialen Netzwerken und kulturellen Traditionen resultieren (Kirkcaldy et al. 2006). Widersprechend dazu konstatiert Stenzel (2016) einen anhaltenden Gesundheitsvorteil und den damit diskutierten „salmon bias“, der besagt, dass kranke und alte Migrant_innen häufig in ihr Herkunftsland zurückkehren und dadurch die Morbiditäts- und Mortalitätskennziffern der Migrant_innen verzerrt und auch nicht in Studienpopulationen erfasst werden.

\footnotetext{
${ }^{5}$ Ausnahme bilden hier Geflüchtete (s. o.).
} 


\subsubsection{Migration als gesundheitlicher Übergang}

Razum und Twardella (2002) erweitern das klassische Erklärungsmodell des Healthy-Migrant-Effects um das Konzept des ,gesundheitlichen Übergangs“ (Health Transition). Hier wird Migration aus einem ärmeren in ein wohlhabenderes Land (entsprechend dem klassischen Muster der Arbeitsmigration) als gesundheitlicher Übergang in hoher Geschwindigkeit betrachtet (Spallek und Razum 2016) und der Wechsel von einer hohen Gesamtsterblichkeit (Infektionskrankheiten, mütterliche und kindliche Ursachen) zu einer niedrigeren Sterblichkeit vorwiegend an nichtübertragbaren Krankheiten bezeichnet (Razum 2009).

Durch die Verbesserungen der Wasser-, Luft- und Nahrungsqualität und der medizinischen Versorgung wandelt sich auch die Mortalitäts- und Morbiditätsstruktur in „modernen Gesellschaften“ (Stenzel 2016). Migrant_innen profitierten dann von einer besseren Gesundheitsversorgung (die allerdings zugänglich sein muss). Das Schwinden des signifikant niedrigeren Risikos für eine Brustkrebserkrankung bei Frauen der ersten Generation in den folgenden Generationen von Frauen mit türkischem Migrationshintergrund (Spallek und Razum 2016), die Konvergenz der Rauchgewohnheiten über den Zeitverlauf (Zunahme des Tabakkonsums unter Migrant_innen) sowie die Zunahme koronarer Herzerkrankungen (durch die Übernahme eines westlichen Lebensstils) gelten als Belege für Health Transitions (Razum und Twardella 2002; Stenzel 2016).

\subsubsection{Lebenslaufansatz}

Innerhalb des Lebensverlaufs eines Individuums und teils über Generationen hinweg wirken biologische wie verhaltens- und psychosoziale Prozesse, die die Ausprägung von Erkrankungs- und Mortalitätsrisiken beeinflussen (Spallek und Razum 2016). Identifiziert und erklärt man selbige und untersucht den gesamten Lebenslauf, gewinnt man nach Spallek und Razum (2016) auch neue Erkenntnisse zur Erklärung gesundheitlicher Ungleichheiten und kann das Entstehen bestimmter Gesundheitsrisiken besser verstehen. Beispielsweise kann das soziale Umfeld auf den Schwangerschaftsverlauf (wie das Auftreten von Komplikationen), das Geburtsergebnis und damit ggf. auf die spätere Gesundheit des Kindes als Erwachsener (geringes Geburtsgewicht erhöht Risiko für Adipositas) einwirken oder die eigene soziale Position und Gesundheit über die Zeit auf verschiedenen Ebenen zusammenhängen (ebd.). „Angewendet auf die gesundheitliche Situation von Migranten bedeutet das: Die jeweilige individuelle und soziale Situation führt zu einer Clusterung negativer und positiver Faktoren über die Zeit und auf verschiedenen Ebenen. Zu welchem Zeitpunkt die Belastungen auftreten und welche Bedeutung sie für die Entstehung von Krankheiten haben, hängt vom jeweiligen Gesundheitsproblem und den kritischen Phasen für seine Ausprägung ab“ (Spallek und Razum 2016, S. 256). 


\subsubsection{Inanspruchnahme Gesundheitsdienste - Zugangsbarrieren}

Auch die Art und Weise der medizinischen Versorgung sowie der Zugang zu Gesundheitsdiensten haben schließlich entscheidenden Einfluss auf Gesundheit und Krankheit. Eine unzureichende medizinische Versorgung im Aufnahmeland kann etwa körperliche und seelische Gesundheitsstörungen zur Folge haben (Krämer und Baune 2004). Dabei ist die Befundlage für Deutschland eindeutig. Migrant_innen suchen die psychosozialen und medizinischen ambulanten Angebote weniger auf, sind aber stärker in den Notfallambulanzen anzutreffen (Kirkcaldy et al. 2006; Knipper und Bilgin 2009; Kutalek 2009). Die Liste der Zugangsbarrieren ist lang: gesetzliche Limitationen wie durch das deutsche Asylbewerberleistungsgesetz oder aufgrund eines illegalisierten Aufenthalts, die oftmals ethnozentristische ${ }^{6}$ Ausrichtung der Angebote und fehlende (interkulturelle) Kommunikationskompetenz des medizinischen Personals, Sprachbarrieren, Informationsdefizite über den Aufbau und die Funktionsweise der Gesundheitsorganisation oder präventivmedizinische Maßnahmen (Impfungen, Vorsorgeuntersuchungen), unterschiedliche Erwartungen von Migrant_innen und ,Einheimischen' im Hinblick auf die gesundheitliche Versorgung etc. (Knipper und Bilgin 2009; Kutalek 2009; Schenk 2007; Sting 2010). Vor allem der Zugang zu Beratungs- und Therapieangeboten im Bereich psychischer Gesundheit erscheint hinsichtlich eines höheren Stigmatisierungsrisikos bei einigen Migrant_ innengruppen, aber auch der nur selten kultursensiblen Versorgung sowie multikulturellen Vermittlung und Übersetzung hochschwellig (Kutalek 2009).

Neben den hier ausgewählten und eben vorgestellten Erklärungsansätzen zum Zusammenhang von Migration, Gesundheit und gesundheitlichen Unterschieden: der Migrationsstresshypothese, der Theorie der Unterprivilegierung, dem Ansatz des gesundheitlichen Übergangs, dem Lebenslaufansatz und den Zugangsbarrieren zum Gesundheitssystem können auch soziale Netzwerke, in die Migrant_innen eingebettet sind, relevanten Einfluss auf Gesundheit und Gesundheitsverhalten nehmen. Dafür soll zunächst phasenweise die Rolle sozialer Netzwerke im Migrationsprozess diskutiert werden, bevor in Abschn. 3 die wenigen international vorhandenen Studien zum Zusammenhang sozialer Netzwerke mit der Gesundheit von Migrant_innen rezipiert werden.

\footnotetext{
${ }^{6}$ Gefühl der Überlegenheit des Herkunftslandes (der eigenen Gruppe) gegenüber anderen Ländern (anderen Gruppen), das sich in überhöhtem Selbstbild sowie negativen Fremdbildern manifestiert und in Einstellungen wie Verhaltensweisen zeigt.
} 


\section{Soziale Netzwerke von Migrationsanderen - Die Rolle sozialer Netzwerke im Migrationsprozess}

Während das Konzept sozialer Netzwerke in der Migrationsforschung sehr früh eine Rolle gespielt hat (z. B. Kettenmigration) (Boyd 1989; Jedlicka 1978), werden Methoden der Netzwerkanalyse erst in jüngerer Zeit eingesetzt (Lubbers et al. 2010; Gamper und Reschke 2010). Auffällig ist jedoch, dass die Netzwerkanalyse hauptsächlich einen Bezug zur Sozialkapitaltheorie aufweist (Gamper 2015) und vor allem die Unterstützungsleistung von Migrant_innenetzwerken untersucht wird (Portes 1995; Pohjola 1991). Vor diesem Hintergrund können die Studien nach strukturbeschreibenden und ressourcenorientierten Forschungsperspektiven unterschieden werden.

Aus einer strukturbeschreibenden Forschungsperspektive werden die Beziehungen und deren Netzwerkstruktur von Migrant_innen wie ihre individuelle Einbettung in das soziale Umfeld untersucht (Lubbers et al. 2010; Gamper et al. 2013). Hier besteht häufig ein starker Bezug zur Netzwerkanalyse, umfasst aber auch andere methodische Ansätze. Bei ressourcenorientierten Ansätzen stehen eher die verfügbaren und zu mobilisierenden Unterstützungsleistungen (z. B. Geldleihen, emotionale Unterstützung) im Mittelpunkt (Haug 2000b). Auch wenn dabei z. T. von Netzwerken gesprochen wird, findet eine Netzwerkanalyse, im engeren Sinne, hierbei selten statt.

Neben der vorangegangenen methodischen Unterscheidung können Netzwerke, theoretisch, in drei unterschiedlichen Phasen der Migration eine bedeutende Rolle einnehmen: Erstens bei der Entscheidung für eine Emigration, zweitens innerhalb der Wanderung bzw. des Migrationsprozesses sowie drittens nach der Ankunft im Zielland. Diese drei genannten Prozesse können sich im Lebenslauf auch wiederholen. In den Forschungen werden hierbei unterschiedliche Schwerpunkte gesetzt.

\subsection{Entscheidungsfindung zur Migration}

Bereits 1964 führten MacDonald und MacDonald (1964) das Konzept der Kettenmigration ein. Hier wird davon ausgegangen, dass Pionier-Migrant_innen die Akteure in ihrem Netzwerk durch Unterstützung und Informationsweitergabe beeinflussen. Es wird behauptet, dass Pioniermigrant_innen hohen Migrationskosten und -risiken ausgesetzt sind, während nachfolgende Migrant_innen einen geringeren Aufwand betreiben müssen, da sie ihre Netzwerkressourcen, die 
Migrant_innen, die vor ihnen gewandert sind, mobilisieren können, um z. B. Arbeit oder Wohnungen zu finden und Hilfe beim Einholen oder Ausfüllen offizieller Dokumente zu erhalten (Fussel und Massey 2004).

Studien konnten belegen, dass, unabhängig von früherer Migrationserfahrung der befragten Personen, die Wahrscheinlichkeit zur Migration steigt, wenn diese Kontakt mit Akteuren im Ankunftsland (z. B. gute Freund_innen, Familie) besitzen (Massey et al.1993; Palloni et al. 2001). Mit Hilfe von Simulationen konnte Teteryatnikova (2013) illustrieren, dass selbst ein kleiner Anstieg der persönlichen Verbindungen zu Personen in einem Zielland die Migrationsrate signifikant erhöhen kann. In einigen Fällen suchen erfahrene Migrant_innen sogar explizit nach Neuankömmlingen, wobei sie sorgfältig auswählen, welche Akteure sie unterstützen (Bashi 2007).

Der Einfluss sozialer Netzwerke auf die Entscheidungsfindung sollte jedoch nicht ausschließlich positiv betrachtet werden. Drei Argumente werden dafür angeführt. Netzwerke können 1) die Auswahl der Auswanderungsziele durch sogenannte „Migrationskorridore“ beschränken, indem sich bestimmte Migrationsgruppen auf bestimmte Zielländer fokussieren, wodurch eine Abhängigkeit (z. B. Kosten für Schleuser) entstehen kann (z. B. De Haas 2007; Parsons et al. 2007). Auch wenn die Auswirkungen von Netzwerkstrukturen noch nicht im Detail erforscht sind, gehen Forscher_innen davon aus, dass 2) dichte Netzwerke und starke, unterstützende Verbindungen im Ausreiseland (z. B. durch enge emotionale Bindungen) Migration auch verhindern können (Haug 2000a; Stelzig-Willutzki 2012). Schließlich kann 3) netzwerkbasierte Migration sowohl zu Abhängigkeit von Personen als auch von ganzen Volkswirtschaften führen, in dem z. B. Länder abhängig von Rücküberweisungen sind (Boyd 1989).

\subsection{Migrant_innennetzwerke in der Transit- oder Grenzübergangsphase}

Ein weiterer Forschungsstrang beleuchtet die Rolle von sozialen Netzwerken während der Wanderung auf den unterschiedlichen Migrationsrouten. Aktuelle Ethnografien (z. B. Andersson 2014) beschreiben die physischen Gefahren, Gewalt und Ausbeutung, denen Migrant_innen häufig auf Süd-Nord-Routen ausgesetzt sind. Die wenigen Studien, die sich mit der Rolle von sozialen Netzwerken in dieser Phase befassen, argumentieren, dass persönliche Bindungen die Grenzüberschreitung erleichtern. Zum Beispiel liefern persönliche Verbindungen wertvolle Informationen über die Suche nach Helfer_innen oder 
Schmuggler_innen, um nationale Grenzen zu überschreiten (z. B. Bilecen 2012; Garip 2016). Koser (1997) argumentiert, dass der Ansatz des sozialen Netzwerks für das Verständnis des Asylverfahrens von entscheidender Bedeutung ist. Koser und Pinkerton (2002) behaupten weiter, dass soziale Netzwerke Einfluss auf das Wann und Wo der Migration nehmen. Neuere Ergebnisse unter syrischen Flüchtlingen in Jordanien weisen zudem darauf hin (Lagarde und Dorai 2016), dass die zunehmend restriktive Einreisepolitik Jordaniens Migrant_innen dazu zwingt auf schwächere Bindungen, professionelle Akteure und Schmuggler_innen zurückzugreifen, die im Folgenden die Reisepläne von Migrant_innen beeinflussen und Bewältigungsstrategien zur Verfügung stellen. Vor diesem Hintergrund wird sowohl auf die Netzwerkanalyse, wie auch auf andere Methoden, für die Beschreibung von Relationen, zurückgegriffen.

\subsection{Migrant_innennetzwerke in der Post- Migrationsphase}

Der Großteil der Migrationsstudien zu sozialen Netzwerken konzentriert sich auf die Postmigrationsphase. Diese Studien fokussieren in erster Linie egozentrierte Netzwerke und setzten diese häufig in Beziehung mit umstrittenen Konzepten wie der sozialen Integration oder sozialen Assimilation. Hierfür analysieren die Forschungsarbeiten allgemeine Merkmale des Netzwerks, wie die Größe und die Zusammensetzung des Netzwerks in Bezug auf die Anzahl der „einheimischen Bevölkerung“, „Landsleuten“ und „,anderen Migrant_innen“. Weitere Faktoren sind beispielsweise die Rolle der Alteri (z. B. Arbeitskolleg_innen, Freund_innen) oder die Stärke und Dauer der Bindung (z. B. Brandes et al. 2008, 2010; Gamper et al. 2013; Kindler et al. 2015). Die Hauptannahme dieser Forschungsrichtung lautet: Je mehr Bindungen Migrant_innen mit der einheimischen Bevölkerung im Einwanderungsland haben, desto höher ist ihre soziale Integration (Eisenstadt 1952; Gordon 1964; Nauck 1989; Facchini et al. 2014). Studien zeigen, dass Migrant_innen in der ersten Ankunftsphase stark von wenigen Kontakten mit ihren Landsleuten in ihrem neuen Wohnsitzland abhängen (z. B. Bashi 2007; Bauer et al. 2009), die Netzwerke mit der Aufenthaltsdauer aber immer heterogener werden (Facchini et al. 2014).

Neben der Beschreibung der persönlichen Netzwerke hinsichtlich ihrer Größe, Zusammensetzung und Struktur haben Forscher_innen die sozialen Unterstützungsleistungen in Netzwerken analysiert. Der Fokus liegt hier auf den Unterstützungsleistungen durch lokale, internationale und transnationale Beziehungen 
(z. B. Bilecen 2016; Herz 2015; Schweizer et al. 1998; Olbermann 2003). Auch wenn die Forschungsarbeiten im Allgemeinen von einem positiven Zusammenhang zwischen wahrgenommenem Stress oder der Gesundheit und Netzwerken ausgehen, greifen diese meist nicht auf die Netzwerkanalyse zurück.

Eine andere Forschungslinie, die sich auf den Austausch von Ressourcen in Migrant_innennetzwerken konzentriert, stellt die Sozialkapitalforschung dar. Theorien des Sozialkapitals neigen dazu, Begriffe der Unterstützung und der sozialen Integration zu verbinden. Im Fokus stehen hier vor allem die „Integration" in den Arbeitsmarkt (z. B. Sommer und Gamper 2018). Dabei zeigen die bislang vorliegenden Studien, dass die Einbindung in den Arbeitsmarkt nicht nur von Netzwerken, sondern insbesondere von den jeweiligen Kontextbedingungen abhängig ist. Auf der Grundlage des Projekts „The Migrations between Africa and Europe Project" (MAFE) konnte eine aktuelle Netzwerkstudie von Toma (2015) zeigen, dass die Verbindung zu früheren Migrant_innen bei der Ankunft positive Auswirkungen auf die wirtschaftliche Lage senegalesischer Männer in Frankreich hat. In Frankreich ist die senegalesische Gemeinschaft sozioökonomisch breitgefächert und bietet damit viele Anknüpfungspunkte. Ein solcher Netzwerkeffekt findet sich hingegen in Spanien oder Italien nicht. Hier sind die Netzwerke meist nur auf den Niedriglohnsektor konzentriert. Diese Ergebnisse legen nahe, dass das Funktionieren persönlicher Netzwerke und ihre Ergebnisse auch stark von dem rechtlichen, wirtschaftlichen und kulturellen Kontext abhängen, in dem diese Netzwerke operieren (z. B. Sommer und Gamper 2018).

Während die eben vorgestellten klassischen Migrationsforschungen den Migrationsprozess als „Einbahnstraße“ verstehen, existieren Forschungen die sich unter den Begriff Transmigration subsumieren lassen. Hier sind besonders soziale Beziehungsgeflechte von großer Bedeutung. $\mathrm{Zu}$ nennen wären hier die Konzepte des „Transnationalismus“ (Pries 2010), der „transstaatlichen Räume“ (Faist 2000) wie auch der „sozialen Felder“ (Levitt und Glick Schiller 2007). Diese Studien richten ihren Fokus auf das Beziehungsgeflecht von (Trans-)Migrant_innen (Lutz 2008), die in der Regel sowohl räumlich wie auch sozial mobil sind, ihr soziales Netzwerk global aufspannen und oftmals zwischen mehreren Staaten hin und her pendeln. „Trans-“ beschreibt hierbei die sozialen, ökonomischen, politischen sowie kulturellen grenzüberschreitenden Relationen von Migrant_innen und die aktive Gestaltung dieser konstruierten Grenzräume. Qualitative wie auch quantitative Netzwerkforschungen untersuchen diesbezüglich z. B. die Art der Beziehungen, den sozialen Nutzen und die Rolle der Alteri in diesen transnationalen Netzwerken (Gamper und Fenecia 2013; Sommer und Gamper 2018; Bilecen und Sienkiewicz 2015; Lubbers et al. 2010). 


\section{$3 \quad$ Migration, soziale Netzwerke und Gesundheit}

Während zahlreiche Studien zu den Themen „Migration und Gesundheit bzw. gesundheitliche Ungleichheiten“ und „Migration und soziale Netzwerke“ existieren, sind Forschungen, die alle drei Bereiche gemeinsam umfassen, sehr selten und betrachten 1) fast immer nur eine Bevölkerungsgruppe - hier ausschließlich Migrant_innen ohne Vergleichsgruppen - und ohne 2) den Blick zusätzlich auf vertikale Ungleichheitsdimensionen wie Einkommen oder Bildung zu weiten. Die meisten Studien benutzen zudem 3) den Begriff des Netzwerkes eher als Metapher, als Synonym für Gruppe oder Sozialkapital oder sie beforschen ausschließlich soziale Unterstützung als zentrale Funktion sozialer Netzwerke ${ }^{7}$. Vor allem bezogen auf die in Abschn. 1.2.1 erwähnte Migrationsstresshypothese und die in Abschn. 2 erwähnte ressourcenorientierte Forschungsperspektive werden dann neben persönlichen Ressourcen (z. B. förderlicher Kontrollüberzeugung, Optimismus, materielle Ressourcen) soziale Unterstützung aus sozialen Netzwerken als Puffer gegen migrationsbedingten Stress untersucht. Dabei ist „der Zusammenhang zwischen sozialer Unterstützung und psychischem Wohlbefinden von Migranten [..] vielfach belegt" (Kirkcaldy et al. 2006, S. 875), indem beispielsweise ein ausreichendes soziales Unterstützungssystem die Auftretenswahrscheinlichkeit manifester psychiatrischer Störungen senkt (Kirkcaldy und Furnham 1995) und effektive soziale Unterstützung vielen Entwicklungsrisiken bei Migrant_innen und ihren Kindern entgegenwirkt.

Im nächsten Schritt stellen wir Forschungsarbeiten vor, die alle drei Bereiche - Migration, Gesundheit und soziale Netzwerke - versuchen zu verbinden. Aufgrund der unbefriedigenden Studienlage bedienen wir uns eines sehr weit gefassten „Migrations“-Begriffes und führen auch Studien auf, die mit dem Begriff ,,race“ oder ,ethnicity“ arbeiten oder die Binnenmigration (etwa von ländlichen in urbane Räume) untersuchen. Die Darstellung ist thematisch gegliedert in Studien zu physischer Gesundheit und Gesundheitsvorsorge, der Bewältigung von Gesundheitsproblemen, zu Schwangerschaft, Verhütung, kindlicher Gesundheit und psychischer Gesundheit und Lebensqualität und muss wie oben angeführt größtenteils ohne Vergleichsgruppen auskommen.

\footnotetext{
${ }^{7}$ siehe zu sozialer Unterstützung u. a. Kupfer (2015).
} 


\subsection{Physische Gesundheit (Transplantation, Krebs) und Gesundheitsversorgung}

Cetingok et al. (2008) untersuchten die Effekte sozialer Unterstützung für psychische wie auch physische Gesundheit von insgesamt 258 Transplantatempfänger_innen. Hierfür greifen die Autor_innen auf Netzwerkkarten zurück, in denen die Proband_innen ihre Beziehungen z. B. zu Freund_innen, Bekannten sowie Familienmitgliedern einzeichnen konnten. Maße wie die Netzwerkgröße und auch die Unterstützungsform wurden dann statistisch ausgewertet. Befragt wurden Personen, die hinsichtlich ihres Geschlechts, sozialer Klasse und „race“ unterschieden wurden. Die meiste Unterstützung erfolgt durch enge und weitere Familienmitglieder. Zudem stellen die Autor_innen heraus: „African American reported a higher frequency and longer duration of social support than did whites (...). Social and nursing intervention may improve the network closeness in males and may also augment support frequency and duration for whites." (Cetingok et al. 2008, S. 87).

Eine weitere Studie arbeitet mit sogenannten Ressourcengeneratoren, um die soziale Unterstützung von krebskranken Chines_innen in Hong Kong zu untersuchen. Hierbei wurden unterschiedliche Unterstützungsarten erhoben, die Rolle der Alteri abgefragt und die Größe des Unterstützungsnetzwerks in die statistische Berechnung miteinbezogen. Die Ergebnisse unterstützen den Zusammenhang zwischen sozialer Unterstützung und erfolgreicher Bewältigung nach einer Krebserkrankung. Während der postoperativen Phase scheinen materielle und informationelle Unterstützung für eine effektive Bewältigung relevanter zu sein als emotionale Unterstützung. Zudem ist der Einbezug von Familienmitgliedern in die Patientenversorgung entscheidend (Chan et al. 2004).

Ralston und Escandells (2012) Sekundärauswertung des Mexican Migration Project (MMP) beforscht für 1776 männliche Mexikaner zwischen 17 und 89 Jahren (interviewt zwischen 1998 und 2009) den Einfluss sozialer Netzwerke auf die Inanspruchnahme von Gesundheitsversorgung im Krankenhaus durch Mexikaner in den USA. Erhoben werden Netzwerkbeziehungen über geschlossene Fragen, wie z. B. ob Mutter, Vater oder Geschwister während einer ihrer letzten Migrationsaufenthalte in den USA gelebt haben (0-6, enger familiärer Kontakt), sodass „social networks as the respondent's family and friends“ past and current migration experience to the United States" konzeptualisiert wird (ebd., S. 327). Das Mexican Migration Project zeigt die Wichtigkeit (vor allem enger) familiärer sozialer Netzwerke von Migrant_innen als Mediatoren in das Gesundheitssystem. Migrant_innen mit einer höheren Anzahl an 
Familienmitgliedern, die selbst migriert sind, nehmen auch eher die Krankenhausversorgung in Anspruch. Freundschaftsnetzwerke zeigten dagegen keinen signifikanten Einfluss. „Mexican migrants likely rely on family members for information about healthcare alternatives because close family networks facilitate higher levels of trust and obligation“ (ebd., S. 333).

\subsection{Bewältigung von Gesundheitsproblemen}

In der explorativen Forschungsarbeit von Li und Wu (2010) wird in Fallstudien der Frage nachgegangen, welche Rolle soziale Netzwerke für aus den ländlichen Regionen in die städtische Region Peking migrierende Chines_innen bei der Bewältigung von Gesundheitsproblemen haben. Hierzu führten die Autoren mit 36 Migrant_innen (16 Frauen, 20 Männer; 18-50 Jahre alt) halb-strukturierte Interviews durch, die anhand der Grounded Theory ausgewertet wurden. Die Netzwerkgröße und -zusammensetzung wurde anhand der Frage, wem sich die Befragten eng verbunden fühlen oder mit wem sie regelmäßig in Kontakt stehen, erhoben. In den Interviews wurden soziale und hier insbesondere familiäre Netzwerkmitglieder angesichts kritischer Lebensereignisse als große Unterstützung gesehen. Bei finanzieller Not werden vor allem Geschwister und Neffen/ Nichten, aber auch Freund_innen mit derselben Migrationsgeschichte um Hilfe gebeten. Auch emotionale Unterstützung kommt vor allem von den genannten Supportquellen. Allerdings hindern der starke Bezug auf sogenannte strong ties, die nicht am Ankunftsort leben, und nur lose Kontakte außerhalb der familiären Netzwerke die Befragten, sich in emotional belastenden Situationen (Einsamkeit, Schlafmangel) der Migration an Menschen in ihrer Umgebung zu wenden. Eingeschränkte und am Ankunftsort fehlende soziale Netzwerke beeinflussen somit den Gesundheitszustand ebenso wie den Zugang zur Gesundheitsversorgung negativ. „However, due to the limited social networks of migrants in urban areas, it is difficult for them to obtain useful health information or information sources at the right time“" (ebd., S. 375).

In der frühen, repräsentativen Forschungsarbeit von Chatters et al. (1985) werden informelle Helfer_innennetzwerke von 581 älteren „Blacks“ erhoben und ihre Struktur als abhängige Variable (Netzwerkgröße und -zusammensetzung) von Gesundheitsfaktoren untersucht. Die Netzwerkerhebung fand hierbei über die Frage statt, wer bei Krankheit und gesundheitlichen Einschränkungen (z. B. körperliche Behinderung) helfen würde. Hierzu wurde eine Liste mit zwölf Personen vorgelegt (Partner_in, Sohn, Schwester, Freund_in, Nachbar_in etc.), die ihrerseits in Kategorien zusammengefasst wurden. Unverheiratete, 
kinderlose Befragte verfügten über kleinere Netzwerke und Frauen gaben mehr Unterstützer_innen an als Männer. Das Erleben von gesundheitlichen Einschränkungen, Behinderungen, Gesundheitsproblemen und die Zufriedenheit oder Unzufriedenheit mit dem eigenen Gesundheitszustand (als Gesundheitsfaktoren) hatten allerdings keinen signifikanten Einfluss auf die Netzwerkgröße und -zusammensetzung (kin/non-kin/mixed).

\subsection{Schwangerschaft, Verhütung und kindliche Gesundheit}

Die qualitative Studie von Chakrabarti (2010) möchte die Bedeutung sozialer Netzwerke für eine gesunde Schwangerschaft von bengalischen Frauen in New York aufzeigen. Anhand von 40 Tiefeninterviews kann die Autorin belegen, dass nicht nur lokale Beziehungen hilfreich sind, sondern auch transnationale Beziehungen eine bedeutende Rolle einnehmen. Materielle und „virtuelle“ Unterstützung aus persönlichen Face-to-Face-Kontakten wie Telefongesprächen schienen dabei bedeutsam. Ratschläge bzgl. einer gesunden Schwangerschaft, gesunder Ernährung und Essenszubereitung, aber auch therapeutische Gespräche, erwiesen sich als wichtige Formen der Unterstützung durch ,therapeutische Netzwerke".

Den Zusammenhang zwischen Schwangerschaft und verfügbarem persönlichen Kapital beleuchten auch Wakeel et al. (2013). Sie stellen sich die Frage, inwieweit die Zugehörigkeit zu unterschiedlichen Ethnizitäten (Hispanic, Black, White, Asian/Pacific Islander, gewonnen aus dem Geburtenregister) das während einer Schwangerschaft verfügbare persönliche Kapital beeinflusst und welche Rolle dabei die soziodemografischen Merkmale der 3716 befragten Mütter sowie deren Akkulturationsfaktoren (Herkunft, zu Hause gesprochene Sprache) einnehmen. Das persönliche Kapital wurde dabei als Skala über insgesamt 30, gruppenweise gewichtete Items erfasst, bestehend aus individuellen Ressourcen (z. B. Selbstwertgefühl, sieben Items), partnerschaftlicher Unterstützung (Fragile Families Study, sechs Items), familiäre und freundschaftliche Unterstützung (Pregnancy Risk Assessment Monitoring System, sieben Items) und nachbarschaftlicher Unterstützung (Project on Human Development in Chicago Neighborhoods, zehn Items). Gerechnet wurde zunächst mit one-way ANOVA-Tests und anschließend mit multivariaten, generalisierten Linearmodellen, um den Zusammenhang von persönlichem Kapital und soziodemografischen Angaben sowie Akkulturationsfaktoren zu verstehen. Hierbei konnten vorhandene Unterschiede im verfügbaren persönlichen Kapital zwischen Black-White und 
Hispanic-White über soziodemografische Merkmale wie Einkommen und Bildung sowie den Ehestand aufgeklärt werden. Es sind demnach vor allem ein geringer sozioökonomischer Status, die Lebensform als Alleinerziehende und geringe Akkulturation, die ausschlaggebend für geringere persönliche und soziale Ressourcen (Kapital) sind, die ihrerseits die mütterliche und kindliche Gesundheit beeinflussen können. Insgesamt finden sich in der Studie demnach, wie sonst kaum, Gruppenvergleiche, allerdings rückt der Fokus auf Gesundheit hierfür in den Hintergrund und wird nur über die Wahl von Müttern als Befragungspersonen und den Blick auf die künftige, ggf. durch das soziale Netzwerk beeinflusste Gesundheit von Mutter und Kind mitgedacht.

Thematisch angrenzend untersuchen Blackstock et al. (2010) den Einfluss sozialer Netzwerke und der medizinischen Grund-/Primärversorgung (wie Hausärzt_innen) auf Familienplanung und Verhütungsmitteleinnahme. Dabei bilden die steigenden Zahlen ungeplanter Schwangerschaften v. a. bei afroamerikanischen Frauen aus den unteren Sozialschichten in städtischen Gebieten den Ausgangspunkt. So stehen ungeplante Schwangerschaften häufig im Zusammenhang mit schlechterer Gesundheit der Mütter und Neugeborenen. In den 20 halbstrukturierten Interviews berichten die Frauen von der Bedeutung vor allem weiblicher Netzwerkmitglieder für beispielsweise (erstmalige) Informationen über Verhütungsmittel (oft weibliche Verwandte), aber auch das Herausbilden von Einstellungen und subjektiven Normen bzgl. der eigenen Familienplanung.

Donato und Duncan (2011) erforschen anhand der Daten aus dem Health and Migration Survey (HMS) die Folgen elterlicher Migration auf die kindliche Gesundheit, indem sie insgesamt 804 Kinder von Eltern, die von Mexiko in die USA migriert, remigriert und nie migriert sind bzgl. ihrer durch die Mutter eingeschätzte Gesundheit miteinander vergleichen. Familiäre Netzwerkressourcen (als unabhängige Variable) und hier die Netzwerkgröße, Kontakthäufigkeit und Koresidenz wurden über geschlossene Fragen zu Beziehungen und Interaktionen sowie Support von Familienmitgliedern (Eltern, Geschwister, Cousins, Onkel/ Tanten, Großeltern, Schwiegerfamilie) sowie eine offene Frage nach weiteren, noch nicht genannten Netzwerkbeziehungen erhoben. Haben Kinder in den USA einen besseren Gesundheitszustand als Kinder in Mexiko und hier vor allem im Vergleich zu Kindern remigrierter Eltern, nehmen soziale Netzwerke keinen (puffernden) Einfluss auf die Gesundheit der remigierten Kinder. Ggf. sind hier nahe Netzwerkmitglieder der remigrierten Familien durch die nun fehlenden finanziellen Zuwendungen enttäuscht oder aber die Abwesenheit durch die Migration hat die Familienbeziehungen geschwächt. Dagegen haben soziale Netzwerke (als wöchentliches Zusammentreffen mit Freund_innen und Familie, zusammen mit 
der Gesundheit und dem Bildungsstand der Mutter) einen positiven Einfluss auf die Gesundheit der in den USA lebenden Kinder.

\subsection{Psychische Gesundheit und Lebensqualität}

Im Zentrum der Arbeit von Vega et al. (1991) steht die Frage nach dem Einfluss sozialer Netzwerke (Rollenbeziehung, Kontakthäufigkeit, Zufriedenheit) und der daraus gewonnenen sozialen Unterstützung auf die psychische Gesundheit (Depression) 679 mexikanischer Migrantinnen in den USA. „Family support and family income are the best predictors of low depression scores for immigrant Mexican women. In contrast, interaction contact frequency with friends and family is not correlated with depression" (ebd., S. 159). Die bedeutsame Rolle (neuer) unterstützender Netzwerke im Ankunftsland, so die Autoren, könnte eine Erklärung dafür sein, warum mexikanische Migrantinnen - trotz großer Herausforderungen - keinem höheren Erkrankungsrisiko ausgesetzt sind.

Die psychische Gesundheit steht auch in der Forschung von Teodorescu et al. (2012) im Vordergrund. Für 55 erwachsene Geflüchtete in psychiatrischer Versorgung (Norwegen) können sie einen starken Zusammenhang zwischen posttraumatischem Stress und depressiven/psycho-pathologischen Symptomen mit schwacher sozialer Integration und kleinen Freundschaftsnetzwerken zeigen - wohingegen größere Netzwerke auch eher mit posttraumatischem Wachstum einhergehen. Als Maß für das soziale Netzwerk wurde über die Frage „Wie viele gute Freunde hast du? Zähle diejenigen, mit denen du vertrauensvoll sprechen kannst und die dir bei Bedarf helfen." die Größe des Freundschaftsnetzwerks gewählt. Soziale Integration, gedacht als Integration in die norwegische Gesellschaft, wurde über vier Items erhoben (Sprache, Lesen norwegischer Zeitung, norwegische Besucher_innen, von Norweger_innen erhaltene Hilfe).

Eine andere Studie von Chandra und Batada (2006) beforscht die Wahrnehmung von Stress, sozialer Unterstützung und Bewältigungsstrategien von 26 jugendlichen Afroamerikaner_innen (9. Klasse) anhand eines triangulativen Forschungsdesigns, über das u. a. mit egozentrierten Netzwerkkarten Supportnetzwerke erhoben wurden. Es zeigt sich, dass abhängig von der Thematik - Stress in der Partnerschaft, Konflikte in der Schule oder Familie - auch unterschiedliche Supportquellen (Partnerschaft - Freunde, Schule - Familie) angefragt wurden. Zudem berichten afroamerikanische Mädchen öfter als Jungen von aktiver Hilfesuche.

Schließlich befragten Baxter et al. (2015) 1039 über 60-jährige Hispanics und „non-Hispanic Whites“ in den USA zum Einfluss u. a. von Netzwerkgröße 
(„Wie viele enge Freund_innen/Verwandte haben Sie?“) und Kontakthäufigkeit auf die subjektiv wahrgenommene Lebensqualität. Unabhängig von „race“ und „ethnicity“ (die als Begriffe unklar bleiben) hat eine größere Anzahl enger Freund_innen und Verwandte und häufigerer Kontakt positiven Einfluss auf die subjektiv wahrgenommene Lebensqualität, wobei dieser Effekt sich für „non-Hispanic Whites" stärker zeigt.

\section{$4 \quad$ Fazit und Desiderata}

\subsection{Desiderata zu Migration und Gesundheit}

Für eine weitere Erforschung des angenommenen und für bestimmte Gruppen belegten Zusammenhangs von Migration und Gesundheit stehen noch einige Arbeiten aus. Um etwa die Einflüsse der Mehrheitsgesellschaft/Dominanzkultur auf die Gesundheit von Migrant_innen zu ermitteln, bräuchte es Vergleichsstudien innerhalb verschiedener Aufnahmeländer (Kirkcaldy et al. 2006). Zudem gibt es in Deutschland laut Stenzel (2016) noch keine Untersuchung, die die oft diskutierte „Healthy-migrant“-Hypothese getestet oder aber Migration als potenziell kritisches Lebensereignis und damit als Stressor für Gesundheit untersucht hat. Des Weiteren fehlt es an Studien zum Einfluss der Kategorie „soziale Schicht" auf Migration und Gesundheit (Stenzel 2016). Inwieweit gesundheitliche Unterschiede zwischen Menschen mit und ohne Migrationsgeschichte kulturell, migrationsbedingt oder sozial zu erklären sind, bedarf demnach weiterer Forschung (Razum et al. 2011; Knipper und Bilgin 2009). Ebenso sind Arbeiten zur Versorgungsforschung (Zugang, Unterschiede in der Nutzung und Compliance) (Razum et al. 2011) und die Auswirkung der Adaption eines ,westlichen Lebensstils“ auf die Gesundheit von Migrant_innen rar (Krämer und Baune 2004).

Es bleibt zu fragen, inwieweit die mit dem Begriff Migration assoziierten Phänomene tatsächlich migrationsspezifisch, $d$. h. beispielsweise verbunden mit einem konkreten Migrationsprozess sind, oder ob nicht andere soziale Gruppenzugehörigkeiten (höheren) Erklärungsgehalt für gesundheitliche Ungleichheiten besitzen. „Pointiert ausgedrückt: Migration ist keine ,Krankheit“ und ist nicht ,pathologisch'. Ein Zusammenhang mit Krankheitsphänomen kann bestehen, ist aber stets aufmerksam und differenziert zu erörtern, bzw. auf eine methodisch adäquate Art zu untersuchen“ (Knipper und Bilgin 2009, S. 17). 


\subsection{Desiderata zu Migration und sozialen Netzwerken}

Wie die in Abschn. 2 vorgestellten Studien zeigen konnten, spielen soziale Beziehungen eine große Rolle bezüglich des Migrationsprozesses. Es muss jedoch gleichzeitig darauf hingewiesen werden, dass viele dieser Forschungen zum Teil zwar Beziehungen untersuchen, eine tiefe strukturelle Analyse (z. B. ERGMs) jedoch meist nicht stattfindet. Hier könnten signifikante Zusammenhänge zwischen persönlichen Attributen (z. B. Alter, Migrationshintergrund) und relationale Aspekte (z. B. Dichte) eruiert werden. Es werden z. B. Maßzahlen wie Größe des Netzwerkes und Netzwerkrollen (z. B. Familie, Freund_innen) als Variablen verwendet, darüber hinaus reichen die Analysen allerdings kaum. Ferner wird der Begriff des Netzwerkes häufig als Synonym für Gruppe, Sozialkapital oder auch soziale Unterstützung angewandt. Die wenigen Netzwerkstudien die existieren, sind der egozentrierten Netzwerkanalyse zuzuordnen und fokussieren hauptsächlich auf die Aspekte der sozialen Integration bzw. Assimilation von Migrant_innen in der „Aufnahmegesellschaft“. Negative Beziehungen (siehe Kap. „Negative Beziehungsaspekte und gesundheitliche Ungleichheiten“) wie beispielsweise rassistische Überbergriffe oder Anfeindungen sind bisher ein Desiderat. Auch Studien über Netzwerke in der Transit-Situation finden sich kaum.

\subsection{Desiderata zu Gesundheit, Migration und sozialen Netzwerken}

Forschungen, die die Faktoren Gesundheit, Netzwerke und Migration verbinden, liegen kaum vor. Die wenigen international vorhandenen beziehen sich - vorrangig im Krankheitsfall (Transplantatempfänger_innen, Krebserkrankung, Gesundheitsprobleme allgemein) - auf das Gesundheitsverhalten, die Gesundheit und die Inanspruchnahme von Gesundheitsversorgung sowie die Unterstützung von Netzwerken. Vereinzelt finden sich auch Studien mit präventivem Fokus auf Lebensqualität, Stressbewältigungsmechanismen oder den Umgang mit besonderen Lebenssituationen, wie beispielsweise Schwangerschaft. Soziale Netzwerke stellen dabei fast ausschließlich die unabhängige Variable dar.

In den vorgestellten Studien wird deutlich, dass soziale Unterstützung vor allem von der Familie und auch als andauernder und über regelmäßige Kontakte verfügbarer Support für Migrant_innen im Krankheitsfall und für den allgemeinen Gesundheitszustand sehr hilfreich sein kann. Auffallend ist weiter, 
dass Studien, die unterschiedliche Migrationskontexte und Zugehörigkeiten miteinander vergleichen, sehr selten sind. Der Fokus liegt hier meist auf einer bestimmten Migrationsgruppe, wie z. B. Chines_innen in Hongkong.

Jenseits der Größe und der Unterscheidung zwischen starken und schwachen Beziehungen, die in den vorliegenden Studien häufig theoretisch nicht diskutiert werden, finden sich jedoch kaum strukturelle Analysen. Wie in Abschn. 2 „Soziale Netzwerke von Migrationsanderen“ wird hier deutlich, dass ein Defizit hinsichtlich der Analyse von sozialen Netzwerken existiert. Dazu kommen fehlende Längsschnittstudien, die die Veränderung von Netzwerken berücksichtigen oder die die Richtung des Zusammenhangs untersuchen: Also ob Netzwerke die Gesundheit bzw. das Gesundheitsverhalten beeinflussen oder Gesundheit bzw. Gesundheitsverhalten die Netzwerke (z. B. Homophilie).

Zudem wurden von uns Studien zitiert, die sowohl Menschen befragen, die eine Wanderung und Lebensortwechsel vollzogen haben (der mit Blick auf Transmigrationsphänomene mehrfach in Pendelbewegungen erfolgen kann) als auch aufgrund ihrer natio-ethno-kulturellen Zugehörigkeit oder einfach aufgrund ihrer „Hautfarbe“ anderen Zugehörigkeitskontexten und ggf. anderen Einflüssen auf ihre Gesundheit ausgesetzt sind. Dies zu unterscheiden erachten wir als notwendig und plädieren für Studien - die vor allem im deutschsprachigen Raum fehlen -, die besonders gefährdete Zielgruppen (z. B. Geflüchtete, arbeitslose Migrant_innen) differenziert befragen.

\section{$5 \quad$ Ausblick}

Auf was sollten zukünftige Studien achten, um die von uns aufgezeigten Forschungslücken zu schließen? Vor dem Hintergrund der fehlenden Gesamtnetzwerkanalysen sollte versucht werden, Forschungsfelder zu finden (z. B. Schulklassen, Altersheime), in denen Gesamtnetzwerkmaßzahlen für die Analyse herangezogen werden können. Hier könnten neue Einblicke gewonnen werden, die besonders strukturelle Aspekte noch besser berücksichtigen und jenseits von individuellen Attributen (z. B. Alter, Rolle) neue Zusammenhänge offenlegen. Bei der egozentrierten Netzwerkanalyse wäre es empirisch wichtig, Namensgeneratoren und Alter-Alter-Beziehungen noch stärker einzubeziehen, um auch hier weitere strukturelle Maßzahlen berechnen zu können. Dichte oder auch Cliquenbildungen wären beispielsweise Attribute, die neue Einblicke geben könnten. Auch eine Ausweitung der bislang stark auf Support konzentrierten Netzwerkstudien auf andere in sozialen Netzwerken realisierten Funktionen und Wirkmechanismen, wie soziale Einbindung, Einfluss, Ansteckung 
oder Belastung (siehe Kap. „Wirkmechanismen in sozialen Netzwerken“ und „Negative Beziehungsaspekte und gesundheitliche Ungleichheiten“), wäre unseres Erachtens sinnvoll. Im Allgemeinen wäre es folgerichtig, gesundheitliche, migrationsbezogene und Netzwerkvariablen noch stärker zu verbinden, ohne dabei aber bestimmte Phänomene direkt als migrationstypisch zu erachten, sondern immer auch das Konzept der Intersektionalität (z. B. Geschlecht, Schicht) in die eigenen Forschungen miteinzubeziehen. Schließlich wäre es - wie in der Dissertation Olbermann (2003) zu sozialen Netzwerken älterer Migrant_innen $(\mathrm{N}=99)$ angedeutet - wichtig, lebensspezifische Besonderheiten der Migrant_innen zu berücksichtigen und soziale Beziehungen auch als abhängige Variable zu betrachten. So fehlten beispielsweise in der genannten Studie den älteren, arbeitslosen oder frühverrenteten Migrant_innen finanzielle Ressourcen zur Pflege sozialer Netzwerkbeziehungen, womit „die bei Hochaltrigen zu beobachtenden gesundheitsbedingten Verkleinerung ihrer sozialen Netzwerke bei den Migranten früher eintreten dürften“ (ebd., S. 144).

\section{Leseempfehlungen}

Cetingok, M., Winsett, R. P., Russell, C. L., \& Hathaway, D. K. (2008). Relationships between sex, race, and social class and social support networks in kidney, liver, and pancreas transplant recipients. Progress in Transplantation, 18 (2), (S. 80-88). Auf soziale Unterstützung konzentrierte explorativ-deskriptive Analyse, die psychische wie auch physische Gesundheit nach sozio-demografischen und ethnischen Merkmalen untersucht.

Donato, K. M., \& Duncan, E. M. (2011). Migration, social networks, and child health in Mexican families. Journal of Marriage and Family, 73 (4), (S. 713-728). Quantitative Vergleichsstudie zwischen migrierten, nie migrierten und remigrierten Familien. Die Ergebnisse sind spannend, die berechneten Netzwerkmaße stehen allerdings nicht im Fokus.

\section{Datensätze}

- Sozio-oekonomisches Panel (SOEP) des Deutschen Instituts für Wirtschaftsforschung (DIW), enthält seit 1994/1995 Stichprobe von Personen mit sogenanntem Migrationshintergrund (Zuwandererstichprobe) und Items zur Abbildung egozentrierter Netzwerke, https://www.diw.de/ soep/. 


\section{Literatur}

Andersson, R. (2014). Illegality.inc: Clandestine migration and the business of bordering Europe. Oakland: California University Press.

Bashi, V. (2007). Survival of the knitted: Immigrant social networks in a stratified world. Stanford: Stanford University Press.

Bauer, T., Epstein, G. S., \& Gang, I. N. (2009). Measuring ethnic linkages among migrants. International Journal of Manpower, 30(1/2), 56-69.

Baxter, J., Shetterly, S. M., Eby, C., Mason, L., Cortese, C. F., \& Hamman, R. F. (2015). Social networks factors associates with perceived quality of life. Journal of Aging and Health, 10(3), 287-310.

Bilecen, B. (2012). How to cross? Migrant Perspectives. In A. Icduygu \& D. Sert (Hrsg.), Borders under stress: The cases of Turkey-EU and Mexico-USA borders (S. 167-182). Istanbul: ISIS.

Bilecen, B. (2016). A mixed-methods design of social network analysis to investigate transnational social protection. International Review of Social Research, 6(4), 233-244.

Bilecen, B., \& Sienkiewicz, J. J. (2015). Informal social protection networks of migrants: Typical patterns in different transnational social spaces. Population, Space and Place, 21(3), 227-243.

Blackstock, O. J., Mba-Jonas, A., \& Sacajiu, G. M. (2010). Family planning knowledge: The role of social networks and primary care providers as information sources for African American women. American Journal of Sexuality Education, 5(2), 128-143.

Boyd, M. (1989). Family and personal networks in international migration: Recent developments and new agendas. International Migration Review, 23(3), 638-670.

BPtK - Bundespsychotherapeutenkammer. (2015). Psychische Erkrankungen bei Flüchtlingen. https://www.bptk.de/aktuell/einzelseite/artikel/mindestens-d.html. Zugegriffen: 26. Juni 2018.

Brandes, U., Lerner, J., Lubbers, M., McCarty, C., \& Molina, J. L. (2008). Visual statistics for collections of clustered graphs. Proceedings of the 2008 IEEE Pacific Visualization Symposium, S. 47-54.

Brandes, U., Lerner, J., Lubbers, M. J., McCarty, C., Molina, J. L., \& Nagel, U. (2010). Recognizing modes of acculturation in personal networks of migrants. Procedia Social and Behavioral Sciences, 4, 4-13.

Cetingok, M., Winsett, R. P., Russell, C. L., \& Hathaway, D. K. (2008). Relationships between sex, race, and social class and social support networks in kidney, liver, and pancreas transplant recipients. Progress in Transplantation, 18(2), 80-88.

Chakrabarti, R. (2010). Therapeutic networks of pregnancy care: Bengali immigrant women in New York City. Social Science and Medicine, 71(2), 362-369.

Chan, C. W., Hon, H. C., Chien, W. T., \& Lopez, V. (2004). Social support and coping in Chinese patients undergoing cancer surgery. Cancer Nursing, 27(3), 230-236.

Chandra, A., \& Batada, A. (2006). Exploring stress and coping among urban African American adolescents: The shifting the lens study. Preventing Chronic Disease. Public Health Research, Practice, and Policy, 3(2), 1-10.

Chatters, L. M., Taylor, Robert J., \& Jackson, J. S. (1985). Size and composition of the informal helper networks of elderly blacks. Journal of Gerontology, 40(5), 605-614.

De Haas, H. (2007). Morocco's migration experience: A transitional perspective. International Migration, 54(4), 39-70. 
Donato, K. M., \& Duncan, E. M. (2011). Migration, social networks, and child health in Mexican families. Journal of Marriage and Family, 73(4), 713-728.

Eisenstadt, S. N. (1952). The process of absorption of new immigrants in Israel. Human Relations, 5, 223-246.

Elkeles, T., \& Seifert, W. (1996). Immigrants and health: unemployment and health-risks of labour migrants in the Federal Republic of Germany, 1984-1992. Social Science and Medicine, 43(7), 1035-1047.

Facchini, G., Patacchini, E., \& Steinhardt, M. F. (2014). Migration, friendship ties and cultural assimilation. IZA Discussion Paper Series, 7881. https://onlinelibrary.wiley.com/ doi/epdf/10.1111/sjoe.12096. Zugegriffen: 28. Juni 2018.

Faist, T. (2000). Grenzen überschreiten. Das Konzept Transstaatliche Räume und seine Anwendungen. In T. Faist (Hrsg.), Transstaatliche Räume: Politik, Wirtschaft und Kultur in und zwischen Deutschland und der Türkei (S. 9-57). Bielefeld: Transcript.

Fussell, E., \& Massey, D. S. (2004). The limits of cumulative causation: International migration from Mexican urban areas. Demography, 41(1), 151-171.

Gamper, M. (2015). Die Sozialkapital-Theorie Bourdieus und ihre Bedeutung für die Migrationsforschung. In J. Reuter \& P. Mecheril (Hrsg.), Schlüsselwerke der Migrationsforschung - Pionierstudien und Referenztheorien (S. 343-360). Wiesbaden: Springer VS.

Gamper, M., \& Fenicia, T. (2013). Transnationale Unterstützungsnetzwerke von Migranten Eine qualitative Studie zu Spätaussiedlern aus der ehemaligen UdSSR. In M. Schönhuth, M. Gamper, M. Kronenwett, \& M. Stark (Hrsg.), Visuelle Netzwerkforschung: Partizipative, qualitative und quantitative Zugänge (S. 249-276). Bielefeld: Transcript.

Gamper, M., \& Reschke, L. (Hrsg.). (2010). Knoten und Kanten: Soziale Netzwerkanalyse in Wirtschafts-und Migrationsforschung. Bielefeld: Transcript.

Gamper, M., Fenicia, T., \& Schönhuth, M. (2013). Transnationale Netzwerke, Sozialkapital und Migration - Eine triangulative Studie über die Vernetzung von Aussiedlern aus der ehemaligen Sowjetunion. In A. Herz \& C. Olivier (Hrsg.), Transmigration und Soziale Arbeit. Theoretische Herausforderungen und gesellschaftliche Praxis (S. 249-272). Hohengehren: Schneider.

Garip, F. (2016). On the move. Changing mechanisms of Mexico-US migration. Princeton: Princeton University Press.

Gordon, M. (1964). Assimilation and American life: The role of race, religion and national origins. Oxford: Oxford University Press.

Haug, S. (2000a). Klassische und neuere Theorien der Migration. Mannheim: MZES.

Haug, S. (2000b). Soziales Kapital und Kettenmigration: Italienische Migranten in Deutschland. Opladen: Leske + Budrich.

Herz, A. (2015). Relational constitution of social support in migrants' transnational personal communities. Social Networks, 40, 64-74.

Jedlicka, D. (1978). Opportunities, information networks and international migration streams. Social Networks, 1(3), 277-284.

Kindler, M., Ratcheva, V., \& Piechowska, M. (2015). Social networks, social capital and migrant integration at local level. European literature review. Iris Working Paper Series No. 6/2015. Birmingham: Institute for Research into Superdiversity.

Kirkcaldy, B., \& Furnham, A. (1995). Coping, seeking, social support and stress among German police management. European Review of Applied Psychology, 45(32), 121-126. 
Kirkcaldy, B., Wittig, U., Furnham, A., Merbach, M., \& Siefen, R. G. (2006). Migration und Gesundheit. Psychosoziale Determinanten. Bundesgesundheitsblätter - Gesundheitsforschung - Gesundheitsschutz, 9(49), 873-883.

Knipper, M., \& Bilgin, Y. (2009). Migration und Gesundheit. Konrad-Adenauer-Stiftung Archiv. http://www.kas.de/wf/doc/kas_16451-544-1-30.pdf?100422141705. Zugegriffen:21. Febr. 2019.

Koser, K. (1997). Social networks and the asylum cycle: The case of Iranians in the Netherlands. International Migration Review, 31(3), 591-611.

Koser, K., \& Pinkerton, C. (2002). The social networks of asylum seekers and the dissemination of information about countries of asylum. http://www.urbanlab.org/articles/ Koser_2002_SocialNetworksOfAsylumSeekers.pdf. Zugegriffen:21. Febr. 2019.

Krämer, A., \& Baune, B. T. (2004). Migrationen eine Herausforderung für die Gesundheitswissenschaften und die gesundheitliche Versorgung. In A. Krämer \& L. Prüfer-Krämer (Hrsg.), Gesundheit von Migranten. Internationale Bestandsaufnahme und Perspektiven (S. 9-20). Weinheim: Juventa.

Kupfer, A. (2015). Wer hilft helfen? Einflüsse sozialer Netzwerke auf Beratung. Tübingen: dgvt.

Kutalek, R. (2009). Migration und Gesundheit: Strukturelle, soziale und kulturelle Faktoren. In M. Six-Hohenbalken \& J. Tošić (Hrsg.), Anthropologie der Migration: Theoretische Grundlagen und interdisziplinäre Aspekte (S. 302-321). Wien: facultas.wuv.

Lagarde, D., \& Doraï, K. (2016). Host state policies and the changing role of social networks for Syrian refugees in Jordan. XIII Annual Conference of the Italian Society of the Italian Society for Middle Eastern Studies (SeSaMO), March 2016, Catane, Italy.

Levitt, P., \& Glick Schiller, N. (2007). Conceptualizing simultaneity: A transnational social field perspective on society. In A. Portes \& J. DeWind (Hrsg), Rethinking migration. New theoretical and empirical perspectives (S. 181-219). New York: Berghahn.

Li, Y., \& Wu, S. (2010). Social networks and health among rural-urban migrants in China: A channel or a constraint? Health Promotion International, 25(3), 371-380.

Lubbers, M. J., Molina, J. L., Lerner, J., Brandes, U., Ávila, J., \& McCarty, C. (2010). Longitudinal analysis of personal networks. The case of Argentinean migrants in Spain. Social Networks, 32(1), 91-104.

Lutz, H. (2008). Vom Weltmarkt in den Privathaushalt. Die neuen Dienstmädchen im Zeitalter der Globalisierung. Opladen: Budrich.

MacDonald, J. S., \& MacDonald, L. D. (1964). Chain migration, ethnic neighborhood formation, and social networks. Milbank Memorial Fund Quarterly, 42, 82-94.

Massey, D. S., Arango, J., Hugo, G., Kouaouci, A., Pellegrino, A., \& Taylor, E. J. (1993). Theories of international migration: A review and appraisal. Population and Development Review, 19(3), 431-466.

Mecheril, P. (2010). Migrationspädagogik. Hinführung zu einer Perspektive. In: P. Mecheril, M. do M. Castro Varela, İ. Dirim, A. Kalpaka, \& C. Melter (2010): Migrationspädagogik (S. 7-22). Weinheim: Beltz.

Nauck, B. (1989). Assimilation process and group integration of migrant families. International Migration, 27(1), 27-48.

Nestmann, F. (1999). Psychische Störungen in der Migration und interkulturelle Beratung. In M. Gemende, W. Schröer, \& S. Sting (Hrsg.), Zwischen den Kulturen. Pädagogische und sozialpädagogische Zugänge zur Interkulturalität (S. 171-193). Weinheim: Juventa. 
Olbermann, E. (2003). Soziale Netzwerke, Alter und Migration: Theoretische und empirische Explorationen zur sozialen Unterstützung älterer Migranten. Dissertation, Universität Dortmund. https://eldorado.tu-dortmund.de/bitstream/2003/2914/1/olbermannunt.pdf. Zugegriffen: 22. März 2018.

Palloni, A., Massey, D. S., Ceballos, M., Espinosa, K., \& Spittel, M. (2001). Social capital and international migration: A test using information on family networks. American Journal of Sociology, 106(5), 1262-1298.

Parsons, C. R., Skeldon, R., Walmsley, T. R., \& Winters, A. L. (2007). Quantifying international migration: A database of bilateral migrant stocks. World Bank Policy Research Working Paper, 4165. https://ssrn.com/abstract=969242. Zugegriffen: 1. März 2019.

Pohjola, A. (1991). Social networks: Help or hindrance to the migrant? International Migration, 29(3), 435-444.

Portes, A. (1995). Economic sociology and the sociology of immigration: A conceptual overview. In A. Portes (Hrsg.), The economic sociology of immigration (S. 1-41). New York: Russel Sage Foundation.

Pries, L. (2010). Transnationalisierung. Theorie und Empirie grenzüberschreitender Vergesellschaftung. Wiesbaden: VS Verlag.

Ralston, M. L., \& Escandell, X. (2012). Networks matter: Male Mexican migrants' use of hospitals. Population Research and Policy Review, 31, 321-337.

Razum, O. (2009). Migration, Mortalität und der Healthy-migrant-Effekt. In M. Richter \& K. Hurrelmann (Hrsg.), Gesundheitliche Ungleichheit. Grundlagen, Probleme, Perspektiven (S. 267-282). Wiesbaden: VS Verlag.

Razum, O., \& Twardella, D. (2002). Time travel with Oliver Twist - Towards an explanation for a paradoxically low mortality among recent immigrants. Tropical Medicine \& International Health, 7(1), 4-10.

Razum, O., Spallek, J., \& Zeeb, H. (2011). Migration und Gesundheit. In T. Schott \& C. Hornberg (Hrsg.), Die Gesellschaft und ihre Gesundheit (S. 555-574). Wiesbaden: VS Verlag.

Schenk, L. (2007). Migration und Gesundheit - Entwicklung eines Erklärungs- und Analysemodells für epidemiologische Studien. International Journal of Public Health, 52(2), 87-96.

Schweizer, T., Schnegg, M., \& Berzbon, S. (1998). Personal networks and social support in a multiethnic community of Southern California. Social Networks, 20, 1-21.

Sommer, E., \& Gamper, M. (2018). Transnational entrepreneurial activities: A qualitative network study of self-employed migrants from the former Soviet Union in Germany. Social Networks, 53, 136-147.

Spallek, J., \& Razum, O. (2016). Migration und Gesundheit. In M. Richter \& K. Hurrelmann (Hrsg.), Soziologie von Gesundheit und Krankheit (S. 153-166). Wiesbaden: VS Verlag.

Stelzig-Willutzki, S. (2012). Soziale Beziehungen im Migrationsverlauf: Brasilianische Frauen in Deutschland. Wiesbaden: Springer.

Stenzel, M. (2016). Migration und Gesundheit. Erklärungsansätze und bisherige Forschungsergebnisse. In J. Stauder, I. Rapp, \& J. Eckhard (Hrsg.), Soziale Bedingungen privater Lebensführung (S. 283-303). Wiesbaden: Springer VS.

Sting, S. (2010). Migration und Gesundheit. In E. Yildiz \& G. Spiel (Hrsg.), Ressourcen im Blick. Tagungsband zur Veranstaltung vom 7. Mai 2010, Klagenfurt. IfEB Alpen-Adriana Universität Klagefurt Archive. http://www.ifeb.uni-klu.ac.at/fileadmin/ib/dateien/ Tagungsband_Ressourcen_im_Blick.pdf.ZZugegriffen: 15. Jan. 2018. 
Teodorescu, D.-S., Siqveland, J., Heir, T., Hauff, E., Wentzel-Larsen, T., \& Lien, L. (2012). Posttraumatic growth, depressive symptoms, posttraumatic stress symptoms, post-migration stressors and quality of life in multi-traumatized psychiatric outpatients with a refugee background in Norway. Health and Quality of Life Outcomes, 10(84), 1-16.

Teteryatnikova, M. (2013). A model of social networks and migration decisions. Vienna: University of Vienna.

Toma, S. (2015). The role of migrant networks in the labour market outcomes of Senegalese men: How destination contexts matter. Ethnic and Racial Studies, 39(4), 593-613.

Vega, W. A., Kolody, B., Valle, R., \& Weir, J. (1991). Social Networks, Social Support, and their Relationship to Depression among Immigrant Mexican Women. Human Organization, 50(2), 154-162.

Wakeel, F., Witt, W., Wisk, L. E., Lu, M. C., \& Chao, S. M. (2013). Racial and ethnic disparities in personal capital during pregnancy: Findings from the 2007 Los Angeles Mommy and Baby (LAMB) Study. Maternal and Child Health Journal, 18(1), 209-222.

Dr. Annett Kupfer ist Wissenschaftliche Mitarbeiterin am Institut für Sozialpädagogik, Sozialarbeit und Wohlfahrtswissenschaften der Fakultät Erziehungswissenschaften der Technischen Universität Dresden.PD Dr. Markus Gamper ist Akademischer Rat am Institut für vergleichende Bildungsforschung und Sozialwissenschaften der Universität zu Köln.

Open Access Dieses Kapitel wird unter der Creative Commons Namensnennung 4.0 International Lizenz (http://creativecommons.org/licenses/by/4.0/deed.de) veröffentlicht, welche die Nutzung, Vervielfältigung, Bearbeitung, Verbreitung und Wiedergabe in jeglichem Medium und Format erlaubt, sofern Sie den/die ursprünglichen Autor(en) und die Quelle ordnungsgemäß nennen, einen Link zur Creative Commons Lizenz beifügen und angeben, ob Änderungen vorgenommen wurden.

Die in diesem Kapitel enthaltenen Bilder und sonstiges Drittmaterial unterliegen ebenfalls der genannten Creative Commons Lizenz, sofern sich aus der Abbildungslegende nichts anderes ergibt. Sofern das betreffende Material nicht unter der genannten Creative Commons Lizenz steht und die betreffende Handlung nicht nach gesetzlichen Vorschriften erlaubt ist, ist für die oben aufgeführten Weiterverwendungen des Materials die Einwilligung des jeweiligen Rechteinhabers einzuholen.

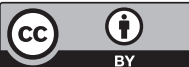




\title{
Desiderata: Soziale Netzwerk und gesundheitliche Ungleichheiten - welche Fragen bleiben offen?
}

\author{
Olaf Reis, Philip Adebahr, Stefan Brandt, Lea Ellwardt, \\ Markus Gamper, Laura Hoffmann, Sylvia Keim-Klärner, \\ Andreas Klärner, André Knabe, Gerhard Krug, \\ Annett Kupfer, Daniel Lois, Martin Mlinarić, \\ Irene Moor, Britta Müller, Mathilde Niehaus, \\ Nancy Reims, Matthias Richter, Julia Seidel, \\ Holger von der Lippe, Nico Vonneilich \\ und Stefan Zapfel
}

O. Reis $(\bowtie) \cdot$ A. Knabe $\cdot$ B. Müller

Rostock, Deutschland

E-Mail: olaf.reis@med.uni-rostock.de

A. Knabe

E-Mail: andre.knabe@uni-rostock.de

B. Müller

E-Mail: britta.mueller@med.uni-rostock.de

P. Adebahr

Chemnitz, Deutschland

E-Mail: philip.adebahr@soziologie.tu-chemnitz.de

S. Brandt $\cdot$ H. von der Lippe

Berlin, Deutschland

E-Mail: brandt@tu-berlin.de

H. von der Lippe

E-Mail: holger.vonderlippe@ medicalschool-berlin.de

L. Ellwardt · M. Gamper · M. Niehaus

Köln, Deutschland

E-Mail: ellwardt@wiso.uni-koeln.de

(C) Der/Die Herausgeber und der/die Autor(en) 2020

A. Klärner et al. (Hrsg.), Soziale Netzwerke und gesundheitliche Ungleichheiten, https://doi.org/10.1007/978-3-658-21659-7_17 
M. Gamper

E-Mail: m.gamper@uni-koeln.de

M. Niehaus

E-Mail: mathilde.niehaus@uni-koeln.de

L. Hoffmann · M. Mlinarić · I. Moor

Halle (Saale), Deutschland

E-Mail: laura.hoffmann@medizin.uni-halle.de

M. Mlinarić

E-Mail: martin.mlinaric@medizin.uni-halle.de

I. Moor

E-Mail: irene.moor@medizin.uni-halle.de

S. Keim-Klärner · A. Klärner

Braunschweig, Deutschland

E-Mail: sylvia.keim-klaerner@thuenen.de

A. Klärner

E-Mail: andreas.klaerner@thuenen.de

G. Krug $\cdot$ N. Reims $\cdot$ S. Zapfel

Nürnberg, Deutschland

E-Mail: gerhard.krug@iab.de

N. Reims

E-Mail: nancy.reims@iab.de

S. Zapfel

E-Mail: stefan.zapfel@ifes.uni-erlangen.de

A. Kupfer · J. Seidel

Dresden, Deutschland

E-Mail: annett.kupfer@tu-dresden.de

J. Seidel

E-Mail: julia.seide14@tu-dresden.de

D. Lois

Neubiberg, Deutschland

E-Mail: daniel.lois@unibw.de

M. Richter

Halle, Deutschland

E-Mail:m.richter@medizin.uni-halle.de

N. Vonneilich

Hamburg, Deutschland

E-Mail: n.vonneilich@uke.de 


\section{$1 \quad$ Einleitung}

„Sag mir, wie viel Deine Freunde verdienen, und ich sage Dir, ob Du rauchst, welche Krankheiten Du hast und wie alt Du werden wirst!" Mit dieser etwas zugespitzten Aussage wurde am Anfang dieses Bandes vorgeschlagen, den empirisch gut bestätigten Zusammenhang von sozialen und gesundheitlichen Ungleichheiten aus der Perspektive der Netzwerkforschung zu beleuchten (siehe Kap. „Soziale Netzwerke und gesundheitliche Ungleichheiten - eine neue Forschungsperspektive"). Soziale Netzwerke werden dabei als vermittelnde Instanz auf einer intermediären oder Meso-Ebene verstanden, deren Struktur und Funktion zwischen vertikalen (Einkommen, Bildung, berufliche Stellung etc.) sowie horizontalen (z. B. Alter, Geschlecht, ethnische Herkunft) und gesundheitlichen Ungleichheiten (z. B. Lebenserwartung, Erkrankungsraten) vermittelt (Mediatorfunktion) oder deren Beziehung beeinflusst (Moderatorfunktion).

Damit wird der Versuch unternommen, zwischen die makro- und die mikrofundierte Gesundheitswissenschaft gewissermaßen eine „mesofundierte“ Forschung zu stellen, die notwendigerweise die Makro- und die Mikro-Perspektiven vereint. Mit diesem Anspruch verortet sich die Netzwerkforschung zwischen klassischen makrosoziologischen Ansätzen, die sich auf große Gruppen (z. B. soziale Klassen, Geschlechter) beziehen, und mikrofundierten Ansätzen, die individuelle gesundheitliche Voraussetzungen, Präferenzen und Verhaltensweisen betonen. Sie greift damit auch die Kritik von Emirbayer (1997) auf, der auf der einen Seite allzu einfache Modelle rationaler und am Eigeninteresse orientierter Akteure kritisiert; auf der anderen Seite aber auch Ansätze bemängelt, die den strikten Vorrang von Normen oder gesellschaftlichen Strukturen behaupten, welche das Handeln von Subjekten „leiten“ (vgl. Klärner und Keim 2019). Im sozialen Netzwerk treffen individuelle Voraussetzungen, wie die genetische Ausstattung, die Persönlichkeit, Vorlieben etc., auf die soziale „Strukturation“ (Giddens 1984) durch vertikale und horizontale Ungleichheiten. Soziale Netzwerke werden einerseits vom Individuum beeinflusst, andererseits wirken sich Netzwerkveränderungen auf das Individuum aus.

Für die Klärung der Zusammenhänge zwischen individueller Gesundheit, Netzwerk und sozialer Ungleichheit bedarf es einiger Voraussetzungen, denen sich der erste Teil dieses Bandes widmet. In der wissenschaftlichen Auseinandersetzung mit den Themen rund um soziale Beziehungen, soziales Kapital und soziale Netzwerke kann festgestellt werden, dass die unterschiedlichen Begriffe nicht klar voneinander abgegrenzt und teilweise synonym verwendet werden. Damit bleiben die Begriffe oft unklar, was eine einheitliche Definition und ein 
einheitliches Verständnis sozialer Beziehungen und sozialer Netzwerke erschwert. Um zu einem klareren Verständnis beizutragen, unternimmt Nico Vonneilich eine Einordnung der Begriffe und Konzepte (siehe Kap. „Soziale Beziehungen, soziales Kapital und soziale Netzwerke“). Markus Gamper (siehe Kap. „Netzwerktheorie(n)") schlägt in seinem Beitrag vor, Netzwerke primär strukturell zu verstehen, als Menge von Knoten (Akteuren auf unterschiedlicher Aggregatsebene), die durch Kanten (Beziehungen verschiedener Art) verbunden sind, über die ein Austausch (von Informationen, Emotionen, Gütern etc.) stattfindet. Soziales Kapital kann damit als Vorhandensein gesundheitlich ertragreicher Knoten und Kanten, soziale Unterstützung als Effekt dieser verstanden werden. Die Auftrittswahrscheinlichkeit ertragreicher Knoten und Kanten würde durch vertikale und horizontale Ungleichheiten moderiert, was sich auf der Mikroebene der Individuen in vor- oder nachteiligen Gesundheitseffekten (bezüglich Morbidität und Mortalität sowie dem subjektiven Gesundheitsempfinden), und auf der Makroebene in sozial ungleich verteilten psychischen und physischen Gesundheitszuständen, d. h. gesundheitlichen Ungleichheiten, niederschlagen sollte.

Neben sozialem Kapital bzw. sozialer Unterstützung werden in dem Beitrag von Andreas Klärner und Holger von der Lippe weitere mögliche Wirkmechanismen in sozialen Netzwerken diskutiert: soziale Integration, sozialer Einfluss und (soziale) Ansteckung (siehe Kap. „Wirkmechanismen“). Diese Konzepte sind, wie der Beitrag zeigt, als Sammelbegriffe heuristisch durchaus nützlich, während ein allgemeines, sparsames und trennscharfes theoretisches Modell, in dem die möglichen Zusammenhänge präzise definiert und differenziert werden können, weiterhin aussteht. Zukünftige Forschung steht den Autoren zufolge vor der Aufgabe, die Unterscheidungen von 1) direkten und indirekten sowie 2) positiven und negativen Gesundheitseffekten durch 3) verschiedene Akteure oder Sektoren von Netzwerken zu berücksichtigen und diese Aspekte für unterschiedliche Krankheitsrisiken differenziert zu analysieren.

In der Literatur, das machen die Autor*innen der einzelnen Beiträge deutlich, wird der Netzwerk-Begriff noch zu häufig lediglich als Metapher gebraucht, steht z. B. für die Kontakthäufigkeit zu Eltern und Freunden oder für soziale Unterstützung, wird dabei aber nicht strukturell operationalisiert. Netzwerkstudien im oben ausgeführten strukturellen Verständnis sind im Bereich der Erforschung gesundheitlicher Ungleichheiten noch relativ selten anzutreffen. Auch weisen die Autor*innen der Beiträge dieses Bandes darauf hin, dass hier noch ein erheblicher theoretischer wie auch methodologischer Entwicklungsbedarf besteht. Damit das Konzept der sozialen Netzwerke die geforderte „Mesofundierung“ der Gesundheitswissenschaften zwischen Makro- und Mikroprozessen leisten kann, 
bedarf es einer Weiterentwicklung der vorliegenden theoretischen Modelle (siehe Kap. „Soziale Netzwerke und gesundheitliche Ungleichheiten“) und einer konsequenten Anwendung der Methoden der Netzwerkanalyse (siehe Kap. „Netzwerkanalyse"). So gilt es zum Beispiel, gesundheitliche Risiken und Ressourcen im Netzwerk zwar als Bestandteil der Lebenswelt, aber auch als relativ unabhängig vom Einzelnen zu sehen. Beispielsweise ist die Exposition gegenüber rauchenden Mitschülern für Jugendliche aus niedrigeren Einkommensschichten größer, unabhängig davon, ob sie selbst rauchen oder nicht. Diesen Übergang leistet die Gesamtnetzwerkanalyse, in die innerhalb eines definierten Raumes alle Knoten und Kanten eingehen. Die Akteure (als Knoten) gehen Beziehungen auch ohne Zutun oder Wissen des Einzelnen ein (Alteri-Kanten). Dabei haben diese (teils vielleicht unbewussten) Beziehungen ihrerseits wieder Auswirkungen auf Knoten und Kanten im egozentrierten Netzwerk, die sich dann auf die individuelle Gesundheit auswirken können. Weiter ermöglichen es qualitative und egozentrierte Netzwerkverfahren aber auch, den Raum möglicher Einflüsse des sozialen Netzwerkes auf Gesundheit durch Hinzunahme bisher unbekannter Akteure (Knoten) durch sogenannte Akteursgeneratoren zu erweitern. Dabei stellen alle Autor*innen dieses Bandes jedoch übereinstimmend fest, dass das Feld der Netzwerkforschung in der Medizin- und Gesundheitssoziologie sowie in der Sozialepidemiologie große Lücken aufweist, sowohl was die Berücksichtigung von Alteri-Beziehungen als auch was die die Hinzunahme möglicher Akteure betrifft.

Eine erhebliche strukturelle Erweiterung der Netzwerkforschung wird von Philip Adebahr (siehe Kap. „Negative Beziehungsaspekte und gesundheitliche Ungleichheiten“) angemahnt - der Einbezug sogenannter negativer Beziehungen (negative relationships) oder präziser ausgedrückt: negativer Beziehungsaspekte (negative ties). Dabei sollten Beziehungsaspekte, die mit Streit, Konflikt, psychischen Belastungen oder physischen Verletzungen verbunden sind, nicht nur als Risiken für Gesundheit verstanden werden; vielmehr ist ihre Wirkung vom Kontext anderer Beziehungen - des gesamten Netzwerkes - abhängig. Ebenso wenig sollte das Konzept der negativen Beziehungen auf Ego-Netzwerke beschränkt werden. Möglicherweise werden moderierende oder mediierende Funktionen des Netzwerkes, wie sie oben formuliert wurden, nur unter Einbezug negativer Beziehungen in Alteri-Beziehungen besser verstehbar und erklärbar. Beispielsweise könnten Limitierungen des Netzwerkes aufgrund eines geringeren Einkommens möglicherweise durch das Vorhandensein von negativen Beziehungen besser beschrieben werden als durch das Nicht-Vorhandensein positiver Beziehungen. Hier klafft eine Forschungslücke, denn bisher ist zu negativen Beziehungsaspekten nicht ausreichend bekannt, inwiefern sie beispielsweise Netzwerke organisieren, inwiefern sie sozial ungleich verteilt sind oder inwiefern 
es Ansteckungsmechanismen gibt, die von vertikalen Ungleichheitsdimensionen abhängen. Sozialer Aufstieg beispielsweise ließe sich nicht nur als Zugewinn positiver Beziehungsaspekte darstellen, sondern auch als die Loslösung von negativen Beziehungsaspekten. Der Einbezug negativer Aspekte sozialer Beziehungen ähnelt in einigen Aspekten anderen Konzepten aus der Beziehungsforschung, beispielsweise dem Konzept der ,intergenerationalen Ambivalenz“ (Lüscher und Pillemer 1998).

Unabhängig von den eben beschriebenen theoretischen und methodischen Herausforderungen an die Netzwerkforschung sollen im Folgenden inhaltliche Lücken aufgelistet werden, wie sie in den Kapiteln dieses Bandes beschrieben werden. Die Beiträge des Bandes stellen den Forschungsstand auf verschiedenen Feldern dar. Diese Forschungsfelder werden einmal entlang der Phasen des Lebenslaufs strukturiert, d. h. von der Kindheit bis ins hohe Alter. Eine zweite Struktur folgt ausgewählten Dimensionen vertikaler und horizontaler Ungleichheiten - vom sozioökonomischen Status bis hin zu natio-ethno-kultureller Zugehörigkeit. Im Folgenden werden wir nun offen gebliebene Fragen aus Sicht der Lebenslaufforschung und aus Sicht der Ungleichheitsforschung benennen und hoffen, damit eine Orientierung für zukünftige Forschungsanstrengungen geben zu können. Um es vorwegzunehmen: Studien, die Gesundheit, Netzwerk und soziale Ungleichheit im Sinne eines einheitlichen Modells zusammenführen, sind nicht vorhanden. Damit wird eine Erwartung an den vorliegenden Band, umfassende Ergebnisse zu ebendiesen Wechselwirkungen zu präsentieren, notwendigerweise enttäuscht.

\section{Offene Fragen aus Sicht der Lebenslaufforschung}

Zur Lebenslaufperspektive verweisen unterschiedliche Autor*innen im zweiten Teil dieses Bandes darauf, dass fast alle bekannten Studien biologische Faktoren aus den Modellen ausklammern (siehe Kap. „Soziale Netzwerke, familiales Sozialkapital und kindliche Gesundheit" und "Soziale Netzwerke und gesundheitliche Ungleichheiten im jungen und mittleren Erwachsenenalter"). Das betrifft insbesondere genetische Faktoren, die nicht nur in der Kindheit, sondern lebenslang wirken und oft in Interaktion mit umweltlichen Ereignissen stehen. Derartige Ereignisse können auch direkt netzwerkbezogen sein, wie etwa Verluste zentraler Beziehungen oder Veränderungen der Positionen im Netzwerk. Dieses Thema ist weitgehend wissenschaftliches Neuland und bedarf großer Studien mit mehrdimensionaler Datenlage. In anderen Worten: Es bedarf vollständiger biopsycho-sozialer Erhebungen (siehe Abschn. 5). 
Weiterhin scheinen unterschiedliche Mechanismen sozialer Netzwerke (siehe Kap. „Wirkmechanismen in sozialen Netzwerken“) in verschiedenen Lebensphasen zu wirken. Beispielsweise dürfte sozialer Einfluss in Form direkter sozialer Kontrolle, zu Beginn des Lebens für die Individualentwicklung (ausgeübt von den Eltern) erheblicher sein als soziale Ansteckung. Soziale Ansteckung dürfte mit zunehmender Autonomie des Individuums im Lebensverlauf eher zunehmen, um möglicherweise zum Lebensende hin gegenüber sozialer Kontrolle (z. B. ausgeübt von Helfern) wieder an Bedeutung zu verlieren. Um diese zeitliche Perspektive der Dynamiken und Veränderungen sozialer Netzwerke zu erforschen, bedarf es weiterer konzeptueller Zusammenschlüsse von soziologischer Netzwerk- und psychologischer Entwicklungsforschung, in denen verschiedene phasenspezifische Regulationsmechanismen angenommen werden.

Für die Netzwerke von Kindern stellt Daniel Lois (siehe Kap. „Soziale Netzwerke, familiales Sozialkapital und kindliche Gesundheit") fest, dass in der empirischen Forschung Familiennetzwerke häufig zu eng gefasst werden und Geschwister, Großeltern, entferntere Verwandte oder optierte Familienmitglieder zu selten eingeschlossen werden. Die sich im Zuge der Modernisierung diversifizierenden Familiennetzwerke würden darüber hinaus vom Einbezug der Alteri-Kanten und deren Formalisierung auch als negative Beziehungen profitieren. So sind Netzwerke von Kindern aus Patchwork-Familien denkbar, die vier oder mehr Paare von Großeltern enthalten, deren Alteri-Beziehungen möglicherweise von den nicht immer konfliktfreien Beziehungen der zugehörigen Eltern, etwa nach einer Scheidung (siehe Kap. „Soziale Netzwerke und gesundheitliche Ungleichheiten im jungen und mittleren Erwachsenenalter"), beeinflusst werden. Die Muster derartiger positiver und negativer Beziehungen von entfernteren Verwandten werden in vielerlei Gestalt relevant für die Gesundheit des Kindes, etwa, wenn bestimmte Großeltern (beispielsweise Eltern des geschiedenen Partners) aufgrund ihres riskanten Gesundheitsverhaltens aus dem Netzwerk eigentlich ausgeschlossen werden (von der Mutter), aufgrund negativer Beziehungen zum nachfolgenden Partner jedoch als Ressource finanzieller oder praktischer Unterstützung benötigt werden.

Das Jugendalter ist unter der Netzwerkperspektive das bisher am besten untersuchte (siehe Kap., ,Soziale Netzwerke, Gesundheit und gesundheitliche Ungleichheiten im Jugendalter"). Hier werden von Irene Moor und Ko-Autor*innen die meisten und größten, methodisch fortgeschrittenen Studien vorgestellt, die dennoch inhaltliche Lücken aufweisen. Ein Großteil der zitierten Studien im Jugendalter richtet sich überwiegend auf schulische Kontexte. Damit wird zu häufig auf wichtige Netzwerkanteile von Familien und außerschulischen Kontakten (z. B. in Vereinen) zugunsten von Erhebungen des Gesamtnetzwerkes (Schule hat 
klar definierte Grenzen) verzichtet. Da die meisten Studien ein querschnittliches Design haben, sind kausale Aussagen selten möglich. Dennoch kommen die Studien zum Jugendalter dem Ziel, Netzwerk und gesundheitliche Ungleichheiten zusammenzudenken, relativ zu Studien aus anderen Lebensabschnitten am nächsten. Die meisten Studien konzentrieren sich auf riskantes Gesundheitsverhalten, vor allem den Nikotingebrauch. Studien zur psychischen Gesundheit gibt es nur in Ansätzen, die so alarmierend wie vielversprechend sind. So fungieren soziale Netze, insbesondere Freundesgruppen, als Mediatoren zwischen dem sozioökonomischen Status von Jugendlichen und ihrem Risikoverhalten. Allerdings sind bislang nur wenige Forschungsarbeiten bekannt, die die Bedeutung der sozialen Netzwerke für gesundheitliche Ungleichheiten (fernab des Tabakkonsums) untersuchen.

Die Assoziation von Netzwerk und Gesundheit im Erwachsenenalter scheint von zwei Faktoren beeinflusst: von lebenslangen Konstanten (etwa verlängerten Freundesnetzwerken oder der Persönlichkeit des Erwachsenen) und biografischen Transitionen, die mit Veränderungen im Netzwerk einhergehen. Nur wenige der referierten Studien betrachten diese Zusammenhänge im Kontext vertikaler Ungleichheiten, obgleich etliche Ereignisse diesen Zusammenhang nahelegen, etwa bei Scheidungen. Holger von der Lippe und Olaf Reis (siehe Kap. „Soziale Netzwerke und gesundheitliche Ungleichheiten im jungen und mittleren Erwachsenenalter") stellen diesbezügliche Anforderungen an die Netzwerkforschung zusammen. Ereignisstrukturen (etwa ihre Reihenfolge) und -zeitpunkte im Lebensverlauf (timing) sollten in der Netzwerkforschung beachtet werden, da gleiche Ereignisse zu unterschiedlichen Zeitpunkten und in Verbindung mit anderen Ereignissen unterschiedliche Effekte auf Netzwerke haben und sich demnach unterschiedlich auf Gesundheit auswirken können. Darüber hinaus betonen die Autoren Effekte säkularen Wandels, der die Muster des Erwachsenseins nachhaltig beeinflussen kann, wobei vertikale Ungleichheiten eine nicht unwesentliche Rolle spielen.

Für das höhere Lebensalter zeigen Britta Müller und Lea Ellwardt (siehe Kap. ,Soziale Netzwerke und gesundheitliche Ungleichheiten im Alter") sowohl inhaltliche als methodische Lücken auf. Vorliegende Studien konzentrieren sich v. a. auf in eigener Häuslichkeit lebende Personen. Bislang ist unklar, inwiefern deren Befunde auch auf Bewohner von Pflegeeinrichtungen übertragbar sind. Auch der Effekt von individuellen Transitionen auf Netzwerke in den späten Lebensphasen ist eine noch offene Frage. $\mathrm{Zu}$ erwarten sind hierbei v. a. Einflüsse von gesundheitlichen Verschlechterungen und Funktionseinbußen. Bisherige Studien analysierten den Zusammenhang von SES, Gesundheit und sozialem Netzwerk vorrangig bezüglich des Krankheitsbildes Depression oder funktionaler 
und subjektiver Gesundheit. Die Frage, ob auch bei Demenzerkrankungen und schmerzassoziierten Erkrankungen Wechselwirkungen mit dem SES und sozialem Netzwerk auftreten, ist hingegen noch nicht geklärt. Die Autor*innen betonen, dass Forschungsdesigns, die komplexe Maße von sozialen Netzwerken im Alter erheben, für die Untersuchung der Beziehung von SES, Gesundheit und sozialem Netzwerk besser geeignet sind als einseitig quantitativ oder qualitativ ausgerichtete Instrumente. Bislang werden Netzwerkmerkmale in der gerontologischen Forschung meist nur indirekt, d. h. über sogenannte Proxy, gemessen. Das Potenzial etablierter Verfahren der Netzwerkanalyse sollte für die zukünftige Erforschung von Menschen im Alter wesentlich stärker genutzt werden.

\section{Offene Fragen aus Sicht der Ungleichheitsforschung}

Im dritten Teil des Bandes nähern sich die Autor*innen der Netzwerkforschung aus der Perspektive der Ungleichheitsforschung. Für Studien zum sozialen Status stellt Nico Vonneilich (siehe Kap., Sozialer Status, soziale Beziehungen und Gesundheit") fest, dass es kaum Untersuchungen gibt, die im Sinne von Mehr-Ebenen-Modellen makrosoziale, mikrosoziale und individuelle Prozesse verknüpfen. Nur selten werden diese Ebenen miteinander in Verbindung gebracht und die sozialstrukturellen Faktoren zur Entstehung oder der Verhinderung stabiler sozialer Netzwerke berücksichtigt und in Bezug zur Gesundheit gesetzt. Da es kaum einschlägige Studien mit umfangreichen Indikatorensätzen zu sozialen Netzwerken gibt, empfiehlt der Autor die Reanalyse vorhandener Datensätze, wie etwa der SHIP-Studie. Allerdings sind Sekundärdaten häufig mit Messproblemen behaftet - entweder auf der Ebene der Gesundheit oder des Netzwerkes. Auch für die relativ gut untersuchte Ungleichheit nach Erwerbslosigkeit (siehe Kap. „Arbeitslosigkeit, soziale Netzwerke und gesundheitliche Ungleichheit") beklagen Gerhard Krug und Ko-Autoren das Fehlen von Studien, die Netzwerke in ihrer Auswirkung auf gesundheitliche Ungleichheit zeigen. Dieses Fehlen ist umso bedauerlicher, da für dieses Ereignis gute Belege für netzwerkbezogene Mediator- und Moderatoreffekte erbracht wurden. Auch für dieses Thema lassen sich zeitliche Prozesse aufgrund des weitgehenden Fehlens von Längsschnittstudien kaum darstellen.

Insbesondere was psychische Gesundheit betrifft, kann bisher schlecht zwischen Ursache und Wirkung differenziert werden, zumal die meisten Studien auf ausgelesene Stichproben zurückgreifen. Derartige „Abwärtsspiralen“, in denen kleiner werdende Netzwerke und schlechtere Gesundheitslagen auftreten, sind 
beispielsweise für Alleinerziehende bisher nur im Ansatz gezeigt worden (siehe Kap. „Soziale Netzwerke und die Gesundheit von Alleinerziehenden“). Wie auch für die Erwerbslosigkeit gibt es für Alleinerziehende Belege, die auf Pufferwirkungen funktionaler Netzwerke hinweisen; differenziertere Analysen fehlen jedoch. Sylvia Keim-Klärner listet verschiedene Ansätze auf, die diesem Mangel abhelfen könnten, wobei sie zwischen Längsschnitt-, Querschnitt- und qualitativen Analysen unterscheidet. Insbesondere vom Einbezug negativer Beziehungen und Beziehungsinhalten verspricht sich die Autorin einen Wissenszuwachs, um der Komplexität und Ambivalenz von Beziehungskonfigurationen und Interaktionen gerecht zu werden.

Zum Thema Gender (siehe Kap. „Gender/Geschlecht und gesundheitliche Ungleichheiten"), einer zentralen Ungleichheitsdimension in der aktuellen sozialwissenschaftlichen Diskussion, stellen Markus Gamper und Ko-Autor*Innen fest, dass die Forschung fast ausschließlich mit den zwei Geschlechtsidentitäten „Mann“ und „Frau“ arbeitet. Im Zuge der gesellschaftlichen Debatte um Geschlechtsidentitäten jenseits der Zweigeschlechtlichkeit und der Entscheidung des Bundesverfassungsgerichtes aus dem Jahr 2017, welche den Gesetzgeber verpflichtet, eine dritte Option (,divers“) für intergeschlechtliche Personen in Geburten- und Einwohnermelderegistern vorzusehen, könnte der gesundheitlichen Lage auch von Personen mit anderen Geschlechtsidentitäten mehr Aufmerksamkeit gewidmet werden (vgl. Brand 2018). Über deren gesundheitliche Lage ist bislang, auch aufgrund der schwierigen Erfassung dieser Gruppe in repräsentativen Surveys, relativ wenig bekannt (vgl. Reisner 2016). Während sich die Forschung zu Geschlechtseffekten besonders auf die Jugendphase und das hohe Alter konzentriert, bleiben die anderen Lebensphasen eher unterrepräsentiert. Methodisch ist die Forschung in diesem Bereich relativ weit entwickelt und es gibt eine große Zahl an quantitativen Netzwerkstudien, darunter auch Längsschnittstudien mit SIENA-Modellen. Qualitative Netzwerkforschungen oder visuelle Netzwerkmethoden, die besonders für die Aufdeckung der Wirkweise von sozialen Netzwerken (siehe Kap.,Wirkmechanismen“) geeignet wären, findet man hingegen kaum. Eine Weiterentwicklung in diesem Bereich wäre lohnenswert.

Verglichen mit den Erwerbslosen und Alleinerziehenden sind Menschen mit Behinderung eine von der Netzwerkforschung weitgehend vernachlässigte Gruppe (siehe Kap. „Soziale Netzwerke und Behinderung“), obwohl sie mit 9,4\% einen verhältnismäßig großen Anteil der Gesamtbevölkerung stellen (Statistisches Bundesamt 2018). Diese Lücke ist umso gewichtiger, als dass Behinderungen erhebliche Konsequenzen für die Aufrechterhaltung und Bildung von Netzwerken und Beschäftigungsverhältnissen haben. Neben 
institutionellen Akteur*innen spielen viele andere Faktoren für die Gesunderhaltung dieser Gruppe eine Rolle, die selten mit Netzwerkparametern verknüpft werden (etwa regionale Zugänglichkeiten). Darüber hinaus verweisen auch Stefan Zapfel und Ko-Autor*innen auf die sich wandelnde Bedeutung verschiedener Institutionen.

Auch Migration ist, ebenso wie Erwerbslosigkeit, der Alleinerziehendenstatus oder Behinderung, keine „Krankheit“ (siehe Kap. „Migration als gesundheitliche Ungleichheitsdimension?"). Die in Zusammenhang mit Migration und natioethno-kultureller (Mehrfach-)Zugehörigkeit auftretenden Gesundheitsrisiken und assoziierte Netzwerkmechanismen - werden dabei über unterschiedliche Modelle, wie bspw. die „Healthy-migrant“-Hypothese, erklärt. Derartige Hypothesen werden forschungsmethodisch jedoch kaum verfolgt. Zudem werden andere Ungleichheitsdimensionen, wie ökonomisches oder kulturelles Kapital von Migrant*innen, kaum modelliert. Auch die Erfassung der Netzwerke von Migrant*innen weist, so die Autor*innen Annett Kupfer und Markus Gamper, noch erhebliche methodische Lücken auf. So fehlt es an Längsschnittstudien oder Studien mit Vergleichsgruppen. Negative Beziehungen (Kanten), die beispielsweise von Anfeindungen, Diskriminierungen oder Rassismus geprägt sein können, werden ebenso wenig wie sozialstaatliche oder institutionelle Knoten als Teil migrantischer Netzwerke erhoben. Schließlich liegen Studien, in denen die Faktoren Gesundheit, Netzwerke und Migration verbunden werden, kaum vor.

Die Autor*innen des dritten Teils des Bandes stellen übereinstimmend fest, dass die Mechanismen des Netzwerkeinflusses eher vorausgesetzt als untersucht werden. Dabei sind verschiedene Hypothesen denkbar, etwa der Verlust an Integration in die Kollegengruppe nach dem Übergang in die Erwerbslosigkeit oder der Zusammenhang von Unterstützung, negativen Beziehungen und Homogenität im Netzwerk bei Alleinerziehenden. Für alle Ungleichheiten gilt, dass in modernen Wohlfahrtsgesellschaften auch Institutionen maßgeblich am Gelingen der Netzwerkarbeit beteiligt sind, z. B. Jobcenter bei Erwerbslosigkeit, Familienhelfer*innen bei Alleinerziehenden, Integrationshelfer*innen bei Behinderten und Migrationsdienste bei Migrant*innen. Hier verschränken sich private und institutionelle Beziehungen, deren Zusammenwirken bisher jedoch kaum untersucht wurde (vgl. aber: Kupfer 2015). Auch für dieses Zusammenwirken lassen sich interessante Hypothesen bilden, deren Prüfung letztendlich auch die Funktionsmechanismen staatlicher Wohlfahrt untersucht. Beispielsweise könnten institutionelle und private Unterstützung sowohl in einem Verdrängungswettbewerb (ähnlich der These zu unterbrochenen Dyaden in der Entwicklung von Freundschaften nach Übergang zur Partnerschaft, siehe Kap. „Soziale Netzwerke und gesundheitliche Ungleichheiten im jungen und mittleren Erwachsenenalter") 
als auch in einer unterstützenden Beziehung zueinander stehen. Die unterschiedlichen Interaktionen ließen sich möglicherweise aus der Stärke der jeweiligen Beziehungen erklären. Bei der Verschränkung von staatlicher und privater Unterstützung bleibt fraglich, ob sich derartige Netzwerke tatsächlich verbinden oder ob definierte Grenzen innerhalb hybrider Netzwerkkonstruktionen bestehen bleiben. Derartige hybride Konstruktionen, in denen private und institutionelle Netzwerkteile verschränkt sind, würden sehr von der Einführung Kanten-spezifischer Mechanismen (beispielsweise Unterstützung in schwachen institutionellen Beziehungen, Ansteckung in starken proximalen Beziehungen) profitieren, ebenso wie von der Hinzunahme von negativen Beziehungen (etwa dem Misstrauen Alleinerziehender gegenüber dem Jugendamt bei gleichzeitiger Abhängigkeit von institutioneller Unterstützung). Wird der Gedanke der extensiven Netzwerkforschung und der Ausdehnung auf soziale Institutionen weiterverfolgt, so stellt sich die Frage nach der Darstellbarkeit von Netzwerkhierarchien und -strukturen, beispielsweise von „Netzwerken innerhalb von Netzwerken“. Ein Vorschlag für derartige Strukturen wurde von Reis (2017) vorgelegt, in dem er DDR-Familien als „Nischen“ innerhalb eines totalitären Staates beschrieb.

\section{$4 \quad$ Lebenslauf, Ungleichheit, Netzwerk, und Gesundheit - einige Hypothesen}

Zusammenfassend muss festgestellt werden, dass die Zusammenführung von Lebenslauf- und Ungleichheitsforschung für soziale Netzwerke und Gesundheit noch weitgehend aussteht. Lebensphasenübergreifende Netzwerkänderungen als Gesundheitsrisiken und -ressourcen zu begreifen, die entweder Folge (Mediation) von sozialen Ungleichheiten sind oder diese in ihrer Auswirkung beeinflussen (Moderation) - hier wartet ein neuer Forschungsbereich darauf, entwickelt zu werden. Mit der erweiterten Netzwerkperspektive, wie sie in der Einleitung dieses Bandes und am Anfang dieses Kapitels vorgestellt wurde, ließen sich viele bisher vermutete Zusammenhänge genauer prüfen, z. B.:

- Erfolg macht einsam und dann krank, aber nur wenn er aus einer sozial niederen Schicht entsteht und nach der Jugend beginnt.

- Gesunderhaltung von Jugendlichen ist zum großen Teil durch die Beziehungsarbeit ihrer Eltern bedingt, indem diese zum Beispiel negative Beziehungen abbauen (z. B. aus einer Risikonachbarschaft fortziehen), was jedoch nur denen gelingt, die über ausreichende Mittel verfügen. 
- Alter-Alter-Beziehungen beeinflussen Netzwerke in reicheren Schichten stärker als in ärmeren, womit Zugänge zum Gesundheitssystem erleichtert werden, wobei die Weichen hierfür schon während der Jugend gestellt werden.

- Mangelnde Pflegebereitschaft im hohen Alter ist oftmals das Resultat von negativen Beziehungen in früheren Zeiten, wobei „ärmere Alte“ schwerer betroffen sind als reichere.

- Gesundheitliches Risikoverhalten ist geeignet, die Position im Netzwerk zu verbessern (etwa die Zentralität), aber nur wenn das Gesamtnetz diese Möglichkeit erfolgreichen Vergleichens befördert - etwa, weil andere Netzwerkteilnehmer*innen besser mit Kapital ausgestattet sind. Derartige Netzwerkmechanismen bleiben auf die Jugend beschränkt, weil sich danach die Netzwerke sozial homogenisieren.

\section{$5 \quad$ Ausblick: Anforderungen an zukünftige Forschung}

Für die Formulierung von Desiderata für die zukünftige Forschung kommen wir noch einmal auf das anfangs vorgestellte Modell zurück (siehe Kap. „Soziale Netzwerke und gesundheitliche Ungleichheiten - eine neue Forschungsperspektive") und ordnen den dort beschriebenen Analyseebenen unsere Schlussfolgerungen $\mathrm{zu}$.

Für die oberste Modell-Ebene in Abb. 1 gilt nach wie vor die Forderung, dass soziale Ungleichheiten eine conditio sine qua non der Gesundheitsforschung sein sollten. Der zunehmende durchschnittliche Wohlstand der westlichen Industriestaaten ist aktuell mit wachsender sozialer Ungleichheit verbunden (Alvaredo et al. 2018), wobei sich beide Entwicklungen auf Gesundheit auswirken. Der soziale Wandel hin zur digitalen Wissensgesellschaft und -ökonomie (Reckwitz 2017) als Teil der „entfesselten Moderne“ (Giddens 2001) birgt erhebliche Risiken für Ungleichheit, Entbindung und Flexibilisierung mit sich, deren Umwandlung in Chancen hohe Aufwendungen, funktionale Netzwerke eingeschlossen, durch das Individuum verlangen. Kategorien von Ungleichheit, sowohl horizontale als auch vertikale, dynamisieren sich möglicherweise im Kontext digitaler Ökonomien. Mobilitäten, soziale wie räumliche, verlangen nach sozialem Kapital, deren Einschluss in Vorhersagemodelle für Gesundheit damit ein Standard werden sollte.

Die Objektivierung dieses sozialen Kapitals verlangt nach der möglichst genauen Messung von sozialen Netzwerken (Modell-Ebene 2 in Abb. 1). Die uneinheitliche und stellenweise nicht zielführende Messung von sozialen 


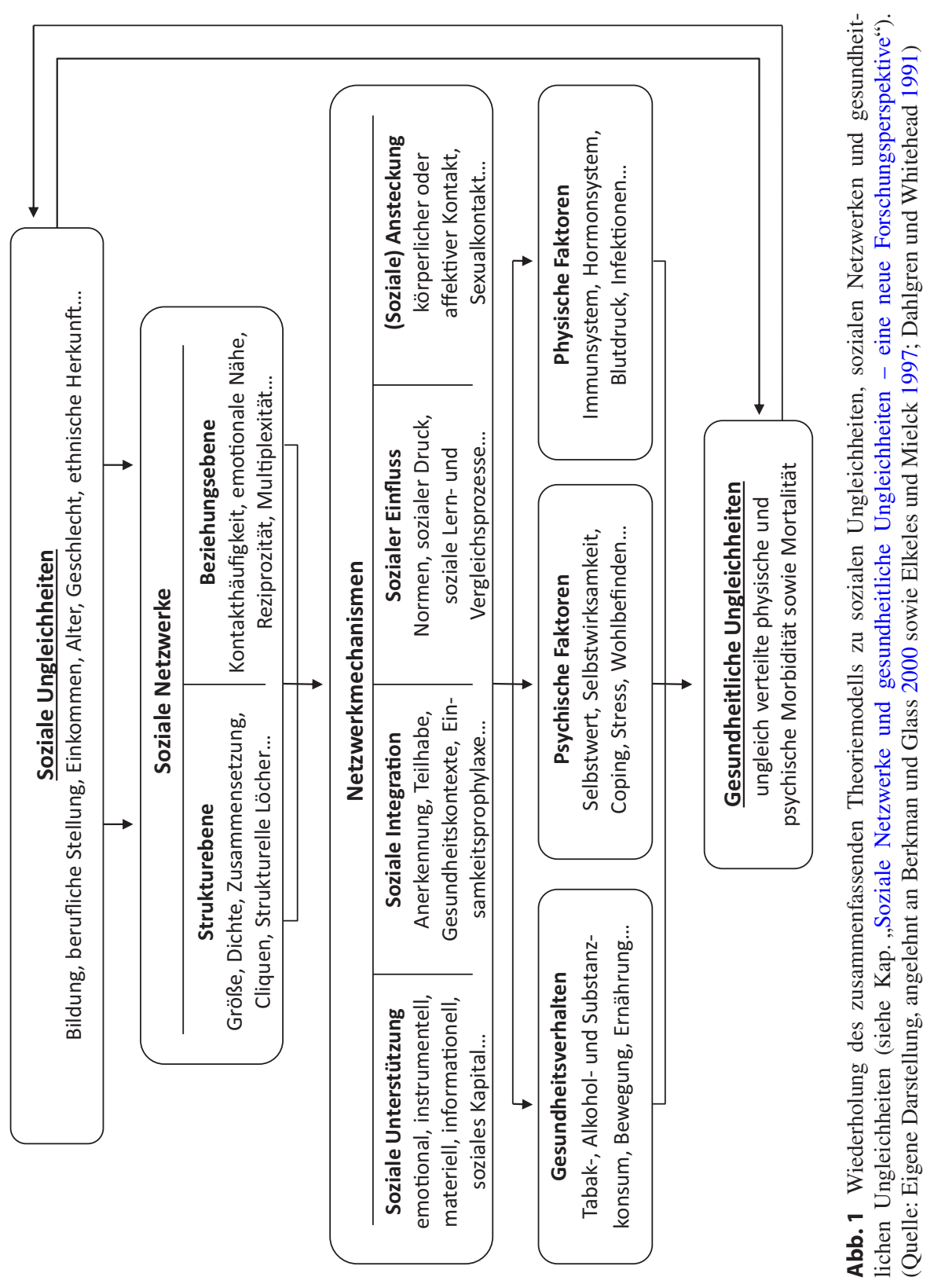


Netzwerken war ein Kritikpunkt, der in allen Beiträgen dieses Bandes geäußert wurde. Im Folgenden werden einige Forderungen an eine Netzwerkforschung aus den einzelnen Kapiteln zusammengetragen, die die angestrebte Mesofundierung von Gesundheit verbessern könnten:

- Das Netzwerk sollte über die Erfassung der Art und Anzahl von Kontakten hinausgehen und Aussagen über die Strukturebene ermöglichen. Hierzu gehören Parameter wie beispielsweise Dichte, Homogenität, Zentralität, Cliquen oder strukturelle Löcher.

- Das Netzwerk sollte weitergehende Informationen über die Alteri samt ihrer Eigenschaften beinhalten, sowohl als neu generierte Knoten (durch Akteursgeneratoren) als auch durch deren Beziehungen (Alter-Alter-Kanten). Hier liegen im deutschsprachigen Raum bereits erste ausgearbeitete Netzwerkmodule vor, die in großen Repräsentativerhebungen eingesetzt werden. Im ALLBUS etwa (siehe: www.gesis.de/allbus) werden zu den fünf wichtigsten Netzwerkpersonen die Alter-Alter-Relationen und zahlreiche Eigenschaften der Personen abgefragt. Das Soziooekonomische Panel (SOEP, siehe: www.diw.de/ soep) zielt eher auf die Netzwerkgröße von Individuen ab und nutzt dazu fünf Akteursgeneratoren mit je fünf Nennungsmöglichkeiten (d. h. einer Netzwerkgröße von maximal bis zu 20 Unterstützer*innen plus maximal bis zu fünf negative/belastende Beziehungen). Dazu kommen noch einige weitere Netzwerkfragen, die überwiegend auf die Größe und z. T. Qualität anderer Netzwerksektoren abzielen, ohne dass Alter-Alter-Kanten erfragt werden. Diese Module stellen jedoch wichtige und praktisch erprobte Ausgangspunkte für praktikable Netzwerkmodule zukünftiger Studien dar.

- Die Beziehungen selbst sollten grundsätzlich nicht nur gesundheitsförderliche (im Sinne von Unterstützung oder sozialem Kapital), sondern auch negative, gesundheitsbeeinträchtigende Aspekte beinhalten (wie es im SOEP bereits im Ansatz der Fall ist). Negative Beziehungen sind geeignet, gesundheitliches Vermögen zu reduzieren, und können sowohl im Nah- als auch im Fernraum des Individuums auftreten und direkt auf Ego wirken bzw. Alteri-Alteri-Beziehungen betreffen. Schließlich können Beziehungen prinzipiell unterstützend und belastend zugleich sein und sollten nicht auf eine (einzige) Funktion reduziert werden.

- Die Netzwerkerfassung sollte möglichst vergleichbar für verschiedene Kontexte sein, dies betrifft sowohl räumliche als auch zeitliche Dimensionen. Mit (sozial)räumlichen Dimensionen sind solche wie Stadt-Land, ArbeitFreizeit, offline-online oder Migrationsereignisse gemeint. Kulturell bedingte Frames - wie etwa unterschiedliche Definitionen von „Familie“, aber auch 
„Gesundheit“ - gehören ebenso hierher wie ereignisassoziierte Änderungen von Sozialräumen, etwa nach Arbeitslosigkeit oder im Leben mit einer Behinderung. Verschiedene Zeitkontexte meinen vor allem alters- und lebenslaufbedingte Netzwerkveränderungen, wobei in den Kapiteln des zweiten Teils dieses Bandes aufgezeigt wurde, dass unterschiedliche Lebensalter nicht nur mit unterschiedlichen Ereignisstrukturen assoziiert sind, sondern auch mit unterschiedlichen individuellen Voraussetzungen, Netzwerke zu gestalten. Grob gesagt, hat die individuelle Gestaltung des Netzwerkes über den Lebensverlauf die Form eines umgekehrten Us, womit sich sowohl Ausdehnung als auch Aktivitätsparameter im Lebensverlauf verändern. Räumliche und zeitliche Kontexte der Netzwerkerfassung stehen dabei in einem wechselseitigen Zusammenhang. Beispielsweise machen ,unzeitige“ Übergänge, d. h. nicht an die gesellschaftlichen Zeit-Normierungen angepasste Übergänge, - wie etwa eine verfrühte Elternschaft - das Betreten bestimmter Sozialräume - etwa der Universität - weniger wahrscheinlich. Ebenso sind die lebenslangen Risiken des Wechsels in die Erwerbslosigkeit unterschiedlich, je nachdem, wann und wie häufig dieser Übergang stattfindet, wobei hier der späte Übergang problematischer scheint.

- Mit der allgemein geltenden Reziprozitätsregel für soziale Beziehungen können dann aber auch zeitlich weit auseinanderliegende Netzwerkveränderungen aufeinander bezogen werden, wenn beispielsweise eine späte Arbeitslosigkeit der Eltern zur Beendigung des Arbeitslebens und gleichzeitig zu erhöhten Investitionen in die eigenen Kinder und Enkel führt - was möglicherweise gesundheitsförderliche Effekte des Familiennetzwerkes oder Unterstützung im Alter wahrscheinlicher macht.

- Gleichzeitig ist nicht davon auszugehen, dass Netzwerke im Sinne von Top-down-Prozessen nur auf passive Individuen einwirken, sondern gleichzeitig von diesen - bewusst, strategisch oder auch unbewusst - verändert werden, also Bottom-up-,,Kopplungen“ und Selektionseffekten unterliegen. Der aktive Beitrag des Einzelnen (etwa qua individueller Geselligkeit oder individuellem Netzwerken) ist eine wichtige zusätzliche Kontrollgröße.

- Eine ideale Netzwerkmessung sollte berücksichtigen, dass Netzwerke wahrscheinlich über unterschiedliche Mechanismen wirken (Modell-Ebene 3 in Abb. 1). Auch wenn sämtliche der von Klärner und von der Lippe (siehe Kap. „Wirkmechanismen in sozialen Netzwerken“) diskutierten Mechanismen in einer einzelnen Studie schwer abbildbar sein werden, sollte dennoch unterschieden werden, ob es sich um soziale Unterstützungs-, Einbindungs-, Einfluss- oder Ansteckungs-Effekte handelt. Hierfür bieten sich Kurzskalen an, wie sie beispielsweise mit der Oslo Social Support Scale (OSSS) (Dalgard 
et al. 2006) oder dem F-SozU K-14 (Fydrich et al. 2007) in validierter Form vorliegen. Während die OSSS soziale Unterstützung mit drei Items erfasst, steuern im F-SozU K-14 ebenfalls drei Items die Beschreibung der sozialen Integration einer Person bei.

- Hierbei sollten zukünftig die offline-Mechanismen in ihrer Verschränkung mit den online-Mechanismen untersucht werden, wobei sich von puren online-Makrostrategien - wie etwa dem berüchtigten Facebook-Experiment, in dem experimentell untersucht wurde, ob der emotionale Zustand der Nutzer*innen durch die Auswahl der im Newsfeed angezeigten Nachrichten manipuliert werden kann (Kramer et al. 2014; kritisch dazu: Kleinsman und Buckley 2015) - bis hin zu mikrosystemalen on/offline-Wechselverhalten etwa dem Übergang von (klassenübergreifenden) Multiplayer-Game-Netzwerken hin $\mathrm{zu}$ offline-Freundschaften alles denken lässt. Im mesosystemalen Bereich der sozialen Netzwerke sind inzwischen die größten Industrien der Neuzeit entstanden, deren Geschäftsmodelle eng an Mechanismen wie Einbindung, sozialen Einfluss oder Ansteckung gebunden sind. Hinter etlichen Knoten dieser Netzwerke stehen Maschinen oder Algorithmen, die sich nicht immer als solche zu erkennen geben. Damit dürften zukünftige Netzwerkstudien auch von den Forschungen zur Mensch-Mensch-Maschine-Interaktion (etwa bei partnerschaftlich geteilten Gesundheits-Apps) oder zur täuschenden Kommunikation profitieren.

Hier lassen sich diverse Hypothesen bilden, über welche Mechanismen soziale Netzwerke an proximale, d. h. mikrofundierte, Faktoren von Gesundheit ,koppeln“. Was die Messung auf dieser vierten Modellebene aus Abb. 1 betrifft, so findet auch hier augenblicklich eine Revolution statt, an der sich zukünftige Netzwerkforschung zu orientieren hat. Ohne diesen Gedanken weiter auszuführen, soll nur darauf verwiesen werden, dass sich beispielsweise Gesundheitsverhalten über sogenannte EMAs (ecological momentary assessment) von beispielsweise psychophysiologischen Parametern (Raugh et al. 2019) in hohem Maße objektivieren lässt. Psychische und physische Marker, vom Hautleitwiderstand, Blutdruck und Hirnaktivität bis hin zur aktuellen Genexpression für die Bildung des schlafsteuernden Hormons Melatonin, werden im Zuge von komplexer werdenden Analysen in den Gesundheitswissenschaften immer zugänglicher und können dynamisch (zeit- und ortsveränderlich) erfasst werden. Die Patient*innen der Zukunft müssen auf vielerlei Weise als verbunden (,,connected“) verstanden werden, womit offline- und online-Beziehungen zu den ,driving forces“ in der ,digitalen Psychiatrie“ und der „E-Health“ gehören (Bughra et al. 2017, S. 799). 
Auch die fünfte Ebene unseres vorgeschlagenen Theoriemodells, die Ungleichheit in psychischer und physischer Morbidität sowie Mortalität, unterliegt einem gewissen Wandel, zumindest was ihre Messung betrifft. So ändern sich Krankheitsdefinitionen beispielsweise mit der Einführung neuer Codiersysteme, wie der erwarteten Novellierung der ICD-10, womit $\mathrm{Zu}$ - oder Abnahmen in Krankheitsprävalenzen auch durch makrosystemale Änderungen in der Zuschreibung bedingt sein können. Der Meta-Text zu Krankheitskosten, wie sie beispielsweise durch das European Brain Council für Hirn-assoziierte Störungen im Sekundentakt bereitgestellt werden (https://www.braincouncil. $\mathrm{eu} /$ ), und ihrer Verteilung sollte in die Modellierung sozialer und gesundheitlicher Ungleichheiten einfließen. So bleibt es eine Forschungsfrage, ob und wie sich die Funktionen von Netzwerken in nach einem Versicherungsmodell finanzierten, in steuerfinanzierten, in rein privatwirtschaftlich finanzierten oder in mischfinanzierten Gesundheitssystemen unterscheiden.

\section{Netzwerk und gesundheitliche Ungleichheit: Hot topics}

Zum Ende sollen kaleidoskopartig einige Themen aufgelistet werden, die wir in diesem Band gern behandelt hätten, für die jedoch keine Zeit, kein Platz oder kein/e AutorIn zu gewinnen war. Wie Christakis und Fowler (2010) glauben auch wir, dass Netzwerke ein überall involviertes Agens menschlicher Entwicklung und damit der Gesundheit sind. Die folgende Aufzählung folgt daher keiner Systematik, sondern beschreibt nur Wünsche und Ideen der am Band beteiligten Forscher*innen.

\subsection{Pendeln, On- und Offline-Netzwerke, soziale Klasse}

Die erhebliche Flexibilisierung des Arbeitsmarktes in allen Sektoren, der zunehmende Teil von Leiharbeit und die Ausdehnung des Billiglohnsektors sind mit einer zunehmenden intra- und internationalen Arbeitsmigration verbunden, die die Beweglichkeit von Familien und convoys of life übersteigt (Rüger 2010). Die steigende Zahl von Arbeitspendler*innen verbringt zunehmend Zeit getrennt von offline-Netzen, wobei die Dauer der Arbeitsaufenthalte oft nicht hinreicht, um vor Ort offline-Netzwerke aufzubauen. Hier wäre z. B. zu fragen, inwieweit die mit der Migration verbundenen Gesundheitsrisiken durch online-Netzwerke moderiert werden, wie räumliche und soziale Mobilität verbunden sind, oder wie 
timing-Effekte, Netzwerk und sozialer Status zusammenhängen. Die Balance von online-offline-Kontakten kann in Abhängigkeit vom sozialen Status variieren, wenn z. B. manuellen Leiharbeitern (Beispiel: Erntehelfer*innen) weniger Ressourcen zur Verfügung stehen, ihre Familien regelmäßig zu sehen, als besser gestellten Leiharbeiter*innen aus der IT-Branche.

\subsection{Psychische Erkrankung, On- und Offline Netzwerke, soziale Klasse}

Grundsätzlich sind psychische Erkrankungen hoch mit dysfunktionalen sozialen Beziehungen vergesellschaftet, wobei diverse Wirkrichtungen sowohl in der Entstehung, Chronifizierung oder Therapie denkbar sind. Daneben waren die seit langem bekannten Zusammenhänge von sozialer Klasse und psychiatrischer Diagnose (Hollingshead und Redlich 1958) in den letzten Jahren selten Gegenstand wissenschaftlicher Forschung (Analyse Datenbank PsychInfo, März 2019) und verdienen es, im Rahmen der Netzwerkanalyse neu belebt zu werden. Ein Praxisbeispiel aus der Therapie soll diese Forderung illustrieren.

Die Behandlung psychischer Erkrankungen erfolgt in der Regel nur mit Einwilligung der Patient*innen. Die relative Isolation (von riskanten sozialen Kontexten) ist essenzieller Bestandteil vieler stationärer Therapien. Die allgemeine, elektronisch vermittelte Vernetzung über Raum- und Zeitgrenzen hinweg ist jedoch so normal geworden, dass viele Patient*innen zwar in eine Therapie, aber nicht in eine Netzabstinenz einwilligen. Viele Kliniken lassen daher zumindest zeitweilig die Kommunikation mit der „Außenwelt“ zu (Handy-Zeit), was ein Risiko für den Therapieerfolg darstellen kann. Beispielsweise wird die Therapie nicht-suizidalen selbstverletzenden Verhaltens mitunter konterkariert, wenn die Patient*innen über WhatsApp mit den Narrativen von Nicht-Patient*innen und Bildern zerschnittener Unterarme konfrontiert werden. $\mathrm{Zu}$ fragen wäre hier beispielsweise, wie Psychotherapie unter den Bedingungen ohne unterbrochene Dyaden gelingen kann, oder wie die Effekte von negativen Beziehungen minimiert werden können, oder wie eine Therapie unter Einbezug krankheitsrelevanter Plattformen verbessert werden kann. Analog zu den Ergebnissen für das jugendliche Rauchverhalten ließe sich beispielsweise vermuten, dass Jugendliche mit niedrigerem sozialen Status in ihren Netzwerken häufiger mit Risikoverhalten konfrontiert sind, da ihre Netzwerke weniger homophil sind. Beispielsweise sollte der Frage nachgegangen werden, ob sogenannte „Werther"- oder „Papageno“-Effekte (soziale Ansteckung suizidalen Verhaltens bzw. Ansteckung suizidpräventiven Verhaltens) unterschiedlich in verschiedenen 
sozialen Strata wirken. Es konnte beispielsweise gezeigt werden, dass mediale Vorbilder, über offline-Netzwerke vermittelt, auf suizidales Verhalten von Jugendlichen wirken (Abrutyn und Mueller 2014), ohne dass hier bisher gesundheitliche Ungleichheiten untersucht worden wären. Im Sinne der klassischen Studie von Hollingshead und Redlich (1958) bleibt auch die Frage bisher offen, ob die statusabhängigen Zugänge zum psychiatrischen Hilfesystem von Netzwerkfunktionen moderiert oder mediiert werden.

\subsection{Armut, Gesundheit und institutionelle Netzwerkbeziehungen}

Institutionen und professionelle Helfer*innen können, besonders für armutsgefährdete Personen, wichtige Akteure bzw. Knoten in einem Netzwerk sein (Klärner und Knabe 2016) und dort nicht nur einen Beitrag zum Wohlbefinden leisten, sondern - etwa durch Vermittlung präventiver oder kurativer Maßnahmen - auch stärker gesundheitsrelevante Wirkung entfalten. Die sozial ungleiche Verteilung und Barrieren des Zugangs in Abhängigkeit vom Wohnort und den Angeboten vor Ort können (gesundheitliche) Ungleichheiten verstärken (oder abmildern). Institutionelle Helfer*innen als Akteure einer sozialstaatlich bekämpften Armut (Paugam 2008) sind vorhanden und erreichbar oder eben nicht. $\mathrm{Zu}$ fragen wäre hier, in welcher Weise diese Akteure in einem sozialen Netzwerk wirken, ob sie Einfluss auf die Beziehungen zu anderen Akteuren haben, welche Netzwerkstrukturen das Wirken institutioneller Unterstützung förderlich werden lassen und welche, im Gegensatz dazu, eher Abhängigkeiten von diesen Akteuren hervorrufen und damit eher abträglich wirken und welche informellen Netzwerke tragen, wenn professionelle Hilfe nicht verfügbar ist.

\subsection{Die räumliche Dimension von sozialen Netzwerken: Gesundheit und soziale Netzwerke in ländlichen Räumen}

Soziale Netzwerke haben auch eine räumliche Dimension: Um direkte interpersonale Kontakte und Interaktionen mit Freund*innen, Bekannten, institutionellen Helfer*innen, Ärzt*innen etc. herzustellen oder bestimmte (Gesundheits-) Dienstleistungen in Kliniken, Apotheken oder durch Pflege- und Rettungsdienste 
in Anspruch zu nehmen, ist in der Regel eine räumliche Distanz zu überwinden. Gerade die Erreichbarkeit von Institutionen und Dienstleistern im Gesundheitsbereich ist räumlich und damit auch sozial ungleich verteilt (Neumeier 2017). $\mathrm{Zu}$ fragen wäre, welche Auswirkungen das Fehlen oder die schlechte Erreichbarkeit dieser institutionalisierten Knoten im Netzwerk hat, ob dies durch andere Bereiche des Netzwerkes abgefedert oder durch neue, digitalisierte Angebote ersetzt und ergänzt werden kann und welche Konsequenzen wiederum eine ungleich verteilte health literacy in diesem Zusammenhang hat. Erste Ansätze, netzwerkanalytische Methoden in diesem Zusammenhang fruchtbar zu machen und eine Form des räumlichen Kapitals (spatial capital) zu rekonstruieren, wurden auf einer von SoNegU organisierten Session bei der Sunbelt Social Network Conference vorgestellt (Galaskiewicz et al. 2016).

\section{Literatur}

Abrutyn, S., \& Mueller, A. S. (2014). Are suicidal behaviors contagious in adolescence? Using longitudinal data to examine suicide suggestion. American Sociological Review, 79, 211-227.

Alvaredo, F., Chancel, L., Piketty, T., Saez, E., \& Zucman, G. (Hrsg.). (2018). Die weltweite Ungleichheit. Der World Inequality Report 2018. München: Beck.

Berkman, L. F., \& Glass, T. (2000). Social integration, social networks, social support, and health. In L. F. Berkman \& I. Kawachi (Hrsg.), Social epidemiology (S. 137-173). New York: Oxford University Press.

Brand, T. (2018). Dimensionen gesundheitlicher Ungleichheit. In R. Haring (Hrsg.), Gesundheitswissenschaften (S. 1-13). Wiesbaden: Springer.

Bughra, D., Tasman, A., Pathare, S., Priebe, S., Smith, S., Torous, J., Arbuckle, M.R., ..., $\&$ Ventriglio, A. (2017). The WPA-Lancet psychiatry commission on the future of psychiatry. Lancet Psychiatry, 4(10), 775-818.

Christakis, N. A., \& Fowler, J. H. (2010). Connected! Die Macht sozialer Netzwerke und warum Glück ansteckend ist. Frankfurt a. M.: Fischer.

Dahlgren, G., \& Whitehead, M. (1991). Policies and strategies to promote social equity in health: Background document to WHO - Strategy paper for Europe. http://www. framtidsstudier.se/wp-content/uploads/2011/01/20080109110739filmZ8UVQv2wQFShMRF6cuT.pdf. Zugegriffen: 18. Apr. 2019.

Dalgard, O. S., Dowrick, C., Lehtinen, V., Vazquez-Barquero, J. L., Casey, P., Wilkinson, G., Ayuso-Mateos, J. L., Page, H., Dunn, G., \& The ODIN Group. (2006). Negative life events, social support and gender difference in depression: A multinational community survey with data from the ODIN study. Social Psychiatry and Psychiatric Epidemiology, 41, 444-451.

Elkeles, T., \& Mielck, A. (1997). Entwicklung eines Modells zur Erklärung gesundheitlicher Ungleichheit. Gesundheitswesen, 59, 137-143. 
Emirbayer, M. (1997). Manifesto for a relational sociology. American Journal of Sociology, 103(2), 281-317.

Fydrich, T., Sommer, G., \& Brähler, E. (2007). F-SozU: Fragebogen zur Sozialen Unterstützung. Manual. Göttingen: Hogrefe.

Galaskiewicz, J., Freeman Anderson, K., \& Thompson-Dyck, K. (2016). "SpatialCapital: Applications for the study of urban inequality.” Paper presented in the session on Social Networks and Health Inequalities. International Sunbelt Social Network Conference, April 5-10, Newport Beach, CA.

Giddens, A. (1984). Die Konstitution der Gesellschaft. Grundzüge einer Theorie der Strukturierung. Frankfurt a. M.: Campus.

Giddens, A. (2001). Entfesselte Welt. Wie die Globalisierung unser Leben verändert. Frankfurt a. M.: Suhrkamp.

Hollingshead, A. B., \& Redlich, F. C. (1958). Social class \& mental illness. New York: Wiley.

Klärner A., \& Keim, S. (2019). Emirbayer (1997). Manifesto for a Relational Sociology. In B. Holzer \& C. Stegbauer (Hrsg.), Schlüsselwerke der Netzwerkforschung (S. 177-180). Wiesbaden: Springer VS.

Klärner, A., \& Knabe, A. (2016). Soziale Netzwerke als Ressource für den Umgang mit den Folgen von Langzeitarbeitslosigkeit. WSI-Mitteilungen, 69(5), 353-364.

Kleinsman, J., \& Buckley, S. (2015). Facebook study: A little bit unethical but worth it? Bioethical Inquiry, 12(2), 179-182.

Kramer, A. D. I., Guillory, J. E., \& Hancock, J. T. (2014). Experimental evidence of massive-scale emotional contagion through social networks. Proceedings of the National Academy of Sciences, 111(24), 8788-8790.

Kupfer, A. (2015). Wer hilft helfen? Einflüsse sozialer Netzwerke auf Beratung. Tübingen: dgvt.

Lüscher, K., \& Pillemer, K. (1998). Intergenerational ambivalence: A new approach to the study of parent-child relations in later life. Journal of Marriage and the Family, 60, $413-425$.

Neumeier, S. (2017). Regionale Erreichbarkeit von ausgewählten Fachärzten, Apotheken, ambulanten Pflegediensten und weiteren ausgewählten Medizindienstleistungen in Deutschland - Abschätzung auf Basis des Thünen-Erreichbarkeitsmodells (Thünen Working Paper 77). Braunschweig: Johann Heinrich von Thünen Institut.

Paugam, S. (2008). Die elementaren Formen der Armut. Hamburg: Hamburger Edition.

Raugh, I. M., Chapman, H. C., Bartolomeo, L. A., Gonzalez, C., \& Strauss, G. P. (2019). A comprehensive review of psychophysiological applications for ecological momentary assessment in psychiatric populations. Psychological Assessment, 31(3), 304-317.

Reckwitz, A. (2017). Die Gesellschaft der Singularitäten. Zum Strukturwandel der Moderne. Berlin: Suhrkamp.

Reis, O. (2017). Nischen im Wandel. Zur Transformation von Familien und Generationenbeziehungen in Ostdeutschland. Gießen: Psychosozial.

Reisner, S. L., Poteat, T., Keatley, J., Cabral, M., Mothopeng, T., Dunham, E., Holland, C. E., Max, R., \& Baral, S. D. (2016). Global health burden and needs of transgender populations: A review. The Lancet, 388(10042), 412-436. 
Rüger, H. (2010). Berufsbedingte räumliche Mobilität in Deutschland und die Folgen für Familie und Gesundheit. Bevölkerungsforschung Aktuell, 31(2), 8-12.

Statistisches Bundesamt. (2018). Statistik der schwerbehinderten Menschen 2017. Kurzbericht. https://www.destatis.de/DE/Themen/Gesellschaft-Umwelt/Gesundheit/BehinderteMenschen/Publikationen/Downloads-Behinderte-Menschen/sozial-schwerbehinderte-kb-5227101179004.pdf. Zugegriffen: 10. Mai 2019.

Open Access Dieses Kapitel wird unter der Creative Commons Namensnennung 4.0 International Lizenz (http://creativecommons.org/licenses/by/4.0/deed.de) veröffentlicht, welche die Nutzung, Vervielfältigung, Bearbeitung, Verbreitung und Wiedergabe in jeglichem Medium und Format erlaubt, sofern Sie den/die ursprünglichen Autor(en) und die Quelle ordnungsgemäß nennen, einen Link zur Creative Commons Lizenz beifügen und angeben, ob Änderungen vorgenommen wurden.

Die in diesem Kapitel enthaltenen Bilder und sonstiges Drittmaterial unterliegen ebenfalls der genannten Creative Commons Lizenz, sofern sich aus der Abbildungslegende nichts anderes ergibt. Sofern das betreffende Material nicht unter der genannten Creative Commons Lizenz steht und die betreffende Handlung nicht nach gesetzlichen Vorschriften erlaubt ist, ist für die oben aufgeführten Weiterverwendungen des Materials die Einwilligung des jeweiligen Rechteinhabers einzuholen.

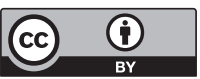

